RODRIGO DE FREITAS

\title{
RECONHECIMENTO, MENSURAÇÃO E TRIBUTAÇÃO DA RENDA NO SETOR IMOBILIÁRIO
}

Dissertação de Mestrado Orientador: Roberto Quiroga Mosquera

Faculdade de Direito da Universidade de São Paulo São Paulo - 2012 


\title{
RODRIGO DE FREITAS
}

\section{RECONHECIMENTO, MENSURAÇÃO E TRIBUTAÇÃO DA RENDA NO SETOR IMOBILIÁRIO}

\author{
Dissertação apresentada como requisito para \\ habilitação ao título de Mestre em Direito, sob a \\ orientação do Prof. Dr. Roberto Quiroga Mosquera, \\ na subárea de Direito Tributário, integrada ao \\ Departamento de Direito Econômico, Financeiro e \\ Tributário da Faculdade de Direito da Universidade \\ de São Paulo.
}

Faculdade de Direito da Universidade de São Paulo São Paulo - 2012 
Ficha Catalográfica

F936r

FREITAS, Rodrigo de.

Reconhecimento, mensuração e tributação da renda no setor imobiliário /

Rodrigo de Freitas. -- São Paulo: 2012.

$349 \mathrm{f}$;; $22 \mathrm{~cm}$.

Orientação Roberto Quiroga Mosquera

Mestrado - Departamento de Direito Econômico Financeiro e Tributário da Faculdade de Direito da USP, 2012.

Inclui anexo e bibliografia.

1. Direito tributário; 2. Imposto de renda; 3. Contabilidade; 4. Negócios imobiliários; 5. Imposto de renda pessoa física; 6 . Imposto de renda pessoa jurídica; 7. Fundos de investimento imobiliário. I. Título. 


\section{DEDICATÓRIA}

Para Simone, com muito amor,

pelo apoio em todos os momentos.

Sem você esta obra não seria possível. 


\section{AGRADECIMENTOS}

A Roberto Quiroga Mosquera, que sempre foi para mim uma referência como advogado, professor, pai de família e amigo. Sou muito grato pelas oportunidades concedidas e especialmente pelo rico aprendizado no exercício da advocacia e da docência. Sua atuação apaixonada na defesa dos clientes e no ensino do Direito Tributário é uma inspiração.

Aos Professores Luis Eduardo Schoueri e Paulo Ayres Barreto, que teceram valiosas considerações sobre o presente trabalho e por todos os ensinamentos. Ao Professor Fernando Aurelio Zilveti, que me orienta e incentiva desde o início das minhas atividades acadêmicas.

Aos meus colegas e amigos de escritório, que sempre me apoiaram. Nossas discussões acaloradas foram fundamentais para a consolidação de muitos dos conceitos e opiniões presentes neste trabalho.

Aos colegas da Especialização em Direito Tributário da USP, que proporcionaram momentos únicos de aprendizado e amizade. Tenho certeza que estão construindo, com afinco e competência, uma brilhante carreira acadêmica.

Em especial aos meus pais, Nilsa e José de Freitas Jr., exemplos de vida para mim, pelo apoio incondicional em todos os momentos e pela paciência e carinho com que criaram seus filhos. 


\section{RESUMO}

Atualmente, verifica-se um momento de grande reflexão dos aplicadores do Direito Tributário, em decorrência do impacto trazido pelos novos métodos e critérios contábeis aplicados à apuração do lucro societário das empresas no Brasil. A aplicação dos princípios contábeis geralmente aceitos passou a estabelecer novos paradigmas para o reconhecimento e mensuração do lucro, influenciando a forma de interpretar a legislação tributária.

Esse contexto ganha grande relevância no que tange à apuração e tributação da renda no setor imobiliário. Isto porque esse setor da economia é cuidadosamente regulamentado, do ponto de vista contábil, tanto pela legislação societária quanto pela fiscal.

Com efeito, o presente estudo analisa a delimitação da competência constitucional para tributação da renda pela União, sobretudo os limites oferecidos pelos princípios constitucionais tributários. Também se analisam as definições de renda pelo CTN e os critérios de definição do momento de realização.

Ocorre que a definição do fato gerador do imposto de renda muitas vezes se vale de conceitos previstos em outras áreas do Direito, especialmente no Direito Privado. Dessa forma, são analisados os conceitos estabelecidos pelo Direito Contábil Societário, pois são fundamentais para a quantificação da matéria tributável.

Após o estabelecimento da base teórica para a tributação da renda, passa-se à análise dos principais aspectos jurídicos das operações imobiliárias (negócios que envolvem a exploração econômica, direta ou indireta, da propriedade imobiliária). Essa primeira análise é necessária para se estabelecerem os parâmetros adequados para o reconhecimento e a mensuração da renda, intrinsecamente relacionada à transferência de riscos e benefícios.

Um segundo passo importante, para a apuração da renda do setor imobiliário, corresponde à análise dos principais métodos e critérios contábeis estabelecidos pela legislação societária, pois esse é o parâmetro inicial para a apuração do montante a ser tributado.

Por fim, analisam-se a coerência e a adequação das regras de tributação da renda no setor imobiliário, para as pessoas físicas e as pessoas jurídicas. Também serão abordados os regimes específicos de tributação previstos na legislação brasileira.

Palavras chaves: 1. Direito Tributário; 2. Imposto de Renda; 3. Direito Contábil; 4. Negócios Imobiliários; 5. Imposto de Renda Pessoa Física; 6. Imposto de Renda Pessoa Jurídica; 7. Fundos de Investimento Imobiliário. 


\begin{abstract}
In recent years, tax law practitioners have been forced to rethink due to the impact of new accounting methods and criteria applied to the calculation of corporate profits in Brazil. The application of generally accepted accounting principles has established new parameters for the recognition and measurement of profits, thereby influencing the interpretation of tax law.

This context has acquired great relevance regarding the calculation and taxation of income in the real estate sector. This is due to the fact that this economic sector is carefully regulated from an accounting standpoint, as much by corporate law as by tax law.

Indeed, this work analyzes the limits of the constitutional authority for Federal taxation of income, especially as regards the bounds set out by constitutional principles of taxation. It also analyses the Brazilian National Tax Code (CTN) definition of income, as well as the definition of the moment when income is realized.

It happens that the definition of the tax-triggering event for income tax often relies on concepts derived from other areas of law, especially privet law. Therefore, the concepts established by corporate accounting law are analyzed here, as they are fundamental concepts for the quantification of the tax bases.

After establishing the theoretical basis for income taxation, the main legal aspects of real estate transactions are analyzed (those involving direct or indirect real estate economic exploration). This first analysis is necessary in order to establish the appropriate parameters for the recognition and measurement of income, intrinsically related to the transfer of risks and benefits.
\end{abstract}

A second important step for the calculation of income in the real estate sector corresponds to the analysis of the main accounting methods and criteria established by corporate law, as this is the initial parameter for the calculation of the tax basis.

Finally, this work analyzes the coherence and proportion of the income taxation rules in the real estate sector, for individuals and corporations. The special tax regimes established by Brazilian law will also be addressed.

Keywords: 1. Tax Law; 2. Income Tax; 3. Accounting Law; 4. Real Estate Transactions; 5. Individual Income Tax; 6. Corporate Income Tax; 7. Funds of Investment in Real Estate. 


\section{Reconhecimento, Mensuração e TRIBUtaÇão da RENDa No SETOR IMOBILIÁRIO}

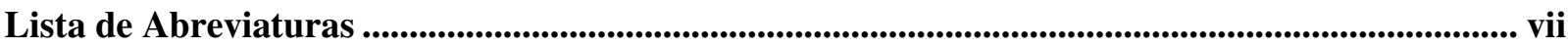

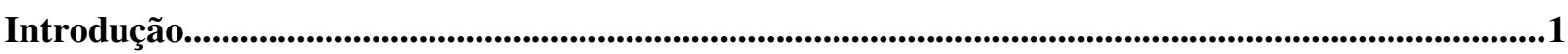

1 - Do Conceito de Renda e o Princípio da Realização na Constituição Federal e no Código

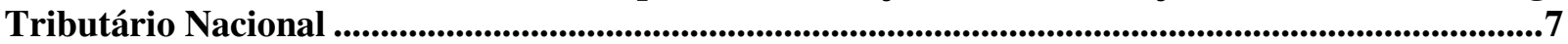

1.1 - Aspectos Gerais do Conceito de Renda e o Momento de sua Realização......................................8

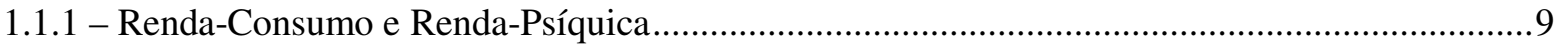

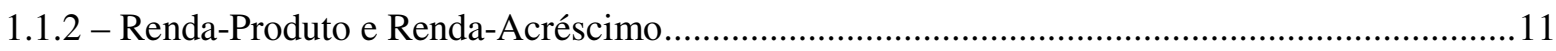

1.2 - Delimitação Tipológica da Renda e o Princípio da Realização na Constituição Federal ........14

1.2.1 - Princípios Gerais Aplicáveis à Tributação da Renda..............................................................21

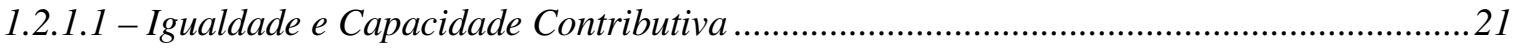

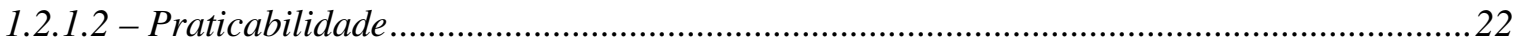

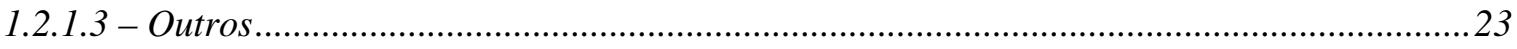

1.2.2 - Princípios Específicos de Tributação da Renda .....................................................................23

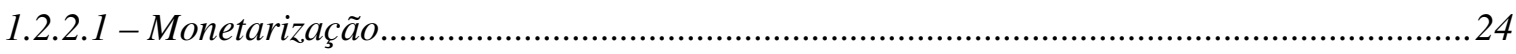

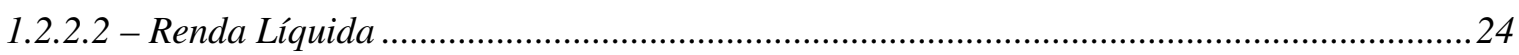

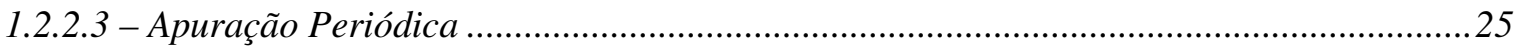



1.3 - Do Conceito de Renda e Critérios de Realização no Código Tributário Nacional....................30

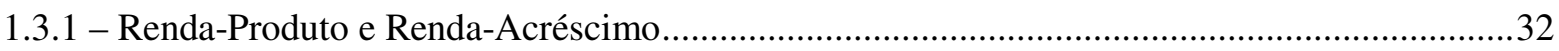



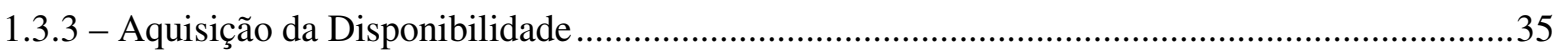

1.4 - Utilização de Conceitos de Direito Privado para Determinar o Conceito de Renda e o

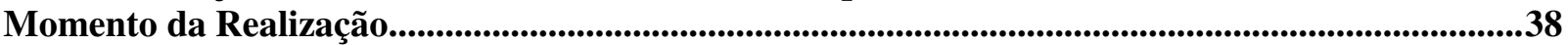

1.4.1 - Tratamento dos Conceitos de Direito Privado pelo CTN …….................................................39

1.4.2 - Formas de Relacionamento entre o Direito Privado e o Direito Tributário ................................42

1.4.2.1 - Recepção do Conceito de Direito Privado pelo Direito Tributário (Expressa ou

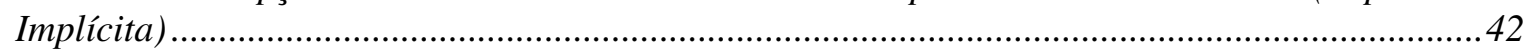

1.4.2.2 - Transformação do Conceito de Direito Privado para Fins Tributários ............................. 43

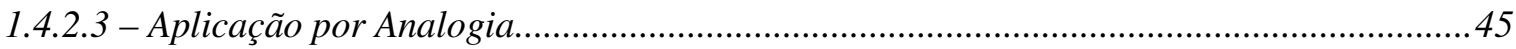

1.4.2.4 - Interpenetração Normativa do Direito Tributário no Direito Privado...............................45 
2 - Utilização da Contabilidade para Reconhecimento, Mensuração e Tributação da Renda ........46

2.1 - Ciência Contábil como Instrumento para Medição do Patrimônio e do Desempenho de uma Entidade

2.1.1 - Ciência Contábil - Objeto e Objetivo .49

2.1.2 - Processo Contábil .50

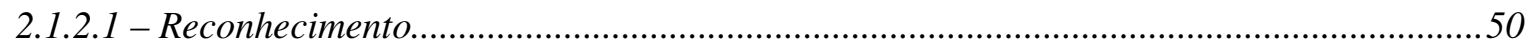



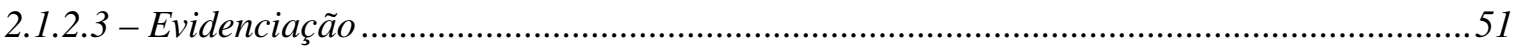

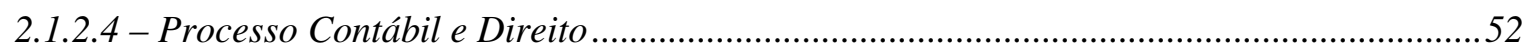

2.1.3 - Conflito de Interesses entre Usuários das Informações Contábeis (Conflito de Agência) .......53

2.2 - Direito Contábil Societário e Apuração do Lucro Comercial ...........................................................57

2.2.1 - Produção Normativa Contábil - Convergência com os Padrões Internacionais.......................59

2.3 - Elementos das Demonstrações Contábeis - Pressupostos para Reconhecimento e Mensuraçãa do Lucro Contábil ...................................................................................................................64

2.3.1 - Balanço Patrimonial (BP) - Posição Patrimonial e Financeira...............................................65

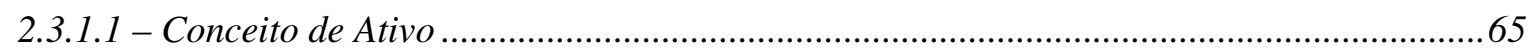

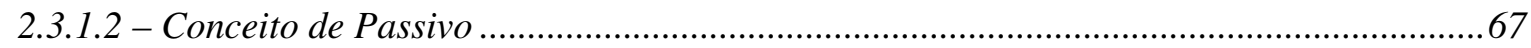

2.3.1.3 - Conceito de Patrimônio Líquido ......................................................................................68

2.3.2 - Demonstração do Resultado do Exercício (DRE) - Desempenho............................................71

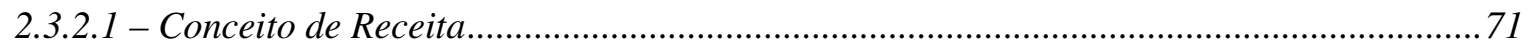



2.3.2.3 - Conceito de Lucro Líquido .............................................................................................. 74

2.4 - Princípios Contábeis Geralmente Aceitos - Reflexos no Reconhecimento e Mensuração do

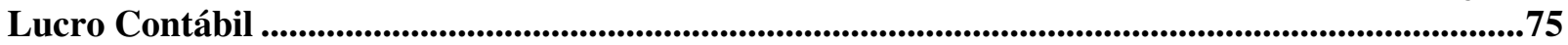

2.4.1 - Pressuposto Conceitual: Dilema entre (i) Relevância e (ii) Confiabilidade da Informação

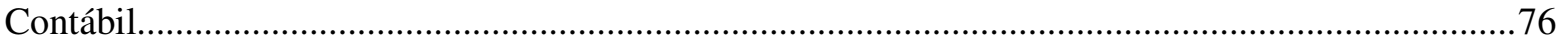

2.4.2 - Reflexo do Dilema: (i) Princípio do Custo Original como Base de Valor ou (ii) "Fair Value"?

2.4.3 - Regime de Competência - Princípios (i) da Realização da Receita e (ii) do Confronto das

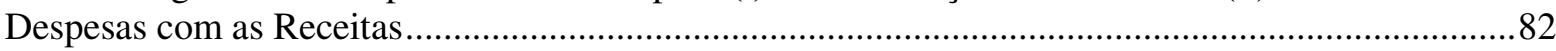

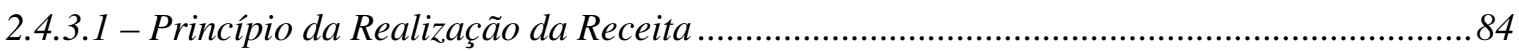

2.4.3.1.a - Reconhecimento da Receita Proporcionalmente ao Decurso do Tempo ........................85

2.4.3.1.b - Reconhecimento da Receita para Produtos ou Serviços de Longo Prazo de Execução86

2.4.3.1.c - Reconhecimento da Receita Antes da Transferência.......................................................86

2.4.3.1.d - Reconhecimento da Receita Após a Transferência ........................................................87

2.4.3.2 - Princípio do Confronto das Despesas com as Receitas ..................................................8

2.5 - Direito Contábil Tributário e a Apuração do Lucro Fiscal..............................................................88 
3 - Natureza Jurídica dos Negócios Imobiliários .....................................................................................94

3.1 - Negócios Jurídico-Imobiliários (Delimitação do Objeto) ….....................................................94

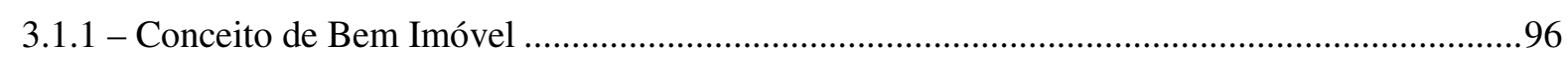

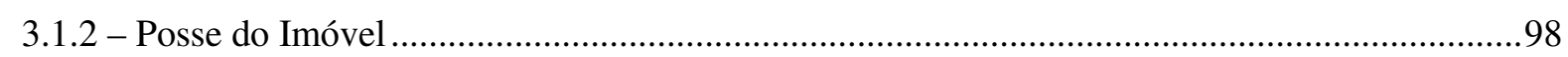



3.1.4 - Condomínio Imobiliário (Conceito e Características) .........................................................105

3.1.5 - Patrimônio para o Direito Civil (Comparação com Direito Societário) ..................................110

3.1.6 - Contratos (Negócios Jurídicos Constitutivos de Obrigações)................................................113

3.2 - Primeiro Gênero: Alienação da Propriedade Imobiliária..........................................................115

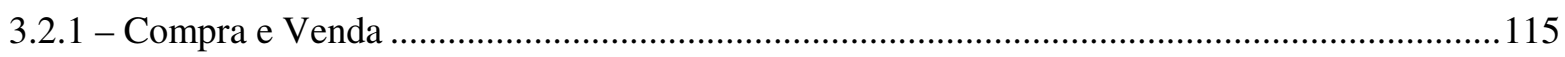

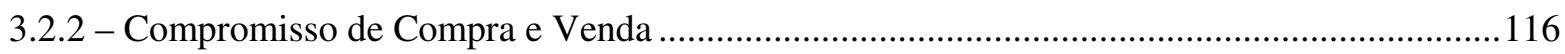

3.2.3 - Procuração em Causa Própria .................................................................................................. 117

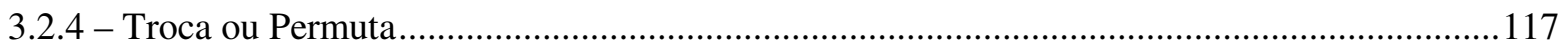

3.3 - Segundo Gênero: Serviços Imobiliários .............................................................................................118

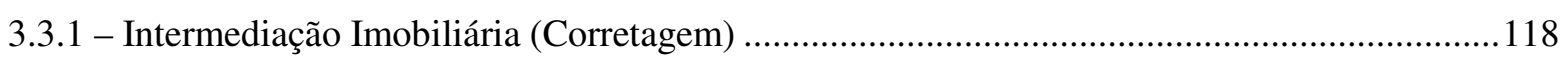

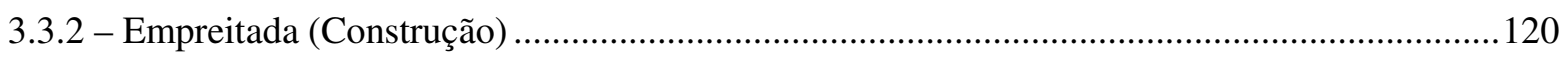

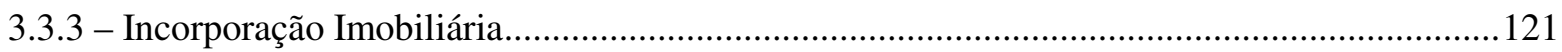

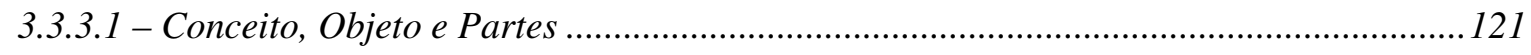

3.3.3.2 - Ciclo Econômico - Etapas: (i) Constituição, (ii) Execução e (iii) Extinção.................... 123

3.3.3.3 - Patrimônio de Afetação............................................................................................. 128

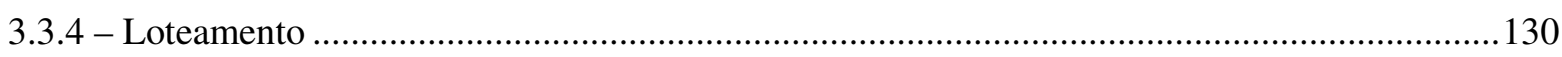

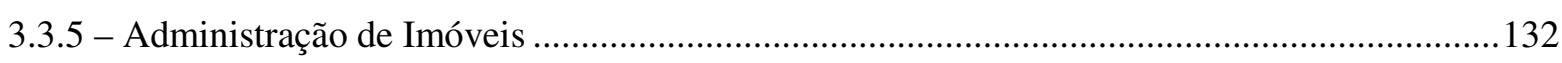

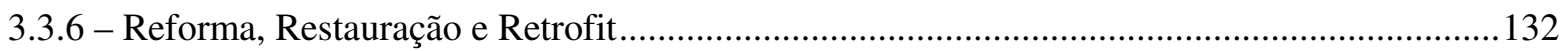

3.4 - Terceiro Gênero: Cessão da Posse do Imóvel...............................................................................133

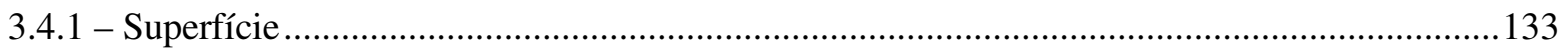

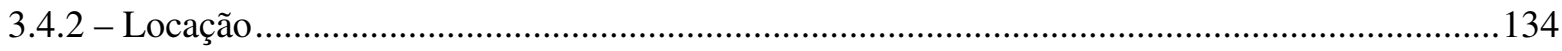

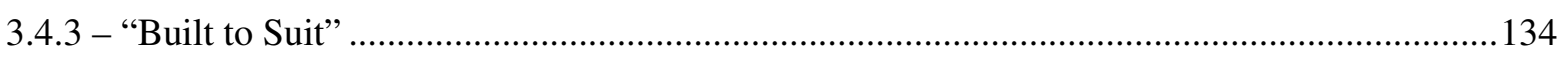

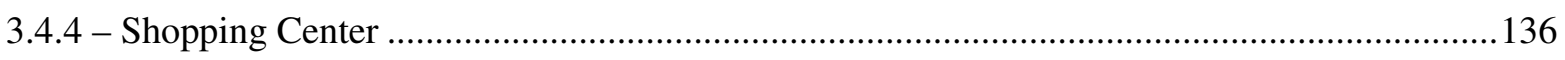

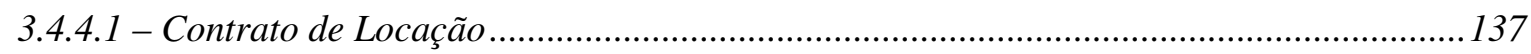

3.4.4.2 - Fundo de Comércio Comum (Investidor e Lojista) ........................................................138

3.4.4.3 - Os Agentes Econômicos: Investidor, Administrador e Lojista.........................................139

3.4.4.4 - Formas de Estruturação: Condomínio, Sociedade ou FII ............................................. 140

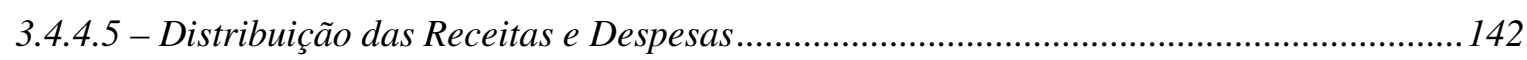

3.5 - Quarto Gênero: Financiamento Imobiliário..............................................................................146

3.5.1 - Financiamento Imobiliário: Conceitos Iniciais .......................................................................146

3.5.2 - Instrumentos de Garantia às Operações de Financiamento Imobiliário....................................148

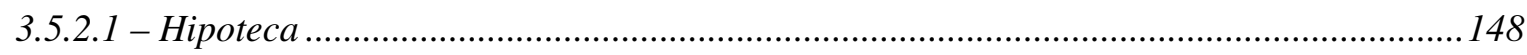




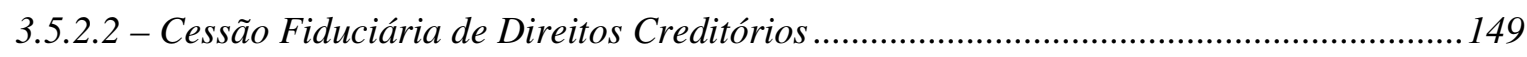

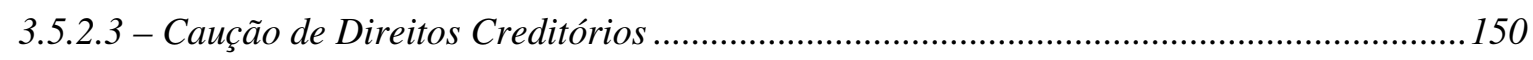

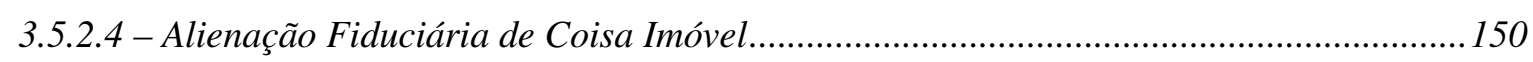

3.5.2.5 - Oferecimento de Cotas de Fundo de Investimento........................................................... 151

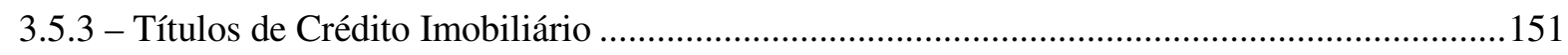

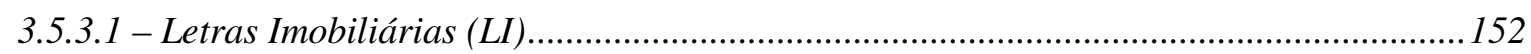



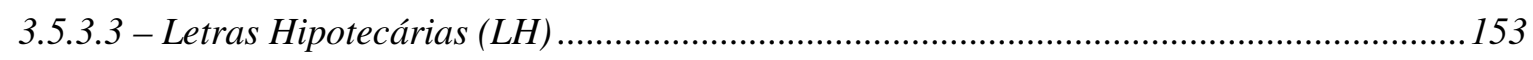

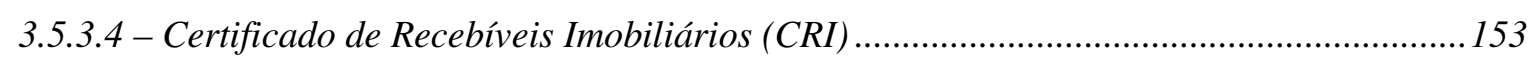

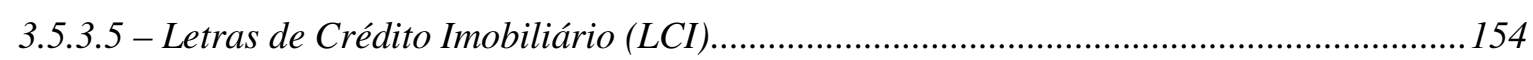

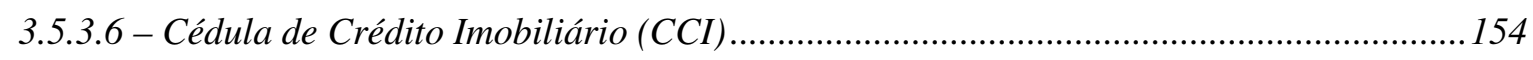

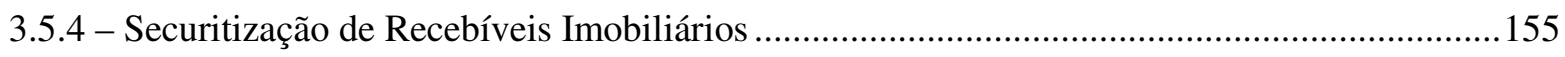

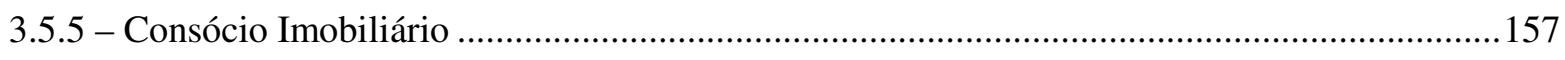

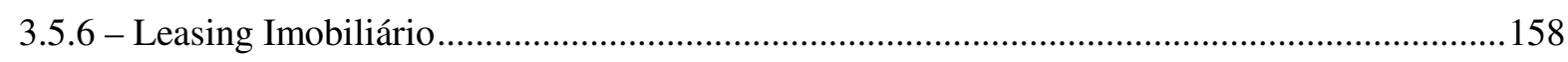

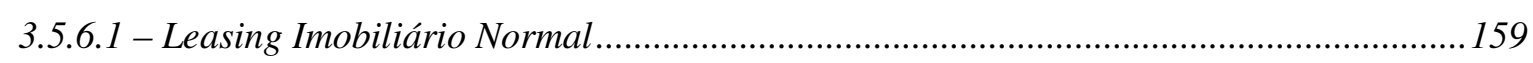

3.5.6.2 - Leasing na Construção de Edifícios................................................................................ 159

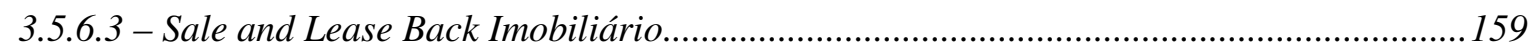

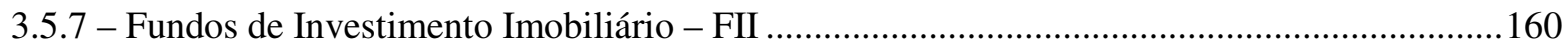

3.5.7.1 - Breve Histórico dos Fundos de Investimentos no Brasil................................................. 160

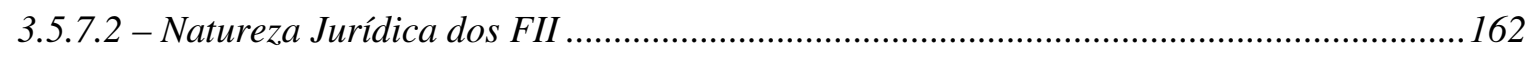

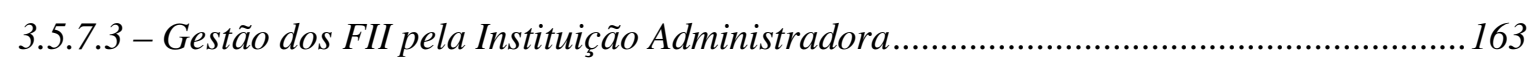



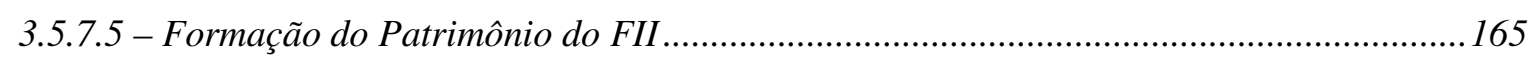

4 - Reconhecimento e Mensuração do Lucro Societário no Setor Imobiliário .................................168

4.1 - Negócios Jurídicos de Alienação da Propriedade Imobiliária ..................................................170

4.1.1 - Aspectos Gerais da Contabilização de Venda de Bens (CPC 30)..........................................170

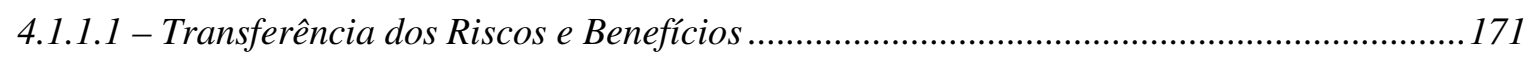

4.1.1.2 - Segurança de Recebimento dos Benefícios Econômicos................................................172

4.1.1.3 - Mensurabilidade das Despesas e Confronto com as Receitas .......................................173

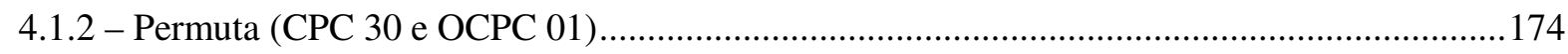

4.2 - Negócios Jurídicos de Prestação de Serviços Vinculados à Propriedade Imobiliária............176

4.2.1 - Aspectos Gerais da Contabilização de Serviços (CPC 30) ....................................................176

4.2.1.1 - Segurança de Recebimento dos Benefícios Econômicos ................................................. 177

4.2.1.2 - Determinação da Percentagem Completada ............................................................... 178

4.2.2 - Regra Geral de Contabilização dos Contratos de Construção (CPC 17) ................................179

4.2.3 - Contabilização do Contrato de Construção no Setor Imobiliário (ICPC 02)..........................186 
4.2.4 - Contabilização do Contrato de Incorporação Imobiliária (OCPC 04).... 192

4.3 - Negócios Jurídicos de Cessão da Posse do Imóvel................................................................................195

4.3.1 - Contabilização da Cessão Onerosa da Posse do Imóvel (Locação e Outros) ..........................195

4.3.2 - Propriedade para Investimento (CPC 28 e ICPC 10) ............................................................196

4.4 - Negócios Jurídicos Relacionados ao Financiamento da Propriedade Imobiliária ..................197

4.4.1 - Leasing Imobiliário (Arrendamento Mercantil - CPC 06) ......................................................197

4.4.2 - Fundos de Investimento Imobiliário (IN/CVM no 516/11) ................................................202

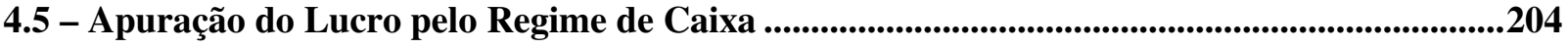

4.6 - Resolução CFC 963/2003 - Entidades Imobiliárias ......................................................................211

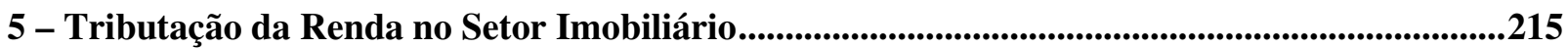

5.1 - Tributação da Renda pelas Pessoas Físicas ........................................................................................216

5.1.1 - Aspectos Gerais da Tributação da PF - Formas de Apuração e Recolhimento (Categorias de

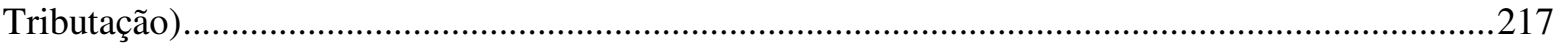

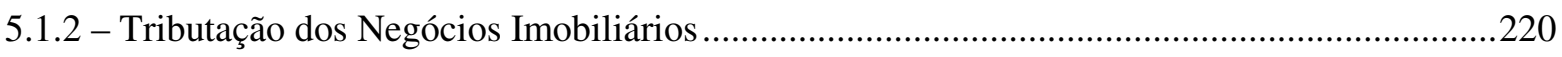

5.1.2.1 - Tributação da Alienação da Propriedade Imobiliária (Ganho de Capital)....................220

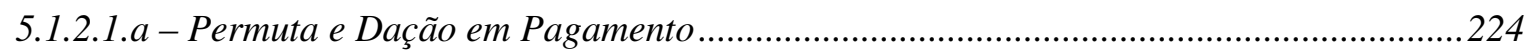

5.1.2.1.b - Isenção: Bens Imóveis de Pequeno Valor ...................................................................226

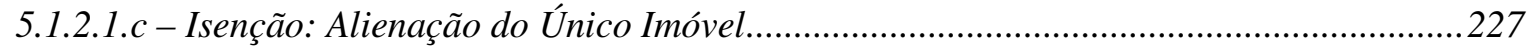

5.1.2.1.d - Isenção: 180 Dias para Reinvestimento em Imóveis Residenciais................................227

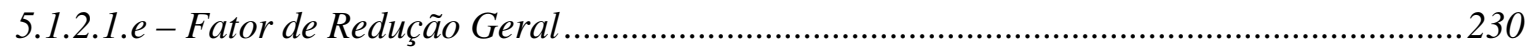

5.1.2.1.f - Imóveis Adquiridos até 1988 - Redução de 5\% a 100\%do Ganho de Capital .............231

5.1.2.2 - Tributação da Cessão da Posse do Imóvel (Locação e Outros) ......................................233

5.1.2.3 - Securitização de Recebíveis e Tributação dos Títulos de Crédito Imobiliários..............234

5.1.2.4 - Equiparação da Pessoa Física à Pessoa Jurídica ..........................................................235

5.2 - Tributação da Renda pelas Pessoas Jurídicas ..........................................................................................237

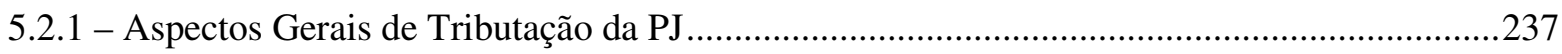

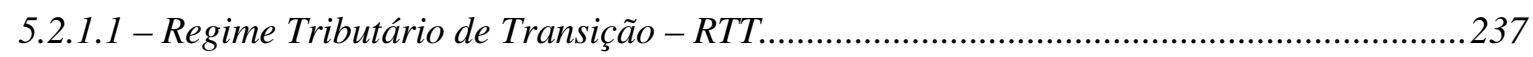

5.2.1.1.a - Métodos e Critérios Contábeis Vigentes em 31/12/2007 ............................................240

5.2.1.1.b - Conflitos Interpretativos entre as Contabilidades Societária e Fiscal .........................243

5.2.1.2 - Tributação pela Sistemática do Lucro Real ......................................................................246

5.2.1.3 - Tributação pela Sistemática do Lucro Presumido ...........................................................248

5.2.1.4 - Tributação pela Sistemática do Lucro Arbitrado............................................................251

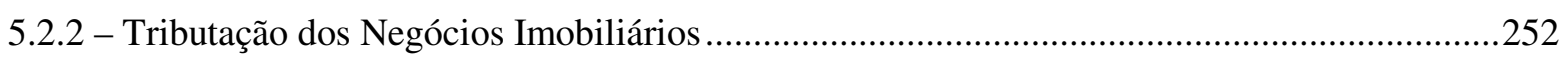

5.2.2.1 - Tributação da Alienação da Propriedade Imobiliária (Ganho de Capital)....................252

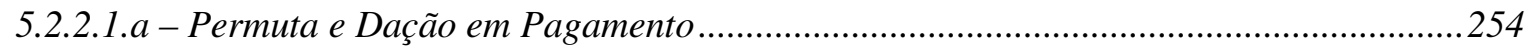

5.2.2.1.b - Depreciação e Reavaliação de Bens Imóveis.................................................................261

5.2.2.2 - Tributação da Prestação de Serviços Imobiliários ............................................................264 
5.2.2.3 - Tributação da Cessão da Posse do Imóvel (Locação e Outros) ......................................265

5.2.2.4 - Tributação da Securitização de Recebíveis...................................................................266

5.3 - Regimes Específicos de Tributação ......................................................................................266

5.3.1 - Tributação das Atividades de (i) Compra e Venda, (ii) Loteamento, (iii) Incorporação e (iv)

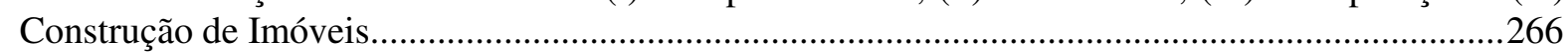

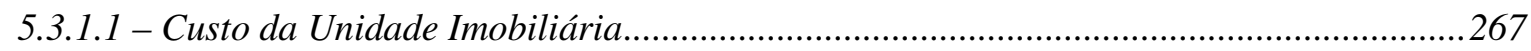

5.3.1.2 - Lucro Bruto - Aplicabilidade do $\S 1^{\circ}$ do artigo 27 do DL $n^{o} 1.598 / 77$.............................269

5.3.1.2 - Custo Orçado - Direito à Adoção do Lucro Presumido ..................................................22

5.3.1.3 - Regime de Caixa - (i) Extinção da conta de Resultados de Exercícios Futuros e (ii)

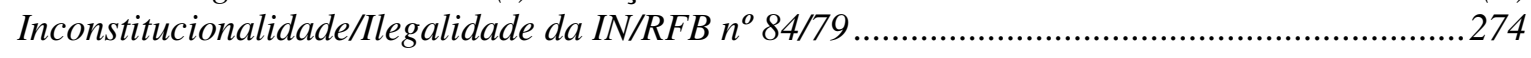

5.3.1.4 - Incorporação Imobiliária - Ciclo Econômico e Regime de Caixa ..................................2279

5.3.1.5 - Correção Monetária e Juros na Venda de Imóveis a Prazo ...........................................280

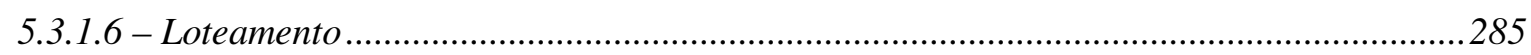

5.3.2 - Regime Especial de Tributação (RET) do Patrimônio de Afetação .......................................285

5.3.2.1 - Construções no Âmbito do Programa Minha Casa Minha Vida (PMCMV)...................287

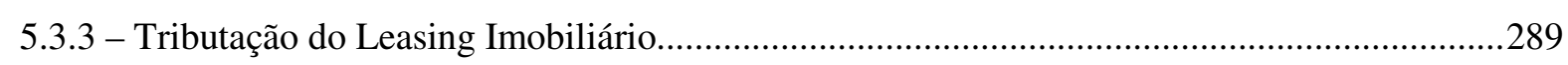

5.3.4 - Tributação dos Fundos de Investimento Imobiliário - FII ....................................................291

5.3.4.1 -Regime Tributário 1: Regra Geral de Tributação do FII .................................................291

5.3.4.2 - Regime Tributário 2: Isenção de Rendimentos do FII Distribuídos à Pessoa Física ....293

5.3.4.3 - Regime Tributário 3: Tributação do FII como Pessoa Jurídica .......................................293

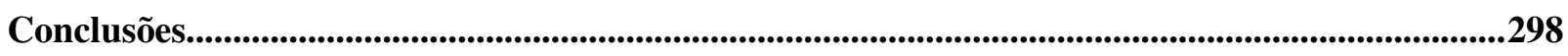

Apêndice A - Entidades de Incorporação Imobiliária (OCPC 04)...................................................304

Apêndice B - Propriedade para Investimento (ICPC 10) ........................................................317

Apêndice C - Fundo de Investimento Imobiliário (IN/CVM n n 516/11) ..............................................319

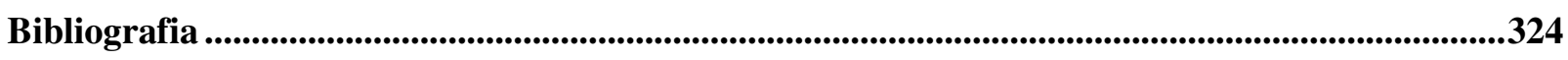




\section{Lista de AbreViaturas}

ABRASCE - Associação Brasileira de Shopping Centers

BACEN - Banco Central do Brasil

BNH - Banco Nacional da Habitação

BP - Balanço Patrimonial

BR-GAAP - Brazilian Generally Accepted Accounting Principles (Princípios de Contabilidade Geralmente Aceitos no Brasil em 31/12/2007, quando a contabilidade societária era fortemente influenciada pela legislação tributária)

BTS - Built-to-Suit

CC - Código Civil (Lei n ${ }^{\circ}$ 10.406/2002)

CCI - Cédula de Crédito Imobiliário

CEF - Caixa Econômica Federal

CF - Constituição Federal

CFC - Conselho Federal de Contabilidade

CH - Cédula Hipotecária

CMN - Conselho Monetário Nacional

CMN - Conselho Monetário Nacional

CPC - Comitê de Pronunciamentos Contábeis

CRI - Certificado de Recebíveis Imobiliários

CSLL - Contribuição Social sobre o Lucro Líquido

CTN - Código Tributário Nacional

CVM - Comissão de Valores Mobiliários

DRE - Demonstração do Resultado do Exercício

FASB - Financial Accounting Standard Board (Conselho de Padrões de Contabilidade Financeira) 
FGTS - Fundo de Garantia do Tempo de Serviço

FII - Fundo de Investimento Imobiliário

GAAP - Generally Accepted Accounting Principles ou Generally Accepted Accounting

Practice (princípios ou práticas de contabilidade geralmente aceitas)

IASB - International Accounting Standard Board (Conselho de Padrões de Internacionais de Contabilidade)

IBRACON - Instituto dos Auditores Independentes do Brasil

ICSC - International Council of Shopping Centers

IFRIC - International Financial Reporting Interpretations Comittee (Comitê Internacional de Interpretação [de Normas] de Relatórios Financeiros)

IFRS - Internacional Financial Reporting Standards (Padrões Internacionais de Relatórios Financeiros)

IRPJ - Imposto de Renda das Pessoas Jurídicas

LALUR - Livro de Apuração do Lucro Real

LCI - Letras de Crédito Imobiliário

LH - Letras Hipotecárias

LI - Letras Imobiliárias

LRP - Lei dos Registros Públicos (Lei nº 6.015/73)

MP - Medida Provisória

NBC - Normas Brasileiras de Contabilidade

NPC - Normas e Procedimentos de Contabilidade

PCGA - Princípios de Contabilidade Geralmente Aceitos

RIR - Regulamento do Imposto de Renda

RTT - Regime Tributário de Transição (previsto na Lei no 11.941/09)

SBPE - Sistema Brasileiro de Poupança e Empréstimo

SCI - Sociedade de Crédito Imobiliário

SEDU/PR - Secretaria Especial de Desenvolvimento Urbano da Presidência da República 
SFH - Sistema Financeiro da Habitação

SFI - Sistema Financeiro Imobiliário

SFN - Sistema Financeiro Nacional

SHS - Schanz-Haig-Simons (autores de modelo de tributação da renda)

SPE - Sociedade de Propósito Específico

STF - Supremo Tribunal Federal

US-GAAP - United States of America Generally Accepted Accounting Principles (Princípios de Contabilidade Geralmente Aceitos nos EUA) 


\section{INTRODUÇÃO}

O mercado imobiliário brasileiro passou por uma grande modernização, nos últimos anos, impulsionado pela estabilidade econômica, pela melhoria do padrão de renda da população brasileira e pela ampliação do crédito imobiliário. Além disso, um fator de grande influência para essa evolução foi o acesso de grandes empresas do setor ao mercado de capitais, o que permitiu a captação de significativo volume de capital para a aquisição de terrenos e realização de novos investimentos.

Essa modernização foi acompanhada por uma grande polêmica acerca da contabilização do lucro pelas entidades de incorporação imobiliária, especialmente quanto ao reconhecimento e à mensuração desse lucro no tempo (durante a evolução da obra ou apenas no momento da entrega das chaves?). Trata-se de uma discussão de grande relevância para fins de avaliação de desempenho perante o mercado de capitais, refletindo diretamente no valor de mercado dessas companhias.

Do mesmo modo, a legislação tributária também contribuiu para o desenvolvimento do setor, na medida em que foram previstos diversos benefícios fiscais para incentivar os negócios jurídico-mobiliários. Destaque-se, neste sentido, que o critério de reconhecimento e mensuração do lucro imobiliário para fins fiscais, vigente há mais de 30 anos, é a tributação pelo regime de caixa.

Com efeito, faz-se necessária uma análise do tratamento tributário conferido às diversas formas de manifestação da atividade imobiliária (como é o caso da tributação do lucro pelo regime de caixa), bem como a legitimidade desse tratamento diferenciado em relação aos demais setores da economia (que devem obedecer a regra societária do regime de competência, por exemplo).

A análise que se passa a fazer pretende ser abrangente e interdisciplinar. Será abrangente na abordagem das diversas formas possíveis de exploração econômica da propriedade imobiliária e interdisciplinar na avaliação das diferentes visões acerca da apuração do lucro nessas atividades, oferecidas (i) pelo Direito (civil, societário e tributário) e (ii) pela Ciência Contábil. 
Para essa análise abrangente e interdisciplinar, verificam-se a natureza jurídica dos fenômenos econômicos que compõe o setor imobiliário, bem como a coerência e a adequação das metodologias de apuração e tributação do lucro dessas atividades. Para tanto, será feita inicialmente uma análise ampla do "mapa" do setor imobiliário, com a verificação das principais estradas que ligam a origem (objetivo) ao destino (resultado), bem como suas características fundamentais (v.g. custo, tempo, distância e segurança). Posteriormente, serão analisados os "caminhos" adotados nos casos concretos, bem como sua coerência e adequação em face dos diversos caminhos disponíveis.

Com efeito, a estrutura escolhida para o estudo das regras de tributação do lucro imobiliário será composta de 4 capítulos iniciais, nos quais serão abordadas as premissas do presente trabalho (análise do "mapa") e de um $5^{\circ}$ capítulo, no qual serão testadas a coerência e a adequação dos critérios adotados pela legislação tributária (análise dos “caminhos"), conforme exposto a seguir:

(i) Do Conceito de Renda e o Princípio da Realização na Constituição Federal e no Código Tributário Nacional

O presente estudo começa com a análise dos principais modelos de apuração da renda, para se ter uma ideia mais ampla das teorias existentes acerca do conceito de renda e o momento em que ela se considera realizada. Em seguida, tratar-se-á dos parâmetros constitucionais para o exercício da competência de tributação da renda pela União, especialmente dos limites oferecidos pelos princípios constitucionais (gerais e específicos).

Como a CF delimita a tributação da renda por meio de um tipo tributário, faz-se necessário analisar o CTN, na qualidade de Lei Complementar, para verificar a definição do conceito de renda. Com efeito, existem dois conceitos de renda positivados, o de renda-acréscimo e o de renda-produto. Também se verifica a importante definição de que a realização da renda depende da aquisição da disponibilidade econômica ou jurídica.

Após a verificação dos limites constitucionais à tributação da renda, bem como o conceito previsto no CTN, será analisado como o Direito Tributário se utiliza dos conceitos de Direito Privado na definição do conceito de renda para fins de tributação, o que pode se dar por meio de (i) recepção, (ii) transformação ou (iii) aplicação por analogia. 
(ii) Utilização da Contabilidade para Reconhecimento, Mensuração e Tributação da Renda

Após o estudo dos parâmetros gerais para a tributação da renda, em conformidade com a CF e com o CTN, faz-se necessária uma análise da Ciência Contábil e seu relacionamento com o Direito.

Assim sendo, a Ciência Contábil tem como objeto a elaboração e organização de informações econômicas acerca do patrimônio de determinada entidade e sua variação no tempo. Com efeito, o Direito se vale dos conceitos dessa Ciência para a elaboração de normas, tornando jurídica a forma de reconhecimento e mensuração dessas informações econômicas.

Os principais ramos do Direito que estabelecem normas acerca do reconhecimento e mensuração de informações econômicas sobre a situação do patrimônio de uma entidade e sua mutação no tempo são o Direito Societário e o Direito Tributário.

O Direito Societário estabelece normas contábeis com o objetivo de regular e proteger o mercado financeiro e de capitais, bem como regulamentar a distribuição de dividendos, para fins de proteção de credores, funcionários etc.

Neste sentido, para melhor compreensão do conjunto de normas jurídicas que tratam do reconhecimento e mensuração do lucro contábil para fins societários (o que se denomina, no presente trabalho, como Contabilidade Societária), faz-se necessário compreender os elementos das demonstrações contábeis, fundamentais para a apuração do patrimônio e sua variação no tempo, e que consistem em elementos estáticos (que demonstram a posição patrimonial e financeira em determinado momento: ativos, passivos e patrimônio líquido) e elementos dinâmicos (que demonstram o desempenho da entidade em determinado período: receitas, despesas e lucro).

Ademais, a Contabilidade Societária prevê expressamente a recepção dos princípios de contabilidade geralmente aceitos, motivo pelo qual serão analisados os princípios que fornecem os parâmetros para reconhecimento e mensuração dos elementos contábeis, tais como o princípio do custo original, como base de valor, e o regime de competência (reflexo da aplicação dos princípios da realização da receita e confrontação das despesas com as receitas).

Após a análise da Contabilidade Societária, passa-se a tratar das diversas normas jurídicas estabelecidas pelo Direito Tributário para o reconhecimento e mensuração do patrimônio de uma entidade e sua variação no tempo (o que se denomina Contabilidade Tributária ou Contabilidade Fiscal). 
Ocorre que a Contabilidade Tributária não é independente da Contabilidade Societária. Ao contrário, ela recepciona os conceitos de Direito Societário, fazendo ajustes específicos nas regras de reconhecimento e mensuração para fins de apuração da base de cálculo do IRPJ.

\section{(iii) Natureza dos Negócios Jurídico-Imobiliários}

Após a análise das balizas constitucionais para a tributação da renda e o conceito previsto no CTN, bem como a definição da natureza jurídica da Contabilidade Societária e da Contabilidade Fiscal, como ramos do Direito que regulamentam a forma de reconhecimento e mensuração do lucro, passa-se à análise específica dos negócios jurídico-imobiliários.

De fato, tanto a apuração da Contabilidade Societária quanto a da Contabilidade Fiscal dependem do correto entendimento acerca da natureza dos negócios jurídico-imobiliários e o seu ciclo econômico.

Dessa forma, serão analisados os conceitos fundamentais para a compreensão desse setor da economia, tais como o conceito de bem imóvel, posse e propriedade, bem como a sua incorporação ao patrimônio de uma pessoa (sob a ótica do Direito Civil). A exploração da atividade imobiliária se dá por meio de obrigações jurídicas que têm como objeto as prestações de dar, fazer ou não fazer, o que será analisado em cada gênero de negócios jurídicos.

A análise do Direito Privado é importante para o reconhecimento e mensuração do lucro, tanto para a Contabilidade Societária quanto para Contabilidade Fiscal, uma vez que dá subsídio para o agente avaliar a existência dos pressupostos para ocorrência de renda e o momento de sua realização (v.g. o momento da transferência de riscos e benefícios, em uma troca de mercado).

Com efeito, as operações imobiliárias foram divididas em quatro gêneros, de acordo com a natureza da preponderante da prestação a que o empreendedor está obrigado:

(a) Primeiro gênero: negócios jurídicos em que se explora economicamente a alienação da propriedade de bens imóveis. A renda/lucro consiste na mais valia entre o valor de aquisição e o valor de alienação.

(b) Segundo gênero: negócios jurídicos em que há prestação de serviços relacionada à propriedade imobiliária ou a outros negócios imobiliários. A renda/lucro decorre diretamente do preço dos serviços prestados. 
(c) Terceiro gênero: negócios jurídicos em que se explora economicamente a cessão temporária da posse sobre bens imóveis. A renda/lucro do proprietário decorre da remuneração recebida como contraprestação pelo direito temporariamente cedido (v.g. uso e gozo).

(d) Quarto gênero: negócios jurídicos que têm como objetivo viabilizar o financiamento da aquisição da propriedade imobiliária. A renda/lucro decorre da remuneração pelo capital disponibilizado para o financiamento.

\section{(iv) Reconhecimento e Mensuração do Lucro Societário no Setor Imobiliário}

Feita a análise das operações imobiliárias sob o ponto de vista do Direito Privado, divididas nos quatro gêneros mencionados (especificamente no que tange ao seu ciclo econômico e natureza jurídica para fins de análise de transferência de riscos e benefícios em uma troca de mercado), passa-se a analisar o reconhecimento e mensuração do patrimônio dessas entidades e sua mutação no tempo, em conformidade com as normas de Direito Contábil Societário.

Em conformidade com as premissas adotadas no presente trabalho, essa análise é de fundamental importância para fins de tributação da renda, uma vez que a Contabilidade Tributária recepciona dos conceitos da Contabilidade Societária, fazendo alguns ajustes quando julgado necessário.

Ressalte-se que a Contabilidade Societária, atualmente em vigor, encontra-se em consonância com os padrões internacionais, sobretudo em decorrência das alterações promovidas na Lei das S/A pela Lei $n^{\circ} 11.638 / 07$ e 11.941/09. Portanto, serão analisados também os métodos e critérios contábeis vigentes em 31/12/2007 para a aplicação do Regime Tributário de Transição - RTT.

\section{(v) Tributação da Renda no Setor Imobiliário}

Nos quatro capítulos iniciais do presente trabalho, foram expostas as premissas necessárias para a avaliação de coerência e adequação das regras tributárias no setor imobiliário. Essas premissas são: (i) aspectos gerais e limites da tributação da renda na CF e no CTN, (ii) papel fundamental da contabilidade, societária e fiscal, para o reconhecimento e mensuração da renda, (iii) natureza jurídica das atividades imobiliárias, com enfoque na 
transferência de riscos e benefícios e (iv) contabilização dessas informações econômicas em conformidade com as regras societárias atualmente em vigor e com as regras vigentes em $31 / 12 / 2007$.

A partir da análise dessas premissas, passa-se a avaliar a coerência e a adequação dos diversos critérios de tributação da renda gerada nesse setor, tanto no que tange à forma de reconhecimento e mensuração, quanto aos diversos tratamentos especiais previstos na legislação tributária.

A análise de coerência e adequação do tratamento fiscal conferido à renda do setor será feita em três etapas:

(a) aspectos gerais da tributação das pessoas físicas e regras específicas de tributação das atividades imobiliárias;

(b) aspectos gerais da tributação da pessoa jurídica e regras específicas de tributação das atividades imobiliárias;

(c) regimes específicos de tributação: (c.i) tributação das atividades de compra e venda, loteamento, incorporação e construção de imóveis; (c.ii) Regime Especial de Tributação - RET para o patrimônio de afetação; (c.iii) tributação do leasing imobiliário; e (c.iv) tributação dos Fundos de Investimentos Imobiliários - FII.

Como se percebe, foi realizada a escolha por uma análise abrangente, de forma a se verificarem as características gerais do setor imobiliário como um todo (análise do "mapa") $\mathrm{e}$, posteriormente, realizar uma reflexão acerca dos tratamentos específicos conferidos às diversas atividades que compõem este setor (análise dos "caminhos"). 


\section{1 - Do Conceito de Renda e o PrincíPio da Realização na Constituição Federal e no Código Tributário NaCional}

O estudo científico e sistematizado da tributação da renda, para qualquer setor da atividade econômica, pressupõe a definição prévia (i) do que se entende pelo conceito de renda, bem como (ii) o momento em que ela se considera realizada. Estes são dois pilares fundamentais para o presente trabalho, motivo pelo qual se faz necessária sua análise tanto no nível constitucional, quanto no nível da legislação complementar.

De fato, conforme se demonstrará brevemente e de forma preliminar, o conceito de renda pode ser estabelecido de diversas formas. Existem muitas teorias sobre a forma ideal de se conceituar a renda. Algumas chegam até a pregar a apuração de uma renda psíquica (renda como bem-estar do indivíduo).

Não obstante os diversos conceitos de renda oferecidos tanto por juristas quanto por economistas, é na Constituição Federal de 1988 - CF/88 que se irão encontrar os parâmetros gerais para a descrição da noção tipológica de renda para fins tributários no Brasil (balizas para o reconhecimento e mensuração da renda).

Dessa forma, é no texto constitucional que será encontrado o conteúdo mínimo do tipo tributário, que é núcleo do fato gerador do imposto sobre a renda. Ocorre que a sua definição por meio de conceitos dependerá também das normas infraconstitucionais para que ganhe contornos mais precisos e concretos.

Neste sentido, a CF/88 delega à lei complementar o papel de definir o fato gerador dos impostos nela discriminados, como é o caso do imposto sobre a renda. Dessa forma, o Código Tributário Nacional (CTN), na qualidade de lei complementar, traz elementos complementares aos estabelecidos constitucionalmente, os quais terão a finalidade de delimitar o conceito de renda com mais precisão e definir os critérios necessários para se determinar quando ela se considera realizada.

Por fim, será analisada a relação existente entre os conceitos de direito privado e de direito tributário de uma forma geral, assim como a sua aplicação para a definição do conceito de renda e o momento de sua realização. Nesta análise, será delimitado o papel do Direito Civil e o do Direito Societário para a definição do conceito de renda. 


\section{1 - Aspectos Gerais do Conceito de Renda e o Momento de sua REALIZAÇÃo}

Antes de se apontar o conceito de renda adotado no presente trabalho e o momento de sua realização, conforme delimitado na CF/88 e estabelecido no CTN, é importante que se tenha uma breve noção dos diferentes conceitos possíveis de renda e das principais questões que envolvem a sua aplicação.

Neste sentido, estabelece-se, como corte metodológico, o estudo do conceito de renda sob a perspectiva do consumo e da produção, conforme classificação proposta por Alcides Jorge Costa. ${ }^{1}$ Estas duas perspectivas se inserem dentro do ciclo econômico de geração de riqueza, que pode ser representado graficamente da seguinte forma:

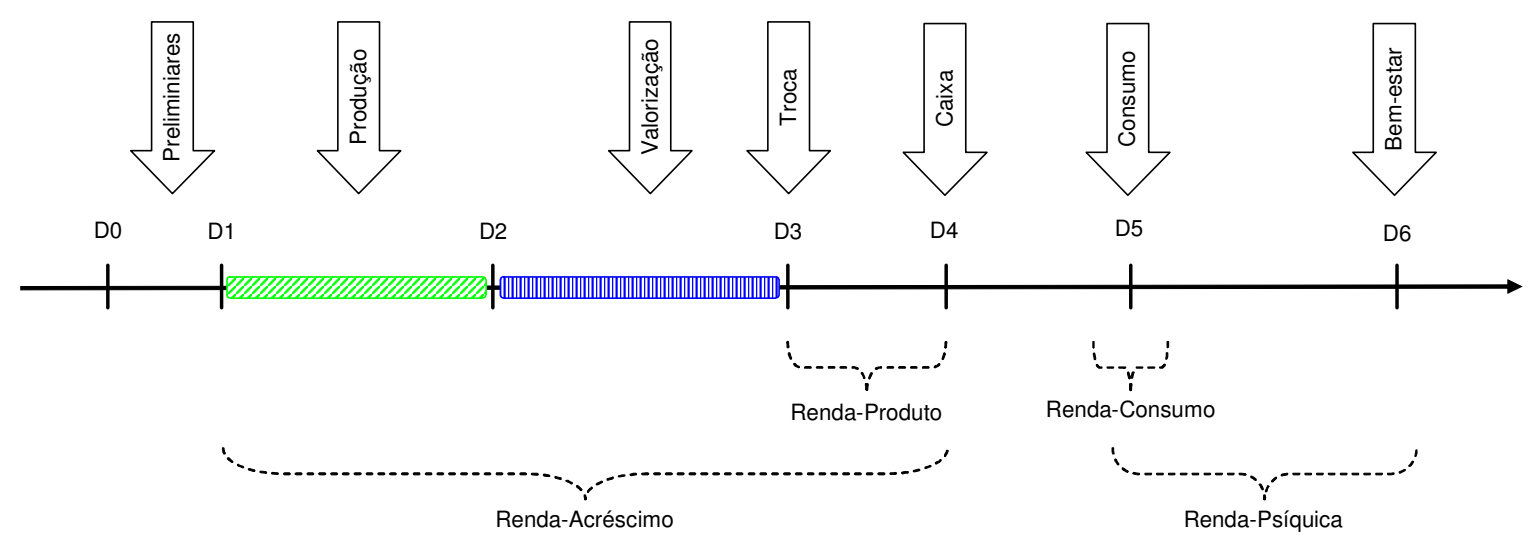

O gráfico acima evidencia as etapas mais comuns do ciclo econômico de geração de riqueza. No período D0-D1, realizam-se atividades preliminares acerca do empreendimento que se pretende concretizar, tais como estudos de viabilidade, projetos e pesquisas.

No período D1-D2 são realizados os esforços necessários para a produção do objeto que será trocado no mercado, com a obtenção de alguma mais valia. Esse objeto pode ser um bem físico ou imaterial como a prestação de serviço.

No período D2-D3, o objeto já produzido sofre valorização (ou desvalorização) por força da variação de preços de mercado, mas ainda não há uma troca com terceiros. Em

\footnotetext{
${ }^{1}$ COSTA, Alcides Jorge. Conceito de Renda Tributável. in MARTINS, Ives Gandra da Silva (coord.). Estudos sobre o Imposto de Renda (em memória de Henry Tilbery). São Paulo: Resenha Tributária. 1994, pp. 20 a 23. Este autor menciona também a ótica da distribuição, na qual "a renda constitui o produto da atividade da empresa distribuído aos diversos agentes da produção."
} 
algumas atividades econômicas, os bens são adquiridos com a finalidade primordial de se obter renda, com a valorização do preço de mercado no tempo.

No momento D3, ocorre a troca de mercado, que consiste na transferência do bem produzido para terceiros. Essa transferência é econômica, com reflexos jurídicos. Para fins econômicos, o que interessa é a transferência dos riscos e benefícios concernentes ao bem para terceiros. Ocorre que essa transferência somente se realiza quando suportada por algum instrumento jurídico, geralmente um contrato (pode ser escrito ou não).

Ressalte-se que a transferência dos riscos e benefícios não pressupõe a transferência da propriedade, pois ela pode ocorrer apenas com a transferência da posse, que também é um direito economicamente avaliável, passível de gerar reflexos patrimoniais, cuja discussão será retomada posteriormente (Capítulo 3.1.5).

No momento D4, a troca de mercado se reverte numa entrada de caixa (ou equivalentes de caixa), como contraprestação pela entrega do produto. Também é possível que a contraprestação se dê em outros bens, como ocorre na permuta. Neste ponto é que se verifica concretamente o resultado final da produção, sob o seu aspecto monetário (disponibilidade de caixa), para que se possa dele usar, fruir e gozar.

No momento D5, ocorre o consumo da renda obtida como resultado do processo produtivo. Esse consumo ocorre com a aquisição de novos bens e serviços pelo indivíduo, para a satisfação de seus interesses pessoais.

No momento D6, por fim, é que se verifica o efetivo bem-estar proporcionado ao indivíduo após a realização do consumo, possível com a renda gerada. Este seria o fim último da renda e o seu reflexo mais subjetivo para o titular.

Dessa forma, tecem-se a seguir breves considerações sobre a aplicabilidade dos conceitos de renda, distribuídos nessas diversas etapas do ciclo econômico em que ela é gerada. Este estudo preliminar será importante para se delimitar a noção tipológica de renda estabelecida na $\mathrm{CF} / 88$.

\subsection{1 - Renda-Consumo e Renda-Psíquica}

$\mathrm{O}$ primeiro grupo de teorias sobre o conceito de renda adota uma visão mais subjetiva, sob a perspectiva do consumo, com o fundamento de que é nesse momento que o contribuinte irá fruir dos benefícios dos rendimentos por ele auferidos. Analisa-se, a seguir, 
apenas a renda-consumo das pessoas físicas, pois a discussão do consumo na pessoa jurídica passa necessariamente pela análise da integração entre sócio e empresa (o que não é objeto do presente estudo).

Dessa forma, o conceito de renda-consumo considera o valor das utilidades consumidas pelo indivíduo. Assim, a renda é o resultado do consumo de bens e serviços pelo indivíduo, ou seja, a renda é uma medida do bem estar proporcionado pelo consumo. Podem ser citados, no Brasil, os trabalhos Carlos Alberto Longo ${ }^{2}$ e Hiroshi Nakao ${ }^{3}$ como exemplos de estudos sobre a tributação da renda na perspectiva do consumo.

Nesta acepção teórica, é possível incluir também o conceito de renda-psíquica como modelo ideal de tributação. Neste caso, a mensuração da renda ocorreria sobre a satisfação auferida pelo indivíduo. Assim, a renda seria a diferença entre as satisfações obtidas pelo indivíduo e os custos psicológicos em que incorreu para sua aferição.

Kevin Holmes, ao citar a obra de Irvin Fisher, destaca que a apuração desse conceito de renda deveria seguir o seguinte cálculo: ${ }^{4}$

(i) Para obter o salário (S), a pessoa incorre em custos psicológicos (CP) na realização de seu trabalho. Assim, a contraprestação monetária do trabalho deve ser líquida dos custos psicológicos para obtê-la [S - CP];

(ii) $\mathrm{O}$ dinheiro obtido com o trabalho (S) é então gasto com o pão, gerando serviços de alimentação. É o que Fischer denomina serviços objetivamente desfrutáveis $(\mathrm{O})$, que provêm de fora do corpo e estimulam as funções psicológicas. Em termos monetários, temos [O-S];

(iii) Por fim, os serviços objetivos decorrentes do consumo de bens são transformados em satisfações psicológicas (SP), ou seja, as satisfações psicológicas são obtidas ao custo de serviços reais de consumo de bens. Com efeito, como resultado do consumo do pão, esta renda subjetiva se concretiza pela satisfação do apetite do homem e pela sensação psicológica de prazer do consumo da comida proporcionado por sua mente [SP-O];

\footnotetext{
${ }^{2}$ LONGO, Carlos Alberto. Em Defesa de um Imposto de Renda Abrangente. São Paulo: FIPE-Pioneira, 1984.

${ }^{3}$ NAKAO, Sílvio Hiroshi. Um Modelo de Tributação da Renda por Fluxos de Caixa Realizados. Tese de doutorado apresentada ao Departamento de Contabilidade e Atuária da Faculdade de Economia, Administração e Contabilidade da Universidade de São Paulo, São Paulo, 2003.

${ }^{4}$ FISHER, Irving. Comment on President Plehn's Address. In: American Economic Review, mar. 1924, p. 64-65. Apud HOLMES, Kevin. The Concept of Income. A Multi-disciplinary Analysis. The Netherlands, IBFD, 2000, pp. 39-41.
} 
(iv) Assim, a renda-psíquica (RP) será aquela obtida pela soma dos três rendimentos acima apontados:

$$
\begin{aligned}
& \mathrm{RP}=[\mathrm{S}-\mathrm{CP}]+[\mathrm{O}-\mathrm{S}]+[\mathrm{SP}-\mathrm{O}] \\
& \mathrm{RP}=\not-\mathrm{CP}+\not \varnothing-\not \gamma+\mathrm{SP}-\not \\
& \mathrm{RP}=\mathrm{SP}-\mathrm{CP}
\end{aligned}
$$

(v) Ou seja, simplificando-se os termos da equação, chega-se ao conceito de renda-psíquica $(\mathrm{RP})$ que é a diferença positiva entre as satisfações psicológicas (SP) e os custos psicológicos (CP).

As dificuldades de apuração e mensuração da renda, de acordo com esse modelo, são evidentes. ${ }^{5}$ É o próprio Irving Fisher que afirma: "Teoricamente, então, um imposto sobre a renda meticuloso deveria perseguir a sua vítima até a mesa de jantar e tributar cada garfada, e deveria segui-lo até o teatro e tributar cada risada. Nenhum imposto que se abstenha de tributar essas satisfações finais poderia ser considerado um imposto da renda perfeitamente exato."

Ressalte-se, por fim, que a adoção dos conceitos de renda-consumo ou de renda-psíquica afasta a possibilidade de tributação da renda poupada, uma vez que essa renda ainda não foi consumida e não está gerando benefícios para o indivíduo. Isto porque, com a poupança dos recursos financeiros, troca-se a possibilidade de consumo no presente pela expectativa de consumo no futuro (ou seja, ocorre o diferimento da fruição do bem-estar gerado pela renda).

\subsection{2 - Renda-Produto e Renda-Acréscimo}

Não obstante a relevância das teorias que analisam a renda sob a perspectiva do consumo, é na perspectiva da produção que se encontram as teorias mais importantes para fins de tributação no Brasil. Existem teorias que analisam a renda sob o enfoque da fonte de

\footnotetext{
${ }^{5}$ Aliomar Baleeiro destaca que um dos conceitos possíveis de renda, segundo os economistas, é o de rendimentos psíquicos ou imateriais, como a fruição dos bens próprios (casa, carro, obras de arte etc.) e até horas de lazer. Contudo esse conceito não é acolhido pelas legislações, em razão da dificuldade prática de aplicação. BALEEIRO, Aliomar. Direito Tributário Brasileiro, 11 $1^{\mathrm{a}}$ ed., Rio de Janeiro: Forense, 2001, p. 284.

${ }^{6}$ Tradução livre de "Theoretically, therefore, a meticulous income tax should pursue its victim to his dining table, and take toll from each mouthful, and should go with him to the theatre and tax every laugh. No tax which stops short of these final satisfactions can ever be a perfectly exact income tax." FISHER, Irving. Op. cit. (nota 4), pp. 64-65.
} 
produção (ou renda-produto) e teorias que qualificam renda como acréscimo patrimonial (ou renda-acréscimo).

A teoria da fonte (renda-produto) está ligada ao conceito de renda como o produto periódico de uma fonte permanente. Neste sentido, costuma-se dar como exemplo os frutos de uma árvore. A árvore seria a fonte (capital) da qual se podem extrair frutos (rendimentos). Nessa teoria, a tributação da renda (fruto) só poderia ser feita no momento em que o fruto se destaca da árvore (momento da realização).

Conforme esclarece Alcides Jorge Costa, a teoria do fruto periódico de uma fonte permanente foi sugerida pela economia agrícola. Contudo, percebeu-se desde logo que nem todo fruto periódico poderia ser considerado renda, pois seria necessário deduzir os custos necessários para a geração desses frutos (tais como fertilizantes e as sementes para o plantio). ${ }^{7}$

Ademais, conforme destaca Luís Eduardo Schoueri, a teoria da renda-produto apresenta dificuldades, visto que não é suficiente para que se possa justificar a tributação de rendimentos que não decorram de uma fonte permanente, como os ganhos da loteria e jogos (windfall gains). Da mesma forma, não seria justificável a tributação do ganho de capital, uma vez que não pode ser qualificado como um fruto da árvore, mas como o acréscimo de seu valor. $^{8}$

Outrossim, também é possível conceituar renda com base na teoria do acréscimo patrimonial (renda-acréscimo), que adota, como conceito de renda, a diferença positiva no patrimônio de uma pessoa, apurada entre dois momentos distintos. Este modelo também sofre críticas, conforme lembra Luís Eduardo Schoueri, pois dá margem a que o contribuinte realize muitos gastos e permaneça no final do período numa situação patrimonial idêntica à inicial. ${ }^{9}$

É interessante destacar também, neste modelo teórico da renda-acréscimo, o sistema SHS (Schanz-Haig-Simons), no qual a renda deve ser calculada a partir do acréscimo patrimonial líquido, ao qual deve-se acrescentar a renda imputada e os gastos com consumo do período. ${ }^{10}$ Contudo, este modelo também não está a salvo de críticas, uma vez que não justifica a possibilidade da tributação exclusiva na fonte, como ocorre em diversas hipóteses na pessoa

\footnotetext{
${ }_{8}^{7}$ COSTA, Alcides Jorge. Op. cit. (nota 1), p. 20.

8 SCHOUERI, Luís Eduardo. O Mito do Lucro Real na Passagem da Disponibilidade Jurídica para a Disponibilidade Econômica. In MOSQUERA, Roberto Quiroga, e LOPES, Alexsandro Broedel (coord.). Controvérsias Jurídico-Contábeis (Aproximações e Distanciamentos). São Paulo : Dialética, 2010, p. 243.

${ }^{9}$ SCHOUERI, Luís Eduardo. Op. cit. (nota 8), p. 243.

${ }^{10}$ HOLMES, Kevin. The Concept of Income. A Multi-disciplinary Analysis. The Netherlands, IBFD, 2000, pp. 35 e 36 .
} 
física e com os rendimentos de não residentes (hipótese de tributação instantânea, que não reflete necessariamente acréscimos patrimoniais).

Também merece destaque a definição clássica oferecida pelo economista John Richard Hicks, para quem o lucro é o máximo valor que podemos consumir durante uma semana (ou um mês, ou ano etc.) e sentir-nos tão bem no final do período quanto nos sentíamos no início. ${ }^{11}$ Kevin Holmes destaca que esse conceito é um desenvolvimento do modelo SHS, uma vez que é fundado nas expectativas e planos dos indivíduos. ${ }^{12}$ Ademais, destaca o autor que o conceito de Hicks é utilizado pela Ciência Contábil para a mensuração do lucro com base no conceito de manutenção do capital (trata-se, portanto, de conceito com aplicação prática, que fundamenta a construção teórica de lucro pela ciência contábil). ${ }^{13}$

Verifica-se ainda que grande parte das dificuldades existentes para a aplicação dessas teorias decorre da determinação do momento em que tais rendimentos serão considerados realizados. No caso da renda-produto, por exemplo, considera-se realizado o rendimento, em geral, no momento da separação. Dessa forma, o fruto não seria considerado rendimento enquanto não destacado da árvore. Por conseguinte, enfrenta-se a dificuldade de tributar o fruto não colhido, caso o proprietário venda a árvore antes da colheita (ganho de capital).

$\mathrm{Na}$ teoria da renda-acréscimo, também há dificuldade de determinar o momento em que se considera ocorrido o fato econômico que gera o acréscimo patrimonial. Neste sentido, questiona-se a tributação da valorização de um bem ou direito, antes da sua alienação para terceiros - troca de mercado (como no caso da marcação a valor de mercado de determinados ativos).

Portanto, no âmbito dessas duas teorias (renda-produto e renda-acréscimo), a discussão acerca do momento em que se considera realizada a renda está colocada em algum momento da linha do tempo representada graficamente a seguir:

\footnotetext{
${ }^{11}$ HICKS, John Richard. Value and Capital. $2^{\mathrm{a}}$ ed., Oxford: Caredon, 1946, p. 172. Apud HOLMES, Kevin. Op.cit. (nota 10), p. 74.

${ }^{12}$ HOLMES, Kevin. Op.cit. (nota 10), p. 74.

${ }^{13}$ HOLMES, Kevin. Op.cit. (nota 10), p. 108 e ss.
} 


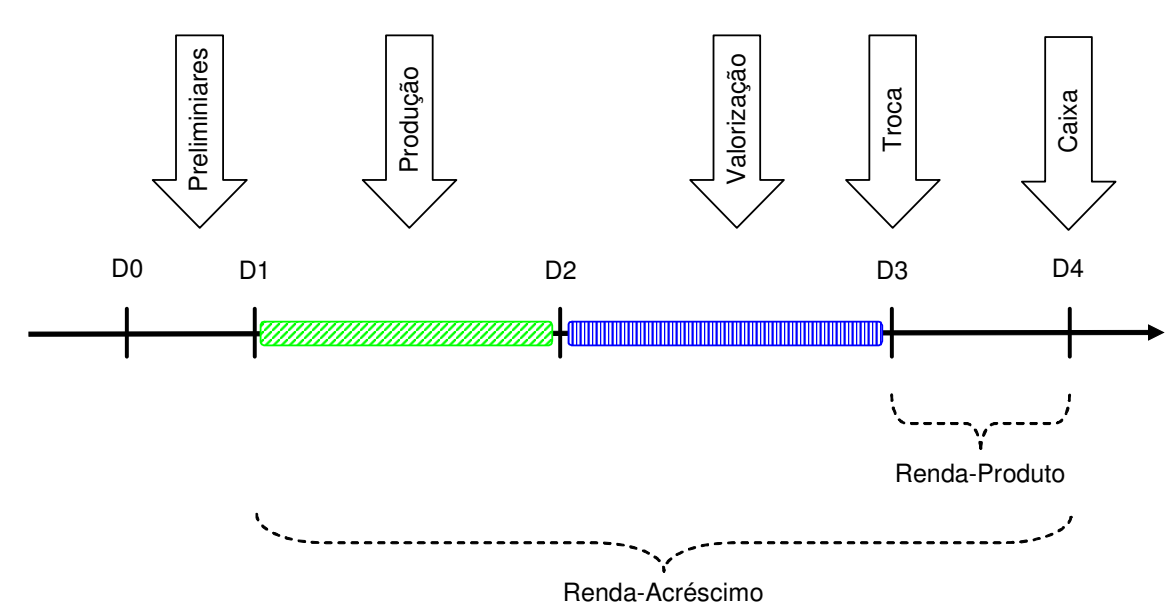

Assim, tendo em vista todas as dificuldades enfrentadas pelas teorias existentes para a determinação do conceito de renda, faz-se necessária uma análise das balizas constitucionais que regem a matéria (tais como a repartição rígida de competências, os princípios da capacidade contributiva e da praticabilidade, entre outros). Ainda, será analisado o conceito de renda definido pelo CTN, em conformidade com a competência constitucional estabelecida pela alínea $a$ do inciso II do artigo 146 da CF/88.

De fato, a análise da Constituição e do CTN faz-se necessária como pressuposto para a verificação da validade da tributação da renda de uma forma geral, bem como na captação, pelo Direito Tributário, de institutos e conceitos do Direito Civil e do Direito Societário para fins de conceituação da renda.

\section{2 - Delimitação Tipológica da Renda e o Princípio da Realização na CONSTITUiÇão Federal}

No que tange à análise do texto constitucional, é importante destacar que foi conferida competência à União para instituir o imposto sobre a renda e proventos de qualquer natureza, nos termos do inciso III do artigo $153 .{ }^{14}$ Um primeiro desafio a ser enfrentado é saber se a Constituição Federal traz em si um conceito constitucional de renda ou se esse conceito deve ser perquirido na legislação infraconstitucional.

\footnotetext{
${ }^{14}$ Não será analisada, neste trabalho, a acepção da expressão "proventos de qualquer natureza", uma vez que se pode considerar que o termo renda já é suficiente para a definição da essência do imposto, englobando o conceito de proventos. Sobre a definição da expressão "proventos de qualquer natureza", ver MOSQUERA, Robeto Quiroga. Renda e Proventos de Qualquer Natureza - O Imposto e o Conceito Constitucional. São Paulo : Dialética, 1996. pp. 59-67.
} 
Além da questão pertinente à existência ou não de um conceito constitucional de renda, também é importante que se estabeleçam os critérios necessários para que se considere a renda realizada, ou seja, qual o momento em que a renda se considera auferida. Não se trata do momento em que se considera ocorrido o fato gerador (aspecto temporal), mas sim o momento em que a renda está efetivamente disponível para o contribuinte e é passível de tributação dentro do aspecto temporal do tributo.

Para uma parcela relevante da doutrina, o Texto Constitucional traz em si (mesmo que de forma implícita) um conteúdo mínimo para o conceito de renda, fora do qual o legislador infraconstitucional não teria liberdade para estabelecer a tributação pelo imposto. Neste sentido, citem-se José Artur Lima Gonçalves, ${ }^{15}$ Bulhões Pedreira, ${ }^{16}$ Roberto Quiroga Mosquera, ${ }^{17}$ Paulo Ayres Barreto, ${ }^{18}$ Roque Carrazza, ${ }^{19}$ João Francisco Bianco, ${ }^{20}$ dentre outros.

No presente trabalho, a hipótese de tributação da renda prevista na Constituição Federal é entendida como um tipo tributário, ou seja, não haveria que se falar em um conceito constitucional propriamente dito, razão pela qual é importante estabelecer a distinção entre tipo e conceito, conforme ensina Ricardo Lobo Torres: ${ }^{21}$

\footnotetext{
"O tipo tributário representa a média ou a normalidade de uma determinada situação concreta, com as suas conexões de sentido. Segue-se, daí, que a noção de tipo admite as dessemelhanças e as especificidades, desde que não se transformem em desigualdade ou anormalidade. Mas o tipo, pela sua própria complexidade, é aberto, não sendo suscetível de definição, mas apenas de descrição. A utilização do tipo contribui para a simplificação do Direito Tributário."
}

Portanto, ao procurar identificar o tipo constitucional da renda, deve-se ter em mente que o objetivo será encontrar uma média dentre as diversas situações concretas diferentes de renda. Assim, o que se procura é uma descrição média do que seja renda, o que poderá comportar variações nos casos concretos.

\footnotetext{
15 "A própria Constituição fornecerá, portanto, ainda que de forma implícita, haurível de sua compeensão sistemática, o conteúdo do conceito de renda por ela - Constituição - pressuposto.” GONÇALVES, José Artur Lima. Imposto sobre a Renda: pressupostos constitucionais. $2^{\mathrm{a}}$ tir. São Paulo: Malheiros, 2002, p. 170-171.

${ }^{16}$ PEDREIRA, José Luiz Bulhões. Imposto sobre a Renda: pessoas jurídicas. Vol. 1, Rio de Janeiro: Justec, 1979, 110 , p. 176.

${ }^{17}$ MOSQUERA, Roberto Quiroga. Op. cit. (nota 14), p. 71-119.

${ }^{18}$ BARRETO, Paulo Ayres. Imposto sobre a Renda e Preços de Transferência. São Paulo: Dialética, 2001, p. 71.

${ }^{19}$ CARRAZZA, Roque Antonio. Imposto sobre a Renda: perfil constitucional e temas específicos. São Paulo: Malheiros, 2005, pp. 34 e ss.

${ }^{20}$ BIANCO, João Francisco. Imposto de Renda da Pessoa Jurídica: uma visão geral. In: SANTI, Eurico Marcos Diniz de; ZILVETI, Fernando Aurelio (coord.) Tributação das Empresas. São Paulo: Quartier Latin, 2006, p. 318. ${ }^{21}$ TORRES, Ricardo Lobo. O Princípio da Tipicidade no Direito Tributário. In: Revista de Direito Administrativo, $\mathrm{n}^{\circ}$ 235, p. 195.
} 
Contudo, determinada situação concreta (objeto) não pode ser tão divergente da descrição média do tipo a ponto de não mais se identificar com ele. Por isso, pode-se dizer que o tipo tributário é um parâmetro (modelo típico), apurado pela média de situações concretas. Este modelo típico também é usado como critério de comparabilidade, segundo o qual é possível incluir ou excluir um determinado objeto.

Os conceitos, por sua vez, representam uma definição de certo objeto. Trata-se também de uma representação abstrata de fatos concretos como o tipo, mas o conceito é definido a partir de algumas características do objeto. Por um lado, determinada situação concreta somente será objeto do conceito caso possua aquelas características específicas que o definem. Assim, conforme ensina Luís Eduardo Schoueri, ${ }^{22}$ o objetos se incluem o excluem no tipo e cada objeto que se inclui no tipo o modifica, alterando o modelo típico. Por outro lado, ou os objetos possuem as características definidas pelo conceito (havendo subsunção do conceito à situação concreta tomada como objeto), ou não possuem essas características e não há subsunção. ${ }^{23}$

Portanto, apesar de não haver um conceito constitucional de renda, há um modelo típico que deve ser obedecido pelo legislador infraconstitucional, motivo pelo qual não se podem tributar situações concretas que não sejam compatíveis com o modelo típico de renda. Não se pode aceitar, por exemplo, a afirmação tão abrangente como a feita pelo Ministro Nelson Jobim no sentido de que "Observo, desde logo, que o substantivo 'RENDA' está, na Constituição, sem qualquer adjetivação. (...) Isso tudo demonstra que o conceito de LUCRO REAL TRIBUTÁVEL é um conceito decorrente da lei. (...) O conceito de renda, para efeitos tributários, é o legal. (...) Para efeitos tributários, não há que se falar em LUCRO REAL que não seja o decorrente da definição legal." ${ }^{24}$

Em que pesem as palavras do Ilustre Ministro, não se pode concordar com a afirmação de que renda é um conceito previsto exclusivamente na lei. Neste sentido, é importante a afirmação de Ricardo Mariz de Oliveira, para quem "a lei não pode determinar

\footnotetext{
${ }^{22}$ SCHOUERI, Luís Eduardo. Discriminação de Competências e Competência Residual. In Direito Tributário: estudos em homenagem a Brandão Machado. Coords. SCHOUERI, Luís Eduardo, ZILVETI, Fernando Aurelio. São Paulo: Dialética, 1998, p. 110.

${ }^{23}$ Confira-se também: SCHOUERI, Luís Eduardo. Direito Tributário. São Paulo: Saraiva, 2011, pp. 248 e ss. ZILVETI, Fernando Aurelio. Obrigação Tributária: Fato Gerador e Tipo. São Paulo: Quartier Latin, 2009, pp. 212 e ss.

${ }^{24}$ RE 201.456-6/MG, Relator Ministro Marco Aurélio, julgamento acerca do artigo $3^{\circ}$ da Lei no 8.200/91.
} 
que o fato de alguém andar a pé na Rua Direita seja considerado renda para efeito da incidência do imposto de renda." 25

Dessa forma, é possível afirmar que Constituição Federal de 88 estabelece a competência para a tributação da renda enquanto um modelo típico. Conforme visto, em todos os conceitos e modelos possíveis de renda mencionados, seja na perspectiva do consumo, seja na perspectiva da produção, existe uma característica comum que é a ocorrência de um acréscimo, um ganho, um ingresso de algo novo.

Inicialmente, esse acréscimo pode ser analisado sob dois enfoques distintos: (i) pela teoria da renda-produto, ou teoria da fonte, que considera o ganho de direitos como o produto de uma fonte, ou seja, apenas o ingresso decorrente do produto gerado pela fonte (v.g. o fruto gerado pela árvore), e não considera eventuais gastos incorridos para a manutenção da fonte (v.g. fertilizantes e irrigação); e (ii) pela teoria da renda-acréscimo, que considera a variação patrimonial positiva em determinado período de tempo, ou seja, quando há um ganho líquido após o cômputo de ingressos e saídas em determinado período.

Neste sentido já se manifestou o STF sobre o conceito de renda: "Na verdade, por mais variado que seja o conceito de renda, todos os economistas, financistas e juristas se unem em um ponto: renda é sempre um ganho ou um acréscimo de patrimônio."26

Ainda, como já visto, a noção tipológica de renda comporta acréscimos ou ganhos de bem-estar, tais como (i) renda consumo - em que se utiliza a renda consumida como forma de mensurar o ganho de bem-estar, embora este índice de mensuração seja passível de críticas; e (ii) renda psíquica - em que se faz uma avaliação subjetiva de qual é o efetivo bem-estar fruído pelo agente (diferença positiva entre as satisfações psicológicas e os custos psicológicos).

Assim, apesar de o texto constitucional não definir o conceito de renda, há de se fazer ao menos um primeiro corte à liberdade do legislador infraconstitucional, que não poderá definir como renda nenhum objeto que não se inclua no modelo típico de renda.

Ademais, apesar de inexistir uma definição de renda na Constituição, não se podem afastar as balizas constitucionais para a delimitação do campo de liberdade do legislador infraconstitucional, como bem expressa Luís Eduardo Schoueri:27

\footnotetext{
${ }^{25}$ OLIVEIRA, Ricardo Mariz de. Fundamentos do Imposto de Renda. São Paulo: Quartier Latin, 2008, p. 177.

${ }^{26}$ RE 89.791/RJ, Rel. Min. Cunha Peixoto, $1^{\text {a }}$ Turma do STF, julgamento de 03/10/1978, DJU de 20/10/1978.

${ }^{27}$ SCHOUERI, Luis Eduardo. Cf. op. cit. (nota 8), p. 245.
} 


\begin{abstract}
“Ora, uma vez que o conceito de renda não é unívoco, havendo diversas teorias que buscam explicá-lo, não se pode dizer que, do texto constitucional, seja possível definir o que é renda para fins de tributação no Brasil. Certamente, argumentos históricos (a evolução da legislação) e sistemáticos (outros dispositivos constitucionais) apontam certas balizas, mas a indeterminação se mantém."
\end{abstract}

Dentre os dispositivos constitucionais balizadores da liberdade do legislador infraconstitucional, destaca-se a rígida repartição de competências tributárias. Com efeito, na delimitação do tipo constitucional da renda, a primeira limitação a ser destacada é que não podem ser qualificadas como renda as materialidades reservadas aos demais entes da Federação, como, por exemplo, a doação e a herança, pois essas situações concretas são de competência dos Estados, conforme o artigo 155 inciso I da CF/88.

Isto não quer dizer, contudo, que a doação e a herança não possam gerar acréscimos patrimoniais passíveis de tributação pelo imposto de renda. Isto porque não se pode confundir (i) o fato transmissão causa mortis (herança), (ii) o fato transmissão a titulo gratuito (doação) com (iii) o fato acréscimo patrimonial (renda), deles decorrente. Ou seja, o acréscimo patrimonial decorrente da doação ou da herança é um fato distinto daqueles reservados à competência tributária dos Estados e passível, portanto, de tributação pelo imposto de renda. ${ }^{28}$

A esse respeito, interessante citar o exemplo mencionado por Roberto Quiroga Mosquera, ora adaptado. A tributação do fato transmissão inter vivos de bens imóveis a título oneroso é de competência dos Municípios (artigo 156, II, da CF/88). Contudo, caso um corretor de imóveis realize a intermediação pela venda de um terreno para uma construtora e receba futuras unidades a serem construídas como dação em pagamento da taxa de intermediação, haverá tributação pelo ITBI (em razão da transmissão onerosa dos imóveis) e também pelo IR (em razão do acréscimo patrimonial do corretor).

Trata-se, portanto, da limitação negativa ao tipo renda, uma vez que a rígida repartição de competências restringe o campo de hipóteses de manifestações de capacidade contributiva tributáveis como renda pela União, pois já foram reservadas para os demais entes da Federação. ${ }^{29}$ Ressalte-se que, em face das nítidas hipóteses de possíveis conflitos de

\footnotetext{
${ }^{28}$ Neste sentido, confira-se MOSQUERA, Robeto Quiroga. Op. cit (nota 14), p. 133. No mesmo sentido, LEMKE, Gisele. Imposto de Renda: os Conceitos de Renda e de Disponibilidade Econômica e Jurídica. São Paulo: Dialética, 1998, pp. 71-74.

29 “(...) no que se refere à regra matriz do imposto sobre a renda e proventos de qualquer natureza, não há campo de liberdade para o legislador federal em vista do sistema rígido de atribuição de competências. (...) a discriminação de competências tributárias acarreta uma dúplice conseqüência, a saber: a) atribui uma faculdade a determinada pessoa política para instituir um certo tributo (sentido afirmativo); b) recusa competência tributária idêntica a outras pessoas políticas não indicadas no dispositivo constitucional de habilitação (sentido negativo);"
} 
competência, estabelece a $\mathrm{CF} / 88$, em seu artigo 146, inciso I, que competirá à Lei Complementar tratar sobre o assunto. ${ }^{30}$

Ainda, de forma geral, é possível afirmar que não há liberdade para o legislador infraconstitucional definir, como conceito de renda, qualquer manifestação de capacidade contributiva que esteja em desacordo com os princípios constitucionais tributários.

Assim sendo, faz-se necessário tecer algumas considerações sobre a natureza dos princípios. Segundo Ronald Dworkin, as regras se distinguem dos princípios por força de sua estrutura lógica. Ou seja, essas duas espécies normativas se distinguem basicamente por dois motivos: o seu modo de aplicação e o seu relacionamento normativo. ${ }^{31}$

Para Dworkin, o modo de aplicação das regras é o "tudo ou nada", ou seja, as regras se aplicam de forma absoluta, não admitindo a contradições. Dessa forma, ocorrendo um fato concreto (previsto em uma hipótese de incidência), só haverá espaço para a aplicação de uma regra. Assim, quando houver conflito entre regras, apenas uma delas será considerada válida para o caso concreto em análise (por exemplo, a regra especial prevalece sobre regra geral no caso concreto).

Já o modo de aplicação dos princípios é o "mais ou menos", ou seja, os princípios são aplicados de forma gradual, por meio da ponderação e sopesamento. Assim, não há que se falar em aplicação dos princípios de forma absoluta (válidos ou inválidos), pois a sua aplicação no caso concreto irá depender da sua ponderação com os demais princípios constitucionalmente previstos, bem como da avaliação do seu maior ou menor peso em determinado caso concreto (aplicam-se todos ao mesmo tempo, ponderando-se a sua direção e peso). O gráfico abaixo ilustra o processo de decisão após a ponderação de dos princípios que apontam para direções diversas:

\footnotetext{
MOSQUERA, Robeto Quiroga. Op. cit (nota 14), p. 77 e 117.

30 “4.4.6.1 É neste sentido que se compreende a decisão do constituinte de não deixar que a fluidez natural aos tipos implicasse conflitos entre as três esferas políticas. $O$ constituinte quis que o legislador ordinário tivesse limites rígidos para a sua atuação. Fazia-se necessário, assim, que aquela realidade, que fora expressa no texto constitucional por meio de tipos, passasse a ter uma expressão conceitual.

4.4.6.2 Encontramos, aqui, o papel da lei complementar: a solução dos conflitos de competência e a definição dos fatos geradores e bases de cálculo implicam a criação, pelo legislador complementar, de definições das realidades contempladas pelo constituinte.

4.4.7 Noutras palavras, enquanto o constituinte contemplou a realidade econômica do ponto de vista tipológico, com fluidez a ele inerente, impôs ele ao legislador complementar a tarefa de expressar a mesma realidade através de conceitos, seja por meio de definições de fatos geradores, bases de cálculo e contribuintes, seja através da imposição de limites em casos de conflitos." SCHOUERI, Luis Eduardo. Cf. op. cit. (nota 22), p. 113.

${ }^{31}$ DOWRKIN, Ronald M. Is law a system of rules? In: DWORKIN, Ronald M. The philosophy of law. Oxford: Oxford University Press, 1977, pp. 43-49. Também: DWORKIN, Ronald M. Taking Rights Seriously. Cambridge, MA: 1978, pp. 22-28.
} 


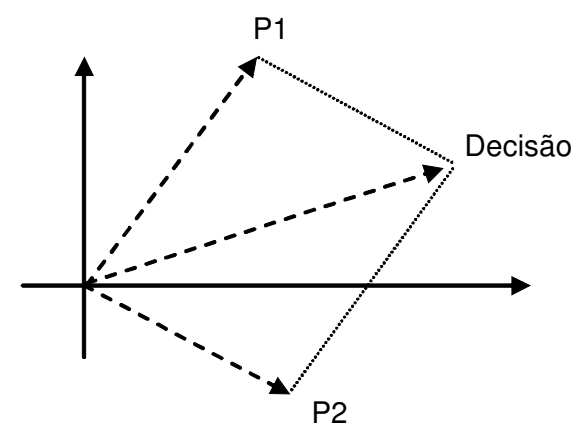

Dessa forma, para que se possa definir quais são os limites estabelecidos pela $\mathrm{CF} / 88$ ao conceito de renda (limites negativos), faz-se necessário pesquisar, no próprio texto constitucional, quais são os princípios $(\mathrm{P})$ que devem ser ponderados e sopesados para se estabelecer até onde o legislador infraconstitucional tem liberdade para definir o conceito de renda (decisão).

Também é relevante a acepção de Robert Alexy, ${ }^{32}$ para quem os princípios são mandamentos de otimização e que podem ser aplicados em diferentes graus, ou seja, são normas que determinam que algo seja realizado da maior forma possível, dentro das possibilidades existentes. As regras, por outro lado, são cumpridas ou não. Na hipótese de confronto, o conflito de regras é uma questão de validade, enquanto o conflito de princípio é uma questão de peso.

É importante ainda a observação de Humberto Ávila, no sentido de que, no plano concreto, a pretensão de eficácia das normas constitucionais determina a "proibição de excesso", pois "a realização de um fim não pode comprometer a realização mínima de outro.",33

Passa-se a analisar, a seguir, duas categorias de princípios aplicáveis à tributação da renda: (i) os princípios gerais tributários e (ii) os princípios específicos de tributação da renda. A partir dessa análise, pretende-se estabelecer os mais importantes limites para que legislador infraconstitucional possa determinar o conceito de renda.

Nesse contexto, também se pretende delimitar a liberdade de determinação do momento de realização da renda, uma vez que não basta delimitar o que é a renda, pois também é necessário estabelecer os parâmetros para se dizer quando a renda pode ser considerada ocorrida.

\footnotetext{
${ }^{32}$ ALEXY, Robert. Teoria dos Direitos Fundamentais, trad. de Virgílio Afonso da Silva, São Paulo: Malheiros, 2008.
} 


\subsection{1 - Princípios Gerais Aplicáveis à Tributação da Renda}

\subsubsection{1 - Igualdade e Capacidade Contributiva}

Inicialmente, é possível tecer algumas considerações sobre as limitações impostas à definição do conceito de renda pelo princípio da igualdade, segundo o qual a lei deve tratar igualmente os iguais (igualdade horizontal) e desigualmente os desiguais, na medida de sua desigualdade (igualdade vertical). ${ }^{34}$

Ocorre que, para a aplicação do princípio da igualdade, faz-se necessário estabelecer um critério de discriminação para que se possa dizer se duas pessoas estão em situação igual ou em situação desigual, ou seja, necessita-se de um parâmetro de comparação. Esse critério, para fins tributários, é a capacidade contributiva (duas pessoas estarão em situação igual se possuírem a mesma capacidade contributiva). ${ }^{35}$

A renda é um fator importante para a mensuração da satisfação obtida pelo indivíduo em face dos benefícios garantidos pelo Estado (bem comum). Isto porque a renda, individualmente considerada, somente pode ser gerada em um ambiente econômico no qual o Estado ofereça garantia à livre iniciativa e à propriedade privada. É nesse sentido que a doutrina geralmente identifica a renda como o elemento ideal para a aferição da capacidade contributiva. ${ }^{36}$

Ademais, ressalte-se que o princípio da capacidade contributiva também é associado à justiça no sistema tributário. Nesta concepção, a apuração da renda líquida passível de tributação pressupõe a consideração da totalidade de ingressos, provenientes de todas as fontes e todas as áreas, pois somente assim será possível atingir a justiça tributária. ${ }^{37}$

Com efeito, pode-se dizer que os princípios da universalidade e generalidade, previstos no $\S 2^{\circ}$, inciso I, do artigo 153 da $\mathrm{CF} / 88$ como informadores do imposto sobre a renda, são corolários do princípio da igualdade horizontal na tributação da renda. Pelo princípio da universalidade, entende-se a orientação de que todos os elementos positivos e

33 ÀVILA, Humberto. Conceito de Renda e Compensação de Prejuízos Fiscais. São Paulo: Malheiros, 2011, p. 19.

${ }^{34}$ Conforme Rui Barbosa, na célebre "Oração aos Moços".

35 ZILVETI, Fernando Aurelio. Princípios de Direito Tributário e a Capacidade Contributiva. São Paulo: Quartier Latin, 2003, pp. 134 a 144.

${ }^{36}$ ZILVETI, Fernando Aurelio. Op. cit. (nota 35), p. 226.

37 “(...) If ability to pay is the foundation of a fair tax system, then all 'income' must be included within the tax 
negativos que atuem para gerar o acréscimo, ganho ou ingresso sejam considerados na apuração da renda em determinado período, sem distinção entre os diversos elementos que repercutem sobre a renda. ${ }^{38}$

No que tange ao princípio da generalidade, entende-se que o imposto sobre a renda deve ser destinado a todas as pessoas que incorram no fato gerador, de forma indistinta, "independentemente de raça, sexo, convicções políticas, credo religioso, cargos ocupados etc." ${ }^{39}$ Com esses princípios, portanto, pretende-se orientar a tributação da renda sobre a totalidade do rendimento da totalidade das pessoas (igualdade horizontal).

\subsubsection{2 - Praticabilidade}

Outro importante princípio a ser sopesado na construção do conceito de renda é o princípio da praticabilidade. Segundo Regina Helena Costa, a praticabilidade pode ser entendida como orientação no sentido de se utilizarem técnicas que têm como objetivo tornar praticáveis os preceitos do ordenamento jurídico como um todo. ${ }^{40}$

A garantia constitucional a este princípio é defendida por Misabel Derzi, nos seguintes termos: ${ }^{41}$

"A praticabilidade não está expressamente em nenhum artigo da Constituição, mas está em todos, porque nada do que dissemos aqui teria sentido se as leis não fossem viáveis, exeqüíveis, executáveis e não fossem efetivamente concretizadas na realidade; portanto, a praticabilidade tem uma profunda relação com a efetividade das normas constitucionais."

Com efeito, na sistemática de aplicação dos princípios constitucionais por meio da ponderação e sopesamento, é possível identificar um vetor decorrente do princípio da igualdade que determina a tributação da totalidade da renda da totalidade das pessoas, igualmente para os iguais e desigualmente para os desiguais, na medida da sua desigualdade. Contudo, este vetor tem sua aplicação restringida por outro vetor que é o princípio da praticabilidade, segundo o qual se restringe o campo de aplicação do conceito de renda para que se possa garantir que essa tributação seja executável.

\footnotetext{
net." HOLMES, Kevin. Op. cit. (nota 10), p. 25.

${ }^{38}$ OLIVEIRA, Ricardo Mariz de. Op. cit. (nota 25), p. 256.

${ }^{39}$ CARRAZA, Roque Antonio. Op. cit. (nota 19), pp. 62 e 63

${ }^{40}$ COSTA, Regina Helena. Praticabilidade e Justiça Tributária: Exequiibilidade de Lei Tributária e Direitos do Contribuinte. São Paulo: Malheiros, 2007, p. 53, 88 e ss.

${ }^{41}$ DERZI, Misabel Abreu Machado. Princípio da Praticabilidade do Direito Tributário (Segurança Jurídica e Tributação). In Revista de Direito Tributário, ano 13, nº7. São Paulo: Revista dos Tribunais, jan-mar. 1989, p. 175.
} 
Neste sentido, por exemplo, a variação de preço de um bem no mercado (marcação a mercado) é um índice que pode integrar o tipo constitucional da renda (como acréscimo patrimonial). No entanto, a valoração desse acréscimo patrimonial, em muitos casos, pode trazer dificuldade tamanha que impeça a sua tributação (problema de exequibilidade - v.g. valoração de uma obra de arte). Em outros casos, a variação positiva de preço do bem é mensurável com segurança e praticabilidade suficiente para ser reconhecida como renda (como ocorre na marcação a mercado de alguns ativos financeiros).

\subsubsection{3 - Outros}

Além dos princípios acima expostos, podem-se também destacar outros dispositivos constitucionais que, direta ou indiretamente, influenciam na limitação do poder do legislador infraconstitucional para definir o conceito de renda, tais como os princípios da ordem econômica, uma vez que esses princípios orientam a tributação como forma de indução a alguma das finalidades econômicas previstas na Constituição Federal. ${ }^{42}$

A título de exemplo, a adoção do regime de caixa para o lucro presumido e para o Simples Nacional (segundo o qual será possível diferir a tributação para o momento do efetivo recebimento) é uma forma de se estimular o desenvolvimento nacional (inciso II, do artigo $3^{\circ}$ da $\mathrm{CF} / 88$ ), oferecer tratamento diferenciado para empresas de pequeno porte (inciso IX do artigo 170 da CF/88) e, ainda que de forma reflexa, a busca do pleno emprego e a redução das desigualdades sociais (conforme os incisos VIII e VII do artigo $170 \mathrm{da}$ CF/88).

Ademais, ressalte-se que o legislador infraconstitucional poderá também instituir regras tributárias que tenham como objetivo promover o direito social à moradia, previsto no artigo $6^{\circ}$ da $\mathrm{CF} / 88$. Este é, sem dúvida, mais um vetor que deve orientar a tributação da renda no setor imobiliário.

\subsection{2 - Princípios Específicos de Tributação da Renda}

Em face dos princípios gerais (especialmente os vetores da capacidade contributiva e da praticabilidade), podem-se construir quatro subprincípios que devem ser

\footnotetext{
${ }^{42}$ Sobre o tema, SCHOUERI, Luís Eduardo. Normas Tributárias Indutoras e Intervenção Econômica. Rio de Janeiro: Forense, 2005.
} 
utilizados para melhor delimitação constitucional ao conceito de renda, conforme proposto por Victor Polizelli: (i) monetarização, (ii) renda líquida, (iii) apuração periódica e (iv) realização. ${ }^{43}$

\subsubsection{1 - Monetarização}

O princípio da monetarização consiste em uma noção básica que merece destaque quando se trata de estabelecer os parâmetros para a delimitação do conceito de renda. De fato, somente podem ser consideradas como renda aquelas manifestações econômicas que possibilitam ser expressas em moeda corrente. Com efeito, conforme lembra Victor Polizelli, não se costuma tributar a renda na forma imputada (como o valor locativo de imóvel próprio), em face da dificuldade de se estabelecer um critério objetivo para a mensuração desse valor econômico. Da mesma forma, o princípio da monetarização da renda afasta a noção de renda psíquica, pois a medida da satisfação e bem-estar gerada pela renda é de difícil mensuração.

Ressalte-se, neste sentido, que o inciso VI do artigo 23 da Lei ${ }^{\circ}$ 4.506/64 pretendeu estabelecer a tributação, pela pessoa física, do "valor locativo do prédio urbano construído, quando cedido seu uso gratuitamente". Contudo, referida Lei não estabeleceu a forma de apuração da base de cálculo para essa renda imputada, o que afasta a possibilidade de sua cobrança em razão do princípio da legalidade (confira-se o Capítulo 5.1.2.2). ${ }^{44}$

Ademais, seria difícil também justificar a tributação da renda imputada nesta hipótese, pois não há motivo/justificativa para se restringir o princípio da monetarização neste caso.

\subsubsection{2 - Renda Líquida}

O princípio da renda líquida é aquele que delimita a concepção do conceito de renda apenas àquelas manifestações econômicas que concretizem acréscimos patrimoniais reais. Neste sentido, apenas após o confronto entre os ganhos e os gastos despendidos para a

\footnotetext{
43 POLIZELLI, Victor Borges. O Princípio da Realização da Renda e sua Aplicação no Imposto de Renda de Pessoas Jurídicas. Dissertação de Mestrado defendida na Faculdade de Direito da Universidade de São Paulo, 2009 , pp. 90 e seguintes.

${ }^{44} \mathrm{O}$ artigo $49, \S 1^{\circ}$, do RIR/99 estabeleceu como base de cálculo do valor locativo o equivalente a $10 \%$ do valor venal de imóvel cedido, ou do valor constante da guia do Imposto Predial e Territorial Urbano - IPTU correspondente ao ano-calendário da declaração. Contudo, não há previsão legal para referida base de cálculo.
} 
geração desse ganho é que se conseguirá chegar ao conceito de renda (renda como índice de capacidade contributiva). ${ }^{45}$

Ressalte-se que o vetor que aponta a direção da tributação de uma renda líquida pode sofrer algumas restrições quando ponderados com outros princípios, especialmente o da praticabilidade. Neste sentido, costumam-se estabelecer limites de deduções permitidas para as pessoas físicas, mas esses limites têm a finalidade de tornar exequível a tributação da renda. ${ }^{46}$

Também se considera renda líquida a base de cálculo apurada por meio da sistemática do lucro presumido, conforme será analisado no Capítulo 5.2.1.3. Neste caso, não há um confronto entre receitas e despesas efetivamente realizadas, mas a aplicação de um percentual de presunção de renda líquida (regime de tributação privilegiado para empresas de menor porte).

\subsubsection{3 - Apuração Periódica}

Para aferir a renda líquida de determinado contribuinte, faz-se necessário estabelecer um período de referência para que se possa comparar a variação desse patrimônio entre dois pontos no tempo. Para isso, vale-se do princípio da apuração periódica, segundo o qual se deve estabelecer um período mínimo para a medição da variação patrimonial do contribuinte.

Costuma-se dizer que o período ideal, para se aferir o efetivo acréscimo patrimonial de um indivíduo, seria o tempo de sua vida, pois somente após esse período é que se pode aferir com exatidão se houve um efetivo acréscimo em seu patrimônio. ${ }^{47}$ Contudo, o princípio da praticabilidade, já mencionado, afasta um período tão longo, por razões inclusive de interesse arrecadatório. Este período também não pode ser tão curto que inviabilize uma aferição razoavelmente segura de tais acréscimos.

Dessa forma, conforme destaca Misabel Derzi, citando a obra de Freitas Pereira, adotou-se o período anual como regra universal para essa tributação, uma vez que este período

\footnotetext{
45 OLIVEIRA, Ricardo Mariz de. Op. cit. (nota 25), pp. 256-ss e 430-434.

46 "Entre nós, o imposto de renda das pessoas físicas, por ser o mais sensível às gentes, está se encaminhando para a simplificação e praticabilidade, ainda que com o sacrifício de alguns princípios jurídicos caros, o da progressividade e o da capacidade contributiva." COÊLHO, Sacha Calmon Navarro. Curso de Direito Tributário Brasileiro, $8^{\text {a }}$ ed., Rio de Janeiro: Forense, 2005, p. 369.

47 ARNOLD, Briean J. Timing and Income Taxation: the principles of income measurement for tax purposes. Toronto: Canadian Tax Foundation, 1983, p. 121.
} 
comporta as quatro estações do ano e é reconhecido como adequado refletir desenvolvimento das atividades econômicas e sociais e, assim, neutralizar efeitos sazonais. ${ }^{48}$

Dos três princípios específicos já expostos, podemos apontar uma noção geral das limitações ao conceito de renda a ser definido pela legislação infraconstitucional. Essa noção geral é muito bem resumida por Lima Gonçalves, no sentido de que o conteúdo mínimo do conceito de renda a ser estabelecido pelo legislador infraconstitucional é: "(i) saldo positivo resultante do (ii) confronto entre (ii.a) certas entradas e (ii.b) certas saídas, ocorridas ao longo de um dado (iii) período”. Complementa ainda o autor, quanto ao saldo positivo, que "renda haverá quando houver sido detectado um acréscimo, um plus; tenha ele, ou não, sido consumido; seja ele, ou não, representado por instrumentos monetários, direitos, ou por bens, imateriais ou físicos, móveis ou imóveis". ${ }^{49}$

Essa definição, conforme já mencionado, está em conformidade com o modelo SHS (Schanz-Haig-Simons), no qual a renda deverá ser calculada a partir do acréscimo patrimonial líquido, acrescentando-se a renda imputada e os gastos com consumo do período. ${ }^{50}$

\subsubsection{4 - Realização}

Além dos princípios apontados até o momento, também é de extrema relevância o princípio da realização da renda. Trata-se do princípio que deve guiar a delimitação do conceito de renda para abranger apenas fatos econômicos efetivamente realizados.

Destaque-se, novamente, que não se está tratando do período em que se considera ocorrido o aspecto temporal do fato gerador (período este que é orientado pelo princípio da apuração periódica), mas sim o momento em que determinado fato econômico irá influenciar o patrimônio (positiva ou negativamente) e, assim, compor a renda de determinado período base.

\footnotetext{
48 "Explica Freitas Pereira que a regra anual foi universalmente adotada, em razão dos seguintes fatores: (i) o período não pode ser tão curto, que seus resultados não sejam significativos, nem tão longo que impeça sua renovação; (ii) a duração do período deve permitir a comparação entre exercícios sucessivos; (iii) o período deve integrar um ciclo completo de estações, de modo a neutralizar influências sazonais. E conclui: 'a adoção de uma base anual para a elaboração das contas preenche estes requisitos e reflete o juízo de uma longa experiência segundo a qual o ano nem e demasiado longo nem demasiado curto e, além disso, projeta o ritmo normal em que se desenvolve a vida econômica e social, toda marcada pelo ciclo das estações.' (Cf. A Periodização do Lucro Tributável. Lisboa. Centro de Estudos Fiscais, 1988)" DERZI, Misabel Abreu Machado. Pressupostos da Periodização Aural. In BALEEIRO, Aliomar. Direito Tributário Brasileiro. Atual. por Misabel Abreu Machado Derzi. $11^{a}$ ed. Rio de Janeiro: Forense, 2001, p. 325.

${ }^{49}$ GONÇALVES, José Artur Lima. Op. cit. (nota 15), pp. 179 a 181.

${ }^{50}$ HOLMES, Kevin. Op. cit. (nota 10), pp. 35 e 36.
} 
Este princípio é importante na ponderação dos limites a serem estabelecidos ao conceito de renda, pois é por meio dele que se estabelece o momento em que há segurança para se determinar que certo direito (ou obrigação) efetivamente se incorpora ao patrimônio do contribuinte para fins de tributação.

Para Fernando Aurelio Zilveti, ${ }^{51}$ "O conteúdo do princípio da realização da renda é a identificação, antes de impor ao contribuinte a obrigação de pagar o imposto, da renda efetivamente realizada." Para o autor, o referido princípio se aplica na apuração da renda das pessoas físicas e jurídicas, mas é nas pessoas físicas que ele se torna mais imperativo.

Neste sentido, ressalte-se que a legislação estabeleceu o critério do recebimento em dinheiro (ou bens) como sendo, em regra, o evento crítico para configurar determinado rendimento como ingressado no patrimônio da pessoa física. ${ }^{52}$ Com efeito, percebe-se que o legislador entendeu que, para as pessoas físicas, o evento crítico mais adequado para considerar o rendimento realizado foi o recebimento em dinheiro ou bens (o que se costuma denominar regime de caixa)..$^{53}$

Destaque-se o entendimento de Victor Polizelli sobre o tema: ${ }^{54}$

"é possível afirmar que o princípio da realização é uma diretriz geral de alocação temporal dos ingressos (de receitas) e egressos (de despesas), que procura atribuir tais elementos ao período-base em que são verificados os fatos substanciais que os geraram (condições de materialidade) sempre e quando exista um certo grau de objetividade na sua mensuração (condição de objetividade) e segurança na sua concreção (condição de prudência)."

Para Bulhões Pedreira, o princípio da realização do lucro pode ser sintetizado da seguinte forma: ${ }^{55}$

“(a) sua conversão em direitos que acresçam ao patrimônio da pessoa jurídica, (b) que essa conversão se processe mediante troca no mercado, (c) que a pessoa jurídica já tenha cumprido as obrigações que para ela nascem dessa troca e (d) que os direitos recebidos na troca tenham valor mensurável e liquidez."

\footnotetext{
${ }^{51}$ ZILVETI, Fernando Aurelio. O Princípio da Realização da Renda. SCHOUERI, Luís Eduardo (org.) Direito Tributário. Homenagem a Alcides Jorge Costa, vol. I. São Paulo: Quartier Latin, 2003, p. 314.

${ }_{52}$ MACHADO, Brandão. Imposto de Renda. Ganhos de Capital. Promessa de Venda de Ações. In: Revista de Direito Tributário Atual, v. 11/12, São Paulo: Resenha Tributária/IBDT, 1992, p. 3201.

${ }_{53}^{3}$ Ressalte-se a opinião de Fernando Aurelio Zilveti, para quem o princípio da realização indicaria a tributação da renda somente quando efetivamente recebida em dinheiro, mesmo para as pessoas jurídicas. Cf. op. cit (nota 51), pp. 326 e 327.

${ }_{54}^{5}$ POLIZELLI, Victor Borges. Op. cit. (nota 43), p. 96.

${ }^{55}$ PEDREIRA, José Luiz Bulhões. Imposto sobre a Renda: pessoas jurídicas. Vol. 1, Rio de Janeiro: Justec, 1979, (165), p. 279.
} 
Da definição do princípio da realização da renda por Bulhões Pedreira, aplicável às pessoas jurídicas, verifica-se que é fundamental o elemento troca no mercado como evento crítico para se considerar realizada a renda (conceito mais amplo do que aquele previsto para as pessoas físicas, que se limita ao recebimento em dinheiro).

Contudo, é interessante a discussão acerca do âmbito de aplicabilidade do conceito de troca no mercado, visto que a primeira interpretação possível é que troca se refere ao próprio bem que é a fonte do rendimento (de propriedade do contribuinte), como dá a entender Bulhões Pedreira ao mencionar "conversão em direitos" e "direitos recebidos na troca". Com efeito, somente haveria realização da renda quando o titular do bem o trocasse no mercado.

Não obstante, conforme ressalta Victor Polizelli, a troca também pode se referir a operações realizadas com bens de terceiros (transações de mercado entre terceiros) ${ }^{56}$ hipótese em que a troca do bem feita por terceiros pode ser utilizada como parâmetro para comparação e determinação do preço de mercado em determinado momento.

Neste sentido, compete ao legislador infraconstitucional estabelecer se a troca de mercado será aquela adotada em sentido estrito (troca do bem do próprio contribuinte) ou em sentido lato (determinação do preço do bem mediante a comparação com trocas realizadas entre terceiros) como critério para que se possa considerar ocorrida a renda. ${ }^{57}$

No entanto, não será qualquer troca de mercado entre terceiros (troca em sentido lato) que será suficiente para servir de parâmetro de comparabilidade. Somente poderá ser estabelecido como valor de mercado aquele que seja apurado com segurança e confiabilidade (como é o caso dos ativos de alta liquidez, negociados em bolsa de valores). Verifica-se, assim, que o princípio da realização possui nítida interface com o princípio da monetarização, embora com ele não se identifique.

A título exemplificativo, é possível que determinada renda seja passível de monetarização, mas não esteja realizada. Determinado rendimento pode já ter valor definido e inclusive ter sido recebido, mas ainda não estar realizado o direito ao seu recebimento (v.g. aluguel antecipado não é receita, somente será com o transcurso do tempo).

\footnotetext{
${ }^{56}$ POLIZELLI, Victor Borges. Op. cit (nota 43), p. 97.

${ }^{57}$ Cite-se como exemplo a tributação das variações cambiais (artigo 30 da MP 2.158-35/01). A variação cambial nada mais é do que uma variação de índice de preço de uma mercadoria (moeda estrangeira), em razão da apuração das negociações feitas em mercado.

Assim, apesar de o ativo detido pelo contribuinte, indexado a uma moeda estrangeira, não ter sido trocado no mercado (troca em sentido estrito), a variação de preço desse ativo com base em transações de mercado (troca em sentido lato) pode ser suficiente para compor a renda dessa pessoa, pois tais valores passíveis de uma mensuração objetiva ( $\S 1^{\circ}$ do artigo 30 da MP 2.158-35/01).
} 
Ante o exposto no presente capítulo, é possível estabelecer uma visão geral das limitações constitucionais à conceituação da renda pelo legislador infraconstitucional, ou seja, quais são as principais balizas previstas na CF/88 ao conceito de renda. Tais balizas são estabelecidas especialmente pela rígida repartição de competências, mas também pelos princípios gerais (especialmente a capacidade contributiva e a praticabilidade) e pelos princípios específicos de tributação da renda (monetarização, apuração periódica, renda líquida e realização).

Fundamental nessa análise, para fins do presente estudo, é a definição da limitação imposta pelo princípio da realização da renda, uma vez que apresenta grande complexidade na sua aplicação. Este princípio pode ser entendido como o vetor que orienta no sentido de que os acréscimos e decréscimos (receitas e despesas) ao patrimônio devem ser alocados temporalmente no momento em que:

(i) existam condições materiais que ofereçam substância suficiente para se determinar a realização da renda (devem existir evidências concretas de ocorrência de um acréscimo/decréscimo, ganho/perda ou ingresso/egresso, como é o caso do cumprimento das obrigações contratuais correlatas ao direito sobre a renda);

(ii) permite-se um certo grau de objetividade na media em que a mensuração não decorra exclusivamente de avaliação subjetiva da parte interessada. Em regra, é no momento da troca de mercado que haverá maior objetividade para mensuração (troca em sentido estrito), mas é possível que se tomem preços e índices de mercado para essa mensuração, comparando-se o preço decorrente da troca entre terceiros (troca em sentido amplo); e

(iii) exista segurança para que se possa afirmar ter ocorrido o evento, tendo como parâmetro a prudência do avaliador (ou conservadorismo). O nível de segurança exigido poderá variar de caso para caso (como a adoção da regra geral de tributação pelo regime de caixa para as pessoas físicas, decorrente de uma exigência de maior segurança quanto ao critério de realização).

Assim, cumpridos esses requisitos, é possível afirmar que há renda realizada, mesmo que o acréscimo, ganho ou ingresso não decorra da troca pelo próprio contribuinte, mas da comparação com trocas de mercado realizadas entre terceiros. Apenas para ilustrar graficamente a discussão em tela, confira-se o seguinte gráfico: 


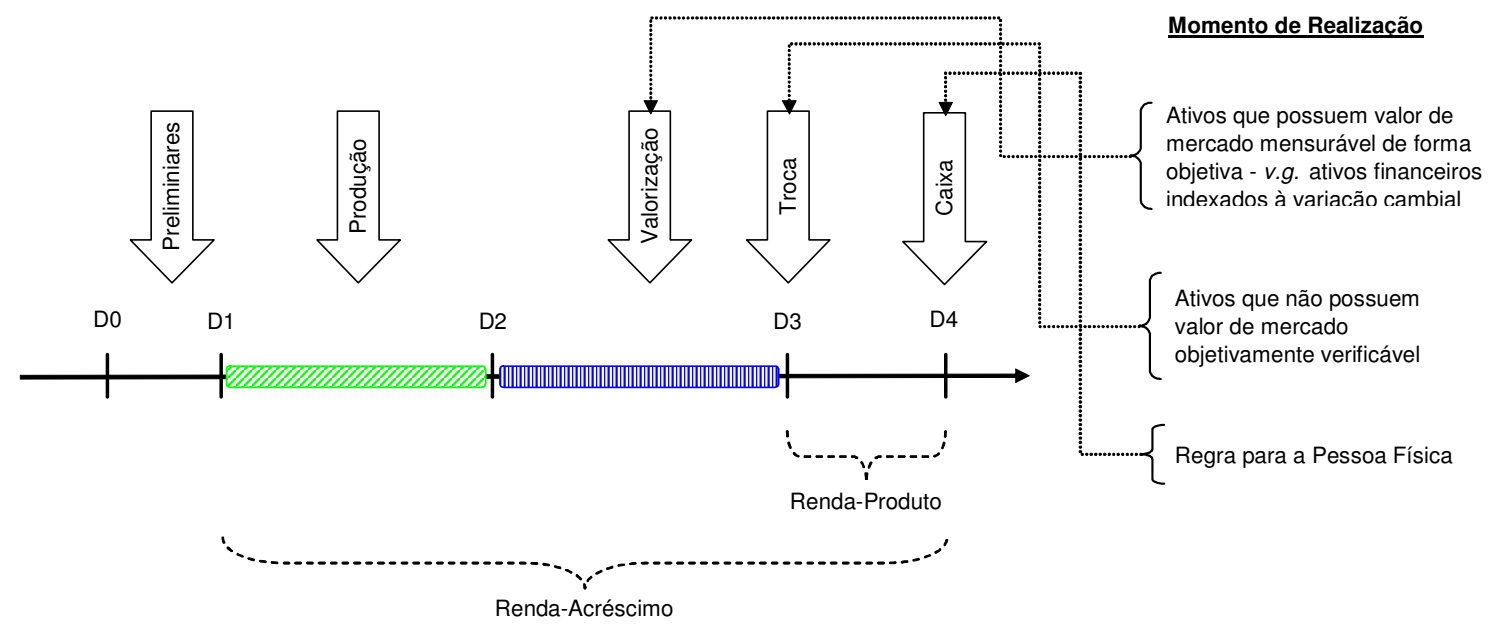

\section{3 - Do Conceito de Renda e Critérios de Realização no Código TRIBUTÁRIO NACIONAL}

Conforme destacado no capítulo anterior, a CF/88 traz as balizas para que o tipo renda seja definido pela legislação infraconstitucional. Portanto, a determinação conceitual está prevista no artigo 146 , inciso III, alínea $a$, da $\mathrm{CF} / 88^{58}$, ao estabelecer a competência da lei complementar definir o fato gerador dos tributos e a sua base de cálculo.

Dessa forma, o CTN, recepcionado pela $\mathrm{CF} / 88$ como lei complementar, traz elementos complementares ao tipo constitucionalmente estabelecido, criando um verdadeiro conceito renda, fora do qual não poderá haver tributação.

Ocorre que, conforme se perceberá da análise que se passa a fazer, embora o CTN traga os elementos para a definição do conceito de renda, esse conceito ainda não é concreto o suficiente para que se possa já ter uma noção completa do fato gerador do imposto sobre a renda. Para se ter uma visão completa, não bastam as lições do Código, faz-se necessária a análise da legislação ordinária, sem a qual não haverá elementos suficientes para a subsunção dos fatos geradores concretos (o que será feito no Capítulo 5 do presente trabalho).

Isto porque a materialidade do fato gerador também será definida concretamente na legislação ordinária, como ocorre com a definição de acréscimo patrimonial para fins

58 “Art. 146. Cabe à lei complementar:(...)

III - estabelecer normas gerais em matéria de legislação tributária, especialmente sobre:

a) definição de tributos e de suas espécies, bem como, em relação aos impostos discriminados nesta Constituição, a dos respectivos fatos geradores, bases de cálculo e contribuintes," 
tributários. De fato, o conceito de patrimônio é definido pelo Direito Privado, mas não é unívoco, pois há conceitos distintos para o sub-ramo do Direito Civil e do Direito Societário.

Contudo, em alguns casos, há particularidades que podem fazer com que o Direito Tributário adote conceito de acréscimo patrimonial distinto do Direito Privado. Nesse sentido, o artigo 44 do CTN estabelece que a base de cálculo do imposto é o montante, real, arbitrado ou presumido, da renda ou dos proventos tributáveis, mas nenhuma dessas bases de cálculo está adstrita ao conceito de acréscimo patrimonial do Direito Privado (sendo muito raro que sejam coincidentes).

Com efeito, um conceito concreto dessas bases de cálculo somente será construído a partir da análise das leis ordinárias. Em outras palavras, é na legislação ordinária que se definirá qual é a base de cálculo real (que possui esse nome por ter como ponto de partida o lucro societário, mas pode sofrer tantos ajustes que acabe se tornando totalmente distinta), bem como qual será a base de cálculo presumida (que, em alguns casos, estabelece margens de lucro que não refletem adequadamente a lucratividade dos setores econômicos) ou arbitrada.

Como visto, a rígida repartição de competências e os princípios constitucionais fornecem os limites mais amplos à definição do conceito de renda. Não obstante, é no CTN que está definido o conceito abstrato de renda a ser obedecido pelo legislador ordinário no processo de concretização desse conceito.

Assim sendo, necessária se faz uma análise dos elementos que compõe o conceito estabelecido no caput do artigo 43 do CTN e nos seus incisos I e II:

“Art. 43. O imposto, de competência da União, sobre a renda e proventos de qualquer natureza tem como fato gerador a aquisição da disponibilidade econômica ou jurídica:

I - de renda, assim entendido o produto do capital, do trabalho ou da combinação de ambos;

II - de proventos de qualquer natureza, assim entendidos os acréscimos patrimoniais não compreendidos no inciso anterior." (g.n.)

Conforme se depreende do dispositivo do CTN acima transcrito, faz-se necessário compreender ao menos os seguintes elementos do conceito de renda para a definição de seu conteúdo e o momento de sua realização: (i) aquisição de disponibilidade (ii) econômica ou jurídica de (iii) renda-produto ou renda-acréscimo patrimonial. 


\subsection{1 - Renda-Produto e Renda-Acréscimo}

Inicialmente, verifica-se que o CTN adota dois conceitos distintos de renda: o de (i) renda-produto e o de (ii) renda-acréscimo patrimonial. Com efeito, pode-se dizer que são afastados os conceitos mais amplos e subjetivos de renda, como a renda-consumo e a renda-psíquica já mencionados no início deste trabalho. ${ }^{59}$

Alguns autores entendem que o CTN teria adotado apenas o conceito de renda como acréscimo patrimonial, uma vez que a leitura do dispositivo deveria ser feita de forma a entender que o inciso I estaria englobado no inciso II (ou seja, o inciso I trataria apenas da renda-produto que represente acréscimo patrimonial). ${ }^{60}$

Contudo, como esclarece Luís Eduardo Schoueri, não há como se afirmar que o inciso I do artigo 43 tenha que ser restringido apenas às situações de renda-produto que também gerem acréscimos patrimoniais.

Há, de fato, intersecção entre esses dois conceitos, mas há também hipóteses em que haverá renda-produto independente da renda-acréscimo, como ocorre com a tributação exclusiva na fonte para as pessoas físicas e a retenção na fonte, no caso de rendimentos pagos a não residentes (hipóteses de tributação instantânea), como também haverá casos em que existe acréscimo patrimonial sem que haja produto (v.g. ganho de capital). Assim representa graficamente o autor: ${ }^{61}$

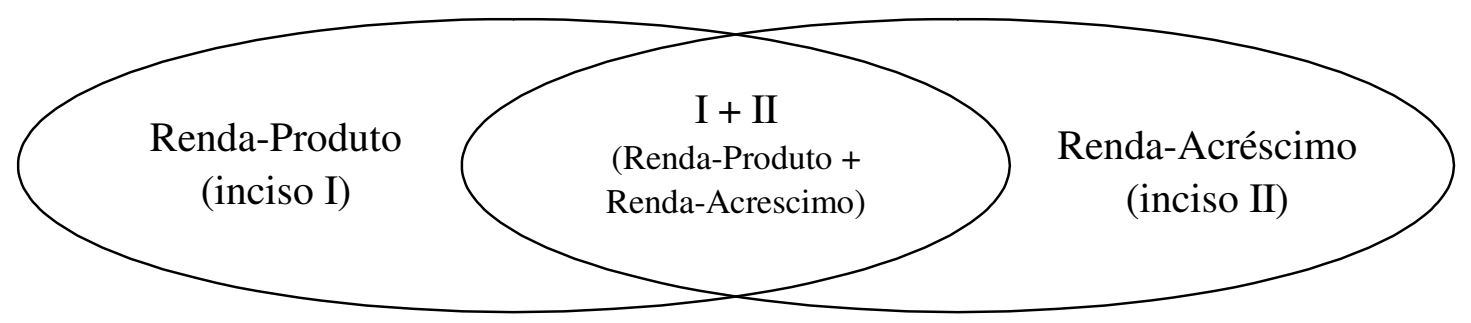

De fato, o tipo renda pressupõe um acréscimo, um ganho, um ingresso ao patrimônio. O produto periódico de uma fonte permanente representa o ingresso de novos recursos ao patrimônio de uma pessoa, mas não representa necessariamente um acréscimo patrimonial (o ingresso do produto não considera os custos para sua obtenção).

\footnotetext{
${ }^{59}$ Neste sentido, confira-se: "Com isso, o art. 43 está afastando outros critérios teoricamente possíveis para a tributação da renda, tais como o da renda consumida, ou o da renda empregada, ou o da renda capitalizada, para fixar no critério da renda adquirida.” OLIVEIRA, Ricardo Mariz de. Op. cit. (nota 25), p. 287.

60 "E, se o inciso II afirma que os proventos são os acréscimos patrimoniais não compreendidos no inciso I, está necessariamente dizendo que a renda também é acréscimo patrimonial, pois sua dicção textual equivale ao seguinte: proventos são acréscimos patrimoniais não compreendidos nos acréscimos patrimoniais compreendidos no inciso anterior.” OLIVEIRA, Ricardo Mariz de. Op. cit. (nota 25), pp. 182-ss e 285-ss.
} 
Superada a questão relativa à corrente teórica adotada pelo CTN para a definição do conceito de renda (como sendo tanto a renda-produto quanto a renda-acréscimo), passa-se a analisar os elementos que foram indicados como determinantes para que se possa considerar realizado o fato gerador do imposto sobre a renda: a aquisição de disponibilidade econômica ou jurídica de renda e proventos de qualquer natureza.

\subsection{2 - Disponibilidade Econômica ou Jurídica}

Quanto à divergência entre disponibilidade econômica ou jurídica, não serão expostas as diversas correntes que tratam do assunto. Apenas merece ser mencionado que há basicamente duas correntes de opiniões: $^{.2}$ a corrente unificadora (segundo a qual as disponibilidades, econômica ou jurídica, seriam apenas dois momentos da mesma renda, pois toda disponibilidade seria jurídica, mas algumas ainda não estariam disponíveis economicamente, como ocorre com o pagamento ${ }^{63}$ e a corrente dicotômica (na qual há duas espécies distintas de disponibilidade).

Sobre a corrente dicotômica, defende Ricardo Mariz de Oliveira que a disponibilidade jurídica é a decorrente de atos lícitos e a disponibilidade econômica, a decorrente de atos ilícitos. ${ }^{64}$ Por outro lado, Luís Eduardo Schoueri defende que o CTN efetivamente distingue o sentido jurídico e o econômico do patrimônio, motivo pelo qual pode haver uma disponibilidade tributável que é econômica, independentemente de algum título jurídico. ${ }^{65}$

\footnotetext{
${ }^{61}$ SCHOUERI, Luís Eduardo. Op. cit. (nota 8), p. 247.

${ }^{62}$ Sintetizando tais correntes, vale conferir: ABE, Cesar Henrique Shogi. Disponibilidade Econômica da Renda. in Revista Direito Tributário Atual $\mathrm{n}^{\circ}$ 21. 2007, p. 191-210.

${ }^{63}$ Neste sentido, MACHADO, Brandão. Breve Exame Crítico do art. 43 do CTN. In: MARTINS, Ives G. S. (coord.). Estudos sobre o Imposto de Renda (em memória de Henry Tilbery). São Paulo: Resenha Tributária, 1994, p. 107-124.

${ }^{64}$ OLIVEIRA, Ricardo Mariz de. Op. cit. (nota 25), pp.313 e 314. A respeito da conceituação da dicotomia jurídico/econômico como lícito ou ilícito, confira-se Luís Eduardo Schoueri: "Não é este o espaço para o exame crítico desta tese, mas deve ser mencionado que se o fruto da atividade ilícita não for protegido pelo direito, i.e., se o direito não assegurar aquela disponibilidade, então não parece correto falar em acréscimo patrimonial e, portanto, não parece acertado cogitar de imposto de renda." SCHOUERI, Luís Eduardo. Prefácio. In OLIVEIRA, Ricardo Mariz de. Op. cit. (nota 25), p. 4.

${ }^{65}$ Confira-se: "Assim, parece que o legislador complementar, ao citar 'disponibilidade econômica' da renda, pode ter buscado fazer referência a um sentido econômico de patrimônio, independente da existência de um título jurídico. A possibilidade de usar e fruir de um bem, assim, seria indicativo de disponibilidade econômica e revelaria, desta forma, a existência de um acréscimo patrimonial passível de tributação pelo imposto de renda." SCHOUERI, Luís Eduardo. Op. cit. (nota 8), p. 251.
} 
Contudo, conforme esclarecem Ricardo Mariz de Oliveira ${ }^{66}$ (apesar de defender a dicotomia lícito/ilícito) e Luís Eduardo Schoueri ${ }^{67}$ (que defende a possibilidade de uma disponibilidade econômica que não respaldada por um título jurídico), a corrente predominante sobre o tema entende que as disponibilidades, econômica ou jurídica, são sinônimas de: (i) regime de competência (disponibilidade jurídica) ou (ii) regime de caixa (disponibilidade econômica), como defendido por Bulhões Pedreira, dentre outros. ${ }^{68}$

Nesta linha, mas em sentido contrário, pode-se citar Rubens Gomes de Sousa, para quem a dicotomia seria entre realização da renda (regime de competência) e separação da renda (regime de caixa). Para o autor, pode-se "distinguir entre a realização, traduzida pela disponibilidade econômica de uma riqueza, e a separação, traduzida pela sua disponibilidade jurídica". Neste sentido, a realização é a "verificação, efetiva ou potencial, de um acréscimo patrimonial" e a separação a "possibilidade de dispor desse acréscimo independentemente e separadamente do capital que o produziu". ${ }^{69}$

Sobre o regime de caixa, é importante se destacar que não se está a indicar a uma mera disponibilidade financeira, como bem alerta Ricardo Mariz de Oliveira, pois é possível que se verifiquem ingressos financeiros na disponibilidade do contribuinte que não irão configurar renda, como ocorre nos casos em que se recebe adiantamentos decorrentes de venda com entrega futura ou decorrentes de serviços a serem prestados, mas que deverão ser devolvidos, caso o objeto da venda não seja entregue ou o serviço não seja prestado. ${ }^{70}$

No presente trabalho, adota-se a corrente teórica que distingue a disponibilidade econômica e a jurídica como sendo os equivalentes a regime de caixa ou de competência, uma vez que esta linha retrata a distinção entre os dois regimes de reconhecimento de receitas e despesas geralmente adotados pelo legislador como critério de realização da renda (regimes de competência e de caixa).

$\mathrm{Na}$ verdade, o regime de competência é o regime contábil adotado como regra geral pela Lei das S/A (artigo 177), cuja aplicação passou a ser regulamentada e fiscalizada

\footnotetext{
${ }^{66}$ Confira-se: "tradicionalmente, a doutrina entende que a aquisição da disponibilidade jurídica se constitui na aquisição do direito à renda, sem ter havido ainda a sua percepção em dinheiro ou em valores suscetíveis de avaliação em dinheiro. Em complemento, o fato de o dinheiro da renda estar em caixa, isto é, no bolso do contribuinte, representaria a disponibilidade econômica da respectiva renda." OLIVEIRA, Ricardo Mariz de. Op. cit. (nota 25), p. 292.

${ }^{67}$ SCHOUERI, Luís Eduardo. Op. cit. (nota 8), p. 248.

${ }^{68}$ PEDREIRA, José Luiz Bulhões. Op. cit. (nota 55), pp.195-200. No mesmo sentido BARRETO, Paulo Ayres. Op. cit. (nota 18), p. 74. ÁVILA, Humberto. Op. cit. (nota 33), p. 35. LEMKE, Gisele. Op. cit. (nota 28), p. 120.

${ }^{69}$ SOUSA, Rubens Gomes de. A evolução do Conceito de Rendimento Tributável. In: Revista de Direito Público, v.14, São Paulo: Revista dos Tribunais, out-dez 1970, p. 344.
} 
com muito mais rigor pela CVM, após a Lei $\mathrm{n}^{\circ} 11.638 / 07$ (enforcement), inclusive por exigências decorrentes de um mercado de capitais muito mais ativo na atualidade. Ademais, o regime de competência, que também é um princípio contábil, encontra-se positivado pela Lei das S/A, motivo pelo qual esse é um regime jurídico previsto no Direito Societário (ou seja, não é apenas conceito econômico, mas também jurídico).

Do mesmo modo, o regime de caixa é uma construção legal que ainda merece um estudo mais aprofundado pela doutrina jurídica e contábil, uma vez que é previsto apenas na legislação contábil tributária. Trata-se de uma forma de facilitar a tributação, visto que se considerará ocorrida uma receita apenas no momento em que há o efetivo ingresso financeiro do recurso.

Não obstante, é muito importante a observação de Ricardo Mariz de Oliveira no sentido de que a mera disponibilidade financeira não pode ser caracterizada como regime de caixa, porquanto há ingressos financeiros que não representam renda (os conceitos de regime de competência e regime de caixa serão explorados nos Capítulos 2.4.3 e 4.5).

Ante o exposto, é possível afirmar que o CTN adota os conceitos de renda-produto (produto periódico de uma fonte permanente) e de renda-acréscimo (acréscimo patrimonial), bem como determina que essa renda tem que estar disponível jurídica ou economicamente, ou seja: realizada, pelo regime de competência (disponibilidade jurídica) ou separada, pelo regime de caixa (disponibilidade econômica). Faz-se necessário definir, então, quando é que essa disponibilidade estará adquirida (aquisição da disponibilidade).

\subsection{3 - Aquisição da Disponibilidade}

Sobre o conceito de aquisição de disponibilidade sobre a renda, entende Modesto Carvalhosa que: ${ }^{71}$

\footnotetext{
“ao se falar em aquisição de disponibilidade, fala-se em acréscimo efetivo ao patrimônio do titular de uma determinada renda. Somente é tributável o acréscimo patrimonial quando ele é efetivamente verificável ou disponível pelo seu titular. Exclui-se, dessa forma, a simples valorização do patrimônio como fato gerador do tributo, já que esta simples valorização nominal de um determinado patrimônio poderia desaparecer em momentos sucessivos pela desvalorização desse mesmo patrimônio, donde impossível mensurar o acréscimo patrimonial, já que ele não se efetivou e não pode, portanto, ser disponível pelo seu titular."

${ }^{70}$ OLIVEIRA, Ricardo Mariz de. Op. cit. (nota 25), p. 306.

${ }^{71}$ CARVAlHOSA, Modesto. Imposto de Renda. Conceituação no Sistema Tributário da Carta Constitucional.
} 
Do exposto, verifica-se que o vocábulo aquisição denota a ideia de um fluxo de algo novo, que estava fora do patrimônio e nele ingressa. Rubens Gomes de Sousa observa também a etimologia da palavra income "que entra - comes in". ${ }^{72}$

Com efeito, verifica-se que o conceito de aquisição retoma a discussão acerca do momento em que se considera que determinado rendimento ingressou no patrimônio do contribuinte, o que já foi objeto de estudo quando da análise do princípio da realização da renda.

O vínculo entre o conceito de aquisição e o princípio da realização da renda é ressaltado por Ricardo Mariz de Oliveira: "a realização da renda confunde-se com a aquisição da disponibilidade econômica ou jurídica de renda ou de provento de qualquer natureza, pois essa aquisição marca o instante a partir do qual há acréscimo patrimonial e o imposto pode ser exigido". ${ }^{73}$

Neste sentido, é ilustrativa também a conceituação de receita, oferecida por Ricardo Mariz de Oliveira, na qual se ressalta a necessidade de um ingresso novo ao patrimônio: ${ }^{74}$

"receita é qualquer ingresso ou entrada de direito que se incorpore positivamente ao patrimônio, e que represente remuneração ou contraprestação de atos, atividades ou operações da pessoa titular do mesmo, ou remuneração ou contraprestação do emprego de recursos materiais, imateriais, ou humanos existentes em seu patrimônio ou por ele custeados, de modo que a receita ainda traz consigo esta característica de ser o produto que vem de fora do patrimônio, mas que é derivada de dentro, por derivar de atos, operações ou atividades da pessoa titular do patrimônio, ou do emprego de recursos que compõem esse patrimônio, de que resulte algum benefício direto para a pessoa a qual, em contraprestação, o remunera por isso."(g.n.)

Portanto, faz-se necessário retomar as balizas constitucionais para a definição do conceito de renda, em especial o princípio da realização, seja ela renda-produto ou renda-acréscimo.

Da mesma forma, ressalte-se novamente, o conteúdo do princípio da realização da renda pode ser entendido como o vetor que orienta a alocação temporal de receitas e despesas (entradas e saídas) deve ser feita no momento em que (i) existam eventos materialmente substanciais, ou seja, que tenham substância suficiente para se considerar realizada a renda,

\footnotetext{
In: Revista de Direito Público, nº 1, jul-set, 1967, p. 193

${ }^{72}$ SOUSA, Rubens Gomes de. Ob. Cit. (nota 69), p. 341 (item 11).

${ }^{73}$ OLIVEIRA, Ricardo Mariz de. Op. cit. (nota 25), p. 372.

${ }^{74}$ OLIVEIRA, Ricardo Mariz de. Op. cit. (nota 25), pp. 89-90.
} 
(ii) exista um certo grau de objetividade para a mensuração da renda, ou seja, que a mensuração não decorra exclusivamente de avaliação subjetiva da parte interessada e (iii) exista segurança suficiente para que se possa afirmar ter ocorrido o evento, tendo como parâmetro a prudência e conservadorismo do avaliador.

Interessante questionar, neste momento, se o vocábulo aquisição estabelecido no CTN determina que apenas os eventos concretos que decorram de trocas de mercado pelo próprio titular da renda (troca em sentido estrito) é que podem ensejar a aquisição da disponibilidade. Neste sentido, destaque-se que o relatório redigido por Rubens Gomes de Sousa ressalta a opinião dos autores do projeto do CTN de que não é qualquer valorização do patrimônio que será considerada renda, mas apenas aquelas reavaliações que gerem efetivo acréscimo patrimonial.

Confira-se o seguinte trecho que menciona a exclusão da reavaliação de ativos do conceito de renda: ${ }^{75}$

“essa exclusão foi deliberada, porquanto só alcança as reavaliações puramente 'monetárias' ou de reajustamento de valores contábeis, que efetivamente não têm conteúdo econômico; inversamente, as reavaliações que traduzem acréscimo patrimonial efetivo continuam no campo da incidência, como ganhos provenientes do capital."

Portanto, verifica-se que os idealizadores do CTN vislumbravam a possibilidade de reavaliações que traduzem efetivo acréscimo patrimonial e que, por isso, estarão dentro do conceito de ganho de capital (sujeito ao campo de incidência do imposto sobre a renda).

Assim, o que se precisa é que a reavaliação de ativos, que gere o acréscimo ou decréscimo de seu valor, seja aquela decorrente da comparação com trocas de mercado entre terceiros (troca em sentido lato), em que (i) haja objetividade suficiente para sua mensuração, na medida em que exista uma definição do preço de mercado, (ii) haja condições materiais que permitam determinar a existência de um mercado ativo para o bem, ou seja, que este bem poderá ser facilmente alienado para terceiros quando interessar ao contribuinte e (iii) haja segurança na determinação do valor de mercado, dentro dos parâmetros de prudência e conservadorismo (ou seja, reavaliações que gerem receitas pelo menor valor e que gerem despesas pelo maior valor).

Não obstante a possibilidade de tributação de reavaliações em alguns casos específicos, o que se observa, em geral, é que o legislador não utiliza a comparação do valor de

${ }^{75}$ MINISTÉRIO DA FAZENDA. Trabalhos da Comissão Especial do Código Tributário Nacional. Rio de 
mercado decorrente de troca entre terceiros como critério de realização da renda, uma vez que se trata de atividade de difícil mensuração e fiscalização (ou seja, a aplicação do princípio da praticabilidade orienta em sentido oposto). Muitas vezes, inclusive, a aplicação desse critério de realização é colocado como opcional para o contribuinte, como ocorre com a variação cambial.

\section{4 - Utilização de Conceitos de Direito Privado para Determinar o CONCEITO de RENDA E O MOMENTO dA REALIZAÇÃo}

Preliminarmente, deve-se esclarecer que qualquer autonomia, que se pretenda dar aos ramos do Direito, só se justifica com o intuito meramente didático de se estudar cientificamente a repercussão dos princípios e valores jurídicos, conferindo maior sistematização aos seus institutos. Esse recurso é utilizado, na ciência do Direito, para o estudo de seu objeto, o Direito Positivo, pois este é uno e indivisível.

A autonomia didática dos ramos do Direito não tem o condão de interferir na interpretação e aplicação das normas jurídicas e o intérprete do Direito se vale dessa autonomia na aplicação dos princípios específicos de cada ramo do Direito, sem perder de vista a unidade do ordenamento jurídico. ${ }^{76}$

São inválidas, portanto, as interpretações que tenham como fundamento a autonomia do Direito Tributário ou de qualquer outro ramo do Direito. O Direito deve ser visto como um sistema de proposições jurídicas válidas, que se costuram de forma homogênea, de tal sorte que se garanta a unidade e se afastem as contradições.

O sistema jurídico do Direito Positivo se caracteriza como um conjunto de normas que tem como objetivo a regulação das condutas em sociedade. O Direito Positivo é um sistema social que faz parte de um sistema social global, no qual estão também os sistemas econômico, contábil, político, sociológico etc., ${ }^{77}$ e tem a função de conferir normatividade a essa estrutura. ${ }^{78}$

\footnotetext{
Janeiro: Ministério da Fazenda, 1954, p.129.

${ }^{76}$ TÔRRES, Heleno, Direito Tributário e Direito Privado - Autonomia Privada - Simulação - Elusão Tributária, São Paulo, Revista dos Tribunais, 2003, p. 32.

77 "As ciências são instrumentos de pesquisa da verdade e como têm todas o mesmo objetivo de alcançar o conhecimento verdadeiro, cada ciência compreende, por assim dizer, o estudo de uma face do grande problema do conhecimento" NOGUEIRA, Ruy Barbosa. Curso de Direito Tributário. 14a ed., São Paulo: Saraiva, 1995 , p. 63.

78 TÔRRES, Heleno, Op. cit. (nota 76), pp. 40 e 41.
} 
Pode-se afirmar também que o sistema jurídico se apresenta como um sistema hierárquico de normas que tem a Constituição como o conjunto de normas postas no mais elevado nível e de maior grau de abstração. São essas normas que regulam a produção de outras normas, num processo de concretização do Direito, até se chegar às normas de maior concretude, como é o lançamento tributário. Conforme já mencionado, a nossa Constituição Federal traz em seu bojo importantes regras para o Direito Tributário, definindo as competências para instituição de tributos e prevendo seus critérios materiais. ${ }^{79}$

A concretização do critério material dos tributos (tipos tributários), previsto de forma descritiva na constituição, se dá com a sua conceituação nas leis infraconstitucionais. Esses conceitos, muitas vezes, não estão previstos exclusivamente no Direito Tributário e dependem de conceitos previstos em outros ramos do Direito (Direito Privado, Direito Administrativo etc.).

Portanto, o Direito Tributário possui autonomia para qualificar e requalificar o critério material da norma tributária, desde que respeite os princípios constitucionais e a repartição de competências, de forma a manter a unidade do sistema. Neste sentido, afirma Paulo de Barros Carvalho que: "Justamente para atender a estipulações dessa índole é que o esforço de pesquisa de enunciados fica tolhido, uma vez que o exegeta não poderá recolhê-los à sua vontade, em qualquer região do direito posto, devendo circunscrever a escolha dentro de certos segmentos da ordem legislada, que o texto constitucional expressamente indica." $" 0$

Essa autonomia para qualificar e requalificar o critério material da norma tributária possui algumas regras específicas estabelecidas no próprio CTN, sobre as quais se passa a tecer breves comentários.

\subsection{1 - Tratamento dos Conceitos de Direito Privado pelo CTN}

$\mathrm{O}$ artigo 109 do CTN dispõe que "os princípios gerais de direito privado utilizam-se para pesquisa da definição, do conteúdo e do alcance de seus institutos, conceitos e formas, mas não para definição dos respectivos efeitos tributários". De fato, os institutos, conceitos e formas do Direito Privado são formulados em conformidade com princípios próprios, destinados às finalidades específicas das relações de Direito Privado. Neste sentido, a

\footnotetext{
${ }^{79}$ SCHOUERI, Luís Eduardo. Op. cit. (nota 22), pp. 82-115.

${ }^{80}$ CARVALHO, Paulo de Barros, Direito Tributário - Fundamentos Jurídicos da Incidência, $2^{\mathrm{a}}$ ed., São Paulo, Saraiva, 1999, p. 73.
} 
pesquisa da definição, do conteúdo e do alcance desses institutos, conceitos e formas deve se pautar pelos princípios gerais próprios do Direito Privado.

A título exemplificativo, as alterações ocorridas na legislação contábil societária, por meio das Leis $\mathrm{n}^{\mathrm{o}} 11.638 / 07$ e $\mathrm{n}^{\mathrm{o}}$ 11.941/09, devem ser interpretadas de acordo com princípios próprios deste ramo do Direito (dentre os quais encontram-se os princípios de contabilidade geralmente aceitos), voltados aos fins societários para os quais foram criados (distribuição de dividendos, por exemplo). Contudo, os respectivos efeitos tributários dessas normas somente serão determinados pela legislação tributária e em harmonia com os princípios da tributação (como será analisado no Capítulo 5.2.1.1).

Sobre a repercussão ou não dessas alterações para fins tributários, é importante citar o disposto no artigo 110 do CTN:

"a lei tributária não pode alterar a definição, o conteúdo e o alcance de institutos, conceitos e formas de direito privado, utilizados, expressa ou implicitamente, pela Constituição Federal, pelas Constituições dos Estados, ou pelas Leis Orgânicas do Distrito Federal ou dos Municípios, para definir ou limitar competências tributárias."

Trata-se de regra que consubstancia a rígida repartição de competências tributárias prevista na $\mathrm{CF} / 88$. Com efeito, quando a Constituição faz referência a algum conceito de Direito Privado para definição ou limitação das competências tributárias, não poderá o legislador tributário alterar referidos conceitos.

Contudo, nem sempre a $\mathrm{CF} / 88$ utiliza conceitos de direito privado para definir ou limitar as competências tributárias. Este é o caso, como visto, do conceito de renda, que não está previsto no Direito Privado, mas sim no CTN, como sendo a aquisição de disponibilidade econômica ou jurídica de renda-acréscimo patrimonial ou de renda-produto.

No mesmo sentido, verifica-se que a $\mathrm{CF} / 88$, ao delimitar as competências tributárias, reservou aos Municípios a competência para tributar a propriedade predial e territorial urbana (artigo 156, inciso I). Contudo, o conceito de propriedade para fins de incidência do imposto municipal não é o conceito de Direito Privado, mas sim o conceito do artigo 32 CTN, que inclui os direitos de posse e domínio útil. Trata-se de propriedade como equivalente de bem imóvel. ${ }^{81}$

${ }^{81}$ SCHOUERI, Luis Eduardo. Op. cit. (nota 8), p. 249. 
É importante ressaltar também que a vedação à alteração dos conceitos de Direito Privado somente pode ser aplicada nos casos em que se pretenda tributar, como renda, um fato concreto que transborde o conceito previsto no artigo 43 do CTN (renda-produto ou renda-acréscimo). Todavia, não há restrição para alterações de conceitos de Direito Privado quando essas alterações forem realizadas dentro dos limites do conceito de renda previsto no $\mathrm{CTN}$, de forma que não se tribute todo e qualquer (i) acréscimo ou (ii) ganho. ${ }^{82}$

Há casos, ainda, em que há uma completa dissociação entre a renda tributária e o acréscimo patrimonial de Direito Privado (como ocorre na tributação do lucro pelas pessoas jurídicas, em que pode haver lucro tributável e o contribuinte ter incorrido num decréscimo patrimonial de Direito Privado no mesmo período-base).

Contudo, mesmo nesses casos, não há como se dizer que o conceito de renda está completamente dissociado do conceito de acréscimo patrimonial, uma vez que a legitimidade da tributação do lucro pela pessoa jurídica está amparada em critérios que reflitam razoavelmente o acréscimo patrimonial. É o caso, por exemplo, do lucro presumido em que há a aplicação de margens de lucro diferentes para cada setor de atividade econômica e o contribuinte possui a faculdade de não adotar essa metodologia de tributação.

Portanto, faz-se necessário pesquisar os conceitos de patrimônio no Direito Privado para que se possa verificar se esses conceitos podem ou não ser recepcionados pelo Direito Tributário como forma de medir o acréscimo patrimonial (um dos conceitos possíveis de renda previstos no CTN). Neste sentido, o conceito de patrimônio para o Direito Privado será abordado nos capítulos seguintes, tanto (i) o conceito previsto no Direito Societário (Capítulo 2), quanto (ii) o previsto no Direito Civil (Capítulo 3).

Com efeito, tendo em vista a existência de mais de um conceito de patrimônio para o Direito Privado, apenas o contexto e a finalidade, considerando-se ainda as relações com outros dispositivos e princípios do ordenamento jurídico, é que irão definir qual será o conceito aplicável ao caso específico como limite à tributação ${ }^{83}$ (em muitos casos, os direitos que integram o patrimônio para o Direito Civil não possuem os atributos para compor base de tributação da renda, como ocorre com ganhos não realizados).

\footnotetext{
${ }^{82}$ Como ocorre com a possibilidade de apuração do lucro pelo regime de caixa para o setor de construção civil, uma vez que se restringe o conceito de lucro para abranger apenas aquelas receitas que se concretizaram em ingresso de caixa, conforme será visto adiante.

${ }^{83}$ SCHOUERI, Luís Eduardo. Op. cit. (nota 8), p. 250.
} 
Por isso, cabem algumas breves considerações sobre os artigos 116 e 117 do CTN ${ }^{84}$ Em conformidade com esses dispositivos, pode-se dizer que a renda, na qualidade de definidora do fato gerador do imposto, é uma situação jurídica que somente será considerada definitivamente constituída nos termos da legislação aplicável. No caso do conceito de renda como acréscimo patrimonial, o direito aplicável é o próprio Direito Tributário, mas que, por diversas vezes, acaba recepcionando os conceitos de Direito Civil ou de Direito Societário.

Feitas essas breves considerações iniciais, passa-se a analisar as diversas formas de relacionamento entre o Direito Privado e o Direito Tributário, bem com as possíveis implicações dessas formas de relacionamento com o conceito de renda.

\subsection{2 - Formas de Relacionamento entre o Direito Privado e o Direito Tributário}

No que tange às formas de relacionamento entre os institutos de Direito Privado e os de Direito Tributário, Ezio Vanoni (com base no ensinamento de Blumenstein) apresenta 3 formas distintas: (i) recepção do suporte fático (expressa ou implícita), (ii) transformação e (iii) aplicação por analogia ${ }^{85}$ Alcides Jorge Costa acrescenta ainda os casos em que há criação de conceitos novos pelo Direito Tributário e que tais conceitos acabam por regular relações de Direito Privado: (iv) interpenetração normativa. ${ }^{86}$

\subsubsection{1 - Recepção do Conceito de Direito Privado pelo Direito Tributário (Expressa ou Implícita)}

Os conceitos delimitadores do fato gerador do tributo podem estar definidos nas normas de Direito Privado, nas quais o aplicador irá buscar os conceitos para verificação da incidência tributária. Esse fenômeno é também conhecido como a recepção do suporte fático.

\footnotetext{
84 “Art. 116. Salvo disposição de lei em contrário, considera-se ocorrido o fato gerador e existentes os seus efeitos: I - tratando-se de situação de fato, desde o momento em que se verifiquem as circunstâncias materiais necessárias a que produza os efeitos que normalmente lhe são próprios;

II - tratando-se de situação jurídica, desde o momento em que esteja definitivamente constituída, nos termos de direito aplicável." (g.n.)

“Art. 117. Para os efeitos do inciso II do artigo anterior e salvo disposição de lei em contrário, os atos ou negócios jurídicos condicionais reputam-se perfeitos e acabados:

I - sendo suspensiva a condição, desde o momento de seu implemento;

II - sendo resolutória a condição, desde o momento da prática do ato ou da celebração do negócio."

${ }^{85}$ VANONI, Ezio. Natura ed Interpretazione delle Leggi Tributrarie. Trad. port. de Rubens Gomes de Sousa. Natureza e Interpretação das Leis Tributárias. Rio de Janeiro : Edições Financeiras, s.d., pp. 158-171

${ }^{86}$ COSTA, Alcides Jorge. Direito Tributário e Direito Privado. in MACHADO, Brandão. Direito Tributário Estudos em Homenagem ao Prof. Ruy Barbosa Nogueira. São Paulo : Saraiva, 1984, p. 222 e ss.
} 
O legislador irá utilizar os institutos de Direito Privado para a qualificação jurídica dos fenômenos sociais, conservando-lhes as características atribuídas pelo Direito Privado. Nesse caso, a lei tributária se limitará a estabelecer os demais elementos necessários para configuração da obrigação tributária.

A recepção pode ser expressa ou implícita. Assim, sempre que a lei tributária mencionar algum conceito de Direito Privado, esse deve ser o conceito adotado, mesmo que sem referência expressa. Alcides Jorge Costa ressalta não ser possível, no sistema constitucional brasileiro, a alteração implícita de conceitos de Direito Privado ou a consideração econômica em detrimento da forma jurídica. ${ }^{87}$

\subsubsection{2 - Transformação do Conceito de Direito Privado para Fins Tributários}

A conceituação própria para cada ramo do Direito é razoável, pois cada ramo pode ter como substrato o mesmo fato material concreto que não são idênticos no plano abstrato ${ }^{88} \mathrm{E}$ por isso que Hensel fala em conceitos funcionais, ou seja, os conceitos têm determinadas características próprias em cada ramo do Direito, em decorrência da diversidade de funções que eles desempenham na regulamentação jurídica. ${ }^{89}$

O fenômeno da transformação se caracteriza pela manutenção do mesmo nomen juris do instituto, mas com o conteúdo diferente, embora semelhante. Assim, o instituto perde sua natureza exclusiva de Direito Privado e passa a ter uma segunda natureza jurídica, para fins de definição do fato gerador da obrigação tributária. Ele deixa de regular somente as relações entre particulares para ser utilizado também nas relações jurídico-tributárias; trata-se de um novo conceito trazido pela lei tributária.

Luís Eduardo Schoueri assevera que a interpretação sistemática deve levar em consideração os princípios constitucionais, como é o caso da capacidade contributiva para os impostos. Assim, deve-se ter em mente que o legislador escolhe fenômenos reveladores de capacidade econômica para a composição do fato gerador e, muitas vezes esses, fenômenos encontram-se regulados pelo Direito Privado. Todavia, o legislador tributário não pode ficar vinculado a esses conceitos, pois o Direito Privado trata de relações entre particulares,

\footnotetext{
${ }^{87}$ COSTA, Alcides Jorge. Op. cit. (nota 86), p. 226.

${ }^{88}$ VANONI, Ezio. Op. cit. (nota 85), pp. 165-166.

89 HENSEL, Albert, Der Einfluss des Steuerrechts auf die Bergriffsbildung des öffentlichen Rechs, in Veröffentlichungen der Vereinigung der Deutschen Staatsrechtslehrer, Heft 3, Berlim, W. de Gruyter \& C., 1927 , pp. 93 e ss. Apud VANONI, Ezio. Op. cit. (nota 85), p. 166.
} 
enquanto o Direito Tributário regula a relação Fisco/Contribuinte, que tem como parâmetro a capacidade contributiva. ${ }^{90}$

Dessa forma, a relação entre o Direito Tributário e o Direito Privado não é autônoma, como vimos, mas uma relação sistemática, em que não cabem antinomias. Acontece que, quando não houver um critério de especialidade para resolver o problema das contradições entre os conceitos de Direito Tributário e de Direito Privado, este último somente deverá prevalecer quando estiver previsto na Constituição, distribuindo ou limitando competência tributária. ${ }^{91}$

Neste sentido, destaque-se que o critério de especialidade é estabelecido pela própria noção de limitação das competências tributárias. Ou seja, quando o Direito Tributário promove uma alteração no conceito de Direito Privado não previsto na Constituição como delimitador da competência tributária, o Direito Tributário irá prevalecer sobre o conceito de Direito Privado, uma vez que o legislador estará atuando dentro da facultatividade do exercício da competência constitucional.

Assim é que os conceitos de Direito Societário alterados pelas Leis 11.638/07 e 11.941/09 que modifiquem o critério de reconhecimento de receitas, custos e despesas computadas na apuração do lucro líquido do exercício, não terão efeitos para fins de apuração do lucro real (também do lucro presumido, da CSLL, do PIS e da COFINS) da pessoa jurídica sujeita ao RTT, devendo ser considerados, para fins tributários, os métodos e critérios contábeis vigentes em 31 de dezembro de 2007 (regra geral de transformação conforme será visto no Capítulo 5.2.1.1). ${ }^{92}$

\footnotetext{
${ }^{90}$ SCHOUERI, Luis Eduardo. Direito Tributário Internacional - Qualificação e Substituição - Tributação no Brasil, de Rendimentos Provenientes de Sociedade de Pessoas Residente na Alemanha, in RDDT n. ${ }^{\circ}$ 54, pp. $134 \mathrm{e}$ 135 .

91 “(...) O legislador tributário somente se vai limitar por uma espécie de princípio conservativo dos tipos e formas dos atos e negócios jurídicos de direito privado, quando esses se encontrarem relacionados com aqueles adotados pela Constituição Federal para a distribuição de competências tributárias, sem que isto implique reconhecer qualquer prevalência do direito privado sobre o direio tributário, porquanto a prevalência seja exclusivamente do direito constitucional." TÔRRES, Heleno, Op.cit. (nota 76), p. 78. No mesmo sentido: COSTA, Alcides Jorge. Op. cit. (nota 86), pp. 225 e 226.

${ }_{92}$ Lei $n^{\circ}$ 11.941/09: "Art. 16. As alterações introduzidas pela Lei $n^{\circ} 11.638$, de 28 de dezembro de 2007, e pelos arts. 37 e 38 desta Lei que modifiquem o critério de reconhecimento de receitas, custos e despesas computadas na apuração do lucro líquido do exercício definido no art. 191 da Lei ${ }^{\circ} 6.404$, de 15 de dezembro de 1976, não terão efeitos para fins de apuração do lucro real da pessoa jurídica sujeita ao RTT, devendo ser considerados, para fins tributários, os métodos e critérios contábeis vigentes em 31 de dezembro de 2007." (g.n.)
} 


\subsubsection{3 - Aplicação por Analogia}

Também se pode falar em aplicação analógica, por meio da qual o Direito Tributário não se refere a um instituto de Direito Privado, nem expressa nem tacitamente. Ezio Vanoni entende que é possível a aplicação analógica desses institutos, como ocorre com regras que determinam prazos, prescrição e decadência, regras de domicílio etc. ${ }^{93}$

Alcides Jorge Costa, por outro lado, entende não ser correto falar-se em aplicação analógica do Direito Privado, mas sim de uma correspondência de institutos (uso de figuras e conceitos comuns a ambos). ${ }^{94}$

\subsubsection{4 - Interpenetração Normativa do Direito Tributário no Direito Privado}

Por fim, é importante destacar as ponderações de Alcides Jorge Costa acerca dos casos em que o Direito Tributário cria novos conceitos não previstos no Direito Privado. Isto porque os conceitos de Direito Tributário podem irradiar efeitos que transbordam a seara da tributação, passando a assumir características de Direito Privado.

Como exemplo de interpenetração normativa, o autor cita o Decreto-lei $\mathrm{n}^{\circ}$ 1.598/77, que trata da legislação do imposto sobre a renda. Este Decreto-lei, em seu artigo 67, $\mathrm{XI}$, determinou que "o lucro líquido do exercício deverá ser apurado, a partir do primeiro exercício social iniciado após 31 de dezembro de 1977, com observância das disposições da Lei $n^{\circ}$ 6.404, de 15 de dezembro de 1976." Com esse dispositivo legal, a norma de Direito Tributário estendeu a todos os tipos de sociedade as normas contábeis estabelecidas pela Lei $n^{\circ}$ 6.404/76, que tinha aplicação restrita às sociedades anônimas. ${ }^{95}$

Tecidas essas considerações iniciais sobre o conceito de renda e o papel do Direito Privado para fins de definição desse conceito, faz-se necessário agora analisar, com mais detalhes, as características próprias desse ramo do Direito, especialmente no que tange ao conceito de acréscimo patrimonial, que será utilizado pelo Direito Tributário para fins de incidência do imposto sobre a renda.

\footnotetext{
${ }^{93}$ VANONI, Ezio. Op. cit. (nota 85), p. 162.

${ }^{94}$ COSTA, Alcides Jorge. Op. cit. (nota 86), p. 224.

${ }^{95}$ COSTA, Alcides Jorge. Op. cit. (nota 86), pp. 231 e 232.
} 


\section{2 - Utilização da Contabilidade Para Reconhecimento, Mensuração E TRIBUTAÇÃo DA RENDA}

O crescimento do fluxo internacional de investimentos, ocorrido na última década, foi acompanhado por um maior aperfeiçoamento e padronização das normas contábeis em diversos países. De fato, essa padronização se fez necessária para que os investidores pudessem dispor de informações claras e confiáveis acerca da situação financeira das companhias em que pretendem investir.

Um dos principais propulsores desta busca por um padrão internacional para as normas contábeis foi o escândalo da Enron, em que a companhia americana maquiava seus balanços, de forma que conseguiu ocultar dívidas da ordem de bilhões de dólares de seus investidores. ${ }^{1}$

Com efeito, principalmente após o escândalo da Enron, passou-se a buscar um padrão contábil internacional, com o objetivo de aumentar a transparência das informações financeiras divulgadas, bem como estabelecer critérios comuns para que se pudesse comparar a situação econômica de empresas de países diferentes.

Como exemplo, a exigência da adoção do US GAAP (Generally Accepted Accounting Principles) passou a ser um grande obstáculo para que empresas estrangeiras pudessem oferecer suas ações nas bolsas americanas. Conforme Hal S. Scott, ${ }^{2}$ a SEC (Security and Exchange Comission), órgão regulador do mercado de capitais americano, destacava uma série de incompatibilidades entre o US GAAP e as normas contábeis alemãs, tais como o tratamento dado a reservas ocultas, que permitiam às empresas alemãs amenizar as demonstrações de lucros durante anos deficitários ou lucrativos.

\footnotetext{
1 "Gigante do setor elétrico americano, empresa admirada e sétima maior dos Estados Unidos, segundo a revista Fortune, a Enron faliu, levando junto os fundos de pensão de seus funcionários e de outros investidores da mesma categoria, num rombo de, no mínimo, US\$ 1,5 bilhão, e arrastando uma dívida de mais de US\$ 13 bilhões. Durante anos, diretores da empresa maquiavam os balancetes, enxugavam os prejuízos e inflavam os lucros. A mágica contábil deu certo até o final do ano passado. (...)

O final trágico da Enron abalou a confiança do sistema financeiro norte-americano. Segundo o processo movido por ex-acionistas, a Enron escondia os prejuízo e turbinava os lucros com a conivência de quem deveria periciar a saúde contábil da empresa, a auditora Arthur Andersen. A ex-auditora da Enron aprovou a contabilidade fradulenta da empresa e os esquemas ilegais que adotou para esconder prejuízos e, depois, destruiu parte das provas do crime." reportagem publicada em 07/02/2002 - Jornal O Estado de S. Paulo - extraído do site http://www.estadao.com.br/arquivo/economia/2002/not20020207p24521.htm em 19/10/2011.

${ }^{2}$ SCOTT, Hal S. International Finance: Law and Regulation, Sweet \& Maxwell, $2^{\mathrm{a}}$ ed., 2007, pp. 122 e 123.
} 
O autor destaca o caso clássico da Daimler-Benz, que obteve sucesso em negociação com a SEC para afastar a aplicação do US GAAP. Nesta negociação, uma das concessões feitas pela empresa alemã foi revelar todas essas reservas ocultas. Após revelar as reservas ocultas, a empresa alemã, que exibia um lucro de US\$ 370 milhões pelas regras locais, passou a exibir um prejuízo de US\$ 1 bilhão. Este exemplo deixa claro que a inexistência de critérios contábeis uniformes gera uma assimetria de informações que podem colocar em xeque o verdadeiro valor da empresa.

Hal S. Scott destaca, também, que a adoção do padrão contábil pode influenciar no preço das ações. Em estudo por ele mencionado, as companhias alemãs, que migraram do padrão alemão de contabilidade para o padrão internacional ou pelo US GAAP, obtiveram maior liquidez para suas ações (lower bid-asked spreads), ${ }^{3}$ o que indica que os investidores acreditam que a adoção de práticas contábeis internacionais reduz a assimetria de informações.

No Brasil, um dos primeiros passos para a padronização das normas contábeis foi dado no âmbito do mercado de capitais, com a exigência da divulgação de balanços em US GAAP ou em IFRS (International Financial Reporting Standards) para se atingirem determinados níveis de governança corporativa da antiga Bolsa de Valores de São Paulo (Bovespa).

Contudo, foi com a edição da Lei $n^{\circ} 11.638 / 07$ e da Lei $n^{\circ} 11.941 / 09$ que se estabeleceu uma mudança substancial no modo de ver a legislação societária brasileira, com a alteração de conceitos fundamentais para a elaboração das demonstrações financeiras das companhias (para que fiquem livres das influências de regras de outros ramos do Direito), de modo a permitir melhor avaliação dessas demonstrações por investidores estrangeiros.

As referidas mudanças trazem vantagens evidentes para o incremento do fluxo de investimentos estrangeiros no Brasil, na medida em que permitem aos investidores calcularem melhor o risco dos investimentos, o que os torna mais atrativos. Contudo, a alteração desses conceitos de Direito Privado (no caso, Direito Contábil Societário, conforme será definido) pode gerar reflexos tributários.

De fato, independentemente dos reflexos diretos dessas alterações para a apuração de tributos, bem como das regras de neutralidade tributária previstas na Lei $\mathrm{n}^{\circ}$ 11.941/09 (confira-se o Capítulo 5.2.1.1), não há como se negar que um dos principais reflexos dessas

\footnotetext{
${ }^{3}$ No comércio, o bid-ask é a diferença entre (i) o preço mais alto que um comprador está disposto a pagar; e (ii) o menor preço que o vendedor está disposto a oferecer.
} 
alterações contábeis foi o aprofundamento do estudo interdisciplinar entre a Ciência Contábil e o Direito, especialmente no que tange à apuração do lucro para fins de tributação.

Dessa forma, as recentes alterações promovidas pela legislação societária tiveram o condão de despertar na doutrina jurídica a reflexão sobre o próprio conceito de renda e sobre o adequado critério de realização, como forma de melhor atingir a Capacidade Contributiva.

Neste capítulo, pretende-se discorrer acerca do relacionamento entre a Ciência Contábil e o Direito, por meio das diversas normas jurídicas que dispõem sobre a matéria contábil. Para tanto e para a compreensão dessas diversas normas jurídicas, faz-se necessário conhecer previamente alguns conceitos contábeis fundamentais.

Dessa forma, serão analisados o objetivo e o objeto da Ciência Contábil, seu relacionamento com o Direito Societário (Direito Contábil Societário), bem como as fontes de normas jurídicas que regulamentam esse ramo do direito e seu âmbito de aplicação.

Após a definição do mencionado ramo do Direito, passa-se a descrever os elementos das demonstrações contábeis, especialmente em razão de seu papel no reconhecimento e mensuração do lucro.

Os elementos das demonstrações contábeis são divididos em duas categorias: (i) aqueles que evidenciam a posição patrimonial da entidade (ativos, passivos e patrimônio líquido) e (ii) aqueles que evidenciam o seu desempenho (receitas e despesas).

Após a definição dos elementos que compõem as demonstrações contábeis, serão analisados os princípios contábeis geralmente aceitos, especificamente quanto ao reconhecimento e mensuração do lucro. Neste sentido, será estudado o dilema entre (i) a confiabilidade da informação contábil e (ii) sua relevância para os usuários, com reflexo na análise (i) do Princípio do Custo Original como Base de Valor e (ii) do Regime de Competência.

É importante destacar que a metodologia de análise desses conceitos tem como pressuposto que o processo contábil (reconhecimento, mensuração e evidenciação) deve ser analisado sob a perspectiva de redução da assimetria informacional que pode ocorrer, por exemplo, no conflito de agência (em especial o poder que administradores têm de manipular os denominados accruals - ajustes advindos do regime de competência).

Tendo sido feitas essas considerações sobre os elementos da contabilidade e sobre os princípios fundamentais diretamente relacionados ao reconhecimento e à mensuração do 
lucro para a Ciência Contábil, assim como a sua positivação por meio da legislação societária (Contabilidade Societária), passa-se a analisar o Direito Tributário, com suas regras próprias para a apuração da denominada Contabilidade Tributária, já traçando as bases para a aplicação das regras de tributação do lucro pelo imposto de renda.

\section{1 - Ciência Contábil como instrumento para Medição do PATRIMônio E do DESEMPENHo de UMA ENTIDAde}

\subsection{1 - Ciência Contábil - Objeto e Objetivo}

Antes de se verificarem as divergências entre as regras de apuração da Contabilidade Societária e da Contabilidade Tributária, bem como seu âmbito de aplicação e análise sistemática, é importante tecer alguns comentários acerca do objeto e do objetivo da

\section{Ciência Contábil.}

A Ciência Contábil é uma ciência social que tem como objeto o patrimônio da entidade (aspecto estático) e sua mutação no decorrer do tempo (aspecto dinâmico). Essa ciência social tem como objetivo fornecer aos usuários informações econômico-financeiras sobre (i) posição patrimonial e financeira, (ii) desempenho e (iii) mudanças na posição financeira de determinada entidade, que sejam úteis para a tomada de decisão de um grande número de usuários (CPC “00” - Estrutura Conceitual - item 12).

Com efeito, a Ciência Contábil oferece regras e princípios para orientar o registro e apuração do patrimônio de uma entidade em determinado momento, assim como a sua variação no tempo, por meio da apuração de lucro ou prejuízo (aspectos que refletem o seu desempenho). Assim, as informações apuradas por essa Ciência são essenciais para a tributação da renda, pois torna viável o reconhecimento e mensuração dos valores adotados como base de cálculo deste imposto (requisito de praticabilidade). Confira-se a seguinte figura ilustrativa:

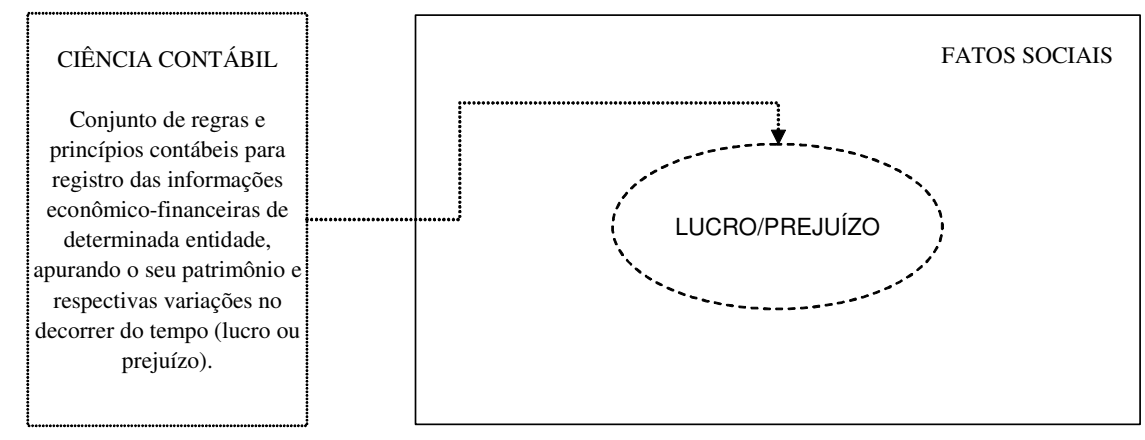


De fato, a figura anteriormente apresentada demonstra que a realidade (fatos sociais) é descrita pela linguagem contábil. Essa linguagem informará se houve lucro (acréscimo patrimonial) ou prejuízo (decréscimo patrimonial) em determinado período.

Em seguida, passa-se a analisar a metodologia utilizada para descrever as etapas compõem esse relato em linguagem, denominada processo contábil.

\subsection{2 - Processo Contábil}

Com base nos ensinamentos de Alexsandro Broedel Lopes e Eliseu Martins, o processo contábil corresponde ao relato de fatos econômicos em linguagem contábil, que ocorre em três etapas: (i) reconhecimento, (ii) mensuração e (iii) evidenciação. ${ }^{4}$

\subsubsection{1 - Reconhecimento}

$\mathrm{Na}$ etapa de reconhecimento, será feita a classificação de uma ação (fato social) de natureza econômica. Exemplificativamente, um gasto (sacrifício econômico de um recurso) pode ser classificado contabilmente como:

(i)

(ii) despesa (se consumido no processo de geração de uma receita - como é o caso do recurso sacrificado para o pagamento de despesas administrativas);

(iii) custo (se incorporado no processo produtivo de um ativo - o custo será registrado como um ativo, se a alienação ocorrer em exercícios futuros, como, por exemplo, o estoque de material para a construção de uma casa antes da venda); ou

(iv) perda (se o sacrifício do recurso não tiver como contrapartida uma receita - como, por exemplo, a perda de um bem em decorrência de um incêndio).

Em muitos casos, a classificação desses fatos é relativamente simples. Em outros, no entanto, ela gera alguma controvérsia. $\mathrm{Na}$ atividade de incorporação imobiliária, por exemplo, é comum que o lançamento de um prédio seja precedido da construção de um estande

\footnotetext{
${ }^{4}$ LOPES, Alexsandro Broedel e MARTINS, Eliseu. Teoria da Contabilidade: uma nova abordagem. São Paulo: Atlas, 2007, pp. 50-52.
} 
de vendas, do apartamento modelo, bem como aquisição de mobília e de itens de decoração. Esses gastos devem ser reconhecidos como um ativo ou uma despesa de venda/propaganda?

Neste exemplo, em face da grande divergência existente no mercado imobiliário, o Comitê de Pronunciamentos Contábeis emitiu a Orientação OCPC 01 (aprovado pela Deliberação CVM n ${ }^{\circ}$ 561/08), definindo que o estande de venda, o apartamento modelo e os itens de decoração (itens 14 a 19) devem ser reconhecidos como ativos e serão depreciados conforme sua vida útil, tendo em vista possuírem caráter tangível. Contudo, se a vida útil for inferior a 12 meses, tais gastos deverão ser reconhecidos diretamente como despesas de vendas. Se houver parcelas recuperadas (venda de mobílias ou de partes do estande de vendas), tais valores devem ser registrados como redutores do custo desses itens.

\subsubsection{2 - Mensuração}

$\mathrm{Na}$ etapa de mensuração, depois de ocorrida a classificação dos fatos de natureza econômica (reconhecimento), será definida a sua base de valoração. É nesta etapa que se decide, por exemplo, como será mensurado o ativo de uma empresa: (i) pelo custo histórico? (ii) pelo valor de mercado ou valor justo? (iii) qual é a base temporal para a amortização, depreciação ou exaustão?

Neste sentido, a Orientação OCPC 01 (item 19) determina a obrigatoriedade de se avaliar, no mínimo, no fim de cada exercício social, se há alguma indicação de que um ativo possa ter sofrido desvalorização. Se houver, a entidade deve estimar o valor recuperável do ativo. Como critério de mensuração, estabelece a OCPC 01 que consideram-se desvalorizados os estandes de vendas no momento em que parte substancial das unidades estiverem vendidas ou por ocasião do término de seu uso.

\subsubsection{3 - Evidenciação}

Por fim, na etapa de evidenciação é que se irá demonstrar, aos usuários externos à entidade, os processos de reconhecimento e mensuração. Em muitos casos, as informações econômico-financeiras encontram-se evidenciadas nas próprias demonstrações financeiras (ou seja, será uma decorrência de estarem reconhecidas e mensuradas).

Contudo, muitas vezes, a evidenciação será complementar aos processos de reconhecimento e mensuração, hipóteses em que as notas explicativas são de fundamental importância. Neste sentido, há níveis distintos de evidenciação para cada usuário: (i) para os 
investidores, no mercado de capitais, há um elevado nível de exigência de informações, especialmente as complementares em notas explicativas (necessárias para a análise de expectativa futura de retorno do investimento); (ii) para o Fisco, são exigidas informações especialmente sobre os critérios de reconhecimento e mensuração das mutações patrimoniais.

\subsubsection{4 - Processo Contábil e Direito}

Como se percebe, dentro do processo contábil, é nas etapas de reconhecimento e mensuração dos fatos econômicos que se deve concentrar a pesquisa acerca das regras e princípios que orientam a identificação do patrimônio contábil e sua mutação no tempo (lucro ou prejuízo).

Essas regras e princípios, conforme se verá, são fundamentais para a identificação do conceito de renda para fins fiscais e os critérios para sua realização, estudados no Capítulo 1. Verifica-se, portanto, a importância do estudo interdisciplinar da Ciência Contábil e do Direito, já que ambas as ciências possuem objetos semelhantes, embora partam de princípios e pressupostos distintos.

Assim sendo, destaque-se a visão do processo contábil proposta por Alexsandro Broedel Lopes e Eliseu Martins: ${ }^{5}$

“O processo contábil é composto pelas etapas de reconhecimento, mensuração e evidenciação das atividades econômicas, sendo resultado de um amplo conjunto de forças econômicas, sociais, institucionais e políticas. Essas forças delineiam as principais características do processo contábil tendo em vista o grau de influência dos agentes interessados em sua evolução.

Dessa forma, o processo contábil e suas etapas, dentro de nossa visão, são resultado do ambiente social, econômico e político que os rodeiam. Para nós, a contabilidade não é uma ciência exata, que possui valores exatos e verdades absolutas. Ao invés de tentar buscar essa crença, neste trabalho tentaremos entender as principais forças definidoras do processo contábil e como elas impactam as suas características. $\boldsymbol{O}$ arcabouço legal é uma das principais forças, senão a mais importante, que influenciam o processo contábil." (g.n)

Nesta perspectiva, é importante destacar, ainda, que as forças definidoras do processo contábil terão maior ou menor peso na apuração do resultado de uma entidade. As normas jurídicas possuem papel fundamental nesse processo, mas os usuários da contabilidade também exercem grande influência no reconhecimento e mensuração desse lucro. 


\subsection{3 - Conflito de Interesses entre Usuários das Informações Contábeis (Conflito de Agência)}

Outro aspecto importante a se destacar é o papel que usuários (agentes) exercem no reconhecimento e mensuração do resultado de uma entidade:

(i) acionistas - possuem interesse nas informações contábeis, especialmente para fins de (a) análise de desempenho e (b) distribuição de dividendos;

(ii) administradores - buscam relatórios contábeis com dados confiáveis e úteis para que possam decidir como conduzir os negócios de acordo com a realidade econômica da entidade, mas também têm interesse em apresentar o melhor resultado possível e, assim, demonstrar eficiência na condução dos negócios e aumentar a remuneração por participação nos lucros (tendem a aceitar riscos maiores);

(iii) credores - analisam informações contábeis para avaliação de risco na concessão de crédito e tendem a interpretar tais informações de forma mais conservadora, para preservar o patrimônio da empresa em caso de eventual inadimplência;

(iv) Fisco - utiliza as informações contábeis para apurar e cobrar tributos, motivo pelo qual tende a exigir o reconhecimento antecipado dos resultados, para fins de aumento de arrecadação, ou postergado, quando estabelece benefícios fiscais.

Com efeito, como são diversos os usuários das informações contábeis, diversos são os interesses envolvidos (conflito de agência). ${ }^{6}$ Esses interesses muitas vezes giram em torno do momento em que se considera realizado o lucro. Por exemplo: (i) os credores desejam que o devedor postergue o reconhecimento do lucro (para evitar a distribuição de dividendos antes de quitada a dívida) - tendência para conservadorismo; (ii) os administradores desejam que o lucro seja antecipado (para melhorar a avaliação de desempenho da entidade e, consequentemente, eficiência de sua gestão e pagamento de participação nos lucros) - tendência para menor conservadorismo; (iii) os sócios/acionistas podem querer antecipar lucros em determinados momentos (para distribuir dividendos) ou postergá-los (para postergar a tributação da renda).

\footnotetext{
${ }^{5}$ LOPES, Alexsandro Broedel e MARTINS, Eliseu. Op. cit. (nota 4), p. 52.

${ }^{6}$ Sobre o tema, conferir LOPES, Alexsandro Broedel e MARTINS, Eliseu. Op. cit. (nota 4), pp. 28 e ss.
} 
É por isso que Fabio Konder Comparato menciona a política de balanço, para ressaltar o subjetivismo na apuração das demonstrações financeiras: ${ }^{7}$

“O balanço, como de resto toda a contabilidade, não pode jamais ser um simples reflexo de fatos econômicos, porque se trata de uma interpretação simbólica e, portanto, convencional da realidade. Os fatos econômicos não passam para os livros contábeis no estado bruto, mas são traduzidos, simbologicamente, em conceitos e valores; ou seja, são previamente estimados e valorados, segundo um critério determinado em função de uma finalidade específica. (...)

A exatidão matemática dos balanços, que o vulgo contempla admiravelmente, é mera coerência interna e recíproca de lançamentos em partidas dobradas, simples exatidão formal. Mas entre a realidade econômica e a sua tradução contábil interfere, necessariamente, um juízo de valor, uma estimativa axiológica, cuja imprecisão e contestabilidade jamais poderão ser suprimidas, porque inerentes ao próprio processo de conhecimento.

A verdade contábil é, pois, simplesmente relativa. O lucro de balanço, por exemplo, é uma realidade meramente contábil e abstrata. A ocorrência de lucros de exploração e o seu exato montante, a rigor, só podem ser verificados, realmente, quando a empresa se extingue e se apura o resultado final. 'Profits can never be determined with certainty until a business adventure has been completely liquidated except in the case where the returns have at least exceeded the capital originally invested (H.R. Hatfield, Accounting, Its Principles and Problems, Nova York, 1972, p. 254). Nem mesmo esta exceção é de ser admitida, pelo menos no que concerne ao montante do retorno sobre o capital investido, pois ele também resulta de um cálculo estimado e, portanto, necessariamente impreciso. (...)

Ademais, como traduzir em linguagem contábil o exato valor dos bens intangíveis, como o aviamento empresarial, as cartas-patentes de concessões e autorizações governamentais, o knowhow industrial ou comercial, os segredos de fabricação ou comercialização?

Tudo isso explica porque é perfeitamente admissível falar-se em 'política de balanço', em função de seus fins ( $f f$. Rosario Grillo, Il Bilancio dele Società per Azioni nella determinazzione de reddito economico e del reddito fiscale, Milão, 1969, v. I/126, 136, 154-155, 226). A lei, de resto, reconhece a existência de balanços distintos para finalidades específicas." (g.n.)

Tendo em vista os diversos interesses dos usuários das informações contábeis, fez-se necessário delimitar um conceito ideal de lucro do período, preocupação que predominou na academia contábil na década de 60, como destacam Roberto Quiroga Mosquera e Alexsandro Broedel Lopes ao comentar a corrente da tradição normativa. ${ }^{8}$

\footnotetext{
${ }^{7}$ COMPARATO, Fábio Konder. A Natureza Jurídica do Balanço. In Ensaios e Pareceres de Direito Empresarial. Rio de Janeiro: Forense, 1978, pp. 31 a 33.

${ }^{8}$ MOSQUERA, Roberto Quiroga, e LOPES, Alexsandro Broedel. O Direito Contábil. Fundamentos Conceituais, Aspectos da Experiência Brasileira e Implicações.. In MOSQUERA, Roberto Quiroga, e LOPES, Alexsandro Broedel (coord.). Controvérsias Jurídico-Contábeis (Aproximações e Distanciamentos). São Paulo : Dialética, 2010, pp. 69 e 70.
} 
Não obstante, foi na corrente teórica da abordagem da informação (information approach) que a Ciência Contábil passou a se preocupar efetivamente com esses conflitos de interesse, passando a focar em duas direções, correlacionadas e complementares: (i) verificar a relevância das informações para os investidores e outros usuários (capacidade de prever fluxos de caixa futuros) e (ii) investigar a eficiência relativa dos mercados. ${ }^{9}$

Como exemplo dessa divergência de enfoque, Alexsandro Broedel Lopes e Eliseu Martins ${ }^{10}$ destacam que, nos países em que a tradição normativa prevalece, há uma preferência para a aplicação do custo histórico corrigido para o registro de certos ativos (pois possui grande objetividade e certeza). Por outro lado, nos países em que predomina a abordagem informacional, tende-se a preferir o fair value (que demanda uma avaliação mais subjetiva, mas fornece informação muito mais útil ao usuário).

Assim, tal como exposto quanto ao princípio da realização da renda, também na Ciência Contábil é de grande relevância o momento em que se considera realizada uma receita ou uma despesa, para fins de alocação temporal do lucro e, então, efetuar a correta distribuição do resultado nos diversos períodos. Esse momento também estará inserido dentro do ciclo econômico da entidade, conforme o gráfico já mencionado no Capítulo 1 :

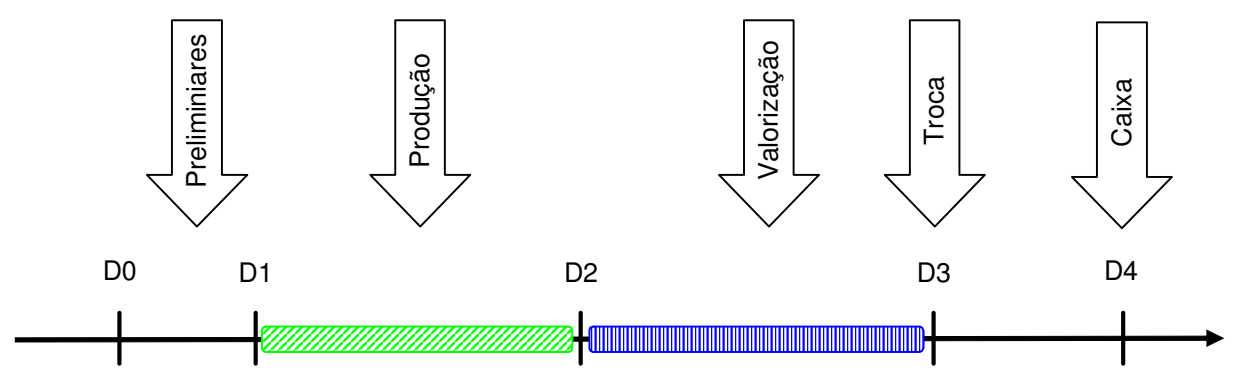

Conforme já destacado no gráfico acima, percebe-se que a geração do lucro está inserida em um ciclo econômico que tem duração prolongada no tempo. Com efeito, percebe-se que os primeiros esforços para a geração do lucro encontram-se nas atividades preliminares (v.g. realização de pesquisas e projetos). Na etapa de produção, inicia-se a efetiva transformação dos fatores de produção para a obtenção do produto a ser trocado no mercado, quando se terá a realização da integralidade do custo do produto, que pode ser denominado custo histórico.

\footnotetext{
${ }^{9}$ LOPES, Alexsandro Broedel e MARTINS, Eliseu. Op. cit. (nota 4), pp. 4 e 5.

${ }^{10}$ LOPES, Alexsandro Broedel e MARTINS, Eliseu. Op. cit. (nota 4), p. 53.
} 
O custo histórico é aferido com relativa facilidade, pois é geralmente gerado por meio de desembolsos de caixa, no caso de pagamento em dinheiro, ou por meio de sacrifício de outros ativos com custo de aquisição já registrado (no caso da permuta, por exemplo).

Uma vez produzido/adquirido o bem (v.g. fabricado, construído ou comprado), pode haver um transcurso de tempo até que ocorra a troca desse bem (por dinheiro ou outros ativos). Durante esse tempo, há uma valorização que nem sempre é facilmente mensurável. Em alguns casos, no entanto, é possível mensurar com segurança a mutação do valor de mercado no tempo, como ocorre com as commodities que possuem valor cotado em bolsa de valores e alta liquidez no mercado.

Na etapa de valorização, dentro do ciclo econômico, somente será reconhecida a alteração no valor do bem se houver segurança para a aferição de seu valor de mercado, com o correspondente reconhecimento dos ganhos/perdas (receitas ou despesas) em relação ao custo histórico.

Em outros casos, contudo, o valor de mercado somente será verificável com segurança no momento em que ocorrer a troca, em que o produto é vendido a terceiros e torna-se possível verificar com segurança o valor efetivamente pago (atribuído) àquele bem. Embora o ponto de troca seja o momento mais comum de reconhecimento da receita, existem casos especiais em que ela deverá ser reconhecida antes ou após esse momento, conforme será demonstrado a seguir.

Com efeito, devem-se procurar os critérios que regem esse processo contábil de reconhecimento e mensuração das informações pertinentes ao ciclo econômico de determinada entidade, de modo que a performance econômica seja adequadamente alocada em cada período de apuração.

Neste sentido, alguns princípios contábeis geralmente aceitos tratam diretamente dos critérios para a mensuração e reconhecimento do resultado alocado em cada período, em especial os derivados do regime de competência (princípio da realização da receita e da confrontação entre receitas e despesa) e o princípio do custo original como base de valor. Estes princípios devem ser ponderados, ainda, com os princípios da relevância e da objetividade. É nessa ponderação de princípios que reside grande parte da dificuldade enfrentada pelo aplicador da Ciência Contábil, em sua tarefa de reconhecimento e mensuração do lucro. 


\section{2 - Direito Contábil Societário e ApuraÇão do LuCro Comercial}

Conforme se pôde observar no capítulo anterior, a Ciência Contábil é um instrumento muito valioso para o relato de fatos econômicos que têm repercussão na apuração do patrimônio e sua variação no tempo. O Direito vale-se dos conceitos estabelecidos por essa Ciência para criação de normas jurídicas que regulamentam os interesses dos diversos usuários.

O conjunto de normas jurídicas que trata da apuração dos registros contábeis é o que se passa a denominar Direito Contábil, o qual se divide em dois principais sub-ramos: (i) Direito Contábil Societário e (ii) Direito Contábil Tributário. A partir das regras de cada um desses sub-ramos, será obtido um resultado contábil distinto e aplicável para os propósitos específicos a que se destinam.

De fato, o arcabouço das normas jurídico-contábeis está previsto na legislação comercial/societária. Segundo o artigo 177 da Lei 6.404/76 (Lei das S/A), as demonstrações financeiras das companhias devem estar em conformidade com a legislação comercial e societária e com os princípios de contabilidade geralmente aceitos, devendo observar métodos ou critérios contábeis uniformes no tempo e registrar as mutações patrimoniais, segundo o regime de competência.

Também determina o artigo 177 da Lei das S/A, em seu $\S 2^{\circ}$, que quaisquer disposições de leis tributárias ou outra legislação específica que tragam métodos ou critérios contábeis diferentes devem ser observadas em livros ou registros auxiliares.

Portanto, resta expressamente previsto na Lei das S/A que as regras contábeis nela estipuladas não podem sofrer a influência de outros ramos do Direito. No caso de regras divergentes, elas devem ser registradas em livros ou registros auxiliares.

Esse conjunto de normas comerciais/societárias, que regulamentam a contabilidade, é o que denominamos Direito Contábil Societário, por meio do qual se apura a Contabilidade Societária: 


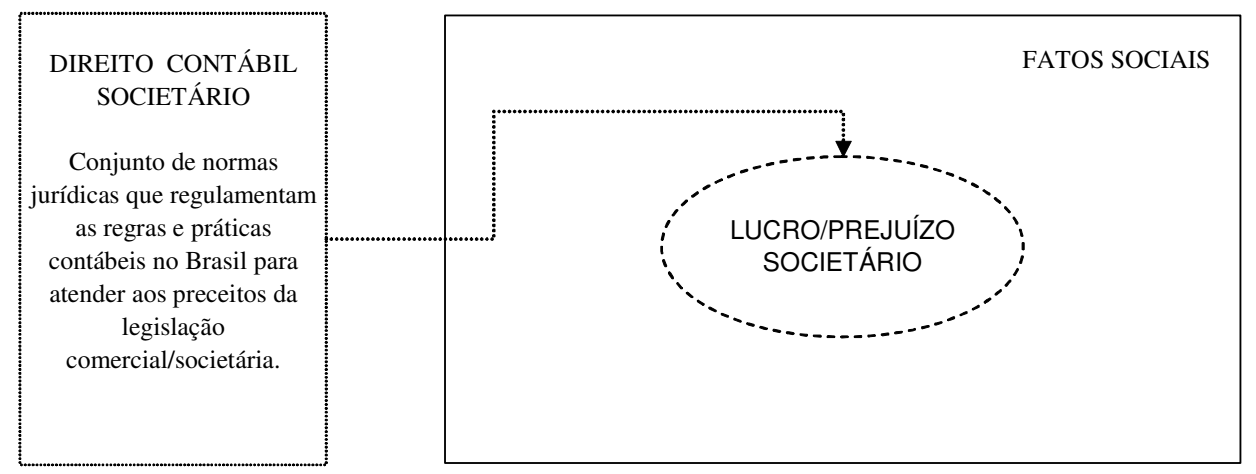

Embora esse ramo do Direito que não se confunda com a Ciência Contábil, ele se aproxima muito quando o artigo 177 da Lei das S/A torna obrigatória a obediência aos princípios de contabilidade geralmente aceitos.

Ressalte-se que o distanciamento entre a Ciência Contábil e o Direito Contábil Societário se tornou evidente com o advento da Lei $\mathrm{n}^{\circ} 11.638 / 07$, que teve por objetivo aproximar um pouco mais essas duas ciências, harmonizando as normas societárias com os princípios fundamentais e as melhores práticas contábeis internacionais. ${ }^{11}$

\section{Com efeito, a Ciência Contábil não será sempre utilizada como parâmetro} para fins de aplicação da legislação societária. De fato, admite-se que há pontos de intersecção entre essas duas ciências, mas o âmbito de aplicação da ciência contábil para a definição dos limites da legislação societária não é irrestrito, e existem hipóteses em que não são coincidentes.

Essas hipóteses de incongruência entre a Ciência Contábil e o Direito Contábil Societário, contudo, devem ser procuradas na própria legislação societária. Apenas a título ilustrativo, destaque-se que a conta de reserva de reavaliação, anteriormente prevista no $\S 3^{\circ}$ do

${ }^{11}$ Confira-se a exposição de motivos dessa Lei:

“A proposição tem por finalidade modernizar e harmonizar as disposições da lei societária em vigor com os princípios fundamentais e melhores práticas contábeis internacionais, o que constitui medida inadiável para uma inserção eficiente do Brasil no atual contexto de globalização econômica.

A idéia de se efetuar uma ampla revisão da lei societária surgiu como resultado de seminários promovidos pela CVM e que contaram com a participação de entidades públicas e privadas. Assim, a partir de amplo debate público e governamental, que conferiu alto grau de legitimidade ao processo, foi definida a redação final do Projeto ora encaminhado.

A reformulação proposta deve-se, portanto, à necessidade de se introduzir, na lei em vigor, modificações com o escopo de corrigir impropriedades e erros que remanesceram na lei societária desde a sua edição, em 1976, bem como adaptar a lei às mudanças sociais e econômicas decorrentes da evolução dos usos e costumes mercantis, objetivando o fortalecimento do mercado de capitais, mediante a implementacão de princípios, normas e padrões de contabilidade e auditoria reconhecidos internacionalmente. Dessa forma, será melhorada a qualidade das informações contábeis e, por conseguinte, a consistência do processo decisório de alocação de recursos, com vistas a promover o desenvolvimento econômico do país." (g.n.) 
artigo 182 da Lei das S/A, foi revogada pela Lei ${ }^{\circ} 11.638 / 07$, eliminando a possibilidade de a empresa reavaliar seus ativos de forma espontânea, sem o trânsito desse valor pelo resultado.

Conforme destacado no Manual de Contabilidade Societária FIPECAFI, a eliminação dessa conta do patrimônio líquido está em desacordo com as normas internacionais, mas foi motivada pelo abuso com que era utilizada no Brasil: ${ }^{12}$

\footnotetext{
"A Lei $n^{\circ}$ 11.638/76 eliminou a possibilidade, introduzida pela Lei $n^{\circ}$ 6.404/76, de uma empresa, de forma espontânea, avaliar os ativos por seu valor de mercado quando este é superior ao custo, ou seja, de se proceder á Reavaliação. Não se pode confundir esse procedimento com a Correção Monetária, que é tão somente a atualização monetária do custo de aquisição, em que continua o vínculo ao preço pago pelo ativo. Na Reavaliação, abandona-se o custo (ou o custo corrigido) $e$ utiliza-se basicamente como fundamento o valor de reposição do ativo em questão.
}

Tal eliminação está em desacordo com as normas internacionais que permitem esse tipo de procedimento. Entretanto, o principal motivador para a impossibilidade de realização de novas reavaliações no Brasil foi o mau uso desse mecanismo. São muitos os exemplos de empresas que procederam a reavaliação de seus ativos para transformar Patrimônios Líquidos negativos em positivos, para diminuir os dividendos a serem distribuídos, para conseguir concordata ou algum tipo de favorecimento jurídico, ou até mesmo participar de concorrência públicas.” (g.n.)

Também deve-se ressaltar que as demonstrações contábeis feitas para fins gerenciais não precisam ser necessariamente elaboradas em conformidade com a legislação societária, o que também demonstra que a Ciência Contábil possui campo de atuação distinto.

De qualquer forma, independentemente da existência de incongruências entre a Ciência Contábil e o Direito Contábil Societário, é possível afirmar que hoje essas duas Ciências estão muito próximas. Essa proximidade decorre da absorção pelo Direito Societário de conceitos da Ciência Contábil, especialmente: (i) dos princípios contábeis geralmente aceitos e (ii) dos padrões internacionais de contabilidade, conforme se passa a demonstrar.

\subsection{1 - Produção Normativa Contábil - Convergência com os Padrões Internacionais}

Após a análise do objeto da Ciência Contábil (elaboração organizada e sistematizada de informações econômico-financeiras acerca do patrimônio de uma entidade e sua variação no tempo), verifica-se a sua vocação para servir como elemento de prova. Assim,

\footnotetext{
${ }^{12}$ IUDÍCIBUS, Sérgio de, MARTINS, Eliseu, GELBECKE, Ernesto Rubens, SANTOS, Ariovaldo dos. Manual de Contabilidade Societária - Aplicável a Todas as Sociedades - de Acordo com as Normas Internacionais e do $C P C$. FIPECAFI - Fundação Instituto de Pesquisas Contábeis, Atuariais e Financeiras, FEA/USP, São Paulo:
} 
é natural que o Direito venha a estabelecer normas jurídicas para regulamentar essa

atividade, de forma a conferir maior precisão e confiabilidade aos registros contábeis, garantindo maior segurança para seus usuários.

Essa vocação é histórica e está intimamente relacionada com o desenvolvimento do Direito Mercantil, como afirma Antonio Lopo Martinez: ${ }^{13}$

“Já no mundo antigo, o Direito utilizava os informes contábeis como meio probatório nos contratos de crédito. Com o surgimento do Direito Mercantil, durante a Idade Média, nas prósperas cidades italianas, o Direito passa a normatizar de forma mais aprofundada a Contabilidade. O Direito, nessa fase da história, regulamentou as formas pelas quais a técnica contábil poderia ser utilizada como meio de prova, e instituiu a obrigação da escrituração contábil, atitude que se conserva até os nossos dias.

Desde o final do século XVIII, no campo do Direito Público, em particular do Direito Tributário, a técnica contábil se converteu no instrumento mais usado para computar os créditos fiscais e para a satisfação das necessidades do erário. Outros ramos do Direito (penal, trabalhista e civil) utilizam as técnicas contábeis para seus objetivos particulares, pela legislação expressa que trata de aspectos contábeis."

No Brasil, a obrigatoriedade para os comerciantes de seguir uma ordem uniforme de contabilidade e escrituração e manter os livros necessários para esses fins surgiu com o Código Comercial de 1850 (Lei ${ }^{\circ} 556 / 1850$ ), nos seus artigos 10 a $20 .{ }^{14}$

Uma regulamentação mais abrangente da contabilidade somente foi realizada pela primeira Lei das S/A (Decreto-Lei $n^{\circ}$ 2.627/40) que, nos artigos 129 e 135, trouxe, por exemplo, importantes normas sobre a forma de apuração do balanço, avaliação de ativos, criação de reservas, apuração e distribuição de lucros, entre outras.

Como se verifica, o arcabouço das normas contábeis está previsto na legislação comercial/societária. Contudo, a legislação tributária acabou exercendo grande influência sobre as regras e práticas contábeis no Brasil. Isto se deve ao fato de que, dentre as diversas funções da contabilidade, a sua utilização como instrumento para apuração de tributos acaba se sobressaindo, especialmente em razão do grande poder coercitivo do Fisco. ${ }^{15}$

Atlas, 2010, p. 378.

${ }^{13}$ MARTINEZ, Atonio Lopo, A Linguagem Contábil no Direito Tributário, Dissertação de Mestrado em Direito, São Paulo: PUC-SP, 2002, p. 39.

14 “Art. 10 - Todos os comerciantes são obrigados:

1 - a seguir uma ordem uniforme de contabilidade e escrituração, e a ter os livros para esse fim necessários;(...)

4 - a formar anualmente um balanço geral do seu ativo e passivo, o qual deverá compreender todos os bens de raiz móveis e semoventes, mercadorias, dinheiro, papéis de crédito, e outra qualquer espécie de valores, e bem assim todas as dívidas e obrigações passivas; e será datado e assinado pelo comerciante a quem pertencer."

15 "A Contabilidade sempre foi muito influenciada pelos limites e critérios fiscais, particularmente os da legislação 
Portanto, as regras tributárias têm, como finalidade, atender aos preceitos de arrecadação estabelecidos pelo sistema tributário nacional. O sistema tributário, por sua vez, é influenciado por princípios e garantias constitucionais que não coincidem, necessariamente, com as necessidades comerciais/societárias e com os princípios da contabilidade.

Este problema tentou ser equacionado pela atual Lei das S/A (Lei ${ }^{\circ}$ 6.404/76), que trouxe regras contábeis mais abrangentes, aplicáveis não só às sociedades por ações, como também às demais sociedades. ${ }^{16}$ Segundo o mencionado artigo 177 dessa Lei, as demonstrações financeiras das companhias devem estar em conformidade com a legislação comercial, societária e com os princípios de contabilidade geralmente aceitos.

Também determinou o artigo 177 da Lei das S/A, em seu $\S 2^{\circ}$, que quaisquer disposições de leis tributárias ou outra legislação específica que trouxessem métodos ou critérios contábeis diferentes deveriam ser observadas em registros auxiliares.

No entanto, a simples previsão legal de que os lançamentos contábeis, determinados pela legislação tributária, deveriam ser observados em registros auxiliares não foi suficiente para que a prática contábil no Brasil continuasse sendo realizada em conformidade com as regras tributárias. Como exemplo, cita-se a observância dos prazos preestabelecidos pela legislação tributária para depreciação de ativos, os quais quase sempre são diferentes daqueles que seriam apuráveis pelo regime de competência. Contudo, mesmo que o registro da depreciação em conformidade com os critérios tributários estivesse em desacordo com o regime de competência, esse era o critério mais utilizado para a elaboração das demonstrações financeiras no Brasil.

Este fato se justifica pela influência do Fisco sobre fiscalização das demonstrações contábeis das empresas no Brasil, sem outra fonte relevante de influência que fizesse com que as empresas elaborassem suas demonstrações totalmente independentes das regras fiscais.

de Imposto de Renda. Esse fato, ao mesmo tempo que trouxe à Contabilidade algumas contribuições importantes e de bons efeitos, limita a evolução dos Princípios Fundamentais da Contabilidade ou, ao menos, dificulta a adoção prática de princípios contábeis adequados, já que a Contabilidade era feita pela maioria das empresas com base nos preceitos e formas de legislação fiscal, a qual nem sempre se baseava em critérios contábeis corretos." (IUDÍCIBUS, Sérgio de, MARTINS, Eliseu e GELBKE, Ernesto Rubens, Manual de Contabilidade das Sociedades por Ações (aplicável às demais sociedades), FIPECAFI - Fundação Instituto de Pesquisas Contábeis, Atuariais e Financeiras, $7^{\mathrm{a}}$ ed., $4^{\mathrm{a}}$ reimpr., São Paulo: Atlas, 2008, p. 5.

${ }^{16}$ De fato, conforme já mencionado, desde 1977 é obrigatória a adoção da Lei ${ }^{\circ}$ 6.404/76 para fins de apuração do lucro líquido de todos os contribuintes brasileiros, uma vez que o Decreto-lei $\mathrm{n}^{\circ} 1.598 / 77$, em seu artigo 67, inciso XI, determinou que "o lucro líquido do exercício deverá ser apurado, a partir do primeiro exercício social iniciado após 31 de dezembro de 1977, com observância das disposições da Lei $n^{\circ}$ 6.404, de 15 de dezembro de 1976." Com esse dispositivo legal, a norma de Direito Tributário estendeu a todos os tipos de sociedades as normas contábeis estabelecidas pela Lei $n^{\circ}$ 6.404/76, que tinha aplicação restrita às sociedades anônimas. 
Tendo em vista essa cultura contábil então dominante no Brasil, sobreveio a Lei ${ }^{\circ}$ 11.638/07, que teve como objetivo a convergência das normas contábeis brasileiras com os padrões internacionais de contabilidade, adotados nos principais mercados de valores mobiliários. Dentre as alterações promovidas pela referida Lei, destaca-se a grande importância dada à CVM como órgão de normatização e fiscalização da adoção das práticas contábeis internacionais. Com isso, surgiu uma nova força para fazer frente à influência do Fisco sobre a prática contábil no Brasil.

Com efeito, estabeleceu a Lei 11.638/07 que as companhias abertas são obrigadas a observar as normas contábeis expedidas pela CVM em suas demonstrações financeiras (auditadas por auditores independentes) e, para as companhias fechadas, foi estabelecida a faculdade de sua adoção. ${ }^{17}$ Também foi estabelecido por essa Lei que as companhias de grande porte, independentemente da sua forma de constituição, estão obrigadas a obedecer a referidas normas. ${ }^{18}$

Quanto à produção normativa contábil pela CVM, ressalte-se que a sua competência deve ser exercida de forma a aplicar os padrões internacionais de contabilidade. Esses padrões estão regulamentados nos IFRS (International Financial Reporting Standards), que têm sido utilizados por diversos países como instrumento para atingir o objetivo de harmonização ou convergência. Os IFRS são estabelecidos pelo IASB (International Accounting Standards Board), que é responsável pela edição das regras contábeis internacionais.

\footnotetext{
${ }^{17}$ Lei das S/A com redação dada pela Lei no 11.638/07:

"Art. 177 (...)

$\S 3^{\circ}$ As demonstrações financeiras das companhias abertas observarão, ainda, as normas expedidas pela Comissão de Valores Mobiliários, e serão obrigatoriamente auditadas por auditores independentes registrados na mesma comissão.(...)

$\S 5^{\circ}$ As normas expedidas pela Comissão de Valores Mobiliários a que se refere o $\S 3^{\circ}$ deste artigo deverão ser elaboradas em consonância com os padrões internacionais de contabilidade adotados nos principais mercados de valores mobiliários.

$\S 6^{\circ}$ As companhias fechadas poderão optar por observar as normas sobre demonstrações financeiras expedidas pela Comissão de Valores Mobiliários para as companhias abertas.

18 "Art. $3^{-}$Aplicam-se às sociedades de grande porte, ainda que não constituídas sob a forma de sociedades por ações, as disposições da Lei $\mathrm{n}^{\circ}$ 6.404, de 15 de dezembro de 1976 , sobre escrituração e elaboração de demonstrações financeiras e a obrigatoriedade de auditoria independente por auditor registrado na Comissão de Valores Mobiliários.

Parágrafo único. Considera-se de grande porte, para os fins exclusivos desta Lei, a sociedade ou conjunto de sociedades sob controle comum que tiver, no exercício social anterior, ativo total superior a $R \$ 240.000 .000,00$ (duzentos e quarenta milhões de reais) ou receita bruta anual superior a $\mathrm{R} \$ 300.000 .000,00$ (trezentos milhões de reais)."
} 
A adoção dos IFRS no Brasil se deu por meio dos Pronunciamentos Técnicos do Comitê de Pronunciamentos Contábeis (os Pronunciamentos CPC) ${ }^{19}$ que ganham força jurídico-normativa por meio de sua aprovação em Deliberações da CVM. ${ }^{20}$

Portanto, por força do $\S 3^{\circ}$ do artigo 177 da Lei das S/A, conjugado com o artigo 10-A da Lei $n^{\circ} 6.385 / 76$, a CVM emite deliberações aprovando os pronunciamentos técnicos do CPC, os quais são elaborados em conformidade com os padrões internacionais de contabilidade. Essas deliberações, por força de expresso dispositivo legal, são de observância obrigatória pelas empresas de capital aberto e de grande porte no Brasil, mas também devem ser observadas pelas demais sociedades, por serem adotadas pelo Conselho Federal de Contabilidade (são, portanto, obrigatórias para todos os profissionais de contabilidade).

Com efeito, é possível se dizer que as normas estabelecidas pela CVM, que regulamentam a aplicação dos padrões internacionais de contabilidade, são obrigatórias para a apuração do lucro líquido das empresas no Brasil, podendo gerar reflexos na apuração da base de cálculo do imposto sobre a renda.

Ressalte-se, nesse sentido, que há outros casos em que a legislação infralegal pode delimitar os aspectos concretos de apuração do fato gerador de tributos previsto em Lei, como se verifica na apuração dos conceitos de atividade preponderante e grau de risco leve, médio e grave para fins de incidência do Seguro Acidente do Trabalho - SAT (artigo 22 da Lei ${ }^{\circ}$ $8.212 / 91) .^{21}$

\footnotetext{
${ }^{19}$ Nos termos da Resolução CFC n ${ }^{\circ} 1.055 / 05$ (que cria o Comitê de Pronunciamentos Contábeis), o órgão é composto pelas seguintes entidades:

a- ABRASCA - Associação Brasileira das Companhias Abertas;

b- APIMEC NACIONAL - Associação dos Analistas e Profissionais de Investimento do Mercado de Capitais;

c- BOVESPA - Bolsa de Valores de São Paulo;

d- CFC - Conselho Federal de Contabilidade;

e- IBRACON - Instituto dos Auditores Independentes do Brasil;

f- FIPECAFI - Fundação Instituto de Pesquisas Contábeis, Atuarias e Financeiras.

E possui como objetivo (artigo $3^{\circ}$ ) o estudo, o preparo e a emissão de Pronunciamentos Técnicos sobre procedimentos de Contabilidade e a divulgação de informações dessa natureza, para permitir a emissão de normas pela entidade reguladora brasileira, visando à centralização e uniformização do seu processo de produção, levando sempre em conta a convergência da Contabilidade Brasileira aos padrões internacionais.

${ }^{20}$ Lei no ${ }^{\circ} 6.385 / 76$, com redação dada pela Lei no $111.638 / 07$ :

“Art. 10-A. A Comissão de Valores Mobiliários, o Banco Central do Brasil e demais órgãos e agências reguladoras poderão celebrar convênio com entidade que tenha por objeto o estudo e a divulgação de princípios, normas e padrões de contabilidade e de auditoria, podendo, no exercício de suas atribuições regulamentares, adotar, no todo ou em parte, os pronunciamentos e demais orientações técnicas emitidas.

Parágrafo único. A entidade referida no caput deste artigo deverá ser majoritariamente composta por contadores, dela fazendo parte, paritariamente, representantes de entidades representativas de sociedades submetidas ao regime de elaboração de demonstrações financeiras previstas nesta Lei, de sociedades que auditam e analisam as demonstrações financeiras, do órgão federal de fiscalização do exercício da profissão contábil e de universidade ou instituto de pesquisa com reconhecida atuação na área contábil e de mercado de capitais."

21 "Os riscos de acidente de trabalho devem ser cobertos pelas empresas que expõem os seus empregados a
} 
Contudo, o poder de regulamentação das normas estabelecidas pela CVM não é absoluto, pois deve estar dentro do campo de atuação delimitado pela Lei das S/A, sob pena de ilegalidade do dispositivo. Seus efeitos tributários também não serão automáticos, pois depende da análise do Regime Tributário de Transição - RTT (conforme será demonstrado no Capítulo 5.2.1.1), bem como dos princípios constitucionais tributários.

Ante o exposto, depois de estabelecida a forma pela qual os conceitos da Ciência Contábil são positivados por meio de normas jurídicas de Direito Societário, é importante se descreverem os elementos que compõem as demonstrações contábeis, pois constituem conceitos pressupostos e fundamentais para o perfeito entendimento dos critérios de reconhecimento e mensuração do lucro.

\section{3 - Elementos das demonstrações Contábeis - Pressupostos para RECONHECIMENTO E MENSURAÇÃo do LuCRO CONTÁBIL}

Conforme exposto anteriormente, o primeiro passo para a apuração do lucro contábil é dado na etapa de reconhecimento, momento em que os eventos de natureza econômica são classificados de acordo com os diversos elementos previstos nas demonstrações contábeis de uma entidade.

Os eventos de natureza econômica que têm maior importância para a tributação da renda são registrados em lançamentos contábeis classificados em duas espécies de demonstração financeira: (i) as que registram a posição patrimonial e financeira da entidade e (ii) as que registram o desempenho da entidade durante determinado período. ${ }^{22}$

atividades que o provoquem. Não há porque repassar o financiamento à sociedade como um todo. Assim sendo, é
legítima a lei que transfere ao regulamento a competência para preencher o conceito indeterminado nela
previsto. Ninguém conhece previamente e a lei formal não poderia determinar o conceito de risco leve, médio ou
grave, tanto mais que tal conceito é cambiante, estando ao sabor do crescimento das atividades econômicas e do
desenvolvimento tecnológico.
Cremos que as normas complementares administrativas não desbordaram os limites traçados pelo Legislador.
Simplesmente enquadraram centenas de atividades econômicas no quadro legal das alíquotas (de 1 a $3 \%$ ),
distribuindo-as segundo o grau de risco individualmente considerado. Não parece, de modo geral, que o
regulamento tenha ofendido o princípio da razoabilidade. Classificou, por exemplo, no grau 1 (riscos leves), o
comércio varejista e os escritórios de advocacia; no grau 2 (riscos médios), a indústria têxtil e a tecelagem; no
grau 3 (riscos graves), a agricultura, a criação de gado, a extração de mármore e a indústria petrolífera.
Extravasaria a sua competência a Administração se, por suposição, optasse pelo enquadramento dos escritórios
de advocacia entre as empresas de risco grave e incluísse a notória e potencialmente poluidora indústria de
petróleo no ricos leve." TORRES, Ricardo Lobo. Legalidade Tributária e Riscos Sociais. In Revista Dialética de
Direito Tributário $n^{\circ} 59$, pp. 104 e 105 .
O STF já se mostrou favorável a esse entendimento no julgamento do RE 343.446/SC, Relator Ministro Carlos
Velloso, Tribunal Pleno, publicado no DJU de 04/04/2003, p. 40)
22 Poderia ainda ser citada a demonstração das mutações da posição financeira (como a demonstração de fluxo de 
A primeira espécie de lançamentos contábeis é registrada no Balanço Patrimonial (BP), que é o demonstrativo contábil que irá evidenciar os aspectos da posição patrimonial e financeira da entidade em determinada data. Por isso, pode-se afirmar que o BP é uma "fotografia", uma vez que reflete uma avaliação do patrimônio em determinada data (posição estática).

A segunda espécie de lançamentos contábeis é registrada na Demonstração do Resultado do Exercício (DRE), na qual são registrados os eventos econômicos relacionados ao desempenho da entidade em determinado período, o que irá refletir o acréscimo (lucro) ou o decréscimo (prejuízo) da posição patrimonial ocorrida entre dois pontos diferentes no tempo. Com efeito, costuma-se comparar a DRE com um "filme", pois ela destaca os eventos econômicos que ocorreram no decorrer do período (posição dinâmica).

Nos termos da Lei das S/A (artigo 176, incisos I e III), tanto o BP quanto a DRE são demonstrações financeiras obrigatórias e devem exprimir com clareza a situação do patrimônio da companhia e as mutações ocorridas no exercício.

A seguir, passa-se a descrever os elementos previstos em cada uma das demonstrações financeiras, uma vez que essa descrição é fundamental para o entendimento do conceito de lucro contábil, bem como para a aplicação dos critérios apropriados de reconhecimento e mensuração.

\subsection{1 - Balanço Patrimonial (BP) - Posição Patrimonial e Financeira}

O BP é a demonstração financeira que tem por objetivo apresentar a posição patrimonial e financeira de uma entidade em determinado momento ("fotografia"). Nessa demonstração, são apresentados 3 elementos distintos: (i) ativo, (ii) passivo e (iii) patrimônio líquido (artigo 178 da Lei das S/A).

\subsubsection{1 - Conceito de Ativo}

Sobre o conceito de ativo, assim define o CPC "00" (Pronunciamento Conceitual Básico - aprovado pela Deliberação CVM no 539/08):

“(i) $\underline{\text { Ativo }}$ é um recurso controlado pela entidade como resultado de eventos passados e do qual se espera que resultem futuros benefícios econômicos para a entidade."

caixa), mas essa demonstração não traz nenhum elemento novo além dos previstos no Balanço Patrimonial e na 
No que concerne ao conceito de ativo apresentado pelo CPC “00”, é importante destacar que o benefício econômico futuro a que ele se refere é o potencial para contribuir, direta ou indiretamente, para o fluxo de caixa ou equivalentes de caixa.

Assim, o CPC "00" apresenta alguns exemplos de como os benefícios econômicos futuros de um ativo podem fluir para a entidade. Nestes exemplos, os ativos podem ser: (a) usados isoladamente ou em conjunto com outros ativos na produção de mercadorias e serviços a serem vendidos pela entidade; (b) trocados por outros ativos; (c) usado para liquidar um passivo; ou (d) distribuído aos proprietários da entidade.

Ressalte-se que, para fins contábeis, a propriedade do bem não é essencial para que se reconheça tal bem como um ativo da entidade. Portanto, se o controle dos benefícios econômicos do bem está à disposição da entidade, este bem será um ativo independentemente da propriedade jurídica sobre ele (v.g. arrendamento financeiro, em que a essência e a realidade econômica demonstram que a arrendatária pode usar e fruir dos benefícios econômicos pertinentes à maior parte da vida útil do bem, pagando como contraprestação um valor muito próximo do seu valor justo, acrescido do respectivo encargo financeiro confira-se o Capítulo 4.4.1).

Entretanto, para que exista o controle de benefícios econômicos sobre determinado bem, deve haver necessariamente algum lastro jurídico que garanta o referido benefício, o que pode ser um direito subjetivo (v.g. decorrente de um contrato de aluguel ou arrendamento) ou um direito real (v.g. posse ou propriedade). Portanto, um bem somente irá compor o ativo de uma entidade caso esteja amparado por uma proteção jurídica decorrente de um direito subjetivo ou um direito real.

Com efeito, os ativos são os bens e direitos que estão à disposição da administração da entidade e que possuem potencial de, direta ou indiretamente, gerar fluxos de caixa futuros.

Para as pessoas jurídicas, a finalidade de obter lucro deixa mais clara essa característica. Todos os ativos de uma pessoa jurídica são adquiridos com a finalidade de obtenção de receitas no futuro, que superem o valor dos ativos sacrificados em troca. A esse respeito, ensinam Sérgio de Iudícibus, José Carlos Marion e Ana Cristina de Faria:23

"Dinheiro é o ativo por excelência. Temporariamente, nos contentamos em ter ativos sob outra

Demonstração do Resultado do Exercício (CPC “00” - §47).

${ }^{23}$ IUDÍCIBUS, Sérgio de, MARION, José Carlos e FARIA, Ana Cristina de, Introdução à Teoria da 
forma, a fim de, no futuro, termos mais dinheiro, que é, em última análise, o que interessa aos acionistas.

Ativo, portanto, pode ser conceituado como algo que possui um potencial de serviços em seu bojo, para a entidade, capaz, direta ou indiretamente, imediata ou no futuro, de gerar fluxos de caixa."

Segundo o disposto na Lei das S/A (artigo 179), os ativos devem ser classificados no BP como: (i) ativo circulante - as disponibilidades, os direitos realizáveis no curso do exercício social subsequente e as aplicações de recursos em despesas do exercício seguinte; (ii) ativo realizável a longo prazo - os direitos realizáveis após o término do exercício seguinte; (iii) investimentos - as participações permanentes em outras sociedades e os direitos de qualquer natureza, não classificáveis no ativo circulante, e que não se destinem à manutenção da atividade da companhia ou da empresa; (iv) ativo imobilizado - os direitos que tenham por objeto bens corpóreos destinados à manutenção das atividades da companhia ou da empresa ou exercidos com essa finalidade, inclusive os decorrentes de operações que transfiram à companhia os benefícios, riscos e controle desses bens; (v) intangível - os direitos que tenham por objeto bens incorpóreos destinados à manutenção da companhia ou exercidos com essa finalidade, inclusive o fundo de comércio adquirido.

\subsubsection{2 - Conceito de Passivo}

Outro elemento fundamental para a demonstração da posição patrimonial da entidade é o passivo. Sobre o conceito de passivo, define o CPC “00” que:

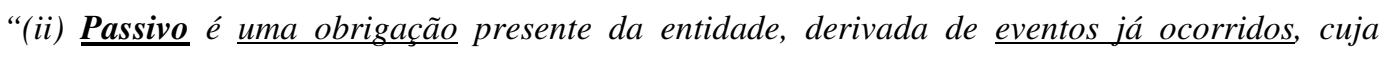
liquidação se espera que resulte em saída de recursos capazes de gerar benefícios econômicos.”

Conforme se verifica da definição acima, os passivos são obrigações presentes da entidade que correspondem ao dever de dar, fazer ou não fazer alguma coisa. Tais obrigações podem surgir por meio de leis (como é o caso dos impostos) ou de contratos (como compra de um bem com pagamento a prazo).

Os passivos também decorrem de eventos já ocorridos como, por exemplo, quando a entidade adquire um ativo (v.g. compra de um bem) para pagamento a prazo, o passivo correspondente (contas a pagar) somente será registrado na contabilidade quando o ativo for recebido. $\mathrm{O}$ registro de um ativo antes da entrega somente ocorre se houver um acordo irrevogável de aquisição desse ativo. 
Assim, o recebimento de ativos ou o uso de serviços resultam no registro de um passivo (contas a pagar). Da mesma forma, o recebimento de um empréstimo resulta em obrigação de pagá-lo (passivo).

Em alguns casos, contudo, os passivos decorrem de práticas usuais de negócios da entidade, que geram a expectativa em seus clientes (por exemplo, o oferecimento de uma garantia estendida além do prazo previsto legal ou contratualmente). Com efeito, diferentemente do que se afirmou para os ativos, os passivos não decorrem exclusivamente de obrigações jurídicas, mas também surgem em decorrência de expectativas do mercado em face de práticas reiteradas.

A extinção dos passivos (obrigações) ocorre, geralmente, mediante a utilização de recursos capazes de gerar benefícios econômicos (fluxos de caixa), suficientes para satisfazer o direito da outra parte. Contudo, também há outras hipóteses de extinção como a novação, o perdão da dívida e o perecimento da obrigação pelo transcurso do tempo (decadência e prescrição).

Segundo o CPC “00”, são exemplos de formas de extinção da obrigação presente: (a) pagamento em dinheiro; (b) transferência de outros ativos; (c) prestação de serviços; (d) substituição da obrigação por outra; (e) conversão da obrigação em capital; (f) renúncia do credor; ou (g) perda dos direitos creditícios.

Em alguns casos, existe certo grau de incerteza na mensuração do passivo que faz com que se tenha que empregar um elevado grau de estimativa. Tais passivos são denominados como provisões (passivos que preenchem todos os requisitos de reconhecimento, mas sua mensuração tem que ser estimada).

Os passivos são classificados pela Lei das S/A (artigo 180) como: (i) passivos circulantes - obrigações com vencimento no exercício seguinte e (ii) passivos não circulantes - se tiverem vencimento em prazo maior.

\subsubsection{3 - Conceito de Patrimônio Líquido}

Por fim, faz-se necessário discorrer sobre o conceito de patrimônio para fins contábeis, que é assim definido pelo CPC “00”:

“(iii) Patrimônio Líquido é o valor residual dos ativos da entidade depois de deduzidos todos os seus passivos." 
O conceito acima transcrito é bastante singelo e merece ser explorado melhor. De fato, nos termos da Lei das S/A (artigos 178 e 182), o Patrimônio Líquido - PL é dividido nos seguintes itens: (a) capital social - capital contribuído pelos sócios e efetivamente integralizado; (b) reservas de capital; (c) ajuste de avaliação patrimonial; (d) reservas de lucros; (e) ações em tesouraria; e (f) prejuízos acumulados.

A constituição de reservas (mediante a apropriação de lucros acumulados, por exemplo) é um mecanismo para proteção do capital da empresa contra efeitos de possíveis prejuízos futuros e pode fornecer uma informação relevante para a tomada de decisão dos usuários.

Conforme destaca Sérgio de Iudícibus, ${ }^{24}$ o PL pode ser visualizado sob perspectivas distintas, por exemplo:

(i) segundo a teoria do proprietário: o PL é a propriedade dos quotistas (aplicável em sociedades de menor porte ou com grande concentração de capital): $[$ Ativo - Passivo $=$ Proprietário $]$;

(ii) segundo a teoria da entidade: o PL não está automaticamente à disposição do acionista, o qual não pode se retirar a qualquer momento da entidade, levando a sua parcela do patrimônio, como ocorre com as sociedades de capital aberto. Neste enfoque, o ativo é igual ao passivo em sentido amplo (passivo em sentido amplo igual ao passivo em sentido estrito mais PL): $[$ Ativo = Obrigações + Patrimônio Líquido $]$ ou $[$ Ativo = Passivo $]$;

(iii) segundo a teoria dos fundos: o PL faz parte da relação de fontes (origem) dos recursos e o Ativo é a respectiva destinação a que foi dada, correspondendo aos item de aplicação dos recursos. Com efeito, a entidade obtém recursos para aquisição de ativos com terceiros (passivo em sentido estrito) ou com os acionistas (PL):

[Ativos = Restrições sobre os ativos (fundos)].

Apenas para fins didáticos, os conceitos de ativo, passivo e patrimônio líquido podem ser representados graficamente da seguinte forma:

${ }^{24}$ IUDÍCIBUS, Sérgio de. Teoria da Contabilidade. $9^{\mathrm{a}}$ ed., $2^{\mathrm{a}}$ reimpr. São Paulo: Atlas, 2009, pp. 167 e ss. 


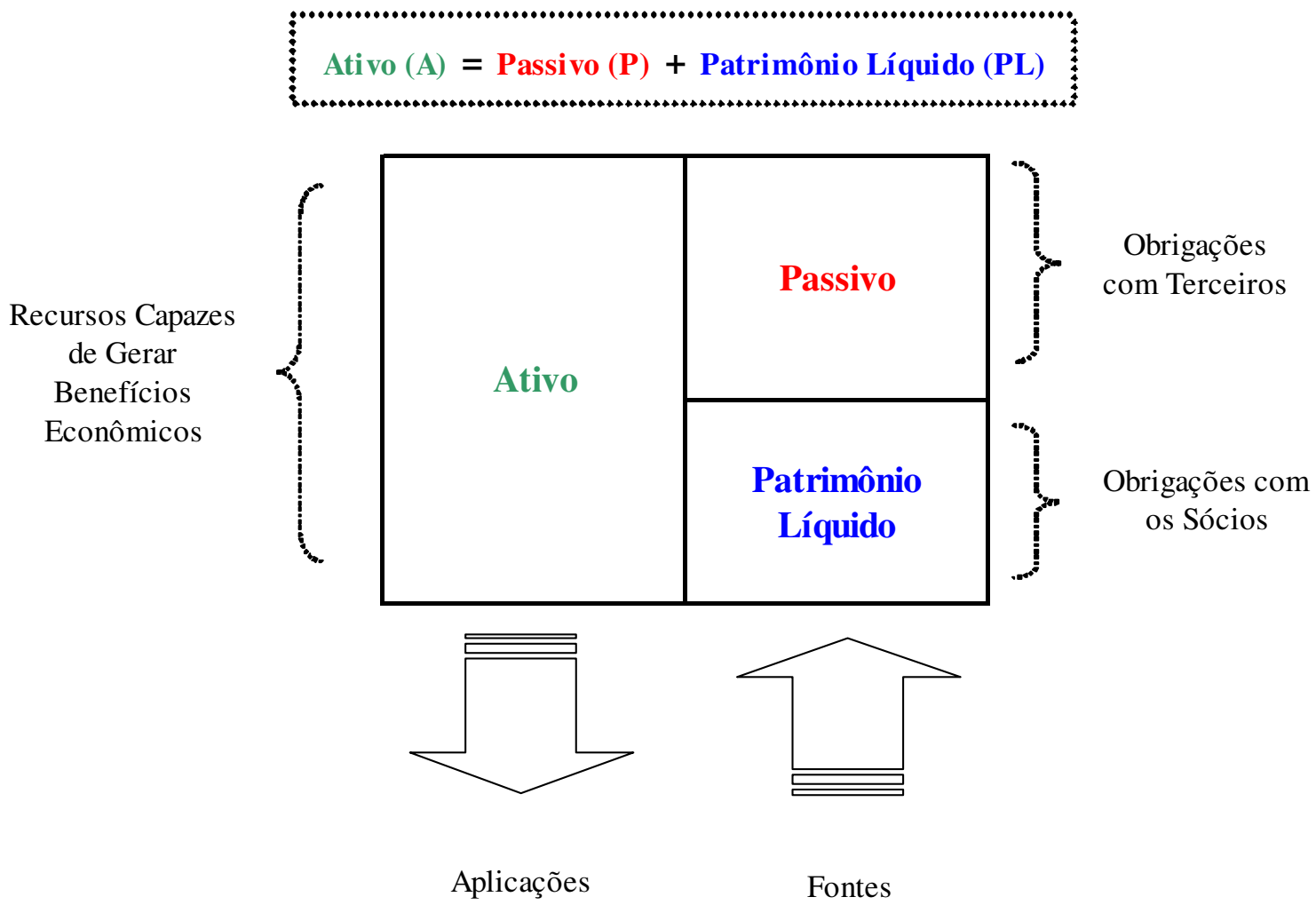

Ainda, conforme destacam Alexsandro Broedel Lopes e Eliseu Martins, há que se ressaltar a importância da diferença entre o valor da empresa (preço das ações negociadas em bolsa de valores) e o valor de patrimônio líquido, no modelo de Ohlson. ${ }^{25}$ Segundo o modelo matemático oferecido por Ohlson, a diferença entre o valor da empresa e o seu PL está no valor presente dos resultados anormais futuros esperados. Isto porque o PL reflete a parte do valor da empresa que já foi realizado, mas o preço de mercado reflete valores de resultado que ainda não foram reconhecidos.

Como exemplo, a contabilidade não pode registrar o acréscimo de receita esperado em decorrência de uma lei que institua um incentivo econômico para determinado setor da economia (não há aumento de PL). Contudo, o mercado irá reconhecer esse valor, por meio do aumento do valor de mercado das ações da empresa.

Após a análise dos elementos que compõem o patrimônio de uma entidade em sentido estático (BP), faz-se necessário também descrever os elementos que compõem a demonstração de resultado, realizada pela entidade dentro de um intervalo temporal, como forma de descrever o seu desempenho em determinado período (DRE).

25 OHLSON, J. A., Earnings, book values and dividends in equity valuation. The Contemporary Accounting Research, v. 11, n 2, 1995, pp. 661-687. Apud LOPES, Alexsandro Broedel e MARTINS, Eliseu. Op. cit. (nota 4), p. 145. 


\subsection{2 - Demonstração do Resultado do Exercício (DRE) - Desempenho}

$\mathrm{O}$ resultado de uma entidade em determinado período é denominado lucro, o qual costuma ser utilizado como medida do seu desempenho. Segundo a mencionada definição clássica oferecida pelo economista John Richard Hicks (confira-se o Capítulo 1.1.2), aplicada em um contexto empresarial, lucro é aquele montante máximo que pode ser distribuído aos acionistas ao final de um período, mantendo-se a mesma potencialidade do patrimônio da entidade para a geração de fluxos líquidos positivos de caixa. ${ }^{26}$

Trata-se, portanto, de uma medida do desempenho econômico da entidade em determinado período de tempo, em que se compara a situação patrimonial inicial, final e quanto foi gerado de fluxo de caixa, positivo ou negativo, no período ("filme").

A comparação da situação do PL no início e no final do período contábil pode fornecer a informação sobre o lucro (no caso de variação positiva do PL), mas não fornece informações sobre a natureza dessas alterações. Neste sentido, a análise de dois momentos estáticos do balanço da entidade não é suficiente, por exemplo, para demonstrar qual parcela desse resultado decorre de lucros operacionais (decorrente das atividades ordinárias da entidade) e não operacionais.

A distinção entre resultado operacional e não operacional é relevante, pois fornece uma avaliação mais precisa sobre a capacidade da entidade de gerar fluxos de caixa positivo no futuro. Isto porque o resultado não operacional é um resultado eventual e não se espera que ele ocorra com frequência no futuro.

Assim, analisam-se os elementos que compõem o resultado do período (receitas/ganhos e despesas/perdas). Esses elementos podem ser apresentados na Demonstração do Resultado do Exercício - DRE por meio de diversas combinações, que permitem demonstrar as várias formas de medir o desempenho da entidade (resultado operacional ou não operacional, antes ou depois dos tributos etc.).

\subsubsection{1 - Conceito de Receita}

Inicialmente, procede-se à análise dos elementos positivos que compõem o lucro da entidade, denominados receitas. Sobre o conceito de receita, define o CPC “00” que:

${ }^{26}$ HICKS, John Richard. Value and Capital. $2^{\mathrm{a}}$ ed., Oxford: Caredon, 1946, p. 172. Apud HOLMES, Kevin. The 


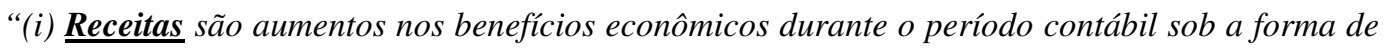
entrada de recursos ou aumento de ativos ou diminuição de passivos, que resultam em aumentos do patrimônio líquido e que não sejam provenientes de aporte dos proprietários da entidade;”

Conforme se depreende da definição acima, receitas são aumentos de benefícios econômicos, correspondentes ao aumento no PL da entidade que não seja proveniente de aporte dos proprietários. Tendo em vista que o valor do PL é igual ao valor do Ativo menos o valor do Passivo da entidade ("PL = A - P"), tem-se que, matematicamente, tanto aumentos de Ativos, quanto diminuição de Passivos resultam em aumentos do PL (receitas).

Esse conceito também é importante para visualizar o inter-relacionamento entre os elementos contábeis, pois o reconhecimento de um determinado elemento requer automaticamente o reconhecimento de outro. Neste sentido, o reconhecimento de um ativo tem, como contrapartida, o reconhecimento: (i) de uma receita (v.g. o recebimento de uma doação) ou (ii) de um passivo (v.g. contas a pagar). Trata-se da aplicação do método das partidas dobradas.

Exemplificativamente, a venda de uma mercadoria (assim como honorários, juros, dividendos, aluguéis etc.) configura o aumento nos benefícios econômicos com a entrada de recursos, motivo pelo qual é qualificada como uma receita. Esse aumento de benefícios econômicos decorre diretamente da aceitação, pelo mercado, dos produtos oferecidos pela entidade.

Caso a receita surja no bojo das atividades ordinárias da entidade (o que varia de entidade para entidade), tratar-se-á de uma receita operacional. No entanto, há aumentos de benefícios econômicos em operações não rotineiras, como na alienação do imóvel sede da empresa (alienação de ativos não correntes). Nestes casos, tem-se um ganho, com o mesmo efeito da receita sobre o PL. O ganho geralmente é reconhecido já líquido de suas despesas relacionadas.

\subsubsection{2 - Conceito de Despesa}

Também é necessário analisar os elementos negativos que compõem o lucro da entidade, denominados despesas. Sobre o conceito de despesa, define o CPC “00” que:

“(ii) Despesas são decréscimos nos benefícios econômicos durante o período contábil sob a forma

de saída de recursos ou redução de ativos ou incrementos em passivos, que resultam em

Concept of Income. A Multi-disciplinary Analysis. The Netherlands, IBFD, 2000, pp. 108 e ss. 
decréscimo do patrimônio líquido e que não sejam provenientes de distribuição aos proprietários da entidade."

Conforme se depreende da definição acima, despesas são reduções de benefícios econômicos, correspondentes à diminuição no PL da entidade que não seja proveniente de redução de capital pelos proprietários. Destaque-se novamente que, tendo em vista que o valor do PL é igual ao valor do Ativo menos o valor do Passivo da entidade (PL = A - P), tem-se matematicamente que tanto diminuição de Ativos, quanto aumento de Passivos resultam em diminuição do PL (despesas).

De forma geral, pode-se dizer que despesas são sacrifícios de ativos em troca do recebimento de receitas (vale dizer, para que exista lucro, as receitas deverão ser em valor superior ao das despesas). Ademais, também em conformidade com o inter-relacionamento entre os elementos contábeis (método das partidas dobradas), o reconhecimento de um passivo requer, automaticamente, o reconhecimento (i) de uma despesa (v.g. uma multa) ou (ii) de um ativo (v.g. compra a prazo de um bem).

Assim sendo, o custo incorrido na venda de uma mercadoria (bem como salários, depreciações etc.) configura a saída de recursos por meio de desembolsos ou redução de ativos, como caixa, estoques e imobilizado. Ocorre que esses recursos são sacrificados para a geração de benefícios econômicos, motivo pelo qual são qualificados como despesa. Caso a despesa surja no bojo das atividades ordinárias da entidade, tratar-se-á de uma despesa operacional.

Por outro lado, por exemplo, existem alguns gastos que não fazem parte da atividade ordinária da empresa, como uma multa de trânsito. Esses gastos se enquadram no conceito de despesa, mas não possuem natureza operacional (despesas não operacionais, pois não fazem parte do objeto social).

Também podem ocorrer reduções de benefícios econômicos em operações não rotineiras, no mesmo caso da alienação do imóvel sede da empresa (alienação de ativos não correntes, ou até sinistros como incêndios ou inundações). Nesses casos, tem-se uma perda, com o mesmo efeito da despesa sobre o PL. A perda geralmente é reconhecida já líquida das respectivas receitas relacionadas.

Alguns sacrifícios de ativos, contudo, não podem ser qualificados como despesas. É o caso dos gastos que somente irão gerar benefícios econômicos em exercícios futuros (por exemplo, desembolsos de caixa para pagamento de gastos com pesquisa e desenvolvimento). 
Nesses casos, os gastos deverão ser registrados como ativos e somente no exercício em que a respectiva receita for gerada é que esse gasto será lançado como despesa.

Por outro lado, quando não for possível identificar o período ou as receitas futuras conectadas ao gasto, deve-se lançá-los como despesa do período (a menos que tais gastos correspondam à aquisição de ativos ou liquidação de dívidas).

Também é importante conhecer o conceito de custo. Custo é o gasto (sacrifício de bens ou serviços) para a produção de outros bens ou serviços. O custo deve ser registrado no ativo até que ocorra a transferência do produto final e a geração do benefício econômico, ou seja, somente quando ocorrer a venda é que esse custo será lançado como despesa.

A construção de uma casa, por exemplo, envolve diversos gastos com material de construção, energia, projetos etc. Todos esses gastos serão registrados no ativo da entidade durante o processo de construção, até que a casa fique pronta, ou seja, registra-se o custo de produção no estoque (ativo). Com a venda da casa, será gerado o benefício econômico correspondente a esses gastos, momento em que o custo será lançado como despesa (contra-partida da baixa do ativo vendido).

Esses gastos poderiam ser denominados despesas do produto vendido, mas se convencionou denominá-los como custo do produto vendido. Com efeito, por convenção, somente são denominados como despesas os gastos de escritório e de administração. ${ }^{27}$

\subsubsection{3 - Conceito de Lucro Líquido}

Ressalte-se, ainda, que a Lei das S/A regulamenta a forma pela qual a DRE será elaborada e o que deve ser discriminado no resultado do exercício (artigo 187), como segue:

(i) receita líquida: receita bruta das vendas e serviços, subtraída das deduções das vendas, dos abatimentos e dos impostos;

(ii) lucro bruto: a receita líquida das vendas e serviços subtraída do custo das mercadorias e serviços vendidos;

(iii) lucro ou prejuízo operacional bruto: lucro bruto subtraído das despesas com as vendas, das despesas financeiras (deduzidas das receitas), das despesas gerais e administrativas e de outras despesas operacionais;

\footnotetext{
${ }^{27}$ IUDÍCIBUS, Sérgio de, MARION, José Carlos e FARIA, Ana Cristina de. Op. cit. (nota 23), 2009, p. 156.
} 
(iv) resultado não operacional: outras receitas e outras despesas;

(v) resultado do exercício antes das participações, deduzido dos prejuízos contábeis acumulados da provisão do imposto sobre a renda (artigo 189 da Lei das S/A);

(vi) participações de (a) debêntures; (b) empregados (v.g. PLR); (c) administradores; (d) partes beneficiárias, mesmo na forma de instrumentos financeiros; e de (e) instituições ou fundos de assistência ou previdência de empregados, que não se caracterizem como despesa;

(vii) o lucro ou prejuízo líquido do exercício: resultado do exercício que remanescer depois de deduzidas as participações (artigo 191 da Lei das S/A).

A partir da apuração do lucro líquido, conforme acima exposto, parte-se para a apuração do IRPJ pelo lucro real (conforme será analisado no Capítulo 5.2.1.2), ${ }^{28}$ bem como serão constituídas as reservas de capital, reserva de lucros e serão distribuídos os dividendos.

\section{4 - Princípios Contábeis Geralmente Aceitos - Reflexos no RECONHECIMENTO E MENSURAÇÃo do LuCRO CONTÁBIL}

Conforme já ressaltado, a Ciência Contábil está longe de ser uma ciência exata, motivo pelo qual a elaboração das informações acerca do patrimônio da entidade e sua mutação no tempo não está livre da subjetividade dos agentes.

Essa atividade subjetiva de elaboração das demonstrações contábeis é guiada pelos princípios contábeis geralmente aceitos. Dessa forma, para a devida compreensão do modo como o lucro contábil é apurado, é preciso compreender antes quais são os princípios que orientam a sua apuração. ${ }^{29}$

Não bastasse a importância dos princípios dentro da Ciência Contábil para reconhecimento e mensuração do lucro, também, juridicamente, sua observância tornou-se obrigatória para a elaboração das demonstrações financeiras exigidas pelo Direito Contábil

\footnotetext{
${ }^{28}$ Art. $6^{\circ}$ do DL $1.598 / 77$.

29 “Os princípios são o núcleo central da teoria contábil e estruturam a resposta da contabilidade aos seus desafios na busca de atingir os seus objetivos dentro do ambiente delimitado pelos postulados fundamentais. Assim, os princípios têm o papel de orientar efetivamente os procedimentos contábeis definindo a produção da informação. (...)" LOPES, Alexsandro Broedel e MARTINS, Eliseu. Op. cit. (nota 4), p. 129.
} 
Societário, nos termos do artigo 177 da Lei das S/A: "A escrituração da companhia será mantida em registros permanentes, com obediência aos preceitos da legislação comercial e desta Lei e aos princípios de contabilidade geralmente aceitos, devendo observar métodos ou critérios contábeis uniformes no tempo e registrar as mutações patrimoniais segundo o regime de competência."

Com efeito, verifica-se a intrínseca relação entre a Ciência Contábil e o Direito Societário, uma vez que a apuração do patrimônio contábil societário, bem como sua variação no tempo pressupõem a correta compreensão dos princípios contábeis geralmente aceitos, especialmente no que tange à aplicação dos accruals (ajustes exigidos pelo regime de competência). ${ }^{30}$

Atualmente, os princípios contábeis encontram-se positivados na Resolução CFC $\mathrm{n}^{\mathrm{o}}$ 750/93, com redação dada pela Resolução CFC $\mathrm{n}^{\circ}$ 1.282/10 (que atualizou e consolidou a Resolução CFC 750/93, após o processo de convergência às normas internacionais de contabilidade). Também há importantes referências aos princípios contábeis no CPC "00” (Resolução CFC no 1.121/08), que tratam da Estrutura Conceitual para a Elaboração e Apresentação das Demonstrações Contábeis, aprovado pela Deliberação CVM no 539/2008.

A seguir, serão analisados apenas os princípios que repercutem mais diretamente nos critérios de reconhecimento e mensuração do lucro.

\subsection{1 - Pressuposto Conceitual: Dilema entre (i) Relevância e (ii) Confiabilidade da Informação Contábil}

Conforme já destacado, a corrente teórica da Ciência Contábil que adota o information approach tem como foco a relevância da informação para seus usuários, entendida como aquela que apresenta o maior grau de utilidade.

Com efeito, ensinam Alexsandro Broedel Lopes e Eliseu Martins ${ }^{31}$ que a informação será tão mais relevante, do ponto de vista econômico e informacional, quanto maior a capacidade para prever fluxos de caixa futuros. Neste sentido, confira-se o que dispõe a estrutura conceitual prevista no CPC "00":

“26. Para serem úteis, as informações devem ser relevantes às necessidades dos usuários na tomada de decisões. As informações são relevantes quando podem influenciar as decisões

\footnotetext{
${ }^{30}$ LOPES, Alexsandro Broedel e MARTINS, Eliseu. Op. cit. (nota 4), p. 55.

${ }^{31}$ LOPES, Alexsandro Broedel e MARTINS, Eliseu. Op. cit. (nota 4), p. 65.
} 
econômicas dos usuários, ajudando-os a avaliar o impacto de eventos passados, presentes ou futuros ou confirmando ou corrigindo as suas avaliações anteriores."

Como exemplo, imagine-se que um banco adquira ações de uma empresa em bolsa de valores, pelo valor de \$100 a ação (custo histórico), no início do período X0. Ao final do período X0, o valor de mercado dessa ação está cotado na bolsa de valores por \$120. Está claro que o custo histórico não é a informação mais relevante, uma vez que não reflete de forma mais adequada a capacidade de geração de fluxos de caixa futuros das ações. Neste caso, o banco não irá registrar o custo histórico, mas sim o valor de mercado.

Do mesmo modo, o critério de utilidade da informação também deve levar em consideração a sua confiabilidade (ou objetividade), na medida em que não pode ser excessivamente subjetiva ao ponto de refletir uma visão distorcida da realidade econômica. Confira-se novamente o disposto no CPC “00”:

“31. Para ser útil, a informação deve ser confiável, ou seja, deve estar livre de erros ou vieses relevantes e representar adequadamente aquilo que se propõe a representar.

32. Uma informação pode ser relevante, mas a tal ponto não confiável em sua natureza ou divulgação que o seu reconhecimento pode potencialmente distorcer as demonstrações contábeis."

Conforme já destacado, os usuários da contabilidade exercem grande influência sobre a sua elaboração. Por isso, é importante notar que os gestores de uma empresa possuem muito mais conhecimento sobre as características econômico-financeiras da empresa do que o mercado.

Os gestores conhecem melhor (i) os riscos de retorno existentes nos projetos da empresa, (ii) os índices de depreciação dos ativos e (iii) os riscos envolvendo o recebimento de créditos. A correta avaliação desses índices é fundamental para a elaboração das informações contábeis, de forma a refletir a efetiva capacidade de geração de fluxos de caixa futuros dos ativos.

Existe, portanto, uma evidente assimetria de informação entre (i) os gestores da entidade e (ii) o mercado, na medida em que este último, muitas vezes, não tem condição de avaliar a qualidade da informação. Tendo em vista essa assimetria de informação entre os agentes, a Ciência Contábil precisa estabelecer meios para evitar o denominado conflito de agência. 
Alexsandro Broedel Lopes e Eliseu Martins ${ }^{32}$ destacam que a preocupação com a assimetria de informação pela teoria econômica teve início na década de 60 , conforme se verifica da obra de George Akerlof “The Market for 'Lemons': Quality Uncertainty and the Market Mechanism", ${ }^{33}$ que culminou no prêmio Nobel de economia de $2001 .^{34}$

Ackerlof trabalha com o exemplo do mercado de automóveis para demonstrar o problema gerado pela assimetria de informação. De forma geral, o problema colocado pode ser assim descrito:

Em um mercado de carros usados, dois modelos de carros são oferecidos aos compradores: os do tipo A (carros bons) e do tipo B (carros ruins - denominados nos EUA como lemons).

$\checkmark \quad$ Suponhamos que o valor dos carros de tipo A seja \$ 10 e os de tipo B seja \$ 5. Os vendedores dos carros do tipo A provavelmente sabem que seus carros são bons (pois sempre os conduziram cuidadosamente e sempre tomaram todas as medidas de conservação e manutenção necessárias). Os vendedores de carros de tipo B provavelmente sabem que seus carros são lemons, pois não tiveram a diligência necessária para sua conservação e manutenção.

Neste cenário, um comprador leigo em mecânica de carros, que esteja disposto a pagar \$ 10 por um carro usado, receberia a oferta de carros tipo A e B, mas teria grande dificuldade de identificar qual deles é um bom carro e qual é um lemon. Diante dessa assimetria de informação entre vendedores e compradores, a tendência é que apenas os carros ruins sejam vendidos, pois os vendedores de carros tipo B estão dispostos a dar descontos que os vendedores de carros tipo A não dariam.

O raciocínio por trás desse exemplo pode ser aplicado à compra de uma empresa (ou de ações em bolsa). Em razão da assimetria de informação, o comprador não possui as mesmas informações que o administrador da empresa possui acerca da sua real condição econômica. Da mesma forma, o comprador teria a mesma dificuldade em estabelecer a comparação entre empresas boas e empresas ruins.

\footnotetext{
${ }^{32}$ LOPES, Alexsandro Broedel e MARTINS, Eliseu. Op. cit. (nota 4), pp. 30 e 31.

33 AKERLOF, George A. The Market for "Lemons": Quality Uncertainty and the Market Mechanism. The Quarterly Journal of Economics, vol. 84, no 3 (Aug., 1970), The MIT Press, pp. 488-500.

${ }^{34}$ George Akerlof (University of Califórnia), Michel Spence (Stanford University) e Joseph Stiglitz (Columbia University).
} 
Para solucionar esse problema decorrente da assimetria de informação entre os agentes de mercado (conflito de agência), o comprador da empresa pode contratar auditores e outros assessores para lhe fornecerem uma opinião sobre a real situação econômica da empresa que pretende adquirir (da mesma forma que o comprador do carro pode contratar um mecânico para assessorá-lo na compra do carro).

Neste contexto é que ganha importância a ciência contábil, conforme ressaltam Alexsandro Broedel Lopes e Eliseu Martins. ${ }^{35}$ Verifica-se que a contabilidade é um instrumento deveras importante para a redução da assimetria de informação entre os agentes do mercado, motivo pelo qual a interpretação dos princípios contábeis deve se pautar nessa premissa fática sobre a forma como os diferentes agentes influenciam o registro das informações contábeis.

De fato, os agentes envolvidos nas relações econômicas da entidade possuem interesses diversos. Conforme já mencionado, os administradores têm interesse em apresentar o melhor resultado possível, pois quanto maiores os lucros, melhor será a avaliação de seu desempenho e maior será a sua remuneração. Para os investidores ou os credores da entidade, por outro lado, a apresentação de resultados excessivamente positivos pode comprometer a sua capacidade para cumprir com suas obrigações no futuro. Assim, em face desses interesses conflitantes, a Ciência Contábil estabelece princípios e regras que permitem a adequada distribuição, no tempo, do reconhecimento dos resultados da entidade.

Para tal, um dos princípios existentes é o da Confiabilidade, ou Objetividade, segundo o qual a informação contábil deve ser confiável e se pautar o máximo possível em dados objetivos. Assim, a informação contábil deve refletir adequadamente a capacidade de geração de fluxos de caixa futuros, mas também deve pautar-se em dados objetivos e confiáveis para evitar distorções que a influência dos agentes econômicos tende a ocasionar.

É por isso que se fala em dilema entre relevância e confiabilidade. Na verdade, o registro da informação deve se basear na ponderação entre esses dois princípios, uma vez que a decisão deve ser no sentido de escolher a informação que melhor atenda aos dois princípios.

Como exemplo, cite-se a depreciação de uma máquina. A informação mais objetiva para a contabilidade será o custo de aquisição (custo histórico). É preciso considerar, no entanto, que a máquina está sujeita a algum desgaste pelo uso no decorrer do tempo (depreciação). Trata-se de uma informação relevante, na medida em que o seu registro é

\footnotetext{
${ }^{35}$ LOPES, Alexsandro Broedel e MARTINS, Eliseu. Op. cit. (nota 4), p. 32.
} 
melhor forma de refletir a capacidade de geração de fluxo de caixa futuro desta máquina. No entanto, o índice de depreciação depende de vários fatores, como manutenção e intensidade de utilização, o que torna a sua avaliação subjetiva. Não obstante, o subjetivismo dessa informação não faz com que ela deixe de ser registrada, mas exige que essa avaliação subjetiva seja embasada em critérios mais objetivos possíveis (como laudos de peritos independentes, em alguns casos, para trazer uma informação independente e não enviesada).

\subsection{2 - Reflexo do Dilema: (i) Princípio do Custo Original como Base de Valor ou (ii) "Fair Value"?}

Um bom exemplo do dilema entre a relevância e a confiabilidade da informação contábil está na aplicação do princípio do custo como base de valor. Conforme ensinam Sérgio de Iudícibus, José Carlos Marion e Ana Cristina de Faria ${ }^{36}$ por muito tempo esse princípio foi entendido como o princípio do custo original como valor (e não como base de valor).

Com efeito, os ativos da sociedade eram registrados pelo valor original sem alterações (sequer eram registradas as variações decorrentes da perda de poder aquisitivo da moeda no tempo - inflação). Também os ativos adquiridos gratuitamente (como a doação) não seriam registrados na contabilidade, mesmo que gerassem benefícios para a entidade, pois não houve sacrifício de recursos para sua aquisição.

Com o tempo, esse princípio sofreu alguns ajustes. Os ativos adquiridos por doação, por exemplo, passaram a poder ser registrados por seu valor de mercado, se existisse. Ao mesmo tempo, passou a ser exigido também o registro da variação do poder aquisitivo da moeda no tempo (princípio do denominador comum monetário ou atualização monetária).

De fato, o valor de transação é uma medida bastante aproximada do valor econômico do bem na data da aquisição (caso a transação tenha ocorrido entre partes independentes, a tendência é que tenha sido utilizado o valor de mercado). Com o passar do tempo, esse valor passa a estar sujeito a variações decorrentes, por exemplo, da inflação, do desgaste físico ou obsolescência.

O princípio do custo original como base de valor é um reflexo do princípio da objetividade, uma vez que se parte de um dado objetivo de mensuração (o valor histórico da transação, com a atualização monetária). Contudo, o custo original, mesmo que corrigido por

\footnotetext{
${ }^{36}$ IUDÍCIBUS, Sérgio de, MARION, José Carlos e FARIA, Ana Cristina de. Op. cit. (nota 23), p. 81.
} 
meio de atualização monetária, muitas vezes não irá refletir o valor econômico de determinado ativo.

Dessa forma, existem alternativas à mensuração do ativo que podem evidenciar melhor o valor econômico do bem, como o fair value (valor justo), o qual seria obtido se o bem fosse negociado em condições justas, num mercado organizado, por vontade livre das partes. Quando o mercado existe de forma minimamente organizada, o valor justo se confunde com o valor de mercado. ${ }^{37}$ Portanto, o valor justo é uma forma de avaliação que pode refletir com mais exatidão o valor dos fluxos de caixa futuros que o bem pode gerar.

A comparação entre essas duas formas de mensuração é um reflexo do dilema entre relevância e objetividade. O custo original é um valor que demonstra uma avaliação mais objetiva, uma vez que se pauta no valor da transação, geralmente suportada por documentos e sem necessidade de avaliação subjetiva dos agentes. O valor justo, por sua vez, é um valor muito mais subjetivo, pois utiliza estimativas dos valores envolvidos, mas reflete com mais exatidão o seu valor econômico.

Como já afirmado anteriormente, o dilema entre relevância e objetividade não permite determinar aprioristicamente um método que seja mais adequado. Isto porque a utilização do valor justo envolve um custo de monitoramento para que a informação possua níveis suficientes de objetividade (ponderação entre objetividade e relevância). Caso esse custo seja muito alto, deve-se manter o custo original como base de valor (princípio da oportunidade).

Com a convergência para as normas internacionais, outros métodos de mensuração foram estabelecidos para serem utilizados, em graus distintos e combinados ao longo do tempo, para o registro dos componentes do patrimônio, como o método do valor presente (artigo $7^{\circ}$ da Resolução CFC n ${ }^{\circ} 750 / 93$ atualizada). ${ }^{38}$

\footnotetext{
${ }^{37}$ LOPES, Alexsandro Broedel e MARTINS, Eliseu. Op. cit. (nota 4), p. 66.

38 “Art. $7^{\circ}$ O Princípio do Registro pelo Valor Original determina que os componentes do patrimônio devem ser inicialmente registrados pelos valores originais das transações, expressos em moeda nacional.

$\S 1^{\circ}$ As seguintes bases de mensuração devem ser utilizadas em graus distintos e combinadas, ao longo do tempo, de diferentes formas:

I - Custo histórico. Os ativos são registrados pelos valores pagos ou a serem pagos em caixa ou equivalentes de caixa ou pelo valor justo dos recursos que são entregues para adquiri-los na data da aquisição. Os passivos são registrados pelos valores dos recursos que foram recebidos em troca da obrigação ou, em algumas circunstâncias, pelos valores em caixa ou equivalentes de caixa, os quais serão necessários para liquidar o passivo no curso normal das operações; e

II - Variação do custo histórico. Uma vez integrado ao patrimônio, os componentes patrimoniais, ativos e passivos, podem sofrer variações decorrentes dos seguintes fatores:
}

a) Custo corrente. Os ativos são reconhecidos pelos valores em caixa ou equivalentes de caixa, os quais teriam de ser pagos se esses ativos ou ativos equivalentes fossem adquiridos na data ou no período das demonstrações 


\title{
2.4.3 - Regime de Competência - Princípios (i) da Realização da Receita e (ii) do Confronto das Despesas com as Receitas
}

O regime de competência é um dos instrumentos mais importantes da contabilidade para o registro de informações sobre o valor econômico dos ativos e passivos, por sua capacidade para gerar fluxo de caixa futuro da entidade. É por meio dos denominados accruals que se fazem ajustes no resultado do exercício para melhor refletir a probabilidade de ocorrência dos fluxos de caixa futuros.

O fluxo de caixa passado (entradas e saídas de caixa) não possui a mesma capacidade de previsão de fluxos de caixa futuros, pois apresenta grandes variações no tempo e, assim, distorce a performance da entidade. Essas variações são equilibradas e o resultado distribuído de maneira uniforme no tempo por meio do registro dos accruals.

Apenas para registrar um exemplo hipotético de comparação do regime de competência com o fluxo de caixa, verifique-se o exemplo de Alexsandro Broedel Lopes e Eliseu Martins: ${ }^{39}$

\begin{abstract}
"Qual a utilidade do regime de competência? Por que ele é tão central dentro da estrutura da contabilidade? O regime de competência faz com que a empresa claramente incorra em custos adicionais em relação à mensuração baseada simplesmente no caixa. Depreciações, amortizações e PDDs precisam ser estimados, acompanhados e controlados. Por que incorrer nesses custos e controles adicionais? A fundamentação do regime de competência está justamente na idéia de relevância, ou seja, capacidade de previsão de fluxos de caixa futuros. Mas o regime de competência afasta a contabilidade de caixa, não é mesmo? Sim, ele diverge do caixa do período, mas é extremamente importante para a previsão do caixa dos próximos períodos.(...)”

“(...) É um engano achar que a depreciação não tem nada a ver com o caixa. Muito pelo contrário, a depreciação reflete a alocação do caixa consumido inicialmente na aquisição do bem por sua
\end{abstract}

contábeis. Os passivos são reconhecidos pelos valores em caixa ou equivalentes de caixa, não descontados, que seriam necessários para liquidar a obrigação na data ou no período das demonstrações contábeis;

b) Valor realizável. Os ativos são mantidos pelos valores em caixa ou equivalentes de caixa, os quais poderiam ser obtidos pela venda em uma forma ordenada. Os passivos são mantidos pelos valores em caixa e equivalentes de caixa, não descontados, que se espera seriam pagos para liquidar as correspondentes obrigações no curso normal das operações da Entidade;

c) Valor presente. Os ativos são mantidos pelo valor presente, descontado do fluxo futuro de entrada líquida de caixa que se espera seja gerado pelo item no curso normal das operações da Entidade. Os passivos são mantidos pelo valor presente, descontado do fluxo futuro de saída líquida de caixa que se espera seja necessário para liquidar o passivo no curso normal das operações da Entidade;

d) Valor justo. É o valor pelo qual um ativo pode ser trocado, ou um passivo liquidado, entre partes conhecedoras, dispostas a isso, em uma transação sem favorecimentos; e

e) Atualização monetária. Os efeitos da alteração do poder aquisitivo da moeda nacional devem ser reconhecidos nos registros contábeis mediante o ajustamento da expressão formal dos valores dos componentes patrimoniais."

${ }^{39}$ LOPES, Alexsandro Broedel e MARTINS, Eliseu. Op. cit. (nota 4), pp. 67 e 68. 
vida útil estimada. Se a depreciação não fosse considerada e, por exemplo, a despesa fosse contabilizada imediatamente na compra do bem, teríamos uma retratação viesada da realidade econômica e conseqüente previsão do fluxo de caixa. Vamos analisar o seguinte exemplo para clarificar melhor a questão. Suponhamos que a empresa A tenha adquirido uma máquina (seu único ativo relevante) por $R \$ 100.000,00$ e que essa máquina tenha vida útil estimada em cinco anos. A máquina será reposta no final do quinto ano após a geração de fluxos de caixa líquidos anuais de $R \$$ 50.000,00. Ignorando outros custos, receitas e despesas da companhia, vejamos como poderíamos representar o fluxo econômico e financeiro da empresa.

\begin{tabular}{|c|c|c|c|c|c|c|c|}
\hline Variáveis & $\begin{array}{c}\text { Período } \\
\text { 0 }\end{array}$ & $\begin{array}{c}\text { Período } \\
1\end{array}$ & $\begin{array}{c}\text { Período } \\
2\end{array}$ & $\begin{array}{c}\text { Período } \\
3\end{array}$ & $\begin{array}{c}\text { Período } \\
4\end{array}$ & $\begin{array}{c}\text { Período } \\
5\end{array}$ & $\begin{array}{c}\text { Período } \\
6\end{array}$ \\
\hline Receita & 0 & 50.000 & 50.000 & 50.000 & 50.000 & 50.000 & 50.000 \\
\hline Saída de caixa & 100.000 & & & & & & 100.000 \\
\hline Depreciação & 0 & 20.000 & 20.000 & 20.000 & 20.000 & 20.000 & 20.000 \\
\hline Fluxo de caixa líquido & $(100.000)$ & 50.000 & 50.000 & 50.000 & 50.000 & 50.000 & $(50.000)$ \\
\hline Lucro & 0 & 30.000 & 30.000 & 30.000 & 30.000 & 30.000 & 30.000 \\
\hline
\end{tabular}

Veja como, nesse exemplo simplificado, o lucro apresenta maior correlação com a realidade econômica da empresa. Dentro das características do exemplo, não ocorreram grandes alterações na realidade econômica da empresa. O lucro, dessa forma, se manteve estável. O fluxo de caixa, por sua vez, apresenta 'saltos' característicos dos desembolsos da empresa. Podemos ver que o fluxo de caixa futuro é mais estável do que o fluxo de caixa passado sugere. O lucro fornece uma base mais adequada para que acertemos a previsão dos fluxos de caixa futuros e operacionais da empresa do que o próprio fluxo de caixa passado. Dessa forma, podemos perceber que fica mais fácil fazer a previsão do fluxo de caixa quando o regime de competência é utilizado do que no caso da utilização simples do fluxo de caixa. Esse aspecto foi demonstrado empiricamente pelo trabalho de Barth et al. (1999), em que os autores mostram que os accruals possuem alto poder preditivo." (g.n.)

Com efeito, conforme nos ensinam Alexsandro Broedel Lopes e Eliseu Martins, somente o lucro apurado pelo regime de competência é que pode fornecer uma informação mais precisa sobre a realidade econômica de uma entidade, inclusive com a previsão para fluxos de caixa futuros que irão considerar os futuros desembolsos que deverão ser feitos pela sociedade.

Devido à sua importância, o já mencionado artigo 177 da Lei das S/A estipula que é obrigatória a contabilização das mutações patrimoniais (receitas, custos e despesas) segundo o regime de competência. ${ }^{40}$

\footnotetext{
40 “Art. 177. A escrituração da companhia será mantida em registros permanentes, com obediência aos preceitos da legislação comercial e desta Lei e aos princípios de contabilidade geralmente aceitos, devendo observar métodos ou critérios contábeis uniformes no tempo e registrar as mutações patrimoniais segundo o regime de competência." (g.n.)
} 
O regime de competência consiste na aplicação de dois princípios. Em conformidade com o artigo $9^{\circ}$ da Resolução CFC n ${ }^{\circ}$ 750/93 atualizada, bem como com o CPC “00” (estrutura conceitual), estabelece o artigo 187 da Lei das S/A que as pessoas jurídicas devem computar, na determinação do resultado do exercício:

a) as receitas e os rendimentos ganhos no período, independentemente da sua realização em moeda (princípio da Realização da Receita);

b) os custos, despesas, encargos e perdas, pagos ou incorridos, correspondentes a essas receitas e rendimentos (princípio do Confronto entre Receitas e Despesas).

\subsubsection{1 - Princípio da Realização da Receita}

O princípio da realização da receita determina que o seu registro deve ser feito no período em que ocorre o fato gerador de sua realização, independentemente de seu recebimento em dinheiro (ingresso de caixa). Há, porém, uma grande dificuldade na alocação temporal dessa receita nos casos em que a ocorrência do fato gerador se prolongue por mais de um exercício contábil.

Em geral, o ponto de transferência é o momento mais usual para o reconhecimento da receita pela Contabilidade (aspecto temporal do fato gerador da receita). Sérgio de Iudícibus, José Carlos Marion e Ana Cristina de Faria ${ }^{41}$ fornecem quatro argumentos para a escolha desse momento:

“Quatro argumentos:

a) a transferência do bem ou serviço normalmente se concretiza quando todo o esforço para obter a receita já foi desenvolvido;

b) nesse ponto configura-se com mais objetividade e exatidão o valor de mercado (de transação) para a transferência;

c) no mesmo ponto já se conhecem todos os custos de produção do produto ou serviço transferido (e que, pela transferência, se transformam em despesa) e outras despesas ou deduções de receita diretamente associáveis ao produto ou serviço, tais como: comissões sobre vendas, despesas com consertos ou reformas parciais decorrentes de garantias concedidas etc. (os desembolsos efetivos com tais despesas frequentemente ocorrem somente após o ponto de transferência, mas são razoavelmente estimáveis já no ato da transferência);

${ }^{41}$ IUDÍCIBUS, Sérgio de, MARION, José Carlos e FARIA, Ana Cristina de. Op. cit. (nota 23), p. 86. 
d) mas, de qualquer forma, é necessário ainda verificar-se se está recebendo em troca dinheiro ou direitos com boa garantia de efetivo recebimento ou, em última instância, ativos com valor de mercado amplamente reconhecido e realizável."

Com efeito, ensinam os autores que somente depois de cumpridas as quatro condições acima expostas é que será possível considerar ocorrido o fato gerador da receita e poderá ser feito seu registro nos livros da entidade (o que ocorre geralmente no ponto de venda).

Segundo alerta Sérgio de Iudícibus, o momento mais adequado para o registro da receita é aquele em que se verifica o maior grau de cumprimento dessas condições (o que não necessariamente corresponde ao ponto de venda). ${ }^{42}$ Dessa forma, não obstante a regra geral de que a receita deve ser reconhecida no ponto de venda, há casos em que ela poderá ser reconhecia antes ou após o momento da transferência.

Por fim, registrem-se quatro situações especiais que merecem tratamento específico:

\subsubsection{1.a - Reconhecimento da Receita Proporcionalmente ao Decurso do Tempo}

Existem certos negócios (serviços, aluguéis e empréstimos) que estão intrinsecamente ligados ao decurso de determinado período de apropriação contábil, por exemplo, o mês. Há, no entanto, negócios são contratados para um maior período de duração (um contrato de aluguel de 3 anos, por exemplo). Nesses casos, reconhece-se uma parcela da receita em cada subperíodo, proporcionalmente ao tempo já decorrido de ocupação e usufruto do imóvel.

Pode ocorrer, também, que algumas entidades possuam contratos com base em horas trabalhadas, como é o caso de escritórios de advocacia. Com efeito, as horas de serviço trabalhadas no mês ou outro período também podem ser o critério para o reconhecimento da receita. Com efeito, nos casos ora analisados, o tempo decorrido ou as horas de esforço aplicadas são fatos geradores do registro dessas receitas.

\footnotetext{
${ }^{42}$ IUDÍ́CIBUS, Ségio de. Op. cit. (nota 24), pp. 47 e 48.
} 


\subsubsection{1.b - Reconhecimento da Receita para Produtos ou Serviços de Longo Prazo de Execução}

Alguns produtos ou serviços necessitam de longo prazo para execução, como ocorre com a construção de navios, de aeronaves ou de certos empreendimentos imobiliários. Nestes casos, em que a execução do produto dura mais de um exercício contábil, pode ser necessário reconhecer uma parcela da receita de venda, antes de ocorrer a transferência do ativo (como exemplo de transferência ao adquirente, cite-se a entrega do navio, da aeronave ou das chaves do imóvel).

Por isso, em alguns casos, o reconhecimento do resultado somente no momento da transferência não reflete adequadamente a distribuição do desempenho da entidade durante os períodos contábeis. ${ }^{43}$

Nos contratos de longo prazo, o reconhecimento geralmente se dá de duas formas distintas: (a) proporcionalmente às etapas físicas de construção completadas (grau de acabamento); ou (b) proporcionalmente aos custos incorridos no período de apuração, em relação aos custos totais orçados para o empreendimento.

As duas formas de mensuração da performance são igualmente válidas como medida de mensurar a proporção do empreendimento que foi realizada em cada período e, assim, reconhecer a proporção da receita correspondente.

Em alguns casos, porém, como ocorre com as grandes obras, que possuem várias etapas com características diferentes, fica difícil determinar um único percentual de acabamento em relação ao total da obra. Então, a utilização do método do custo incorrido será mais apropriado, embora também não seja exato dizer que a performance está ligada apenas ao percentual de custo incorrido no empreendimento.

A análise do reconhecimento da receita nos contratos de construção de imóveis será objeto do Capítulo 4.2 do presente trabalho.

\subsubsection{1.c - Reconhecimento da Receita Antes da Transferência}

Apesar de o ponto de transferência ser o momento normal de reconhecimento da receita, conforme já analisado, há casos em que a receita é reconhecida em momento anterior à

\footnotetext{
${ }^{43}$ IUDÍCIBUS, Sérgio de, MARION, José Carlos e FARIA, Ana Cristina de. Op. cit. (nota 23), pp. 90 e ss.
} 
transferência a terceiros. Para que ocorra o reconhecimento antecipado, faz-se necessária a observância de três condições: ${ }^{44}$

"Três condições:

a) os estoques, no final do período de apuração contábil, são avaliados pelo valor de realização (venda) naquele momento, desde que determinado de forma afiançável, por meio de amplo consenso do mercado sobre o valor do estoque, e desde que seja possível deduzir, por estimativa, as despesas necessárias até, efetivamente, vender o produto. Se estiver totalmente maturado ou acabado, deverão ser deduzidas as despesas para vendê-lo como produto final;

b) a atividade é primária e seu custo de produção é muito difícil de ser estimado ou, por não conter ele o custo de oportunidade do capital aplicado na obtenção do produto, revela-se muito reduzido em face do valor líquido de realização (venda) caracterizada em a;

c) o processo de obtenção de lucro caracteriza-se muito mais (quase que exclusivamente) pelo processo vegetativo de crescimento, nascimento, envelhecimento ou outro qualquer do que pela operação de venda e entrega do bem."

Como exemplo de produtos que preenchem as condições acima apontadas, é possível citar: (i) aqueles em que o crescimento vegetativo ou o acréscimo de valor natural ocorre principalmente durante o processo de produção (entidades agropecuárias, produtores de vinho, exploradores de reservas florestais etc.); (ii) os que possuem valor de mercado facilmente verificável (alguns instrumentos financeiros); e (iii) o risco de não venda é quase nulo (mineração e lapidação de pedras preciosas).

\subsubsection{1.d - Reconhecimento da Receita Após a Transferência}

Em alguns casos também pode ocorrer o reconhecimento da receita após o ponto de transferência. Trata-se das hipóteses em que o recebimento do pagamento pela transferência do ativo (ou prestação de serviço) é a etapa mais difícil da operação.

A título exemplificativo, destacam-se as atividades econômicas altamente especulativas, com recebimento em prestações e com grande incerteza quanto ao recebimento futuro. Nesses casos, pode haver o diferimento da receita, pois os recebimentos iniciais podem ser considerados como pagamento pelos custos incorridos (o lucro somente é apurado após todos os custos terem sido recuperados).

\footnotetext{
${ }^{44}$ IUDÍCIBUS, Sérgio de, MARION, José Carlos e FARIA, Ana Cristina de. Op. cit. (nota 23), pp. 93 e 94.
} 


\subsubsection{2 - Princípio do Confronto das Despesas com as Receitas}

O segundo princípio que compõe o regime de competência enfoca o aspecto do reconhecimento da despesa. Em suma, o reconhecimento da despesa depende do consumo de ativos (gasto). Contudo, também será necessário o confronto com as receitas atribuídas ao período, conforme o princípio da realização da receita.

Assim, quando um gasto somente será confrontado com uma receita futura, esse gasto deve ser registrado como um ativo para ser baixado como despesa no momento da realização da receita (como é o caso dos gastos com pesquisa e tecnologia para o desenvolvimento de produtos a serem vendidos no futuro). Caso não seja possível atribuir referida despesa a uma receita específica, ela deverá ser integralmente registrada no próprio período de consumo dos ativos.

Conforme ensina Sérgio de Iudícibus, é comum que se analise o princípio da realização da receita isoladamente, sem se atentar para a análise do reconhecimento das despesas. De fato, essa consideração há sempre de ser feita conjuntamente, pois, em geral, não se pode reconhecer a receita enquanto as despesas correspondentes não puderem ser confiavelmente mensuradas. ${ }^{45}$

Ressalte-se, todavia, que o confronto entre despesas e receitas não pressupõe, necessariamente, que os desembolsos de caixa ocorram no mesmo período. De fato, é possível que os gastos para a geração de uma receita possam ser anteriores, concomitantes, ou até mesmo posteriores ao ingresso da receita (o importante é que esses gastos sejam determináveis).

\section{5 - Direito Contábil Tributário e a Apuração do LuCro FisCal}

Na seara tributária, a previsão de normas contábeis ganhou grande relevância após a entrada em vigor da Lei $n^{\circ}$ 6.404, em 1976 (Lei das S/A), uma vez que a legislação tributária trouxe regulamentação específica para os registros contábeis utilizados na apuração do imposto de renda. Assim, o Decreto-Lei $\mathrm{n}^{\circ} 1.598$, de 1977, determinou, em seu artigo $8^{\circ}$, que os registros contábeis específicos para fins tributários deveriam ser feitos no livro de apuração do lucro real (LALUR) ou em livros auxiliares.

\footnotetext{
${ }^{45}$ IUDÍCIBUS, Ségio de. Op. cit. (nota 24), pp. 45 e 46.
} 
Este é o reconhecimento, pelo legislador de 1977, de que a legislação tributária traz regras contábeis específicas para fins de apuração de tributos. Essas regras servem ao interesse arrecadatório do Fisco, mas não existe a obrigatoriedade de que sigam os princípios de contabilidade geralmente aceitos. Esse conjunto de normas jurídicas estabelecidas pela legislação tributária é o que passamos a denominar Direito Contábil Tributário, que tem como objetivo a apuração da contabilidade tributária:

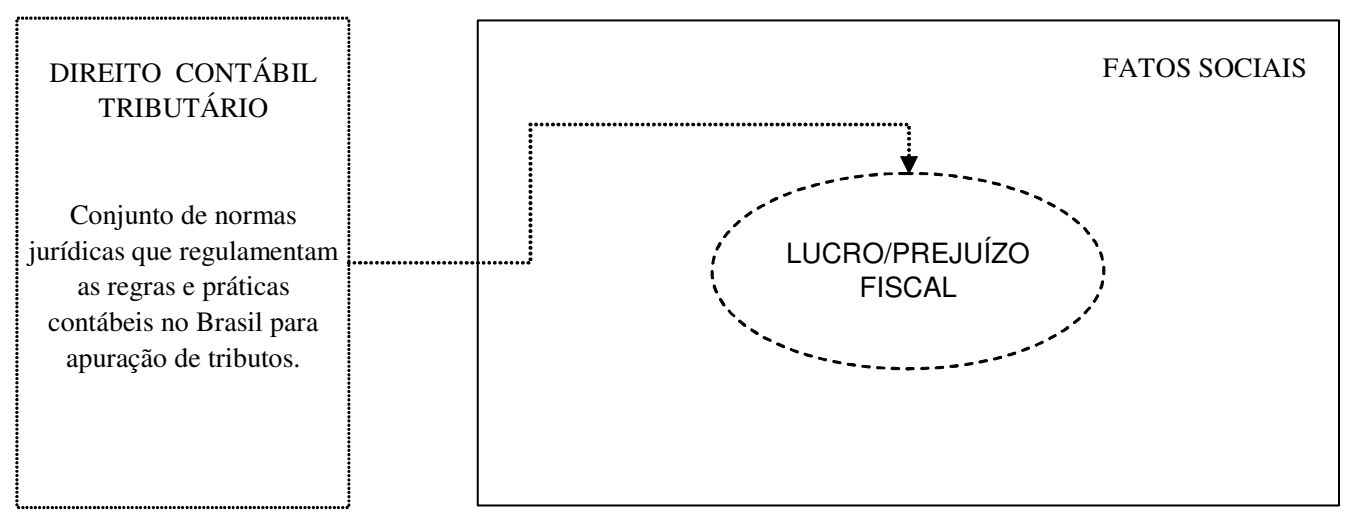

Ocorre que, conforme mencionado, mesmo em face das alterações legislativas introduzidas pelo DL $\mathrm{n}^{\circ} 1.598 / 77$, que tiveram como objetivo a purificação da contabilidade societária dos efeitos da contabilidade tributária (criação do LALUR), a legislação tributária continuou influenciando sobremaneira a elaboração das demonstrações contábeis no Brasil.

Essa busca por uma Contabilidade Societária (Direito Contábil Societário) livre da influência da Contabilidade Tributária (Direito Contábil Tributário), bem como a tendência internacional de convergência das normas contábeis fizeram com que fossem editadas as Leis $\mathrm{n}^{\circ} 11.638 / 07$ e $\mathrm{n}^{\circ} 11.941 / 09$, nas quais se exaltou a necessidade de separação dessas duas contabilidades.

Assim, mais uma vez reconhece o legislador que o Direito Contábil Societário possui campo de aplicação distinto do Direito Contábil Tributário, prevalecendo este último quando se tratar da apuração de tributos. Estabelece-se, portanto, a aplicação da regra segundo a qual a norma especial (contabilidade tributária) prevalece sobre a norma geral (contabilidade societária), quando se tratar do caso específico (apuração do IRPJ).

A Ciência Contábil, como vimos, é utilizada por diversas áreas do Direito, em especial pelo Direito Societário e pelo Direito Tributário, como instrumento para a apuração da riqueza gerada pelas pessoas jurídicas. 
Assim, verifica-se que a apuração de muitos tributos depende de conceitos formados a partir da Ciência Contábil, mas positivados pelo Direito Contábil Societário e Tributário. Estes conceitos, contudo, devem ser buscados inicialmente no Direito Privado (recepção dos conceitos de Contabilidade Societária), mas faz-se necessária uma análise posterior para saber se não existe um tratamento diferenciado na norma tributária (transformação do conceito de Direito Privado pelo Direito Tributário).

No que tange ao presente estudo, a base de cálculo do IRPJ é o lucro (lucro real, presumido ou arbitrado). Contudo, lucro é um conceito econômico (mensurado pela Ciência Contábil) que deve estar previsto em lei, para que possa ser utilizado como base de cálculo do referido tributo (princípio da legalidade).

Ademais, mesmo que previsto em lei, este conceito também deve estar em conformidade com o tipo constitucional da renda e com os princípios constitucionais pertinentes à sua tributação, como o princípio da realização e da capacidade contributiva.

Neste sentido, Antonio Lopo Martinez entende que as normas jurídicas de natureza contábil tributária (ou seja, criadas para a apuração de tributos) não podem estar em desacordo com os preceitos constitucionais, confira-se: ${ }^{46}$

\footnotetext{
“Para a formulação do conceito de 'lucro', o legislador ordinário goza de autonomia e liberdade relativas. Pode escolher entre os diversos conceitos oferecidos pelos contadores e financistas, ou criar um completamente distinto, desde que em consonância com o que preceitua a Constituição.

Assim, se a significação jurídica atribuída ao termo 'lucro' implicar dissensão entre a norma tributária de incidência e os preceitos constitucionais, aquela estará inexoravelmente sujeita a questionamento de constitucionalidade.

Caso a hipótese normativa da regra-matriz de incidência estabeleça para tal palavra conceito que implique tributação do patrimônio, e não da renda, a conceituação será inaceitável, por ferir preceitos constitucionais.”
}

Novamente, ressalte-se que, caso exista conflito entre a contabilidade societária e a contabilidade tributária, esta última deverá prevalecer quando se tratar de apuração de algum dos aspectos do fato gerador do tributo, uma vez que se trata da aplicação de norma específica em face de um uma norma geral.

Neste sentido, para a apuração do lucro real (base de cálculo do IRPJ), parte-se do lucro líquido (apurado pelas regras da legislação societária - contabilidade societária) para,

\footnotetext{
${ }^{46}$ MARTINEZ, Atonio Lopo. Op. cit. (nota 13), p. 91.
} 
então, serem feitas as adições, exclusões ou compensações, chegando-se ao conceito de lucro para fins fiscais (contabilidade tributária):

lucro líquido (lucro societário)
(+) adições
(-) exclusões
(=) lucro real antes das compensações
(-) compensação de prejuízos fiscais acumulados
(=) lucro real (lucro fiscal)

Apenas para fins didáticos, confira-se o seguinte diagrama de intersecção entre a Ciência Contábil, a Contabilidade Societária e a Contabilidade Fiscal:

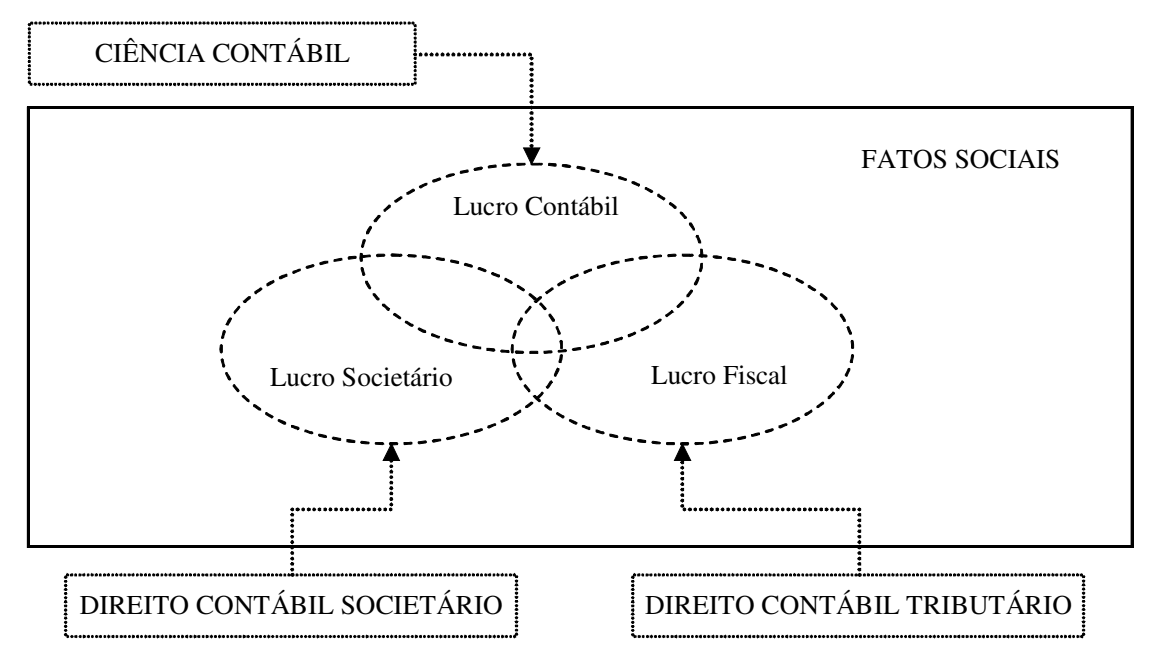

Portanto, verifica-se que há muitos pontos de intersecção entre a Ciência Contábil, o Direito Contábil Societário e o Direito Contábil Tributário, especialmente no que tange às regras de apuração da base de cálculo do IRPJ (contabilidade tributária), mas nem todas as regras são coincidentes.

A seguir, passamos a expor alguns exemplos em que as regras contábeis societárias divergem das regras contábeis tributárias: 


\begin{tabular}{|c|c|c|}
\hline Exemplo & Direito Contábil Societário & Direito Contábil Tributário \\
\hline $\begin{array}{ll}\text { (i) Regime de } & \\
\text { Competência } & v s . \\
\text { Regime de Caixa }\end{array}$ & $\begin{array}{l}\text { Nos termos do artigo } 177 \text { da } \\
\text { Lei das S/A, a regra de } \\
\text { apuração de receitas e } \\
\text { despesas é o regime de } \\
\text { competência. }\end{array}$ & $\begin{array}{l}\text { Algumas pessoas jurídicas podem apurar seu lucro pelo } \\
\text { regime de caixa para fins de apuração da base de cálculo do } \\
\text { IRPJ e da CSLL, como aquelas optantes pelo regime do } \\
\text { lucro presumido e as que exercem atividade imobiliária. }\end{array}$ \\
\hline $\begin{array}{l}\text { (ii) Arrendamento } \\
\text { Mercantil - Leasing }\end{array}$ & $\begin{array}{l}\text { Para fins da legislação } \\
\text { societária, com as alterações } \\
\text { promovidas pela Lei } \mathrm{n}^{\circ} \\
11.638 / 07, \text { os } \\
\text { arrendados na modalidade de } \\
\text { leasing financeiro passam a } \\
\text { ser registrados no ativo do } \\
\text { arrendatário. }\end{array}$ & $\begin{array}{l}\text { Conforme se depreende da leitura dos artigos } 11 \text { e } 15 \text { da Lei } \\
\mathrm{n}^{\circ} 6.099 / 74 \text {, os valores pagos pelo arrendamento mercantil } \\
\text { são considerados como custo ou despesa operacional do } \\
\text { arrendatário e o bem somente irá integrar o seu ativo no } \\
\text { momento em que for exercida a opção de compra. Por outro } \\
\text { lado, nos termos do artigo } 12 \text { dessa Lei, o bem arrendado } \\
\text { figura no ativo da pessoa jurídica arrendadora, que irá } \\
\text { registrar como custo as cotas de depreciação do preço de } \\
\text { aquisição de bem arrendado, calculadas de acordo com a } \\
\text { vida útil do bem. }\end{array}$ \\
\hline $\begin{array}{l}\text { (iii) Dividendos e } \\
\text { Juros sobre Capital } \\
\text { Próprio - JCP }\end{array}$ & $\begin{array}{l}\text { O lucro apurado pela pessoa } \\
\text { jurídica e distribuído aos } \\
\text { sócios ou acionistas possui } \\
\text { natureza de dividendos } \\
\text { (remuneração pelo capital } \\
\text { investido). Neste sentido, as } \\
\text { sociedades estão obrigadas a } \\
\text { pagar dividendos aos seus } \\
\text { acionistas, conforme artigo } \\
202 \text { da Lei das S/A. }\end{array}$ & $\begin{array}{l}\text { A legislação tributária, por meio da Lei } \mathrm{n}^{\circ} \text { 9.249/95, } \\
\text { estabeleceu a possibilidade de se remunerarem os sócios, } \\
\text { pelo capital próprio, por meio do pagamento de juros. } \\
\text { Portanto, verifica-se um pagamento que, para fins } \\
\text { societários, tem natureza de dividendos, mas, para fins } \\
\text { tributários (contabilidade fiscal), pode ter natureza de juros. } \\
\text { Esta distinção fica clara quando se percebe que a legislação } \\
\text { tributária estabelece que os próprios dividendos obrigatórios } \\
\text { podem ter natureza de juros para fins tributários, nos termos } \\
\text { do artigo } 9^{\circ}, \S 7^{\circ} \text {, da Lei } n^{\circ} 9.249 / 95 \text {. }\end{array}$ \\
\hline
\end{tabular}


Ressalte-se que, conforme mencionado, as Leis n. ${ }^{\circ} 11.638 / 07$ e $n^{\circ} 11.941 / 09$ introduziram diversas alterações em conceitos de Direito Contábil Societário (Direito Privado). Contudo, para que essas alterações não gerassem efeitos tributários, foram criadas regras de neutralização, por meio do denominado Regime Tributário de Transição - RTT. ${ }^{47}$

Conforme será demonstrado no Capítulo 5.2.1.1, a aplicação do RTT representa a introdução de uma etapa prévia à apuração do lucro tributável (real, presumido ou arbitrado), qual seja: a apuração do lucro líquido fiscal, de acordo com os métodos e critérios contábeis vigentes em 31 de dezembro de 2007 (sem as alterações promovidas pela Lei nº 11.638/07 e pela Lei no 11.941/09 - atual lucro líquido societário).

${ }^{47}$ Aplicável à apuração do lucro real, presumido, arbitrado, CSLL, PIS e COFINS. 


\section{3 - NATUREZA JURÍDICA dOS NEGÓCIOS IMOBILIÁRIOS}

No presente capítulo, serão analisados os principais aspectos da natureza jurídica de diversos negócios imobiliários, classificados em quatro gêneros distintos, conforme seu objeto preponderante: (i) a alienação da propriedade imobiliária; (ii) prestação de serviços vinculados à propriedade imobiliária; (iii) cessão da posse do imóvel; e (iv) financiamento imobiliário.

Essa análise não pretende ser completa e exaustiva sobre todos os aspectos da natureza desses negócios jurídicos, mas se foca apenas nas características que podem influenciar no reconhecimento e na mensuração do lucro. Como visto, o regime de competência e os princípios contábeis são a base para orientar o reconhecimento e mensuração de um elemento contábil (ativo ou passivo, receita ou despesa). Neste sentido, somente será reconhecido um elemento contábil quando se tiver segurança suficiente acerca da transferência dos riscos e benefícios.

Todavia, é muito difícil determinar em que momento ocorre a transferência de riscos e benefícios dentro do ciclo econômico de alguns setores da economia, assim como ocorre para algumas operações imobiliárias. Com efeito, serão analisados os conceitos de direito privado que podem fornecer subsídios para o interprete formar sua convicção acerca dos requisitos necessários para a transferência dos riscos e benefício em cada operação imobiliária.

Antes, contudo, passa-se a delimitar com mais precisão o âmbito de atividades econômicas que são objeto do presente estudo, por meio da definição do conceito de negócios jurídico-imobiliários, bem como alguns conceitos tangenciais como os de bem imóvel, posse, propriedade e patrimônio para o Direito Civil.

\section{1 - NegóCiOS JURÍdICO-IMOBILIÁRIOS (DELIMITAÇÃo DO OBJETO)}

Na realização de determinada atividade econômica, há diversas etapas necessárias para operacionalizar o objetivo negocial pretendido pelos agentes. Alguns objetivos econômicos possuem uma natureza jurídica relativamente simples e de fácil operacionalização. Assim, um agente econômico que seja proprietário de salas comerciais e pretenda ceder os 
direitos de usar e gozar referidas unidades imobiliárias para terceiros, mediante remuneração periódica, tem à sua disposição o contrato de locação para regulamentar os efeitos desse negócio.

Outras atividades econômicas, contudo, não possuem uma natureza jurídica verificável de forma simples e requerem um maior esforço para construir as relações jurídicas entre as partes envolvidas. Neste sentido, um shopping center é uma atividade econômica que pode conter o substrato básico semelhante ao de uma locação (ceder os direitos de uso e gozo da propriedade imobiliária a terceiros).

Entretanto, o complexo de atividades econômicas envolvidas em um shopping center faz com que seja necessária a construção de diversas relações negociais entre as partes envolvidas, para que essa atividade se torne operacional (v.g. a regulamentação dos interesses dos proprietários das unidades imobiliárias entre si, caso exista mais de um; a regulamentação dos interesses dos diversos lojistas entre si e perante os proprietários; e a regulamentação das estratégias publicitárias para a promoção do empreendimento como um todo e dos lojistas individualmente).

Com efeito, os instrumentos previstos pelo direito para a regulamentação desses interesses são os denominados negócios jurídicos. Os negócios jurídicos são conceituados como manifestações de vontade destinadas a produzir determinados efeitos jurídicos.

No presente capítulo, serão analisados os negócios jurídicos que envolvem direta ou indiretamente a propriedade de bens imóveis. Ou seja, serão analisados os negócios jurídicos que se consubstanciam em manifestações de vontade destinadas a produzir efeitos jurídicos sobre a exploração econômica da propriedade imobiliária, direta ou indiretamente.

Trata-se de corte metodológico necessário para estabelecer o conjunto de negócios jurídicos que estará sujeito à análise no presente estudo. Apenas para fins didáticos, será feita uma subdivisão desse conjunto que, tendo em vista a natureza econômica preponderante do negócio jurídico, podem ser classificados como:

(e) Primeiro gênero: negócios jurídicos em que se explora economicamente a alienação da propriedade de bens imóveis. A renda/lucro consiste na mais valia entre o valor de aquisição e o valor de alienação.

(f) Segundo gênero: negócios jurídicos em que há prestação de serviços relacionados à propriedade imobiliária ou a outros negócios imobiliários. A renda/lucro decorre diretamente do preço dos serviços prestados. 
(g) Terceiro gênero: negócios jurídicos em que se explora economicamente a cessão temporária da posse sobre bens imóveis. A renda/lucro do proprietário decorre da remuneração recebida como contraprestação pelo direito temporariamente cedido (v.g. uso e gozo).

(h) Quarto gênero: negócios jurídicos que têm como objetivo viabilizar o financiamento da aquisição da propriedade imobiliária. A renda/lucro decorre da remuneração pelo capital disponibilizado para o financiamento.

A classificação acima sugerida decorre da natureza preponderante de cada gênero de negócios jurídicos, de forma a agrupar as operações imobiliárias específicas que tenham objetos semelhantes. É uma divisão segundo a natureza preponderante, pois é possível que determinada espécie de negócio jurídico possua uma natureza híbrida, como ocorre com a incorporação imobiliária: trata-se de uma atividade primordialmente destinada à alienação de unidades imobiliárias, mas que possui grande parte de seu valor econômico gerado pelos serviços a ela relacionados (v.g. planejamento, construção, esforço de vendas etc.).

Antes de iniciar a análise dos quatro gêneros de negócios jurídico-imobiliários, serão verificados alguns conceitos tangenciais ao objeto do presente estudo, mas que são pressupostos fundamentais para a sua correta compreensão: o conceito de bem imóvel, de posse, de propriedade, de patrimônio (sob o prisma do Direito Civil) e de contrato.

\subsection{1 - Conceito de Bem Imóvel}

Qualquer direito é aplicável sobre um determinado objeto. Esse objeto pode ser uma ação humana, consistente em uma obrigação de dar, fazer ou deixar de fazer algo. Contudo, também pode ser uma coisa (ou um bem), como é o caso dos bens imóveis.

Neste sentido, os bens (ou coisas) são todos os objetos passíveis de gerar alguma utilidade para o ser humano (pecuniária ou axiológica). Com efeito, os bens podem ser objetos corpóreos (v.g. uma casa, um terreno) ou incorpóreos (v.g. direitos autorais), desde que gerem utilidade passível de ser apropriada pelo homem.

Dentre as classificações dos bens, a distinção entre bens móveis e imóveis é a que merece maior destaque para os fins do presente trabalho. A importância da distinção entre esses bens é fundamental por diversos motivos (v.g. forma de aquisição da propriedade, constituição de direitos reais de garantia etc.), mas, especialmente para os fins deste estudo, no que tange às diversas formas de tributação dos rendimentos decorrentes dos bens imóveis. 
Apenas a título exemplificativo, os negócios jurídicos em geral não necessitam de forma especial, a não ser quando a lei expressamente exigir (artigo 107 do CC). Contudo, a não ser que exista lei dispondo em contrário, a escritura pública é essencial à validade dos negócios jurídicos que visem à constituição, transferência, modificação ou renúncia de direitos reais sobre imóveis de valor superior a trinta vezes o maior salário mínimo vigente no País (artigo 108 do CC).

Com efeito, segundo Clovis Bevilaqua, ${ }^{1}$ podem-se definir bens imóveis como as coisas "que se não podem transportar, sem destruição, de um lugar para o outro". Esse conceito é aplicável somente para os bens imóveis por natureza.

Segundo Teixeira de Freitas, ${ }^{2}$ "O solo unicamente é imóvel por natureza, a saber, o agregado de suas partes sólidas e fluidas, não suscetíveis de movimento, que formam sua superfície, e sua profundidade e altura perpendiculares."

O Código Civil (artigo 79), por sua vez, estabelece como imóveis não só os bens que são imóveis por natureza (solo), mas também aqueles que se lhe incorporem por acessão (justaposição, aderência) natural ou artificial. ${ }^{3}$ Os artigos 80 e 81 do CC complementam esse conceito, ao dispor que também há bens imóveis que são assim considerados por força de lei. ${ }^{4}$

Com efeito, é possível classificar os bens imóveis em quatro categorias:

(i) bens imóveis por natureza: o solo, sua superfície, o subsolo e o espaço aéreo;

(ii) bens imóveis por acessão física natural (artigos 1.249 a 1.252 do CC): a formação de ilhas, aluvião (acréscimos formados, sucessiva e imperceptivelmente, por depósitos e aterros naturais ao longo das margens das correntes, ou pelo desvio das suas águas), avulsão (quando, por força natural violenta, uma porção de terra se destacar de um prédio e se juntar a outro) ou abandono de álveo (leito do rio após a mudança de curso das águas);

\footnotetext{
${ }^{1}$ BEVILAQUA, Clovis. Código Civil dos Estados Unidos do Brasil Comentado. 5a ed., vol. 1, Rio de Janeiro: Livraria Francisco Alves, 1936, p. 261.

${ }^{2}$ Apud RODRIGUES, Silvio. Direito civil: Parte Geral. Vol. 1, 32a ed., São Paulo: Saraiva, 2002, p. 122.

3 “Art. 79. São bens imóveis o solo e tudo quanto se lhe incorporar natural ou artificialmente."

4 “Art. 80. Consideram-se imóveis para os efeitos legais:

I - os direitos reais sobre imóveis e as ações que os asseguram;

II - o direito à sucessão aberta.

Art. 81. Não perdem o caráter de imóveis:

I - as edificações que, separadas do solo, mas conservando a sua unidade, forem removidas para outro local;
} 
(iii) bens imóveis por acessão física artificial (artigos 1.253 a 1.259 do CC): como as construções e plantações, que decorrem do emprego de trabalho pelo homem; e

(iv) bens imóveis por determinação legal: direitos reais sobre bens imóveis (usufruto, hipoteca, servidão predial etc.), ações que os assegurem (ações reivindicatórias, hipotecárias etc.) e o direito à sucessão aberta, ainda que a herança seja composta exclusivamente por bens móveis.

\subsection{2 - Posse do Imóvel}

A posse é uma relação de fato entre uma pessoa e um bem, que faz nascer uma relação jurídica (um direito). Conforme ensina Caio Mario da Silva Pereira, a tendência da doutrina moderna é classificar a posse como um direito, uma vez que, caracterizada a posse, nasce uma relação jurídica. Para ele, trata-se de um direito real (ou seja, oponível erga omnes, conforme será visto adiante), mas um direito real provisório (diferentemente da propriedade que é um direito real definitivo). ${ }^{5}$

Contudo, a posse também pode ser entendida como um estado de aparência juridicamente relevante (estado de fato protegido pelo direito). Neste sentido, a posse é entendida sob seu aspecto de aparência de propriedade, que deve ser protegida pelo Direito, mesmo que o possuidor não tenha uma relação jurídica direta com a coisa.

Trata-se de proteção à pessoa que mantém a aparência de propriedade, até que se verifique a quem o direito de propriedade efetivamente pertence. Também, essa situação de fato pode dar ensejo à aquisição da propriedade, como ocorre com a usucapião.

É importante ressaltar que é essa relação de fato com a coisa, protegida pelo direito, que faz com que o direito de propriedade seja fruível, conforme ensina Sílvio de Salvo Venosa: ${ }^{6}$

“Assim, a posse é o fato que permite e possibilita o exercício do direito de propriedade. Quem não
tem a posse não pode utilizar-se da coisa. Essa a razão fundamental, entre outras, de ser protegido
esse estado de aparência, como vimos. Sem proteção à posse, estaria desprotegido o proprietário.
Por conseguinte, prefere o ordenamento proteger sempre e com maior celeridade e eficácia o que

II - os materiais provisoriamente separados de um prédio, para nele se reempregarem."

${ }^{5}$ PEREIRA, Caio Mário da Silva. Instituições de Direito Civil. Vol. IV, Direitos Reais, 19a ed., Rio de Janeiro: Forense, 2006, pp. 27 e 28.

${ }^{6}$ VENOSA, Silvio de Salvo. Direito Civil: Direitos Reais, Coleção Direito Civil vol. 5, 6ª ed., São Paulo: Atlas, 
detém o aspecto externo da propriedade, a investigar em cada caso, e demoradamente, o título de proprietário e senhor."

O conceito de posse demanda dois elementos fundamentais para a sua compreensão: o corpus e o animus. O corpus é o vínculo, ou relação material, existente entre a pessoa e a coisa. Esse vínculo pode ser um vínculo físico, de mais fácil percepção, mas também se aplica a bens incorpóreos que podem ser apropriados economicamente.

No entanto, a mera relação material entre a pessoa e a coisa não é suficiente para evidenciar, para o mundo exterior, a aparência de propriedade. Faz-se necessária a existência do animus. O animus é o elemento que evidencia a intenção da pessoa de agir como se a coisa fosse sua. Esse conceito possui duas vertentes: (i) a teoria subjetiva (Savigny), segundo a qual se deve perquirir a intenção subjetiva do agente de possuir a coisa; (ii) a teoria objetiva (Jhering), segundo a qual o que importa é a manifestação exterior da pessoa de utilizar a coisa segundo sua destinação econômica (ou seja, o animus está integrado ao conceito de corpus). ${ }^{7}$

O CC encampa majoritariamente a teoria objetiva da posse, conforme se verifica no seguinte artigo: "Art. 1.196. Considera-se possuidor todo aquele que tem de fato o exercício, pleno ou não, de algum dos poderes inerentes à propriedade."

Em alguns momentos, contudo, o CC adota a teoria subjetiva da posse, como ocorre no caso do seu reconhecimento para fins de aquisição de propriedade por usucapião, em que o possuidor deve "possuir como seu um imóvel" (artigos 1.238 e ss), ficando claro que se faz necessária a evidência da intenção subjetiva do agente.

A posse pode ser classificada como direita ou indireta, nos termos do CC: “Art. 1.197. A posse direta, de pessoa que tem a coisa em seu poder, temporariamente, em virtude de direito pessoal, ou real, não anula a indireta, de quem aquela foi havida, podendo o possuidor direto defender a sua posse contra o indireto."

A posse direta (ou imediata) é exercida por aquele que a detém temporariamente, em virtude de um ato ou negócio jurídico (como ocorre com a locação, em que o locatário detém a posse direta e o locador detém a posse indireta). Trata-se, portanto, de hipóteses em que duas ou mais pessoas detém a posse de uma coisa. O locatário (possuidor direto), por exemplo, pode se proteger contra o locador (possuidor indireto) em caso de ofensa que lhe

2006, p. 30.

${ }^{7}$ VENOSA, Sílvio de Salvo. Op. cit (nota 6), p. 38. 
turbe ou esbulhe a posse. ${ }^{8}$ Ambos, no entanto, são legitimados a proteger a posse contra terceiros, mediante as competentes ações possessórias.

Para uma melhor compreensão da aquisição da posse, é importante que se retome o seu conceito: posse é uma situação de fato, que se caracteriza pela aparência da propriedade, protegida pelo direito. Com efeito, a aquisição da posse se dará a partir do momento em que se configurar essa aparência de propriedade, por meio do corpus e do animus. Neste sentido, confira-se o disposto no CC: “Art. 1.204. Adquire-se a posse desde o momento em que se torna possível o exercício, em nome próprio, de qualquer dos poderes inerentes à propriedade.”

Assim, a apreensão da coisa, de forma consciente, caracteriza a posse. Essa aquisição pode ocorrer por meio de um ato jurídico (que não decorre da vontade dos agentes, como é o caso da formação de ilhas), de um negócio jurídico (ato de vontade destinado à produção de efeitos jurídicos, como a locação, a compra e venda etc.) ou por força de lei (v.g. o herdeiro que adquire posse da herança, mesmo que não tenha ciência da morte do de cujus).

A posse pode ser classificada também como originária (em que não há vínculo com o possuidor original, o adquirente obtém a posse por ato unilateral) ou derivada, em que a posse é transferida de um sujeito para outro (pode decorrer de um negócio jurídico ou de lei, como na herança).

A tradição (forma derivada de aquisição da posse) pode ser efetiva, simbólica ou consensual. A tradição efetiva de um imóvel, por exemplo, é aquela em que o transmitente leva o adquirente ao local e indica pessoalmente a coisa, sua área e seus limites. A tradição simbólica (ou ficta) ocorre por gestos ou condutas que evidenciam a intenção de transferência da posse, como a entrega das chaves de um imóvel.

Na tradição consensual, não há transferência real do corpus, mas apenas uma alteração do animus do possuidor, como ocorre no caso em que (i) o locatário adquire a propriedade (passando a ser possuidor direto do imóvel) ou em que (ii) o proprietário aliena o imóvel transferindo a posse direta, mas mantém a posse indireta por locação. ${ }^{9}$

\footnotetext{
8 “Art. 1.210. O possuidor tem direito a ser mantido na posse em caso de turbação, restituído no de esbulho, e segurado de violência iminente, se tiver justo receio de ser molestado.

$\S 1^{\circ} \mathrm{O}$ possuidor turbado, ou esbulhado, poderá manter-se ou restituir-se por sua própria força, contanto que o faça logo; os atos de defesa, ou de desforço, não podem ir além do indispensável à manutenção, ou restituição da posse.

$\S 2^{\underline{0}}$ Não obsta à manutenção ou reintegração na posse a alegação de propriedade, ou de outro direito sobre a coisa."

${ }^{9}$ GOMES, Orlando. Direitos Reais. $19^{\mathrm{a}}$ ed., atualizada por Luiz Edson Fachin, Rio de Janeiro: Forense, pp. 74 e 75.
} 
Quanto aos seus efeitos, destaca-se o já mencionado direito do possuidor de ser mantido na posse em caso de turbação e ser restituído no caso de esbulho (artigo 1.210 do CC). Não obstante, merecem ser mencionados também:

(a) Frutos: é assegurado ao possuidor de boa-fé o direito aos frutos percebidos. ${ }^{10}$ Portanto, a posse de boa-fé tem o condão de conferir a propriedade sobre os frutos percebidos ao possuidor (enquanto ela durar), independentemente de ser o proprietário da coisa (como ocorre na locação, em que os frutos do bem locado pertencem ao locatário). O mesmo já não ocorre com o possuidor de má-fé. ${ }^{11}$

(b) Perda e deterioração: o possuidor de boa-fé não responde pela perda e deterioração da coisa, a que não der causa (artigo 1.217). Já o possuidor de má-fé responde por perda ou deterioração mesmo que acidentais, a não ser que prove que de igual modo teria se dado, caso a coisa estivesse na posse do reivindicante (artigo 1.218).

(c) Benfeitorias: o possuidor de boa-fé tem direito à indenização das benfeitorias necessárias e úteis. Quanto às voluptuárias, se não lhe forem pagas, poderá levantá-las quando isso for possível sem detrimento da coisa, podendo também exercer o direito de retenção pelo valor das benfeitorias necessárias e úteis (artigo 1.219). Já o possuidor de má-fé somente pode ser ressarcido pelas benfeitorias necessárias, sem direito de retenção, nem de levantar as voluptuárias (artigo 1.220).

Por fim, destaque-se que ocorre a perda da posse quando cessar aquela aparência de propriedade, que se configura pela relação material ou física com o bem (corpus) e pela intenção subjetiva de ser proprietário (animus), que se configura pelo comportamento social de exercer algum dos poderes da propriedade (usar e gozar). ${ }^{12}$

\footnotetext{
10 "Art. 1.214. O possuidor de boa-fé tem direito, enquanto ela durar, aos frutos percebidos.

Parágrafo único. Os frutos pendentes ao tempo em que cessar a boa-fé devem ser restituídos, depois de deduzidas as despesas da produção e custeio; devem ser também restituídos os frutos colhidos com antecipação.

Art. 1.215. Os frutos naturais e industriais reputam-se colhidos e percebidos, logo que são separados; os civis reputam-se percebidos dia por dia."

11 "Art. 1.216. O possuidor de má-fé responde por todos os frutos colhidos e percebidos, bem como pelos que, por culpa sua, deixou de perceber, desde o momento em que se constituiu de má-fé; tem direito às despesas da produção e custeio."

12 "Art. 1.223. Perde-se a posse quando cessa, embora contra a vontade do possuidor, o poder sobre o bem, ao qual se refere o art. 1.196.

Art. 1.224. Só se considera perdida a posse para quem não presenciou o esbulho, quando, tendo notícia dele, se abstém de retornar a coisa, ou, tentando recuperá-la, é violentamente repelido."
} 


\subsection{3 - Propriedade Imobiliária}

A propriedade é um direito fundamental, previsto no artigo $5^{\circ}$ da Constituição Federal ${ }^{13}$ ao lado dos direitos à vida, à liberdade, à igualdade, à segurança. Trata-se, de fato, do direito mais amplo que uma pessoa pode possuir em relação a uma coisa (direito real).

O Código Civil descreve esse direito por meio dos poderes conferidos ao proprietário de usar, gozar e dispor da coisa: "Art. 1.228. O proprietário tem a faculdade de usar, gozar e dispor da coisa, e o direito de reavê-la do poder de quem quer que injustamente a possua ou detenha."

Em síntese, pode-se afirmar que:

(i) Usar é colocar a coisa a serviço do titular, sem a alteração de sua substância. Neste sentido, o proprietário pode usar o imóvel para habitação ou permitindo que outro o habite. Também pode usá-lo para mera manutenção, sem utilização ativa.

(ii) Gozar é extrair benefícios e vantagens da coisa, no sentido de percepção de frutos (naturais ou civis).

(iii) Dispor é o poder de consumir, alterar a substância, alienar ou gravar o bem. Esse é o poder que efetivamente caracteriza o direito de propriedade, uma vez que os poderes de usar e gozar também podem ser atribuídos a terceiros que não sejam proprietários.

Trata-se do mais amplo direito da pessoa sobre a coisa, mas ele não é absoluto ou irrestrito. $\mathrm{Na}$ verdade, há diversos dispositivos no ordenamento jurídico que restringem esse direito. Neste sentido, a propriedade sobre o bem imóvel abrange o solo, sua superfície, o subsolo e o espaço aéreo. No entanto, o exercício desse poder, no que tange à profundidade e à altura perpendiculares, não pode obstar atividades realizadas por terceiros, sem que seja possível justificar seu interesse legítimo:

"Art. 1.229. A propriedade do solo abrange a do espaço aéreo e subsolo correspondentes, em altura e profundidade úteis ao seu exercício, não podendo o proprietário opor-se a atividades que

\footnotetext{
13 “Art. $5^{\circ}$ Todos são iguais perante a lei, sem distinção de qualquer natureza, garantindo-se aos brasileiros e aos estrangeiros residentes no País a inviolabilidade do direito à vida, à liberdade, à igualdade, à segurança e à propriedade, nos termos seguintes:"
} 
sejam realizadas, por terceiros, a uma altura ou profundidade tais, que não tenha ele interesse legítimo em impedi-las."

Quanto à aquisição das coisas, o instrumento utilizado é o contrato, embora não seja o único. Ocorre que o contrato simplesmente (como o de compra e venda, por exemplo) não é suficiente para a transferência da propriedade. Com a celebração do contrato, cria-se uma obrigação entre as partes (direito pessoal), mas a propriedade somente será transferida por meio das hipóteses previstas em lei, como é o caso da tradição como forma de transferência da propriedade de bens móveis por exemplo. ${ }^{14}$

Especificamente com relação à aquisição da propriedade dos bens imóveis, estabelece o CC que poderá se dar de três formas (artigo 1.238 e ss): (i) usucapião, (ii) registro do título ou (iii) acessão física natural (formação de ilhas, aluvião, avulsão ou abandono de álveo) ou artificial (construção ou plantação).

Para os fins do presente estudo, a aquisição por registro do título é a forma mais importante, uma vez que se trata da forma mais comum e rotineira nas relações econômicas. De fato, a propriedade somente se transfere entre vivos mediante o registro do título translativo no Registro de Imóveis:

“Art. 1.245. Transfere-se entre vivos a propriedade mediante o registro do título translativo no Registro de Imóveis.

$\S 1^{o}$ Enquanto não se registrar o título translativo, o alienante continua a ser havido como dono do imóvel.

$\S 2^{o}$ Enquanto não se promover, por meio de ação própria, a decretação de invalidade do registro, e o respectivo cancelamento, o adquirente continua a ser havido como dono do imóvel.

Conforme se verifica do dispositivo acima transcrito, a existência do título translativo ( $v . g$. contrato de compra e venda, permuta) não é suficiente para a transferência da propriedade imobiliária, enquanto não registrado no Registro de Imóveis. Portanto, o título translativo constitui uma relação pessoal entre o alienante e o adquirente. Além disso, mesmo que inválido o registro, o adquirente continua a ser havido como proprietário até que seja decretada a invalidade do registro por meio de ação judicial própria.

O Código Civil estabelece a necessidade de registro público para conferir autenticidade, segurança e eficácia a diversos fatos, atos e negócios jurídicos. Neste sentido, o Registro Público abrange (i) o registro civil de pessoas naturais, (ii) o registro civil de pessoas

14 “Art. 1.267. A propriedade das coisas não se transfere pelos negócios jurídicos antes da tradição.” 
jurídicas, (iii) o registro de títulos e documentos e (iv) o registro de imóveis. Essa atividade encontra-se regulamentada pela Lei dos Registros Públicos - LRP (Lei no 6.015/73).

Os registros pertinentes aos bens imóveis são de competência do Registro de Imóveis (artigo $2^{\circ}$ da LRP), onde serão feitos os registros (v.g. compra e venda, permuta) e averbações ( $v . g$. convenções antenupciais e mudança de denominação ou numeração dos prédios) previstos no artigo 167 da LRP.

Dessa forma, todo imóvel objeto de título a ser registrado deve estar matriculado (artigo 227 da LRP). Ademais, nenhum registro poderá ser feito sem que o imóvel esteja matriculado (artigo 236 da LRP). Portanto, a matrícula é o instrumento hábil e necessário para a realização do registro do título translativo da propriedade do bem imóvel.

A matrícula será efetuada por ocasião do primeiro registro a ser lançado, mediante os elementos constantes do título apresentado e do registro anterior nele mencionado (artigo 228 da LRP). Com efeito, a matrícula do imóvel é a base para o acompanhamento de toda a vida jurídica dos bens imóveis, segundo o princípio da continuidade do registro (artigo 237 da LRP).

$\mathrm{O}$ registro do título translativo produz eficácia desde o momento em que $\mathrm{o}$ oficial do registro o prenotar no protocolo. ${ }^{15} \mathrm{O}$ teor do registro também pode ser retificado ou anulado, caso não exprima a verdade. Uma vez cancelado o registro, o proprietário poderá reivindicar o imóvel, independentemente da boa-fé ou do título do terceiro adquirente. ${ }^{16}$ Segundo os artigos 212 e 213 da LRP, o próprio oficial poderá retificar o registro nas hipóteses em que a averbação for omissa, imprecisa ou não exprimir a verdade.

Por fim, o artigo 1.275 do CC estabelece como causas de perda da propriedade, dentre outras previstas no mesmo diploma (v.g. usucapião e acessão) as seguintes: (i) por alienação, (ii) pela renúncia, (iii) por abandono, (iv) por perecimento da coisa e (v) por

\footnotetext{
${ }^{15}$ CC/2002: "Art. 1.246. O registro é eficaz desde o momento em que se apresentar o título ao oficial do registro, e este o prenotar no protocolo."

LRP: “Art. 182 - Todos os títulos tomarão, no Protocolo, o número de ordem que lhes competir em razão da sequiência rigorosa de sua apresentação.

Art. 183 - Reproduzir-se-á, em cada título, o número de ordem respectivo e a data de sua prenotação. (...)

Art. 190 - Não serão registrados, no mesmo dia, títulos pelos quais se constituam direitos reais contraditórios sobre o mesmo imóvel.

Art. 191 - Prevalecerão, para efeito de prioridade de registro, quando apresentados no mesmo dia, os títulos prenotados no Protocolo sob número de ordem mais baixo, protelando-se o registro dos apresentados posteriormente, pelo prazo correspondente a, pelo menos, um dia útil."

16 “Art. 1.247. Se o teor do registro não exprimir a verdade, poderá o interessado reclamar que se retifique ou anule.

Parágrafo único. Cancelado o registro, poderá o proprietário reivindicar o imóvel, independentemente da boa-fé
} 
desapropriação. Nos dois primeiros casos, os efeitos da perda da propriedade do imóvel serão subordinados ao registro do título transmissivo ou do ato renunciativo no Registro de Imóveis.

\subsection{4 - Condomínio Imobiliário (Conceito e Características)}

Um dos institutos reflexos do direito de propriedade é o condomínio, que se caracteriza pelo direito comum de propriedade sobre determinado bem (comunhão de direitos sobre a mesma coisa), detido por uma ou mais pessoas ao mesmo tempo, cada uma exercendo seu direito em idêntica graduação, de forma harmônica e compatível com o direito dos demais comunheiros.

Também conhecido como copropriedade (ou compropriedade), o condomínio constitui-se numa relação jurídica em que cada condômino possui os mesmos direitos, na proporção de seu quinhão, denominada parte ideal. A parte ideal é a percentagem ou fração que cada comunheiro possui no título, o que se reflete nos direitos e deveres pertinentes à propriedade.

Quanto às espécies de condomínio existentes, é possível verificar diversas classificações. Uma das classificações possíveis é a decorrente da sua origem, ou motivo de formação. Com efeito, um condomínio pode originar-se da vontade das partes ou por força alheia a essa vontade. Tem-se, assim, o condomínio voluntário (convencional, que nasce do contrato em que duas ou mais pessoas adquirem a propriedade em comunhão, para dela usar e fruir), incidente (ou eventual, que não depende da vontade das partes - v.g. herança) ou legal (ou forçado - decorre de imposição de lei). ${ }^{17}$

Com relação à forma, o condomínio poderá ser pro diviso (em que há mera aparência de condomínio, uma vez que os comunheiros exercem propriedade exclusiva sobre as unidades autônomas) ou pro indiviso. Para melhor elucidar essas duas classificações, leciona Silvio de Salvo Venosa ${ }^{18}$ que:

"No condomínio pro diviso, existe mera aparência de condomínio, porque os comunheiros localizaram-se em parte certa e determinada da coisa, sobre a qual exercem exclusivamente o direito de propriedade. Nos edifícios de apartamentos e outros condomínios assemelhados, cada unidade autônoma é independente das demais, por força de lei. Os condôminos nessa situação exercem a comunhão pro indiviso apenas no tocante às áreas comuns dos prédios. Nessas áreas,

\footnotetext{
ou do título do terceiro adquirente."

${ }^{17}$ PEREIRA, Caio Mário da Silva. Op. cit (nota 5), pp. 176 e 177.

${ }^{18}$ VENOSA, Silvio de Salvo. Op. cit. (nota 6), pp. 319 e 320.
} 
não podem exercer domínio pro diviso. (...) Na comunhão pro indiviso, a indivisibilidade é de direito e de fato. A propriedade é exercida em comum, sob a égide das quotas ideais. O fenômeno é mais corrente nos imóveis, mas também possível nos móveis".

Dentre os direitos e deveres dos condôminos, no condomínio voluntário (artigos 1.314 e ss do CC), destacam-se, para os fins do presente estudo:

(i) Cada condômino pode usar da coisa conforme sua destinação, sobre ela exercer todos os direitos compatíveis com a indivisão, reivindicá-la de terceiro, defender a sua posse e alhear a respectiva parte ideal, ou gravá-la.

(ii) Nenhum dos condôminos pode alterar a destinação da coisa comum, nem dar posse, uso ou gozo dela a estranhos, sem o consenso dos outros.

(iii) O condômino é obrigado, na proporção de sua parte, a concorrer para as despesas de conservação ou divisão da coisa, e a suportar os ônus a que estiver sujeita. Presumem-se iguais as partes ideais dos condôminos.

(iv) Cada condômino responde aos outros pelos frutos que percebeu da coisa e pelo dano que lhe causou.

(v) Os frutos da coisa comum, não havendo em contrário estipulação ou disposição de última vontade, serão partilhados na proporção dos quinhões.

Pelo exposto, verifica-se que sendo a propriedade exercida por várias pessoas ao mesmo tempo, a utilização, exploração e aproveitamento do bem também será exercida de forma coletiva, de forma a evitar que o benefício de um não perturbe o uso da coisa pelos demais.

Ocorrendo, entretanto, circunstâncias ou desentendimentos que impossibilitem ou dificultem o uso comum do bem, os condôminos podem deliberar se a coisa deverá ser (i) administrada por um dos proprietários ou por terceiros ou (ii) se será alugada. ${ }^{19} \mathrm{~A}$ esse respeito, Orlando Gomes ${ }^{20}$ afirma que:

\footnotetext{
${ }^{19}$ Código Civil:

"Art. 1.323. Deliberando a maioria sobre a administração da coisa comum, escolherá o administrador, que poderá ser estranho ao condomínio; resolvendo alugá-la, preferir-se-á, em condições iguais, o condômino ao que não o é. Art. 1.324. O condômino que administrar sem oposição dos outros presume-se representante comum.

Art. 1.325. A maioria será calculada pelo valor dos quinhões.

$\S 1^{\circ}$ As deliberações serão obrigatórias, sendo tomadas por maioria absoluta.

$\S 2^{\circ}$ Não sendo possível alcançar maioria absoluta, decidirá o juiz, a requerimento de qualquer condômino, ouvidos os outros.

§ $3^{\circ}$ Havendo dúvida quanto ao valor do quinhão, será este avaliado judicialmente." (g.n.)

${ }^{20}$ GOMES, Orlando. Op. cit. (nota 9), pp. 244 e 245.
} 
"Se algum dos condôminos não exigir a divisão da coisa comum, ou a sua venda para repartição do preço, podem todos usá-la, livremente, conforme seu destino. Mas, se esse uso comum for impossivel ou inconveniente, por circunstâncias de fato ou desacordo, a coisa deve ser administrada, ou locada".

Sobre a extinção do condomínio voluntário, Orlando Gomes ${ }^{21}$ ensina que:

"O condomínio extingue-se: $1^{o}$ ) pela alienação da coisa; $2^{\circ}$ ) pela divisão. A alienação é voluntária ou forçada. No primeiro caso, a título gratuito ou oneroso. Tanto de coisas divisíveis como indivisíveis. Quando não é possível o uso e gozo em comum, podem os condôminos deliberar a venda do bem. Se um deles opta pela venda, os outros não podem decidir que seja administrada ou alugada. O condomínio só não se extingue pela venda se a unanimidade dos condôminos resolver que deve ser mantido. Em se tratando de coisa indivisível, a extinção só se verifica, necessariamente, por alienação. Se a coisa é divisível, termina com a partilha, conseqüente à ação de divisão (...)".

Dentre as modalidades especiais de condomínio, merece destaque o condomínio edilício (também denominado como propriedade horizontal). Este condomínio foi inicialmente regulamentado na Lei $\mathrm{n}^{\mathrm{o}}$ 4.591/64, aplicável no âmbito das edificações ou conjuntos de edificações, de um ou mais pavimentos, construídos sob a forma de unidades isoladas entre si, destinadas a fins residenciais ou não residenciais.

Com o advento do Código Civil de 2002, essa modalidade de condomínio foi integralmente disciplinada. Com efeito, nos termos do artigo 1.331 do $\mathrm{CC}$, pode haver em edificações partes de propriedade exclusiva (unidades autônomas que constituem o condomínio pro diviso) e partes de propriedade comum (objeto do condomínio pro indiviso):

“Art. 1.331. Pode haver, em edificações, partes que são propriedade exclusiva, e partes que são propriedade comum dos condôminos.

$\S 1^{o}$ As partes suscetíveis de utilização independente, tais como apartamentos, escritórios, salas, lojas, sobrelojas ou abrigos para veículos, com as respectivas frações ideais no solo e nas outras partes comuns, sujeitam-se a propriedade exclusiva, podendo ser alienadas e gravadas livremente por seus proprietários.

$\S 2^{\circ}$ O solo, a estrutura do prédio, o telhado, a rede geral de distribuição de água, esgoto, gás e eletricidade, a calefação e refrigeração centrais, e as demais partes comuns, inclusive o acesso ao logradouro público, são utilizados em comum pelos condôminos, não podendo ser alienados separadamente, ou divididos."

\footnotetext{
${ }^{21}$ GOMES, Orlando. Op. cit. (nota 9), pp. 245 e 246.
} 
A constituição do condomínio edilício (artigo 1.332) dá-se por ato de vontade (entre vivos ou por testamento), na qual deve ocorrer a particularização da sua estrutura (identificação das unidades autônomas, das áreas comuns e das frações ideais do terreno).

A convenção de condomínio tem o fim de regular os direitos e deveres dos condôminos, de modo a criar uma lei fundamental do condomínio, para determinar, por exemplo: (i) a proporção e o modo pelo qual deverão ser pagas as despesas do condomínio, (ii) a forma de administração e (iii) sanções a que estão sujeitos os condôminos ou possuidores (artigo 1.334). Para ser oponível a terceiros, a convenção do condomínio deverá ser registrada no Cartório de Registro de Imóveis. ${ }^{22}$

São direitos dos condôminos (artigo 1.335): (i) usar, fruir e livremente dispor das suas unidades, (ii) usar das partes comuns, conforme a sua destinação, e contanto que não exclua a utilização dos demais compossuidores e (iii) votar nas deliberações da assembléia e delas participar, estando quite.

São deveres dos condôminos (artigo 1.336): (i) contribuir para as despesas do condomínio na proporção das suas frações ideais, salvo disposição em contrário na convenção, (ii) não realizar obras que comprometam a segurança da edificação, (iii) não alterar a forma e a cor da fachada, das partes e esquadrias externas e (iv) dar às suas partes a mesma destinação que tem a edificação, e não as utilizar de maneira prejudicial ao sossego, salubridade e segurança dos possuidores, ou aos bons costumes.

No que tange à administração do condomínio (artigos 1.347 e ss do CC), a assembléia geral escolherá um síndico que poderá não ser condômino. Ao síndico compete, entre outras atribuições: (i) representar, ativa e passivamente, o condomínio, praticando, em juízo ou fora dele, os atos necessários à defesa dos interesses comuns, (ii) elaborar o orçamento da receita e da despesa relativa a cada ano e (iii) cobrar dos condôminos as suas contribuições, bem como impor e cobrar as multas devidas.

A extinção do condomínio edilício pode se dar caso a edificação for total ou consideravelmente destruída, ou ameace ruína, os condôminos deliberarão em assembléia sobre a reconstrução, ou venda, por votos que representem metade mais uma das frações ideais (artigo 1.357).

\footnotetext{
22 “Art. 1.333. A convenção que constitui o condomínio edilício deve ser subscrita pelos titulares de, no mínimo, dois terços das frações ideais e torna-se, desde logo, obrigatória para os titulares de direito sobre as unidades, ou para quantos sobre elas tenham posse ou detenção.

Parágrafo único. Para ser oponível contra terceiros, a convenção do condomínio deverá ser registrada no Cartório
} 
Por fim, é interessante também traçar um breve paralelo do condomínio com a sociedade. Para tanto, transcrevem-se as lições de Washington de Barros Monteiro ${ }^{23}$, verbis:

"Paralelo entre comunhão e sociedade - A comunhão e a sociedade têm muitos pontos de contacto. Em ambas, é condição essencial para a sua existência a pluralidade de sujeitos. Tanto numa como noutra, torna-se mister exista res comum, que, no condomínio, é a coisa e na sociedade o acervo social. Além disso, uma e outra reclamam conjugação de esforços para a respectiva administração, respondendo todos, sócios e condôminos, pelas despesas.

Estremam-se, todavia, por caracteres inconfundiveis. Na sociedade, os direitos dos sócios decorrem do contrato social, ao passo que no condomínio derivam da situação da coisa pertencente a vários titulares. Além disso, a sociedade só pode existir em virtude do acordo de vontade, ou da affectio societatis, ao passo que o condomínio resulta não só desse acordo como de outros acontecimentos estranhos à vontade dos condôminos, como a herança e o testamento, bem como da própria lei. Ademais, na sociedade, falecendo um dos sócios, procede-se geralmente à sua dissolução e liquidação, o que não sucede no condomínio, que prossegue com os herdeiros do condômino falecido, podendo subsistir até contra a vontade daqueles que se tornaram condôminos. Ainda não é tudo: as sociedades são administradas pela forma prevista no contrato social, enquanto por lei é regulada a administração do condomínio. Finalmente, sociedade é relação jurídica de natureza pessoal, enquanto o condomínio participa da natureza real."

Verifica-se, assim, que os institutos do condomínio e da sociedade não se confundem. Conforme demonstrado, o condomínio constitui uma relação jurídica decorrente de um direito de natureza real (dos condôminos sobre a coisa). A sociedade, por outro lado, é configurada por uma reunião de pessoas, com affectio societatis, objetivando atividades e interesses em comum com natureza pessoal.

Não obstante a inexistência de personalidade jurídica, ressalta Silvio de Salvo Venosa que o condomínio edilício possui uma personalidade anômola, uma vez que pode comprar, vender, emprestar, prestar serviço, ser empregador, pagar tributos etc. Segundo ele, nada impede, por exemplo, que o condomínio seja proprietário de unidades autônomas, lojas no térreo ou garagens, e pode locá-las e utilizar os referidos rendimentos em favor dos condôminos. $^{24}$

de Registro de Imóveis.”

${ }^{23}$ MONTEIRO, Washington de Barros. Curso de Direito Civil. Vol. III, Direito das Coisas, $20^{\mathrm{a}}$ ed., São Paulo: Saraiva, 1981, p.208.

${ }^{24}$ VENOSA, Silvio de Salvo. Op. cit. (nota 6), p. 338. 


\subsection{5 - Patrimônio para o Direito Civil (Comparação com Direito Societário)}

Faz-se necessário também expor uma breve noção sobre o conceito de patrimônio para o Direito Civil, uma vez que esse conceito possui estreito relacionamento com o conceito de renda a ser tributada: renda como acréscimo patrimonial.

Inicialmente, pode-se extrair o conceito de patrimônio do Direito Civil (como sendo um bem coletivo para o seu titular, nos termos do artigo 91 do Código Civil: "Constitui universalidade de direito o complexo de relações jurídicas, de uma pessoa, dotadas de valor econômico"). Portanto, para o Direito Civil, o patrimônio de uma pessoa é uma universalidade de direito, que configura um complexo de relações jurídicas dotadas de valor econômico.

Toda pessoa (natural ou jurídica) possui capacidade para ser titular de direitos e deveres. Para cada direito de que a pessoa é titular, existe um dever correlato de outra pessoa (v.g. o direito do locador receber o aluguel é correlato ao dever do locatário pagá-lo).

São duas as espécies de direitos passíveis de integrar o patrimônio de uma pessoa: ${ }^{25} \mathrm{o}$ direito real e o direito obrigacional. $\mathrm{O}$ direito real é uma faculdade detida por uma pessoa sobre uma coisa, com exclusão da faculdade de qualquer outra pessoa, ou seja, oponível erga omnes (como a faculdade de usar, gozar e dispor da coisa no caso do direito de propriedade). Essa faculdade é única, mas pode ser exercida de forma coletiva (como ocorre com a propriedade em condomínio).

O direito real mais amplo da pessoa é a propriedade, mas também há outras espécies como a posse, o usufruto, a superfície e a hipoteca, entre outros.

O direito obrigacional, por sua vez, é um direito pessoal, pois se configura como a faculdade de uma pessoa exigir uma prestação de outra pessoa. Ou seja, na relação jurídica obrigacional, a pessoa titular do direito (credor) tem o direito de exigir uma conduta (dar, fazer ou não fazer) da pessoa titular do dever (devedor).

Com efeito, o patrimônio é o conjunto de direitos reais e de direitos obrigacionais da pessoa. O patrimônio engloba apenas os direitos pecuniários (com o que se excluem os direitos puros de personalidade como a honra e a liberdade). Os direitos obrigacionais somente

\footnotetext{
${ }^{25}$ Pontes de Miranda classifica os direitos patrimoniais em três espécies: (i) os direitos reais; (ii) os direitos sobre bens imateriais (que nem sempre são redutíveis a valor pecuniário); e (iii) direitos de crédito. Os direitos sobre bens imateriais são classificados como direitos reais no presente trabalho. MIRANDA, Pontes de, Tratado de Direito Privado: Parte Geral - Bens. Fatos Jurídicos. Tomo II, atualizada por Vilson Rodrigues Alves, $1^{\mathrm{a}}$ ed., Campinas: Bookseller, 2000, p. 49. Este autor também cita outros direitos que não são patrimoniais, como (i) os direitos sobre a pessoa (v.g. vida e liberdade); (ii) os direitos sobre a pessoa de outrem (v.g. direitos de família, como casamento, paternidade etc.); e (iii) os direitos hereditários (herança). (pp. 47-51)
} 
integram o patrimônio por terem conteúdo passível de avaliação pecuniária, mesmo que sob o enfoque da execução forçada.

Ressalte-se que esse conjunto de bens e direitos que constituem o patrimônio de uma pessoa é considerado uno, de forma que existe apenas um patrimônio para cada pessoa. É nesse sentido que se fala em universalidade.

Ocorre que o conceito de patrimônio também é definido pelo Direito Societário, que possui metodologia própria de apuração, nos termos da Lei das S/A, artigo 177:

“Art. 177. A escrituração da companhia será mantida em registros permanentes, com obediência aos preceitos da legislação comercial e desta Lei e aos princípios de contabilidade geralmente aceitos, devendo observar métodos ou critérios contábeis uniformes no tempo e registrar as mutações patrimoniais segundo o regime de competência".

Com efeito, verifica-se que o Direito Societário determina que a escrituração da companhia deve ser elaborada em conformidade com o preceitos da legislação comercial e da própria Lei das S/A, motivo pelo qual o patrimônio, segundo este ramo do Direito Privado, possui regras próprias que não necessariamente coincidem com as regras de Direito Civil ou outros ramos do Direito Privado.

Neste sentido, o patrimônio do Direito Societário será mensurado de acordo com os princípios de contabilidade geralmente aceitos, que não são necessariamente aplicáveis na apuração do patrimônio para o Direito Civil. A Lei das S/A também determina o registro das mutações patrimoniais segundo o regime de competência, mas não há obrigatoriedade dessa metodologia de registro para o Direito Civil.

Assim, nos termos dos princípios da objetividade e conservadorismo contábeis (confira-se o Capítulo 2.4.1), as alterações patrimoniais, para fins de Direito Societário, somente são registradas quando houver a segurança da ocorrência da transferência de riscos e benefícios referentes a um ativo (o que não ocorre com o Direito Civil).

Apenas para esclarecer o motivo da distinção ora apontada, cite-se o exemplo da posse. A posse é um direito e, portanto, integra o patrimônio de uma pessoa nos termos do Direito Civil (patrimônio civil). ${ }^{26}$ Contudo, nem sempre a posse será registrada no patrimônio apurado em conformidade com as regras de Direito Contábil Societário (patrimônio societário).

\footnotetext{
${ }^{26}$ Sobre a posse como elemento do patrimônio, confira-se MIRANDA, Pontes de, Tratado de Direito Privado: Parte Geral - Eficácia Jurídica. Determinações Inexatas e Anexas. Direitos. Pretensões. Ações. Tomo V, atualizada por Vilson Rodrigues Alves, $1^{\mathrm{a}}$ ed., Campinas: Bookseller, 2000, p. 418.
} 
Em determinadas situações (como ocorre no caso do leasing financeiro), a entidade arrendatária não detém a propriedade do bem, mas a posse é suficiente para que seja registrada em seu balanço patrimonial como um ativo para fins societários (confira-se o Capítulo 4.4.1).

De fato, a posse caracteriza-se pela possibilidade de usar e gozar da coisa (fruir seus benefícios econômicos) e responder por perda ou deterioração (vivenciar os riscos), embora não se tenha a capacidade de dispor dela. Contudo, em algumas situações, não é possível o seu registro como um ativo da entidade sob o ponto de vista do Direito Contábil Societário, especialmente quando não houver segurança de mensuração de seu valor.

Assim, pode-se afirmar que o patrimônio civil é mais amplo do que o patrimônio societário. Isto ocorre, principalmente, porque o Direito Civil não possui como objetivo oferecer informações úteis a seus usuários sob o aspecto de reconhecimento e mensuração do patrimônio (o que faz com que o patrimônio societário seja mais conservador).

No que tange à posse, trata-se de um direito que necessariamente integrará o patrimônio civil do seu titular. Neste sentido, o direito à posse de um imóvel, decorrente de um contrato de leasing, necessariamente integrará o patrimônio civil do arrendatário.

Contudo, o direito à posse nem sempre será registrado no patrimônio societário. Conforme será visto no Capítulo 4.4.1, o registro do direito à posse decorrente de contratos de leasing somente será registrado no patrimônio societário quando se tratar de leasing financeiro (quando houver a transferência dos riscos e benefícios do bem arrendado), mas não nos casos em que se configurar o leasing operacional (geralmente realizado por tempo inferior à vida útil do bem arrendado).

Apesar de nem sempre ser passível de registro no patrimônio societário, a posse não deixa de existir para o patrimônio civil. Em alguns casos, esse direito integra o patrimônio civil, mas somente será passível de mensuração mediante acordo entre as partes ou decisão judicial (v.g. herança e separação judicial dos cônjuges).

Quanto às obrigações, nem sempre haverá coincidência entre os patrimônios. Isto porque o direito societário prevê o princípio do conservadorismo, segundo o qual até mesmo uma possível obrigação futura poderá ser registrada contabilmente. Assim, o patrimônio civil pode ainda não ter sido afetado por essa futura obrigação, mas ela poderá ser passível de registro para fins do patrimônio societário. 
Em suma, é possível afirmar que a diferença entre os patrimônios de Direito Civil e de Direito Societário decorrem de diferentes critérios de reconhecimento e mensuração, já que os princípios contábeis geralmente aceitos acabam por (i) restringir os direitos passíveis de registro no patrimônio societário e (ii) ampliar o número de obrigações, pois registra obrigações ainda não existentes. Confira-se a planilha abaixo:

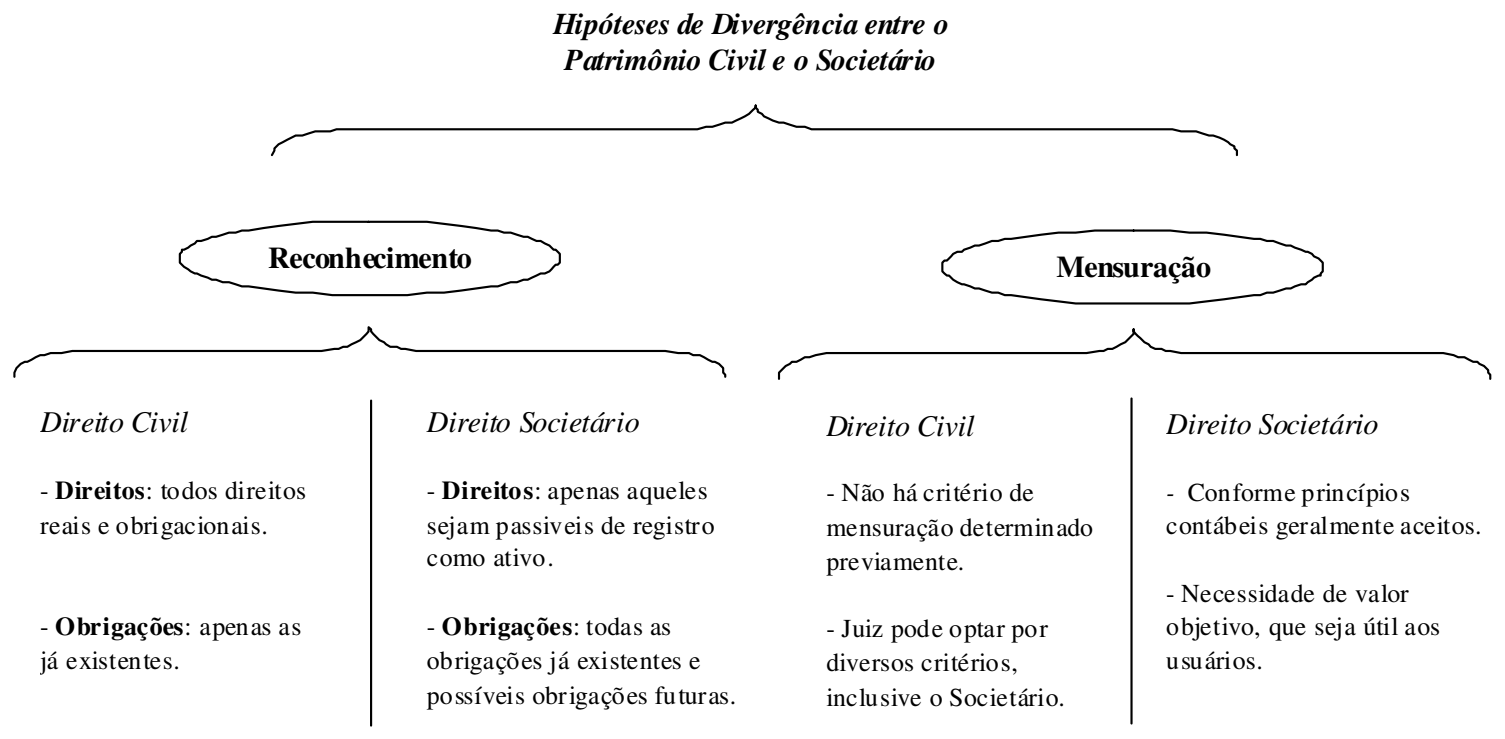

\subsection{6 - Contratos (Negócios Jurídicos Constitutivos de Obrigações)}

Conforme mencionado, as obrigações podem ser definidas como o vínculo jurídico transitório existente entre duas pessoas, em que uma será titular do direito (credor - sujeito ativo) e terá o direito de exigir uma conduta (uma prestação dar, fazer ou não fazer alguma coisa de natureza econômica) da outra pessoa, titular do dever (devedor - sujeito passivo).

\section{Obrigação Jurídica}




As obrigações jurídicas podem ter como fonte (origem) a lei ou os atos de vontade (como é o caso dos contratos). Os contratos, portanto, são fontes de obrigações jurídicas e estão amparados na autonomia da vontade - liberdade conferida aos particulares para que possam criar regulamentar suas condutas, estipulando direitos e deveres (obrigações de dar, fazer ou não fazer).

A distinção entre obrigação de dar e de fazer nem sempre é muito clara. Washington Monteiro de Barros, ${ }^{27}$ por exemplo, ensina que a diferença está em definir:

"se o dar ou entregar é ou não conseqüência do fazer. Assim, se o devedor tem de dar ou de entregar alguma coisa, não tendo, porém, de fazê-la previamente, a obrigação é de dar; todavia, se, primeiramente, tem ele de confeccionar a coisa para depois entregá-la, tendo de realizar algum ato, do qual será mero corolário o de dar, tecnicamente a obrigação é de fazer."

O correto entendimento da natureza jurídica de um contrato é importante para os fins do presente estudo, uma vez que obrigações de dar e de fazer costumam ter tratamentos contábeis diferenciados, com consequências tributárias distintas. Esse tema será retomado no capítulo 4, quando serão abordados os diferentes tratamentos contábeis dados às operações de "compra e venda" e de "prestação de serviço".

Cumpre destacar também que os contratos podem ser classificados em unilaterais ou bilaterais. Trata-se de uma classificação que toma como critério de distinção a carga de obrigações existente entre as partes do negócio jurídico (outro fator determinante para o registro de informações contábeis e suas consequências tributárias, conforme será demonstrado).

Nos contratos bilaterais, cada parte do negócio jurídico assume obrigações perante a outra, ou seja, há um sinalagma entre as partes (dependência recíproca de obrigações). Assim, em um contrato de compra e venda, o vendedor tem a obrigação de entregar a coisa e o comprador tem a obrigação de pagar o preço. Nos contratos unilaterais, somente há obrigações para uma das partes, como ocorre com a doação.

Esta é uma distinção importante, pois o próprio Código Civil estabelece que nos contratos bilaterais, nenhum contratante poderá exigir o implemento da obrigação da outra parte enquanto não houver adimplido a sua parte (artigo 476 - exceção do contrato não cumprido).

${ }^{27}$ MONTEIRO, Washington de Barros. Curso de Direito Civil: direito das obrigações, $1^{a}$ parte, $16^{a}$ ed., São Paulo: Saraiva, 1981, p. 87. 
Ressalte-se, por fim, que a modalidade normal de adimplemento e extinção das obrigações é o pagamento (artigos 304 e seguintes do CC). O pagamento que é mais facilmente percebido pelo senso comum é o realizado em dinheiro. Contudo, qualquer prestação empreendida para a extinção de uma obrigação é considerada um pagamento. Com efeito, num contrato de compra e venda, será pagamento a entrega da coisa vendida. Também é pagamento o término da obra em um contrato de empreitada, bem como a entrega do bem em uma permuta.

Feitas essas breves considerações acerca de conceitos fundamentais para a compreensão dos negócios jurídico-imobiliários, passa-se a analisar as características específicas de cada modalidade de operação imobiliária, especialmente sob o aspecto da transferência de riscos e benefícios.

\section{2 - Primeiro Gênero: AlienaÇão da Propriedade Imobiliária}

\subsection{1 - Compra e Venda}

$\mathrm{O}$ contrato de compra e venda encontra-se regulamentado pelos artigos $481 \mathrm{e}$ seguintes do Código Civil de 2002 e pode ser definido como um negócio jurídico, pelo qual um dos contratantes se obriga a transferir o domínio de certa coisa e o outro se obriga pagar o preço em dinheiro.

Uma primeira observação a ser feita é que a compra e venda necessariamente envolve a contratação da entrega de um bem e o recebimento do preço em dinheiro. Essa é uma característica que distingue a compra e venda da permuta (troca ou escambo), na qual um dos contratantes assume a obrigação da transferência do domínio de certa coisa e receberá o domínio de outra coisa em troca.

Não obstante a definição do preço tenha que ser feita em dinheiro, não há vedação a que o vendedor receba o preço mediante a dação de outros bens. Ou seja, o pagamento do preço pode ser feito mediante o recebimento de uma prestação diversa (bens) daquela que lhe é devida (dinheiro). Neste caso, tem-se uma compra e venda com dação em pagamento (artigo 356 e seguintes do Código Civil de 2002), que não se confunde com a permuta que tem a entrega do bem como prestação originária do contrato. 
O contrato de compra e venda é oneroso. Assim, o preço definido entre as partes deve ser em montante suficiente para se configurar a contraprestação pela aquisição do bem, caso contrário será mera liberalidade do vendedor - hipótese de doação (artigos 538 e seguintes do Código Civil de 2002).

$\mathrm{Na}$ compra e venda de imóveis, o vendedor se obriga a transferir o domínio do imóvel (que ocorrerá com o registro na matrícula perante o Cartório de Registro de Imóveis). O comprador assume a obrigação de pagar o preço, o que pode ser feito em prestações (venda a prazo).

\subsection{2 - Compromisso de Compra e Venda}

A promessa de compra e venda de imóveis (ou compromisso de compra e venda de imóveis) $)^{28}$ possui natureza de contrato perfeito e acabado, não se tratando de meras negociações preliminares. Trata-se de uma obrigação de fazer (contratação definitiva, depois de cumpridas certas condições) e uma obrigação de dar (entregar o bem imóvel). Conforme ensina Silvio de Salvo Venosa, no "compromisso de compra e venda imobiliário, o objetivo claro das partes não é precipuamente a conclusão de outro contrato, mas a compra definitiva de um imóvel." 29

Nos termos do artigo 1.417 do CC/02, a promessa de compra e venda confere direito real ao promitente comprador à aquisição do imóvel, desde que não tenha sido pactuado arrependimento e tenha sido celebrada por instrumento público ou particular e registrada no Cartório de Registro de Imóveis.

Como decorrência desse direito real, o promitente comprador pode exigir do promitente vendedor (ou de terceiros, a quem os direitos deste forem cedidos) a outorga da escritura definitiva de compra e venda, conforme o disposto no instrumento preliminar. No caso de recusa da outorga da escritura definitiva, poderá requerer ao juiz a adjudicação do imóvel (artigo 1.418 do CC/02).

\footnotetext{
${ }^{28}$ Como consagrado pela Lei $\mathrm{n}^{\circ}$ 6.766/79 que regulamenta o parcelamento do solo urbano.

${ }^{29}$ VENOSA, Silvio de Salvo. Direito Civil: Contratos em Espécie, Coleção Direito Civil vol. 3, 8a ed., São Paulo: Atlas, 2008, pp. 487 e seguintes.
} 


\subsection{3 - Procuração em Causa Própria}

O mandato é o contrato em que alguém (mandatário) recebe de outrem (mandante) poderes para, em seu nome, praticar atos ou administrar interesses (conforme artigo 653 do $\mathrm{CC} / 02)$. Com efeito, a procuração em causa própria é um instrumento utilizado em negociações imobiliárias em que o mandante (proprietário do imóvel) autoriza o mandatário (adquirente) a transferir o imóvel para seu nome.

Dessa forma, o comprador poderá representar o vendedor perante o cartório de registro de imóveis para que lhe seja outorgada a escritura pública. Este contrato é celebrado, em geral, quando as partes têm urgência na realização do negócio, mas não têm interesse no registro da transferência na matrícula do imóvel (por razões de tempo ou de custo de transferência).

Assim, o vendedor confere a procuração em causa própria ao comprador em caráter irrevogável e irretratável, mediante o pagamento do preço do imóvel. Dessa forma, a revogação deste mandato não terá eficácia e nem se extinguirá pela morte de qualquer das partes (artigo 685 do CC/02).

\subsection{4 - Troca ou Permuta}

A permuta é um negócio jurídico pelo qual uma das partes se obriga à transferência do domínio de um bem, mediante o recebimento de outro bem em contraprestação (troca de um bem por outro).

Neste contrato, nenhuma das prestações é pactuada em dinheiro (como ocorre com a compra e venda), embora seja possível o pagamento de um percentual em dinheiro (denominada torna). Contudo, quando a torna for expressiva em relação ao valor dado em bens, o contrato será de compra e venda e não de permuta. ${ }^{30}$

Segundo o artigo 533 do Código Civil de 2002, aplicam-se à permuta as disposições pertinentes ao contrato de compra e venda. Contudo, este negócio jurídico se diferencia da compra e venda no que tange à formação do preço. Na verdade, na permuta não há preço propriamente dito, mas o compromisso de trocar bens reciprocamente (que não sejam dinheiro). ${ }^{31}$

\footnotetext{
${ }^{30}$ FRANCO, Vera Helena de Mello. Contratos - Direito Civil e Empresarial. $2^{\mathrm{a}}$ ed. São Paulo: Editora Revista dos Tribunais, 2011, p. 76.

${ }^{31}$ VENOSA, Silvio de Salvo. Op. cit. (nota 29), pp. 86 e 87.
} 
Neste sentido, confira-se o entendimento de Orlando Gomes ${ }^{32}$ :

"Na permuta, um dos contratantes promete uma coisa em troca de outra. Na compra e venda, a contraprestação há de se consistir, necessariamente, em dinheiro. Na troca não há preço, como na compra e venda, mas é irrelevante que as coisas permutadas tenham valores desiguais. (...)

Em virtude da analogia entre a troca e a compra e venda, as legislações prescrevem que se apliquem as mesmas regras. (...)

A analogia entre a compra e venda e a troca não significa identidade, reconhecida sendo a impossibilidade de submeter totalmente a troca ao regime legal da compra e venda. (...)”.

Com efeito, tendo em vista o objeto do presente trabalho, é fundamental o entendimento de que não há definição de preço em um contrato de permuta. Isto porque, se não há definição de preço contratual, faz-se necessário determinar qual o valor a ser atribuído à operação para fins contábeis (ver Capítulo 4.1.2) e fiscais (ver Capítulos 5.1.2.1.a e 5.2.2.1.a).

\section{3 - SEGUNDO GÊNERO: SERVIÇOS IMOBILIÁRIOS}

A prestação de serviço propriamente dita é um negócio jurídico previsto no Código Civil, artigos 593 e seguintes. Tem como objeto a realização de uma atividade (obrigação de fazer) material ou imaterial, desde que não configure relação de emprego sujeita às leis trabalhistas.

Embora existam muitas atividades passíveis de serem contratadas como prestação de serviço, verifica-se que o atual Código Civil distingue esse contrato dos demais contratos a seguir examinados, motivo pelo qual serão analisados individualizadamente.

\subsection{1 - Intermediação Imobiliária (Corretagem)}

A atividade do corretor de imóveis é de fundamental importância para o setor imobiliário. De fato, uma das características do setor é a baixa liquidez do investimento em imóveis, pois a conversão do imóvel em dinheiro não ocorre geralmente em um curto prazo. Após a decisão do proprietário de se desfazer do imóvel e a realização da venda, pode decorrer um longo prazo de oferta e negociação, razão pela qual a atividade do corretor se destaca como um instrumento para aumentar a liquidez desse investimento. O mesmo ocorre com a locação

\footnotetext{
${ }^{32}$ GOMES, Orlando. Contratos. 26 ${ }^{\mathrm{a}}$ ed. Rio de Janeiro: Forense, 2008, pp. 325 e ss.
} 
do imóvel, pois a intermediação de um corretor permite que se encontre um locatário com maior agilidade.

As regras gerais da atividade de corretagem encontram-se previstas nos artigos 722 e seguintes do Código Civil de 2002. Pelo contrato de corretagem, uma pessoa assume a obrigação de obter um ou mais negócios para outra pessoa, segundo suas instruções, desde que não estejam ligadas em virtude de mandato, prestação de serviço ou qualquer outra relação de dependência.

Trata-se, portanto, da intermediação de um negócio, que será remunerada por meio de uma taxa percentual sobre o valor do negócio realizado diretamente entre as partes (taxa de corretagem). Conforme leciona Vera Helena de Mello Franco, este é um contrato de intermediação direta, pois o corretor apenas aproxima as partes, que realizam o contrato diretamente. Diferencia-se da intermediação indireta, como é o caso da intermediação bancária, em que a instituição financeira atua em nome próprio. ${ }^{33}$

Especificamente em relação à corretagem imobiliária, verifica-se a existência de legislação especial que regulamenta a profissão, a Lei $n^{\circ} 6.530 / 78$, que atribui a competência ao corretor de imóveis para exercer a intermediação na compra, venda, permuta e locação de imóveis, podendo, ainda, opinar quanto à comercialização imobiliária.

Quanto à remuneração do corretor, caso não esteja fixada em lei ou negociada entre as partes, será arbitrada segundo a natureza do negócio e os usos locais (no caso da corretagem imobiliária, os usos locais estabelecem $6 \%$ sobre o preço do imóvel). ${ }^{34}$

A remuneração somente será devida quando e se o resultado previsto no contrato de corretagem efetivamente ocorrer. Trata-se, portanto, de contrato aleatório, pois o corretor somente será remunerado se o negócio for realizado (embora também seja devida se o resultado não se efetivar por arrependimento das partes).

Para fazer jus à remuneração, é necessário que o corretor comprove sua mediação no negócio. Porém, essa comprovação não é necessária se houver cláusula de exclusividade na intermediação por escrito. A remuneração será devida mesmo que o negócio seja concluído após a dispensa do corretor ou após o término do prazo do contrato, desde que esteja comprovada a sua mediação.

\footnotetext{
${ }^{33}$ FRANCO, Vera Helena de Mello. Op. cit. (nota 30), p. 254.

${ }^{34}$ Confira-se Apelação 9079904-38.2008.8.26.0000, Órgão julgador: 30a Câmara de Direito Privado, Data do julgamento: 19/01/2011 TJ/SP.
} 


\subsection{2 - Empreitada (Construção)}

A empreitada está regulamentada nos artigos 610 e seguintes do Código Civil. Há duas modalidades de empreitada: (i) a empreitada de lavor, em que o empreiteiro apenas emprega sua força de trabalho na realização da obra (assemelha-se ao contrato de prestação de serviço) e (ii) empreitada de trabalho e materiais, em que o empreiteiro também fornece os materiais necessários à realização da obra

Diferentemente da prestação de serviço, a empreitada compreende uma obrigação de fazer (realização de uma obra) e, também, uma obrigação de dar (entrega da obra depois de concluída) que é uma consequência da obrigação de fazer. ${ }^{35}$

Com efeito, mesmo com o fornecimento de materiais, a empreitada não se confunde com a compra e venda de coisa futura, pois o vendedor é o proprietário da coisa vendida e o empreiteiro apenas adquire o material para que possa empregar sua força de trabalho na obtenção do resultado pretendido (realização da obra a ser entregue) ${ }^{36}$

Uma importante consequência dessa distinção é a atribuição dos riscos. Como regra: (i) caso a empreitada seja realizada com fornecimento de materiais, é o empreiteiro que responde pelos riscos até o momento da entrega da obra (e pelo prazo adicional de 5 anos, no caso de empreitada de edifícios ou outras construções consideráveis), ${ }^{37}$ mas, (ii) caso se trate apenas de empreitada de lavor, é o empreitante que responde pelos riscos da obra.

Especificamente no que tange à construção de imóveis, verifica-se regulamentação própria prevista nos artigos 48 e seguintes da Lei $n^{\circ}$ 4.591/64. Segundo esta Lei, a construção de imóveis, objeto de incorporação, pode ser contratada sob o regime de empreitada ou de administração. A definição do regime pode ser estabelecida no contrato com o incorporador ou ser objeto de contratação direta dos adquirentes com o construtor.

Conforme previsão expressa na mencionada Lei, a construção pelo regime de empreitada pode ser remunerada por preço fixo ou preço reajustável. Na empreitada por preço fixo, a remuneração é fixa e não poderá ser reajustada, mesmo que o custo das obras sofra

\footnotetext{
${ }^{35}$ FRANCO, Vera Helena de Mello. Op. cit. (nota 30), p. 131.

${ }^{36}$ WALD, Arnoldo. Direito Civil - Contratos em Espécie. Vol. 3, $18^{\text {a }}$ ed., São Paulo: Saraiva, 2009, p. 151.

${ }^{37}$ CC/02: "Art. 618. Nos contratos de empreitada de edifícios ou outras construções consideráveis, o empreiteiro de materiais e execução responderá, durante o prazo irredutível de cinco anos, pela solidez e segurança do trabalho, assim em razão dos materiais, como do solo."
} 
variações. Na empreita a preço reajustável, poderão ser feitos ajustes por índices previamente determinados e previstos no contrato.

No que tange à construção pelo regime de administração (também denominado a preço de custo), os adquirentes ou proprietários são responsáveis pelo pagamento do custo total da obra, sendo o empreiteiro responsável apenas pela obrigação de lavor (obrigação de fazer a obra e obrigação de dar depois de terminada).

\subsection{3 - Incorporação Imobiliária}

\subsubsection{1 - Conceito, Objeto e Partes}

A atividade de incorporação imobiliária encontra-se regulamentada pela Lei $\mathrm{n}^{\circ}$ 4.591/64. Nos termos do parágrafo único do artigo 28 da referida Lei, trata-se de (i) atividade exercida com o intuito de promover e realizar a construção, para (ii) alienação total ou parcial, de edificações ou conjunto de edificações compostas de unidades autônomas.

Inicialmente, é importante destacar que o intuito da incorporação imobiliária é a alienação de edificações compostas de unidades autônomas. Dessa forma, somente configura incorporação imobiliária a atividade que tenha por objetivo a venda para terceiros de unidades autônomas. Trata-se do já mencionado condomínio edilício, ${ }^{38}$ em que existe a divisão da edificação em unidades autônomas de propriedade exclusiva (área privativa) e partes que são propriedade comum (área comum).

Desse modo, não haverá incorporação imobiliária quando o empreendimento é executado pelos próprios condôminos, sob sua responsabilidade. Isto porque esse negócio jurídico pressupõe a alienação das unidades autônomas para terceiros.

Ademais, como a incorporação imobiliária pressupõe que o incorporador irá promover e realizar a construção, a alienação de unidades autônomas já construídas não configura incorporação imobiliária.

\footnotetext{
${ }^{38}$ Código Civil 2002: “Art. 1.331. Pode haver, em edificações, partes que são propriedade exclusiva, e partes que são propriedade comum dos condôminos."
} 
Neste sentido, segundo Maria Helena Diniz, ${ }^{39}$ trata-se de uma atividade econômica que envolve duas obrigações distintas: uma obrigação de fazer (promover e realizar a construção) e uma obrigação de dar (entrega das unidades autônomas).

Por suas características, este tipo de empreendimento imobiliário é geralmente utilizado como meio para viabilizar a construção de edifícios (dividido em unidades autônomas, como prédios residenciais, prédios comerciais, garagens etc), em que os adquirentes das unidades antecipam pagamentos para que o incorporador possa complementar as vultosas somas de capital que geralmente se fazem necessárias.

Com efeito, a incorporação imobiliária é um instituto jurídico que tem como principal objetivo proteger a relação comercial existente entre o incorporador e os adquirentes das unidades, já que o incorporador precisa ter garantias de recebimento dos recursos para finalizar a obra e os adquirentes precisam ter garantias de que os recursos adiantados serão aplicados da melhor forma possível.

Nos termos dos artigos 29 e 30 da Lei $n^{\circ} 4.591 / 64$, considera-se incorporador:

(i) a pessoa física ou jurídica, comerciante ou não, que embora não efetuando a construção, compromisse ou efetive a venda de frações ideais de terreno objetivando a vinculação ${ }^{40}$ de tais frações a unidades autônomas, em edificações a serem construídas ou em construção sob regime condominial, ou que meramente aceite propostas para efetivação de tais transações, coordenando e levando a termo a incorporação e responsabilizando-se, conforme o caso, pela entrega, a certo prazo, preço e determinadas condições, das obras concluídas;

(ii) estende-se a condição de incorporador aos proprietários e titulares de direitos aquisitivos (inclusive por meio de permuta, nos termo do artigo 39 da Lei $\left.n^{\circ} 4.591 / 64\right)$ que contratem a construção de edifícios que se destinem à constituição em condomínio, quando iniciarem a alienação das unidades autônomas antes da conclusão das obras.

\footnotetext{
${ }^{39}$ DINIZ, Maria Helena, Curso de Direito Civil Brasileiro: teoria das obrigações contratuais e extracontratuais. $24^{\mathrm{a}}$ ed., São Paulo: Saraiva, 2008, p. 650.

${ }^{40}$ Lei 4.591/64, artigo 29, parágrafo único: "presume-se a vinculação entre a alienação das frações do terreno e o negócio de construção, se, ao ser contratada a venda, ou promessa de venda ou de cessão das frações de terreno, já houver sido aprovado e estiver em vigor, ou pender de aprovação de autoridade administrativa, o respectivo projeto de construção, respondendo o alienante como incorporador".
} 
Somente poderá ser incorporador: ${ }^{41}$ (a) o proprietário do terreno, o promitente comprador, o cessionário deste ou promitente cessionário com título devidamente registrado; (b) o construtor; ou (c) o corretor de imóveis. Dessa forma, não é necessário que o incorporador seja também o construtor, mas ele sempre será o responsável por administrar e concluir o empreendimento (mesmo que terceirizando a construção).

Os adquirentes, por outro lado, podem ser pessoas físicas ou jurídicas que adquiram as unidades autônomas a construir. Nos termos do artigo 49 da Lei 4.591/64, eles podem se reunir em assembléia para tratar de seus interesses, cujas deliberações (aprovadas por maioria simples) são obrigatórias para todos.

\subsubsection{2 - Ciclo Econômico - Etapas: (i) Constituição, (ii) Execução e (iii) Extinção}

O ciclo econômico da atividade de incorporação imobiliária pode ser divido em 3 etapas principais, a saber:

\section{(a) Constituição (Atividades Preliminares)}

Para que seja constituída uma incorporação imobiliária, é preciso realizar previamente (i) pesquisa e aquisição do terreno onde será erguido o edifício, (ii) elaboração de projeto de construção devidamente aprovado perante órgãos públicos, (iii) elaboração de memorial descritivo da obra, (iii) avaliação do custo total da obra, (iv) preparação da minuta da futura convenção de condomínio, dentre outras atividades. A negociação das unidades autônomas somente poderá ser realizada pelo incorporador após o registro desses documentos no Registro de Imóveis, bem como dos demais documentos previstos no artigo 32 da Lei $n^{\circ}$ 4.591/64.

É importante destacar, desde já, a natureza jurídica dos contratos de alienação das unidades. Nos termos do $\S 2^{\circ}$ do artigo 32 da referida Lei, ${ }^{42}$ qualquer contrato, uma vez registrado no cartório de registro de imóveis, terá natureza de direito real, ou seja, será oponível a terceiros e pode ser exercido compulsoriamente perante o incorporador ou a quem o suceder, inclusive na hipótese de insolvência posterior ao término da obra.

\footnotetext{
${ }^{41}$ Lei 4.591/64, artigo 31.

42 "§ $2^{-}$Os contratos de compra e venda, promessa de venda, cessão ou promessa de cessão de unidades autônomas são irretratáveis e, uma vez registrados, conferem direito real oponível a terceiros, atribuindo direito a adjudicação compulsória perante o incorporador ou a quem o suceder, inclusive na hipótese de insolvência posterior ao término da obra. (Redação dada pela Lei n ${ }^{\circ} 10.931$, de 2004)"
} 
É possível, ainda, que exista alguma cláusula suspensiva para incorporação (estipulação de prazo de carência), que condicione a sua efetivação a algum fator externo relevante. ${ }^{43}$ São exemplos de cláusulas suspensivas: (i) a estipulação de condição para a efetivação do empreendimento imobiliário somente após a venda de determinada quantidade de unidades; (ii) a condição de que somente se considera efetivado o título translativo quando liberado o financiamento do saldo devedor. Caso não se concretizem as condicionantes para a efetivação da obra, poderá ser denunciada a desistência da incorporação, por escrito, ao Registro de Imóveis e aos adquirentes ou candidatos a adquirentes.

Nos termos do artigo 35 da Lei $n^{\circ} 4.591 / 64$, o incorporador terá o prazo máximo de 60 dias, a contar do termo final do prazo de carência, se houver, para promover a celebração do competente contrato relativo à fração ideal de terreno e, também, do contrato de construção e da Convenção do condomínio, de acordo com discriminação das frações ideais de terreno com as unidades autônomas que a elas corresponderão.

\section{(b) Execução (Produção)}

Conforme visto, a execução da construção da obra pode ser feita diretamente pelo incorporador, mas também pode ser feita por terceiro. Contudo, em qualquer hipótese, nos termos do artigo 43 da Lei $n^{\circ} 4.591 / 64$, o incorporador deverá respeitar as seguintes obrigações:

(i) informar obrigatoriamente aos adquirentes, por escrito, no mínimo de seis em seis meses, o estado da obra;

(ii) responder civilmente pela execução da incorporação, devendo indenizar os adquirentes ou compromissários, dos prejuízos que a estes advierem do fato de não se concluir a edificação ou de se retardar injustificadamente a conclusão das obras, cabendo-lhe ação regressiva contra o construtor, se for o caso e se a este couber a culpa;

(iii) em caso de insolvência ou falência do incorporador, pessoa física ou jurídica, e não ser possível à maioria dos adquirentes prosseguir na construção das edificações, os subscritores ou candidatos à aquisição de unidades serão credores privilegiados pelas quantias que houverem pago ao incorporador, respondendo subsidiariamente os bens pessoais deste;

\footnotetext{
${ }^{43}$ Lei no 4.591/64: "Art. 34. O incorporador poderá fixar, para efetivação da incorporação, prazo de carência, dentro do qual lhe é lícito desistir do empreendimento."
} 
(iv) é vedado ao incorporador alterar o projeto, especialmente no que se refere à unidade do adquirente e às partes comuns, modificar as especificações, ou desviar-se do plano da construção, salvo autorização unânime dos interessados ou exigência legal;

(v) não poderá modificar as condições de pagamento nem reajustar o preço das unidades, ainda no caso de elevação dos preços dos materiais e da mão de obra, salvo se tiver sido expressamente ajustada a faculdade de reajustamento, procedendo-se, então, nas condições estipuladas;

(vi) se o incorporador, sem justa causa devidamente comprovada, paralisar as obras por mais de 30 dias, ou retardar-lhes excessivamente o andamento, poderá o Juiz notificá-lo para que, no prazo mínimo de 30, dias as reinicie ou torne a dar-lhes o andamento normal. Desatendida a notificação, poderá o incorporador ser destituído pela maioria absoluta dos votos dos adquirentes, sem prejuízo da responsabilidade civil ou penal que couber, sujeito à cobrança executiva das importâncias comprovadamente devidas, facultando-se aos interessados prosseguir na obra.

Conforme se verifica das restrições e obrigações legais impostas ao incorporador pela legislação brasileira, bem como das garantias oferecidas aos adquirentes, é possível afirmar que não se trata de uma simples obrigação de entregar o produto da construção aos adquirentes, mas primordialmente de uma obrigação de fazer, ou seja, garantir que a obra seja construída e entregue nos termos contratados.

De fato, segundo a Lei $\mathrm{n}^{\circ} 4.591 / 64$, grande parte dos riscos e benefícios do empreendimento é transferida aos adquirentes, que poderão inclusive optar por destituir o incorporador caso as obras sejam paralisadas por mais de 30 dias, ou tenham seu andamento excessivamente retardado.

Conforme já destacado no início do capítulo, a distinção entre obrigação de dar e de fazer nem sempre é muito clara, o que também ocorre no caso do contrato de incorporação imobiliária. Neste sentido, conforme o entendimento já destacado de Washington Monteiro de Barros, ${ }^{44}$ o cerne da diferença entre os dois tipos de contrato está em saber se a obrigação de dar (ou entregar) é ou não uma consequência da obrigação de fazer.

\footnotetext{
${ }^{44}$ BARROS, Washington Monteiro de. Op. cit. (nota 23), p. 87.
} 
No caso da incorporação imobiliária, existe uma obrigação de dar (o bem imóvel), mas o cerne do contrato encontra-se na atividade que precede essa entrega (promover e realizar a construção). Com efeito, nos termos da Lei $n^{\circ} 4.591 / 64$, todos os requisitos, direitos e obrigações do incorporador são regulamentados de forma a garantir a entrega das unidades autônomas aos adquirentes (o que faz com que a obrigação de dar seja apenas uma consequência do adimplemento da obrigação de fazer).

É importante o correto entendimento da natureza jurídica do contrato de incorporação imobiliária, uma vez que, conforme já mencionado, obrigações de dar e de fazer costumam ter tratamentos contábeis diferenciados, com consequências tributárias distintas, o que será analisado nos Capítulos 4.2.4 e 5.3.1. ${ }^{45}$

\section{(c) Extinção (Troca)}

Segundo Orlando Gomes, ${ }^{46}$ a incorporação pode ser extinta: (i) por inadimplemento de uma obrigação essencial de alguma das partes, (ii) atraso nos pagamentos do preço pelos adquirentes (artigo 63 da Lei $n^{\circ} 4.591 / 64$ ), (iii) algum motivo alheio às partes (força maior ou caso fortuito), (iv) por distrato ou (v) pelo término da execução do contrato.

Ressalte-se que a extinção da incorporação pelo término da execução do contrato pressupõe a concessão do habite-se pela autoridade administrativa, bem como a posterior averbação da construção das edificações, para efeito de individualização e discriminação das unidades (artigo 44 da Lei $n^{\circ} 4.591 / 64$ ).

\footnotetext{
${ }^{45}$ Neste sentido, menciona-se ainda como exemplos de transferência dos riscos e benefícios das unidades em construção aos adquirentes a possibilidade de o comprador "vender" o imóvel ainda em construção (cessão de direitos decorrentes do compromisso de compra e venda). No mesmo sentido, em caso de desapropriação, o "adquirentes" (promitentes compradores) devem receber parcela da indenização paga pelo governo.

${ }^{46}$ Apud. DINIZ, Maria Helena. Op. cit (nota 39), p. 659.
} 
(d) Ciclo Econômico da Incorporação Imobiliária - Gráfico
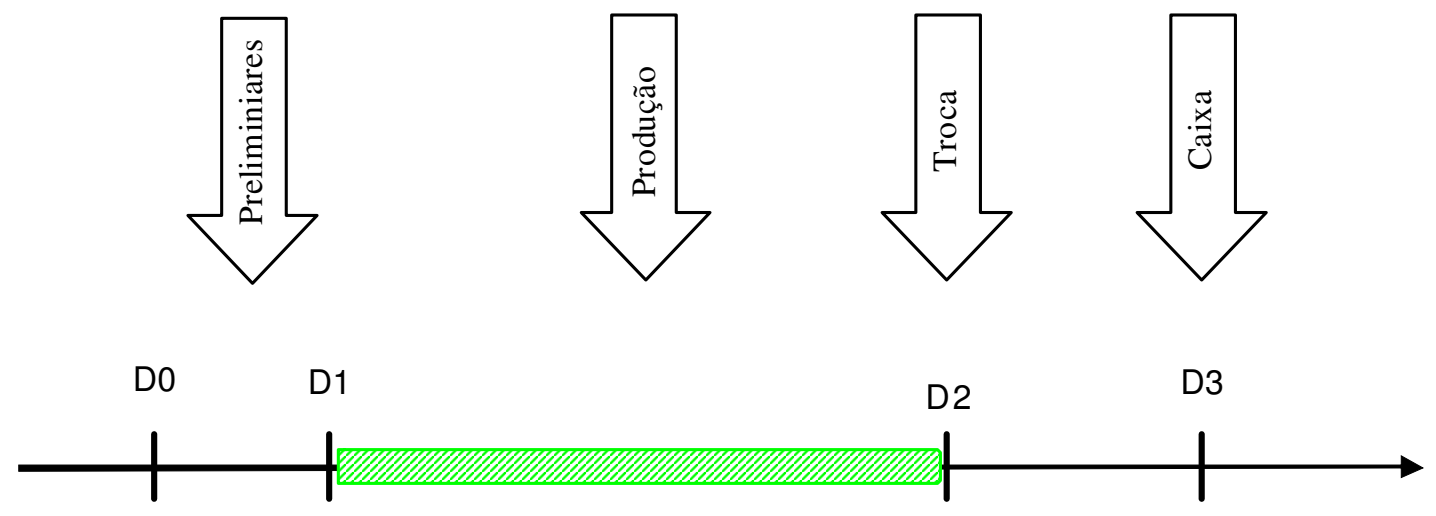

Atividades preliminares: (i) pesquisa e aquisição do terreno onde será erguido o edifício; (ii) elaboração de projeto de construção devidamente aprovado perante órgãos públicos; (iii) elabora ção de memorial descritivo da obra; (iii) avaliação do custo total da obra; (iv) pre paração da minuta da futura convenção de condomínio; dentre outras atividades.

Produção das Unidades Imobiliárias - há duas obrigações assumidas pelo incorporador: (i) uma obrigação de entregar o produto da construção aos adquirentes; e (ii) uma obrigação de fazer, consistente em garantir que a obra seja construída e entregue nos termos contratados.

Troca - após a concessão do habite-se e averbação da construção, com a respecti va individuali zação das unidades autônomas, entregam-se as chaves como ato de transferência da posse. A propriedade é transferida com o registro na matrícula das unidades desmembradas.

Ingresso no Caixa - parte das receitas de vendas das unidades imobiliárias são recebidas já no início da construção, bem como durante a execução do empreendimento, como forma de financiamento de parte da obra pelos adquirentes (divisão dos ri scos com os adquirentes). 


\subsubsection{3 - Patrimônio de Afetação}

O regime do patrimônio de afetação foi instituído pela Medida Provisória $n^{\circ}$ 2.221/2001. Posteriormente, essa Medida Provisória foi revogada pela Lei $\mathrm{n}^{\mathrm{o}}$ 10.931/2004, atualmente em vigor. ${ }^{47}$ Esse regime patrimonial foi instituído como forma de proteção dos adquirentes das unidades imobiliárias, no caso de falência ou insolvência civil do incorporador.

Esse regime patrimonial também é um importante instrumento à disposição dos incorporadores para facilitar a obtenção de financiamentos imobiliários ou securitização de recebíveis, uma vez que permite a segregação de riscos e benefícios do empreendimento.

Inicialmente, é importante destacar que o regime de afetação é opcional para as pessoas físicas ou jurídicas que exerçam a atividade de incorporação imobiliária (conforme descrito anteriormente).

Nas incorporações imobiliárias sujeitas ao patrimônio de afetação, o terreno, as acessões e os demais bens e direitos a ela vinculados serão segregados do patrimônio do incorporador, devendo ser destinados exclusivamente à consecução da incorporação correspondente e à entrega das unidades imobiliárias aos respectivos adquirentes.

Dessa forma, os demais bens, direitos e obrigações que integrem o patrimônio do incorporador, mesmo que objeto de outros patrimônios de afetação por ele constituídos, não se comunicam com o patrimônio de afetação. Ou seja, o regime de afetação de patrimônio de pessoa física ou jurídica promove a sua segregação quanto aos débitos de natureza fiscal, previdenciária ou trabalhista, bem como quanto às suas garantias e aos seus privilégios (artigo 10 da Lei $\left.n^{\circ} 10.931 / 2004\right)$.

Ademais, é importante destacar que os efeitos de eventual decretação da falência ou da insolvência civil do incorporador não atingem os patrimônios de afetação constituídos, motivo pelo qual não serão objeto da massa concursal: o terreno, as acessões e demais bens, direitos creditórios, obrigações e encargos objeto da incorporação afetada.

No caso de securitização de recebíveis correspondente aos direitos creditórios oriundos da comercialização das unidades imobiliárias que integram a incorporação, o produto da securitização também passará a integrar o patrimônio de afetação.

\footnotetext{
${ }^{47}$ A Lei no 10.931/2004 inseriu os artigos 31-A a 31-F na Lei no 4.591/64, que tratam do patrimônio de afetação.
} 
É importante ressaltar que os recursos financeiros, objeto do patrimônio de afetação, serão utilizados preferencialmente para pagamento ou reembolso das despesas da incorporação. No que tange ao reembolso do preço de aquisição do terreno, somente será permitido quando da alienação das unidades autônomas, na proporção (i) das respectivas frações ideais e (ii) dos valores efetivamente recebidos pela alienação.

Dessa forma, pretende-se resguardar os recursos financeiros pagos pelos adquirentes das unidades autônomas, pois o regime de afetação estabelece um "represamento" desses recursos para pagamento ou reembolso das despesas inerentes à incorporação (inclusive o preço de aquisição do terreno, na proporção das respectivas frações ideais). Com isso, evita-se que esses recursos sejam utilizados pelo incorporador para o pagamento de despesas referentes a outras atividades ou empreendimentos.

Neste sentido, somente serão excluídos do patrimônio de afetação e passíveis de distribuição ao incorporador: (i) os recursos financeiros que ultrapassarem o valor necessário para a finalização da obra, o que abrange os valores a receber até sua conclusão e os recursos necessários à quitação de financiamento para a construção, se houver; (ii) o valor referente ao preço de alienação da fração ideal de terreno de cada unidade vendida, no caso de incorporação em que a construção seja contratada sob o regime por empreitada ou por administração.

A constituição do patrimônio de afetação poderá ser realizada a qualquer tempo, mediante a averbação de termo firmado pelo incorporador no Registro de Imóveis ${ }^{48}$.

Cabe ao incorporador titular do patrimônio afetado, dentre outras obrigações, manter apartados os bens e direitos, objeto de cada incorporação, e entregar à Comissão de Representantes, no mínimo a cada três meses, demonstrativo do estado da obra e de sua correspondência com o prazo pactuado ou com os recursos financeiros recebidos no período que integrem o patrimônio de afetação.

Poderá ainda ser nomeada uma pessoa física ou jurídica para fiscalizar e acompanhar o patrimônio de afetação. Esta pessoa será nomeada pela Comissão de Representantes e a instituição financiadora da construção, às suas custas. Será assegurado à pessoa nomeada o livre acesso à obra, aos livros, aos contratos, à conta de depósito que será constituída exclusivamente para a movimentação dos recursos financeiros do patrimônio de afetação, bem como quaisquer outros documentos a ele relativos.

\footnotetext{
${ }^{48}$ Quando for o caso, termo também deverá ser firmado pelos titulares de direitos reais de aquisição sobre o terreno.
} 
Em caso de decretação da falência ou da insolvência civil do incorporador, os adquirentes realizarão assembléia geral, na qual se instituirá o condomínio da construção e se deliberará sobre os termos da continuação da obra ou da liquidação do patrimônio de afetação.

Por fim, destaque-se que o patrimônio de afetação será extinto: (i) pela conclusão do empreendimento, mediante a averbação da construção, o registro dos títulos de domínio ou de direito de aquisição em nome dos respectivos adquirentes e, quando for o caso, após a extinção das obrigações do incorporador com a instituição financiadora do empreendimento; (ii) por sua revogação em razão de denúncia da incorporação, depois de restituídas aos adquirentes as quantias por eles pagas, ou de outras hipóteses previstas em lei; e (iii) pela liquidação deliberada pela assembléia geral em caso de falência ou insolvência civil do incorporador.

\subsection{4 - Loteamento}

A atividade de parcelamento do solo urbano encontra-se regulamentada pela Lei $n^{\circ}$ $6.766 / 79,{ }^{49}$ e pode ocorrer de duas formas distintas: o loteamento ou o desmembramento. $\mathrm{O}$ loteamento, objeto do presente estudo, corresponde à “subdivisão de gleba em lotes destinados a edificação, com abertura de novas vias de circulação, de logradouros públicos ou prolongamento, modificação ou ampliação das vias existentes" $\left(\operatorname{artigo} 2^{\circ}, \S^{\circ}{ }^{\circ} .^{50}\right.$

A gleba é o terreno que não foi objeto de loteamento ou desmembramento, nos termos da Lei $n^{\circ}$ 6.779/79. Após o loteamento ou desmembramento, a gleba é dividida em lotes. O lote pode ser definido como "o terreno servido de infra-estrutura básica cujas dimensões atendam aos índices urbanísticos definidos pelo plano diretor ou lei municipal para a zona em que se situe" (artigo $\left.2^{\circ}, \S 4^{\circ}\right)$.

Segundo a lei de parcelamento do solo urbano, considera-se infraestrutura básica aquela constituída de (i) escoamento das águas pluviais, (ii) iluminação pública, (iii) esgotamento sanitário, (iv) abastecimento de água potável, energia elétrica pública e domiciliar e (v) vias de circulação.

\footnotetext{
${ }^{49}$ Não obstante a previsão na lei federal, esta atividade também deverá observar as disposições da legislação estadual e municipal que a adaptem às peculiaridades regionais e locais.

${ }^{50} \mathrm{O}$ desmembramento não será objeto do presente estudo, mas trata-se de forma distinta de parcelamento do solo urbano, pois não implica na abertura de novas vias e logradouros públicos, nem no prolongamento, modificação ou ampliação dos já existentes.
} 
Nos casos de parcelamentos situados nas zonas habitacionais declaradas por lei como de interesse social (ZHIS), a infraestrutura básica será constituída, no mínimo, de: (i) vias de circulação, (ii) escoamento das águas pluviais, (iii) rede para o abastecimento de água potável e (iv) soluções para o esgotamento sanitário e para a energia elétrica domiciliar.

Em vista da importância dessa atividade, instituiu-se uma rígida regulamentação para proteger não só o interesse público na ocupação do solo urbano, mas também o interesse dos particulares adquirentes dos lotes. Neste sentido, a Lei $n^{\circ}$ 6.779/79 estabelece os requisitos para o loteamento (artigos $4^{\circ}$ e $5^{\circ}$ ), as diretrizes prévias que devem ser solicitadas à Prefeitura Municipal ou ao Distrito Federal e o conteúdo do projeto de loteamento (artigos $6^{\circ}$ e seguintes), o procedimento para aprovação (artigos 12 e seguintes) e o procedimento para registro no cartório de Registro Imobiliário (artigos 18 e seguintes).

Essa Lei também regulamentou o conteúdo dos contratos de aquisição dos lotes nos artigos 25 e seguintes (compromissos de compra e venda, cessões e promessa de cessão). Estabeleceu também que constitui crime contra a Administração Pública a realização de loteamento ou desmembramento em desacordo com as diretrizes por ela estabelecidas (artigos $50,51$ e 52$)$.

Com efeito, a atividade de loteamento é semelhante à atividade de incorporação imobiliária, pois tem como objeto a alienação de parcelas do solo urbano (glebas) que ainda não foram constituídas em lotes, objeto de registro em matrícula individualizada.

Da mesma forma que ocorre com a incorporação imobiliária, o loteador geralmente é o responsável pelos estudos para definição do melhor produto, pela realização das obras de infraestrutura básica e pelos esforços de venda. Também é possível que seja o proprietário da gleba de terra objeto de loteamento, mas é mais comum que ele trabalhe em parceria com o proprietário da gleba de terra, recebendo um percentual sobre o total das vendas.

Dessa forma, classifica-se a atividade de loteamento como sendo um contrato de empreitada, que consiste na obrigação de fazer (realização da infraestrutura básica) e na consequente obrigação de dar (entrega do lote). Sua remuneração será decorrente da alienação dos lotes aos adquirentes finais. 


\subsection{5 - Administração de Imóveis}

A administração de bens imóveis é um negócio jurídico em que o administrador recebe poderes do titular do imóvel para, em seu nome, praticar todos os atos necessários para satisfazer seus interesses imobiliários. Trata-se de contrato de mandato, constituído mediante instrumento particular ou público de procuração (artigos 653 e seguintes do CC/2002).

Com efeito, o administrador de imóveis é obrigado a prestar, com sua diligência habitual, todos os atos que façam parte da gestão dos negócios imobiliários para os quais tenha sido constituído mandatário, recebendo para tanto uma taxa de administração.

\subsection{6 - Reforma, Restauração e Retrofit}

A atividade de reforma consiste realização de melhorias ao imóvel. Trata-se de uma prestação de serviço que tem como objeto uma obrigação de fazer. Quando a reforma é feita em imóvel próprio, não resta configurada uma prestação de serviço, pois a atividade é prestada a si mesmo. Neste caso, trata-se de melhorias feitas pelo proprietário com o objetivo de valorizar o imóvel próprio.

Dentre as possíveis modalidades de reforma de imóveis, podem-se destacar a restauração e o retrofit. A restauração de imóveis consiste na reconstituição das suas condições originais. Nesta atividade, o empreendedor irá realizar melhorias no imóvel, mas preservando as características históricas do imóvel.

O retrofit, por sua vez, é um termo que vem sendo utilizado para designar uma atividade que introduz melhorias profundas no imóvel, tendo em vista obter uma elevada valorização imobiliária. Trata-se da atividade de revitalização de edifícios antigos, mantendo ou não parte de suas características arquitetônicas originais, mas introduzindo tecnologias avançadas e equipamentos modernos (v.g. reforma de portaria, hall e fachada, instalação de sistemas de ar-condicionado central, substituição de elevadores, reconfiguração da planta do imóvel de acordo com as necessidades do mercado etc.).

Esta atividade surge em decorrência da necessidade de preservação e valorização do patrimônio histórico, mas também se apresenta como uma alternativa para valorização de edifícios antigos em áreas com potencial construtivo esgotado, como se verifica no centro de algumas metrópoles. 
O retrofit é uma atividade de alto custo e se mostra interessante quando o custo for comparativamente menor em relação à construção de edifícios novos, ou quando um edifício histórico pode adquirir novas funções e ampliar a facilidade de uso. Nesses casos, o retrofit será uma alternativa viável, especialmente em razão do prazo mais curto do empreendimento e a possibilidade de explorar uma região geográfica com grande liquidez, mas com potencial construtivo esgotado.

\section{4 - Terceiro Gênero: Cessão da Posse do Imóvel}

\subsection{1 - Superfície}

O direito de superfície é o direito de construir ou plantar concedido pelo proprietário do terreno ao superficiário, por prazo determinado. Dessa forma, o superficiário é detentor da posse direta do imóvel e o proprietário (fundeiro) titular da posse indireta.

Esse direito é constituído mediante escritura pública, instrumento válido entre as partes. A escritura pública deve ser registrada no Cartório de Registro de Imóveis para possuir natureza de direito real (oponível a terceiros). O instituto encontra-se regulamentado pelos artigos 1.369 e seguintes do $\mathrm{CC} / 02^{51}$ e previsto, também, no Estatuto da Cidade (Lei $\mathrm{n}^{\circ}$ 10.257/01, artigos 21 e seguintes), havendo, porém, dúvida quanto à aplicabilidade dessas leis sobre o mesmo tema. ${ }^{52}$

Quanto à remuneração, o direito de superfície poderá ser concedido de forma gratuita ou onerosa. Caso seja concedido onerosamente, será estipulado se o pagamento será feito de uma só vez ou de forma parcelada. O superficiário é responsável pelos encargos e tributos que incidirem sobre o imóvel.

Após a extinção do direito de superfície, a propriedade plena sobre o terreno, bem como construção ou plantação retornarão ao proprietário. Caso não haja estipulação em contrário, não será devida indenização ao superficiário pela construção ou plantação.

\footnotetext{
${ }^{51}$ O direito de superfície substitui hoje o revogado regime de enfiteuse existente no Código Civil de 1916, embora as enfiteuses constituídas antes do advento do Código Civil de 2002 continuem existindo (artigo 2.038).

${ }^{52}$ VENOSA, Silvio de Salvo. Direito Civil: Direitos Reais, Coleção Direito Civil vol. 5, 9a ed., São Paulo: Atlas, 2009, pp. 433 e ss.
} 


\subsection{2 - Locação}

A locação imobiliária é uma atividade que tem como objetivo a cessão da posse direta do imóvel ao locatário, que irá remunerar o locador mediante o pagamento de aluguéis. O proprietário também se beneficia da valorização imobiliária, mas esse acréscimo de valor só terá liquidez no momento em que ele realizar a venda do imóvel.

Com efeito, a locação de bens imóveis é o contrato pelo qual o locador cede ao locatário o uso e o gozo do imóvel, por tempo determinado ou não, mediante o pagamento de um preço em retribuição (denominado aluguel).

A locação de imóveis urbanos encontra-se disciplinada pela Lei $n^{\circ}$ 8.245/91 (Lei do Inquilinato), o que é reconhecido expressamente pelo artigo 2.036 do CC/2002. Segundo essa Lei, é livre a convenção do valor do aluguel, vedada a estipulação em moeda estrangeira e sua vinculação à variação cambial ou ao salário mínimo (artigo 17).

Quando ao valor do aluguel, ressalte-se que não poderá ser ínfimo ou irrisório, caso contrário tratar-se-á de comodato (previsto nos artigos 579 e seguintes do CC/02).

Importante ressaltar ainda, para fins do presente trabalho, que a Lei do Inquilinato delimita os deveres do locador e do locatário (artigos 22 e seguintes), estabelecendo quais despesas são de responsabilidade de cada parte (v.g. as despesas extraordinárias de condomínio são de responsabilidade do locador e as despesas ordinárias de condomínio são do locatário).

\subsection{3 - "Built to Suit"}

A expressão inglesa Built to Suit (BTS), em português "construir para servir", é a denominação para a atividade imobiliária que tem como objeto a construção de um prédio por encomenda, para atender às necessidades de um locatário predeterminado, em um contrato de locação de longo prazo.

Em geral, o negócio de BTS é contratado por empresas que têm necessidades específicas e procuram imóveis para locação com características especiais. Estas empresas não desejam ou não podem adquirir a propriedade imobiliária, mas necessitam de um edifício com características próprias e que não se encontra disponível para locação na região em que pretendem exercer suas atividades.

Portanto, para o locatário, haverá a vantagem de dispor de um imóvel com as características personalizadas e no local que lhe seja mais adequado do ponto de vista de 
planejamento estratégico. Ademais, não terá que adquirir a sua propriedade, o que reduz o índice de imobilização do capital.

O empreendedor tem como responsabilidade a garantia do sucesso do empreendimento, que consiste em (i) uma obrigação de fazer: desde a procura por imóveis disponíveis nas áreas de interesse do contratante, bem como a responsabilidade pelo planejamento, elaboração de projetos e execução da construção da obra e (ii) uma obrigação de dar: entregar o imóvel para o contratante em condições de uso - sistema turnkey.

A remuneração pela atividade de BTS é realizada pelo valor do futuro aluguel a ser pago pelo contratante. Assim, o valor do aluguel a ser pago e o prazo de duração do contrato de locação (geralmente longo prazo) são calculados de forma a remunerar os custos de planejamento e projetos, aquisição do terreno e os gastos de construção, bem como o risco do empreendimento.

Tendo em vista que o imóvel BTS é construído para atender a necessidades especiais de determinado locatário (intuito personae), o valor do aluguel tende a ser maior do que a média do mercado. Contudo, se não houver muitas exigências de adequação do empreendimento a necessidades especiais, bem como tratar-se de um imóvel inserido em determinado padrão do mercado, maior será a tendência de que o aluguel se aproxime do valor do mercado.

Ante o exposto, verifica-se que o contrato BTS configura-se como uma locação atípica. Ocorre que, para que tais contratos sejam operacionais, faz-se necessário garantir a aplicação de algumas regras específicas, tais como a impossibilidade de revisão judicial do aluguel após decorridos 3 anos de vigência do contrato (com renúncia expressa ao artigo 19 da Lei do Inquilinato).

Também é necessária a fixação da multa contratual em valor correspondente ao total dos aluguéis remanescentes, caso ocorra a rescisão antecipada. Com efeito, deixa-se de aplicar o artigo $4^{\circ}$ da Lei no Inquilinato (pagamento proporcional da multa), uma vez que é necessário garantir o ressarcimento dos investimentos feitos para a construção do empreendimento (mas em conformidade com o 473 do $\mathrm{CC} / 02$ ).

Tendo em vista os possíveis questionamentos acima apontados, as operações de BTS também têm sido estruturadas por meio de contratos de superfície ou com previsão de que eventuais conflitos sejam resolvidos por meio de arbitragem. 


\subsection{4 - Shopping Center}

Segundo o ICSC (International Council of Shopping Centers), pode-se definir o SC como "Um grupo de varejo e outros estabelecimentos comerciais que é planejado, desenvolvido, possuído e administrado como se fosse uma única propriedade. $O$ estacionamento é fornecido no local. O tamanho do centro e sua orientação são geralmente determinados pelas características do mercado da zona de comércio servida pelo empreendimento." ${ }^{53}$

No mesmo sentido, a ABRASCE define os SC como: "um centro comercial planejado, sob administração única e centralizada, composto de lojas destinadas à exploração de ramos diversificados de comércio, e que permaneçam, na sua maior parte, objeto de locação, ficando os locatários sujeitos a normas contratuais padronizadas que visam à conservação do equilíbrio da oferta e da funcionalidade, para assegurar, como objetivo básico, a convivência integrada e que varie o preço da locação, ao menos em parte, de acordo com o faturamento dos locatários - centro que ofereça aos usuários estacionamento permanente e tecnicamente bastante." ${ }^{54}$

Nestas definições do conceito de SC, percebe-se que uma das principais características desta atividade econômica é a combinação de um conjunto de estabelecimentos comerciais concentrados em determinado local (um "centro de compras" devidamente planejado e organizado).

O local, onde essa atividade econômica geralmente é exercida, é um edifício comercial (bem imóvel correspondente ao terreno e respectiva edificação), arquitetonicamente planejado, de forma a proporcionar um ambiente agradável, atrativo e estimulante aos consumidores.

A aquisição do terreno e construção do edifício, onde será localizado o SC, demanda grandes investimentos, os quais são feitos geralmente por investidores (não lojistas) que têm como objetivo a obtenção de retorno financeiro por meio de aluguéis e da valorização da propriedade imobiliária.

\footnotetext{
53 ICSC. ICSC Shopping Center Definitions - Basic Configurations and Types [online]. Citado em 12/05/2011. Disponível em <http://www.icsc.org/srch/lib/SCDefinitions99.pdf $>$.Tradução livre.

${ }^{54}$ Shopping Center e Desenvolvimento Econômico e Social. ABRASCE, 1984, p. 34. Apud VERRI, Maria Elisa Gualandi, Shopping Centers - Aspectos Jurídicos e suas Origens. Belo Horizonte: Del Rey, 1996, p. 21.
} 
Ademais, verifica-se que a existência do SC depende de uma gestão centralizada que compreende a seleção do mix de estabelecimentos comerciais que irão compor o conjunto (considerando-se as características do público alvo) e sua distribuição dentro do espaço físico.

Assim, o SC diferencia-se de um edifício composto por diversos estabelecimentos comerciais por causa do planejamento operacional do empreendimento que compreende: o projeto de arquitetura diferenciado, a escolha das lojas que compõem o conjunto do empreendimento (ramos de atividade, marcas e localização dentro do espaço físico - mix de estabelecimentos), as estratégias conjuntas de publicidade em razão do objeto comum de atração de frequentadores, dentre outros aspectos.

Com efeito, o estudo e o desenvolvimento cuidadoso do empreendimento comercial geram uma sinergia entre os lojistas, não existente em outros tipos de empreendimentos imobiliários, o que maximiza o potencial de atração de clientes e realização de negócios (v.g. um cliente pode ser atraído ao SC para alimentação ou lazer, mas a estrutura desse empreendimento é planejada de forma a incentivar o consumo de outros produtos e serviços).

\subsubsection{1 - Contrato de Locação}

Orlando Gomes destaca três características fundamentais do SC: (i) o aluguel percentual, (ii) a associação dos lojistas e (iii) o regimento interno. ${ }^{55}$

Como já mencionado, não é comum que os titulares do investimento para a construção do SC sejam os próprios lojistas. De fato, a existência de investidores/empreendedores independentes da atividade de varejo é importante para permitir maior flexibilidade para a gestão do mix de lojas e sua localização dentro do espaço físico.

A estrutura jurídica que possibilita a instalação planejada e organizada das lojas dentro do edifício é o contrato de locação, ${ }^{56}$ que possui características diferenciadas para viabilizar o empreendimento de SC. Os locatários se obrigam a pagar um aluguel mínimo

${ }^{55}$ GOMES, Orlando. Traços do Perfil Jurídico de um Shopping Center. In ARRUDA, José Soares e LÔBO, Carlos Augusto da Silveira (coord.). "Shopping Centers" - Aspectos Jurídicos. São Paulo: Revista dos Tribunais, 1984 , p. 89.

${ }^{56}$ PEREIRA, Caio Mario da Silva Pereira. Shopping Centers - Organização Econômica e Disciplina Jurídica. In ARRUDA, José Soares e LÔBO, Carlos Augusto da Silveira (coord.). "Shopping Centers" - Aspectos Jurídicos. São Paulo: Revista dos Tribunais, p. 77. No mesmo sentido: MONTEIRO, Washington de Barros. Shopping Centers. In ARRUDA, José Soares e LÔBO, Carlos Augusto da Silveira (coord.). "Shopping Centers" - Aspectos Jurídicos. São Paulo: Revista dos Tribunais, p. 166. 
(valor mínimo fixo) e um aluguel percentual (valor variável e proporcional ao faturamento mensal do lojista).

Para subsidiar a estruturação do empreendimento comercial, acompanhando o contrato de locação, estabelecem-se normas complementares de convivência (regimento interno) e também o estatuto da associação de lojistas (que pressupõe que todos os locatários devem ser associados).

\subsubsection{2 - Fundo de Comércio Comum (Investidor e Lojista)}

Outra característica marcante do SC é o seu fundo de comércio, decorrente do exercício dessa atividade empresarial planejada. Segundo Fran Martins, o fundo de comércio é a totalidade dos bens corpóreos (bens físicos móveis ou imóveis) e incorpóreos (como clientela e marca). ${ }^{57}$.

No SC, discute-se a existência (i) de apenas um único fundo de comércio, composto pela infraestrutura fornecida pelo empreendedor, somado aos demais bens de valor econômico fornecidos pelos lojistas; ou (ii) de dois fundos de comércio, compostos pela mesma estrutura mencionada, mas sendo um dos investidores (empreendedores/locadores) e outro dos comerciantes (locatários/lojistas).

Para Modesto Carvalhosa, "não há, na hipótese, dois fundos de comércio, mas um único fundo com dois titulares". ${ }^{58}$ Em sentido oposto, defendendo a existência de dois fundos de comércio, Caio Mario da Silva Pereira afirma que "Dentro do shopping center há essa duplicidade de conceito de fundo de comércio. É fundo de comércio o global do shopping, como o é também aquele que é construído pelo usuário. É a 'achalandagem', é o aviamento promovido por um lojista". ${ }^{9}$

Independentemente das discussões acima apontadas, o que se deve ressaltar é que, em conjunto ou em separado, o fundo de comércio configura aspecto relevante na formação do SC e decorre do esforço conjunto dos comerciantes (locatários/lojistas) e dos empreendedores (proprietários/investidores) e que possibilita a geração de lucros para ambos.

\footnotetext{
${ }^{57}$ MARTINS, Fran. Curso de Direito Comercial: empresa comercial, empresários individuais, microempresas, sociedades comerciais, fundo de comércio. Ed. rev. e atual. - Rio de Janeiro: Forense, 2009, p. 421.

${ }^{58}$ CARVAlHOSA, Modesto. Considerações sobre Relações Jurídicas em "Shopping Centers". In PINTO, Roberto Wilson Renault e OLIVEIRA, Fernando A. Albino de (coord.). Shopping Centers - Questões Jurídicas (Doutrina e Jurisprudência), São Paulo: Saraiva, 1991, p. 173.
} 
Com efeito, todos os investimentos feitos para se desenvolver o fundo de comércio do SC (especialmente os gastos com promoção e publicidade) devem ser patrocinados tanto por lojistas quanto por empreendedores.

\subsubsection{3 - Os Agentes Econômicos: Investidor, Administrador e Lojista}

\section{Empreendedor/Investidor (Locador)}

$\mathrm{O}$ foco do presente trabalho são o empreendedor e o investidor. Trata-se do agente econômico responsável pela realização do investimento para a aquisição da propriedade imobiliária. Sua função, portanto, é a de realizar o aporte de recursos para a concretização física do empreendimento.

Henrique Barbosa Primon e Eliane Monetti destacam a diferença conceitual entre esses dois tipos de agentes financiadores: (i) os empreendedores são diretamente ligados ao desenvolvimento do empreendimento e (ii) os investidores geralmente ingressam no empreendimento já em fase operacional, para obter o retorno financeiro do aporte de capital. ${ }^{60}$

\section{$\checkmark \quad$ Lojistas (Locatários)}

Os lojistas são os comerciantes, aqueles que possuem interface direta com os consumidores. Em geral, são locatários dos espaços dentro do empreendimento, nos quais exercerão sua atividade comercial (venda de bens e serviços). A definição da natureza das lojas que irão compor o empreendimento e de sua localização dentro do espaço físico é uma tarefa que compete ao administrador.

Dentre os lojistas, assume papel fundamental a Loja Âncora, que é a loja que atrai o maior número de consumidores ao SC. São geralmente lojas de departamento ou supermercados, que possuem grande variedade de produtos e preços atrativos.

De fundamental importância para a configuração do SC é a Associação de Lojistas (com adesão obrigatória pelos lojistas). Trata-se de uma associação civil, com personalidade

\footnotetext{
${ }^{59}$ PEREIRA, Caio Mário da Silva. Súmula do Simpósio sobre os Centros Comerciais. In ARRUDA, José Soares e LÔBO, Carlos Augusto da Silveira (coord.). "Shopping Centers" - Aspectos Jurídicos. São Paulo: Revista dos Tribunais, p. 17.

${ }^{60}$ PRIMON, Henrique Barbosa e MONETTI, Eliane, Implantação e Expansão de Shopping Centers no Brasil: um Estudo da Evolução Recente das Fontes de Investimentos. 10a Conferência Internacional da Lares, São Paulo, 2010, pp. 3 e 4.
} 
jurídica, que funciona como um instrumento de representação dos interesses de seus associados (lojistas), ${ }^{61}$ inclusive quanto a estratégias promocionais.

\section{$\checkmark \quad$ Administrador}

Outra parte importante para o desenvolvimento do SC é o seu administrador. Trata-se da parte especializada na gestão deste tipo de empreendimento e seus serviços serão prestados no interesse tanto dos empreendedores quanto dos lojistas. Assim, o contrato de administração é celebrado com os investidores/empreendedores e com os lojitas, o que confere ao administrador amplos poderes de gestão e estruturação do empreendimento, bem como de controle e fiscalização da atividade e do faturamento dos lojistas. ${ }^{62}$

Nesse sentido, a administração será centralizada e suportada por meio de regras de convivência previamente estabelecidas (Regimento Interno), que fará parte do contrato de locação entre empreendedores e lojistas. A adesão ao regimento do SC implica limitações à liberdade dos locatários, mas é um elemento essencial para a gestão e o controle do empreendimento.

\subsubsection{4 - Formas de Estruturação: Condomínio, Sociedade ou FII Condomínio}

Uma das formas de organização dos investidores e empreendedores na atividade de SC é a aquisição compartilhada do direito de propriedade sobre o bem imóvel (mediante a participação em frações ideais). Assim, cada investidor ou empreendedor detém a propriedade do bem imóvel ao mesmo tempo, cada um exercendo seu direito em idêntica graduação, de forma harmônica e compatível com o direito dos demais comunheiros.

Trata-se do condomínio, que pode ser constituído de duas formas: (i) o condomínio pro indiviso, regido pelos artigos 1.314 e seguintes do Código Civil (cada condômino terá um percentual do imóvel como um todo - não há divisão em unidades autônomas); ou (ii) o condomínio especial ou condomínio edilício, em que haverá partes de propriedade exclusiva (unidades autônomas que constituem o condomínio pro diviso) e partes de propriedade comum (objeto do condomínio pro indiviso). ${ }^{63}$

\footnotetext{
${ }^{61}$ GOMES, Orlando. Op. cit. (nota 55), p. 90.

${ }^{62}$ PINTO, Dinah Sonia Renault. Shopping Center, Uma Nova Era Empresarial. Revista e Atualizada por Vânia Renault Bechara Gomes e Antonio Marcos de Bragança Gomes. Rio de Janeiro: Forense, 2001, pp. 61 e 62.

${ }^{63}$ Este condomínio encontrava-se inicialmente regulamentado na Lei $\mathrm{n}^{\circ}$ 4.591/64 e era aplicável no âmbito das edificações ou conjuntos de edificações, de um ou mais pavimentos, construídos sob a forma de unidades isoladas
} 
No que concerne ao objeto do presente estudo, o importante é destacar que o investimento por meio da estrutura de condomínio pode ser feito na qualidade de pessoa física, pessoa jurídica ou de fundo de investimento imobiliário - FII. Cada investidor será proprietário (i) de uma fração ideal do edifício como um todo (condomínio pro indiviso), ou (ii) de unidades autônomas de propriedade exclusiva (condomínio edilício).

Assim, a tributação direta ocorrerá sobre a parcela do aluguel devido a cada proprietário, sendo: (i) proporcional à fração ideal no caso de condomínio pro indiviso ou (ii) o aluguel específico de cada unidade autônoma no caso do condomínio edilício.

\section{Sociedade (pessoa jurídica)}

Também é possível a reunião de todos os investidores/empreendedores como sócios de uma pessoa jurídica, cada um realizando sua parcela do investimento por meio de aportes de capital. Esta pessoa jurídica será a proprietária do imóvel onde está localizado o empreendimento, de forma que o relacionamento entre os investidores/empreendedores ocorre na qualidade de sócios da pessoa jurídica (única proprietária do edifício comercial) ${ }^{64}$

Neste modelo de estruturação, todo o aluguel recebido se concentra em uma única pessoa jurídica que irá tributá-lo individualmente. Os investidores receberão o retorno de seu investimento por meio de dividendos (isentos no Brasil).

\section{Fundo de Investimento Imobiliário - FII}

O FII é um instrumento para a realização de investimentos na atividade imobiliária e encontra-se regulamentado pela Lei $\mathrm{n}^{\circ}$ 8.668/93. É geralmente um instrumento de investimento coletivo, embora suas quotas possam ser de propriedade de um único investidor.

Neste modelo de estruturação jurídica, os investidores fazem o aporte de capital por meio da aquisição de quotas do FII. Se, por um lado, o titular das quotas do FII não pode exercer qualquer direito real sobre os imóveis e empreendimentos integrantes do patrimônio do fundo, por outro lado também não responde pessoalmente por qualquer obrigação legal ou contratual, relativamente aos imóveis e empreendimentos integrantes do fundo ou da administradora, salvo quanto à obrigação de pagamento do valor integral das quotas subscritas.

entre si, destinadas a fins residenciais ou não residenciais. Com o advento do Código Civil de 2002, essa modalidade de condomínio foi integralmente disciplinada (artigo 1.331 e seguintes), motivo pelo qual foi revogada a parte da Lei $n^{\circ} 4.595 / 64$ no que tange a essa matéria.

${ }^{64}$ Priscila Maria Pereira Corrêa da Fonseca defende que a forma jurídica que mais se adapta à constituição do Shopping Center é a sociedade anônima (nos termos da Lei no 6.404/76). FONSECA, Priscila Maria Pereira Corrêa da. O Regime Jurídico Aplicável aos Shopping Centers, in Revista de Direito Mercantil, Industrial, Econômico e Financeiro, São Paulo, jan./mar. 1987, v.65, pp.21-29. 
O quotista do FII exerce um papel semelhante ao acionista da companhia aberta, inclusive por meio das competências atribuídas à assembléia geral, dentre as quais estão: deliberação sobre as demonstrações financeiras apresentadas pelo administrador, alteração do regulamento, destituição ou substituição do administrador e escolha de seu substituto, emissão de novas quotas, entre outras.

\subsubsection{5 - Distribuição das Receitas e Despesas}

Empreendedor (Investidor) - Receitas de Aluguel e Valorização Imobiliária

A remuneração do empreendedor (ou investidor) pela cessão de uso das lojas é o aluguel, regido legalmente pela Lei $\mathrm{n}^{\mathrm{o}}$ 8.245/91. Conforme mencionado, por um lado, os contratos de locação preveem um aluguel fixo ou mínimo, baseado no espaço cedido para uso da loja, o que pode ser objeto de reajustes periódicos. Por outro lado, exige-se também um aluguel móvel ou percentual, calculado com base em um percentual do faturamento mensal do lojista. Em razão desse aluguel percentual, é permitido ao administrador do SC o exame da contabilidade dos lojistas, para fiscalizar o valor das vendas. ${ }^{65}$

\section{$\checkmark \quad$ Lojista (Locatário)-Receitas de Venda de Bens e Serviços \\ O lojista aufere suas receitas em decorrência da venda de bens e serviços} diretamente aos consumidores. Dessa forma, quanto maior o número de consumidores que frequentem o SC, maior o potencial para a geração de negócios e de faturamento (o que também irá beneficiar o empreendedor por meio do aluguel percentual).

\section{$\checkmark \quad$ Administrador - Receitas de Taxa de Administração \\ Conforme mencionado, o administrador é responsável pela gestão do empreendimento, prestando serviços diretamente ou por meio de subcontratação, inclusive definindo alterações estruturais ou de composição e diversidade dos lojistas (tenant mix). Para realizar essa atividade, é cobrada uma taxa de administração que será paga tanto por empreendedores quanto por lojistas.}

${ }^{65}$ DINIZ, Maria Helena. Tratado Teórico e Prático dos Contratos, vol. 3, 6a ed., São Paulo: Saraiva, 2006, p. 62. 
Resumo do fluxo de receitas na atividade de Shopping Center.

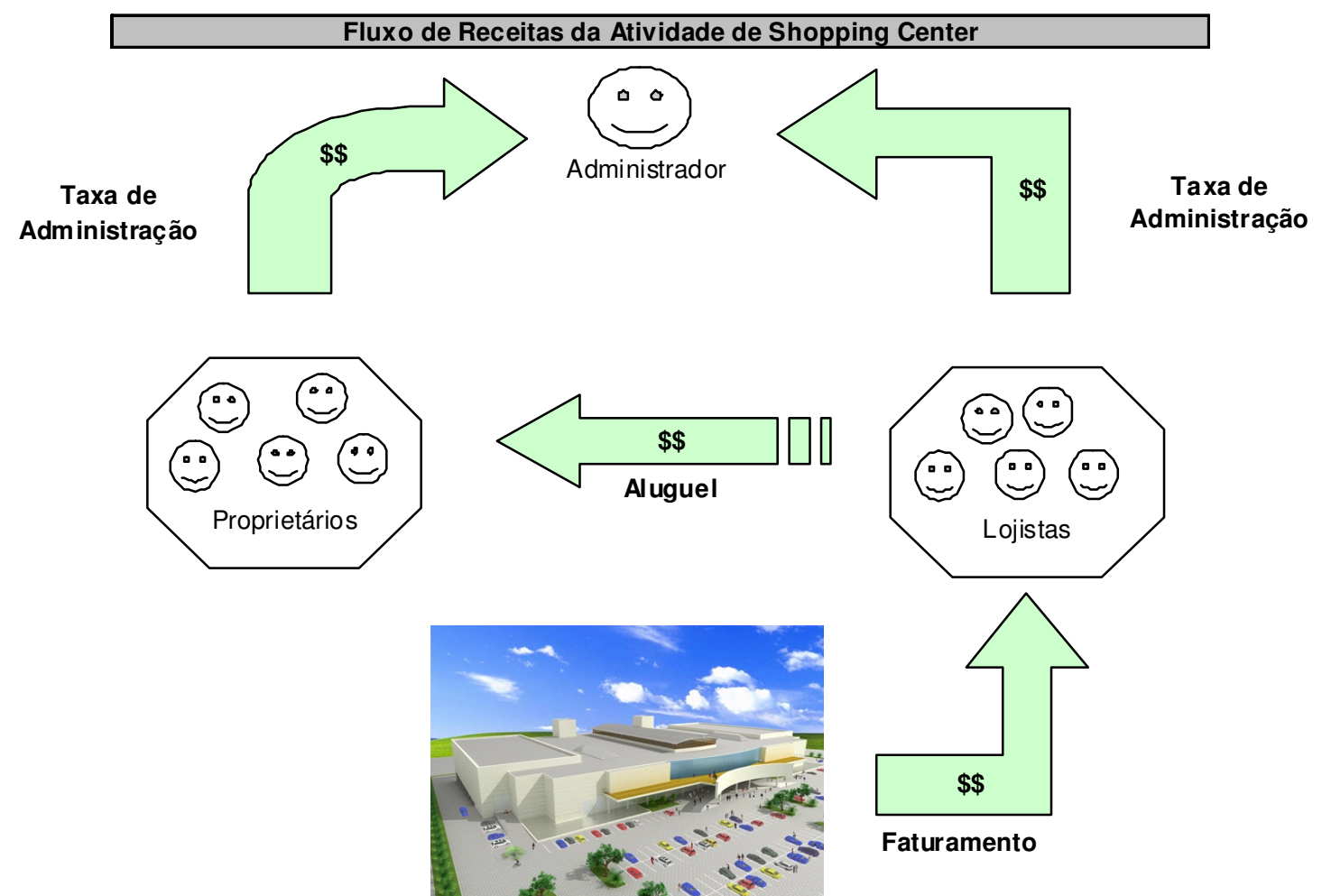

\section{$\checkmark \quad$ Lojista-Despesas Decorrentes do Contrato de Locação}

No que tange à locação de unidades imobiliárias, a Lei $n^{\circ} 8.245 / 91$ estabelece expressamente quais são as despesas de titularidade do locatário, tais como telefone, consumo de energia, gás, água e demais despesas ordinárias do condomínio. ${ }^{66}$ Quanto ao que se refere às despesas do SC, o artigo 54 da referida Lei adota como premissa a liberdade de contratação entre empreendedores e lojistas, apenas excluindo algumas despesas específicas que necessariamente são de titularidade do empreendedor. Portanto, verifica-se que as despesas atribuídas ao locatário são aquelas definidas no contrato de locação, conforme expressamente previsto em lei.

Outra despesa devida pelo lojista corresponde à taxa de administração, que deve ser paga direitamente ao administrador, em razão dos serviços por ele prestados na gestão do empreendimento (caso previsto em contrato).

\footnotetext{
66 “Art. 23. O locatário é obrigado a:

I - pagar pontualmente o aluguel e os encargos da locação, legal ou contratualmente exigíveis, no prazo estipulado ou, em sua falta, até o sexto dia útil do mês seguinte ao vencido, no imóvel locado, quando outro local não tiver sido indicado no contrato; (...)

VIII - pagar as despesas de telefone e de consumo de força, luz e gás, água e esgoto; (...)

XII - pagar as despesas ordinárias de condomínio. (...)

Art. 25. Atribuída ao locatário a responsabilidade pelo pagamento dos tributos, encargos e despesas ordinárias de condomínio, o locador poderá cobrar tais verbas juntamente com o aluguel do mês a que se refiram."
} 


\section{Empreendedores (Investidores) - Despesas Gerais}

Conforme mencionado, a distribuição de despesas entre locador e locatário no SC dependerá do estipulado no contrato de locação. O empreendedor figura como locador no contrato de locação e possui responsabilidade exclusiva sobre determinadas despesas, conforme $\S 1^{\circ}$ do artigo 54 da Lei $n^{\circ} 8.245 / 91 .^{67}$ Além dessas despesas, os empreendedores devem arcar com as despesas correspondentes às lojas não locadas, bem como com a sua parcela da taxa de administração.

\section{Fundo de Promoções (Despesas de Investimento Comum em Publicidade)}

Outro importante instrumento jurídico para a atividade do SC é o Fundo de Promoções. Trata-se de ferramenta utilizada para arrecadação e destinação dos valores necessários à publicidade do empreendimento, o que gera benefícios para todos os integrantes.

A contribuição dos lojistas ao fundo é obrigatória pelo contrato de locação, mas o locador também participa dessas despesas. ${ }^{68}$ Dessa forma, verifica-se que o Fundo de Promoções configura instrumento de fundamental importância para que comerciantes (locatários) e investidores (empreendedores) possam realizar investimentos conjuntos em publicidade.

\footnotetext{
67 "Art. 54. Nas relações entre lojistas e empreendedores de shopping center, prevalecerão as condições livremente pactuadas nos contratos de locação respectivos e as disposições procedimentais previstas nesta lei.

$\S 1^{\circ} \mathrm{O}$ empreendedor não poderá cobrar do locatário em shopping center:

a) as despesas referidas nas alíneas a, b e d do parágrafo único do art. 22; e

b) as despesas com obras ou substituições de equipamentos, que impliquem modificar o projeto ou o memorial descritivo da data do habite-se e obras de paisagismo nas partes de uso comum.

$\S 2^{\circ}$ As despesas cobradas do locatário devem ser previstas em orçamento, salvo casos de urgência ou força maior, devidamente demonstradas, podendo o locatário, a cada sessenta dias, por si ou entidade de classe exigir a comprovação das mesmas." (g.n.)

${ }^{68}$ Conforme destaca Rubens Requião: "Esse fundo destinar-se-á a manter as despesas de propaganda e promoções, para o qual o locatário concorrerá com uma contribuição periódica, (...) O locador concorrerá, também, para a constituição do fundo com importância mensal previamente estipulada, em proporção à parte das contribuições, dessa natureza, dos locatários." In REQUIÃO, Rubens. Considerações Jurídicas sobre os Centros Comerciais (Shopping Center) no Brasil, In ARRUDA, José Soares e LÔBO, Carlos Augusto da Silveira (coord.). "Shopping Centers" - Aspectos Jurídicos. São Paulo: Revista dos Tribunais, p. 149.
} 
Resumo do fluxo de despesas na atividade de Shopping Center.

\section{Fluxo de Despesas do Shopping Center}

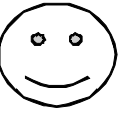

Administrador
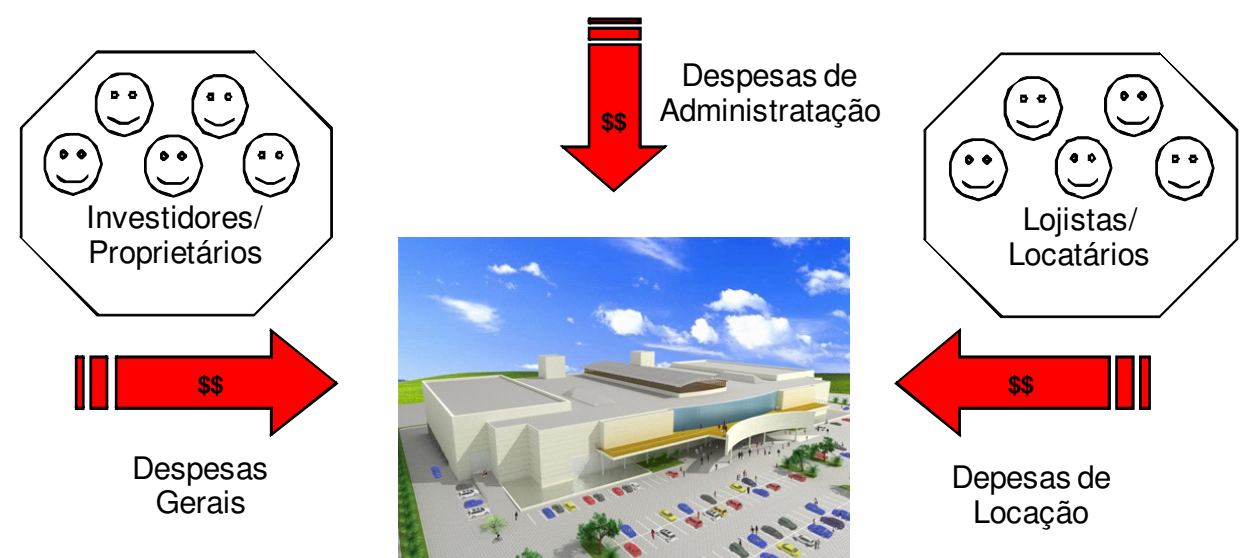

Resumo do fluxo de despesas de publicidade.

\section{Fundo de Promoções (Fluxo de Despesas)}
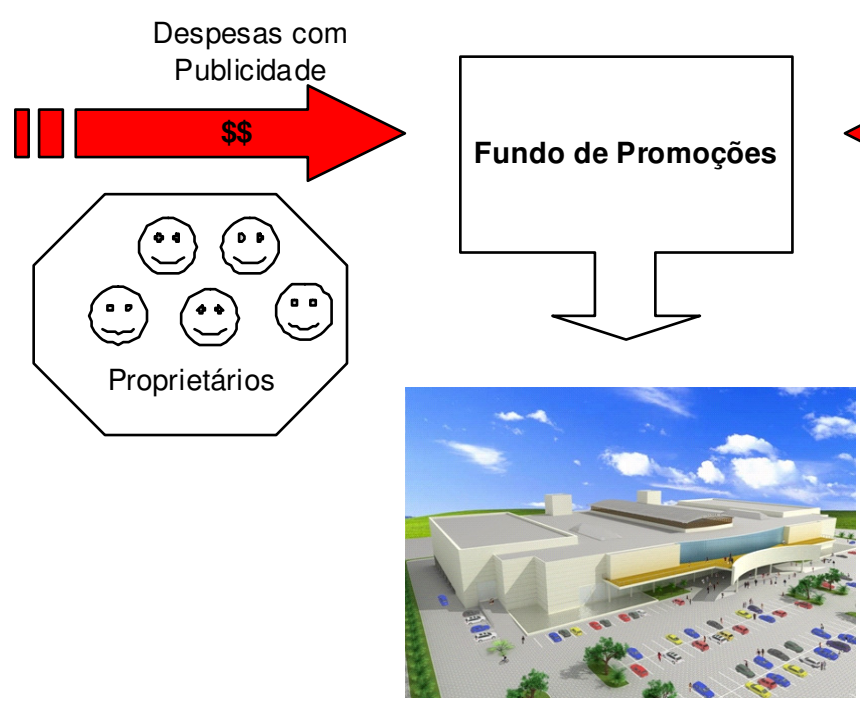

Despesas com

Publicidade






\section{5 - QUARTO GÊNERO: FinANCIAMENTO IMOBILIÁRIO}

\subsection{1 - Financiamento Imobiliário: Conceitos Iniciais}

Antes de se adentrar no estudo dos negócios jurídicos relacionados ao financiamento imobiliário, faz-se uma breve análise da importância deste tema dentro do Sistema Financeiro Nacional (SFN).

Pode-se definir o SFN como o conjunto de instituições dedicadas a viabilizar a intermediação de recursos entre aqueles que necessitam de crédito (tomadores) e aqueles que possuem reservas de recursos para aplicação (poupadores). ${ }^{69} \mathrm{Ou}$ seja, é o conjunto de instituições que regulamentam e operacionalizam o mercado financeiro, de forma a permitir que os recursos dos poupadores cheguem aos tomadores.

De uma forma geral, pode-se descrever graficamente o papel da instituição financeira como a intermediária na captação e na aplicação de recursos financeiros, que é remunerada pelo denominado spread bancário (diferença entre os juros que paga aos poupadores e os juros que recebe dos tomadores):



O gráfico acima também é ilustrativo dos dois tipos de operações realizadas pelas Instituições Financeiras: (i) operações passivas, por meio das quais as instituições financeiras captam recursos com os poupadores e (ii) operações ativas, por meio das quais realizam o repasse dos recursos obtidos com os poupadores para os tomadores.

Além do Mercado Financeiro (ou Mercado de Crédito), em que ocorre a intermediação financeira acima mencionada, também é importante destacar o papel do

${ }^{69}$ FORTUNA, Eduardo. Mercado Financeiro - Produtos e Serviços. 17 ${ }^{\mathrm{a}}$ ed., Rio de Janeiro: Qualimark, 2008, p. 16. 
Mercado de Capitais, no qual a negociação entre poupadores e tomadores ocorre diretamente. A instituição financeira é apenas interveniente obrigatória para viabilizar a operação: ${ }^{70}$
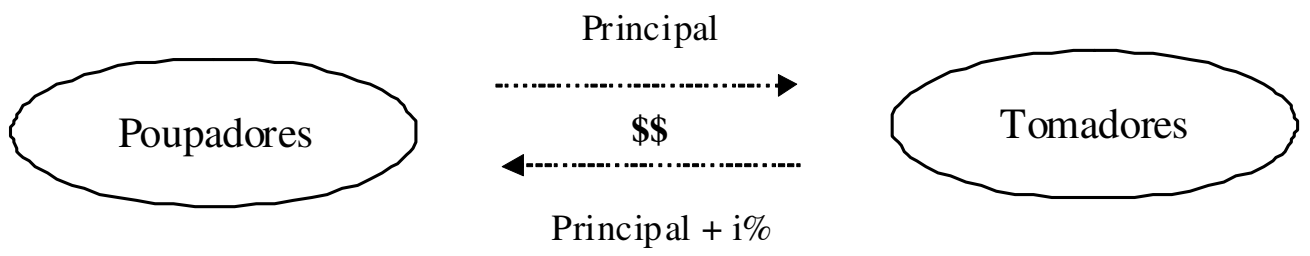

A formatação dos mercados financeiro e de capitais, nos moldes em que se encontra hoje estruturada, teve origem com a Lei de Reforma do SFN (Lei $n^{\circ} 4.595 / 64$ ), por meio da qual foram criados (i) o Conselho Monetário Nacional (CMN) - órgão responsável pela definição da política monetária, creditícia e monetária e (ii) o Banco Central do Brasil (BACEN) - instituição responsável por exercer a função executiva do SFN e fiscalizar as instituições que o compõem.

Posteriormente, com o advento da Lei $n^{\circ}$ 6.835/76, foi criada a Comissão de Valores Mobiliários (CVM), a quem foram transferidas as funções de regulamentar e fiscalizar as operações no âmbito do Mercado de Capitais.

O segmento do SFN que trata do financiamento imobiliário é o Sistema Financeiro da Habitação (SFH), instituído no contexto de reforma do SFN, por meio da Lei $n^{\circ}$ 4.380/64. Esta Lei criou também o antigo Banco Nacional da Habitação (BNH), órgão central que orientava e disciplinava a política habitacional no Brasil.

Com a extinção do BNH em 1986, suas atribuições foram distribuídas: (i) à Secretaria Especial de Desenvolvimento Urbano da Presidência da República - SEDU/PR (a quem compete a formulação de propostas de política habitacional e de desenvolvimento urbano), (ii) ao CMN (para exercer as funções de órgão central do SFH, para orientá-lo, discipliná-lo e controlá-lo), (iii) ao BACEN (para fiscalizar as instituições financeiras que integram o SFH) e (iv) à Caixa Econômica Federal - CEF (a quem foi transferida a

\footnotetext{
70 “O mercado de capitais, também denominado mercado de valores mobiliários, é o mercado da desintermediação financeira. Nele, a entidade financeira não se interpõe entre o indivíduo que dispõe de poupança e aquele que está necessitado dela: o trânsito de recursos financeiros do detentor de poupança para o necessitado de financiamento dá-se diretamente. A instituição financeira insere-se na relação apenas como interveniente obrigatória, atuando como instrumento para viabilizar a realização das operações realizadas no âmbito do mercado de capitais." In MOSQUERA, Roberto Quiroga. Tributação do Mercado Financeiro e de Capitais. 2a ed., São Paulo: Dialética, 1999, pp. 22 e 23.
} 
administração do passivo, ativo, do pessoal e dos bens móveis e imóveis do BNH, bem como a gestão do Fundo de Garantia do Tempo de Serviço - FGTS). ${ }^{71}$

O SFH sempre teve como principais fontes de recursos (operações passivas): (i) a poupança voluntária, cujos depósitos são captados pelas instituições autorizadas a trabalhar com esse tipo de aplicação financeira e que constituem o Sistema Brasileiro de Poupança e Empréstimo (SBPE); e (ii) o FGTS, que é operado pela CEF.

Atualmente, para atender à necessidade de financiamento das classes de maior poder aquisitivo, foi criado o Sistema Financeiro Imobiliário - SFI (Lei no 9.514/97), que se caracteriza pela desregulamentação, ou seja, seu funcionamento não está pautado pelo dirigismo estatal, ${ }^{72}$ mas sim pela liberdade de negociação das entidades autorizadas a operar no SFI, conforme artigos $4^{\circ}$ e $5^{\circ}$ dessa Lei.

Com o advento do SFI, possibilitou-se a cobrança de taxas de juros mais baixas em razão da substituição do sistema de garantia da hipoteca pela alienação fiduciária. Outro fator que influenciou a redução das taxas de juros foi a possibilidade de utilizar os créditos imobiliários para constituição de títulos que podem ser negociados no mercado financeiro (operação de securitização de recebíveis).

Feita essa breve explicação acerca do papel do financiamento imobiliário dentro do SFN e do SFI, passa-se a analisar as principais características dos instrumentos que viabilizam esse sistema.

\subsection{2 - Instrumentos de Garantia às Operações de Financiamento Imobiliário}

\subsubsection{1 - Hipoteca}

A hipoteca é o direito sobre um bem imóvel dado em garantia de uma dívida (artigo 1.419 e seguintes do Código Civil de 2002). Trata-se de um contrato acessório, pois este direito de garantia sobre o imóvel subsistirá enquanto a dívida não for quitada.

\footnotetext{
71 Histórico do SFN disponível no site do BACEN. Informação obtida em 12/08/2011, no endereço: http://www.bcb.gov.br/?SFHHIST

${ }_{72}$ CHALHUB, Melhim Namem, Propriedade Imobiliária: Função Social e Outros Aspectos. Rio de Janeiro: Renovar, 2000, p. 134.
} 
É importante destacar que a hipoteca é um direito real. Uma vez registrada a hipoteca na matrícula do imóvel no Cartório de Registro de Imóveis, ela é válida perante terceiros (antes do registro imobiliário a hipoteca é válida apenas perante as partes).

Conforme ensina Silvio de Salvo Venosa, ${ }^{73}$ o principal efeito da hipoteca é vincular o bem imóvel ao pagamento da dívida objeto de garantia. Dessa forma, trata-se de um instrumento jurídico de suma importância para viabilizar a concessão do crédito imobiliário, pois diminui o risco do financiamento, ao estabelecer uma garantia real sobre o bem imóvel que será expropriado, em caso de não pagamento.

Neste sentido, é importante destacar as principais hipóteses de extinção da hipoteca, previstas no artigo 1.499 do CC/2002: (i) extinção da obrigação principal (quitação da dívida - cumprimento da obrigação pelo devedor), (ii) perecimento do imóvel (mesmo que a dívida continue existindo, a hipoteca será extinta em razão do perecimento do imóvel que iria garanti-la) e (iii) arrematação (no caso de venda em praça ou leilão público) ou adjudicação (transferência judicial do imóvel ao credor para quitação da dívida).

Por fim, destaque-se que a hipoteca pode ser objeto de execução judicial pelo procedimento geral previsto no Código de Processo Civil (artigos 566 e seguintes) ou por meio do procedimento específico previsto na Lei $n^{\circ} 5.741 / 71$. Existe também o sistema de cobrança extrajudicial, instituído pelo Decreto-Lei $\mathrm{n}^{\circ}$ 70/66, que suscitou diversos questionamentos acerca de sua constitucionalidade perante o poder judiciário, pois acabou sendo usado muitas vezes como um mecanismo arbitrário de cobrança, que suprime o direito de defesa pelo devedor. ${ }^{74}$

\subsubsection{2 - Cessão Fiduciária de Direitos Creditórios}

Nos termos do artigo 18 da Lei $n^{\circ}$ 9.514/97, o contrato de cessão fiduciária em garantia é o instrumento pelo qual se transfere a titularidade dos créditos decorrentes de contratos de alienação de imóveis, até que a dívida garantida seja liquidada.

\footnotetext{
${ }^{73}$ VENOSA, Silvio de Salvo. Op. cit. (nota 52), p. 581.

${ }^{74}$ O Supremo Tribunal Federal, contudo, "EMENTA: EXECUÇÃO EXTRAJUDICIAL. DECRETO-LEI No 70/66. CONSTITUCIONALIDADE. Compatibilidade do aludido diploma legal com a Carta da República, posto que, além de prever uma fase de controle judicial, conquanto a posteriori, da venda do imóvel objeto da garantia pelo agente fiduciário, não impede que eventual ilegalidade perpetrada no curso do procedimento seja reprimida, de logo, pelos meios processuais adequados. Recurso conhecido e provido." RE 223075 / DF, Relator: Min. ILMAR GALVÃO, Julgamento: 23/06/1998, $1^{\text {a }}$ Turma.
} 
Trata-se também de direito real sobre os direitos creditórios objeto de cessão, motivo pelo qual é oponível perante terceiros. Ao credor fiduciário compete, dentre outros direitos, o de receber diretamente dos devedores os créditos cedidos fiduciariamente, devendo restituir ao cedente o valor que receber além do que este lhe devia.

\subsubsection{3 - Caução de Direitos Creditórios}

A Lei $n^{\circ}$ 9.514/97 também prevê, em seu artigo 21, a possibilidade de garantia do financiamento imobiliário por meio de caução dos direitos creditórios ou aquisitivos decorrentes de contratos de venda ou promessa de venda de imóveis. É possível oferecer a caução ainda que o imóvel esteja em construção, desde que os direitos creditórios sejam transmissíveis. Trata-se também de direito real, oponível a terceiros.

\subsubsection{4 - Alienação Fiduciária de Coisa Imóvel}

A alienação fiduciária de bens imóveis está regulamentada nos artigos 22 e seguintes da Lei $n^{\circ}$ 9.514/97. Trata-se de negócio jurídico com finalidade de garantia, pelo qual o devedor (fiduciante) contrata a transferência da propriedade resolúvel de coisa imóvel ao credor (fiduciário).

A alienação fiduciária não é privativa das entidades que operam no SFI e pode ser contratada por pessoa física ou jurídica. Além da propriedade plena do imóvel (direitos de usar, gozar e dispor), a alienação fiduciária poderá ter como objeto: (i) bens enfitêuticos, hipótese em que será exigível o pagamento do laudêmio, se houver a consolidação do domínio útil no fiduciário, (ii) o direito de uso especial para fins de moradia; (iii) o direito real de uso, desde que suscetível de alienação e (iv) a propriedade superficiária.

Trata-se, também, de direito real oponível perante terceiros, que se constitui mediante registro do contrato que lhe serve de título no competente Registro de Imóveis. A constituição da propriedade fiduciária tem, como conseqüência, o desdobramento da posse do bem imóvel: (i) o fiduciante detém a posse direta e (ii) o fiduciário detém a posse indireta.

Caso a dívida e seus encargos sejam liquidados, resolve-se a propriedade fiduciária do imóvel e o seu registro será cancelado perante o competente Registro de Imóveis. Se, no entanto, a dívida estiver vencida e não paga, e seja constituído em mora o fiduciante, a propriedade do imóvel será consolidada em nome do fiduciário, que deverá promover público leilão para a alienação do imóvel. 
Com efeito, verifica-se que a alienação fiduciária trouxe maior garantia ao crédito imobiliário, pois prevê instrumentos de execução extrajudicial mais eficientes e simples.

\subsubsection{5 - Oferecimento de Cotas de Fundo de Investimento}

Por fim, é importante destacar a faculdade instituída pela Lei $\mathrm{n}^{\circ} 11.196 / 05$, para que os participantes de plano de previdência complementar possam oferecer as quotas de sua titularidade dos fundos de investimento vinculados como garantia de financiamento imobiliário.

Trata-se das quotas dos fundos de investimento constituídos nos termos do artigo 76 dessa Lei, pelas entidades abertas de previdência complementar e pelas sociedades seguradoras, com patrimônio segregado, vinculado exclusivamente a planos de previdência complementar ou a seguros de vida, com cláusula de cobertura por sobrevivência, estruturados na modalidade de contribuição variável, por elas comercializados e administrados.

Esta faculdade também é atribuída (i) aos cotistas de Fundo de Aposentadoria Programada Individual - FAPI e (ii) aos segurados titulares de seguro de vida com cláusula de cobertura por sobrevivência, enquadrado na estrutura prevista no art. 76 da referida Lei.

\subsection{3 - Títulos de Crédito Imobiliário}

Antes de se adentrar na análise das características dos títulos de crédito imobiliário, é necessário tecer alguns comentários sobre o conceito de instrumento financeiro e sobre títulos de dívida privados. Neste sentido, confira-se o ensinamento de Alexandro Broedel Lopes, Fernando Caio Galdi e Iran Siqueira Lima: ${ }^{.5}$

\footnotetext{
“Os instrumentos financeiros exercem papel fundamental na economia moderna como ferramentas operacionais da transferência de recursos entre poupadores e tomadores, dinamizando o fluxo de recursos na economia. (...)

Instrumento financeiro é definido, de maneira ampla, como qualquer contrato que origina um ativo financeiro em uma entidade e um passivo financeiro ou título patrimonial em outra entidade. (...)

Títulos de dívida privados são aqueles emitidos pelas empresas com o objetivo de captação de recursos para investimentos em suas atividades operacionais, para suprimento de suas necessidades
} ${ }^{75}$ LOPES, Alexandro Broedel, GALDI, Fernando Caio e LIMA, Iran Siqueira. Manual de Contabilidade e
Tributação de Instrumentos Financeiros e Derivativos. $2^{\mathrm{a}}$ ed., São Paulo: Atlas, 2011, pp. 14 e ss. 
de capital de giro ou para readequação de sua estrutura de capital. Esses títulos podem ser emitidos por empresas financeiras ou não financeiras junto ao mercado ou em colocações privadas. (...)”

Conforme a definição acima, os títulos de crédito imobiliário são classificados como instrumentos financeiros que permitem o fluxo de recursos entre poupadores e tomadores e estarão lastreados em garantias imobiliárias. Trata-se, assim, de títulos privados, utilizados para o financiamento de projetos imobiliários.

\subsubsection{1 - Letras Imobiliárias (LI)}

As Letras Imobiliárias - LI foram instituídas por meio dos artigos 44 e seguintes da Lei $n^{\circ} 4.380 / 64$ com a finalidade de captar recursos para o financiamento imobiliário. Tratase de título de crédito passível de ser negociado no mercado de capitais e que configura promessa de pagamento em data futura. Embora sua data de vencimento não possa ser inferior a 12 meses, é possível que contenham cupons destinados ao pagamento autônomo de juros. ${ }^{76}$

Esses títulos de crédito podem ser emitidos pelas Sociedades de Crédito Imobiliário - SCI e por bancos múltiplos com carteira de crédito imobiliário, mas sua emissão depende de prévia autorização do órgão competente.

\subsubsection{2 - Cédulas Hipotecárias (CH)}

Outro instrumento criado para estimular os financiamentos no âmbito do SFH é a Cédula Hipotecária - CH, instituída pelo Decreto-Lei no 70/66 (artigo $9^{\circ}$ e seguintes). Trata-se de um título de crédito com lastro na garantia hipotecária do imóvel financiado, nominativo e de emissão do credor da respectiva hipoteca, podendo ser transferido por endosso.

A CH é instituída para hipotecas inscritas no Registro de Imóveis e configuram instrumento hábil para a representação dos respectivos créditos hipotecários e somente pode ser lançada à circulação depois de averbada à margem da inscrição da respectiva hipoteca. Neste sentido, o artigo 1.486 do Código Civil de 2002 estabelece que credor e devedor poderão autorizar a emissão das correspondentes cédulas hipotecárias no ato constitutivo da hipoteca.

Este título de crédito poderá ser integral (quando corresponder à totalidade do crédito hipotecário) ou fracionário (quando corresponder apenas à parte do crédito, mas a soma das $\mathrm{CH}$ fracionárias não pode exceder o valor total do respectivo crédito hipotecário). O prazo

\footnotetext{
${ }^{76}$ FORTUNA, Eduardo. Op. cit. (nota 69), p. 182.
} 
de vencimento da $\mathrm{CH}$ não pode ser diferente do prazo da respectiva dívida hipotecária. Se houver o vencimento antecipado da hipoteca, antecipa-se também o vencimento das $\mathrm{CH}$ sobre ela emitidas.

\subsubsection{3 - Letras Hipotecárias (LH)}

As Letras Hipotecárias - LH, regulamentadas pela Lei $n^{\circ} 7.684 / 88$, são títulos emitidos por instituições financeiras autorizadas a conceder créditos hipotecários, que serão objeto de garantia para esses títulos.

Poderão ser utilizados um ou mais créditos hipotecários para garantir a LH, mas a soma do principal das LH, emitidas pela instituição financeira, não poderá ser superior ao valor total dos créditos hipotecários por ela detidos.

Esses títulos são remunerados com juros prefixados e seu prazo mínimo é de 180 dias. Caso ocorra o resgate antes de findo esse prazo, o investidor não receberá nenhuma remuneração. Quanto ao prazo máximo, não poderá ser superior ao prazo dos créditos hipotecários que lhe servem de garantia.

Conforme ensina Eduardo Fortuna, as instituições financeiras podem emitir esses títulos (operações passivas) quando estiverem sem lastro para a concessão de financiamentos imobiliários (operações ativas), mas também podem comprar tais títulos quando o valor de sua carteira de financiamentos imobiliários estiver menor do que o valor captado em caderneta de poupança. ${ }^{77}$

\subsubsection{4 - Certificado de Recebíveis Imobiliários (CRI)}

O CRI é um título de crédito criado pela Lei no 9.541/97 (Lei do SFI). Trata-se de título lastreado em créditos imobiliários, constituindo-se em promessa de pagamento em dinheiro. As condições específicas de remuneração desse título foram objeto da Decisão Conjunta BACEN/CVM n $n^{\circ} 13 / 03$ e as condições para cessão de crédito às companhias securitizadoras são regulamentadas pela Resolução 2.686/00.

A emissão do CRI é de competência exclusiva das companhias securitizadoras e poderá ter garantia flutuante, que lhe assegurará privilégio geral sobre o ativo da companhia emissora, mas não impedirá a negociação dos bens que compõem esse ativo.

\footnotetext{
${ }^{77}$ FORTUNA, Eduardo. Op. cit. (nota 69), p. 181.
} 
Trata-se de um valor mobiliário passível de negociação no mercado de capitais, conforme definido pela Resolução CMN 2.517/98.

\subsubsection{5 - Letras de Crédito Imobiliário (LCI)}

As LCI, instituídas pela Lei $n^{\circ} 10.931 / 04$, são títulos muito semelhantes às LH. De fato, elas foram criadas como uma alternativa para o financiamento imobiliário, pois são lastreadas por créditos imobiliários garantidos por hipoteca (como as LH), mas também podem ser garantidas por créditos decorrentes da alienação fiduciária de coisa imóvel.

Sua emissão pode ser feita por bancos comerciais, bancos múltiplos com carteira de crédito imobiliário, pela CEF, pelas SCI, pelas associações de poupança e empréstimo, pelas companhias hipotecárias e demais espécies de instituições que sejam expressamente autorizadas pelo BACEN.

Além do direito ao crédito pelo valor nominal, os seus tomadores são remunerados por juros e atualização monetária nelas estipulados (se for o caso).

Poderão ser utilizados um ou mais créditos imobiliários para garantir a LCI, mas a soma do principal das LCI, emitidas pela instituição financeira, não poderá ser superior ao valor total dos créditos imobiliários por ela detidos.

Segundo a Circular BACEN no 3.152/02, o prazo mínimo para resgate da LCI, contado da data de sua emissão, é de:

(a) 36 meses, quando atualizada mensalmente por índice de preços;

(b) 12 meses, quando atualizada anualmente por índice de preços;

(c) 60 dias, nos demais casos.

Quanto ao prazo máximo, não poderá ser superior ao prazo dos créditos imobiliários que lhe servem de garantia.

\subsubsection{6 - Cédula de Crédito Imobiliário (CCI)}

A CCI foi criada pela Lei $n^{\circ} 10.931 / 04$ (artigo 18 e seguintes) como um título representativo de créditos imobiliários e tem como objetivo facilitar as operações de 
securitização rios, pois torna mais eficiente a transferência de créditos decorrentes de financiamentos imobiliários para companhias securitizadoras. ${ }^{78}$

Para a emissão e a negociação de CCI, não há necessidade de autorização do devedor do respectivo crédito imobiliário (artigo 21 da referida Lei). Esses títulos podem ser comprados por companhias securitizadoras para serem utilizados como lastro para a emissão de CRI no mercado secundário.

O título de crédito poderá ser integral (quando corresponder à totalidade do crédito imobiliário) ou fracionário (quando corresponder apenas à parte do crédito, mas a soma das CCI fracionárias não pode exceder o valor total do respectivo crédito hipotecário).

A CCI, emitida com lastro em crédito imobiliário garantido por direito real, deve ser averbada no Registro de Imóveis da situação do imóvel, na respectiva matrícula. Trata-se de título executivo extrajudicial e exigível pelo valor apurado, de acordo com as cláusulas e condições pactuadas no contrato que lhe deram origem.

\subsection{4 - Securitização de Recebíveis Imobiliários}

As companhias securitizadoras de créditos imobiliários foram criadas pela Lei $n^{\circ}$ 9.514/97 (Lei do SFI) como mais um mecanismo para alavancar o crédito imobiliário. Essas companhias são instituições não financeiras que têm por finalidade (i) a aquisição e securitização dos créditos imobiliários e (ii) a emissão e colocação dos CRI no mercado financeiro. Podem ainda emitir outros títulos de crédito, realizar negócios e prestar serviços compatíveis com as suas atividades (artigo $3^{\circ}$ da Lei do SFI).

Conforme destacado no Manual de Contabilidade Societária FIPECAFI, a securitização de recebíveis consiste em operações estruturadas para a obtenção de recursos a taxas mais competitivas, por meio da conversão de ativos a receber da empresa em títulos negociáveis: $:^{79}$

"Com o intuito de obter recursos a taxas mais competitivas, as empresas têm se utilizado de operações estruturadas de maneira a transferir o risco para outros investidores. A securitização é uma operação financeira que faz a conversão de ativos a receber da empresa em títulos negociáveis - as securities (que em inglês se referem aos valores mobiliários e aos títulos de crédito). Esses

\footnotetext{
${ }^{78}$ FORTUNA, Eduardo. Op. cit. (nota 69), p. 185.

${ }^{79}$ IUDÍCIBUS, Sérgio de, MARTINS, Eliseu, GELBECKE, Ernesto Rubens, SANTOS, Ariovaldo dos. Manual de Contabilidade Societária - Aplicável a Todas as Sociedades - de Acordo com as Normas Internacionais e do CPC. FIPECAFI - Fundação Instituto de Pesquisas Contábeis, Atuariais e Financeiras, FEA/USP, São Paulo:
} 
títulos são vendidos a investidores que passam a ser os novos beneficiários dos fluxos gerados pelos ativos. (...)"

Nos termos do artigo $8^{\circ}$ da Lei do SFI, a securitização de créditos imobiliários é a operação pela qual a companhia securitizadora emite uma série de títulos de crédito expressamente vinculados a créditos imobiliários (recebíveis decorrentes de venda a prazo de bens, serviços ou operações imobiliárias). É expressamente permitida a securitização de créditos decorrente da alienação de unidades em construção, sob regime de incorporação imobiliária.

Ressalte-se que, nos termos da legislação que regulamenta essa atividade no Brasil, não é possível a securitização de créditos futuros, decorrentes de vendas ainda não realizadas. Na verdade, o título emitido pela companhia securitizadora deve estar expressamente lastreado em créditos imobiliários, com identificação do devedor e do valor nominal de cada crédito que confira lastro à sua emissão, com a individualização dos imóveis a que esteja vinculado e a indicação do Cartório de Registro de Imóveis e da respectiva matrícula em que esteja registrado, bem como a indicação do ato pelo qual o crédito foi cedido (artigo $8^{\circ}$, inciso I, da Lei $n^{\circ}$ 9.514/97).

De fundamental importância para viabilizar a securitização de créditos imobiliários foi a instituição do regime fiduciário (artigos $9^{\circ}$ e seguintes da Lei do SFI). Trata-se da faculdade conferida às companhias securitizadoras de lastrear a emissão de CRI em créditos imobiliários objeto de regime fiduciário.

O regime fiduciário será constituído por meio de declaração unilateral da companhia securitizadora, que se submeterá às seguintes condições (artigo 10 da Lei do SFI): (i) a constituição do regime fiduciário sobre os créditos que lastreiem a emissão, (ii) a constituição de patrimônio separado, composto pela totalidade dos créditos submetidos ao regime fiduciário que lastreiem a emissão, (iii) a afetação dos créditos como lastro da emissão da respectiva série de títulos, (iv) a nomeação do agente fiduciário, com a definição de seus deveres, responsabilidades e remuneração, bem como as hipóteses, condições e forma de sua destituição ou substituição e as demais condições de sua atuação e (v) a forma de liquidação do patrimônio separado.

Com efeito, após a constituição do regime fiduciário, os créditos imobiliários serão separados do patrimônio da companhia securitizadora, destinando-se exclusivamente ao 
pagamento dos títulos a que estiverem afetados e respectivos custos administrativos e obrigações fiscais. Neste sentido, deverão ser mantidos inclusive registros contábeis independentes para cada patrimônio separado pelo regime fiduciário.

O regime fiduciário será extinto após o implemento das condições previstas no Termo de Securitização de Créditos que o tenha instituído e após satisfeitos os créditos dos beneficiários adquirentes dos CRI. Após a baixa da averbação do regime fiduciário no competente Registro de Imóveis, da averbação que tenha instituído o regime fiduciário, os recebíveis imobiliários remanescentes reintegrarão o patrimônio comum da companhia securitizadora.

A regulamentação da atividade se dá por meio da Instrução CVM 281/88 (com alterações pela Instrução CVM 307/99) e da Instrução CVM no 414/04. Segundo este normativo, a companhia securitizadora deve requerer à CVM o registro de companhia aberta para que possa negociar CRI no mercado de capitais.

\subsection{5 - Consócio Imobiliário}

O sistema de consórcio encontra-se regulamentado pela Lei $\mathrm{n}^{\mathrm{o}}$ 11.795/08 e pela Circular $\mathrm{n}^{\circ} 3.432 / 09$. Trata-se de uma alternativa ao financiamento imobiliário, que tem como principal característica a formação de poupança para a aquisição futura do imóvel.

O consórcio pode ser definido como uma reunião de pessoas (físicas ou jurídicas) que irão contribuir com prestações mensais para um fundo comum, de valor previamente determinado em função da carta de crédito objeto do plano.

Os consorciados somente terão acesso ao valor da carta de crédito objeto do plano após serem contemplados. Trata-se de uma modalidade de financiamento para as pessoas que não têm urgência para adquirir o imóvel, pois precisam aguardar serem contempladas em sorteios periódicos. Também é possível que os consorciados sejam contemplados por meio da realização de lances.

O consorciado contemplado pode utilizar o crédito para aquisição de imóveis construídos ou na planta, terreno, ou também para construção ou reforma. É necessário que o imóvel esteja localizado em município em que a administradora opere (ou em município diverso, desde que autorizado pela administradora). 


\subsection{6 - Leasing Imobiliário}

O leasing ou arrendamento mercantil é regulamentado pela Lei ${ }^{\circ} 6.099 / 74$, com alterações posteriores, e pela Resolução $n^{\circ}$ 2.309/96, com alterações posteriores. Trata-se de negócio jurídico, realizado entre a arrendadora (necessariamente pessoa jurídica) e a arrendatária (pessoa física ou jurídica), e tem por objeto o arrendamento de bens adquiridos pela arrendadora, mas em conformidade com os projetos e especificações exigidos pela arrendatária, pois será destinado ao uso próprio desta, mediante o pagamento de uma contraprestação.

Conforme ensina Eduardo Fortuna, o princípio básico que orienta as operações de leasing é que o lucro decorrente da exploração econômica de um bem não decorre da detenção da propriedade do bem, mas sim de sua utilização. ${ }^{80}$

O leasing pode ser financeiro ou operacional (conforme será analisado no Capítulo 4.4.1). Em linhas gerais, pode-se dizer que o leasing financeiro é aquele realizado com a finalidade de financiar a aquisição do bem, em médio ou longo prazo. $O$ adquirente (arrendatário) paga uma remuneração pelo uso do bem que é de propriedade do alienante (arrendador), mas que será transferido ao arrendatário ao final do contrato.

O leasing operacional, por sua vez, é geralmente realizado diretamente entre produtor do bem (arrendador) e o usuário (arrendatário), mas por período de tempo inferior à vida útil do bem arrendado. Dessa forma, o bem arrendado ainda possuirá alto valor de revenda ao final do contrato e a opção de compra pelo arrendatário será exercida a valor de mercado.

Ao final do período de vigência do contrato de leasing: (i) ele poderá ser renovado, (ii) o bem arrendado poderá ser devolvido ou (iii) poderá haver a opção de compra do bem pelo valor de mercado, pelo valor simbólico ou pelo valor residual garantido - VRG.

Especificamente no que tange à operação de leasing realizada por pessoa jurídica para aquisição de imóveis, verifica-se, na maior parte das vezes, a utilização do leasing financeiro, quando o objetivo é a aquisição do imóvel para uso próprio.

Ressalte-se, desde já, que o artigo 37 da Lei no 9.514/97 é expresso no sentido de que não se aplica à operação de leasing imobiliário a legislação pertinente à locação de imóveis residenciais, não residenciais ou comerciais. Em razão disso, passa-se a analisar as três modalidades de leasing de imóveis.

${ }^{80}$ FORTUNA, Eduardo. Op. cit. (nota 69), p. 289. 


\subsubsection{1 - Leasing Imobiliário Normal}

Nesta modalidade de arrendamento mercantil, uma pessoa jurídica tem interesse na aquisição de determinado imóvel já edificado. Em vez de realizar empréstimo para a aquisição do imóvel, celebra um contrato com a arrendadora que adquire o imóvel alvo à vista e o arrenda à adquirente final (arrendatária).

Neste caso, a arrendatária irá pagar uma contraprestação à arrendadora equivalente à amortização do principal mais juros. No final do contrato, poderá exercer a opção de compra pelo valor residual.

\subsubsection{2 - Leasing na Construção de Edifícios}

Nesta modalidade, o imóvel a ser adquirido ainda não se encontra edificado. Com efeito, o terreno pode ser adquirido de terceiros pela arrendadora, ou do próprio arrendatário, na modalidade de sale and lease back que será analisada adiante. ${ }^{81}$

Enquanto o imóvel estiver sendo construído, o arrendatário irá remunerar o arrendador por meio de uma taxa de compromisso, incidente sobre o valor dos gastos de construção (período pré-leasing). O contrato de leasing somente será celebrado depois de concluída a obra, sendo possível capitalizar a taxa de compromisso no valor da obra como custo da operação.

\subsubsection{3 - Sale and Lease Back Imobiliário}

Uma alternativa para empresas que pretendem reduzir o índice de imobilização de seu ativo é a venda do imóvel em que desenvolve sua atividade operacional, concomitantemente com a celebração do contrato de arrendamento com o adquirente, operação denominada sale and lease back.

Uma das vantagens para a empresa que irá alienar o imóvel (com a constituição simultânea do arrendamento mercantil) é aumentar o capital disponível para investimentos e desenvolvimento de sua atividade operacional. Há também a vantagem tributária, que será objeto de estudo em capítulo próprio.

\footnotetext{
${ }^{81}$ FORTUNA, Eduardo. Op. cit. (nota 69), p. 296.
} 
Ademais, em decorrência do contrato de arrendamento de longo prazo, a empresa continuará a usar e gozar do imóvel onde está sediada, podendo exercer a opção de compra ao final do contrato.

Outro aspecto positivo é a realização de eventuais ganhos de detenção decorrentes da valorização do bem imóvel, os quais geralmente estão registrados na contabilidade em valores de custo histórico de aquisição e podem estar bem abaixo do valor de mercado atual.

\subsection{7 - Fundos de Investimento Imobiliário - FII}

Os FII são instrumentos para a realização de investimentos na atividade imobiliária. São geralmente instrumentos de investimento coletivo, embora suas quotas possam ser de propriedade de um único investidor. Com a captação de um grande volume de recursos, geridos por instituições especializadas, permite-se o ganho de escala para os investidores.

Os recursos dos FII podem ser aplicados em atividades que tenham como núcleo a propriedade imobiliária, tais como a construção de imóveis, compra e venda e aquisição de imóveis para locação ou arrendamento.

Os investidores dos FII geralmente procuram a segurança que a atividade imobiliária proporciona, numa visão de longo prazo, embora consigam maior liquidez na negociação de seus ativos do que no investimento direto em imóveis.

No Brasil, estes fundos agregam vultosos recursos. Conforme informações extraídas do site da Comissão de Valores Mobiliários - CVM em 02/11/11, atualmente existem 125 FII em atividade, que reúnem investimentos no total aproximado de R $\$ 11,777$ bilhões. ${ }^{82}$

A análise da natureza jurídica deste importante instrumento de investimento coletivo será objeto do presente estudo.

\subsubsection{1 - Breve Histórico dos Fundos de Investimentos no Brasil}

A disciplina legal dos fundos de investimentos foi introduzida no Brasil por meio da Lei $n^{\circ} 4.728 / 65$, com o objetivo de disciplinar o mercado de capitais e seu desenvolvimento.

Inicialmente, o órgão regulador do mercado de capitais era o BACEN, a quem era atribuída a competência, nos termos dos artigos 49 e 50 da Lei ${ }^{\circ} 4.728 / 65$, para autorizar o

\footnotetext{
${ }^{82}$ Informações disponíveis no site http://cvmweb.cvm.gov.br/SWB/defaultCPublica.asp, consulta em 02/11/11.
} 
funcionamento das sociedades de investimentos e fiscalizar os fundos de investimento por elas administrados, respectivamente (i) fundos em condomínio para aplicação em valores mobiliários e (ii) fundos mútuos de investimento em condomínio - com composição flexível de carteira.

Posteriormente, com a evolução do Mercado de Capitais Brasileiro, foi editada a Lei $n^{\circ}$ 6.385/76, que criou a Comissão de Valores Mobiliários - CVM e estabeleceu a sua competência para regular o funcionamento do Mercado de Capitais Brasileiro.

Atualmente, após o advento da Lei $n^{\circ}$ 10.303/01 (que promoveu alterações na Lei $\mathrm{n}^{\mathrm{o}}$ 6.385/76), as cotas de fundos de investimento em valores mobiliários ou de clubes de investimento em quaisquer ativos passaram a ser expressamente consideradas como valores mobiliários, sujeitos à fiscalização exclusiva da CVM.

No exercício desta competência, foi instituída a Instrução CVM nº 409/04, que dispõe sobre a constituição, a administração, o funcionamento e a divulgação de informações dos fundos de investimento.

Ressalte-se que a legislação destacada trata de normas gerais para a criação de fundos de investimentos (Leis $n^{\circ} 4.728 / 65$ e 6.385/76). Com base nesta competência, há hoje diversos fundos de investimento, classificados de acordo com a composição de sua carteira (previstos na Instrução CVM n ${ }^{\circ}$ 409/04 ou em outras Instruções específicas para determinados fundos).

Ocorre que alguns fundos de investimentos possuem tratamento especial, expressamente previsto em lei específica, tal como ocorre com o FII, que foi instituído pela Lei $n^{\circ} 8.668 / 93$ (posteriormente alterada pelas Leis $n^{\circ} 8.894 / 94,9.779 / 99$ e 11.196/05).

Com base na competência conferida pelo artigo $4^{\circ}$ da Lei $n^{\circ} 8.668 / 93$, está hoje em vigor a Instrução CVM 472/08, que dispõe sobre a constituição, a administração, o funcionamento, a oferta pública de distribuição de cotas e a divulgação de informações dos FII. Também merece destaque a Instrução CVM n 206/94, que dispõe sobre normas contábeis aplicáveis às Demonstrações Financeiras dos FII (que será objeto de análise no Capítulo 4.4.2).

Com efeito, em face desse histórico legislativo acerca da disciplina dos FII no Brasil, passa-se agora a analisar os aspectos específicos acerca da sua natureza jurídica e principais características. 


\subsubsection{2 - Natureza Jurídica dos FII}

Os FII são instrumentos utilizados para a captação de recursos para investimento em empreendimentos imobiliários. Trata-se de uma importante ferramenta que permite a reunião de diversos investidores para a formação de um volume expressivo de capital necessário à realização de investimentos em empreendimentos que normalmente exigem grandes aportes de dinheiro.

Roberto Quiroga Mosquera ressalta que os fundos podem ser considerados como um instrumento para que as pessoas possam fazer aplicações de forma indireta e coletiva, pois as inversões financeiras se farão mediante a comunhão de recursos de várias pessoas. ${ }^{83}$

Trata-se de entidade que não possui personalidade jurídica, constituída na forma de condomínio fechado ( $\operatorname{artigo} 2^{\circ}$ da Lei $\mathrm{n}^{\circ}$ 8.668/93), caracterizada pela comunhão de recursos captados por meio do Sistema de Distribuição de Valores Mobiliários e destinados à aplicação em empreendimentos imobiliários.

Conforme ensina o Professor Arnoldo Wald, ${ }^{84}$ é inegável que os Fundos de Investimento (tais como o FII) são titulares de direitos e obrigações e estão numa situação intermediária entre a personalidade jurídica própria e o condomínio do Código Civil.

Neste sentido, apesar de não possuírem personalidade jurídica, os FII possuem (i) capacidade processual (representados pela instituição administradora), (ii) patrimônio próprio $^{85}$ (distinto do patrimônio da instituição administradora e do patrimônio dos quotistas), (iii) escrituração contábil própria e (iv) órgão representativo de investidores (Assembléia Geral).

A Professora Rachel Sztajn destaca também que os FII se assemelham com o condomínio do tipo germânico, resultando de convenção que tem caráter de negócio associativo. Em suas palavras: ${ }^{86}$

\footnotetext{
${ }^{83}$ MOSQUERA, Roberto Quiroga. Op. cit. (nota 70), p. 244.

${ }^{84}$ WALD, Arnoldo. Da Natureza Jurídica do Fundo Imobiliário. In Revista de Direito Mercantil no 80, 1990, pp. 17 e 23.

${ }^{85}$ Lei n $n^{\circ}$ 8.668/93: “Art. $6^{\circ} \mathrm{O}$ patrimônio do Fundo será constituído pelos bens e direitos adquiridos pela instituição administradora, em caráter fiduciário.

Art. $7^{\circ}$ Os bens e direitos integrantes do patrimônio do Fundo de Investimento Imobiliário, em especial os bens imóveis mantidos sob a propriedade fiduciária da instituição administradora, bem como seus frutos e rendimentos, não se comunicam com o patrimônio desta, observadas, quanto a tais bens e direitos, as seguintes restrições: (...)"

${ }^{86}$ SZTAJN, Rachel. Quotas de Fundos Imobiliários - Novo Valor Mobiliário. In Revista de Direito Mercantil n ${ }^{\circ}$ 93, 1994, pp. 104 e 105.
} 


\begin{abstract}
"Na outra modalidade de condomínio, de origem germânica, a coisa pertence à coletividade e não aos condôminos individualmente, os quais têm apenas direito de uso e gozo em face da relação em que se encontram e não por serem titulares de direitos, individualmente, sobre a coisa. A propriedade é coletiva, exercida de mão comum, conhecida no direito alemão como 'Gesamnteigenthum ou gemeinschaft sur gesamnten Hand.','
\end{abstract}

Ademais, verifica-se que a Lei $n^{\circ} 8.668 / 93$ determina que os FII sejam constituídos na forma de condomínios fechados. Apesar de não existir nesta Lei o conceito de condomínio fechado, deve-se entender como aberto ou fechado o fundo que permite ou não o resgate antecipado de quotas por seus detentores. Otavio Yazbek ensina que os fundos fechados, como os FII, são equiparados às companhias abertas, como forma de angariar recursos para atividades específicas. ${ }^{87}$

Como não é permitido o resgate de quotas dos FII, ou ele terá duração determinada (constituído para um empreendimento imobiliário específico e extinguindo-se ao término deste empreendimento - analogamente ao que ocorre com as Sociedades de Propósito Específico SPE) ou indeterminada (como ocorre com as pessoas jurídicas em geral).

Com efeito, pode-se afirmar que os FII possuem uma natureza jurídica própria, intermediária entre os condomínios e as pessoas jurídicas. Trata-se, portanto, de uma entidade de caráter associativo, mas sem personalidade jurídica, passível de ser titular de direitos e deveres, possuindo patrimônio próprio e distinto do patrimônio dos quotistas.

\title{
3.5.7.3 - Gestão dos FII pela Instituição Administradora
}

A gestão dos FII é atribuída à instituição administradora autorizada pela CVM, que deverá ser exclusivamente: (i) banco múltiplo com carteira de investimento ou com carteira de crédito imobiliário, (ii) banco de investimento, (iii) sociedade de crédito imobiliário, (iv) sociedade corretora ou sociedade distribuidora de títulos e valores mobiliários ou (v) outras entidades legalmente equiparadas.

À instituição administradora do FII compete (i) representá-lo ativa e passivamente, judicial e extrajudicialmente e (ii) responder pessoalmente pela evicção de direito, no caso de alienação de imóveis pelo fundo.

${ }^{87}$ YAZBEK, Otavio. Regulação do Mercado Financeiro e de Capitais. Rio de Janeiro : Elseivier, 2007, p. 172. 
Quando o investimento do FII se der em projetos de construção, caberá ao administrador exercer controle efetivo sobre o desenvolvimento do projeto, independentemente da contratação de terceiros especializados (Instrução CVM nº472/08, artigo 45).

A instituição administradora, portanto, assume o papel semelhante ao desempenhado pelos administradores das sociedades mercantis ${ }^{88}$ respondendo por má gestão, gestão temerária, conflito de interesses, descumprimento do regulamento do fundo ou de determinação da assembléia de quotistas.

\subsubsection{4 - Responsabilidade dos Quotistas do FII}

O titular das quotas do FII não pode exercer qualquer direito real sobre os imóveis e empreendimentos integrantes do patrimônio do fundo. Também, o titular das quotas do FII não responde pessoalmente por qualquer obrigação legal ou contratual, relativamente aos imóveis e empreendimentos integrantes do fundo ou da administradora, salvo quanto à obrigação de pagamento do valor integral das quotas subscritas.

O quotista que não integralizar as quotas subscritas, nas condições estabelecidas no regulamento do fundo ou no boletim de subscrição, ficará constituído em mora, de pleno direito, podendo a administradora promover contra o quotista processo de execução para cobrar as importâncias devidas, servindo-se do boletim de subscrição como título extrajudicial, nos termos do Código de Processo Civil, ou vender as quotas a terceiros, mesmo após iniciada a cobrança judicial.

O quotista do FII, portanto, exerce um papel semelhante ao acionista da companhia aberta, inclusive por meio das competências atribuídas à assembléia geral, dentre as quais estão a deliberação sobre as demonstrações financeiras apresentadas pelo administrador, alteração do regulamento, destituição ou substituição do administrador e escolha de seu substituto, emissão de novas quotas, entre outras.

As deliberações da assembléia geral serão tomadas, em geral, por maioria de votos dos quotistas presentes, cabendo a cada quota 1 voto. Algumas matérias exigirão quorum qualificado, como a alteração do regulamento (parágrafo único do artigo 20 da Instrução CVM $\left.n^{\circ} 472 / 08\right)$.

${ }^{88}$ SZTAJN, Rachel. Op. cit. (nota 86), p. 107. 


\subsubsection{5 - Formação do Patrimônio do FII}

O patrimônio do Fundo é constituído pelos bens e direitos adquiridos pela instituição administradora, em caráter fiduciário, ou seja: os bens e direitos integrantes do patrimônio do FII, em especial os bens imóveis mantidos sob a propriedade fiduciária da instituição administradora, bem como seus frutos e rendimentos, não se comunicam com o patrimônio da instituição administradora.

Com efeito, é da instituição administradora a propriedade (fiduciária) dos bens afetados ao FII. Contudo, tais bens não integram o seu patrimônio, mas sim o patrimônio do FII. Como consequência, os bens pertencentes ao patrimônio do FII: (i) não integram o ativo da administradora, (ii) não respondem direta ou indiretamente por qualquer obrigação da instituição administradora, (iii) não compõem a lista de bens e direitos da administradora, para efeito de liquidação judicial ou extrajudicial, (iv) não podem ser dados em garantia de débito de operação da instituição administradora, (v) não serão passíveis de execução por quaisquer credores da administradora, por mais privilegiados que possam ser e (vi) não podem ser objeto de quaisquer ônus reais sobre os imóveis.

Ademais, ressalte-se que os recursos resultantes da alienação destes bens, mesmo sendo de propriedade da instituição administradora, constituirão acréscimo ao patrimônio do fundo.

Feito este esclarecimento inicial quanto à natureza jurídica do patrimônio do FII sob o ponto de vista formal, passa-se a analisar agora a sua natureza jurídica sob o ponto de vista material, determinado pela natureza dos ativos que podem ser adquiridos pelo fundo.

De fato, os diversos fundos de investimento são identificáveis de acordo com a materialidade dos bens e direitos que irão compor o seu ativo. Os FII são fundos que devem investir seus recursos na aquisição de ativos imobiliários, que se encontram taxativamente arrolados pela CVM.

Nos termos da Instrução CVM no 472/08 (artigos 45 e 46), o patrimônio do FII poderá ser formado por meio da aquisição dos seguintes ativos:

(i) quaisquer direitos reais sobre bens imóveis;

(ii) desde que a emissão ou negociação tenha sido objeto de registro ou de autorização pela CVM, ações, debêntures, bônus de subscrição, seus cupons, direitos, recibos de subscrição e certificados de desdobramentos, certificados de depósito de valores mobiliários, cédulas de debêntures, cotas de fundos de 
investimento, notas promissórias, e quaisquer outros valores mobiliários, desde que se trate de emissores cujas atividades preponderantes sejam permitidas aos FII;

(iii) ações ou quotas de sociedades cujo único propósito se enquadre entre as atividades permitidas aos FII;

(iv) quotas de fundos de investimento em participações (FIP) que tenham como política de investimento, exclusivamente, atividades permitidas aos FII ou de fundos de investimento em ações que sejam setoriais e que invistam exclusivamente em construção civil ou no mercado imobiliário;

(v) certificados de potencial adicional de construção emitidos com base na Instrução CVM no 401, de 29 de dezembro de 2003;

(vi) quotas de outros FII;

(vii) certificados de recebíveis imobiliários e cotas de fundos de investimento em direitos creditórios (FIDC) que tenham como política de investimento, exclusivamente, atividades permitidas aos FII e desde que sua emissão ou negociação tenha sido registrada na CVM;

(viii)letras hipotecárias; e

(ix) letras de crédito imobiliário.

Com efeito, verifica-se que a natureza jurídica do FII é determinada, sob o aspecto material, pela aplicação de recursos na aquisição de direitos reais sobre bens imóveis. Esta aquisição pode ser de forma direta (em direitos reais sobre bens imóveis), mas também de forma indireta (por meio, por exemplo, da aquisição de valores mobiliários cujos emissores tenham atividade preponderante permitida ao FII, ou da aquisição de títulos de créditos e instrumentos de financiamento da atividade imobiliária).

Ademais, no que tange à aquisição direta de direitos reais sobre bens imóveis, registre-se também que os FII estão autorizados a incorrer em despesas referentes à manutenção e desenvolvimento desses ativos. Com efeito, determina a CVM que o administrador pode adiantar quantias para projetos de construção, desde que tais recursos se destinem exclusivamente à aquisição do terreno, execução da obra ou lançamento comercial do empreendimento e sejam compatíveis com o seu cronograma físico-financeiro. 
Ainda, após a integralização das quotas objeto da oferta pública, parcela do patrimônio do FII poderá, temporariamente, não estar aplicada em empreendimentos imobiliários, por força do cronograma físico-financeiro das obras constante do prospecto. Neste caso, tais recursos deverão ser aplicados em (i) quotas de fundos de investimento ou títulos de renda fixa, públicos ou privados, de liquidez compatível com as necessidades do fundo; e (ii) derivativos, exclusivamente para fins de proteção patrimonial, cuja exposição seja sempre, no máximo, o valor do patrimônio líquido do fundo e desde que previsto na política de investimento do FII.

O FII pode manter parcela do seu patrimônio permanentemente aplicada em cotas de fundos de investimento ou títulos de renda fixa, públicos ou privados, para atender suas necessidades de liquidez. 


\section{4 - Reconhecimento e Mensuração do Lucro Societário no Setor IMOBILIÁRIO}

Conforme se verificou no Capítulo 2, os elementos contábeis que tratam a situação econômica de uma entidade, sob o ponto de vista estático, são os ativos, os passivos e o patrimônio líquido, os quais integram o BP. O lucro, por sua vez, é uma medida de desempenho apurada a partir dos elementos contábeis que demonstram a situação econômica da empresa sob o ponto de vista dinâmico, ou seja: as receitas e as despesas, que integram a DRE.

Não obstante a noção básica acerca da natureza dos elementos contábeis acima mencionados, os problemas específicos de reconhecimento e mensuração somente podem ser corretamente solucionados a partir da aplicação dos PCGA, especialmente (i) o princípio do custo como base de valor (ponderado com outros critérios de mensuração em alguns casos específicos); e (ii) o regime de competência, que compreende o princípio da realização da receita e o princípio do confronto das despesas com as receitas e com os períodos contábeis.

Ocorre que a aplicação dessas premissas teóricas pressupõe um elevado conhecimento concreto das atividades econômicas que se pretende reconhecer e mensurar, sobretudo algumas características técnicas específicas e o complexo de relações jurídicas que as envolvem. Trata-se de análise necessária para a compreensão da transferência de riscos e benefícios nos casos concretos, determinante para o reconhecimento de receitas e despesas.

Neste sentido, analisaram-se no, Capítulo 3, os diversos negócios jurídico-imobiliários sob o ponto de vista da prática comercial e os principais aspectos jurídicos que os envolvem. De fato, esta análise é importante para o reconhecimento de uma receita, pois ela será contabilizada em função do negócio a partir do qual se origina, tais como receitas de vendas, de honorários, de aluguéis, de financiamento etc.

Conforme se depreende da análise dos PCGA, uma das tarefas mais difíceis para o aplicador da ciência contábil é a definição dos critérios de reconhecimento e mensuração dos elementos contábeis, uma vez que envolve o juízo subjetivo na ponderação de princípios.

Com efeito, a receita somente é reconhecida quando (i) for provável que benefícios econômicos futuros fluam para a entidade, ou seja, houver a transferência dos riscos 
e benefícios significativos associados com a venda dos bens ou prestação dos serviços; e (ii) esses benefícios possam ser confiavelmente mensurados.

Quanto à mensuração, a receita deve ser registrada pelo valor justo da contraprestação recebida ou a receber. Em regra, a contraprestação constitui-se em caixa ou equivalente de caixa, devendo a receita ser mensurada pelo valor recebido ou a receber.

Além das dificuldades para o reconhecimento e mensuração das receitas (objeto do princípio da realização da receita), também há dificuldades inerentes ao reconhecimento e mensuração das despesas (objeto do princípio do custo como base de valor e do princípio do confronto das despesas com as receitas e com os períodos contábeis).

Portanto, é com base nesse contexto que se faz necessária a análise das características específicas da contabilização da atividade imobiliária. Para tanto, serão abordados especialmente os seguintes diplomas normativos:

(i) Orientação OCPC 01 - Entidades de Incorporação Imobiliária (Deliberação CVM no 561/08);

(ii) Pronunciamento Técnico CPC 06 - Operações de Arrendamento Mercantil (Deliberação CVM n ${ }^{\circ}$ 554/08);

(iii) Pronunciamento Técnico CPC 17 - Contratos de Construção (Deliberação CVM nº 576/09);

(iv) Pronunciamento Técnico CPC 28 - Propriedade para Investimento (Deliberação CVM nº 594/09);

(v) Pronunciamento Técnico CPC 30 - Receitas (Deliberação CVM no 597/09);

(vi) Interpretação Técnica ICPC 02 - Contrato de Construção do Setor Imobiliário (Deliberação CVM nº 612/09);

(vii) Interpretação Técnica ICPC 10 - Ativo Imobilizado e Propriedade para Investimento (Deliberação CVM nº 619/09);

(viii) Orientação OCPC 04 - Aplicação da Interpretação Técnica ICPC 02 às Entidades de Incorporação Imobiliárias Brasileiras (Deliberação CVM n ${ }^{\circ}$ $653 / 10)$ 
Ademais, tendo em vista a necessidade de análise dos métodos e critérios contábeis vigentes em 31/12/2007, para fins de aplicação do Regime Tributário de Transição RTT (confira-se o Capítulo 5.2.1.1), também será analisada a Resolução do Conselho Federal de Contabilidade - CFC n ${ }^{\circ}$ 963/2003, que aprovou a NBC T 10.5 - Entidades Imobiliárias.

\section{1 - Negócios JURídicos de AlienaÇão da Propriedade Imobiliária}

\subsection{1 - Aspectos Gerais da Contabilização de Venda de Bens (CPC 30)}

Como regra geral, os negócios jurídicos de alienação da propriedade de um bem podem ser contabilizados em conformidade com o tratamento dispensado pelo Pronunciamento Técnico CPC 30 - Receitas sobre Venda de Bens (itens 14 e seguintes). Esse tratamento será reproduzido a seguir, com os devidos comentários e considerações julgados necessários.

Usualmente, aplica-se o item 14 do Pronunciamento CPC 30 para o reconhecimento da receita proveniente da venda de bens. Neste sentido, determina o Pronunciamento que a receita somente será reconhecida depois de satisfeitas as seguintes condições:

“(a) a entidade tenha transferido para o comprador os riscos e beneficios mais significativos inerentes à propriedade dos bens;

(b) a entidade não mantenha envolvimento continuado na gestão dos bens vendidos em grau normalmente associado à propriedade nem efetivo controle de tais bens;

(c) o valor da receita possa ser confiavelmente mensurado;

(d) for provável que os benefícios econômicos associados à transação fluirão para a entidade; $e$

(e) as despesas incorridas ou a serem incorridas, referentes à transação, possam ser confiavelmente mensuradas."(g.n.)

Com efeito, todo negócio imobiliário que tenha como característica fundamental a 
venda de bens ${ }^{1}$ deverá observar as condições acima expostas para o reconhecimento da receita. A seguir, passa-se a descrever alguns aspectos importantes que devem ser observados neste processo de reconhecimento.

\subsubsection{1 - Transferência dos Riscos e Benefícios}

Um dos aspectos mais importantes para o reconhecimento da receita de qualquer atividade é a transferência dos riscos e benefícios da propriedade do bem vendido. De fato, a propriedade de um bem implica riscos e benefícios para o proprietário, motivo pelo qual a receita da venda de um bem somente poderá ser reconhecida após a transferência desses riscos e benefícios para o comprador. Seguem alguns comentários sobre o tema extraídos do Pronunciamento CPC 30:

"15. A avaliação do momento em que a entidade transfere os riscos e benefícios significativos da propriedade para o comprador exige o exame das circunstâncias da transação. Na maior parte dos casos a transferência dos riscos e dos benefícios inerentes à propriedade coincide com a transferência da titularidade legal ou da transferência da posse do ativo para o comprador. Tais casos são típicos das vendas a varejo. Em outros casos, porém, a transferência dos riscos e benefícios da propriedade ocorre em momento diferente da transferência da titularidade legal ou da transferência da posse do ativo.

16. Se a entidade retiver riscos significativos da propriedade, a transação não é uma venda e a receita não pode ser reconhecida. A retenção de risco significativo inerente à propriedade pode ocorrer de várias formas. Por exemplo:

(a) quando a entidade vendedora retém uma obrigação em decorrência de desempenho insatisfatório que não esteja coberto por cláusulas normais de garantia;

(b) nos casos em que o recebimento da receita é dependente da venda dos bens pelo comprador (genuína consignação);

(c) quando os bens expedidos estão sujeitos a instalação, sendo esta uma parte significativa do contrato e ainda não tenha sido completada pela entidade; $e$

\footnotetext{
${ }^{1}$ Em certas operações, é possível que existam circunstâncias que tornem necessário reconhecer separadamente dois ou mais componentes identificáveis em uma única operação. Como exemplo (constante no Pronunciamento Técnico CPC 30 - Receitas, item 13), pode ocorrer que "o preço da venda de um produto inclui valores identificáveis, correspondentes a serviços a serem executados posteriormente. Para esses casos, tais valores são diferidos e reconhecidos como receita durante o período em que o serviço vier a ser executado."

Neste mesmo item do Pronunciamento, também é citado o exemplo contrário, em que duas ou mais operações devem ser reconhecidas de forma conjunta, nas hipóteses em que exista evidência de que elas estejam ligadas de tal forma que o resultado econômico não seja identificável sem a visualização das transações em conjunto. Neste sentido, "a entidade pode vender bens e, ao mesmo tempo, firmar um contrato separado para recomprá-los em data posterior, invalidando assim a essência da transação. Em tais casos, as duas transações são tratadas conjuntamente."
} 
(d) quando o comprador tem o direito de rescindir a compra por uma razão especificada no contrato de venda e a entidade vendedora não está segura acerca da probabilidade de devolução.

17. Se a entidade retiver somente um risco insignificante inerente à propriedade, a transação é uma venda e a receita pode ser reconhecida. Por exemplo, um vendedor pode reter a titularidade legal sobre os bens unicamente para garantir o recebimento do valor devido. Em tal caso, se a entidade tiver transferido os riscos e benefícios significativos inerente à propriedade, a transação é uma venda e a receita pode ser reconhecida. Outro exemplo diz respeito às vendas a varejo em que o valor da compra pode ser reembolsado se o cliente não ficar satisfeito. A receita em tais casos é reconhecida no momento da venda, desde que o vendedor possa estimar confiavelmente as devoluções futuras. O passivo correspondente a tais devoluções deve ser calculado tomando por base experiências anteriores e outros fatores relevantes."

Como se pode notar, a transferência dos riscos e benefícios ocorre geralmente com a transferência da propriedade ou da posse do bem. Essas transferências, para o Direito Civil, têm como consequência a mudança de titularidade de um direito do patrimônio do vendedor para o patrimônio do comprador. Contudo, para a Contabilidade Societária, este direito (posse ou propriedade) somente será considerado transferido após a efetiva transferência dos riscos e benefícios pertinentes ao bem (o que implica a análise concreta da operação para se determinar a inexistência de retenção de riscos pelo alienante).

Com efeito, os itens acima transcritos do CPC 30 demonstram que o conceito de patrimônio para fins da Contabilidade Societária é mais restrito do que o conceito previsto no Direito Civil (confira-se o Capítulo 3.1.5). Isto porque o ingresso do direito (posse ou propriedade) no patrimônio da entidade para o Direito Civil não está sujeito à limitação da transferência de riscos e benefícios (basta a transferência da titularidade legal ou a relação de fato que configure a posse).

\subsubsection{2 - Segurança de Recebimento dos Benefícios Econômicos}

Outra característica importante para o reconhecimento de uma receita é a segurança de recebimento dos benefícios econômicos. Trata-se de mais uma restrição ao ingresso de um direito ao patrimônio para o Direito Societário, o que não existe para o Direito Civil. Confira-se o que dispõe o item 18 do CPC 30 sobre o assunto:

“18. A receita só deve ser reconhecida quando for provável que os benefícios econômicos associados à transação fluirão para a entidade. Em alguns casos específicos isso só pode 
ser determinado quando do recebimento ou quando a incerteza for removida. Por exemplo, pode ser incerto que a autoridade governamental estrangeira conceda permissão para que a entidade compradora remeta o pagamento da venda efetuada a um país estrangeiro. Quando a permissão for concedida, a incerteza desaparece, e a receita deve ser reconhecida. Quando surgir uma incerteza relativa à realização de valor já reconhecido na receita, o valor incobrável ou a parcela do valor cuja recuperação é improvável devem ser reconhecidos como despesa e não como redução do montante da receita originalmente reconhecida."

Em face do exposto no CPC 30, verifica-se que o ingresso de uma receita no patrimônio de uma entidade depende da análise da probabilidade de recebimento dos benefícios econômicos da operação. Assim, para o reconhecimento da receita decorrente da venda de um bem imóvel, faz-se necessária a segurança do recebimento dos benefícios econômicos (pode estar configurada uma incerteza, por exemplo, quando a venda de um terreno estiver sujeita a condição de aprovação de futuro empreendimento pelas autoridades).

\subsubsection{3 - Mensurabilidade das Despesas e Confronto com as Receitas}

Por fim, registre-se que uma receita somente pode ser reconhecida para fins do Direito Contábil Societário quando todas as despesas a ela relacionadas possam ser confiavelmente mensuradas. Confira-se o item 19 do CPC 30:

“19. A receita e as despesas relacionadas à mesma transação são reconhecidas simultaneamente; esse processo está vinculado ao princípio da confrontação das despesas com as receitas (regime de competência). As despesas, incluindo garantias e outros custos a serem incorridos após a entrega dos bens, podem ser confiavelmente mensuradas quando as outras condições para o reconhecimento da receita tenham sido satisfeitas. Porém, quando as despesas não possam ser mensuradas confiavelmente, a receita não pode ser reconhecida. Em tais circunstâncias, quaisquer valores já recebidos pela venda dos bens serão reconhecidos como um passivo." (g.n.)

Portanto, mesmo que ocorra o ingresso financeiro decorrente de uma venda em que as despesas ainda não estejam mensuradas com segurança, referido ingresso será registrado como um passivo, pois tem natureza de uma dívida com o comprador (adiantamento de clientes), correspondente à obrigação de entrega/produção do bem vendido. 


\subsection{2 - Permuta (СРС 30 e OCPC 01)}

Conforme já destacado no Capítulo 3.2.4, a permuta é um negócio jurídico em que ocorre a troca de um bem por outro bem (que não seja dinheiro). Ocorre que, para fins da Contabilidade Societária, a alienação de bens por meio de permuta poderá ou não ensejar o reconhecimento de uma receita.

Caso a permuta ocorra entre bens de natureza e valor semelhantes, não haverá o registro de receita. Contudo, caso a permuta ocorra entre bens de natureza distinta, haverá o registro da receita. Sobre o assunto, confira-se o CPC 30 - Receitas (item 12):

“12. Quando os bens ou serviços forem objeto de troca ou de permuta, por bens ou serviços que sejam de natureza e valor semelhantes, a troca não é vista como transação que gera receita. Exemplificam tais casos as transações envolvendo petróleo ou leite em que os fornecedores trocam ou realizam permuta de estoques em vários locais para satisfazer a procura, em base tempestiva e em local específico. Por outro lado, quando os bens são vendidos ou os serviços são prestados em troca de bens ou serviços não semelhantes, tais trocas são vistas como transações que geram receita. Nesses casos a receita é mensurada pelo valor justo dos bens ou serviços recebidos, ajustados pela quantia transferida em caixa ou equivalente. Quando o valor justo dos bens ou serviços recebidos não possa ser satisfatoriamente mensurado, a receita é determinada utilizando-se como parâmetro o valor justo dos bens ou serviços entregues, ajustado pelo valor transferido em caixa ou seu equivalente."

Como se pode verificar do exposto, o CPC 30 cita petróleo e leite como bens natureza e valor semelhantes. Ocorre que esses bens são commodities, comercializados em grande escala e com natureza uniforme. Contudo, quando se trata de permuta no setor imobiliário, a definição de semelhança demanda maior atenção.

A permuta é um negócio jurídico muito comum no setor imobiliário, especialmente nos casos em que os incorporadores adquirem terrenos para construção de futuras unidades. Ocorre que as características dos bens imóveis (terreno e edificação) podem ser muito distintas. Pode-se questionar a semelhança entre um imóvel urbano e um rural, entre um imóvel de alta renda e um de baixa renda, um imóvel residencial e um comercial etc.

Dessa forma, a definição de bens imóveis de mesma natureza foi definida na Orientação OCPC 01 - Entidades de Incorporação Imobiliária (itens 20 e seguintes). Estabeleceu-se que apartamentos não são bens de natureza semelhante a terrenos, motivo pelo qual a permuta de terreno por apartamentos a construir, por exemplo, enseja o reconhecimento de uma receita. Confira-se: 
“20. Quando unidades imobiliárias de mesma natureza e valor são permutados entre si (apartamentos por apartamentos, terrenos por terrenos, etc.), essa troca não é considerada uma transação que gera ganho ou perda.

21. Quando há a permuta de unidades imobiliárias que não tenham a mesma natureza e o mesmo valor (por exemplo, apartamentos construídos ou a construir por terrenos), esta é considerada uma transação com substância comercial e, portanto, gera ganho ou perda. A receita deve ser mensurada pelo seu valor justo. Entende-se como valor justo a quantia pela qual um ativo poderia ser trocado, ou um passivo liquidado, entre partes conhecedoras e dispostas a isso em uma transação em que não existe relacionamento entre elas. Neste tipo de operação, a receita é determinada pelo valor de venda dos imóveis ou terrenos recebidos. Excepcionalmente, quando esse valor não puder ser mensurado com segurança, a receita deve ser determinada com base no valor de venda das unidades imobiliárias entregues.” (g.n.)

Conforme destacado no Capítulo 3.2.4, a permuta é uma operação em que não há definição de preço, apenas uma relação de troca entre bens. Para a Contabilidade Societária, contudo, a receita deve ser mensurada pelo valor justo. Aplicando-se esse critério, a receita decorrente da alienação das unidades futuras entregues na permuta deve ser feita, em princípio, pelo valor de venda dos bens recebidos (terrenos ou outros imóveis). Contudo, pode ser que esse valor não seja passível de mensuração com segurança, hipótese em que se adota o valor de venda das unidades a serem entregues.

Por fim, a OCPC 01 trouxe o tratamento específico de registro da permuta de terrenos por unidades a serem construídas. Confira-se:

“22. No caso de permuta de terrenos, tendo por objeto a entrega de apartamento a ser construído, o valor do terreno adquirido pela entidade de incorporação imobiliária, apurado conforme critérios descritos no item 21, deve ser contabilizado por seu valor justo, como um componente do estoque de terrenos de imóveis a comercializar, em contrapartida a adiantamento de clientes no passivo, no momento da assinatura do instrumento particular ou do contrato relacionado à referida transação.

23. Prevalecem para as transações descritas no item 22 os mesmos critérios de apropriação aplicados para o resultado de incorporação imobiliária em seu todo." (g.n.)

Verifica-se desta Orientação que o terreno recebido é registrado no ativo da adquirente, mas não há o reconhecimento imediato de uma receita pela alienação das unidades a construir. $\mathrm{Na}$ verdade, registra-se inicialmente um passivo (adiantamento de clientes), da mesma forma que ocorre com a venda de unidades na planta pela incorporadora, com recebimento à vista. A receita decorrente da permuta das unidades a construir deverá ser 
reconhecida pelos mesmos critérios utilizados para o reconhecimento da receita de venda das demais unidades (durante a evolução da obra ou na entrega das chaves, conforme o caso).

\section{2 - Negócios Jurídicos de Prestação de Serviços Vinculados À PROPRIEDADE IMOBILIÁRIA}

\subsection{1 - Aspectos Gerais da Contabilização de Serviços (CPC 30)}

No que tange aos negócios jurídicos de prestação de serviços, a regra geral de contabilização deve estar em conformidade com o tratamento dispensado pelo Pronunciamento Técnico CPC 30 - Receitas sobre Prestação de Serviços (itens 20 e seguintes).

Neste Pronunciamento, verifica-se que o reconhecimento de uma receita ocorre na mesma proporção em que o serviço é prestado (método da percentagem completada). Ocorre que, para que a receita seja reconhecida, pressupõem-se que o desfecho da transação possa ser confiavelmente estimado.

O item 20 do CPC 30 estabelece as condições em que se considera que o desfecho da transação pode ser estimado de forma confiável:

"20. Quando o desfecho de transação que envolva a prestação de serviços puder ser confiavelmente estimado, a receita associada à transação deve ser reconhecida tomando por base a proporção dos serviços prestados até a data do balanço. $O$ desfecho de uma transação pode ser confiavelmente estimado quando todas as seguintes condições forem satisfeitas:

(a) o valor da receita puder ser confiavelmente mensurado;

(b) for provável que os benefícios econômicos associados à transação fluirão para a entidade;

(c) a proporção dos serviços executados até a data do balanço puder ser confiavelmente mensurada; $e$

(d) as despesas incorridas com a transação assim como as despesas para concluí-la possam ser confiavelmente mensuradas."

Quanto ao método da percentagem completada, deve-se reconhecer a receita proporcionalmente aos exercícios em que o serviço for prestado, fazendo com que o resultado seja diluído durante o prazo de execução do serviço:

“21. O reconhecimento da receita com referência à proporção dos serviços executados relativos a uma transação é usualmente denominado método da percentagem completada. 
Por esse método, a receita é reconhecida nos períodos contábeis em que os serviços forem prestados. $O$ reconhecimento da receita nessa base proporciona informação útil sobre a extensão da atividade e o desempenho dos serviços prestados durante o período. $O$ Pronunciamento Técnico CPC 17 - Contratos de Construção também exige o reconhecimento da receita nessa mesma base. As exigências naquele Pronunciamento são geralmente aplicáveis ao reconhecimento da receita e aos gastos associados a uma transação que envolva a prestação de serviços."

É interessante notar que o método da percentagem completada também é aplicável às operações objeto do Pronunciamento Técnico CPC 17 - Contratos de Construção. Dessa forma, as exigências do CPC 17 são geralmente aplicáveis ao reconhecimento da receita e aos gastos associados a uma transação que envolva a prestação de serviços. Entretanto, os serviços de construção receberam um Pronunciamento específico para tratar de suas peculiaridades, em razão do longo prazo de duração do negócio, ou seja, o início e o término do contrato caem, geralmente, em exercícios contábeis distintos (conforme se verá adiante).

\subsubsection{1 - Segurança de Recebimento dos Benefícios Econômicos}

Também para a prestação de serviços é importante que exista segurança de recebimento dos benefícios econômicos dela decorrentes. Neste sentido, o CPC 30 traz algumas condições de segurança para o reconhecimento:

“22. A receita somente é reconhecida quando for provável que os benefícios econômicos associados à transação fluirão para a entidade. Porém, quando surja uma incerteza acerca da realização de valor já incluído na receita, o valor incobrável, ou o valor com respeito ao qual a recuperação tenha deixado de ser provável, é reconhecido como despesa, e não como ajuste (dedução) do valor da receita originalmente reconhecida.

23. A entidade geralmente é capaz de fazer estimativas confiáveis após ter concordado com os outros parceiros da transação a respeito do seguinte:

(a) os direitos que cada uma das partes está habilitada a receber quanto ao serviço a ser prestado e recebido pelas partes;

(b) a contraprestação a ser trocada; $e$

(c) o modo e os termos da liquidação da operação.

É também importante que a entidade tenha um sistema interno eficaz de orçamento e de relatórios financeiros. Tomando ambos por base, a entidade poderá revisar e, quando necessário, alterar as estimativas de receita à medida que os serviços estão sendo executados. A necessidade de tais revisões não é indício de que o término da transação não possa ser estimado confiavelmente." 
Com efeito, verifica-se que a segurança quanto ao recebimento dos benefícios econômicos, no caso da prestação de serviços, decorre basicamente dos termos contratuais que suportam a transação, nos quais devem estar definidos os direitos e obrigações de todas as partes. Ademais, a entidade irá acompanhar o desempenho do serviço prestado por meio de um sistema interno de orçamento e relatórios financeiros (por meio do qual poderão ser revistas as estimativas de receita).

\subsubsection{2 - Determinação da Percentagem Completada}

Quanto à apuração da percentagem completada do serviço, são diversos os métodos para a sua determinação. O CPC 30 indica três formas possíveis, cuja aplicação depende da natureza da transação: (i) a medição do trabalho executado, (ii) percentual executado do total dos serviços a serem prestados e (iii) proporção do custo incorrido em relação ao custo total estimado. Confira-se:

“24. A fase de conclusão da transação pode ser determinada por diversos métodos. A entidade deve escolher um que mensure confiavelmente os serviços executados. Dependendo da natureza da transação, os métodos podem incluir:

(a) levantamento ou medição do trabalho executado;

(b) serviços executados até a data, indicados como um percentual do total dos serviços a serem executados; ou

(c) a proporção entre os custos incorridos até a data e os custos totais estimados da transação. Somente os custos que efetivamente possam ser identificados relativamente aos serviços executados devem ser incluídos nos custos incorridos até a data de mensuração. Da mesma forma, somente os custos que reflitam serviços executados ou a serem executados devem ser incluídos nos custos totais estimados da transação.

Para efeitos de reconhecimento das receitas de prestação de serviços, os pagamentos parcelados e os adiantamentos recebidos de clientes não correspondem, necessariamente, aos serviços executados.”

O CPC 30 também trata dos casos em que há dificuldade na determinação da percentagem completada. A primeira hipótese é aquela em que o serviço possui um número indeterminado de etapas, mas período específico de tempo (reconhecimento linear):

“25. Para fins práticos, quando os serviços prestados correspondam a um número indeterminado de etapas, durante um período específico de tempo, a receita deve ser reconhecida linearmente durante tal período, a menos que haja evidências de que outro método represente melhor a fase da execução do serviço. Quando uma determinada etapa 
for muito mais significativa do que quaisquer outras, o reconhecimento da receita deve ser adiado até que essa etapa seja executada."

Também são mencionados os serviços em que a conclusão não pode ser confiavelmente estimada, mas é provável que a entidade recupere os custos incorridos. Neste caso, reconhece-se a receita estritamente na proporção dos gastos recuperáveis (sem reconhecimento de lucro):

"26. Quando a conclusão da transação que envolva a prestação de serviços não puder ser estimada confiavelmente, a receita somente deve ser reconhecida na proporção dos gastos recuperáveis.

27. Durante as primeiras fases da transação, é frequente ocorrer que a conclusão da transação não possa ser confiavelmente estimada. Contudo, pode ser provável que a entidade recupere os custos incorridos até aquela data. Dessa forma, a receita deve ser reconhecida somente na medida em que haja indícios consistentes de recuperação dos custos incorridos. Quando a conclusão da transação não puder ser confiavelmente estimada, não deve ser reconhecido qualquer lucro."

Por fim, cite-se a hipótese em que a conclusão do serviço não pode ser confiavelmente estimada e não é provável que a entidade recupere os custos incorridos. Neste caso, não se reconhece a receita e os custos incorridos são reconhecidos como despesa:

28. Quando a conclusão da transação não puder ser confiavelmente estimada e não for provável que os custos incorridos sejam recuperados, a receita não deve ser reconhecida e os custos incorridos devem ser reconhecidos como despesa. Quando deixarem de existir tais incertezas, a receita deve ser reconhecida de acordo com o item 20 e não de acordo com o item 26."

Ante o exposto, verifica-se que as regras de reconhecimento de receita da prestação de serviço, de modo geral, determinam a apropriação proporcional à execução do serviço, determinada pelos métodos acima expostos. Essa regra encontra-se em conformidade com os preceitos de Direito Civil, no sentido de que o direito ao recebimento referente a um contrato somente se torna exigível após o cumprimento da obrigação correspondente.

\subsection{2 - Regra Geral de Contabilização dos Contratos de Construção (CPC 17)}

Especificamente em relação aos contratos de Construção por Empreitada (ou Preço Fixo) e Construção por Administração (ou Custo mais Margem), a regra geral de 
reconhecimento das receitas e dos custos deve estar em conformidade com o tratamento dispensado pelo Pronunciamento Técnico CPC 17 - Contratos de Construção. ${ }^{2}$

O objetivo deste Pronunciamento é o de prescrever o tratamento contábil das receitas e despesas decorrentes da prestação de serviços de construção de quaisquer bens, como navios, aeronaves, ou construção civil.

Conforme mencionado, esse tipo de serviço possui um Pronunciamento específico para tratar das características peculiares que o envolvem, em especial o fato de que as datas de início e término do contrato caem, em geral, em exercícios contábeis distintos (ou seja, a duração da execução do contrato perdura por mais de um período contábil). Por isso, é fundamental que se determinem, com clareza, as regras referentes ao reconhecimento das receitas e despesas durante os períodos de execução da obra.

Neste sentido, o CPC 17 estabelece os critérios para que se possa estimar a conclusão de um contrato de empreitada (preço fixo):

“25. No caso de um contrato de preço fixo, a conclusão da construção pode ser confiavelmente estimada quando estiverem satisfeitas todas as condições seguintes:

(a) a receita do contrato pode ser mensurada confiavelmente;

(b) é provável que os benefícios econômicos associados ao contrato fluirão para a empresa;

(c) as despesas para concluir o contrato, tanto quanto a proporção executada até a data do balanço podem ser confiavelmente mensuradas; $e$

(d) as custos atribuíveis ao contrato podem ser claramente identificadas e confiavelmente mensuradas de forma que as despesas efetivamente incorridas possam ser comparadas com estimativas anteriores.”

Estabelece também o CPC 17 os critérios para que se possa estimar a conclusão de um contrato de administração (cost plus):

“26. Para os contratos na modalidade «cost plus», sua conclusão poderá ser confiavelmente mensurada quando estiverem satisfeitas todas as condições seguintes:

\footnotetext{
2 “5. São usados neste Pronunciamento alguns termos cujos significados encontram-se especificados a seguir: Contrato de construção é um contrato especificamente negociado para a construção de um ativo ou de uma combinação de ativos que sejam interrelacionados ou interdependentes em função da sua concepção, tecnologia e função ou do seu propósito ou uso final.

Contrato de preço fixado é um contrato de construção em que o contratante concorda com um preço pré-fixado ou com uma taxa pré-fixada, por unidade concluída que, em alguns casos, está sujeito às cláusulas de custos escalonados.

Contrato de custo mais margem (cost plus) é um contrato de construção em que o contratado é reembolsado por custos projetados e aprovados pelas partes - ou de outra forma definidos - acrescido de um percentual sobre tais custos ou por uma remuneração pré-fixada.” (g.n.)
} 
(a) seja provável que os benefícios econômicos associados ao contrato fluirão para a entidade; $e$

(b) as despesas atribuiveis ao contrato, sejam ou não reembolsáveis, possam ser claramente identificadas e confiavelmente mensuradas."

Para os contratos de construção, uma vez sendo possível estimar a conclusão da obra, de acordo com critério acima apontados, determina o CPC 17 que a receita e as despesas devem ser reconhecidas pelo percentual de conclusão:

"24. Quando a conclusão de um contrato de construção puder ser confiavelmente estimada, a receita e as despesas associadas ao contrato de construção devem ser reconhecidas tomando como base a proporção do trabalho executado até a data do balanço. Uma perda esperada no contrato de construção deve ser reconhecida imediatamente como uma despesa de acordo com o item 36.

(...)

27. O reconhecimento da receita e das despesas referentes à fase de conclusão de um contrato é muitas vezes referido como o método da percentagem completada. Segundo esse método, a receita contratual é proporcional aos custos contratuais incorridos em cada etapa de medição. Esse método proporciona informação útil sobre a extensão da atividade $e$ desempenho do contratado durante a execução do contrato.

28. Pelo método da percentagem completada, a receita do contrato é reconhecida na Demonstração do Resultado nos períodos contábeis em que o trabalho for executado, o mesmo ocorrendo com os custos do trabalho com os quais se relaciona. Porém, qualquer excedente dos custos totais esperados sobre as receitas totais do contrato deverá ser reconhecido imediatamente como uma despesa (perda) de acordo com o item 36.

29. Um contratado pode ter incorrido em custos que se relacionem com uma atividade a ser executada futuramente. Tais custos são reconhecidos no ativo, desde que seja provável que venham a ser recuperados. Eles representam uma quantia devida pelo contratante e muitas vezes são classificados como trabalho em andamento.

(...)

36. Os custos do contrato que provavelmente não venham a ser recuperados são reconhecidos imediatamente como uma despesa. Servem como exemplo de tais casos contratos:

(a) que não podem ser forçados a serem completados, isto é, sua validade está seriamente em dúvida;

(b) cuja conclusão esteja sujeita ao desfecho de litígio ou de legislação pendente;

(c) relacionados com propriedades que tenham a possibilidade de ser condenadas ou expropriadas ; 
(d) em que o contratante não esteja em condições financeiras de cumprir com as suas obrigações;

(e) em que o contratado é incapaz de completar o contrato ou de cumprir com as suas obrigações segundo o contrato."

Registre-se que o percentual de acabamento da obra pode ser determinado de três formas: (i) proporção dos custos incorridos em relação aos custos totais estimados, (ii) medição do trabalho executado ou (iii) execução de proporção física da obra. Confira-se:

“32. A fase de acabamento de um contrato pode ser determinada de várias maneiras. A entidade usa o método que mensura de forma mais confiável o trabalho executado. Dependendo da natureza do contrato, os métodos podem incluir:

(a) a proporção dos custos incorridos até a data, em contraposição aos custos estimados totais do contrato;

(b) medição do trabalho executado; $e$

(c) execução de uma proporção física do trabalho contratado.

Os pagamentos progressivos e os adiantamentos recebidos dos clientes não refletem, necessariamente, o trabalho executado e não devem servir de parâmetro para mensuração da receita.

33. Quando a fase de acabamento tenha por base os custos do contrato incorridos até a data, somente os custos do contrato que reflitam o trabalho executado serão considerados até à data. São exemplos de custos de contrato que não devem ser considerados como incorridos:

(a) custos que se relacionem com as atividades futuras do contrato, tais como: materiais que tenham sido entregues no local da obra ou reservados para posterior utilização, mas que não foram instalados, usados ou aplicados durante a execução do contrato, a menos que tais materiais tenham sido produzidos especificamente para o contrato; $e$

(b) pagamentos adiantados a sub-contratados por trabalho a ser executado segundo um subcontrato."

O CPC 17 traz alguns exemplos ilustrativos aplicáveis ao reconhecimento do resultado dos contratos de construção. Com efeito: (i) nos contratos de construção por empreitada (preço fixo), as receitas são geralmente reconhecidas pelo método de percentual de execução (ou seja, mede-se a receita a partir do percentual de horas de trabalho incorridas, em relação às horas totais estimadas); e (ii) nos contratos por administração (cost plus) as receitas são geralmente reconhecidas com base nos custos recuperáveis incorridos no período, acrescidos da taxa de administração (os custos incorridos proporcionalizados em relação aos 
totais estimados).

Para o registro da receita, também é necessária a certeza quanto ao recebimento dos benefícios econômicos do contrato, o qual está relacionado com os termos contratuais que estabeleçam com clareza as obrigações das partes:

“30. O término de um contrato de construção só pode ser confiavelmente estimado quando for provável que os benefícios econômicos a ele associados fluirão para a entidade. Porém, quando surge uma incerteza acerca da realização de uma quantia já reconhecida como receita do contrato na Demonstração do Resultado, o montante não realizável é reconhecido como uma despesa e não como um ajuste às receitas do contrato.

31. Uma entidade está geralmente em condições de fazer estimativas confiáveis após aceitar um contrato que estabeleça:

(a) os direitos e deveres de cada uma das partes, no que diz respeito ao ativo a ser construído;

(b) a remuneração a ser paga; $e$

(c) a forma e os termos de liquidação.

Para tanto, usualmente é necessário que a entidade possua registros financeiros $e$ contábeis confiáveis e um sistema orçamentário eficaz. A entidade revê, e quando necessário revisa, as estimativas das receitas e custos do contrato, na medida em que o trabalho progride. Isso não significa que a conclusão do contrato não possa ser estimada confiavelmente."

Nos casos em que o encerramento do contrato não puder ser estimado com segurança, passa a ser relevante a recuperabilidade dos custos incorridos (para que se reconheçam as receitas apenas na medida em que os custos sejam recuperáveis:

“34. Quando o encerramento de um contrato de construção não puder ser confiavelmente estimado:

(a) a receita será reconhecida até o ponto em que seja provável que os custos incorridos do contrato serão recuperados; $e$

(b) os custos do contrato devem ser reconhecidos como uma despesa no periodo em que forem incorridos;

(c) Uma perda esperada num contrato de construção deve ser reconhecida imediatamente como um gasto de acordo com o item 36.

35. Durante as fases iniciais de um contrato dá-se muitas vezes o caso da impossibilidade de projetar confiavelmente a data de seu encerramento. Não obstante, pode ser provável que a entidade recupere os custos incorridos do contrato. Em tais circunstâncias, a receita do contrato somente é reconhecida no montante dos custos incorridos que se espera sejam recuperados. Uma vez que o encerramento do contrato não pode ser confiavelmente 
projetado, nenhum lucro é reconhecido. Porém, mesmo quando o encerramento do contrato não pode ser confiavelmente estimado, é possível que os custos totais excedam as receitas totais do contrato. Em tais casos, o montante que ultrapassar as receitas será reconhecido imediatamente como uma despesa de acordo com o item 36.

Assim, quando deixarem de existir as incertezas quanto ao contrato, o reconhecimento das receitas e despesas deve ser feito pelo percentual de conclusão da obra:

“37. Quando já não existirem as incertezas que impediam que o contrato fosse confiavelmente estimado, a receita e as despesas associadas ao contrato de construção devem ser reconhecidas de acordo com o item 22 [leia-se 24] e não de acordo com o item 32 [leia-se 34]."

Ainda, em conformidade com o princípio do conservadorismo, quando se verificar que o custo total do contrato irá superar o valor das receitas, essa perda deve ser reconhecida imediatamente como despesa. Confira-se:

\section{“Reconhecimento de Perdas Esperadas}

38. Quando for provável que os custos totais do contrato excedam à receita total do contrato, a perda esperada deve ser reconhecida imediatamente como uma despesa.

39. A quantia de tal perda é determinada independentemente:

(a) de haver ou não sido iniciado o trabalho relativo ao contrato;

(b) da fase de acabamento da atividade do contrato; ou

(c) da quantia de lucros que se espere que surjam noutros contratos que não são tratados como um contrato de construção único de acordo com o item 9."

É possível também que ocorram alterações nas estimativas utilizadas para determinação do percentual de conclusão da obra, as quais serão registradas na Demonstração de Resultado do período em que é verificada essa alteração de estimativa e nas demonstrações seguintes:

\section{“Alterações nas Estimativas}

40. O método da percentagem completada é aplicado cumulativamente a cada período contábil às estimativas de receitas e custos do contrato. Por isso, os efeitos de uma alteração na estimativa da receita e dos custos do contrato, ou os efeitos de uma alteração na estimativa da conclusão de um contrato, são contabilizados como uma alteração na estimativa contábil (ver Pronunciamento Técnico CPC 23 - Políticas Contábeis, Mudanças de Estimativas Contábeis e Erros). As alterações das estimativas são usadas na determinação do montante de receitas e despesas reconhecidas na Demonstração do Resultado no período em que a alteração seja feita e em períodos subseqüentes." 
É bastante elucidativo o exemplo trazido pelo CPC 17 acerca da determinação do estágio de execução de um contrato e o momento de reconhecimento de receitas e despesas:

“A Construtora XYZ assinou um contrato na modalidade preço fixo para edificar uma ponte por \$ 9 milhões. Quando da assinatura, a construtora estimava os custos totais em $\$ 8$ milhões. O prazo de construção foi fixado em três anos.

Ao final do primeiro ano da construção, os custos foram revistos e passaram para \$ 8,050 milhões.

Durante o segundo ano o contratante aprovou alterações que resultaram em um acréscimo de $\$ 200$ mil na receita e $\$ 150$ mil nos custos.

Ao final do segundo ano, os custos incorridos pela construtora incluíam \$100 mil relativos a materiais adquiridos e estocados, para serem utilizados no terceiro ano, próximo à conclusão da obra.

A Construtora XYZ determina o estágio de execução das obras calculando a proporção dos custos incorridos relacionados aos trabalhos executados até a data da mensuração, contrapondo-os às últimas estimativas de custos totais para executar a obra.

O resumo das informações financeiras durante o período de construção da obra é o seguinte:

\begin{tabular}{|l|r|r|r|}
\cline { 2 - 4 } \multicolumn{1}{c|}{} & \multicolumn{1}{c|}{ Ano 1 } & Ano 2 & \multicolumn{1}{c|}{ Ano 3 } \\
\hline Receita Inicialmente Projetada (a) & 9.000 & 9.000 & 9.000 \\
\hline Variação (b) & 0 & 200 & 200 \\
\hline Receita total (c) = (a) + (b) & 9.000 & 9.200 & 9.200 \\
\hline Custos Incorridos (d) & 2.093 & 6.068 & 8.200 \\
\hline Custos a Incorrer (e) = (d) - (f) & 5.957 & 2.132 & 0 \\
\hline Custos Totais Estimados (f) & 8.050 & 8.200 & 8.200 \\
\hline Resultado Estimado (g) =(c) - (f) & 950 & 1.000 & 1.000 \\
\hline$\%$ de Execução $(\mathrm{h})=(\mathrm{d}) /(\mathrm{f})$ & $26,00 \%$ & $74,00 \%$ & $100,00 \%$ \\
\hline
\end{tabular}

O estágio de execução relativo ao $2^{\circ}$ ano $(74 \%)$ é obtido após eliminar os custos incorridos no $1^{o}$ ano e os \$100 mil relativos aos materiais estocados que somente serão utilizados no $3^{\circ}$ ano.

Os montantes de receitas, despesas e resultado reconhecidos nas demonstrações contábeis ao longo dos três anos são os seguintes:

\begin{tabular}{|c|c|c|c|}
\hline & Até a Data & $\begin{array}{c}\text { Reconhecido } \\
\text { em Anos } \\
\text { Anteriores } \\
\end{array}$ & $\begin{array}{c}\text { Reconhecido } \\
\text { no Ano }\end{array}$ \\
\hline Ano 1 & (a) & (b) & (a) - (b) \\
\hline Receita $(9.000 \times 26 \%)$ & 2.340 & 0 & 2.340 \\
\hline Despesas $(8.050 \times 26 \%)$ & 2.093 & 0 & 2.093 \\
\hline Resultado & 247 & 0 & 247 \\
\hline Ano 2 & (a) & $\nabla(\mathrm{b})$ & (a) - (b) \\
\hline $\operatorname{Receita}(9.200 \times 74 \%)$ & 6.808 & 2.340 & 4.468 \\
\hline Despesas $(8.200 \times 74 \%)$ & 6.068 & 2.093 & 3.975 \\
\hline Resultado & 740 & 247 & 493 \\
\hline Ano 3 & (a) & $\nabla(b)$ & (a) - (b) \\
\hline Receita $(9.200 \times 100 \%)$ & 9.200 & 6.808 & 2.392 \\
\hline Despesas & 8.200 & 6.068 & 2.132 \\
\hline Resultado & 1.000 & 740 & 260 \\
\hline
\end{tabular}


Com base nas considerações feitas, verifica-se que o contrato de construção é contabilizado como uma prestação de serviço, sendo as receitas e despesas reconhecidas pelo critério de conclusão da obra.

Contudo, conforme já mencionado (Capítulo 3.3.2), diferentemente da prestação de serviço, a empreitada compreende uma obrigação de fazer (realização de uma obra), mas também uma obrigação de dar (entrega da obra depois de concluída), embora a obrigação de dar seja apenas uma consequência da obrigação de fazer.

Dessa forma, tendo em vista a distinção entre o contrato de empreitada e o contrato de prestação de serviço, verifica-se que, em alguns casos, a empreitada pode ser contabilizada como se fosse uma venda de bens, em razão da ênfase dada à obrigação de dar. Essa polêmica permeia os contratos de construção no setor imobiliáirio, conforme se passa a demonstrar.

\subsection{3 - Contabilização do Contrato de Construção no Setor Imobiliário (ICPC 02)}

Para o reconhecimento da receita nos contratos de construção do setor imobiliário, discute-se a aplicabilidade do Pronunciamento CPC 17 - Contratos de Construção (reconhecimento da receita de acordo com a evolução da obra), ou do Pronunciamento CPC 30 - Receitas (que pode se dar de duas formas: reconhecimento da receita de acordo com a evolução da obra ou apenas quando da entrega final do imóvel construído).

No bojo dessa discussão, foi aprovada a Interpretação Técnica ICPC 02 Contratos de Construção do Setor Imobiliário, para apresentar os critérios para a aplicação do CPC 17 ou do CPC 30, considerando as características contratuais específicas em cada caso.

Ressalte-se, contudo, que a referida Interpretação Técnica não foi suficiente para esclarecer a aplicabilidade do CPC 17 ou do CPC 30 para a atividade de Incorporação Imobiliária no Brasil, o que culminou com a aprovação da Orientação OCPC 04 - Aplicação da Interpretação Técnica ICPC 02 às Entidades de Incorporação Imobiliária Brasileiras, que será objeto de análise no próximo capítulo.

Com efeito, passa-se a expor os aspectos gerais do reconhecimento e mensuração das receitas no setor de construção imobiliária, que devem pautar a interpretação e juízo de valor em cada caso concreto. 
Inicialmente, é importante transcrever o contexto em que se insere a ICPC 02:

“1. No setor imobiliário, as entidades que realizam a incorporação elou a construção de imóveis, diretamente ou por meio de subempreiteiras, podem firmar contratos com um ou mais compradores antes do término da construção. Esses contratos podem assumir diversas formas.

2. As entidades que incorporam elou constroem imóveis residenciais, por exemplo, podem começar a comercialização de unidades imobiliárias (apartamentos ou casas) "na planta", ou seja, enquanto a construção ainda estiver em andamento, ou até mesmo antes de seu início. Cada comprador firma um contrato com a entidade para adquirir uma unidade imobiliária quando a mesma estiver pronta para ser ocupada. Normalmente, o comprador efetua um adiantamento que será reembolsado apenas se a entidade deixar de entregar a unidade imobiliária concluída de acordo com os termos contratados. O restante do preço de compra é geralmente pago à entidade apenas ao término do contrato, quando o comprador obtém a posse da unidade.

3. As entidades que constroem imóveis comerciais ou industriais geralmente firmam um contrato com um único comprador. Podem ser exigidos do comprador pagamentos de parcelas entre a época do início e do fim do contrato. A construção pode ocorrer em terreno que o comprador possuía antes do início da construção."

Assim sendo, ganha relevância a discussão acerca da aplicação do CPC 17 ou do CPC 30 aos contratos de construção de imóveis, o que irá depender das características específicas do contrato analisado e dos fatos e circunstâncias relacionados.

Neste sentido, determina a ICPC 02 que o contrato será qualificado como sendo de construção quando houver a possibilidade de o contratante especificar elementos estruturais do projeto (1). Confira-se:

“11. O Pronunciamento Técnico CPC 17 - Contratos de Construção é aplicável quando o contrato se enquadra na definição de contrato de construção exposta no item 5 do Pronunciamento Técnico CPC 17 - Contratos de Construção: 'um contrato especificamente negociado para a construção de um ativo ou de uma combinação de ativos ...' Um contrato de construção de imóvel enquadra-se na definição de contrato de construção quando o comprador é capaz de especificar os principais elementos estruturais do projeto do imóvel antes de começar a construção elou especificar mudanças estruturais significativas após o início da construção (quer, ou não, o comprador exerça essa possibilidade). Quando se aplicar o Pronunciamento Técnico CPC 17 - Contratos de Construção, o contrato de construção também deve incluir todos os contratos ou componentes para a prestação de serviços diretamente relacionados com a construção do imóvel, de acordo com o item 7(a) do Pronunciamento Técnico CPC 17 Contratos de Construção e o item 4 do Pronunciamento Técnico CPC 30 - Receitas.” 
Por outro lado, quando não se tratar de um contrato de construção, estabelece a ICPC 02 que haverá 3 possibilidades de qualificação do contrato em conformidade com o CPC 30: (2.1) como prestação de serviços; (2.2) como venda de bens com transferência gradual dos riscos e benefícios; e (2.3) como venda de bens com a transferência dos riscos e benefícios apenas com a entrega final do bem. Confira-se:

“12. Ao contrário, um contrato de construção de imóvel, mediante o qual os compradores têm apenas uma possibilidade limitada de influenciar no projeto do imóvel, como, por exemplo, a possibilidade de selecionar um projeto entre um leque de opções

2 especificadas pela entidade ou especificar apenas pequenas variações do projeto básico, é um contrato de venda de bens, de acordo com o alcance do Pronunciamento Técnico CPC 30 - Receitas. (...)

\section{O contrato é um contrato de prestação de serviços}

15. Se a entidade não for obrigada a comprar e fornecer materiais de construção, o contrato pode ser apenas um contrato de prestação de serviços de acordo com o Pronunciamento Técnico CPC 30 - Receitas. Nesse caso, se forem atendidos os critérios do item 20 do

\section{1} Pronunciamento Técnico CPC 30 - Receitas, essa norma exige que a receita seja reconhecida pelo percentual de evolução da obra. As exigências do Pronunciamento Técnico CPC 17 - Contratos de Construção aplicam-se, em geral, ao reconhecimento da receita e dos correspondentes custos e despesas (item 21 do Pronunciamento Técnico CPC 30 - Receitas).

\section{O contrato é um contrato de venda de bens}

16. Se a entidade for requerida a prestar serviços, em conjunto com o fornecimento de materiais de construção, para cumprir sua obrigação contratual, a fim de entregar o imóvel ao comprador, como aqueles aplicáveis aos contratos de venda decorrentes da incorporação de unidades imobiliárias, o contrato é um contrato de venda de bens, devendo ser aplicados os critérios de reconhecimento de receita descritos no item 14 do Pronunciamento Técnico CPC 30 - Receitas.

17. A entidade pode transferir ao comprador o controle, os riscos e os benefícios da propriedade do imóvel em construção em seu estágio atual de acordo com a evolução da obra. Nesse caso, se todos os critérios do item 14 do Pronunciamento Técnico CPC 30 Receitas forem continuamente atendidos à medida que a construção avança, a entidade deve reconhecer a receita pelo percentual de evolução da obra. As exigências do Pronunciamento Técnico CPC 17 - Contratos de Construção aplicam-se, em geral, ao reconhecimento da receita e dos correspondentes custos e despesas. 
18. Quando a entidade transferir ao comprador o controle, os riscos e os benefícios da propriedade do imóvel, em sua totalidade, de uma única vez, a entidade somente deve 2.3 reconhecer a receita quando todos os critérios do item 14 do Pronunciamento Técnico CPC 30 - Receitas forem satisfeitos.”

As hipóteses acima destacadas refletem a discussão inerente à natureza dos contratos de empreitada (construção). Como visto (Capítulo 3.3.2), o contrato de empreitada é um contrato autônomo, que não se confunde nem com o contrato de prestação de serviço (que contempla uma obrigação de fazer) nem com o contrato de compra e venda (que contempla uma obrigação de dar).

$\mathrm{Na}$ verdade, o contrato de empreitada contempla duas obrigações distintas, uma obrigação de fazer (realizar a obra) e uma obrigação de dar (entregar a obra depois de pronta), sendo que a obrigação de dar é mera consequência da obrigação de fazer. O contrato de incorporação imobiliária possui a mesma natureza e está sujeito aos mesmos questionamentos (Capítulo 3.3.3). 
As diretrizes apontadas pela ICPC 02 para a contabilização das receitas de construção de imóveis foram sintetizadas em um fluxograma, a seguir reproduzido:

\section{$\checkmark$ Fluxograma de Análise de Contrato de Construção de Imóveis}

(segregação dos componentes do contrato para isolar a atividade de construção)

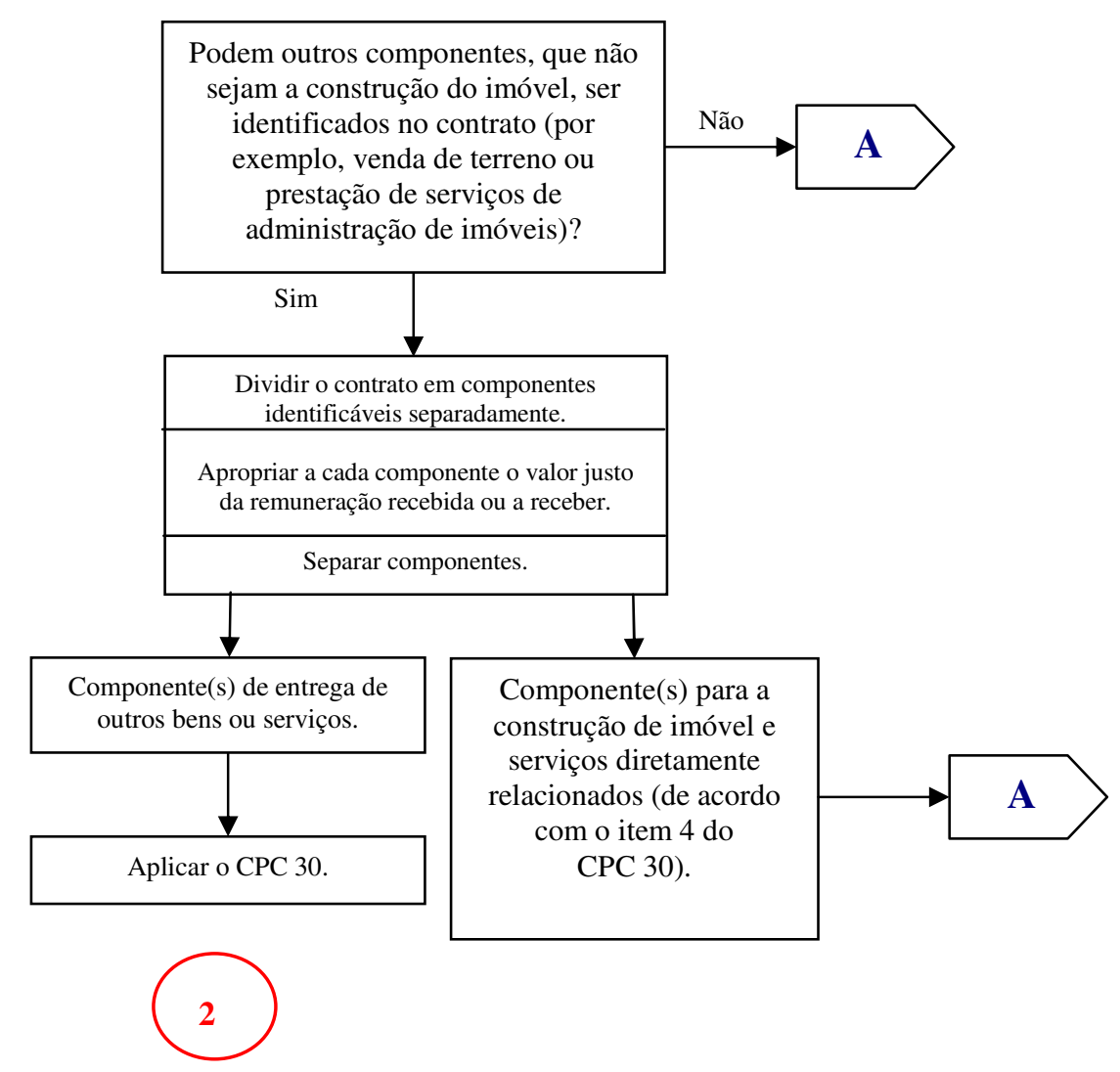




\section{Fluxograma de Análise de Contrato de Construção de Imóveis}

(identificação da natureza do contrato de construção)

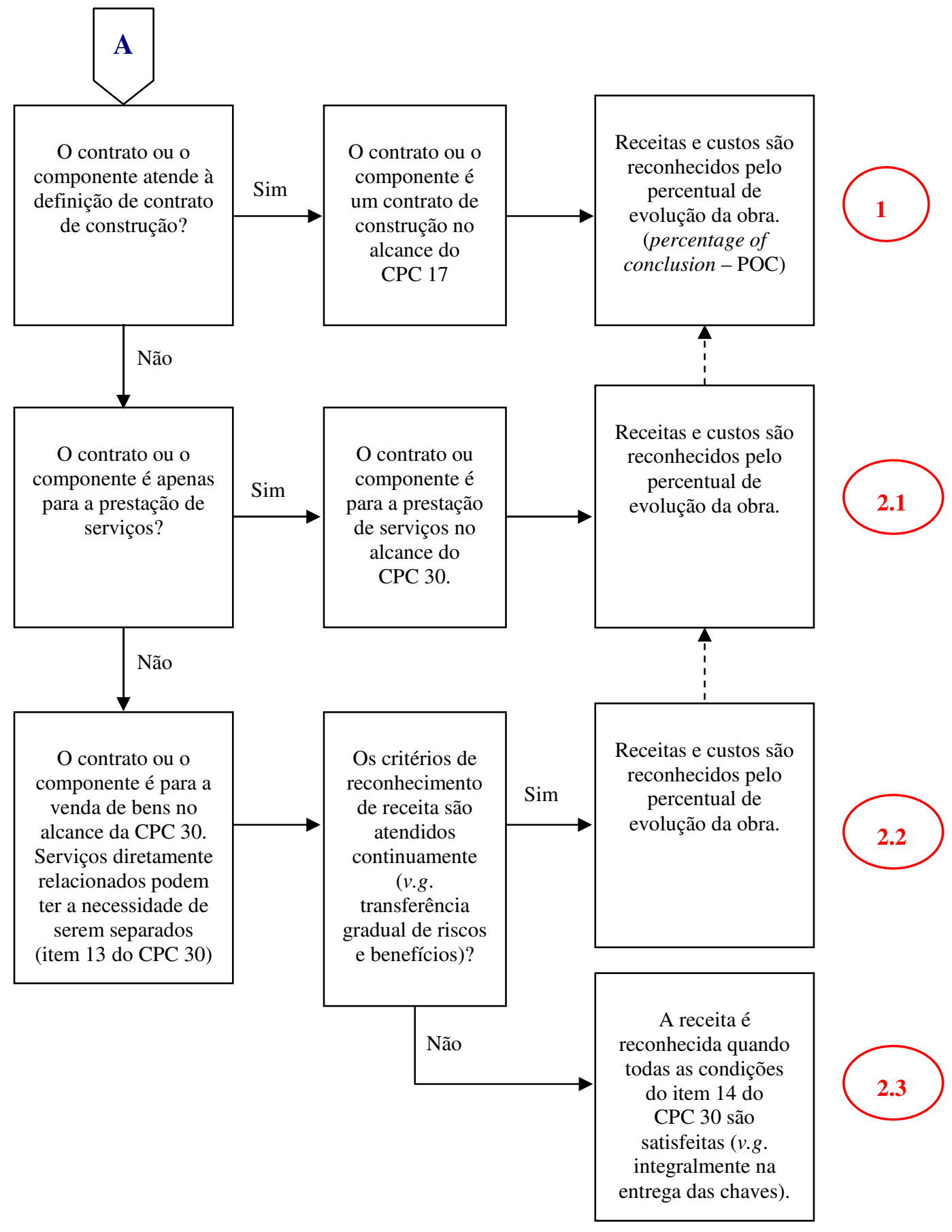

Ante o exposto, fica clara a razão para a existência da controvérsia contábil: pretende-se qualificar a natureza de um contrato (empreitada) com base em conceitos que não contemplam sua natureza (prestação de serviços ou venda de bens). 
Conforme já destacado, há duas modalidades de empreitada: (i) a empreitada de lavor, em que o empreiteiro apenas emprega sua força de trabalho na realização da obra (assemelha-se ao contrato de prestação de serviço), e (ii) empreitada de trabalho e materiais, em que o empreiteiro também fornece os materiais necessários à realização da obra.

Esta última hipótese é que gera a controvérsia contábil, pois quando o empreiteiro fornece os materiais, ele retém parcela substancial dos riscos da obra a ser realizada. Ocorre que, nos contratos de empreitada de edifícios, o empreiteiro de trabalho e materiais permanece responsável durante o prazo de cinco anos, pela solidez e segurança do trabalho. ${ }^{3}$

Destarte, os riscos do empreiteiro no contrato de construção imobiliária com fornecimento de materiais não estão relacionados à entrega do imóvel ou não, mas decorre da própria natureza jurídica do contrato e permanece mesmo após a entrega da obra. Com efeito, a hipótese prevista no item 2.3 do fluxograma acima descrito somente será aplicável quando não se tratar de contrato de empreitada (construção), mas de compra e venda de coisa futura.

\subsection{4 - Contabilização do Contrato de Incorporação Imobiliária (OCPC 04)}

Conforme mencionado, a Orientação OCPC 04 - Aplicação da Interpretação Técnica ICPC 02 às Entidades de Incorporação Imobiliária Brasileiras teve como objetivo servir de subsídio para a análise de contratos de incorporação imobiliária no Brasil e seu enquadramento nas regras previstas no CPC 17 ou no CPC 30.

Esta Orientação é complementar à aplicação da Interpretação Técnica ICPC 02, uma vez que serve de subsídio para sua aplicação no ambiente econômico e jurídico brasileiro. Portanto, sua aplicação não abrange as atividades exercidas fora do contexto brasileiro ou que, mesmo que exercidas no Brasil, tenham, por disposições legais, contratuais ou outras, condições diferentes das que foram nela reproduzidas.

\footnotetext{
${ }^{3}$ CC/02: “Art. 618. Nos contratos de empreitada de edifícios ou outras construções consideráveis, o empreiteiro de materiais e execução responderá, durante o prazo irredutível de cinco anos, pela solidez e segurança do trabalho, assim em razão dos materiais, como do solo."
} 
Apenas para fins didáticos, reproduz-se abaixo o gráfico que contempla as principais etapas do ciclo econômico da incorporação imobiliária (conforme já exposto no Capítulo 3.3.3.2):
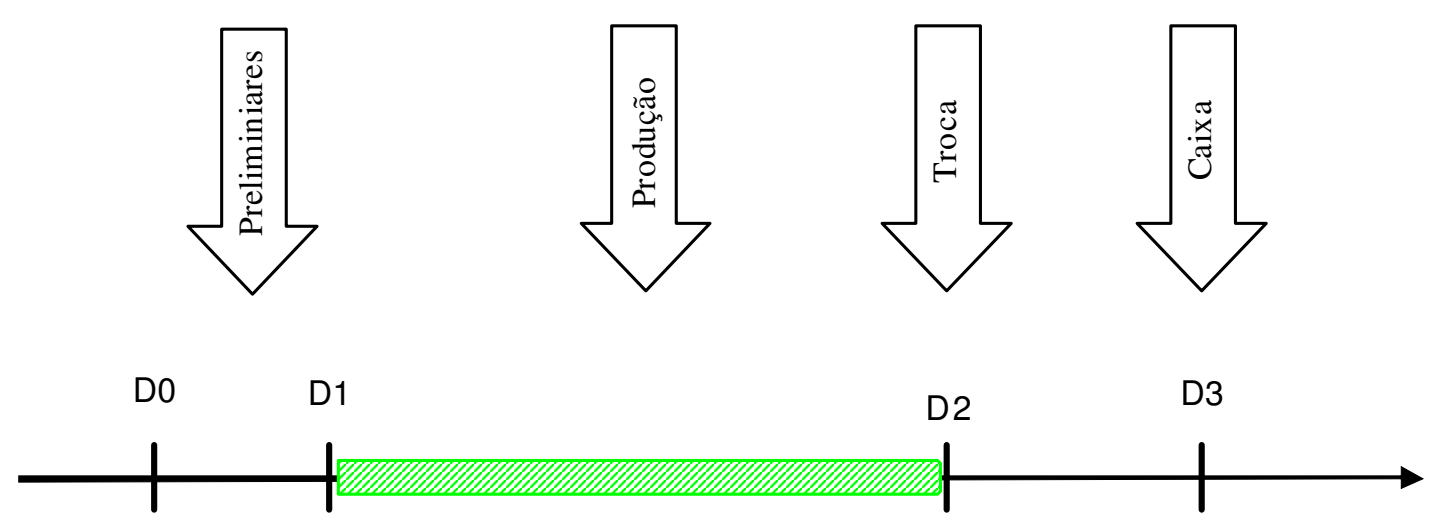

Atividades preliminares: (i) pesquisa e aquisição do terreno onde será erguido o edifício; (ii) el aboração de projeto de construção devidamente aprovado perante órgãos públicos; (iii) elaboração de memorial descritivo da obra; (iii) avaliação do custo total da obra; (iv) preparação da minuta da futura convenção de condomínio; dentre outras atividades.

Produção das Unidades Imobiliárias - há duas obrigações assumidas pelo incorporador: (i) uma obrigação de entregar o produto da construção aos adquirentes e (ii) uma obrigação de fazer, consistente em garantir que a obra seja construída e entregue nos termos contratados.

Troca - após a concessão do habite-se e averbação da construção, com a respectiva individuali zação das unidades autônomas, entregam-se as chaves como ato de transferência da posse. A propriedade é transferida com o registro na matrícula das unidades desmembradas.

Ingresso no Caixa - parte das receitas de vendas das unidades imobiliárias são recebidas já no início da construção, bem como durante a execução do empreendimento, como forma de financiamento de parte da obra pelos adquirentes (divisão dos riscos com os adquirentes).

Com efeito, considerando-se as variantes concretas existentes "caso a caso", o lucro para fins societários da atividade de incorporação imobiliária no Brasil (apurado pelo regime de competência) poderá ser reconhecido de duas formas: 
(i) durante a evolução da obra (quadro verde - período entre D1 e D2), o que pode se dar nos termos do CPC 17 (contrato de construção) ou do CPC 30 (como prestação de serviço ou como venda de bens com transferência gradual dos riscos e benefícios);

(ii) no ponto de troca, o que se costuma denominar no Brasil como a entrega das chaves (momento D2), nos termos do CPC 30 para venda de bens em que a transferência de riscos e benefícios somente se opera com a entrega do bem - transferência da posse.

Nos contratos de construção imobiliária por administração (custo mais margem), em que a entidade é contratada apenas para a construção e gerenciamento da obra, não há dúvida acerca da aplicação do CPC 17 para fins de reconhecimento e mensuração do lucro (conforme a evolução da obra).

Contudo, geralmente há grande dificuldade nos casos de contrato de empreitada (preço fixo), em que o reconhecimento e a mensuração podem ocorrer (i) durante a evolução da obra (CPC 17 ou CPC 30 nas hipóteses de prestação de serviço ou de venda de bens com transferência gradual de riscos e benefícios), ou (ii) na entrega das chaves, em que não se trata de empreitada propriamente dita, mas compra e venda de coisa futura (CPC 30 para venda de bens com transferência de riscos e benefícios apenas no ponto de troca).

No Brasil, há diversos argumentos do ponto de vista econômico e jurídico (listados na Orientação OCPC 04 - transcrita no Apêndice do presente trabalho) indicando que deve haver a apuração do lucro conforme a evolução da obra.

Com efeito, todos os argumentos listados pela OCPC 04 são exemplos concretos analisados no contexto brasileiro, os quais permitem determinar que, em regra, as entidades de incorporação imobiliária devem registrar suas receitas de acordo com o CPC 17 (construção), uma vez que os riscos e benefícios significativos são continuamente transferidos ao adquirente da unidade imobiliária, durante o período de construção.

Estas conclusões estão em conformidade com o tratamento jurídico para o contrato de incorporação imobiliária objeto de análise no Capítulo 3.3.3, pois se trata de um negócio jurídico que envolve uma obrigação de dar (o bem imóvel) e uma obrigação de fazer (construção). Contudo, conforme destacado, a obrigação de dar é mera consequência da obrigação de fazer (o que enseja o tratamento equiparado à prestação de serviço).

Contudo, existem argumentos no sentido de que a incorporação imobiliária estaria 
sujeita ao reconhecimento de receitas nos termos do CPC 30 (especialmente o fato de que os adquirentes não têm o poder de especificar as características do bem construído).

Não obstante, mesmo que sujeito às regras de registro de receita previstas no CPC 30, a OCPC 04 apresenta os fundamentos para afirmar que as entidades de incorporação imobiliária devem reconhecer o resultado durante a evolução da obra, uma vez que os riscos e benefícios significativos são continuamente transferidos ao adquirente da unidade imobiliária.

\section{3 - Negócios JuRÍdicos de CeSSÃo dA PoSSE do IMóvEL}

\subsection{1 - Contabilização da Cessão Onerosa da Posse do Imóvel (Locação e Outros)}

Conforme destacado anteriormente (Capítulo 2.4.3.1.a), existem alguns contratos que têm como característica essencial o transcurso do tempo. Esse é o caso dos contratos de cessão da posse de imóveis (superfície, locação, "built to suit” e shopping center).

Tais contratos foram objeto de análise no Capítulo 3.4. Verificou-se que, nesses contratos, o proprietário do imóvel cede temporariamente a posse direta do imóvel para terceiros (locador ou superficiário), que irá remunerá-lo com base no prazo em que perdurar a cessão da posse.

Dessa forma, a receita decorrente do aluguel (ou direito de superfície) ${ }^{4}$ será reconhecida proporcionalmente ao transcurso dos meses em que o imóvel estiver na posse do locatário (ou superficiário). Com efeito, para os negócios de cessão da posse do imóvel, o fator determinante para a realização da receita é o transcurso do prazo contratual, proporcionalmente à fração do tempo total pactuado.

Ocorre que, muitas vezes, o contrato que dá suporte à cessão da posse direta do imóvel é estabelecido por longos períodos de duração e a remuneração pode não ser estipulada de forma fracionada no tempo. Mesmo nesses casos, como ensina Sérgio de Iudícibus, o registro deve ser feito com base mensal (ou período de avaliação contábil). Confira-se: ${ }^{5}$

\footnotetext{
"Tais lançamentos são feitos, normalmente, por meio de partidas de ajuste no final de cada mês ou período de avaliação contábil. Assim, a empresa que alugou um imóvel a terceios poderá fazer, no final de cada período contábil, um lançamento do tipo aluguéis a receber a receita de aluguéis, por
}

\footnotetext{
${ }^{4} \mathrm{O}$ mesmo raciocínio se aplica para o registro da despesa para o locatário ou superficiário.
} 
um valor proporcional à fração que o tempo de avaliação representa com relação ao tempo total do contrato. Veja bem que tal apropriação (digamos, mensal) é independente da periodicidade de recebimento em dinheiro do aluguel, embora normalmente haja, de forma aproximada, esta correspondência. Suponhamos que uma empesa aluguem um imóvel por um ano, por \$100.000,00, recebíveis, de uma só vez, somente no final do ano. Ao levantar o balanço semestral, poderia perfeitamente (deveria, aliás) lançar $50 \%$ do valor anual do aluguel como receita no semestre encerrado. (...)"

Ante o exposto, verifica-se que a receita decorrente dos contratos de cessão onerosa da posse direta de bens imóveis deve ser registrada proporcionalmente ao decurso do prazo contratual, independentemente da forma de pagamento.

Contudo, conforme determina o item 6 do Pronunciamento Técnico CPC 06 Operações de Arrendamento Mercantil (aprovado pela Deliberação CVM no 554/2008), caso o contrato de aluguel contenha cláusula de opção de compra pelo locatário, este contrato estará sujeito às regras de contabilização previstas para o arrendamento mercantil, conforme será analisado no Capítulo 4.4.1 do presente trabalho. ${ }^{6}$

\subsection{2 - Propriedade para Investimento (CPC 28 e ICPC 10)}

O bem imóvel (terreno e edifício) é um ativo que pode ser classificado como: (i) estoque (CPC 16), se for adquirido para revenda, (ii) imobilizado (CPC 27), se for utilizado na produção ou no fornecimento de mercadorias ou serviços ou (iii) investimento (CPC 28), se for utilizado para obter rendas ou valorização do capital. ${ }^{7}$

Nos termos do CPC 28, a mensuração da propriedade para investimento deve ser feita inicialmente pelo seu custo. Contudo, após o reconhecimento inicial, poderá ser adotado, como política contábil, o método do valor justo ou o método do custo (em alguns casos o método do valor justo é obrigatório).

Caso adote o método do custo, a entidade deverá aplicar os mesmos procedimentos previstos para a mensuração do ativo imobilizado (CPC 27). Se adotar o método do valor justo, deverá registrar as variações de valor do imóvel no resultado do período (como receita ou despesa).

\footnotetext{
${ }^{5}$ IUDÍCIBUS, Ségio de. Teoria da Contabilidade. $9^{a}$ ed., São Paulo: Atlas, 2009, p. 49.

6 " 6 . A definição de arrendamento mercantil inclui contratos para o aluguel de ativo que contenha condição dando ao arrendatário a opção de adquirir o ativo após o cumprimento das condições acordadas. Esses contratos são por vezes conhecidos por contratos de aluguel-compra."

${ }^{7}$ Sobre a diferença entre Ativo Imobilizado e Propriedade para Investimento, confira-se o Anexo B.
} 
Dessa forma, caso o imóvel seja mantido para a obtenção de renda (aluguel), a entidade irá registrar dois eventos econômicos distintos: (i) a receita decorrente do aluguel e (ii) a variação do valor justo de um período para outro (que pode ser uma receita ou uma despesa).

É interessante citar, neste sentido, o comentário previsto no ICPC 10 sobre a natureza da receita ou despesa decorrente da variação do valor justo para as entidades que tenham, como objeto principal, a administração de propriedades com intenção de obter rendimentos. Neste caso, se o valor justo for alterado em função da gestão direta da propriedade e de fatores externos, que interagem entre si e se complementam, as receitas e despesas decorrentes do ajuste do valor justo devem ser classificadas como receita operacional.

Contudo, se o investimento em imóveis é puramente especulativo (mesmo que não seja o objeto principal da entidade), esse investimento se equipara a instrumentos financeiros, motivo pelo qual as receitas e despesas decorrentes do ajuste do valor justo devem ser classificadas como receita financeira.

\section{4 - Negócios JuRídicos Relacionados Ao Financiamento DA PropriedAde IMOBILIÁRIA}

\subsection{1 - Leasing Imobiliário (Arrendamento Mercantil - CPC 06)}

Conforme já analisado (Capítulo 3.5.6), o arrendamento mercantil (ou leasing) é objeto de expressa regulamentação jurídica na Lei $n^{\circ}$ 6.099/74, com alterações posteriores. Essa lei estabelece o tratamento a ser dado pela legislação privada (pertinente às relações contratuais) e pela legislação tributária (efeitos fiscais).

Especificamente no que se refere à contabilização dessas operações, faz-se necessária a análise do Pronunciamento Técnico CPC 06 - Operações de Arrendamento Mercantil (aprovado pela Deliberação CVM no 554/2008), que tem como objetivo estabelecer a política contábil societária para arrendatários e arrendadores.

Em suma, esse negócio jurídico tem como objetivo o arrendamento de bens adquiridos pela arrendadora, mas em conformidade com os projetos e especificações exigidos 
pela arrendatária, pois estes bens serão destinados ao seu uso próprio, mediante o pagamento de uma contraprestação financeira à arrendadora.

Quanto à sua classificação, o arrendamento mercantil pode ser financeiro (aquele que tem a finalidade de financiar a aquisição do bem) ou operacional (geralmente realizado diretamente entre o produtor do bem e o usuário, mas por período de tempo inferior à vida útil do bem arrendado).

Nos termos do Pronunciamento CPC 06, o arrendo mercantil financeiro é aquele em que ocorre a transferência substancial dos riscos e benefícios inerentes à propriedade do ativo arrendado (tais como perdas decorrentes de obsolescência e ganhos decorrentes do aumento de valor de mercado).

Segundo os itens 10 e 11 do referido Pronunciamento, podem-se citar os seguintes exemplos de indicativos para a classificação do arrendamento mercantil como financeiro (embora não sejam absolutos e possam existir outros elementos):

“10. A classificação de um arrendamento mercantil como arrendamento mercantil financeiro ou arrendamento mercantil operacional depende da essência da transação e não da forma do contrato. Exemplos de situações que individualmente ou em conjunto levariam normalmente a que um arrendamento mercantil fosse classificado como arrendamento mercantil financeiro são:

(a) o arrendamento mercantil transfere a propriedade do ativo para o arrendatário no fim do prazo do arrendamento mercantil;

(b) o arrendatário tem a opção de comprar o ativo por um preço que se espera seja suficientemente mais baixo do que o valor justo à data em que a opção se torne exercível de forma que, no início do arrendamento mercantil, seja razoavelmente certo que a opção será exercida;

(c) o prazo do arrendamento mercantil refere-se à maior parte da vida econômica do ativo mesmo que a propriedade não seja transferida;

(d) no início do arrendamento mercantil, o valor presente dos pagamentos mínimos do arrendamento mercantil totaliza pelo menos substancialmente todo o valor justo do ativo arrendado; e

(e) os ativos arrendados são de natureza especializada de tal forma que apenas o arrendatário pode usá-los sem grandes modificações.

11. Os indicadores de situações que individualmente ou em combinação também podem levar a que um arrendamento mercantil seja classificado como arrendamento mercantil financeiro são: 
(a) se o arrendatário puder cancelar o arrendamento mercantil, as perdas do arrendador associadas ao cancelamento são suportadas pelo arrendatário;

(b) os ganhos ou as perdas da flutuação no valor justo do valor residual são atribuídos ao arrendatário (por exemplo, na forma de abatimento que equalize a maior parte do valor da venda no fim do arrendamento mercantil); e

(c) o arrendatário tem a capacidade de continuar o arrendamento mercantil por um período adicional com pagamentos que sejam substancialmente inferiores ao valor de mercado."

As operações de leasing imobiliário geralmente são contratadas na modalidade de leasing financeiro, pois o objetivo, na maioria dos casos, é o financiamento da aquisição do imóvel para uso próprio. As três modalidades de leasing de imóveis são:

(i) leasing imobiliário normal: a pessoa jurídica tem interesse na aquisição de determinado imóvel já edificado. Em vez de realizar empréstimo para a aquisição do imóvel, celebra um contrato com a arrendadora, que adquire o imóvel alvo à vista e o arrenda à adquirente final (arrendatária).

(ii) leasing para a construção de edifícios: a arrendadora que adquire o terreno alvo à vista e o arrenda à adquirente final (arrendatária). Enquanto o edifício estiver sendo construído, o arrendatário irá remunerar o arrendador por meio de uma taxa de compromisso, incidente sobre o valor dos gastos de construção (período préleasing). O contrato de leasing somente será celebrado depois de concluída a obra, sendo possível capitalizar a taxa de compromisso no valor da obra como custo da operação.

(iii) sale and lease back imobiliário: trata-se de uma alternativa para empresas que pretendem reduzir o índice de imobilização de seu ativo, mediante a venda do imóvel em que desenvolve sua atividade operacional, concomitantemente com a celebração do contrato de arrendamento com o adquirente.

Especificamente sobre o arrendamento mercantil de terrenos e edifícios, o Pronunciamento CPC 06 traz algumas disposições expressas nos itens 14 a 19. Neste sentido, o elemento característico desse tipo de operação é que o terreno geralmente possui vida econômica útil de prazo indefinido. Dessa forma, somente haverá o arrendamento mercantil financeiro do terreno, quando houver a previsão de transferência da propriedade ao 
arrendatário ao final do contrato. Caso contrário, tratar-se-á de um arrendamento operacional (item 14). ${ }^{8}$

Ressalte-se também que o terreno e o edifício sobre ele construído podem ser classificados de forma separada (itens 15 a 17), caso a finalidade de arrendamento mercantil de cada um seja distinta (v.g. é possível que haja o arrendamento operacional do terreno, pois não há objetivo de aquisição de sua propriedade, mas haja o arrendamento financeiro do edifício durante sua vida econômica útil). ${ }^{9}$

Distinguem-se, contudo, os casos em que o imóvel é adquirido para investimento (imóvel destinado a renda por aluguel, por valorização ou ambos), em que a mensuração do terreno e do edifício pode ser feita em conjunto, pelo modelo do valor justo (itens 18 e 19). ${ }^{10}$

8 “14. Os arrendamentos mercantis de terrenos e edifícios são classificados como arrendamentos mercantis operacionais ou financeiros da mesma forma que os arrendamentos mercantis de outros ativos. Contudo, uma característica dos terrenos é a de que têm normalmente vida econômica indefinida e, se não for esperado que a propriedade passe para o arrendatário no fim do prazo do arrendamento mercantil, normalmente o arrendatário não recebe substancialmente todos os riscos e benefícios inerentes à propriedade, e nesse caso o arrendamento mercantil do terreno será um arrendamento mercantil operacional. Um pagamento feito na celebração ou aquisição de um arrendamento mercantil que seja contabilizado como arrendamento mercantil operacional representa pagamento antecipado que é amortizado durante o prazo do arrendamento mercantil de acordo com o modelo de benefícios proporcionado." (g.n.)

9 “15. Os elementos terreno e edifícios componentes de um contrato de arrendamento mercantil são considerados separadamente para a finalidade de classificação do arrendamento mercantil. Caso se espere que a propriedade de ambos os elementos passe para o arrendatário no final do prazo do arrendamento mercantil, ambos os elementos são classificados como arrendamento mercantil financeiro, quer sejam analisados como contrato de arrendamento mercantil ou como dois, a não ser que seja claro, com base em outras características, que o arrendamento mercantil não transfere substancialmente todos os riscos e benefícios inerentes à propriedade de um ou ambos os elementos. Quando o terreno tem vida econômica indefinida, o elemento terreno é normalmente classificado como arrendamento mercantil operacional a não ser que se espere que a propriedade passe para o arrendatário no final do prazo do arrendamento mercantil, de acordo com o item 14. O elemento edifício é classificado como arrendamento mercantil financeiro ou operacional de acordo com os itens 7 a 13 .

16. Para classificar e contabilizar um arrendamento mercantil de terreno e edifícios, os pagamentos mínimos do arrendamento mercantil (incluindo qualquer pagamento inicial, antecipado), sempre que for necessário, são alocados entre os elementos terreno e edifícios em proporção aos valores justos de cada um no início do arrendamento mercantil. Se os pagamentos do arrendamento mercantil não puderem ser seguramente alocados entre esses dois elementos, a totalidade do arrendamento mercantil é classificada como arrendamento mercantil financeiro, a não ser que esteja claro que ambos os elementos são arrendamentos mercantis operacionais, em cujo caso a totalidade do arrendamento mercantil é classificada como arrendamento mercantil operacional.

17. Para um arrendamento mercantil de terreno e edifícios no qual a quantia que seria inicialmente reconhecida para o elemento terreno, de acordo com o item 20, seja imaterial, o terreno e os edifícios podem ser tratados como uma única unidade para a finalidade da classificação do arrendamento mercantil e classificados como arrendamento mercantil financeiro ou operacional de acordo com os itens 7 a 13. Em tal caso, a vida econômica dos edifícios é considerada como a vida econômica da totalidade do ativo arrendado."

10 “18. A mensuração separada dos elementos terreno e edifícios não é exigida quando os interesses do arrendatário tanto com o terreno como com os edifícios forem classificados como propriedade de investimento e for adotado o modelo do valor justo. São necessários cálculos pormenorizados para essa avaliação apenas se a classificação de um ou ambos os elementos for incerta. 
Quanto ao reconhecimento e à mensuração do arrendamento mercantil

financeiro, deve-se adotar o seguinte procedimento (itens 20 e 25): (i) o bem recebido pelo arrendatário será registrado em seu ativo, pelo valor justo da propriedade arrendada ou pelo valor presente dos pagamentos mínimos (caso inferior), e a obrigação com a arrendadora registrada como um passivo; (ii) os pagamentos devem ser segregados em encargos financeiros e redução do passivo em aberto. ${ }^{11}$

Com efeito, para o arrendatário, haverá o registro de duas despesas distintas (item 27): (i) despesas financeiras decorrentes dos juros implícitos no contrato e (ii) despesas de depreciação do ativo. ${ }^{12}$

No arrendamento mercantil operacional (item 33), por outro lado, o arrendatário não registra o bem arrendado em seu ativo, reconhecendo as despesas com

19. É possível a um arrendatário classificar uma propriedade detida mediante um arrendamento mercantil operacional como propriedade de investimento, ou seja, destinada a obter rendas ou valorização do capital ou ambas. Se assim fizer, a propriedade é contabilizada como se fosse um arrendamento mercantil financeiro e, além disso, o modelo do valor justo é usado para o reconhecimento do ativo. O arrendatário deve continuar a contabilizar o arrendamento mercantil como arrendamento mercantil financeiro, mesmo que um evento posterior altere a natureza do interesse na propriedade do arrendatário que já não esteja classificada como propriedade de investimento. Esse é o caso se, por exemplo, o arrendatário:

(a) ocupar a propriedade, que venha a ser depois transferida para ocupação pelo proprietário por um custo considerado igual ao seu valor justo à data da alteração no uso; ou

(b) conceder um subarrendamento mercantil (sublease) que transfira substancialmente todos os riscos e benefícios inerentes à propriedade para parte não relacionada. Um subarrendamento mercantil é contabilizado pelo arrendatário como arrendamento mercantil financeiro a um terceiro, embora possa ser contabilizado como arrendamento mercantil operacional pelo terceiro."

11 "Reconhecimento Inicial

20. No começo do prazo de arrendamento mercantil, os arrendatários devem reconhecer, em contas específicas, os arrendamentos mercantis financeiros como ativos e passivos nos seus balanços por quantias iguais ao valor justo da propriedade arrendada ou, se inferior, ao valor presente dos pagamentos mínimos do arrendamento mercantil, cada um determinado no início do arrendamento mercantil. A taxa de desconto a ser utilizada no cálculo do valor presente dos pagamentos mínimos do arrendamento mercantil é a taxa de juros implícita no arrendamento mercantil, se for praticável determinar essa taxa; se não for, deve ser usada a taxa incremental de financiamento do arrendatário. Quaisquer custos diretos iniciais do arrendatário são adicionados à quantia reconhecida como ativo. (...)

\section{Mensuração subseqüiente}

25. Os pagamentos mínimos do arrendamento mercantil devem ser segregados entre encargo financeiro e redução do passivo em aberto. $\mathrm{O}$ encargo financeiro deve ser imputado a cada período durante o prazo do arrendamento mercantil de forma a produzir uma taxa de juros periódica constante sobre o saldo remanescente do passivo. Os pagamentos contingentes devem ser contabilizados como despesa nos períodos em que são incorridos."

12 "27. Um arrendamento mercantil financeiro dá origem a uma despesa de depreciação relativa a ativos depreciáveis, assim como uma despesa financeira para cada período contábil. A política de depreciação para os ativos arrendados depreciáveis deve ser consistente com a dos demais ativos depreciáveis e a depreciação reconhecida deve ser calculada de acordo com as regras aplicáveis aos ativos imobilizados (e com as relativas à amortização dos ativos intangíveis quando pertinente). Se não houver certeza razoável de que o arrendatário virá a obter a propriedade no fim do prazo do arrendamento mercantil, o ativo deve ser totalmente depreciado durante o prazo do arrendamento mercantil ou da sua vida útil, o que for menor." 
pagamento das prestações em base linear, durante o prazo do arrendamento (exceto se outra base seja mais adequada). ${ }^{13}$

Por fim, registre-se que a operação de sale and lease back possui tratamento especial previsto no Pronunciamento CPC 06 (itens 58 a 66). Segundo este normativo, a contabilização da operação depente do tipo de arrendamento adotado: (i) caso ocorra a venda do bem e o arrendamento financeiro, a operação será equiparada a um financiamento com o bem dado como garantia (eventual ganho de capital deverá ser amortizado durante o prazo do arrendamento); e (ii) caso ocorra a venda e o arrendamento operacional, trata-se de venda efetiva e o ganho/perda de capital deverá ser imediatamente reconhecido. ${ }^{14}$

\subsection{2 - Fundos de Investimento Imobiliário (IN/CVM n 516/11)}

Conforme já exposto no presente trabalho, o FII é uma entidade sem personalidade jurídica, mas passível de ser titular de direitos e deveres, bem como de patrimônio contábil

\footnotetext{
13 “Arrendamento mercantil operacional
}

33. Os pagamentos da prestação do arrendamento mercantil segundo um arrendamento mercantil operacional devem ser reconhecidos como despesa em base linear durante o prazo do arrendamento mercantil, exceto se outra base sistemática for mais representativa do modelo temporal do benefício do usuário.”

14 “Transação de venda e leaseback

58. Uma transação de venda e leaseback (retroarrendamento pelo vendedor junto ao comprador) envolve a venda de um ativo e o concomitante arrendamento mercantil do mesmo ativo pelo comprador ao vendedor. O pagamento do arrendamento mercantil e o preço de venda são geralmente interdependentes por serem negociados como um pacote. O tratamento contábil de uma transação de venda e leaseback depende do tipo de arrendamento mercantil envolvido.

59. Se uma transação de venda e leaseback resultar em arrendamento mercantil financeiro, qualquer excesso de receita de venda obtido acima do valor contábil não deve ser imediatamente reconhecido como receita por um vendedor-arrendatário. Em vez disso, tal valor deve ser diferido e amortizado durante o prazo do arrendamento mercantil.

60. Se o leaseback for um arrendamento mercantil financeiro, a transação é um meio pelo qual o arrendador financia o arrendatário, com o ativo como garantia. Por essa razão, não é apropriado considerar como receita um excesso de vendas obtido sobre o valor contábil. Tal excesso é diferido e amortizado durante o prazo do arrendamento mercantil.

61. Se uma transação de venda e leaseback resultar em arrendamento mercantil operacional, e se for claro que a transação é estabelecida pelo valor justo, qualquer lucro ou prejuízo deve ser imediatamente reconhecido. Se o preço de venda estiver abaixo do valor justo, qualquer lucro ou prejuízo deve ser imediatamente reconhecido, exceto se o prejuízo for compensado por futuros pagamentos do arrendamento mercantil a preço inferior ao de mercado, situação em que ela deve ser diferida e amortizada proporcionalmente aos pagamentos do arrendamento mercantil durante o período pelo qual se espera que o ativo seja usado. Se o preço de venda estiver acima do valor justo, o excesso sobre o valor justo deve ser diferido e amortizado durante o período pelo qual se espera que o ativo seja usado.

62. Se o leaseback for um arrendamento mercantil operacional, e os pagamentos do arrendamento mercantil e o preço de venda estiverem estabelecidos pelo valor justo, na verdade houve uma transação de venda normal, e qualquer lucro ou prejuízo é imediatamente reconhecido.

63. Para os arrendamentos mercantis operacionais, se o valor justo no momento de transação de venda e leaseback for menor do que o valor contábil do ativo, uma perda igual ao valor da diferença entre o valor contábil e o valor justo deve ser imediatamente reconhecida." 
próprio. Com efeito, o artigo 15 da Lei 8.668/93 ${ }^{15}$ estabeleceu a competência da CVM para regulamentar as normas contábeis aplicáveis às Demonstrações Financeiras dos FII. No exercício dessa competência, foi editada a Instrução CVM nº 516, de 29 de dezembro de $2011 .^{16}$

Conforme estabelece o artigo $2^{\circ}$ da IN/CVM ${ }^{\circ}$ 516/11, o FII deve aplicar os métodos e critérios contábeis estabelecidos pelas normas aplicáveis às companhias abertas emitidas pela CVM. Portanto, em regra, aplicam-se para o FII as regras gerais de contabilidade societária analisadas até o momento, sujeitas aos princípios de contabilidade geralmente aceitos e ao regime de competência, inclusive com as alterações para convergência com os padrões internacionais de contabilidade.

No que tange aos critérios contábeis especialmente previstos para o FII pela IN/CVM n $n^{\circ} 516 / 11$ (transcritas no Apêndice C do presente trabalho), foram estabelecidas algumas exceções, tais como os critérios de mensuração de imóveis para renda (propriedade para investimento avaliado exclusivamente pelo valor justo) e ao registro do valor justo e do impairment de ativos financeiros. ${ }^{17}$

Com base nas regras e critérios contábeis mencionados, chega-se ao resultado contábil apurado pelo regime de competência. Este resultado contábil será utilizado para fins de divulgação ao mercado, caracterizando-se como importante ferramenta de informação aos investidores.

O lucro contábil será utilizado, em princípio, como parâmetro para a distribuição de resultados aos quotistas. Neste sentido, é importante destacar que o FII disporá, em seu regulamento (elaborado pela instituição administradora), sobre a política de distribuição de rendimentos (inciso XI do artigo 15 da IN/CVM n ${ }^{\circ} 472 / 08$ ).

Contudo, nos termos do parágrafo único do artigo 10 da Lei $\mathrm{n}^{\circ}$ 8.668/93 (incluído pela Lei $n^{\circ}$ 9.779/99), deverão ser distribuídos aos quotistas, no mínimo, 95\% dos lucros auferidos pelo FII, apurados segundo o regime de caixa, com base em balanço ou balancete semestral encerrado em 30 de junho e 31 de dezembro de cada ano.

\footnotetext{
15 “Art. 15. As demonstrações financeiras dos Fundos de Investimento Imobiliário serão publicadas pelas administradoras, na forma que vier a ser regulamentada pela Comissão de Valores Mobiliários."

${ }^{16}$ Revoga a IN/CVM n ${ }^{\circ}$ 206/94.

${ }^{17}$ Esta Instrução Normativa dispõe ainda sobre demonstrações financeiras e divulgação de informações. Neste sentido, vale mencionar que a IN/CVM no 517/11 alterou a alínea $a$ do inciso IV do artigo 39 da IN/CVM $n^{\circ}$ 472/08 para substituir a apresentação semestral do balancete pela demonstração do fluxo de caixa do período.
} 
Ocorre que não foi definido conceito legal ou normativo acerca da forma de apuração do lucro pelo regime de caixa. Com efeito, tendo em vista a necessidade de determinação desse montante mínimo a ser distribuído aos quotistas (base também para a tributação pelo imposto de renda), serão definidos adiante os contornos aplicáveis à definição desse conceito, especialmente considerando os aspectos societários que envolvem a distribuição de resultados e os aspectos fiscais que envolvem a tributação da renda.

\section{5 - Apuração do LuCro Pelo Regime de CaiXa}

Conforme destacado no Capítulo anterior, a Lei $n^{\circ}$ 8.668/93 estabeleceu uma regra específica para distribuição de dividendos mínimos pelo FII, qual seja: deverão ser distribuídos aos quotistas, no mínimo, $95 \%$ dos lucros apurados segundo o regime de caixa.

A finalidade da instituição dessa regra foi eminentemente tributária, pois se pretendia evitar que os lucros gerados pelos FII fossem sendo acumulados e sua tributação diferida (os lucros são isentos e sua tributação só ocorre no momento da distribuição, conforme será analisado no Capítulo 5.3.4).

Não obstante a finalidade fiscal do dispositivo, trata-se de uma regra de distribuição de resultados pela entidade, o que a qualifica como uma norma de Contabilidade Societária. Dessa forma, os lucros apurados segundo o regime de caixa devem estar em conformidade com os princípios de contabilidade geralmente aceitos, bem como com as demais regras que regem a distribuição de lucros para fins societários.

A referida Lei, porém, não estabeleceu o conceito de lucro a ser apurado pelo regime de caixa. Além disso, também não há em nenhum outro dispositivo legal ou infralegal que defina em que consiste a apuração de lucro pelo regime de caixa. Dessa forma, faz-se necessário tecer aqui algumas considerações acerca da forma de apuração desse lucro, sobretudo quanto aos critérios para reconhecimento e mensuração.

Essa análise também será de fundamental importância para o estudo da apuração do lucro tributário (contabilidade fiscal) das atividades de (i) compra de imóvel para venda, (ii) desmembramento ou loteamento de terrenos, (iii) incorporação imobiliária ou (iv) construção de prédio destinado à venda (previstas nos artigos 27 a 29 do Decreto Lei $\mathrm{n}^{\circ}$ 1.598/77, 
regulamentadas pela IN/RFB $n^{\circ} 84 / 79$, que dispõe sobre os critérios fiscais de reconhecimento e mensuração do custo e do lucro).

O primeiro conceito que se poderia pretender estabelecer para lucro apurado pelo regime de caixa seria o resultado decorrente impacto de receitas, custos e despesas no fluxo de caixa do período. Neste sentido, confira-se o que afirmam Sérgio de Iudícibus e José Carlos Marion: ${ }^{18}$

"O regime de caixa é uma forma simplificada de contabilidade; é aplicado basicamente às microempresas ou às entidades sem fins lucrativos, tais como igrejas, clubes, sociedades filantrópicas etc.

As regras básicas para a contabilidade por esse regime são:

- A receita será contabilizada no momento de seu recebimento, ou seja, quando entrar dinheiro no caixa (encaixe).

- A despesa será contabilizada no momento do pagamento, ou seja, quando sair direito do caixa (desembolso).

Assim, o lucro será apurado subtraindo-se toda a despesa paga (saída de dinheiro do caixa) da receita recebida (entrada de dinheiro no caixa). (...)

É exatamente a Técnica do Regime de Caixa que dá base para a estruturação de um instrumento indispensável para tomar decisões para todos os tipos de empresa: Demonstração do fluxo de caixa.

Esta demonstração vai muito mais longe que a simples apuração de resultado no período (receita recebida menos despesa paga). Consideram-se investimentos, amortização de financiamentos, dividendos etc.

De forma condensada, a Demonstração de Fluxo de Caixa (DFC) indica a origem de todo o dinheiro que entrou no caixa, bem como a aplicação de todo o dinheiro que saiu do Caixa em determinado período e, ainda, o Resultado do Fluxo Financeiro."

Contudo, deve ser afastado logo de plano o conceito de lucro pelo regime de caixa como sendo o reflexo de receitas, custos e despesas no fluxo de caixa da entidade. Apesar de o fluxo de caixa do período possuir conteúdo informacional muito importante, não pode ser utilizado como parâmetro para a distribuição de lucros ou para a tributação. Isto porque, nesta hipótese, poder-se-iam criar situações em que haveria a distribuição e a tributação de valores que não correspondem ao conceito de lucro.

\footnotetext{
${ }^{18}$ IUDÍCIBUS, Sérgio de. MARION, José Carlos. Curso de Contabilidade para Não Contadores - Para as Áreas de Administração, Economia, Direito e Engenharia. $4^{\mathrm{a}}$ ed. São Paulo: Atlas, 2006, pp. 110 e 111.
} 
Por exemplo, imagine-se um FII que seja constituído para a construção de um edifício comercial, com patrimônio líquido de \$50 milhões, integralmente gastos para aquisição do terreno e para demais procedimentos para o lançamento. Logo no primeiro semestre do lançamento do empreendimento (06/X1), são vendidas todas as futuras unidades a serem construídas, no valor total de \$200 milhões. O custo orçado para esse empreendimento é de \$ 170 milhões. No primeiro ano, só serão incorridos os \$ 50 milhões iniciais. Os \$ 120 milhões restantes serão incorridos a partir do segundo ano (01/X2) à fração de, aproximadamente, um sessenta avos (1/60) ao mês, ou seja, \$ 2 milhões ao mês.

Ocorre que, antes do final do segundo semestre do primeiro ano (12/X1), o FII já repassou todos os direitos creditórios que possuía, decorrentes da venda do empreendimento, a uma instituição financeira, pelo valor de $\$ 180$ milhões $^{19}$ e que é registrado como ingresso de receita no caixa do FII.

Caso se admita que o lucro auferido pelo regime de caixa é o decorrente da variação do fluxo de caixa, teríamos a receita que ingressou no caixa (\$180 milhões), menos a despesa que foi paga (\$ 50 milhões), totalizando o lucro de \$ 130 milhões. Dessa forma, deveriam ser distribuídos aos quotistas 95\% desse valor, ou seja, \$ 123,5 milhões:

\begin{tabular}{|c|c|c|}
\hline & Ano 1/Semestre 1 & \\
\hline Caixa Inicial & 50.000 & \\
\hline Receita Inicialmente Projetada & 200.000 & (a) \\
\hline Custos Totais Estimados & 170.000 & (b) \\
\hline Lucro Estimado & 30.000 & $(c)=(a)-(b)$ \\
\hline & Ano 1/Semestre 2 & \\
\hline Caixa inicial & 50.000 & (d) \\
\hline Ingresso de Receita no Caixa & 180.000 & (e) \\
\hline Custo Incorrido & 50.000 & (f) \\
\hline Fluxo de Caixa & 130.000 & $(g)=(e)-(f)$ \\
\hline Distribuição de 95\% do Ingresso de Caixa & 123.500 & $(h)=(g)^{*} 95 \%$ \\
\hline Caixa Final Ano 1 & 56.500 & $(\mathrm{i})=(\mathrm{d})+(\mathrm{e})-(\mathrm{f})-(\mathrm{h})$ \\
\hline
\end{tabular}

Nesta hipótese, considerando a inexistência de quaisquer outras receitas e despesas do período, restaria no caixa deste FII apenas o valor de $\mathrm{R} \$ 56,5$ milhões. Contudo, este FII possui um custo orçado para os próximos 5 anos de R $\$ 120$ milhões (\$ 24 milhões ao ano) que não poderão ser pagos por insuficiência de caixa:

\footnotetext{
${ }^{19}$ Securitização dos recebíveis com um deságio de \$ 20 milhões.
} 


\begin{tabular}{|l|r|r|r|r|r|}
\cline { 2 - 6 } \multicolumn{1}{c|}{} & \multicolumn{1}{c|}{ Ano 2 } & \multicolumn{1}{c|}{ Ano 3 } & \multicolumn{1}{c|}{ Ano 4 } & \multicolumn{1}{c|}{ Ano 5 } & \multicolumn{1}{c|}{ Ano 6 } \\
\hline Caixa Inicial & 56.500 & 32.500 & 8.500 & 0 & 0 \\
\hline Despesas Pagas & 24.000 & 24.000 & 24.000 & 24.000 & 24.000 \\
\hline Resultado & 32.500 & 8.500 & -15.500 & -24.000 & -24.000 \\
\hline
\end{tabular}

(a)

(b)

(c)

\begin{tabular}{|l|l|}
\hline Total Distribuído Indevidamente como Dividendos & -63.500 \\
\hline
\end{tabular}

Com este exemplo, resta evidente que o fluxo de caixa do período não é um parâmetro adequado para a apuração de lucro, seja para fins de distribuição, seja para fins de tributação, pois não caracteriza um efetivo acréscimo patrimonial. Isto porque o acréscimo patrimonial projetado era de \$ 10 milhões (após o deságio de \$ 20 milhões na securitização dos créditos) e somente esse valor é que poderia ser considerado como lucro pelo regime de caixa.

Assim, do valor distribuído a título de "lucro" (\$ 123,5 milhões), parte se refere ao capital inicialmente investido (\$50 milhões) e parte ao custo orçado que ainda não foi incorrido (\$ 63,5 milhões). Tais valores não podem ser considerados como lucro, pois representam um mero ingresso financeiro.

Conforme já mencionado no Capítulo 2.4.3, este problema é afastado com a aplicação do regime de competência, conforme esclarecem Alexsandro Broedel Lopes e Eliseu Martins: o regime de competência se afasta da contabilidade de caixa, mas é importante exatamente por registrar a previsão de caixa para os próximos períodos. ${ }^{20}$

Com efeito, somente o lucro apurado pelo regime de competência pode fornecer a informação correta sobre a realidade econômica de uma entidade em determinado período, uma vez que o resultado de um período não pode desconsiderar a previsão para fluxos de caixa futuros, inclusive os futuros desembolsos que deverão ser feitos pela entidade.

Como visto no Capítulo 2.4.3, o regime de competência possui dois pilares: (i) o princípio da realização da receita e (ii) o princípio do confronto despesas com as receitas e com os períodos contábeis. Esses pilares estão previstos no artigo 187 da Lei das S/A, segundo o qual as pessoas jurídicas devem computar, na determinação do resultado do exercício:

i. receitas e rendimentos ganhos no período, independentemente da sua realização em moeda;

ii. custos, despesas, encargos e perdas, pagos ou incorridos, correspondentes a essas receitas e rendimentos.

${ }^{20}$ LOPES, Alexsandro Broedel e MARTINS, Eliseu. Teoria da Contabilidade: uma nova abordagem. $2^{\mathrm{a}}$ reimpr. 
Assim, o regime de caixa para apuração do lucro afasta apenas um dos fundamentos do regime de competência, qual seja: o registro das receitas independentemente da sua realização em moeda. Pelo regime de caixa, as receitas somente podem ser registradas quando de sua realização em moeda, mas não se afasta a necessidade de confronto com as despesas correspondentes.

É importante que se esclareça esse ponto. O regime de caixa não é independente do regime de competência. Na verdade, um ingresso financeiro somente será considerado receita depois de cumpridos alguns requisitos para tanto. Antes de cumpridos esses requisitos, trata-se de mera expectativa de receita, como ocorre com os adiantamentos feitos por cliente em decorrência de vendas a serem entregues no futuro ou serviços a serem prestados. Apesar de o valor já ter ingressado no caixa, ele ainda não possui natureza de receita realizada.

Dessa forma, no exemplo dado, o montante recebido a título de ingresso financeiro pela securitização de recebíveis deve ser registrado como um ativo do FII (caixa) e a parcela de \$ 10 milhões de lucro somente será reconhecida proporcionalmente ao valor da receita realizada (v.g. com a evolução da obra, com a entrega das chaves, no decorrer do contrato de locação etc.).

Com efeito, o disposto no artigo 10 da Lei $n^{\circ}$ 8.668/93 (incluído pela Lei $n^{\circ}$ 9.779/99) não pode ser interpretado como a obrigatoriedade de distribuição do resultado de receitas, despesas e custos no fluxo de caixa do período. Tal dispositivo somente pode ser interpretado como uma regra de distribuição de lucro do período, apurado pelo regime de caixa.

Este conceito de lucro do período é distinto do conceito de fluxo de caixa, uma vez que o lucro do período necessariamente deve refletir tanto (i) a realização do ingresso financeiro em receita, quanto (ii) os desembolsos futuros de caixa.

Portanto, faz-se necessário primeiro definir qual é o lucro do período, o que somente pode ser feito pelo regime de competência (único regime capaz de alocar o resultado da entidade dentro de determinado período). Após apuração do lucro do período, considerar-se-á como lucro apurado pelo regime de caixa somente a parcela desse lucro que tenha sido realizada em moeda. Dito de outra forma, somente são computados na determinação do resultado do exercício pelo regime de caixa: (a) as receitas e os rendimentos 
ganhos no período, realizados em moeda; e (b) os custos, despesas, encargos e perdas, pagos ou incorridos, correspondentes a essas receitas e rendimentos.

Neste sentido, interessante citar o entendimento da própria RFB quando regulamenta as normas para apuração do Lucro Presumido com base no regime de caixa (IN/RFB $n^{\circ}$ 104/98). Segundo este ato normativo, os valores recebidos adiantadamente somente configuram lucro quando ocorrer a receita pelo regime de competência (v.g. faturamento, entrega do bem ou conclusão do serviço). Confira-se:

“Art. $1^{\circ}$ A pessoa jurídica, optante pelo regime de tributação com base no lucro presumido, que adotar o critério de reconhecimento de suas receitas de venda de bens ou direitos ou de prestação de serviços com pagamento a prazo ou em parcelas na medida do recebimento e mantiver a escrituração do livro Caixa, deverá:

(...)

$\S 2^{\circ}$ Os valores recebidos adiantadamente, por conta de venda de bens ou direitos ou da prestação de serviços, serão computados como receita do mês em que se der o faturamento, a entrega do bem ou do direito ou a conclusão dos serviços, o que primeiro ocorrer.” (g.n.)

Portanto, para a apuração do lucro pelo regime de caixa, as receitas e os ganhos só serão registrados quando da sua realização em moeda. Não obstante, os custos, despesas, encargos e perdas correspondentes a essas receitas e ganhos também deverão ser registrados no mesmo período (ainda que não ocorridos os desembolsos de caixa).

Destaque-se, também, que meros ingressos financeiros correspondentes a futuras receitas a serem realizadas não podem configurar lucro pelo regime de caixa. Isto porque, mesmo que exista uma expectativa de que o ingresso financeiro se realize em uma receita, ele somente comporá o lucro do período no momento em que efetivamente realizado.

Neste sentido, já se manifestou expressamente a RFB quanto à tributação do pagamento à vista na compra de unidades a construir pelo regime de caixa. Em diversas Soluções de Consulta, entendeu que mesmo ocorrendo o pagamento à vista, a tributação da receita somente ocorrerá mês do faturamento ou da entrega do bem, o que ocorrer antes. ${ }^{21}$

\footnotetext{
21 “SOLUÇÃO DE CONSULTA No 64 de 16 de Novembro de 2010

ASSUNTO: Imposto sobre a Renda de Pessoa Jurídica - IRPJ

EMENTA: LUCRO PRESUMIDO. ATIVIDADE IMOBILIÁRIA. FATURAMENTO ANTECIPADO. Na hipótese de atividades imobiliárias relativas construção de prédios destinados à venda, na ausência de procedimento específico na legislação tributária para o caso de faturamento antecipado na opção do regime de tributação pelo lucro presumido com a adoção do regime de competência, considera-se efetivada ou realizada a venda da unidade imobiliária e o reconhecimento da receita bruta para fins de tributação, no momento da efetivação do contrato da operação de compra e venda, ainda que mediante instrumento de promessa, carta de reserva com princípio de pagamento ou qualquer outro documento representativo de compromisso. Uma vez
} 
Dessa forma, é possível concluir que o valor do lucro apurado pelo regime de caixa será necessariamente menor do que o valor do lucro realizado pelo regime de competência, pois o regime de competência considera as receitas realizadas independentemente da sua realização em moeda (ingresso no caixa), ou seja, o lucro pelo regime de caixa é apurado mediante a exclusão da parcela do lucro apurado pelo regime de competência que ainda não foi realizada em moeda. Essa parcela excluída somente será reconhecida como lucro no exercício em que houver o ingresso financeiro correspondente.

A metodologia de apuração do lucro pelo regime de caixa também é aplicável para fins de tributação para os contratos de construção de longo prazo $^{22}$. Especificamente para a atividade imobiliária, ${ }^{23}$ as particularidades quanto à aplicação desse regime serão analisadas no Capítulo 5.3.1.

Por fim, faz-se necessário destacar também que a Lei das S/A, após definir o conceito de lucro líquido, ${ }^{24}$ traz uma regulamentação exaustiva de qual deverá ser sua destinação. Assim, parte do lucro líquido deve ser obrigatoriamente destinada à constituição da

adotado o regime de caixa na tributação do lucro presumido, os valores recebidos antecipadamente por conta unidades imobiliárias negociadas na planta através de contrato de compra e venda e com previsão de entrega na conclusão das unidades serão computados como receita bruta do mês em que se der o faturamento ou a entrega do bem, o que primeiro ocorrer. A adoção do regime de caixa está condicionada à adoção do mesmo critério em relação ao Imposto de Renda, à Contribuição Social sobre o Lucro Líquido (CSLL), à Contribuição para o Financiamento da Seguridade Social - Cofins e para o PIS/Pasep." No mesmo sentido, Soluções de Consulta da RFB no 66/2011, no 182/2011 e n ${ }^{\circ}$ 205/2011.

${ }^{22} \mathrm{DL} \mathrm{n}^{\circ} 1.598 / 77$ “Art. 10 - Na apuração do resultado de contratos, com prazo de execução superior a um ano, de construção por empreitada ou de fornecimento, a preço predeterminado, de bens ou serviços a serem produzidos, serão computados em cada período:

I - o custo de construção ou de produção dos bens ou serviços incorrido durante o período;

II - parte do preço total da empreitada, ou dos bens ou serviços a serem fornecidos, determinada mediante aplicação, sobre esse preço total, da porcentagem do contrato ou da produção executada no período.

(...)

$\S 3^{\circ}$ - No caso de empreitada ou fornecimento contratado, nas condições deste artigo, ou do $\S 2^{\circ}$, com pessoa jurídica de direito público, ou empresa sob seu controle, empresa pública, sociedade de economia mista ou sua subsidiária, o contribuinte poderá diferir a tributação do lucro até sua realização, observadas as seguintes normas:

a) poderá ser excluída do lucro líquido do exercício, para efeito de determinar o lucro real, parcela do lucro da empreitada ou fornecimento computado no resultado do exercício, proporcional à receita dessas operações consideradas nesse resultado e não recebida até a data do balanco de encerramento do mesmo exercício social; (...)"

${ }^{23} \mathrm{DL} \mathrm{n}^{\circ} 1.598 / 77$ : “Art 27 - O contribuinte que comprar imóvel para venda ou promover empreendimento de desmembramento ou loteamento de terrenos, incorporação imobiliária ou construção de prédio destinado à venda, deverá, para efeito de determinar o lucro real, manter, com observância das normas seguintes, registro permanente de estoques para determinar o custo dos imóveis vendidos:

(...)

Art 29 - Na venda a prazo, ou em prestações, com pagamento após o término do período-base da venda, o lucro bruto poderá, para efeito de determinação do lucro real, ser reconhecido nas contas de resultado de cada exercício social proporcionalmente à receita da venda recebida, observadas as seguintes normas: (...)"

${ }^{24}$ Para se chegar ao lucro líquido, são deduzidos do resultado do exercício os prejuízos acumulados e a provisão para o imposto sobre a renda. Posteriormente, deduzem-se as participações estatutárias de empregados, administradores e partes beneficiárias e chega-se ao lucro líquido (artigos 189 a 191 da Lei das S/A). 
reserva legal prevista no artigo 193, que tem como objetivo assegurar a integridade do capital social e somente poderá ser utilizada para compensar prejuízos ou aumentar o capital.

Ademais, de acordo com ao artigo 197 da Lei das S/A, a assembleia geral poderá, por proposta dos órgãos de administração, destinar o excesso de dividendos à constituição de reserva de lucros a realizar, no exercício em que o montante do dividendo obrigatório ultrapassar a parcela realizada do lucro líquido do exercício.

Também disciplina a Lei das S/A a forma de distribuição de dividendos, bem como a responsabilidade solidária dos administradores e fiscais que, no caso de distribuição de dividendos de forma irregular, deverão repor ao caixa social a importância distribuída, sem prejuízo da ação penal que no caso couber (artigo 201).

Com efeito, a rigidez das regras sobre apuração dos lucros, constituição de reservas e distribuição de dividendos tem como objetivo primordial preservar o capital social da entidade, com isso garantindo o seu regular funcionamento em exercícios futuros e resguardando direitos dos demais credores desta sociedade (como é o caso dos adquirentes das unidades imobiliárias a construir no exemplo citado).

Portanto, não se pode considerar o lucro pelo regime de caixa como o mero reflexo das receitas e despesas no fluxo de caixa, uma vez que o ingresso financeiro não reflete eventuais desembolsos futuros de caixa. Uma distribuição de valores que representam meros ingressos financeiros (e não lucro) acabaria inclusive por prejudicar o direito de terceiros (credores) e ocasionar o enriquecimento ilícito por parte dos quotistas.

\section{6 - RESOLUÇÃo CFC 963/2003 - ENTIDADES IMOBILIÁRIAS}

Conforme será abordado no Capítulo 5.2.1.1, o Regime Tributário de Transição RTT estabeleceu uma etapa prévia para apuração da base de cálculo do imposto de renda das pessoas jurídicas, denominada lucro líquido fiscal, apurada em conformidade com os métodos e critérios contábeis vigentes em 31/12/2007.

Especificamente no que tange às entidades imobiliárias, estava em vigor a Resolução do Conselho Federal de Contabilidade - CFC nº 963/2003, que aprovou as Normas Brasileiras de Contabilidade NBC T 10.5 - Dos Aspectos Contábeis Específicos em Entidades Imobiliárias. 
Com efeito, a Resolução CFC n 963/03 deveria ser a norma contábil utilizada como base para a apuração da Contabilidade Societária dessas entidades, em atendimento aos princípios fundamentais da contabilidade, inclusive o regime de competência. ${ }^{25}$ Ocorre que essa norma teve aplicação muito restrita, tendo sido aplicada apenas pelas companhias de capital aberto. A maior parte das entidades imobiliárias brasileiras adotava os métodos e critérios contábeis previstos na legislação fiscal (IN/RFB nº 84/79).

Segundo as regras contábeis estabelecidas na Resolução CFC n 963/03, as entidades imobiliárias podem ser divididas em três tipos, de acordo com a atividade por elas exercida: (i) compra e venda de direitos reais sobre imóveis, incorporação em terreno próprio ou em terreno de terceiros e loteamento de terrenos em áreas próprias ou em áreas de terceiros, (ii) intermediação na compra ou venda de direitos reais sobre imóveis e (iii) administração e locação de imóveis.

\section{$\checkmark \quad$ Compra e Venda de Imóveis, Incorporação e Loteamento}

As atividades de compra e venda de imóveis, incorporação e loteamento encontram-se expressamente regulamentadas por meio dos itens 10.5.2.2 a 10.5.2.7. Com efeito, a receita decorrente das atividades de compra e venda de direitos reais sobre imóveis deve ser reconhecida no momento da assinatura do contrato de alienação, independentemente do recebimento do valor contratado. Este critério também é aplicável às atividades de incorporação e loteamento, desde que a venda tenha sido realizada após a conclusão das obras (unidades já concluídas)

Caso exista cláusula suspensiva no contrato, a receita somente deve ser reconhecida quando superado o fator condicionante para sua efetivação. São exemplos de cláusulas suspensivas: (i) a estipulação de condição para a efetivação do empreendimento imobiliário somente após a venda de determinada quantidade de unidades (prazo de

\footnotetext{
${ }^{25}$ NBC T 10.5 aprovado pela Resolução CFC n ${ }^{\circ}$ 963/03:

"10.5.1.1. Esta norma estabelece critérios e procedimentos específicos de avaliação, de registro das variações patrimoniais e de estruturação das demonstrações contábeis, e as informações mínimas a serem divulgadas em notas explicativas para as entidades imobiliárias.

(...)

10.5.1.3. Aplicam-se às entidades imobiliárias os Princípios Fundamentais de Contabilidade, bem como as Normas Brasileiras de Contabilidade e as suas Interpretações e Comunicados Técnicos, editados pelo Conselho Federal de Contabilidade.

(...)

10.5.2.1. As receitas, custos e despesas devem ser reconhecidos mensalmente, respeitando, em especial, os Princípios da Oportunidade e da Competência."
} 
carência) ${ }^{26}$; (iii) a condição de que somente se considera efetivado o título translativo quando liberado o financiamento do saldo devedor.

Os valores recebidos antes do momento determinado para o reconhecimento da receita devem ser registrados como adiantamentos de clientes, no passivo circulante ou exigível a longo prazo.

Nas vendas de unidades imobiliárias em fase de construção (item 10.5.2.5.), mesmo não iniciadas, ou de unidades de loteamento com obras de infraestrutura em andamento, a receita deve ser reconhecida pela produção, como se aplica nos contratos de longo prazo para o fornecimento de bens ou serviços. O reconhecimento da receita pela produção se dará da seguinte forma:

(i) apura-se a proporção dos custos incorridos até o momento da apuração, em relação ao custo total previsto até a conclusão da obra (soma do custo incorrido com os custos orçados e contratados);

(ii) a proporção apurada deve ser aplicada ao preço de venda previsto no contrato, para que se possa apurar a receita a ser reconhecida;

(iii) o valor a ser reconhecido deverá ser deduzido do total das receitas já reconhecidas nos períodos anteriores, relativo à unidade vendida;

(iv) deve ser feito o confronto do custo do imóvel vendido com a receita apurada nos termos do item anterior. Os impostos, as contribuições e as taxas incidentes sobre a receita, bem como as comissões somente compreendem os registrados no período de apuração daquela receita;

(v) a contrapartida da receita reconhecida no período deve ser uma conta apropriada do ativo circulante ou realizável a longo prazo; e

(vi) os recebimentos superiores ao saldo dos créditos a receber, conforme o item anterior, devem ser registrados no passivo circulante ou no exigível a longo prazo, como adiantamento de clientes.

\section{Intermediação na Compra ou Venda de Imóveis (Corretagem)}

A atividade de corretagem encontra-se expressamente regulamentada por meio do item 10.5.2.8. A receita decorrente da atividade de intermediação na compra ou venda de direitos reais sobre imóveis deve ser reconhecida no momento da assinatura do contrato de

\footnotetext{
${ }^{26}$ Neste sentido, confira-se o disposto na Lei no 4.591/64: "Art. 34. O incorporador poderá fixar, para efetivação da incorporação, prazo de carência, dentro do qual the é lícito desistir do empreendimento."
} 
compra e venda. O montante a ser reconhecido deve corresponder ao valor da comissão de corretagem obtida na transação, independentemente do seu recebimento em dinheiro.

\section{$\checkmark \quad$ Administração e Locação de Imóveis}

As atividades de administração e locação de imóveis encontram-se expressamente regulamentadas por meio do item 10.5.2.9. Nessas atividades, a receita deve ser reconhecida no período a que se refere o esforço de administrar o bem, ou de colocá-lo à disposição do locatário, e deve compreender o valor da taxa de administração ou do aluguel, independentemente do recebimento do valor contratado. 


\section{5 - TRIBUTAÇÃo DA RENDA NO SETOR IMOBILIÁRIO}

No presente capítulo, passa-se à análise do tratamento tributário conferido às diversas atividades do setor imobiliário.

Para a realização desse trabalho, será necessário o confronto com as premissas desenvolvidas nos 4 Capítulos anteriores, quanto: (i) aos aspectos gerais e limites da tributação da renda na $\mathrm{CF}$ e no CTN, (ii) ao papel fundamental da contabilidade societária e fiscal para o reconhecimento e mensuração da renda, (iii) à natureza jurídica das atividades imobiliárias, com enfoque na transferência de riscos e benefícios e (iv) à contabilização dessas operações em conformidade com as regras de Direito Societário.

Como se percebe, optou-se no presente trabalho por uma análise abrangente, de forma a se verificarem as características gerais do setor imobiliário como um todo (análise do "mapa"). Passa-se, agora, à analise da coerência e adequação dos diversos critérios de tributação da renda gerada nesse setor (análise dos "caminhos"), no que tange tanto (i) à forma de reconhecimento e mensuração, quanto (ii) aos diversos tratamentos especiais previstos na legislação tributária.

Com efeito, a análise de coerência e adequação do tratamento fiscal conferido à renda do setor imobiliário será feita em três etapas:

(d) aspectos gerais da tributação das pessoas físicas e regras específicas de tributação das atividades imobiliárias;

(e) aspectos gerais da tributação da pessoa jurídica e regras específicas de tributação das atividades imobiliárias;

(f) regimes específicos de tributação: (c.i) tributação das atividades de compra e venda, loteamento, incorporação e construção de imóveis; (c.ii) Regime Especial de Tributação - RET para o patrimônio de afetação; (c.iii) tributação do leasing imobiliário; e (c.iv) tributação dos Fundos de Investimentos Imobiliários - FII. 


\section{1 - Tributação da Renda Pelas Pessoas Físicas}

Até 1988, o Imposto sobre a Renda das Pessoas Físicas - IRPF era um imposto incidente sobre categorias de rendimentos, classificados em cédulas (Imposto Cedular). ${ }^{1}$ Assim, cada tipo de rendimento era classificado em uma cédula específica, como ocorria com os rendimentos imobiliários. Neste sentido, a tributação dos aluguéis estava prevista na cédula "E", 2 e a tributação do ganho de capital na cédula "H". ${ }^{3}$

Com a edição da Lei $n^{0}$ 7.713/88, abandonou-se a tributação cedular da pessoa física, passando-se a tributar a renda de uma forma muito mais ampla (em conformidade com os princípios constitucionais da generalidade e da universalidade - Capítulo 1.2.1.1). ${ }^{4}$

Verifica-se, portanto, que a partir de 1988, o IRPF deixou de tributar a renda das pessoas físicas de acordo com a classificação em cédulas. Nos termos da legislação atualmente em vigor, os diversos rendimentos da pessoa física podem ser divididos em seis categorias, de acordo com a sua forma de apuração e recolhimento: (i) Imposto de Renda na Fonte por Antecipação - IRF-A, (ii) Imposto sobre a Renda na Fonte Exclusivo - IRF-E, (iii) Imposto sobre a Renda por Alíquota Fixa - AF, (iv) Recolhimento Mensal Obrigatório - RMO, (vi) Recolhimento Complementar Facultativo - RCF e (vi) Complementação Anual Obrigatória CAO.

\footnotetext{
${ }^{1}$ RIR/80: "Art. 20 - Constituem rendimentos bruto, em cada cédula, o produto do capital, do trabalho, ou da combinação de ambos, os alimentos e pensões percebidos em dinheiro, e demais proventos previstos neste Regulamento, assim também entendidos os acréscimos patrimoniais não correspondentes com os rendimentos declarados (Decreto-lei no 5.844/43, art. 10, Lei no 5.172/66, art. 43, I e II, e Decreto-lei no $1.301 / 73$, art. $3^{\circ}$ ). (...) Art. 23 - Para os fins de declaração, os rendimentos serão classificados em oito cédulas que se coordenam e denominam pelas primeiras letras do alfabeto (Decreto-lei $n^{\circ} 5.844 / 43$, art. $2^{\circ}$, e Lei ${ }^{\circ} 154 / 47$, art. $1^{\circ}$ )."

${ }^{2}$ RIR/80: "Art. 31 - Na cédula $\mathbf{E}$ serão classificados, como aluguéis, os rendimentos de qualquer espécie oriundos da ocupação, uso ou exploração de bens corpóreos, tais como (Decreto-lei $n^{\circ} 5.844 / 43$, art. $3^{\circ}$, e Lei ${ }^{\circ}$ 4.506/64, art. 21):"

${ }^{3}$ RIR/80: "Art. 41 - Constitui, também, rendimento tributável na cédula $\mathbf{H}$, o lucro apurado em decorrência de alienações de imóveis, no que exceder a Cr\$4.000.000,00 (quatro milhões de cruzeiros) no ano-base (Decreto-lei $\mathrm{n}^{\circ} 1.641 / 78$, arts. $1^{\circ}$ e $10^{\circ}$, e Decreto-lei $n^{\circ} 1.814 / 80$, art. $8^{\circ}$ )."

${ }^{4}$ Lei $n^{\circ} 7713 / 88$ : "Art. $3^{\circ} \mathrm{O}$ imposto incidirá sobre o rendimento bruto, sem qualquer dedução, ressalvado o disposto nos arts. $9^{\circ}$ a 14 desta Lei.

$\S 1^{\circ}$ Constituem rendimento bruto todo o produto do capital, do trabalho ou da combinação de ambos, os alimentos e pensões percebidos em dinheiro, e ainda os proventos de qualquer natureza, assim também entendidos os acréscimos patrimoniais não correspondentes aos rendimentos declarados.

$\S 2^{\circ}$ Integrará o rendimento bruto, como ganho de capital, o resultado da soma dos ganhos auferidos no mês, decorrentes de alienação de bens ou direitos de qualquer natureza, considerando-se como ganho a diferença positiva entre o valor de transmissão do bem ou direito e o respectivo custo de aquisição corrigido monetariamente, observado o disposto nos arts. 15 a 22 desta Lei. (...)

$\S 4^{\circ} \mathrm{A}$ tributação independe da denominação dos rendimentos, títulos ou direitos, da localização, condição jurídica ou nacionalidade da fonte, da origem dos bens produtores da renda, e da forma de percepção das rendas ou proventos, bastando, para a incidência do imposto, o benefício do contribuinte por qualquer forma e a qualquer título. (...)

Art. $4^{\circ}$ Fica suprimida a classificação por cédulas dos rendimentos e ganhos de capital percebidos pelas pessoas físicas."
} 
A seguir serão analisados os aspectos gerais das categorias de tributação da renda pessoa física, especialmente considerando seus critérios de reconhecimento e mensuração. ${ }^{5}$

\subsection{1 - Aspectos Gerais da Tributação da PF - Formas de Apuração e Recolhimento (Categorias de Tributação)}

\section{$\checkmark$ Imposto de Renda na Fonte por Antecipação (IRF-A)}

O IRF-A é a modalidade de apuração e recolhimento aplicável aos rendimentos pagos de uma pessoa jurídica - PJ para uma pessoa física - PF. Trata-se, portanto, de uma regra geral de tributação para pessoa física que tem como principal característica a natureza do agente pagador. Esta modalidade de tributação será aplicável sempre que uma PJ fizer um pagamento para uma PF, a não ser que outra modalidade seja expressamente aplicável.

São exemplos de rendimentos classificados como IRF-A o aluguel e os honorários recebidos a título de prestação de serviços, quando pagos por pessoa jurídica.

A base de cálculo para a apuração do IRF-A é o valor bruto do pagamento. Contudo, são admitidas algumas deduções, tais como despesas com dependentes (valor fixo estabelecido na legislação). Sobre a base de cálculo, serão aplicadas as alíquotas de 0\%, 7,5\%, $15 \%, 22,5 \%$ e $27,5 \%$, incidentes sobre as faixas de rendimento estabelecidas na tabela progressiva.

Nesta categoria de apuração e recolhimento, a tributação é uma mera antecipação, ou seja, não é definitiva. Dessa forma, a fonte pagadora (PJ) está obrigada a recolher o IRF-A, mas o contribuinte (PF) deverá apurar novamente o imposto devido no final do ano-calendário (na apuração da CAO, conforme será analisado adiante), compensando os valores já pagos pela fonte de forma antecipada.

Com efeito, ao final do ano-calendário, o contribuinte irá (i) recolher eventual diferença, caso o valor devido de imposto na CAO seja superior aos valores retidos de forma antecipada; ou (ii) receber eventual restituição, caso o valor anual seja inferior à somatória dos valores retidos.

\footnotetext{
${ }^{5}$ Para um estudo mais completo sobre o imposto de renda da pessoa física, confira-se: LUI, Ana Paula Schincariol. Imposto sobre a Renda e Proventos de Qualquer Natureza Auferidos pela Pessoa Física - Princípios Constitucionais e Sistemática de Apuração. Dissertação de Mestrado defendida na Pontifícia Universidade Católica de São Paulo, 2007.
} 


\section{Imposto sobre a Renda na Fonte Exclusivo (IRF-E)}

A modalidade IRF-E incide sobre algumas espécies de rendimentos pagos por $\mathbf{P J}$ a PF, de modo exclusivo (tributação definitiva). Ou seja, uma vez tendo sido feita a retenção do imposto na fonte pela pessoa jurídica, o rendimento líquido pode ser fruído pelo contribuinte sem que exista a necessidade de submetê-lo a novo cálculo na CAO, ao final do ano-calendário.

São exemplos de rendimentos sujeitos ao IRF-E os decorrentes de aplicações de renda fixa auferida no mercado financeiro ou de capitais e os rendimentos recebidos de Fundos de Investimento Imobiliários - FII (quando não isentos).

A base de cálculo para a apuração do IRF-E é o valor bruto do rendimento pago, sem deduções. Sobre a base de cálculo, será aplicada a alíquota correspondente à espécie de rendimento (por exemplo, os rendimentos provenientes do FII são tributados, em regra, à alíquota de $20 \%$ ).

Esta modalidade de tributação pode ser menos onerosa quando comparada ao IRF-A, mas apenas quando o rendimento seria tributado na alíquota mais alta na CAO. Neste sentido, o IRF-E será mais oneroso quando, comparativamente, o rendimento estivesse em uma alíquota inferior ou isento na CAO (v.g. caso o total dos rendimentos da PF fosse inferior ao limite de isenção da tabela progressiva).

\section{$\checkmark$ Imposto sobre a Renda por Alíquota Fixa (AF)}

Os rendimentos sujeitos à apuração e recolhimento por AF são aqueles em que o próprio contribuinte apura e recolhe o tributo (trata-se de autorrecolhimento, pois não há retenção na fonte como nas modalidades vistas até agora). Da mesma forma em que ocorre para os rendimentos sujeitos ao IRF-E, trata-se de tributação definitiva, ou seja, o rendimento não se submete a novo cálculo no final do ano-calendário para fins de tributação na CAO.

São exemplos de AF o ganho de capital na alienação de bens (móveis ou imóveis) e renda variável auferida no mercado financeiro ou de capitais.

A base de cálculo é o valor líquido do ganho, ou seja, o valor correspondente à diferença a maior entre o valor de alienação do bem e o valor do custo de aquisição (o fato gerador ocorre no momento da alienação). A alíquota aplicável é, em geral, de $15 \%$. 


\section{Recolhimento Mensal Obrigatório (RMO) - "Carnê-Leão"}

Esta modalidade de apuração e recolhimento é comumente denominada de “carnê-leão". Trata-se de modalidade semelhante ao IRF-A, mas nestes casos o recolhimento é feito pelo próprio contribuinte (trata-se de autorrecolhimento, não há retenção na fonte).

Em geral, o RMO é aplicado sempre que a PF recebe rendimentos: (i) de outras $\mathrm{PF}$, (ii) de fontes no exterior ou (iii) que revelem outros acréscimos patrimoniais, não justificados. São exemplos de rendimentos classificados como RMO o aluguel e os honorários recebidos a título de prestação de serviços, quando pagos por pessoa física.

A base de cálculo para a apuração do RMO é o total dos rendimentos recebidos no mês. Contudo, da mesma forma que para o IRF-A, são admitidas algumas deduções, tais como despesas com dependentes (valor fixo estabelecido na legislação). Sobre a base de cálculo, serão aplicadas as alíquotas de $0 \%, 7,5 \%, 15 \%, 22,5 \%$ e 27,5\%, incidentes sobre as faixas de rendimento estabelecidas na tabela progressiva.

Assim como o IRF-A, a tributação dos rendimentos sujeitos ao RMO é apenas uma antecipação do que será devido ao final do ano-calendário, que deverá ser compensada na apuração da CAO.

\section{$\checkmark$ Complementação Anual Obrigatória (CAO)}

O IRPF é um imposto que tem como aspecto temporal o ano-calendário (fato gerador anual). Portanto, o contribuinte deve entregar anualmente sua Declaração de Ajuste Anual à Receita Federal do Brasil (RFB). Nesta declaração, irá ser apurada a base de cálculo, correspondente à totalidade de seus rendimentos auferidos durante o ano, com exceção (i) dos rendimentos isentos e não tributáveis e (ii) dos rendimentos que foram tributados de forma definitiva na fonte (IRF-E) ou que foram tributados de forma definitiva por autorrecolhimento (AF). Na apuração da base de cálculo para a CAO, são admitidas as mesmas deduções previstas para o IRF-A e para o RMO (caso não se opte pelo Desconto Simplificado). ${ }^{6}$

Sobre a base de cálculo, serão aplicadas as alíquotas de 0\%, 7,5\%, 15\%, 22,5\% e $27,5 \%$, incidentes sobre as faixas de rendimento estabelecidas na tabela progressiva. 
Ademais, como visto, parte dos rendimentos são tributados de forma antecipada durante o ano-calendário, tanto por meio de retenções na fonte (IRF-A), quanto por meio de autorrecolhimento (RMO - "carnê leão"). Assim, esses pagamentos geram créditos a serem compensados com o imposto apurado na CAO. Caso o valor devido no final do ano-calendário seja maior do que os valores recolhidos a título de antecipação, a diferença deverá ser recolhida pelo contribuinte. Caso contrário, surgirá o direito à restituição da diferença recolhida a maior durante o ano-calendário.

\section{Recolhimento Complementar Facultativo (RCF)}

O RCF é uma faculdade concedida ao contribuinte de antecipar, durante o ano, o imposto que será compensado na CAO.

O recolhimento facultativo pode ser feito, por exemplo, nos casos em que a pessoa física recebe rendimentos provenientes de diversas fontes diferentes. Neste caso, a aplicação da tabela progressiva de forma isolada para cada fonte pagadora resultará em uma tributação menor do que aquela aplicável, caso fossem considerados todos os rendimentos em conjunto.

Sendo mera faculdade de antecipar o pagamento do imposto, dificilmente ocorre sua aplicação.

\subsection{2 - Tributação dos Negócios Imobiliários}

\subsubsection{1 - Tributação da Alienação da Propriedade Imobiliária (Ganho de Capital)}

A renda a ser tributada na alienação da propriedade imobiliária é aquela decorrente da valorização ocorrida entre o momento da aquisição do bem imóvel e o momento de sua alienação, que se qualifica na modalidade ganho de capital. Conforme ensina Aliomar Baleeiro, são diversas as causas para esse acréscimo de valor dos imóveis: ${ }^{7}$

"Independentemente de melhoramentos públicos, ou de esforços concretos dos proprietários,
imóveis sobem de valor por efeito do crescimento demográfico, expansão econômica do meio e
outras causas, dentre as quais a de que, sobretudo nas cidades, os terrenos são limitados, de sorte

\footnotetext{
${ }^{6}$ Trata-se da opção de aplicar o desconto de $20 \%$ sobre os rendimentos tributáveis, até o limite estabelecido na legislação, para o qual não há necessidade de qualquer comprovação. Caso se aplique esse desconto, não poderão ser utilizadas as deduções legais cabíveis.

${ }^{7}$ BALEEIRO, Aliomar. Uma Introdução à Ciência das Finanças. 15 ${ }^{\mathrm{a}}$ ed. Rev. e atualizada por Dejalma de Campos, Rio de Janeiro: Forense, 1997, p. 340.
} 
que seus proprietários gozam de verdadeiro oligopólio, que se reforça à proporção que a área urbana se torna mais densa e ficam mais escassos os lotes disponíveis."

O ganho de capital é considerado renda na modalidade acréscimo patrimonial, ou seja, enquadra-se na no conceito de renda-acréscimo, em conformidade com o conceito de renda previsto no CTN (conforme Capítulo 1.3.1).

Conforme já destacado, a mais valia na alienação de bens imóveis pela pessoa física é tributada como ganho de capital, sujeita ao regime da Alíquota Fixa - AF (alíquota de 15\%). Trata-se de uma tributação exclusiva e definitiva, que considera o ganho ocorrido de forma isolada dos demais rendimentos (não é possível deduzir ou compensar este imposto na $\mathrm{CAO})^{8}$

Considera-se ocorrido o ganho de capital: ${ }^{9}$ (i) na alienação do bem imóvel, a qualquer título (são exemplos de alienação: a compra e venda, a permuta, a adjudicação, a desapropriação a doação e a dação em pagamento) e (ii) na cessão ou promessa de cessão de direitos à sua aquisição (são exemplos de cessão e direitos ou promessa de cessão de direitos: a procuração em causa própria e a promessa/compromisso de compra e venda).

Verifica-se, portanto, que a legislação tributária estabeleceu como critério de realização da renda o momento da troca entre terceiros, ou seja, somente haverá tributação da valorização imobiliária quando houver a transferência do imóvel para terceiros (ou cessão ou promessa de cessão de direitos à aquisição).

Ocorrerá o ganho de capital quando o valor de alienação do bem imóvel for maior que o valor de custo de aquisição, após os descontos e abatimentos previstos em lei. Considera-se custo de aquisição o preço ou o valor pago. Quando não houver pagamento, serão considerados os seguintes valores, conforme o caso: $:^{10}$

(i) o valor atribuído para efeito de pagamento do imposto de transmissão;

(ii) o valor da avaliação do inventário ou arrolamento;

(iii) o valor de transmissão, utilizado na aquisição, para cálculo do ganho de capital do alienante; ou

(iv) seu valor corrente, na data da aquisição. O valor da contribuição de melhoria integra o custo do imóvel.

\footnotetext{
${ }^{8}$ Conforme artigo 21 da Lei $n^{\circ} 8.981 / 95$.

${ }^{9}$ Conforme $\$ 3^{\circ}$ do artigo $3^{\circ}$ da Lei $n^{\circ} 7.713 / 88$.

${ }^{10}$ Conforme artigo 16 da Lei $n^{\circ} 7.713 / 88$.
} 
Além do valor de aquisição do imóvel, poderão ser acrescidos ao custo os seguintes gastos, desde que comprovados por documentação hábil e idônea, bem como estejam discriminados na declaração de bens apresentada à RFB: ${ }^{11}$

(i) os dispêndios com a construção, ampliação, reforma, conservação, reparos e pequenas obras, tais como pintura, reparos em azulejos, encanamentos;

(ii) os dispêndios com a demolição de prédio existente no terreno, desde que seja condição para se efetivar a alienação;

(iii) as despesas de corretagem referentes à aquisição do imóvel vendido, desde que suportado o ônus pelo contribuinte;

(iv) os dispêndios pagos pelo proprietário do imóvel com a realização de obras públicas, tais como colocação de meio-fio, sarjetas, pavimentação de vias, instalação de rede de esgoto e de eletricidade que tenham beneficiado o imóvel;

(v) o valor do imposto de transmissão pago pelo alienante;

(vi) o valor da contribuição de melhoria.

Até 31 de dezembro de 1995, era possível corrigir o custo de aquisição dos imóveis, desde que observada a legislação aplicável no período. Após essa data, não é possível atribuir qualquer atualização monetária ao custo dos bens e direitos.

O Fisco poderá arbitrar o valor ou preço de alienação informado pelo contribuinte quando não mereça fé, por notoriamente diferente do valor de mercado, com a ressalva de avaliação contraditória em contestação administrativa ou judicial. ${ }^{12}$

Caso ocorra a mais valia no momento da alienação do bem imóvel (diferença positiva entre o valor de alienação e o custo de aquisição), esse valor será utilizado como base de cálculo para fins de apuração do imposto de renda. A alíquota aplicável ao ganho de capital é de $15 \%$ (alíquota mais benéfica em relação à tributação máxima da tabela progressiva). $\mathrm{O}$ imposto incidente sobre os ganhos de capital é considerado auferido mensalmente, devendo ser declarado e pago até o último dia útil do mês seguinte à alienação.

\section{Venda a Prazo}

Nos casos em que a alienação do imóvel seja feita a prazo, considera-se o ganho de capital apurado como se a venda fosse feita à vista, ${ }^{13}$ mas a tributação ocorrerá na proporção das parcelas recebidas em cada mês. ${ }^{14} \mathrm{Ou}$ seja, na hipótese de venda parcelada,

\footnotetext{
${ }^{11}$ Conforme artigo 128 do RIR/99.

${ }^{12}$ Conforme artigo 20 da Lei $n^{\circ} 7.713 / 88$.

${ }^{13}$ Conforme artigo 140 do RIR/99.

${ }^{14}$ Conforme artigo 21 da Lei $\mathrm{n}^{\mathrm{o}} 7.713 / 88$.
} 
deve-se apurar o percentual do ganho de capital correspondente ao valor de alienação em cada parcela recebida.

Com efeito, verifica-se que a tributação do ganho de capital na pessoa física não se dá pelo regime de caixa propriamente dito, pois se considera ocorrido o fato gerador no momento da alienação do bem imóvel (momento em que ocorre a incidência tributária) independentemente do recebimento do preço em dinheiro. O que estabelece a legislação é apenas que o pagamento do tributo devido será postergado para o momento em que a renda for recebida (ingresso de caixa). ${ }^{15}$

O regime de caixa propriamente dito é verificado para os regimentos de fundos de investimento imobiliário e para as pessoas jurídicas que tenham como atividade a compra e venda, o loteamento, a incorporação e a construção de imóveis, em que o fato gerador só ocorre com o ingresso de caixa (Capítulos 4.5 e 5.3.1.5).

Caso haja atualização monetária nas parcelas recebidas, esse valor será considerado no ganho de capital, conforme seu recebimento (regime de caixa). Importante destacar que o $\$ 6^{\circ}$ do artigo 123 do RIR/99 estabeleceu que os juros recebidos não compõem o valor de alienação, devendo ser tributados mensalmente (IRF-A ou RMO) e na CAO, pela tabela progressiva (alíquotas de 0\% a 27,5\% e tributado independentemente da existência ou não de ganho de capital).

\section{Doação e Herança}

Conforme já destacado no Capítulo 1.2, os bens recebidos a título de doação e herança geram acréscimo patrimonial passível de incidência do imposto de renda pelo beneficiário. Contudo, especificamente no que tange à tributação pela pessoa física, optou o legislador por isentar de tributação esses valores (conforme inciso XVI do artigo $6^{\circ}$ da Lei $n^{\circ}$ 7.713/88).

Quanto à transferência de direito de propriedade por sucessão nos casos de herança e legado ou por doação em adiantamento da legítima, o artigo 23 da Lei no 9.532/97 estabeleceu a possibilidade de avaliação do bem entregue: (i) a valor de mercado ou (ii) pelo valor constante da declaração de bens do de cujus ou do doador.

\footnotetext{
${ }^{15}$ No mesmo sentido, confira-se NISHIOKA, Alexandre Naoki. Do Critério Temporal do Imposto sobre a Renda de Pessoa Física nos Casos de Promessa de Compra e Venda a Prazo. In Revista Direito Tributário Atual, vol. 25, Dialética: São Paulo, 2011, pp. 48 de ss.
} 
Ocorre que, ao optar pela avaliação a valor de mercado, a diferença a maior, entre esse e o valor pelo qual os bens constavam da declaração de bens do de cujus ou do doador, será tributada como ganho de capital, à alíquota de 15\%. O imposto deverá ser pago pelo inventariante ou pelo doador. ${ }^{16}$

A mesma sistemática de tributação será aplicada aos bens ou direitos atribuídos a cada cônjuge, na hipótese de dissolução da sociedade conjugal ou da unidade familiar. Neste caso, o imposto deverá ser pago pelo ex-cônjuge a quem for atribuído o bem ou direito, até o último dia útil do mês subsequente à data da sentença homologatória do formal de partilha.

\subsubsection{1.a - Permuta e Dação em Pagamento}

Como visto (Capítulo 3.2.4), o novo Código Civil define a permuta como um negócio jurídico de alienação de bens para o qual se aplicam as disposições referentes à compra e venda. Contudo, este negócio jurídico se diferencia da compra e venda quanto à formação do preço. Na verdade, na permuta não há preço propriamente dito, mas o compromisso de trocar bens reciprocamente (desde que esse bem não seja dinheiro).

A permuta, portanto, é uma troca de mercado em que é possível a identificação de acréscimo de capacidade contributiva, especialmente quando se trata de bens de natureza e valor econômico distintos. Com efeito, os princípios da capacidade contributiva e da igualdade orientam no sentido de que tais valores deveriam ser tributados pelo imposto de renda.

Contudo, considerando-se o princípio da realização renda, verifica-se que geralmente não será possível a tributação neste caso, porquanto ausentes os requisitos mínimos para que o ganho se considere realizado. Isto porque, mesmo que o bem recebido na permuta tenha valor econômico maior que o bem entregue, não é possível mensurar essa mais valia, já que não há definição de um preço objetivo na operação.

Assim, a tributação do acréscimo patrimonial verificado na permuta é diferida para eventual venda futura do bem recebido como pagamento. ${ }^{17}$

\footnotetext{
${ }^{16}$ A avaliação a valor de mercado de bens na doação ou herança sofre a incidência de dois impostos: o IRPF e o ITCMD. Dessa forma, mesmo que o ganho de capital seja isento do imposto de renda, deve-se sopesar a incidência do ITCMD no cálculo da carga tributária total.

${ }^{17}$ Conforme o item 1.2 da IN/RFB no $107 / 88$, é possível realizar permuta a preço de mercado, desde que apoiada em laudo de avaliação dos imóveis permutados, feito por três peritos, ou por entidade ou empresa especializada, desvinculados dos interesses dos contratantes, com a indicação dos critérios de avaliação e dos elementos de comparação adotados e instruído com os documentos relativos aos bens avaliados.
} 
Segundo Kornhauser, ${ }^{18}$ os motivos para que o acréscimo de capacidade contributiva ainda não possa ser considerado realizado no caso da permuta são: (i) ausência de mensurabilidade do valor do bem recebido na troca (ii) ausência de liquidez para o pagamento do imposto e (iii) continuidade do investimento, pois o ganho é decorrente do recebimento de um bem, sujeito aos riscos da propriedade.

Dessa forma, apesar da troca de mercado verificada na alienação por meio da permuta, Victor Borges Polizelli destaca que nem sempre se verifica uma mudança de posição patrimonial, pois nem sempre haverá (i) uma mudança na substancia do direito de propriedade trocado ou (ii) uma conversão desse bem em novos direitos. ${ }^{19}$

Apesar da polêmica em relação à possibilidade de tributação na permuta, a legislação tributária houve por bem considerar não tributável o ganho de capital da pessoa física, quando decorrente de permuta realizada exclusivamente entre unidades imobiliárias, desde que objeto de escritura pública e que não exista torna em dinheiro. ${ }^{20}$

Equipara-se à permuta, para fins de isenção do imposto de renda, a operação de compra e venda de terreno, com confissão de dívida, quitada por escritura pública de dação em pagamento de unidades imobiliárias construídas ou a construir. ${ }^{21}$

Caso ocorra o recebimento de torna na permuta, apura-se o ganho de capital exclusivamente sobre a torna recebida. Com efeito, considera-se o valor de alienação somente o valor da torna recebida ou a receber..$^{22}$ Neste caso, a base de cálculo do ganho de capital será apurada da seguinte forma:

(i) o valor da torna (v.g. \$20) será adicionado ao custo do imóvel dado em permuta (v.g. \$80);

(ii) será efetuada a divisão do valor da torna (\$20) pelo valor apurado no item anterior $(\$ 20+\$ 80=\$ 100)$, devendo o resultado $(0,2)$ ser multiplicado por cem $(20 \%)$

\footnotetext{
${ }^{18}$ KORNHOUSER, Marjorie E. The Story of Macomber: the continuing legacy of realization. In: CARON, Paul L. Tax Stories: an in-depth look at ten leading federal income tax cases. New York: Foundation Press, 2003, p. 53-96. Apud POLIZELLI, Victor Borges. O Princípio da Realização da Renda e sua Aplicação no Imposto de Renda de Pessoas Jurídicas. Dissertação de Mestrado defendida na Faculdade de Direito da Universidade de São Paulo, 2009, p. 217.

${ }^{19}$ POLIZELLI, Victor Borges. Op. cit. (nota 18), pp. 168 e 218.

${ }^{20}$ Conforme artigo 121, inciso II, do RIR/99.

${ }^{21}$ Conforme artigo $121, \S 1^{\circ}$, do RIR/99.

${ }^{22}$ Conforme artigo 123, § $3^{\circ}$, do RIR/99.
} 
(iii) o custo dedutível da torna para fins de apuração do ganho de capital será obtido aplicando-se $(a)$ o percentual encontrado sobre $(b)$ o valor da torna recebido $(\$ 20 * 20 \%=\$ 4)$.

Para fins de registro do custo de aquisição do bem recebido na permuta, considera-se o valor do bem dado em permuta acrescido da torna paga, se for o caso. Caso haja o recebimento de torna, o custo de aquisição será diminuído do valor deduzido na apuração do ganho de capital, em relação à torna recebida ou a receber.

Por fim, registre-se que nas operações que envolvam a permuta de uma unidade imobiliária por duas ou mais unidades, o permutante que as receber deverá determinar o valor individual de cada uma delas proporcionalmente a um dos seguintes parâmetros, utilizados na ordem a seguir indicada (item 1.8 da IN/RFB n¹07/88): (i) o valor adotado como base de cálculo do imposto de transmissão incidente sobre a operação de permuta dessas duas ou mais unidades imobiliárias; (ii) o valor da base de cálculo do último imposto sobre a propriedade predial e territorial urbana ou rural lançado em relação a cada uma dessas duas ou mais unidades imobiliárias; ou (iii) o valor de mercado de cada unidade, apurado na forma do subitem 1.2 da IN/RFB nº 107/88 (três laudos de avaliação).

\subsubsection{1.b - Isenção: Bens Imóveis de Pequeno Valor}

Uma primeira isenção que merece ser destacada é para a alienação de bens de pequeno valor, qualquer que seja a sua natureza. Estabeleceu-se como pequeno valor de alienação o limite de até R \$ 35.000,00. Dessa forma, se o bem imóvel for alienado até o limite mencionado, não há que se falar em apuração de ganho de capital.

Destaque-se apenas que, caso ocorra a alienação de mais de um imóvel no mês, o valor total dos imóveis alienados não poderá ser superior ao limite de $\mathrm{R} \$ 35.000,00$ para que a pessoa física continue fazendo jus ao benefício (artigo 22 da Lei no 9.249/95).

A isenção ora em análise aplica-se à alienação de qualquer bem, móvel ou imóvel. Portanto, a alienação de qualquer bem imóvel está sujeita à presente isenção, seja residencial, comercial, terreno urbano ou rural. 


\subsubsection{1.c - Isenção: Alienação do Único Imóvel}

Será isenta também a alienação do único imóvel da pessoa física, desde que o valor de alienação seja de até $\mathrm{R} \$ 440.000,00$ e não tenha sido realizada qualquer outra alienação de imóveis nos últimos cinco anos (artigo 23 da Lei no 9.249/95).

O primeiro requisito para a isenção ora em análise é a existência de um único imóvel em nome da pessoa física, motivo pelo qual é possível fruir dessa isenção, mesmo que a pessoa física seja sócia de uma pessoa jurídica que possua imóveis em seu ativo.

O segundo requisito é o valor de alienação do imóvel, que deve ser de até $\mathrm{R} \$ 440.000,00$. Adotou-se, portanto, um critério objetivo de capacidade contributiva para a isenção (o valor máximo de venda do imóvel). ${ }^{23}$ No entanto, o critério eleito não avalia a capacidade contributiva subjetiva, pois não considera nem o patrimônio total do sujeito nem o ganho efetivamente auferido.

O terceiro critério é a inexistência de qualquer outra alienação nos últimos cinco anos, o que também denota a intenção de conceder a isenção apenas aos imóveis que sejam ativos relevantes para a pessoa física, em geral aqueles em que firmam sua residência.

Deve-se destacar, ainda, que a legislação tributária não restringe a natureza do imóvel alienado para fins de aplicação da isenção. Dessa forma, mesmo que o imóvel seja comercial, terreno, urbano ou rural, aplica-se a isenção.

\subsubsection{1.d - Isenção: 180 Dias para Reinvestimento em Imóveis Residenciais}

Com o advento do artigo 39 da Lei $n^{\circ}$ 11.196/2005, foi estabelecida a isenção do imposto de renda sobre o ganho de capital da pessoa física residente no País, decorrente da venda de imóveis residenciais, desde que o produto da alienação seja aplicado na aquisição de imóveis residenciais, localizados no País, no prazo de 180 dias.

\footnotetext{
${ }^{23}$ Este valor já sofreu grande defasagem nos últimos anos, em razão da forte valorização imobiliária verificada no período.
} 


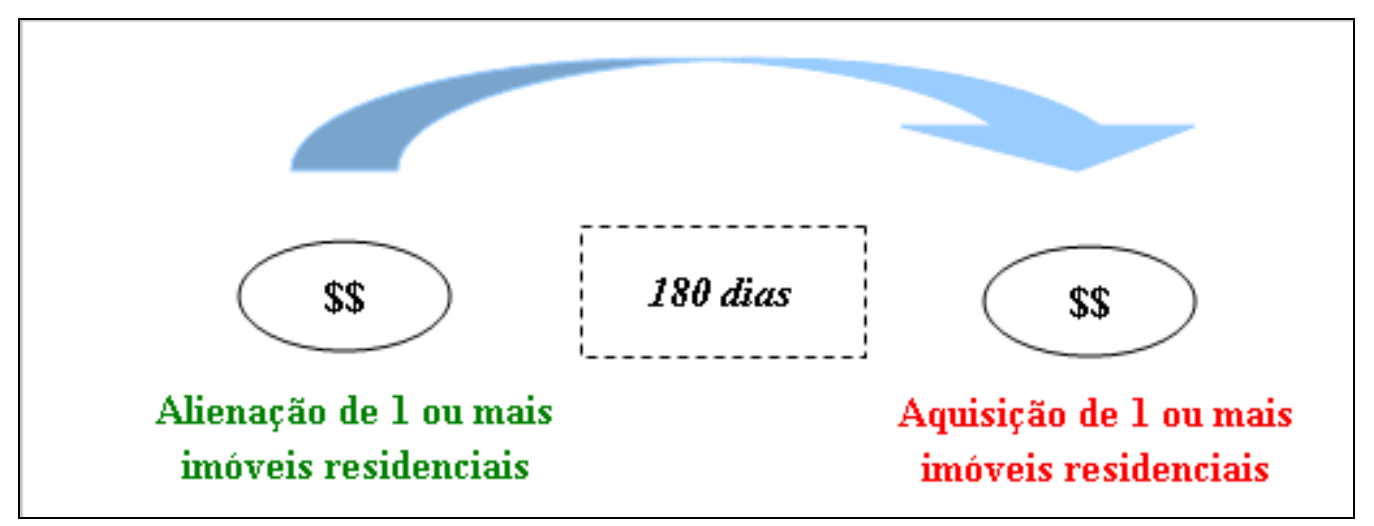

Trata-se de isenção criada para estimular o mercado imobiliário, pois incentiva os alienantes de imóveis residenciais a reinvestir o produto da venda na aquisição de novos imóveis residenciais.

Para fins de aplicação da isenção, deve-se analisar a legislação municipal que disciplina as edificações do local em que o imóvel se situa (plano diretor). Com efeito, considera-se imóvel residencial a unidade localizada em zona urbana ou rural que seja destinada para fins residenciais, conforme estabelecido no plano diretor do Município em que esteja localizado.

É possível aplicar essa isenção mesmo no caso de venda de mais de um imóvel, mas o prazo de 180 dias para o reinvestimento será contado a partir da data de celebração do contrato relativo à primeira operação. Também será possível o reinvestimento na aquisição de mais de um imóvel, desde que sejam residenciais.

Nos termos do $\S 10$ do artigo $2^{\circ}$ da IN/RFB no 599/05, a referida isenção é expressamente aplicável às hipóteses de (i) permuta de imóveis residenciais (ou seja, torna recebida será isenta de tributação) e de (ii) venda ou aquisição de imóvel residencial em construção ou na planta.

Caso o produto da venda seja aplicado parcialmente, o valor da parcela não aplicada deverá ser tributado proporcionalmente. A isenção, ora em análise, somente poderá ser aplicada uma vez a cada 5 anos.

Se as condições para a fruição do benefício não forem observadas, deverá ser pago o imposto sobre o ganho de capital, acrescido (i) de juros de mora (desde o segundo mês seguinte ao recebimento do valor) e (ii) multa (de mora ou de ofício), calculada a partir do primeiro dia útil do segundo mês seguinte ao recebimento do valor, caso o imposto não seja pago em 30 dias contado a partir do término do prazo de 180 dias. 
Ressalte-se que a IN/RFB n 599/2005, a pretexto de regulamentar a aplicação da presente isenção, estabeleceu algumas restrições não previstas na Lei. Neste sentido, o $\S 6^{\circ}$ do artigo $2^{\circ}$ determina que, na hipótese da venda de mais de um imóvel residencial dentro do prazo de 180 dias, consideram-se isentos somente os ganhos de capital auferidos nas vendas anteriores à primeira aquisição de imóvel residencial. Ocorre que o artigo 39 da Lei $n^{\circ}$ 11.196/05 não estabelece qualquer restrição neste sentido, motivo pelo qual a instrução normativa é manifestamente ilegal neste ponto.

Ademais, a Lei determina que a pessoa física "aplique o produto da venda na aquisição" de imóveis residenciais no prazo de 180 dias. Logo, o $\S 7^{\circ}$ do artigo $2^{\circ}$ da IN/RFB $n^{\text {o }}$ 599/2005 limitou a isenção apenas para os valores recebidos e os pagamentos feitos dentro do prazo de 180 dias. Confira-se:

(i) nas vendas a prestação $\mathrm{e}$ nas aquisições à vista, a isenção aplica-se à soma dos valores recebidos dentro do prazo de 180 (cento e oitenta) dias, contado da data da celebração do primeiro contrato de venda e até a(s) data(s) da(s) aquisição(ões) do(s) imóvel(is) residencial(is);

(ii) nas vendas à vista e nas aquisições a prestação, a isenção aplica-se aos valores recebidos à vista e utilizados nos pagamentos dentro do prazo de 180 (cento e oitenta) dias, contado da data da celebração do primeiro contrato de venda;

(iii) nas vendas e aquisições a prestação, a isenção aplica-se à soma dos valores recebidos e utilizados para o pagamento das prestações, ambos dentro do prazo de 180 (cento e oitenta) dias, contado da data da celebração do primeiro contrato de venda.

Ocorre que a Lei, ora em análise, estabelece apenas a necessidade de aplicação do produto da venda na aquisição de imóveis residenciais no prazo de 180 dias, sem qualquer previsão quanto a vendas ou aquisições a prestação. Dessa forma, a limitação estabelecida pela instrução normativa é manifestamente ilegal.

Isto porque, mesmo que a venda seja feita a prestação, o direito ao recebimento do preço já é considerado como resultado jurídico do negócio. O pagamento do preço correspondente à venda é apenas o cumprimento da obrigação pelo comprador, mas o fato de o pagamento ainda não ter ocorrido não é suficiente para desqualificar a existência do produto da venda (direito ao recebimento do preço).

Além disso, mesmo nas hipóteses de venda a prazo, a aplicação do valor correspondente ao preço de venda na aquisição de imóveis residenciais já é suficiente para a 
fruição da isenção sobre o ganho de capital, por estar cumprida a finalidade de reinvestimento em imóveis residenciais.

Da mesma forma, mesmo quando a aquisição é feita a prazo, já está configurada a obrigação jurídica de pagamento do preço. Com efeito, ainda que o pagamento não tenha sido integralmente efetuado, verifica-se a aplicação do produto da venda, porquanto este valor já está comprometido na aquisição do imóvel (ou seja, o produto da venda foi reinvestido em imóveis residenciais).

Por fim, registre-se que o $\S 11^{\circ}$ do artigo $2^{\circ}$ da IN/RFB $n^{\circ} 599 / 2005$ estabeleceu que a isenção, ora em análise, não é aplicável à venda ou à aquisição de terreno. De fato, o terreno em si não é considerado imóvel residencial, motivo pelo qual não é possível a aplicação do benefício fiscal para o produto de sua venda.

Contudo, esta restrição nem sempre será válida para fins de aquisição (aplicação do produto da venda). Isto porque um terreno pode ser adquirido para fins residenciais, mas é necessário que o projeto de construção do imóvel residencial seja registrado nos órgãos competentes dentro do prazo de 180 dias (hipótese semelhante à aquisição de imóvel residencial em construção ou na planta).

\subsubsection{1.e - Fator de Redução Geral}

Conforme já mencionado, o ganho de capital é um rendimento que se qualifica dentro do conceito de renda como acréscimo patrimonial. Dessa forma, a simples recomposição do valor da moeda no tempo (ou seja, a atualização monetária decorrente dos efeitos da inflação) não pode ser considerada renda tributável.

Com efeito, até o advento do Plano Real, em 1995, o custo de aquisição dos imóveis era corrigido monetariamente pela UFIR - procedimento esse que vigorou até 31/12/1995. Ocorre que, para bens adquiridos após essa data, foi vedada qualquer atualização monetária. $^{24}$

Foi somente com a Lei $\mathrm{n}^{\mathrm{o}} 11.196 / 2005$ que se estabeleceu um novo mecanismo para se corrigir o custo de aquisição dos bens adquiridos após 1995, para evitar que se considerasse, como ganho de capital, a mais valia que está apenas recompondo o efeito da inflação do período.

\footnotetext{
${ }^{24}$ Artigo 17 da Lei no 9.249/95.
} 
Assim, nos termos do artigo 40 dessa Lei, foram estabelecidos dois Fatores de Redução (FR) para a apuração da base de cálculo do imposto de renda sobre o ganho de capital na alienação de imóveis por pessoa física residente no País. Para o período de $1^{\circ}$ de janeiro de 1996 até 31 de novembro de 2005, considera-se o fator de redução de 0,60\% ao mês. Para o período de $1^{\circ}$ de dezembro de 2005 em diante, aplica-se o fator de redução de $0,35 \%$ ao mês. Confiram-se as fórmulas para os dois fatores de redução:

(i) $\quad$ FR1 $=1 / 1,0060^{\mathrm{m} 1}$, onde "m1" corresponde ao número de meses-calendário ou fração decorrido entre a data de aquisição do imóvel e o mês de novembro de 2005, inclusive na hipótese de a alienação ocorrer no referido mês (para os imóveis adquiridos até 31 de dezembro de 1995, o fator de redução será aplicado a partir de $1^{\circ}$ de janeiro de 1996);

(ii) $\quad \mathrm{FR} 2=1 / 1,0035^{\mathrm{m} 2}$, onde "m2" corresponde ao número de meses-calendário ou fração decorrido entre o mês de dezembro de 2005 (ou o mês da aquisição do imóvel, se posterior) e o de sua alienação.

Conforme visto no Capítulo 5.1.2.1, a transferência de direito de propriedade por doação ou herança poderá ser avaliada a valor de mercado, hipótese em que o montante, que superar o valor constante da Declaração de Bens do doador, será tributado como ganho de capital. Não obstante, aplicam-se, ao cálculo do ganho, os fatores de redução prevista no art. 40 da Lei $n^{\circ} 11.196 / 05$.

\subsubsection{1.f - Imóveis Adquiridos até 1988 - Redução de $5 \%$ a $100 \%$ do Ganho de Capital}

Outro importante fator de redução do ganho de capital foi o estabelecido pelo artigo 18 da Lei $n^{\circ} 7.713 / 88$, que previu percentuais regressivos de redução, conforme o ano de aquisição do bem imóvel. Dessa forma, para os imóveis adquiridos até 31 de dezembro de 1988, foram estabelecidos os seguintes percentuais de redução: 


\begin{tabular}{|c|c||c|c||}
\hline $\begin{array}{c}\text { Ano de Aquisição } \\
\text { ou Incorporação }\end{array}$ & $\begin{array}{c}\text { Percentual } \\
\text { de Redução }\end{array}$ & $\begin{array}{c}\text { Ano de Aquisição } \\
\text { ou Incorporação }\end{array}$ & $\begin{array}{c}\text { Percentual } \\
\text { de Redução }\end{array}$ \\
\hline \hline 1969 & $100 \%$ & 1979 & $50 \%$ \\
\hline \hline 1970 & $95 \%$ & 1980 & $45 \%$ \\
\hline 1971 & $90 \%$ & 1981 & $40 \%$ \\
\hline 1972 & $85 \%$ & 1982 & $35 \%$ \\
\hline 1973 & $80 \%$ & 1983 & $30 \%$ \\
\hline \hline 1974 & $75 \%$ & 1984 & $25 \%$ \\
\hline 1975 & $70 \%$ & 1985 & $20 \%$ \\
\hline \hline 1976 & $65 \%$ & 1986 & $15 \%$ \\
\hline \hline 1977 & $60 \%$ & 1987 & $10 \%$ \\
\hline \hline 1978 & $55 \%$ & 1988 & $5 \%$ \\
\hline \hline
\end{tabular}

Conforme se verifica na tabela acima, quanto maior o tempo de permanência do imóvel no patrimônio do contribuinte, maior é a redução do ganho de capital aplicável, podendo a chegar a $100 \%$. Como bem observa Henry Tilbery, a intenção do legislador foi "aliviar a carga tributária em ordem decrescente conforme os anos de posse, presumindo menor intensidade de eventual intenção especulativa". ${ }^{25}$

Na hipótese em que a alienação de imóvel, cuja edificação, ampliação ou reforma tenha sido iniciada até 31 de dezembro de 1988, em terreno próprio, será considerado o ano de aquisição do terreno para efeito de aplicação do percentual de redução a todo o imóvel.

$\mathrm{Na}$ alienação de imóvel, cuja construção, ampliação ou reforma tenha sido iniciada a partir de janeiro de 1989, em imóvel adquirido até 31 de dezembro de 1988, o percentual de redução aplica-se apenas à proporção do ganho de capital correspondente à parte existente em 31 de dezembro de 1988.

No caso de imóveis havidos por herança ou legado, cuja abertura da sucessão ocorreu até 31 de dezembro de 1988, a data para a aplicação da redução percentual se reporta ao ano da abertura da sucessão, mesmo que a avaliação e partilha ocorram em anos posteriores.

Por fim, conforme visto no Capítulo 5.1.2.1, a transferência de direito de propriedade por doação ou herança poderá ser avaliada a valor de mercado, hipótese em que o montante que superar, o valor constante da Declaração de Bens do doador, será tributado como

${ }^{25}$ TILBERY, Henry. O novo imposto de renda no Brasil: comentários à Lei $n^{\circ} 7.713 / 88$ ajustado aos novos métodos de atualização monetária. São Paulo: IOB, 1989, p. 73. 
ganho de capital. Não obstante, para os bens imóveis adquiridos até 31 de dezembro de 1988, aplica-se a redução prevista no art. 18 da Lei no $7.713 / 88$ ao cálculo do ganho. ${ }^{26}$

\subsubsection{2 - Tributação da Cessão da Posse do Imóvel (Locação e Outros)}

Conforme já mencionado, os rendimentos provenientes da cessão da posse de imóvel, como é a locação, estão sujeitos ao Recolhimento Mensal Obrigatório - RMO, comumente denominado de "carnê-leão" (a não ser que sejam pagos por PJ). Com efeito, a apuração e recolhimento do imposto devem ser feitos mensalmente, pelo próprio contribuinte (autorrecolhimento).

Nos termos do artigo 21 da Lei $n^{\circ} 4.506 / 64$, são classificados como aluguéis os rendimentos de qualquer espécie oriundos da ocupação, uso ou exploração de bens corpóreos, tais como o aforamento (enfiteuse), a locação ou a sublocação, o arrendamento ou o subarrendamento, o direito de uso ou passagem de terrenos, seus acrescidos e benfeitorias, inclusive construções de qualquer natureza.

Também são classificados como aluguéis todas as espécies de rendimentos percebidos pela ocupação, uso, fruição ou exploração dos bens imóveis, tais como: (i) as luvas, os prêmios, as gratificações ou quaisquer outras importâncias pagas ao locador, ou cedente do direito, pelo contrato celebrado; e (ii) as benfeitorias e quaisquer melhoramentos realizados no bem locado e as despesas para preservação dos direitos cedidos, se previstas no contrato e fizerem parte da compensação pelo uso do bem ou direito. ${ }^{27}$

A base de cálculo para o pagamento mensal é o total dos rendimentos recebidos no mês, sujeitos ao recolhimento pelo "carnê-leão". Nos termos do artigo 14 da Lei no 7.739/89, não integrará a base de cálculo do imposto: (i) o valor dos impostos, taxas e emolumentos incidentes sobre o bem que produzir o rendimento, (ii) o aluguel pago pela locação do imóvel sublocado, (iii) as despesas pagas para cobrança ou recebimento do rendimento e (iv) as despesas de condomínio.

Sobre a base de cálculo, serão aplicadas as alíquotas de 0\%, 7,5\%, 15\%, 22,5\% e $27,5 \%$, incidentes sobre as faixas de rendimento estabelecidas na tabela progressiva. Dessa forma, considerando-se a alíquota máxima da tabela progressiva, a tributação do aluguel na

\footnotetext{
${ }^{26}$ Ressalte-se novamente: a avaliação a valor de mercado de bens na doação ou herança sofre a incidência de dois impostos: o IRPF e o ITCMD. Dessa forma, mesmo que o ganho de capital seja isento do imposto de renda, devese sopesar a incidência do ITCMD no cálculo da carga tributária total.

${ }^{27}$ Artigo 23, inciso IV, da Lei no ${ }^{4} .506 / 64$.
} 
pessoa física é geralmente mais onerosa do que a tributação pela pessoa jurídica no lucro presumido, a qual estará sujeita a uma alíquota efetiva de 7,49\% ou 14,53\% (conforme será demonstrado adiante).

Ressalte-se que, diferentemente da tributação isolada verificada para o ganho de capital, os rendimentos decorrentes de aluguel são tributados a título de antecipação do que será devido ao final do ano-calendário, antecipação esta que deverá ser compensada na apuração da CAO. Ocorre que, mesmo que a pessoa física opte pelo desconto simplificado na CAO, os rendimentos decorrentes de aluguéis recebidos poderão ser descontados pelos abatimentos previstos no artigo 14 da Lei $\mathrm{n}^{\mathrm{o}} 7.739 / 89$.

Conforme já mencionado (Capítulo 1.2.2.1), o inciso VI do artigo 23 da Lei ${ }^{\circ}$ 4.506/64 pretendeu estabelecer como hipótese de tributação pela pessoa física o "valor locativo do prédio urbano construído, quando cedido seu uso gratuitamente". Contudo, a referida Lei não estabeleceu a forma de apuração da base de cálculo para essa renda imputada, o que afasta sua possibilidade de cobrança em razão do princípio da legalidade. ${ }^{28}$

Não obstante, quando o imóvel for ocupado por seu proprietário ou cedido gratuitamente para uso do cônjuge ou de parentes de primeiro grau, o valor locativo do prédio construído é considerado isento (inciso III do artigo $6^{\circ}$ da Lei $n^{\circ} 7.713 / 88$ ).

\subsubsection{3 - Securitização de Recebíveis e Tributação dos Títulos de Crédito Imobiliários}

Conforme destacado anteriormente (capítulo 3.5.3 e 3.5.4), a securitização de recebíveis é uma alternativa ao financiamento da atividade imobiliária, uma vez que é possível a captação de recursos no mercado de capitais para antecipar o recebimento de créditos imobiliários. Nos termos do artigo $8^{\circ}$ da Lei do SFI, a securitização de créditos imobiliários é a operação pela qual a companhia securitizadora emite uma série de títulos de crédito expressamente vinculados a créditos imobiliários (recebíveis decorrentes de venda a prazo de bens, serviços ou operações imobiliárias).

Trata-se de um instrumento de extrema relevância tanto para construtores/incorporadores (pois permite a securitização de créditos próprios) quanto para as instituições financeiras (que podem obter maior liquidez para conceder novos financiamentos).

\footnotetext{
${ }^{28} \mathrm{O}$ artigo $49, \S 1^{\circ}$, do RIR/99 estabeleceu, como base de cálculo do valor locativo, o equivalente a $10 \%$ do valor venal de imóvel cedido, ou do valor constante da guia do Imposto Predial e Territorial Urbano - IPTU correspondente ao ano-calendário da declaração. Contudo, não há previsão legal para referida base de cálculo.
} 
Como medida de incentivo à securitização de créditos imobiliários, a Lei $\mathrm{n}^{\mathrm{o}}$ 11.033/04 (artigo $3^{\circ}$ ) isentou do imposto de renda na fonte e na declaração de ajuste anual das pessoas físicas, a remuneração produzida por: (i) Letras Hipotecárias - LH, (ii) Certificados de Recebíveis Imobiliários - CRI e (iii) Letras de Crédito Imobiliário - LCI.

\subsubsection{4 - Equiparação da Pessoa Física à Pessoa Jurídica}

Conforme já mencionado, o Direito Tributário pode recepcionar diversos conceitos previstos no Direito Privado. Contudo, o legislador tributário não está limitado a esses conceitos, podendo estabelecer conceitos próprios e específicos para fins de tributação (confira-se o Capítulo 1.4.2).

Este é o caso da equiparação da pessoa física à pessoa jurídica (artigo $150 \mathrm{e}$ seguintes do RIR/99). Em regra, são equiparadas à pessoa jurídica, as pessoas físicas que explorem, habitual e profissionalmente, em nome individual, qualquer atividade econômica de natureza civil ou comercial, com o fim especulativo de lucro, mediante venda a terceiros de bens ou serviços. ${ }^{29}$

São exceções a essa regra, dentre outros, os corretores e as pessoas físicas que explorem individualmente contratos de empreitada unicamente de lavor ${ }^{30}$ (qualquer que seja a natureza) e também aquelas que executem trabalhos arquitetônicos, topográficos, terraplenagem, construções de alvenaria e outros congêneres, serviços de utilidade pública, tanto de estudos como de construções. ${ }^{31}$

Especificamente nos casos de incorporações imobiliárias ou loteamentos com ou sem construção, o Decreto-lei no 1.381/74 determina que será equiparada à pessoa jurídica:

(i) a pessoa física que assumir a iniciativa e a responsabilidade de incorporação ou loteamento em terrenos urbanos ou rurais, quando documentação referente à incorporação ou loteamento esteja arquivada no Registro Imobiliário;

(ii) o titular de terrenos ou glebas de terra que outorgue mandato a construtor ou corretor de imóveis com poderes para alienação de frações ideais ou

\footnotetext{
${ }^{29}$ Na Solução de Consulta no 104/99, a Receita Federal entendeu que a locação de imóveis próprios não configura hipótese de equiparação a pessoa jurídica.

${ }^{30} \mathrm{Sem}$ fornecimento de materiais, conforme capítulo 3.3.2.

${ }^{31}$ Artigo 150 do RIR/99.
} 
lotes de terreno, quando documentação referente à incorporação ou loteamento esteja arquivada no Registro Imobiliário;

(iii) o proprietário ou titular de terrenos ou glebas de terra que, sem efetuar o registro dos documentos de incorporação ou loteamento, neles promova a construção de prédio com mais de 2 unidades imobiliárias ou a execução de loteamento e inicie a alienação das unidades imobiliárias ou dos lotes de terreno antes de decorrido o prazo de 60 meses contados da data da averbação, no Registro Imobiliário, da construção do prédio ou da aceitação das obras do loteamento.

Equipara-se a loteamento, para fins de equiparação da pessoa física à pessoa jurídica, a subdivisão ou desmembramento de imóvel rural em mais de dez lotes, ou a alienação de mais de dez quinhões ou frações ideais desse imóvel.

A equiparação ocorrerá: (i) na data de arquivamento da documentação do empreendimento, (ii) na data da primeira alienação, caso não tenham sido registrados os documentos de incorporação ou loteamento, ou (iii) na data em que ocorrer a subdivisão ou desmembramento do imóvel em mais de dez lotes ou a alienação de mais de dez quinhões ou frações ideais desse imóvel.

Após a equiparação, a pessoa jurídica deverá apurar o lucro ao término de cada período de apuração, que compreenderá: (i) o resultado da operação que determinar a equiparação, (ii) o resultado de incorporações ou loteamentos promovidos pelo titular da empresa individual a partir da data da equiparação, abrangendo o resultado das alienações de todas as unidades imobiliárias ou de todos os lotes de terreno integrantes do empreendimento, (iii) as atualizações monetárias do preço das alienações de unidades e (iv) os juros convencionados sobre a parte financiada do preço das alienações contratadas a partir da data da equiparação, bem como as multas e juros de mora recebidos por atrasos de pagamento.

É importante destacar que não serão computados, para efeito de apuração do lucro da empresa individual: (i) os rendimentos de locação, sublocação ou arrendamento de quaisquer imóveis, percebidos pelo titular da empresa individual, bem como os decorrentes da exploração econômica de imóveis rurais, ainda que sejam imóveis cuja alienação acarrete a inclusão do correspondente resultado no lucro da empresa individual; e (ii) outros rendimentos percebidos pelo titular da empresa individual. 
Portanto, a tributação da pessoa física como pessoa jurídica somente se aplica às operações que ensejam essa equiparação. Os demais rendimentos da pessoa física equiparada à jurídica continuarão sendo tributados como renda da pessoa física. Neste sentido, caso sejam alienados imóveis não integrantes da incorporação ou loteamento (alienação eventual), ela será tributada como ganho de capital pela pessoa física, inclusive no que tange às hipóteses de isenção e de redução da base de cálculo já mencionadas.

O término da equiparação ocorrerá quando a pessoa física não promover nenhum empreendimento de incorporação ou loteamento, nem efetuar nenhuma alienação de unidades objeto desses empreendimentos, durante o prazo de 36 meses consecutivos. A partir do término deste prazo, a pessoa física deixará de ser equiparada à pessoa jurídica, salvo quanto aos efeitos tributários das operações então em andamento.

\section{2 - Tributação da Renda Pelas Pessoas Jurídicas}

No que tange à base de cálculo do Imposto sobre a Renda das Pessoas Jurídicas (IRPJ), estabelece o artigo 44 do CTN que será o montante real, presumido ou arbitrado da renda ou dos proventos tributáveis. ${ }^{32}$ Com efeito, passa-se a analisar as regras gerais de apuração dessas possíveis bases de cálculo, considerando, sobretudo, os critérios gerais de reconhecimento e mensuração desse lucro. Posteriormente, serão analisados critérios específicos de reconhecimento e mensuração do lucro para os contribuintes da atividade imobiliária.

\subsection{1 - Aspectos Gerais de Tributação da PJ}

\subsubsection{1 - Regime Tributário de Transição - RTT}

Conforme já mencionado (Capítulo 2.2), a Lei no 11.638/07 estabeleceu diversas alterações na legislação societária, com o intuito de harmonizar as normas contábeis brasileiras com os padrões internacionais. De fato, foram realizadas alterações contábeis societárias referentes (i) à apuração do patrimônio das empresas e (ii) sua variação no tempo (lucro ou

\footnotetext{
32 “Art. 44. A base de cálculo do imposto é o montante, real, arbitrado ou presumido, da renda ou dos proventos tributáveis." (g.n.)
} 
prejuízo), de forma que a contabilidade societária se tornasse completamente independente das normas de contabilidade fiscal.

Ocorre que tais alterações nas regras de Direito Societário trouxeram certa insegurança aos contribuintes quanto a eventuais reflexos tributários. Por isso, foi editada a Lei $\mathrm{n}^{\mathrm{o}}$ 11.941/09, que também alterou e revogou alguns dispositivos da Lei das S/A, mas instituiu o Regime Tributário de Transição - RTT para neutralizar os efeitos tributários decorrentes da adoção dos novos métodos e critérios contábeis. ${ }^{33}$

Trata-se, portanto, de uma regra geral de neutralização das alterações ocorridas em conceitos de Direito Contábil Societário (Direito Privado), para que não gerem efeitos para fins tributários. Além da apuração do lucro real, este regime também é aplicável na apuração do lucro presumido, arbitrado, CSLL, PIS e COFINS.

Dessa forma, a aplicação do RTT representa a introdução de uma etapa intermediária na apuração do lucro tributável. Confira-se o disposto no artigo 16 da Lei $\mathrm{n}^{\circ}$ 11.941/09:

“Art. 16. As alterações introduzidas pela Lei $\mathrm{n}^{\circ}$ 11.638, de 28 de dezembro de 2007, e pelos arts. 37 e 38 desta Lei que modifiquem o critério de reconhecimento de receitas, custos e despesas computadas na apuração do lucro líquido do exercício definido no art. 191 da Lei no 6.404, de 15 de dezembro de 1976, não terão efeitos para fins de apuração do lucro real da pessoa jurídica sujeita ao RTT, devendo ser considerados, para fins tributários, os métodos e critérios contábeis vigentes em 31 de dezembro de 2007." (g.n.)

Conforme a previsão legal mencionada, apura-se inicialmente o Lucro Líquido Societário a partir das atuais regras previstas na Lei das S/A, ou seja, com as alterações promovidas pela Lei $n^{\circ} 11.638 / 07$ e pela Lei $n^{\circ} 11.941 / 09$, bem como com as normas expedidas pela CVM para compatibilizar a legislação com os padrões internacionais de contabilidade (em conformidade também com as alíneas $a$ e $b$ do inciso I do artigo 17 da Lei $\mathrm{n}^{\circ}$ 11.941/09).

Até o advento do RTT, era o lucro líquido societário que servia de base para a apuração do lucro real. Com o advento do RTT, passa a existir uma etapa intermediária no processo de apuração do lucro tributável. Antes da apuração da base de cálculo do imposto de renda, realizam-se os ajustes no lucro líquido societário para que sejam expurgados os efeitos

\footnotetext{
${ }^{33}$ Lei no 11.941/09 “Art. 15. Fica instituído o Regime Tributário de Transição - RTT de apuração do lucro real, que trata dos ajustes tributários decorrentes dos novos métodos e critérios contábeis introduzidos pela Lei no 11.638 , de 28 de dezembro de 2007, e pelos arts. 37 e 38 desta Lei."
} 
das alterações legislativas, apurando-se o que passa a denominar-se de lucro líquido fiscal (em conformidade com os métodos e critérios contábeis vigentes em 31 de dezembro de 2007).

Assim, pode-se dizer que o RTT pressupõe a apuração do lucro líquido societário e a realização de adições e exclusões para a apuração do lucro líquido fiscal:



Conforme estabelecido pela IN/RFB no 949/09, o lucro líquido fiscal é apurado por meio do Controle Fiscal Contábil de Transição (FCONT), no qual são escrituradas as contas patrimoniais e de resultado, em conformidade com os critérios contábeis vigentes em 31/12/2007. O FCONT é o instrumento para a realização dos registros previstos no inciso II do $\S 2^{\circ}$ do art. $8^{\circ}$ do Decreto-Lei $n^{\circ} 1.598 / 77$ (livros fiscais), destinado à apuração do lucro real, em conformidade com o RTT.

Conforme disposto no inciso II artigo 17 da Lei $\mathrm{n}^{\circ} 11.941 / 09$, as diferenças apuradas entre o lucro líquido societário e o lucro líquido fiscal comporão ajuste específico a ser efetuado no Livro de Apuração do Lucro Real (LALUR). Com efeito, a apuração do lucro real parte do lucro líquido fiscal, para, posteriormente, realizarem-se os ajustes previstos na legislação tributária a título de adição, exclusão e compensação, os quais também devem ser registrados no LALUR (inciso III do artigo 17 da Lei $\mathrm{n}^{\circ} 11.941 / 09$ ).

Graficamente, pode-se representar o processo de apuração do lucro tributável da seguinte forma:

Lucro Líquido Fiscal - apurado

conforme regras contábies vigentes até






\subsubsection{1.a - Métodos e Critérios Contábeis Vigentes em 31/12/2007}

A aplicação do RTT desperta diversos questionamentos, dentre as quais destaca-se o seguinte: Quais são os métodos e critérios contábeis vigentes em 31 de dezembro de 2007 ?

De fato, até o advento das Leis $n^{\circ} 11.638 / 07$ e $n^{\circ} 11.941 / 09$, não havia uma distinção muito clara entre os métodos e critérios contábeis societários e fiscais. É neste sentido que se falava em um BR GAAP, como um conjunto de regras contábeis próprias adotadas no Brasil, fortemente influenciada pela legislação tributária: ${ }^{34}$

\footnotetext{
“Assim, o trabalho da Contabilidade tinha autonomia, mas não independência. Isso porque estava sob constante supervisão e intervenção da perspectiva fiscal, que dependia de seu trabalho. Tal cenário criou o que se convencionou apelidar de 'BR GAAP', um sistema de contabilização único no Brasil, fortemente influenciado pelo tratamento tributário brasileiro e pouco informativo para qualquer um que não tenha experiência com nosso sistema. (...)”
}

Dessa forma, há duas hipóteses distintas de alteração legislativa que são passíveis de reversão para fins de apuração do lucro líquido fiscal (objeto do RTT).

A primeira hipótese é aquela em que os usos e costumes contábeis societários (prática contábil societária), vigentes em 31/12/2007, eram independentes das normas contábeis fiscais. Dessa forma, o método ou critério contábil era aquele previsto na legislação societária e que acabou sendo revogado ou modificado pela legislação superveniente (alteração de regras contábeis societárias propriamente ditas).

Este é o caso, por exemplo, do registro de bens imóveis como propriedade para investimento, nos termos do CPC 28 (conforme Capítulo 4.3.2). De fato, os métodos e critérios contábeis vigentes em 31/12/2007 determinavam o registro dos bens imóveis no ativo apenas como estoque ou imobilizado. Com base nas novas regras contábeis, os imóveis podem ser registrados também como investimento.

Outro exemplo de alterações de cunho eminentemente societário foram os critérios de avaliação de bens do ativo e do passivo. Neste sentido, um dos critérios societários para a avaliação de bens do ativo passou a ser o valor justo (inciso I e $\S 1^{\circ}$ do artigo 183 da Lei das S/A), critério societário não vigente em 31/12/2007. No mesmo sentido, o bem do ativo decorrente de operação realizável a longo prazo (inciso VIII do artigo 183) e obrigação,

\footnotetext{
${ }^{34}$ SCHOUERI, Luís Eduardo e TERSI, Vinícius Feliciano. As Inter-relações entre a Contabilidade e o Direito: atender ao RTT significa obter neutralidade tributária? In: MOSQUERA, Roberto Quiroga e LOPES, Alexsandro Broedel (coord.). Controvérsias Jurídico-Contábeis (Aproximações e Distanciamentos). $2^{\circ}$ Vol. São Paulo : Dialética, 2011, pp. 112 e113.
} 
encargo ou risco do passivo não circulante (inciso II do artigo 184 da Lei nas S/A) passaram a ser ajustados a valor presente.

Com efeito, essas alterações realizadas nos métodos e critérios contábeis societários vigentes em 31/12/2007 devem ser revertidas na apuração do lucro líquido fiscal, por força da aplicação do RTT.

A segunda e principal hipótese de alteração dos métodos e critérios societários é aquela em que os usos e costumes contábeis societários vigentes em 31/12/2007 eram definidos pela legislação fiscal. Ou seja, são práticas contábeis previstas na legislação tributária, mas que eram adotadas como regras societárias.

Trata-se do fenômeno da interpenetração normativa do Direito Tributário no Direito Privado (analisada no Capítulo 1.4.2.4), em que o Direito Tributário ultrapassa o campo da tributação, influenciando outros ramos do Direito.

Nestes casos, verifica-se que o lucro líquido fiscal deve ser apurado de acordo com os métodos e critérios contábeis previstos na legislação tributária, pois a eles se submetia também a contabilidade societária.

A título exemplificativo, mencione-se que a contabilidade societária no Brasil praticada até 31/12/2007 se submetia às normas contábeis tributárias sobre depreciação de bens do ativo, o que foi reconhecido no ICPC n 10 , que trata da aplicação do CPC 27 (ativo imobilizado) e do CPC 28 (propriedade para investimento):

“Taxas de depreciação atualmente utilizadas no Brasil

9. Uma prática utilizada por muitas entidades no Brasil foi a de considerar, como taxas de depreciação, aquelas aceitas pela legislação tributária. Segundo essa legislação, “A taxa anual de depreciação será fixada em função do prazo durante o qual se possa esperar utilização econômica do bem pelo contribuinte na produção de seus rendimentos" (Art. 310 do vigente Regulamento do Imposto de Renda - R.I.R./99, por remissão à Lei $n^{\circ} 4.506$, de 1964, art. 57, § 2º. Também, segundo a legislação fiscal, “A Secretaria da Receita Federal publicará periodicamente o prazo de vida útil admissível, em condições normais ou médias, para cada espécie de bem, ficando assegurado ao contribuinte o direito de computar a quota efetivamente adequada às condições de depreciação de seus bens, desde que faça a prova dessa adequação, quando adotar taxa diferente" (art. 310, § $1^{\circ}$, do R.I.R./99, por remissão à Lei $\mathrm{n}^{\circ} 4.506$, de 1964 , art. 57, § $3^{\circ}$ ).

10. Observa-se que a legislação tributária procurou se basear em vidas úteis econômicas em condições normais ou médias. Além dessa regra geral, a legislação tributária permite acréscimos substanciais nessas taxas no caso de utilização por dois ou três turnos de 
trabalho, sem necessariamente haver comprovação de ter havido redução na vida útil desses ativos nessa mesma proporção. Isso tudo pode ter provocado distorções nos valores contábeis de alguns ativos, especialmente pela exigência anterior da Secretaria da Receita Federal do Brasil - RFB da contabilização desses valores adicionais para seu aproveitamento fiscal. Já em algumas outras situações houve, a título de incentivo fiscal, depreciações em dobro ou o cômputo de toda a depreciação no próprio ano em que o bem foi adquirido. Nessas outras situações, as entidades normalmente fizeram o registro da depreciação incentivada em livros fiscais, sem alterar a escrituração societária.

11. Dessa forma, como regra geral, a utilizacão das tabelas emitidas pela RFB tem representado a intenção do fisco e das empresas em utilizar prazos estimados de vidas úteis econômicas, com base nos parâmetros que partiram de estudos no passado. Pode ter havido, em muitas situações, mesmo com a utilização dessas taxas admitidas fiscalmente, razoável aproximação com a realidade dos ativos. Todavia, podem ter ocorrido significativos desvios." (g.n.)

Com efeito, verifica-se que os métodos e critérios contábeis vigentes em 31/12/2007 correspondiam à utilização das taxas de depreciação em conformidade com as tabelas emitidas pela RFB, que se pautavam em prazos estimados de vida útil econômica (prazos estabelecidos com base em estudos de vida útil média de cada espécie de bem), sendo este o parâmetro para a apuração do lucro líquido fiscal.

Ocorre que, com as alterações promovidas na Nova Contabilidade, deixou de ser possível a utilização de taxas de depreciação prefixadas. De fato, de acordo com a legislação atualmente em vigor, "o valor depreciável de um ativo deve ser apropriado de forma sistemática ao longo da sua vida útil estimada" (item 50 do CPC 27 - Ativo Imobilizado) parâmetro para a apuração do lucro líquido societário.

No que tange às regras para a apuração do lucro nas atividades de compra e venda, loteamento, incorporação e construção de imóveis, surge a dúvida sobre quais os métodos e critérios contábeis vigentes em 31/12/2007. De fato, conforme analisado no Capítulo 4.6, já havia norma societária própria para essas atividades, que determinava o registro do lucro pelo regime de competência, nos termos da Resolução do Conselho Federal de Contabilidade - CFC $n^{\circ}$ 963/2003, que aprovou as Normas Brasileiras de Contabilidade NBC T 10.5 - Dos Aspectos Contábeis Específicos em Entidades Imobiliárias.

Não obstante, a legislação tributária estabelecia também métodos e critérios contábeis próprios para a apuração do lucro dessas atividades para fins fiscais, os quais determinam a apuração do lucro pelo regime de caixa, nos termos dos artigos 27 a 29 do DL n ${ }^{\circ}$ 1.598/77, regulamentados pela IN/RFB nº 84/79 (que será objeto de análise no Capítulo 5.3.1). 
Neste caso específico, apesar da tentativa de implantação de métodos e critérios contábeis próprios para fins societários, verifica-se que os métodos e critérios contábeis vigentes em 31/12/2007 eram aqueles determinados pela legislação fiscal. Isto porque a Resolução CFC 963/03 teve aplicação muito restrita pelas empresas brasileiras, em geral aquelas de capital aberto. Na prática contábil em geral, permaneceu válida a norma tributária (IN/RFB 84/79). ${ }^{35}$

\subsubsection{1.b - Conflitos Interpretativos entre as Contabilidades Societária e Fiscal}

Outra importante questão concernente às alterações introduzidas pelas Leis $n^{\circ}$ 11.638/07 e 11.941/09 é saber até que ponto as informações contábeis fornecidas pela atual Contabilidade Societária são efetivamente neutras para fins fiscais. Isto porque os mecanismos criados para a realização dos registros contábeis tributários (FCONT e LALUR) suscitam algumas dúvidas de como devem ser resolvidas algumas hipóteses específicas de conflitos interpretativos entre essas duas contabilidades.

Neste sentido, é importante reportar-se à natureza do relacionamento entre o Direito Privado e o Direito Tributário. Conforme visto no Capítulo 1.4.2, dentre as formas de relacionamento entre esses dois ramos do Direito, destacam-se: (i) a recepção do conceito de Direito Privado pelo Direito Tributário e (ii) a transformação do conceito de Direito Privado pelo Direito Tributário.

Com efeito, quando a legislação tributária tiver conceito próprio para determinado método ou critério contábil, verifica-se que houve a sua transformação pelo Direito Tributário. Ou seja, o método ou critério contábil tem fundamento de validade extraído diretamente da legislação tributária, independentemente do que dispõe a legislação societária.

Nestes casos em que há a transformação dos conceitos de Contabilidade Societária, as alterações promovidas na legislação societária para se adequarem aos padrões internacionais não são suficientes para a alteração do tratamento tributário, pois continuam em vigor as regras tributárias específicas.

\footnotetext{
${ }^{35}$ Neste contexto, vale mencionar a manifestação da Receita Federal no sentido de que a norma societária não seria aplicável para fins de tributação (nem pelo regime de competência): Ato Declaratório Interpretativo $\mathrm{ADI} / \mathrm{RFB} \mathrm{n}^{\circ}$ 18/05: "Artigo único. A pessoa jurídica que comprar imóvel para venda ou promover empreendimento de desmembramento ou loteamento de terrenos, incorporação imobiliária ou construção de prédio destinado à venda, deverá observar o disposto nos arts. 27 a 29 do Decreto-lei $n^{o} 1.598$, de 26 de dezembro de 1977, e no art. 30 da Lei $n^{\circ}$ 8.981, de 20 de janeiro de 1995, não se aplicando, para fins tributários, as disposições contidas nas NBC T 10.5 - Entidades Imobiliárias, aprovadas pela Resolução $n^{o}$ 963, de 16 de maio de 2003, do Conselho Federal de Contabilidade." (g.n.)
} 
Este é o caso, por exemplo, das regras de depreciação dos bens do ativo. Conforme mencionado no Capítulo anterior, a legislação tributária traz regras próprias para o registro dos encargos de depreciação para fins fiscais (às quais se submetia a contabilidade societária). Atualmente, a nova Contabilidade Societária não se pauta mais pelos critérios fiscais (métodos e critérios contábeis societários que foram transformados pelo Direito Tributário).

Dessa forma, mesmo que não existisse o RTT, as regras fiscais para a depreciação de bens do ativo continuariam a seguir o disposto na legislação tributária, pois as alterações promovidas pelas novas regras de Contabilidade Societária não revogaram as normas de Contabilidade Fiscal.

Contudo, nos casos em que a legislação tributária importa os conceitos da Contabilidade Societária (fenômeno da recepção), não é possível falar em neutralidade tributária propriamente dita, pois mesmo a aplicação do RTT não é capaz de impedir que as alterações promovidas pela nova Contabilidade Societária deixem de gerar resultados.

É o que ocorre com os dividendos que, com o advento da Lei $\mathrm{n}^{\circ}$ 9.249/95 (artigo 10), passaram a ser isentos para fins tributários. No entanto, o conceito de dividendo é importado da legislação societária pela legislação tributária, com a ressalva feita à apuração dos Juros sobre Capital Próprio - JCP (previsto no artigo $9^{\circ}$ da Lei $n^{\circ}$ 9.249/95), em que os dividendos para fins societários são "transformados” em juros para fins fiscais.

Assim sendo, é muito provável que a apuração de dividendos por uma sociedade poderá sofrer alterações em decorrência da aplicação dos conceitos trazidos pela nova Contabilidade Societária, já que muitos critérios de reconhecimento e mensuração foram alterados. Portanto, esses dividendos, definidos pelas novas regras contábeis societárias, serão isentos para a pessoa jurídica ou física que os recebe, pois se trata de um conceito recepcionado pela legislação tributária. Ou seja, trata-se de hipótese em que as alterações promovidas na legislação societária geram reflexos fiscais. ${ }^{36}$

Em face das discussões expostas, é interessante citar a tipologia de conflitos entre a nova Contabilidade Societária e a legislação tributária apresentada por Luís Eduardo Schoueri e Vinícius Feliciano Tersi. ${ }^{37}$

\footnotetext{
${ }^{36}$ Neste sentido, confira-se SCHOUERI, Luís Eduardo e TERSI, Vinícius Feliciano. Cf. op. cit. (nota 34), pp. 126-129.

${ }^{37}$ SCHOUERI, Luís Eduardo e TERSI, Vinícius Feliciano. Cf. op. cit. (nota 34), p. 115.
} 
Estes autores mencionam três categorias de conflitos interpretativos, as quais poderão ser classificadas nas duas categorias adotadas no presente trabalho:

(i) alteração da base contábil (hipótese de recepção adotada no presente trabalho) em que "o Direito Tributário 'importa' conceitos da Contabilidade, bem como os métodos de controle contábeis, e lhes dá determinado tratamento tributário";

(ii) contraste de conceitos de mesma determinação (hipótese de "transformação") em que "o Direito Tributário contém um conceito cuja denominação também existe na Contabilidade"; e

(iii) eliminação de alternativa contábil, em que "a Contabilidade previa originalmente determinada forma de contabilização, para a qual era atribuído um tratamento tributário correspondente. Embora esse tratamento tributário permaneça vigente, a possibilidade se de fazer aquela contabilização não mais existe. Os mesmos fatos terão que ser contabilizados de outra maneira."

Contextualizando essa terceira categoria com os conceitos adotados no presente trabalho, verifica-se que se pode estar diante de uma hipótese de recepção ou de transformação. Este é o caso das contas de reserva de reavaliação, de ativo diferido e de resultados de exercícios futuros, extintas da Contabilidade Societária.

Nestes casos: (i) quando a legislação tributária fizer remissão expressa à necessidade de registro nas referidas contas nos termos estabelecidos pela legislação societária, tem-se uma hipótese de recepção (em que as alterações societárias serão recepcionadas pela legislação tributária); e (ii) quando o registro das informações contábeis nas referidas contas for determinado pela própria legislação tributária, tem-se uma hipótese de transformação (ou seja, deve-se manter o tratamento previsto na legislação tributária para fins fiscais). ${ }^{38}$

Conforme destacam Luís Eduardo Schoueri e Vinícius Feliciano Tersi, existe uma grande dificuldade de aplicar o RTT nos casos em que uma conta contábil foi extinta para fins societários. Isto porque o FCONT, segundo o artigo $1^{\text {o }}$ da IN/RFB n 967/2009, é apenas um programa em que (i) são expurgados os lançamentos contábeis para fins societários que tenham

38 Neste sentido, confira-se HILÚ NETO, Miguel. A extinção do "Ativo Diferido": Reflexos sobre suas Repercussões Contábeis e Tributárias. In: FERNANDES, Edison Carlos; e PEIXOTO, Marcelo Magalhães (coords.). Aspectos Tributários da Nova Lei Contábil: Lei 11.638/07 (com a Lei 11.941/09). São Paulo: MP, 2010, pp. $185-225$. 
sido inseridos pela Nova Contabilidade e (ii) são inseridos os lançamentos considerando os métodos e critérios contábeis vigentes em 31/12/2007. Ocorre que, conforme destacam os autores, o programa não permite a utilização dos dados de um exercício nos próximos, o que permitiria efetivamente a realização de uma contabilidade fiscal completa. ${ }^{39}$

O RTT teve vigência optativa para o biênio 2008-2009, sendo vedada sua aplicação em apenas um desses anos-calendário. A partir do ano-calendário de 2010, esse regime passou a ser obrigatório e terá vigência até o advento de lei que discipline os efeitos tributários dos novos métodos e critérios contábeis supramencionados, buscando a neutralidade tributária.

Com efeito, passa-se agora a analisar as regras gerais de apuração do lucro tributável pela pessoa jurídica: o lucro real, presumido e arbitrado e, em seguida, as regras específicas aplicáveis ao setor imobiliário.

\subsubsection{2 - Tributação pela Sistemática do Lucro Real}

O lucro real é a base de cálculo apurada a partir do lucro líquido, ajustado pelas adições, exclusões ou compensações prescritas ou autorizadas por lei. ${ }^{40}$ Conforme mencionado, as Leis $n .^{\circ} 11.638 / 07$ e $n^{\circ}$ 11.941/09 introduziram diversas alterações em conceitos de Direito Contábil Societário (Direito Privado), mas que, via de regra, não podem gerar efeitos para fins tributários por força das regras de neutralização estabelecidas por essas próprias leis (RTT).

Dessa forma, parte-se de um lucro líquido fiscal (apurado de acordo com os métodos e critérios contábeis vigentes em 31 de dezembro de 2007) para fazer as adições, exclusões e compensações necessárias à apuração do lucro real:

\footnotetext{
${ }^{39}$ SCHOUERI, Luís Eduardo e TERSI, Vinícius Feliciano. Cf. op. cit. (nota 34), pp. 145 e 146.

40 "Conceito de Lucro Real

Art. 247. Lucro real é o lucro líquido do período de apuração ajustado pelas adições, exclusões ou compensações prescritas ou autorizadas por este Decreto (Decreto-Lei no 1.598, de 1977, art. 6으).

§ 1o A determinação do lucro real será precedida da apuração do lucro líquido de cada período de apuração com observância das disposições das leis comerciais (Lei no 8.981 , de 1995, art. 37, § 1ํo).” (g.n.)
} 
lucro societário (critérios contábeis societários atuais)

(+) adições

(-) exclusões

(=) lucro líquido fiscal (critérios contábeis vigentes em 31/12/07)

(+) adições

(-) exclusões

(=) lucro real antes das compensações

(-) compensação de prejuízos fiscais acumulados

(=) lucro real (lucro fiscal)

Adições são (i) os custos, despesas, encargos, perdas, provisões, participações e quaisquer outros valores deduzidos na apuração do lucro líquido que não sejam dedutíveis na determinação do lucro real; ${ }^{41}$ ou (ii) os resultados, rendimentos, receitas e quaisquer outros valores não reconhecidos na apuração do lucro líquido, mas que devam ser computados na determinação do lucro real. ${ }^{42}$

Exclusões são (i) os valores cuja dedução seja autorizada pela legislação tributária e que não tenham sido computados na apuração do lucro líquido do período de apuração; ${ }^{43}$ ou (ii) os resultados, rendimentos, receitas e quaisquer outros valores incluídos na apuração do lucro líquido que, de acordo com a legislação tributária, não sejam computados no lucro real ${ }^{44}$.

Ademais, conforme mencionado no Capítulo 1, somente é possível determinar se uma entidade teve lucro caso seja apurada a evolução de sua atividade econômica desde o seu início até a sua extinção. A apuração periódica trimestral ou anual é apenas uma forma de antecipar a tributação de uma renda que somente pode ser auferida com precisão no momento de sua extinção.

\footnotetext{
${ }^{41}$ Como exemplo de despesas indedutíveis, é possível citar as doações e as multas, pois não se configuram como despesas usuais, normais e necessárias para a atividade da pessoa jurídica (artigo 299 do RIR/99).

${ }^{42}$ Tais como os justes exigidos pela legislação que trata da "Distribuição Disfarçada de Lucros" na alienação de bens, em que não há o reconhecimento de uma receita ou essa receita é reconhecida em valor inferior para fins societários, mas a legislação tributária exige a adição da receita para fins de apuração do lucro real (artigo 464 do RIR/99).

${ }^{43}$ Em alguns casos, é possível deduzir gastos com pesquisa e tecnologia, embora esses gastos ainda não sejam despesa para fins societários (artigos 39 a 43 da Lei no 10.637/02).

${ }^{44}$ Os valores recebidos a título de dividendos são receitas para fins societários, mas não para fins fiscais, pois não integram o lucro real (artigo 10 da Lei $n^{\circ} 9.249 / 95$ ).
} 
Assim, a compensação de prejuízos fiscais acumulados é o mecanismo para que se possa refletir, no lucro presente, o efeito dos prejuízos auferidos em períodos anteriores, de forma a se apurar o efetivo acréscimo patrimonial da entidade no decorrer do tempo (de certo, somente há acréscimo patrimonial a partir do momento em que os prejuízos anteriores sejam compensados). ${ }^{45}$

Após a apuração do lucro real (base de cálculo), aplica-se a alíquota de $15 \%$. Aplica-se também a alíquota adicional de $10 \%$ sobre a parcela do lucro que exceder o valor de $\mathrm{R} \$ 20.000,00$ por mês ( $\mathrm{R} \$ 240.000,00$ ao ano).

Por fim, registre-se que o regime de tributação pelo lucro real é obrigatório para algumas pessoas jurídicas. Em especial, são obrigadas a adotar o lucro real as pessoas (i) que tenham apurado receita total superior ao limite de $\mathrm{R} \$ 48$ milhões, ou proporcional ao número de meses, se inferior a 12; (ii) que tiverem lucros, rendimentos e ganhos de capital oriundos do exterior; e (iii) que sejam qualificadas como instituição financeira.

Especificamente no que tange à atividade imobiliária, estão obrigadas à apuração do lucro real as sociedades de crédito imobiliário e as que explorem as atividades de securitização de créditos imobiliários (artigo 14 da Lei n 9.718/98).

\subsubsection{3 - Tributação pela Sistemática do Lucro Presumido}

O lucro presumido é a base de cálculo apurada a partir da aplicação de coeficientes de presunção de lucro sobre a receita bruta auferida pela pessoa jurídica. $\mathrm{O}$ percentual de presunção (coeficiente) aplicável para a formação da base de cálculo é variável em função da natureza da atividade econômica que gerou a respectiva receita.

Verifica-se, portanto, que esta base de cálculo no lucro presumido não possui qualquer vinculo com o lucro líquido societário (lucro contábil societário), pois não se consideram as despesas incorridas durante o período como ocorre com o lucro real. No lucro presumido, aplica-se uma presunção de margem de lucro para cada atividade econômica específica (existe um coeficiente de lucratividade média para cada atividade), sem qualquer vínculo com o lucro societário.

\footnotetext{
${ }^{45}$ Ocorre que, nos termos da legislação atualmente vigente, foi estabelecido como limite de compensação o valor de $30 \%$ do lucro líquido ajustado (lucro real). O saldo dos valores não compensados será acumulado para compensação em exercícios futuros (artigos 509 e seguintes do RIR/99).
} 
Trata-se de uma tributação simplificada do ponto de vista contábil (basta a demonstração das receitas) e mais vantajosa para o contribuinte (pois as margens presumidas de lucro são geralmente inferiores às margens reais). É uma opção oferecida pelo legislador para as pessoas jurídicas não obrigadas à apuração do lucro real, objetivando tornar a fiscalização e arrecadação mais prática e simples. ${ }^{46}$

Para a apuração do lucro presumido, a contabilidade societária continua sendo o parâmetro inicial: (i) parte-se das receitas apuradas em conformidade com a legislação contábil vigente em 31/12/2007 (aplicação do RTT, nos termos do artigo $10^{\circ}$ da IN/RFB no 949/09); (ii) segregam-se tais receitas por espécie de atividade econômica; e (iii) aplicam-se os coeficientes de presunção de lucro sobre cada atividade, para se chegar ao lucro presumido:

Receitas Societárias (critérios contábeis societários atuais)

$(+)$ adições

(-) exclusões

(=) Receitas Fiscais (critérios contábeis vigentes em 31/12/07)

(x) coeficiente presunção de lucro

(=) Lucro Presumido

\footnotetext{
${ }^{46}$ Ressalte-se que a Lei 8.981/95 estabelecia que as pessoas jurídicas que se dedicavam à compra e venda, ao loteamento, à incorporação ou à construção de imóveis e à execução de obras da construção civil estavam obrigadas à tributação pelo lucro real (artigo 36, inciso IV). No entanto, com a edição da Lei 9.718/98, essa obrigatoriedade deixou de existir, uma vez que referidas pessoas jurídicas não constam mais do rol daquelas que são obrigadas à tributação pelo lucro real, nos termos do artigo 14 desta Lei.
} 
No que tange especificamente à presunção de lucro aplicável ao setor imobiliário, aplicam-se os seguintes coeficientes:

\begin{tabular}{|c|c|}
\hline Coeficiente & Natureza da Receita \\
\hline $8 \%$ & $\begin{array}{l}\text { (i) Regra geral de presunção de lucro sobre a receita bruta. } \\
\text { (ii) Atividades de loteamento de terrenos, incorporação imobiliária e venda de imóveis } \\
\text { construídos ou adquiridos para revenda (expressamente previsto no } \S 7^{\circ} \text { do art. } 3^{\circ} \text { da } \\
\text { IN/RFB no 93/97). } \\
\text { (iii) Receita financeira da pessoa jurídica que explore atividades imobiliárias relativas } \\
\text { a loteamento de terrenos, incorporação imobiliária, construção de prédios destinados à } \\
\text { venda, bem como a venda de imóveis construídos ou adquiridos para a revenda, } \\
\text { quando decorrente da comercialização de imóveis e for apurada por meio de índices } \\
\text { ou coeficientes previstos em contrato (incluído pela Lei no } 1.196 / 05 \text { ). } \\
\text { (iv) Construção por administração ou empreitada, quando houver emprego de } \\
\text { materiais. }\end{array}$ \\
\hline $32 \%$ & $\begin{array}{l}\text { (i) Prestação de serviços imobiliários em geral. } \\
\text { (ii) Intermediação de negócios. } \\
\text { (iii) Administração, locação ou cessão de bens, imóveis, móveis e direitos de qualquer } \\
\text { natureza. }\end{array}$ \\
\hline $100 \%$ & $\begin{array}{l}\text { (i) Aluguéis de bens imóveis do ativo permanente. } \\
\text { (ii) Renda fixa ou variável - receita financeira em geral. } \\
\text { (iii) Ganho de capital na venda de bens do ativo permanente (ganho líquido). }\end{array}$ \\
\hline
\end{tabular}

No caso de atividades diversificadas exercidas pela mesma pessoa jurídica, será aplicado o coeficiente correspondente a cada atividade, sobre a respectiva receita auferida.

O lucro presumido (base de cálculo) apura-se trimestralmente (aspecto temporal), aplicando-se a alíquota de $15 \%$. Aplica-se também a alíquota adicional de $10 \%$ sobre a parcela do lucro que exceder o valor de $\mathrm{R} \$ 20.000,00$ por mês ( $\mathrm{R} \$ 60.000,00$ por trimestre). Nesta sistemática de tributação, não é possível a compensação de prejuízos apurados em exercícios anteriores.

Conforme mencionado, o lucro presumido é uma opção legal conferida aos contribuintes de pequeno e médio porte (com faturamento de até $\mathrm{R} \$ 48$ milhões ao ano). Contudo, esse regime de tributação é adotado em larga escala no mercado imobiliário, especialmente por empresas que têm por objeto as atividades de loteamento de terrenos, incorporação imobiliária e venda de imóveis construídos ou adquiridos para revenda. 
Isso porque as características e peculiaridades do mercado imobiliário permitem e até induzem que as empresas segreguem suas atividades em diversas empresas, individualizadas por obra. Com efeito, cada obra específica poderá ser realizada por uma empresa diferente (dentro do mesmo grupo econômico), denominada Sociedade de Propósito Específico - SPE.

A SPE é uma sociedade subsidiária (Ltda. ou S/A), com personalidade jurídica própria e distinta da personalidade dos seus sócios, criada com objeto e prazo determinados, alcançando apenas um empreendimento imobiliário, conforme previsão contida no parágrafo único do artigo 981 da Lei n ${ }^{\circ} 10.406$, de 10 de janeiro de 2002 (Código Civil). ${ }^{47}$

Dessa forma, é possível que um grupo empresarial considerado como um todo possua uma receita bruta total muito superior ao limite de $\mathrm{R} \$ 48$ milhões ao ano, mas sua atividade esteja distribuída em diversas SPE (i.e. uma sociedade por empreendimento) e cada uma auferindo receitas dentro desse limite (todas tributadas pelo lucro presumido). ${ }^{48}$

\subsubsection{4 - Tributação pela Sistemática do Lucro Arbitrado}

O lucro arbitrado é a base de cálculo que deve ser apurada em situações em que não é possível a apuração do lucro real ou presumido em decorrência de descumprimento de normas da legislação tributária (artigo 530 do RIR/99).

A apuração desta base de cálculo é realizada mediante a aplicação de coeficientes de presunção de lucro previstas para o lucro presumido, majoradas em $20 \%$, quando conhecida a receita bruta (artigo 532 do RIR/99). Quando não conhecida a receita bruta, serão aplicáveis outros índices previstos em lei (artigo 535 do RIR/99).

Conforme o artigo 49 da Lei $n^{\circ} 8.981 / 95$, as pessoas jurídicas que se dedicarem (i) à venda de imóveis construídos ou adquiridos para revenda, (ii) ao loteamento de terrenos e (iii) à incorporação de prédios em condomínio - terão seus lucros arbitrados, deduzindo-se da receita bruta o custo do imóvel devidamente comprovado.

Nas vendas a prazo ou em prestações, o lucro arbitrado será tributado na proporção da receita recebida ou cujo recebimento esteja previsto para o próprio mês.

\footnotetext{
47 “Art. 981. Celebram contrato de sociedade as pessoas que reciprocamente se obrigam a contribuir, com bens ou serviços, para o exercício de atividade econômica e a partilha, entre si, dos resultados. Parágrafo único. A atividade pode restringir-se à realização de um ou mais negócios determinados”.

48 A tributação pelo lucro presumido se mostra vantajosa também em relação à CSLL (com coeficiente de presunção de lucro de 12\%) e para o PIS e COFINS (tributados pelo regime cumulativo à alíquota de 3,65\%).
} 


\subsection{2 - Tributação dos Negócios Imobiliários}

\subsubsection{1 - Tributação da Alienação da Propriedade Imobiliária (Ganho de Capital)}

Inicialmente, destaca-se que a finalidade/destinação econômica da propriedade imobiliária é fator de extrema relevância para fins de tributação pelo IRPJ. ${ }^{49}$ De fato, a pessoa jurídica pode ter como objeto social a venda de bens imóveis, hipótese em que a alienação da propriedade imobiliária irá configurar uma atividade comercial e o produto da venda uma receita operacional.

Nesta hipótese, a pessoa jurídica geralmente irá registrar o bem imóvel em seu estoque (ativo circulante) ${ }^{50}$ e o valor de alienação (receita operacional) será contraposto aos respectivos custos e despesas para fins de apuração do lucro real. No regime do lucro presumido, referida receita será adotada como base para a aplicação dos coeficientes de presunção de lucro (8\%).

O tratamento tributário da alienação da propriedade imobiliária para os contribuintes que tenham como atividade a compra e venda, o loteamento, a incorporação e a construção de imóveis será analisado no capítulo 5.3.1.

Por outro lado, se a pessoa jurídica não tem como objeto social a venda de bens imóveis, a alienação da propriedade imobiliária não possui natureza operacional e o resultado de sua venda será tratado como ganho de capital. Assim, em geral, o bem imóvel é integrante do ativo imobilizado, ${ }^{51}$ como é o caso do imóvel onde a pessoa jurídica tem sua sede. Portanto, diferentemente do bem imóvel alienado no exercício da atividade operacional da pessoa jurídica, o produto da venda do imóvel registrado no seu ativo imobilizado será reconhecido por seu valor líquido (mais valia entre o valor de venda e o valor de registro contábil) e tributado como ganho de capital. ${ }^{52}$

Com o advento da Lei ${ }^{\circ} 11.941 / 09$, a conta de ativo permanente deixou de existir. Não obstante, o tratamento fiscal conferido à alienação de bens do ativo permanente, previsto

\footnotetext{
49 "Um dos traços mais característicos do conceito de ganhos ou perdas de capital é o que trata de diferenças apuradas em atos não repetitivos com bens de capital, em contraposição às operações normais realizadas regularmente com as mercadorias, bens realizáveis e serviços que são objeto da atividade principal." TILBERY, Henry, A Tributação dos Ganhos de Capital das Pessoas Jurídicas: Comentários ao Decreto-lei no 1.598/77, São Paulo: Resenha Tributária: Instituto Brasileiro de Direito Tributário, 1978, p. 55.

${ }^{50}$ Conforme inciso I do artigo 179 da Lei das S/A.

${ }^{51}$ Conforme inciso IV do artigo 179 da Lei das S/A.
} 
no artigo 31 do $\mathrm{DL} \mathrm{n}^{\circ} 1.598 / 77$, continua válido. Isto porque as subcontas imobilizado e investimento continuam existindo, apenas passam a ser integrantes do grupo ativo não circulante (conforme destacado no Capítulo 5.2.1.1).

Com efeito, quando a venda do bem imóvel registrado no ativo imobilizado for feita a prazo ou em prestações, em que o recebimento do preço (parcial ou total) ocorra após o término do exercício social seguinte ao da contratação, a pessoa jurídica sujeita ao lucro real poderá reconhecer o lucro na proporção da parcela do preço recebida em cada período-base (regime de caixa). ${ }^{53}$

Registre-se que, quando a pessoa jurídica for tributada pelo lucro real, o prejuízo na venda de bens imóveis integrantes do ativo imobilizado (prejuízos não operacionais) somente podem ser compensados com ganhos da mesma natureza (artigo 31 da Lei $n^{\circ}$ 9.249/95).

Ademais, também não se admite a dedução do lucro real de despesas de depreciação, amortização, manutenção, reparo, conservação, impostos, taxas, seguros e quaisquer outros gastos com bens imóveis, exceto se intrinsecamente relacionados com a produção ou comercialização dos bens e serviços. ${ }^{54}$

Destaque-se, ainda, que o ganho de capital é tributado pelo lucro presumido e pelo lucro arbitrado sem a aplicação de coeficientes de presunção de lucro ou de arbitramento, mas pelo seu valor líquido (diferença entre o valor de alienação e o respectivo valor contábil). ${ }^{55}$

Por fim, é importante ressaltar que os imóveis podem ser classificados como propriedade para investimento, nos termos do Pronunciamento Técnico CPC 28 (analisado no Capítulo 4.3.2). Serão reconhecidos com essa natureza quando forem utilizados para obter rendas (v.g. aluguel), valorização do capital (finalidade especulativa), ou ambos.

Ocorre que a classificação do imóvel como propriedade para investimento passou a ser prevista apenas a partir das alterações promovidas pelas Leis $n^{\circ} 11.638 / 07$ e $\mathrm{n}^{\circ}$ 11.941/09, ou seja, não se tratava de método ou critério contábil vigente em 31/12/2007. Assim, a alienação do imóvel classificado como propriedade para investimento (nova Contabilidade Societária) deve ser revertida para fins de apuração do lucro líquido fiscal e classificada como

\footnotetext{
${ }^{52}$ Conforme artigo 31 do DL n ${ }^{\circ} 1.598 / 77$.

${ }^{53}$ Conforme $\S 2^{\circ}$ do artigo 31 do DL n ${ }^{\circ} 1.598 / 77$.

${ }^{54}$ Conforme inciso III do artigo 13 da Lei $n^{\circ} 9.249 / 95$.

${ }^{55}$ Conforme artigos 521 e 536 do RIR/99.
} 
alienação de bem do imobilizado ou do estoque para fins de tributação (confira-se o Capítulo 5.2.1.1 sobre a aplicação do RTT).

\subsubsection{1.a - Permuta e Dação em Pagamento}

Conforme já destacado nos capítulos 3.2.4 e 5.1.2.1.a, a permuta é um contrato distinto do contrato de compra e venda, pois, na permuta, não há preço propriamente dito (elemento essencial no contrato de compra e venda), mas o compromisso de trocar bens reciprocamente.

Apenas a título ilustrativo, é comum no setor imobiliário que o incorporador/construtor realize a aquisição de terrenos por meio de contratos de permuta. Neste caso, o proprietário do terreno se compromete a entregar o terreno e o incorporador/construtor se compromete a entregar um número determinado de unidades a serem construídas (com ou sem pagamento de parcela em dinheiro - torna). ${ }^{56}$

Neste caso, é possível que exista um acréscimo de capacidade contributiva para o construtor/incorporador, decorrente da mais valia entre (i) o custo de construção das unidades a serem entregues e (ii) o valor de mercado do terreno. Da mesma forma, pode haver uma mais valia para o proprietário do terreno, decorrente da diferença entre (i) o custo contábil do terreno e (ii) o valor de mercado das unidades recebidas em permuta.

Contudo, geralmente não será possível a tributação dessa eventual mais valia obtida na permuta, porquanto ausente um importante requisito para que se considere realizado o ganho: não há definição objetiva para o preço da operação.

De fato, conforme já mencionado (capítulo 4.1.2), a permuta entre bens de natureza e valor distintos enseja o reconhecimento de uma receita contábil. Especificamente para fins societários, essa receita contábil deve ser mensurada pelo seu valor justo, considerado como: (i) o valor de venda dos imóveis ou terrenos recebidos ou, excepcionalmente, quando esse valor não puder ser mensurado com segurança, (ii) o valor de venda das unidades imobiliárias entregues.

\footnotetext{
56 Destaque-se que a parcela em dinheiro não pode ser o valor predominante na operação, caso contrário o contrato se configura como compra e venda. Confira-se o seguinte julgado do CARF: "PERMUTA DE IMÓVEIS COM PAGAMENTO DE TORNA. CARACTERIZAÇÃO. Para que fique caracterizado o contrato de permuta com pagamento de torna, em vez de compra e venda, faz-se necessário que a coisa seja objeto predominante do contrato e não o montante em dinheiro." (Acórdão 103-22.974)
} 
A regulamentação da permuta para fins de apuração do lucro real encontra-se prevista na IN/RFB $n^{\circ}$ 107/88. Conforme o item 2.1.1 dessa instrução normativa, caso a permuta ocorra sem pagamento de torna, não haverá resultado a apurar, visto que os permutantes atribuirão (i) ao bem que receber, o mesmo valor contábil (ii) do bem baixado em sua escrituração (ou o custo de produção, no caso de unidade a construir - item 2.2.1). ${ }^{57}$

Com efeito, verifica-se que a legislação tributária adota, como premissa, a inexistência de um valor objetivo para a determinação do preço de mercado, motivo pelo qual se considera como valor de alienação do bem dado em permuta o seu custo contábil (não havendo lucro real a ser registrado). Da mesma forma que para a pessoa física, somente haverá lucro a ser tributado caso a permuta seja realizada com pagamento de torna em dinheiro.

Portanto, (conforme item 2.1.2 da referida Instrução Normativa) se houver pagamento de torna, a permutante que a receber deverá tributá-la nos mesmos moldes estabelecidos para a pessoa física (capítulo 5.1.2.1.a). A permutante que pagar ou prometer pagar a torna irá acrescentar esse valor ao valor contábil do bem dado em permuta (ou o custo de produção, no caso de unidade a construir - item 2.2.2), para fins de registro do custo de aquisição do bem recebido.

Segundo o item 1.6 da referida instrução normativa, a torna poderá ser tributada pela pessoa jurídica na medida de seu recebimento (regime de caixa), desde que alienação da unidade imobiliária seja contratada nas condições dispostas no artigo 29 (receita operacional) ou no $\S 2^{\circ}$ do artigo 31 (ganho de capital) do DL $n^{\circ} 1.598 / 77$.

A IN/RFB n 107/88 (item 4.1) estabelece, ainda, que são aplicáveis às operações quitadas de compra e venda de terreno seguidas de confissão de dívida e promessa de dação em pagamento de unidade imobiliária construída ou a construir, todos os procedimentos e normas aplicáveis à permuta, desde que observadas as seguintes condições cumulativas: (i) a alienação do terreno e o compromisso de dação em pagamento sejam levados a efeito na mesma data, mediante instrumento público; e (ii) o terreno objeto da operação de compra e venda seja dado em hipoteca para obtenção de financiamento ou, no caso de loteamento,

\footnotetext{
57 “2.1.1 No caso de permuta sem pagamento de torna, as permutantes não terão resultado a apurar, uma vez que cada pessoa jurídica atribuirá ao bem que receber o mesmo valor contábil do bem baixado em sua escrituração.

(...)

2.2.1 No caso de permuta sem pagamento de torna, a permutante que alienar a unidade pronta observará as disposições da divisão de subitem 2.1.1. A permutante que prometer entregar unidade imobiliária a construir deverá considerar o custo de produção desta como integrante do custo da unidade adquirida.” (g.n.)
} 
oferecido em garantia ao poder público, até o final do período-base seguinte à realização do negócio, nos termos da Lei ${ }^{\circ}$ 6.766/79.

\section{$\checkmark$ Tributação da Permuta no Lucro Presumido}

Especificamente no que tange à tributação pelo lucro presumido, é possível apontar ao menos três polêmicas: (i) considerando que a IN/RFB $n^{\circ}$ 107/88 trata da tributação pelo lucro real e do lucro imobiliário das pessoas físicas, a alienação da unidade dada em permuta (ou dação em pagamento) configura uma receita passível de tributação pelo lucro presumido? (ii) caso se trate de receita tributável, qual o valor pelo qual deve ser mensurada? e (iii) aplicando-se o regime de caixa, quando deve ser tributada a receita no caso de permuta de “unidades a construir”?

Estas polêmicas se ampliaram com o advento dos novos métodos e critérios contábeis (Nova Contabilidade). Como visto no Capítulo 4.1.2, a permuta entre bens de natureza e valor distintos enseja o reconhecimento de uma receita contábil societária, mensurada pelo seu valor justo. Na seara imobiliária, convencionou-se que a permuta de terreno com unidades construídas ou a construir não configura permuta de bens de natureza semelhante, motivo pelo qual se deve registrar uma receita, mensurada pelo valor justo (item 21 do OCPC 01).

Ocorre que essa regra societária não é aplicável à apuração do lucro real, uma vez que a legislação tributária (IN/RFB n 107/88, item 2.1.1) é expressa no sentido de que "as permutantes não terão resultado a apurar, uma vez que cada pessoa jurídica atribuirá ao bem que receber o mesmo valor contábil do bem baixado em sua escrituração".

Esse dispositivo comporta duas possíveis interpretações, em razão da inexistência de resultado que pode decorrer tanto (i) da mera troca de bens do ativo, sem trânsito por contas de resultado, quanto (ii) da atribuição do mesmo valor à receita e ao custo do bem alienado, com efeito nulo no resultado contábil.

Essas diferentes interpretações não geram consequências na apuração do IRPJ pelo lucro real, pois o que se tributa neste caso é o resultado. Ambas as interpretações, portanto, atendem ao princípio da realização, visto que não há tributação dos ganhos de detenção.

Contudo, conforme destacado no Capítulo 5.2.1.3, a apuração da base de cálculo do IRPJ na sistemática do lucro presumido consiste na aplicação de um coeficiente de presunção de lucro sobre a receita auferida pela pessoa jurídica. Ou seja, para a apuração do 
lucro presumido, não interessa o confronto entre receitas e despesas, pois se adota uma margem presumida de lucro sobre a receita.

Dessa forma, a adoção da segunda interpretação (não há resultado porque a receita é igual à despesa) acaba tendo, como conseqüência, a apuração de uma base tributável pelo IRPJ no lucro presumido.

A interpretação inicial das autoridades fiscais sobre a aplicação desse dispositivo era no sentido de que a permuta acarretava apenas o trânsito de valores por contas de ativo, sem qualquer registro em contas de resultado (como receita e despesa). ${ }^{58}$

Ocorre que a segunda interpretação vem se consolidando, no sentido de que não haverá resultado a apurar porque a receita deverá ser mensurada pelo mesmo valor do bem baixado em sua escrituração. A necessidade de registro de receita/faturamento nas operações de permuta possui amparo em decisões do CARF e do próprio STJ, especialmente quando tratam da base de cálculo da contribuição ao PIS e da COFINS. Confira-se:

“Todavia, as ponderações da Recorrente não são suficientes para permitir estender o tratamento previsto na IN 107/88 para a apuração do lucro presumido. A Instrução Normativa em referência leva em consideração os custos, o que é incompatível com apuração pelo lucro presumido, em que só as receitas têm relevância. Veja-se, por exemplo, o caso de permuta entre pessoa jurídica e pessoa física, com torna. Os itens da IN aplicáveis são os itens 3.1.2 e 2.1.2, que dispõem expressamente sobre a consideração do custo.

Assim, as operações de permuta só têm relevância na apuração do resultado para fins de tributação, pelo IRPJ e pela CSLL, em caso de tributação pelo lucro real. A base de cálculo do IRPJ e da CSLL das empresas que optam pelo lucro presumido, e a base de cálculo do PIS e da COFINS levam em consideração a receita bruta ou o produto da venda (faturamento), que independe da forma como é feito o pagamento (em moeda ou por dação de bens)." (Relatora Conselheira Sandra Maria Faroni, Acórdão 101-96.524, pp. 10 e 11, janeiro de 2008)

\footnotetext{
${ }^{58}$ Neste sentido, cite-se a Solução de Consulta n ${ }^{\circ}$ 241/08: "Ementa: As pessoas jurídicas que explorem atividades imobiliárias relativas a loteamento de terrenos, incorporação imobiliária, construção de prédios destinados à venda, bem como a venda de imóveis construídos ou adquiridos para revenda, deverão considerar como receita bruta o montante, em bens ou dinheiro, recebido em pagamento, relativo às unidades imobiliárias vendidas.Na hipótese de permuta de unidades imobiliárias, o valor dos bens recebidos na troca não integra a base de cálculo do IRPJ, ainda que o contribuinte tenha feito a opção pelo lucro presumido . A alienação desses bens constitui nova operação de venda. Dispositivos Legais: Lei no 8.981, de 1995, art. 30; RIR/1999, arts. 227, 410 a 414; IN SRF no 107, de 1988."

Cite-se também o seguinte trecho do voto da Conselheira Sandra Maria Faroni, que posteriormente alterou seu entendimento em julgados mais recentes: "Assim, sob a ótica da incorporação imobiliária, a operação se identifica como a permuta referida no artigo 39 da Lei $n^{o} 4.591 / 64$. Dessa forma, aplicam-se a ela as disposições da Instrução Normativa SRF 107/88, computando-se como receita apenas o valor da torna recebida." (Acórdão 101-95.000 - p. 11 maio de 2005).
} 
"PERMUTA DE IMÓVEIS. O regime instituído pela Instrução Normativa SRF n” 107/88 para a permuta de imóveis não se aplica à contribuição ao PIS. Isto porque a contribuição incide sobre o faturamento e não sobre o resultado da operação. (...)

As orientações da IN 107/88 não se referem à Contribuição para o PIS. O fato gerador da contribuição não é o lucro, mas o faturamento (art. $2^{\circ}$ da Lei Complementar $n^{\circ} 70 / 91$ ). Os custos não são dedutíveis de sua base de cálculo e não lhe interessa a forma através da qual o faturamento foi pago, se em bens ou em espécie." (g.n.) (Relator Antônio José Praga de Souza, Acórdão no 1402-00.339, dezembro de 2010)

“(...) Depreende-se de seu voto condutor de minha autoria que a COFINS incidirá sobre o faturamento mensal, assim considerado a receita bruta das vendas de mercadorias, de mercadorias e serviços e serviços de qualquer natureza (Lei Complementar $n^{\circ} 70 / 91$, artigo $2^{\circ}$ ) e incide sobre as atividades da embargante: indústria da construção civil, administração e conservação de prédio, incorporação imobiliária, compra, venda, permuta e locação de imóveis, intermediação em operações imobiliárias e projetos de planejamento de engenharia civil. Estas atividades estão sujeitas a COFINS porque caracterizam a compra e venda de mercadoria, em sentido amplo, como empregou o legislador.” (g.n.) (Embargos de Declaração no Recurso Especial nº 149.094 fevereiro de 1998)

Registre-se, neste sentido, que o artigo 30 da Lei $n^{\circ} 8.981 / 95$ reitera a regra fiscal de que a receita bruta das pessoas jurídicas que explorem atividades imobiliárias deve ser reconhecida pelo regime de caixa (o montante efetivamente recebido). Contudo, não há nesse dispositivo qualquer preceito que possa desconstituir a natureza de receita decorrente da alienação de imóvel em permuta, nem mesmo sua natureza de receita operacional (se o imóvel dado em permuta pertencer a seu estoque). ${ }^{59}$

Dessa forma, uma vez que a permuta é uma operação que gera uma receita para a pessoa jurídica, tem-se duas hipóteses distintas de tributação na sistemática de tributação pelo lucro presumido: (i) como receita operacional ou (ii) como ganho de capital.

\section{(i) Permuta de bens do estoque (receita operacional)}

Quando o imóvel entregue está registrado no estoque da pessoa jurídica dedicada à atividade imobiliária (v.g. casas ou apartamentos destinados à comercialização pelo

\footnotetext{
${ }^{59}$ Lei $n^{\circ}$ 8.981/95: “Art. 30. As pessoas jurídicas que explorem atividades imobiliárias relativa a loteamento de terrenos, incorporação imobiliária, construção de prédios destinados à venda, bem como a venda de imóveis construídos ou adquiridos para revenda, deverão considerar como receita bruta o montante efetivamente recebido, relativo às unidades imobiliárias vendidas."
} 
construtor/incorporador), a tributação pelo lucro presumido será feita com base no coeficiente de presunção de $8 \%$, aplicável sobre o valor da receita/faturamento.

Neste sentido, a RFB acabou consolidando seu entendimento no sentido de que a operação de permuta tem como contrapartida uma receita tributável. Confira-se a Solução de Divergência da RFB no 5/10:

“Solução de Divergência n" 5, de $1^{\circ}$ de dezembro de 2010

ASSUNTO: Imposto sobre a Renda de Pessoa Jurídica - IRPJ

EMENTA: LUCRO PRESUMIDO. PERMUTA DE IMÓVEIS. RECEITA BRUTA. Na operação de permuta de imóveis sem recebimento de torna, realizada por pessoa jurídica tributada pelo IRPJ com base no lucro presumido, dedicada à atividade imobiliária, constitui receita bruta o preço do imóvel recebido em permuta. DISPOSITIVOS LEGAIS: art. 533 da Lei $n^{o}$ 10.406, de 2002 (Código Civil); arts. 224, 518 e 519 do Decreto no 3.000, de 1999."

Ocorre que, conforme se verifica da ementa da acima transcrita, a RFB considera como receita bruta o preço do imóvel recebido em permuta. Trata-se da segunda grande polêmica quanto à tributação das operações de permuta de imóveis no lucro presumido.

Conforme já mencionado, na permuta não há preço (como ocorre nos contratos de compra e venda), mas sim o compromisso de entrega de um bem em troca do recebimento de outro. Com efeito, a inexistência de condições objetivas para definição do preço de mercado do imóvel recebido em permuta impossibilita atribuir um valor para ser utilizado como base para a apuração da renda.

Os únicos valores que preenchem esse requisito são aqueles definidos pela própria IN/RFB no 107/88: (i) o valor contábil do próprio bem dado em permuta e baixado em sua escrituração ou (ii) o custo de produção, no caso de permuta de unidade a construir. Apenas estes valores podem ser utilizados como base para a mensuração da receita no caso de permuta, mesmo na sistemática do lucro presumido.

Ainda que seja possível, para fins da Contabilidade Societária, o registro da permuta pelo valor justo do terreno recebido ou da unidade a ser entregue (critérios de mensuração de receita previstos no CPC 30 e no OCPC 01), estes valores não serão utilizados como base para a tributação, seja (i) pela impossibilidade de tributação de ganhos de detenção que não preenchem os critérios de realização da renda, seja (ii) por não se tratar de critério contábil vigente em 31/12/2007 (aplicação do RTT, conforme Capítulo 5.2.1.1). 
Por fim, merece destaque também o polêmico entendimento da RFB, manifestado em algumas Soluções de Consulta, no sentido de que a receita decorrente da operação de permuta deve ser registrada no período em que houver a negociação/recebimento do terreno (momento em que se considera realizada a renda). ${ }^{60}$

Conforme destacado no Capítulo 1.2.2.4, o reconhecimento de uma receita pressupõe que estejam presentes todos os pressupostos para que ela se considere realizada (princípio da realização). Contudo, no momento da negociação da permuta e do recebimento do terreno, ainda não é possível que seja registrada a receita pela entrega das unidades a serem construídas, pois se tem uma operação com natureza de passivo (adiantamento de clientes).

$\mathrm{Na}$ verdade, somente será possível registrar o ingresso definitivo, passível de tributação pelo imposto de renda, no momento em que forem cumpridas todas as obrigações decorrentes do negócio realizado (condição de materialidade). Antes deste momento, tem-se apenas uma expectativa de receita.

No caso da permuta em que o incorporador/construtor recebe o terreno e se compromete a entregar unidades a serem construídas, a receita somente será registrada em conformidade com a realização de sua obrigação contratual de entregar as futuras unidades (durante a construção da obra ou na entrega das chaves, conforme o caso).

Trata-se, portanto, de tributação semelhante àquela correspondente ao pagamento à vista de unidade a construir, em que a tributação da receita pelo regime de caixa somente irá ocorrer no mês em que a receita for registrada pelo regime de competência (conforme exposto no Capítulo 4.5). Neste sentido, já se manifestou a própria RFB quanto à tributação do pagamento à vista na compra de unidades a construir pelo regime de caixa, entendendo que a tributação deve se dar no mês em que ocorrer o faturamento ou a entrega do bem, o que ocorrer antes. $^{61}$

\footnotetext{
${ }^{60}$ Neste sentido: "Processo de Consulta $\mathrm{n}^{\mathrm{o}}$ 134/10 - Superintendência Regional da Receita Federal $6{ }^{\mathrm{a}} \mathrm{RF}$ Assunto: Imposto sobre a Renda de Pessoa Jurídica - IRPJ.

Ementa: LUCRO PRESUMIDO. INCORPORAÇÃO IMOBILIÁRIA. PERMUTA DE IMÓVEIS SEM TORNA. RECEITA BRUTA. Na permuta sem torna de terreno por imóveis que irá construir, a empresa, optante pelo lucro presumido, que se dedica a compra e venda, permuta, desmembramento, incorporação, construção e comercialização de unidades imobiliárias, deve incluir na base de cálculo do IRPJ, no período em que houve a negociacãa e, conseqüentemente, o recebimento do terreno, o valor do terreno, assim considerado o que seria esperado em negociações no mercado de compra e venda. DISPOSITIVOS LEGAIS: artigos 224, 518, 519 e 994 do Decreto $\mathrm{n}^{\circ} 3.000$, de 1999 (RIR/99); art. $1^{\circ}$ da IN SRF n 104, de 1998; IN SRF no 107/88, subitens 2.1.1 e 3.1.1." (g.n.)
} 


\section{(ii) Permuta de bens do ativo imobilizado (ganho de capital)}

As considerações expostas até o momento referem-se ao tratamento tributário conferido ao permutante que se compromete a entregar imóveis pertencentes ao seu estoque (ativo circulante). Ocorre que o imóvel a ser entregue em permuta pode possuir natureza de ativo imobilizado (antigo grupo ativo permanente, atual ativo não circulante), como é o caso do imóvel sede das atividades da empresa.

Assim sendo, mesmo que a pessoa jurídica esteja sujeita à tributação do imposto de renda pelo lucro presumido, a tributação deverá se realizar na sistemática do ganho de capital apenas sobre a eventual mais valia na alienação. Ou seja, somente haverá ganho de capital quando houver pagamento de torna.

\subsubsection{1.b - Depreciação e Reavaliação de Bens Imóveis}

Os bens de uma pessoa jurídica são ativos que podem estar registrados na contabilidade societária em contas de diferentes naturezas. Em razão da aplicação do RTT, deve-se partir da classificação contábil vigente em 31/12/2007, para que se possa apurar o lucro líquido fiscal.

Com efeito, especificamente no que tange aos bens imóveis, o registro contábil deveria ser feito em uma das seguintes contas: (i) no "estoque", como é o caso dos apartamentos destinados à venda pela incorporadora ou (ii) no "imobilizado", como é o caso do imóvel onde a pessoa jurídica possui sua sede. ${ }^{62}$

Ainda, de acordo com os métodos e critérios vigentes em 31/12/2007 (conforme exposto no Capítulo 5.2.1.1.a), as edificações são registradas por seu custo de aquisição, ajustado pela depreciação no decorrer do prazo de vida útil (com a adoção do prazo médio de 25 anos estabelecido pela IN/RFB n ${ }^{\circ}$ 162/98, ou seja, taxa anual de $4 \%$ de depreciação). ${ }^{63}$

Com efeito, tendo em vista que até 31/12/2007 adotava-se no Brasil uma taxa de depreciação fixa para os bens do ativo, era possível que as edificações estivessem registradas

\footnotetext{
${ }^{61}$ Soluções de Consulta da RFB nº 64/2010, nº 66/2011, no 182/2011 e no 205/2011. Confira-se Capítulo 4.5 do presente trabalho.

${ }^{62}$ Com o advento das novas regras contábeis, os imóveis utilizados para obter rendas ou valorização do capital, passaram a ser classificados como "investimento" (Pronunciamento Técnico CPC 28).

${ }^{63}$ Neste sentido, confira-se: LAULETTA, Andrea Bazzo e NOVELLO, Guilherme Lautenschlaeger. Os Efeitos Tributários Decorrentes das Novas Regras Contábeis de Depreciação. In: MOSQUERA, Roberto Quiroga e LOPES, Alexsandro Broedel (coord.). Controvérsias Jurídico-Contábeis (Aproximações e Distanciamentos). $2^{\circ}$ Vol. São Paulo : Dialética, 2011, pp. 20-35.
} 
no ativo da entidade com valores que não refletiam o seu valor de mercado. Também, poderia ter sido necessário que a entidade realizasse a sua reavaliação a valor de mercado, o que era permitido pela legislação societária (Lei $n^{\circ}$ 6.404/76) até as alterações promovidas pela Lei $n^{\circ}$ $11.638 / 07$.

De fato, conforme já mencionado no Capítulo 2.2, a conta de reserva de reavaliação, anteriormente prevista no $\S 3^{\circ}$ do artigo 182 da Lei das S/A, foi revogada pela Lei $n^{\circ}$ 11.638/07. Conforme destacado, a eliminação dessa conta do patrimônio líquido está em desacordo com as normas internacionais (pois vai de encontro com a finalidade da contabilidade de avaliar o patrimônio), mas foi motivada pelo abuso com que essa conta era utilizada no Brasil.

Dessa forma, as normas Contábeis Societárias atualmente em vigor não permitem a reavaliação espontânea dos ativos da entidade. Não obstante, as normas fiscais que tratam da reavaliação de bens continuam válidas, mas ineficazes por impossibilidade de novas reavaliações societárias. Neste sentido, confira-se o entendimento de Luís Eduardo Schoueri e Vinícius Feliciano Tersi: ${ }^{64}$

\footnotetext{
"No caso de reserva de reavaliação, a solução é consideravelmente mais fácil. As normas contábeis existentes preveem seu tratamento na hipótese de um dia a legislação brasileira permiti-la, de forma que o tratamento tributário continua válido e vigente. Apenas não é eficaz, em razão de não haver autorização na legislação societária para seu uso. As normas tributárias, por ora, apenas continuam aplicáveis para os saldos ainda existentes de reserva de reavaliação, os quais o artigo $6^{\circ}$ da Lei ${ }^{\circ}$ 11.638/2007 permitiu que fossem mantidos até sua efetiva realização."

Trata-se, portanto, de hipótese de alteração de conceito de Direito Societário que era recepcionado pelo Direito Tributário. Assim, sua revogação tem como consequência a ineficácia da regra tributária enquanto não for possível a realização de novas reavaliações
} societárias. ${ }^{65}$

Nos termos do artigo $4^{\circ}$ da Lei $n^{\circ} 9.959 / 00$, foi estabelecido que a reavaliação de quaisquer bens da pessoa jurídica somente poderá ser tributada pelo IRPJ e pela CSLL quando

\footnotetext{
${ }^{64}$ SCHOUERI, Luís Eduardo e TERSI, Vinícius Feliciano. Cf. op. cit. (nota 34), p. 139.

${ }^{65}$ Este inclusive é o entendimento da RFB, manifestado por meio de diversas Soluções de Consulta: "SOLUÇÃO DE CONSULTA No 216 de 06 de Setembro de 2011

ASSUNTO: Imposto sobre a Renda de Pessoa Jurídica - IRPJ

EMENTA: REAVALIAÇÃO DE BENS A partir de $1^{\circ}$ de janeiro de 2008 , data de vigência da Lei $\mathrm{n}^{\circ}$ 11.638/2007, vedou-se às empresas a possibilidade de fazer, de forma espontânea, registros contábeis de reavaliação de ativos, face à extinção da conta "Reservas de Reavaliação". Entretanto, o saldo existente em 31/12/2007, caso mantido de acordo com o artigo $6^{\circ}$ da mesma lei, somente poderá ser computado em conta de resultado ou na determinação do lucro real quando ocorrer a efetiva realização do bem reavaliado."
} 
efetivamente realizada. ${ }^{66}$ Com efeito, a partir da vigência desse dispositivo, conclui-se que inclusive a reavaliação de imóveis registrados no estoque da pessoa jurídica (ativo circulante) somente poderá ser tributada quando ocorrer sua realização.

De fato, a realização da renda no caso de bens imóveis (conforme analisado no Capítulo 1.2.2.4) somente ocorre quando de sua venda para terceiros, pois inexistem as condições de objetividade e segurança necessárias para a tributação antes desse momento. No entanto, este tratamento fiscal somente seria aplicado se houvesse a reavaliação dos bens do ativo da empresa, o que não pode mais ocorrer de acordo com as normas societárias atuais, motivo pelo qual este dispositivo não possui eficácia.

Registre-se, ainda, que, com o advento da Lei $n^{\circ} 11.638 / 07$, foi criada uma nova conta de patrimônio líquido denominada ajustes de avaliação patrimonial, prevista no artigo 178, $\S 2^{\circ}$, inciso III, da Lei das S/A. Conforme o Manual de Contabilidade Societária FIPECAFI,${ }^{67}$ essa conta foi instituída com a seguinte finalidade:

“receber as contrapartidas de aumentos ou diminuições de valor atribuído a elementos do ativo e do passivo, em decorrência de sua avaliação a valor justo, enquanto não computados no resultado do exercício em obediência ao regime de competência. São registrados nessa conta, por exemplo, as variações de preço de mercado dos instrumentos financeiros, quando destinados à venda futura (...) Cabe salientar que a conta Ajustes de Avaliação Patrimonial não corresponde a uma conta de reserva, uma vez que seus valores não transitaram pelo resultado. (...) Como regra geral, os valores registrados nessa conta deverão ser transferidos para o resultado do exercício à medida que os ativos e passivos forem sendo realizados."

Portanto, verifica-se que a conta de ajustes de avaliação patrimonial, integrante do patrimônio líquido da pessoa jurídica, é uma conta transitória para registro das contrapartidas de ajuste a valor justo de alguns bens do ativo, sem trânsito pelo resultado enquanto não realizados.

Nos termos do $\S 3^{\circ}$ do artigo 182 da Lei das S/A, a conta de ajuste de avaliação patrimonial somente se aplica às contrapartidas de aumentos ou diminuições de valor atribuídos a elementos do ativo e do passivo, em decorrência da sua avaliação a valor justo, enquanto não computadas no resultado do exercício em obediência ao regime de competência.

\footnotetext{
66 “Art. 4- A contrapartida da reavaliação de quaisquer bens da pessoa jurídica somente poderá ser computada em conta de resultado ou na determinação do lucro real e da base de cálculo da contribuição social sobre o lucro líquido quando ocorrer a efetiva realização do bem reavaliado."

${ }^{67}$ IUDÍCIBUS, Sérgio de, MARTINS, Eliseu, GELBECKE, Ernesto Rubens, SANTOS, Ariovaldo dos. Manual de Contabilidade Societária - Aplicável a Todas as Sociedades - de Acordo com as Normas Internacionais e do $C P C$. FIPECAFI - Fundação Instituto de Pesquisas Contábeis, Atuariais e Financeiras, FEA/USP, São Paulo: Atlas, 2010, p. 348.
} 
São casos específicos, previstos na Lei das S/A ou em normas expedidas pela CVM ( v.g. item 62 do CPC 28, quando trata da transferência do imóvel ocupado pelo proprietários para propriedade para investimento). Assim, a referida conta contábil não poderá ser utilizada como substitua para a conta de reserva de reavaliação. ${ }^{68}$

Por fim, conforme já mencionado, a classificação do imóvel como propriedade para investimento não era método ou critério contábil vigente em 31/12/2007. Dessa forma, em razão da aplicação do RTT, as receitas/despesas decorrentes da avaliação de imóveis a valor justo não serão tributadas (deve ser feita a exclusão/adição ao lucro líquido societário para a apuração do lucro líquido fiscal).

\subsubsection{2 - Tributação da Prestação de Serviços Imobiliários}

Conforme já mencionado (capítulo 5.2.1.2), a regra geral para a tributação de serviços na sistemática do lucro presumido é a aplicação do coeficiente de $32 \%$ de presunção de lucro sobre a receita.

Dessa forma, no caso de construção por empreitada em que houver o emprego exclusivo de mão de obra na prestação do serviço, será aplicado o coeficiente de presunção de $32 \%$ sobre a receita bruta. Contudo, quando houver emprego de mão de obra e fornecimento de materiais, aplica-se o coeficiente de presunção de $8 \%$ para a apuração da base de cálculo do IRPJ. $^{69}$

\footnotetext{
${ }^{68}$ Este inclusive é o entendimento da RFB, manifestado por meio da SOLUÇÃO DE CONSULTA No 19 de 09 de Marco de 2009:

ASSUNTO: Imposto sobre a Renda de Pessoa Jurídica - IRPJ

EMENTA: REAVALIAÇÃO DE BENS DO ATIVO INTANGÍVEL APÓS A VIGÊNCIA DA LEI 11.638/2007. IMPOSSIBILIDADE. A partir de $1^{\circ}$ de janeiro de 2008, data de vigência da Lei $n^{\circ} 11.638 / 2007$, vedou-se às empresas a possibilidade de fazer, de forma espontânea, registros contábeis de reavaliação de ativos, face à extinção da conta "Reservas de Reavaliação". AJUSTES DE AVALIAÇÃO PATRIMONIAL. UTILIZAÇÃO RESTRITA AOS CASOS PREVISTOS NA LEI N ${ }^{\circ}$ 6.404/1976 E ÀQUELES ESTABELECIDOS PELA CVM. A "Reserva de Reavaliação" não foi substituída pela conta de "Ajustes de Avaliação Patrimonial", que tem natureza e finalidade distinta. Esta se destina a escriturar, exclusivamente, os valores decorrentes de avaliação de instrumentos financeiros, além dos casos estabelecidos pela CVM com base na competência que lhe foi atribuída pela Lei $\mathrm{n}^{\circ}$ 11.638/2007 e MP n ${ }^{\circ} 449 / 2008$. Aquela se destinava a escriturar as contrapartidas de valores atribuídos a quaisquer elementos do ativo em virtude de novas avaliações com base em laudo."

${ }^{69}$ Solução de Consulta 30/2002

"ASSUNTO: Imposto sobre a Renda de Pessoa Jurídica - IRPJ

EMENTA: CONSTRUÇÃO POR EMPREITADA. O percentual a ser aplicado sobre a receita bruta para determinação da base de cálculo do imposto de renda mensal por estimativa, ou pelo lucro presumido, será de $32 \%$ (trinta e dois por cento) quando houver emprego unicamente de mão-de-obra, e de $8 \%$ (oito por cento) quando houver fornecimento de materiais, em qualquer quantidade, circunstância esta comprovada através dos contratos de execução juntamente com a escrita contábil." (no mesmo sentido, Soluções de Consultas no $106 / 02, n^{\circ}$ $84 / 02, n^{\circ} 248 / 01, n^{\circ} 81 / 02, n^{\circ} 36 / 03$ e $n^{\circ} 16 / 03$ ).
} 
Para as pessoas jurídicas prestadoras de serviços em geral, com receita bruta anual de até $\mathrm{R} \$ 120.000,00$, apura-se a base de cálculo do lucro presumido mediante a aplicação do coeficiente de $16 \%$ sobre a receita bruta auferida mensalmente (artigo 40 da Lei $\mathrm{n}^{\circ}$ 9.250/95).

\subsubsection{3 - Tributação da Cessão da Posse do Imóvel (Locação e Outros)}

Na sistemática do lucro presumido, tem-se como regra a aplicação do coeficiente de $32 \%$ de presunção de lucro sobre a receita operacional decorrente da locação/cessão de bens imóveis (mesmo coeficiente aplicável à presunção de lucro decorrente da prestação de serviços). Trata-se de um coeficiente muito vantajoso em geral, pois a atividade de locação não gera muitos gastos e possui uma alta taxa de lucratividade.

Para as pessoas jurídicas que tenham como objeto exclusivamente a locação de imóveis próprios, com receita bruta anual de até $\mathrm{R} \$ 120.000,00$, também é possível a apuração da base de cálculo do lucro presumido mediante a aplicação do coeficiente de $16 \%$ sobre a receita bruta auferida mensalmente (por equiparação ao benefício previsto para prestadores de serviço prevista no artigo 40 da Lei $\left.n^{0} 9.250 / 95\right) .{ }^{70}$ Esse benefício também se aplica às pessoas jurídicas que tenham como objeto social a locação de imóveis próprios em conjunto com a prestação de serviços em geral. ${ }^{71}$

As pessoas jurídicas tributadas pelo lucro real devem apurar a base de cálculo mediante a dedução de custos e despesas, bem como adições e exclusões previstas em lei. Neste sentido, há previsão legal expressa de que apenas serão dedutíveis as contraprestações de

\footnotetext{
70 “SOLUÇÃO DE CONSULTA Nº 6 de 26 de Janeiro de 2011 - Disit 08 ASSUNTO: Imposto sobre a Renda de Pessoa Jurídica - IRPJ

EMENTA: A pessoa jurídica que exerça exclusivamente a atividade de locação de imóveis próprios, para determinação da base de cálculo do imposto de renda com base no lucro presumido, deve aplicar o percentual de $32 \%$ (trinta e dois por cento). Caso a receita bruta anual seja de até R $\$ 120.000,00$ (cento e vinte mil reais), poderá utilizar o percentual de $16 \%$ (dezesseis por cento)."

71 "SOLUÇÃO DE CONSULTA No 15 de 21 de Janeiro de 2008 - Disit 10

ASSUNTO: Imposto sobre a Renda de Pessoa Jurídica - IRPJ

EMENTA: LUCRO PRESUMIDO. ATIVIDADE DE LOCAÇÃO DE IMÓVEIS PRÓPRIOS. PERCENTUAL DE PRESUNÇÃO APLICÁVEL. Pessoa jurídica exclusivamente prestadora de serviços em geral, conforme definição normativa, que tenha por objeto social também a locação de imóveis próprios, cuja receita bruta anual seja de até $\mathrm{R} \$ 120.000,00$ (cento e vinte mil reais), poderá utilizar o coeficiente de presunção de $16 \%$ (dezesseis por cento) para fins de determinar o lucro presumido, inclusive sobre as receitas de aluguel. Caso conste de seu contrato social a previsão de outras atividades, além da prestação de serviços em geral, ela não se caracteriza como uma pessoa jurídica exclusivamente prestadora de serviços e, independentemente do valor da receita bruta anual, deverá utilizar o percentual de presunção correspondente a cada atividade, devendo aplicar o coeficiente de $32 \%$ às receitas de aluguel."
} 
pagamento de aluguel de bens imóveis, quando relacionados intrinsecamente com a produção ou comercialização dos bens e serviços. ${ }^{72}$

\subsubsection{4 - Tributação da Securitização de Recebíveis}

A securitização de recebíveis, conforme já mencionado, é a operação pela qual a companhia securitizadora emite uma série de títulos de crédito expressamente vinculados a créditos imobiliários (recebíveis decorrentes de venda a prazo de bens, serviços ou operações imobiliárias). É expressamente permitida a securitização de créditos decorrente da alienação de unidades em construção, sob regime de incorporação imobiliária (artigo $8^{\circ}$ da Lei no 9.514/97).

Os créditos imobiliários podem ser da instituição financeira ou do próprio alienante da unidade imobiliária (no caso de venda a prazo). Quando os créditos imobiliários decorrerem de vendas a prazo contratadas diretamente com o alienante ( $v . g$. venda direta pelo incorporador, sem a intermediação de uma instituição financeira), o recebimento pela venda dos títulos deverá ser tributada como venda de unidade à vista (conforme será exposto no Capítulo 5.3.1).

\section{3 - REGIMES ESPECÍFICOS DE TRIBUTAÇÃO}

\subsection{1 - Tributação das Atividades de (i) Compra e Venda, (ii) Loteamento, (iii) Incorporação e (iv) Construção de Imóveis}

A legislação tributária estabelece critérios específicos de reconhecimento e mensuração do custo e do lucro das atividades de (i) compra de imóvel para venda, (ii) desmembramento ou loteamento de terrenos, (iii) incorporação imobiliária ou (iv) construção de prédio destinado à venda. Tais critérios estão previstos nos artigos 27 a 29 do Decreto Lei n $^{\circ}$ 1.598/77, regulamentados pela IN/RFB nº 84/79.

Conforme já destacado no Capítulo 5.2.1.1, as regras tributárias que se passa a analisar são normas de Contabilidade Tributária, que compõem os métodos e critérios contábeis vigentes em 31/12/2007 (critério de apuração do lucro líquido fiscal) e que não se confundem com as normas de apuração do lucro societário atualmente em vigor, analisadas no Capítulo 4.

\footnotetext{
${ }^{72}$ Conforme inciso II do artigo 13 da Lei $\mathrm{n}^{\circ}$ 9.249/95.
} 
A IN/RFB $n^{\circ}$ 84/79 define unidade imobiliária como sendo: (i) o terreno adquirido para venda, com ou sem construção, (ii) cada lote oriundo de desmembramento de terreno, (iii) cada terreno decorrente de loteamento, (iv) cada unidade distinta resultante de incorporação imobiliária, (v) o prédio construído para venda como unidade isolada ou autônoma.

Ressalte-se também que a IN/RFB n 84/79, no subitem 1.2, adverte que, para fins de apuração da contabilidade fiscal, também serão considerados contribuintes, sujeitos a essas regras especiais de apuração do IRPJ, a pessoa física considerada empresa individual por promover a incorporação de prédios em condomínio, ou o loteamento de terrenos, nos termos dos Decretos-Leis n ${ }^{\circ}$ s 1.381/74 e 1.510/76 (confira-se o Capítulo 5.1.2.4).

A seguir, passa-se a discorrer sobre os critérios fiscais específicos de reconhecimento e mensuração do lucro das referidas atividades imobiliárias, seja por pessoas jurídicas, seja por pessoas físicas equiparadas às pessoas jurídicas para fins de tributação.

\subsubsection{1 - Custo da Unidade Imobiliária}

Conforme dispõe o inciso I do artigo 27 do DL n ${ }^{\circ} 1.598 / 77$, o contribuinte, para determinar o custo dos imóveis vendidos, deverá manter registros permanentes de estoque com as seguintes informações:

(i) o custo de aquisição de terrenos ou prédios, inclusive os tributos devidos na aquisição e as despesas de legalização;

(ii) os custos diretos de (a) estudo, (b) planejamento, (c) legalização e (d) execução dos planos ou projetos de desmembramento, loteamento, incorporação, construção e quaisquer obras ou melhoramentos; e

(iii) os custos mencionados no item anterior são considerados como custos para produção de bens ou serviços, conforme previstos no $\S 1^{\circ}$ do artigo 13 do DL $n^{\circ} 1.598 / 77$, e deverão compreender, obrigatoriamente: (a) custo de aquisição de matérias-primas e quaisquer outros bens ou serviços aplicados ou consumidos na produção; (b) custo do pessoal aplicado na produção, inclusive de supervisão direta, manutenção e guarda das instalações de produção; (c) custos de locação, manutenção e reparo e os encargos de depreciação dos bens aplicados na produção; (d) encargos de amortização 
diretamente relacionados com a produção; (e) encargos de exaustão dos recursos naturais utilizados na produção.

Quando o empreendimento compreender mais de uma unidade que serão vendidas separadamente, o registro do estoque deverá discriminar o custo de cada unidade distinta.

\section{Custos Financeiros}

Merece destaque o tratamento conferido aos encargos financeiros pela IN/RFB $n^{\circ}$ $84 / 79$, a pretexto de regulamentar as normas de apuração de custos estipuladas pelo DL $\mathrm{n}^{\circ}$ 1.598/77:

\footnotetext{
"6.4 - As despesas com as vendas, as despesas financeiras, as despesas gerais e administrativas e quaisquer outras, operacionais e não operacionais, não poderão ser computadas no custo dos imóveis vendidos, sob nenhum pretexto.” (g.n.)
}

Verifica-se, portanto, que os encargos financeiros (v.g. taxas de abertura de crédito, juros e atualização monetária), nos termos da IN/RFB 84/79, devem ser tratados como despesa financeira e não poderão ser computados no custo dos imóveis vendidos.

Contudo, como esse instrumento normativo não tem força de lei (princípio da legalidade tributária), é necessário verificar se há fundamento legal para referida regra de contabilidade fiscal (regra de reconhecimento).

Ao se analisarem as disposições do DL $n^{0}$ 1.598/77 e a legislação tributária superveniente, verifica-se que não há qualquer previsão expressa acerca do assunto. Dessa forma, não havendo uma regra específica para apuração da contabilidade fiscal prevista em lei (normas suplementares de caráter específico), faz-se necessário verificar qual o tratamento dado a esses gastos pelas normas de apuração da contabilidade societária (normas gerais).

Conforme destacado no Capítulo 4.6, a Resolução CFC nº 963/2003, que aprovou a NBC T 10.5 - Entidades Imobiliárias, estabelecia métodos e critérios em conformidade com os PCGA, obrigatórios pela Lei das S/A. Segundo essa norma, o custo do imóvel compreende todos os gastos incorridos para sua obtenção, abrangendo os encargos financeiros diretamente associados ao financiamento da construção (alínea "e" do item 10.5.2.7).

No mesmo sentido dispõem os métodos e critérios contábeis atualmente vigentes. A Deliberação CVM no 561/2008, que aprova a Orientação OCPC - 01, estabelece que as Entidades de Incorporação Imobiliária devem reconhecer os encargos financeiros, diretamente 
associados ao financiamento do empreendimento imobiliário, como custo do imóvel (item 2.e).

Estas normas, conforme já analisadas, estão em conformidade com os PCGA vigentes em 31/12/2007, bem como com as regras de produção normativa da contabilidade societária atualmente em vigor. Dessa forma, referida interpretação possui fundamento de validade na própria Lei das S/A.

Não pode, portanto, a IN/RFB n ${ }^{\circ}$ 84/79 dispor de forma contraditória, sob pena de criar uma regra contrária aos PCGA previstos em lei. De fato, na falta de norma com força de lei que trate da apuração dos custos financeiros para fins tributários, prevalece a regra geral nos termos das normas societárias.

Assim, tendo em vista que a regra trazida pela IN/RFB 84/79 fere o princípio da legalidade, os encargos financeiros devem ser contabilizados como custo dos imóveis vendidos e também terão o tratamento de custo para fins tributários.

\subsubsection{2 - Lucro Bruto - Aplicabilidade do $§ 1^{\circ}$ do artigo 27 do DL $\mathbf{n}^{\circ}$ 1.598/77}

$\mathrm{O} \S 1^{\circ}$ do artigo 27 do $\mathrm{DL} \mathrm{n}^{\circ}$ 1.598/77 estabeleceu que o critério de reconhecimento do lucro bruto para fins fiscais, decorrente da venda de cada unidade, é o momento em que (i) é contratada a venda, ainda que mediante instrumento de promessa, ou (ii) é implementada a condição suspensiva a que estiver sujeita a venda.

Verifica-se, portanto, que a legislação fiscal estabeleceu o momento da contratação da venda como suficiente para se considerar ocorrido o lucro bruto, base de cálculo para apuração do imposto de renda. Ocorre que o referido dispositivo legal não distinguiu as hipóteses (i) de venda de imóveis já construídos e (ii) de imóveis ainda em fase de construção ou "na planta", motivo pelo qual se deve averiguar a legitimidade de sua aplicação nestes casos.

Conforme já mencionado no Capítulo 1.2.2, o princípio da realização da renda determina que a tributação somente seja possível quando o ingresso/acréscimo patrimonial tenha as características de (i) materialidade, (ii) objetividade e (iii) segurança.

No momento da contratação da venda da unidade imobiliário ainda em fase de construção, já existe objetividade quanto à mensuração da renda (valor contratual determinado entre partes independentes). Contudo, não há ainda materialidade, pois o direito 
ao recebimento do preço só se verifica com a transferência dos riscos e benefícios, correspondente à entrega do bem ou à execução da obra, conforme o caso. Também não se verifica geralmente um nível adequado de segurança quanto ao recebimento da renda, pois os contratos costumam ser financiados a longo prazo.

Dessa forma, exigir a tributação da renda decorrente da venda de unidades imobiliárias em construção, com base simplesmente no contrato de venda, fere frontalmente o princípio constitucional da realização da renda. Portanto, não pode ser esse o critério de tributação da renda pelo regime de competência, motivo pelo qual se faz necessária a análise da legislação societária sobre o tema.

Neste sentido, o regime de competência para a contabilização das vendas de unidades em construção, em conformidade com a contabilidade societária, também será aplicável à apuração da contabilidade fiscal (em conformidade com o RTT, analisado no Capítulo 5.2.1.1).

Conforme já analisado no Capítulo 4.6, a contabilidade societária vigente em 31/12/2007 para as entidades imobiliárias (Resolução CFC no 963/2003) determinava que, na venda de unidades imobiliárias em fase de construção, a receita deveria ser reconhecida pela produção, ou seja, na proporção do custo incorrido em relação ao custo total previsto até a conclusão da obra (item 10.5.2.5). ${ }^{73}$

Com efeito, em conformidade com o princípio constitucional da realização da renda (bem como com os critérios de disponibilidade jurídica ou econômica previstos no CTN), o lucro imobiliário, apurado pelo regime de competência, pressupõe que seja contratada a venda, mas somente poderá ser reconhecido gradualmente durante a evolução da obra.

De fato, o direito definitivo ao recebimento do valor da venda nos casos de incorporação imobiliária somente se verifica com o transcorrer da evolução da obra, pois, antes desse momento o vendedor ainda não cumpriu sua obrigação contratual. Assim, a mera assinatura do contrato consubstancia uma mera expectativa de direito ao recebimento do preço (o que não pode ser utilizado como base para tributação).

\footnotetext{
73 Tendo em vista a inconstitucionalidade da tributação do lucro de unidade em fase de construção no momento da celebração do contrato, a RFB equivocou-se ao manifestar entendimento no sentido de que a norma societária não seria aplicável, nos termos do Ato Declaratório Interpretativo ADI/RFB nº 18/05: "Artigo único. A pessoa jurídica que comprar imóvel para venda ou promover empreendimento de desmembramento ou loteamento de terrenos, incorporação imobiliária ou construção de prédio destinado à venda, deverá observar o disposto nos arts. 27 a 29 do Decreto-lei $n^{\circ}$ 1.598, de 26 de dezembro de 1977, e no art. 30 da Lei $n^{\circ}$ 8.981, de 20 de janeiro de 1995, não se aplicando, para fins tributários, as disposições contidas nas NBC T 10.5 - Entidades Imobiliárias, aprovadas pela Resolução n 963, de 16 de maio de 2003, do Conselho Federal de Contabilidade." (g.n.)
} 
Registre-se, no mesmo sentido, que a IN/RFB no 84/79 (item 10.1) estabeleceu como critério de realização da venda (para fins de apuração do lucro bruto) a contratação de "carta de reserva com princípio de pagamento ou qualquer outro documento representativo de compromisso". De fato, apenas a carta de reserva que represente um compromisso de compra e venda (não importa o nome dado pelas partes, mas sim a análise da causa do negócio jurídico) é negócio jurídico suficiente para conferir objetividade, mas não pode ser fato gerador do imposto de renda enquanto não iniciada a realização da obra (para que se tenha materialidade quanto ao direito de recebimento do preço).

\section{$\checkmark$ Condição suspensiva}

Em geral, as incorporações imobiliárias são contratadas com condição suspensiva. Trata-se de prazo de carência dentro do qual poderá ocorrer a desistência do empreendimento. Conforme artigo 34 da Lei $n^{\circ} 4.591 / 64$, esse prazo não pode ser superior ao da validade do registro da incorporação (180 dias) ou de sua revalidação, se for o caso.

Exemplos de condição suspensiva são o direito à desistência da incorporação no caso de não ser atingido um número mínimo de venda das unidades, ou o contrato somente ter eficácia após a liberação de hipoteca que esteja gravando o imóvel negociado.

Com efeito, verifica-se que, enquanto não implementada a condição suspensiva, não há sequer que se falar em materialidade quanto ao direito ao recebimento, necessária para que seja considerada realizada a renda, o que foi corretamente reconhecido pelo DL $\mathrm{n}^{\circ}$ $1.598 / 77$.

De fato, nos termos do artigo 121 do CC/2002, a condição é uma cláusula contratual que deriva exclusivamente da vontade das partes e que subordina a eficácia do negócio jurídico a evento futuro e incerto.

Se a condição for suspensiva, não se considera adquirido o direito decorrente do contrato enquanto não implementada a condição (conforme o artigo 125 do CC/2002). Se, contudo, a condição for resolutiva, o negócio jurídico vigerá enquanto a condição não se realizar, motivo pelo qual os direitos decorrentes do contrato já podem ser exercidos desde sua conclusão (conforme o artigo 127 do CC/2002).

Neste sentido, é cláusula suspensiva a condição de que a venda somente será considerada perfeita e acabada após a obtenção de financiamento junto a terceiros (prevista 
expressamente no item 10.2 da IN/RFB 84/79). Contudo, essa clausula pode ser considerada uma condição resolutiva, caso o próprio alienante esteja obrigado a arcar com o financiamento ou não ocorra o financiamento com terceiros. ${ }^{74}$

\subsubsection{2 - Custo Orçado - Direito à Adoção do Lucro Presumido}

Conforme o artigo 28 do DL $\mathrm{n}^{\circ} 1.598 / 77$, se a venda for contratada antes de completado o empreendimento, o contribuinte poderá (faculdade do contribuinte) computar no custo do imóvel vendido, além dos custos pagos, incorridos ou contratados, os orçados para a conclusão das obras ou melhoramentos que estiver contratualmente obrigado a realizar.

O custo orçado será baseado nos custos usuais para o tipo de empreendimento imobiliário e corresponderá à diferença entre (i) o custo total previsto para o empreendimento e (ii) os custos pagos, incorridos ou contratados até a data da efetivação da venda.

O valor orçado para a conclusão das obras ou melhoramentos poderá ser modificado, em qualquer época, em decorrência (subitem 9.9, 1 e 2, e subitem 9.11 da IN/RFB 84/79): (i) de sua atualização monetária e (ii) de alterações no projeto ou nas especificações do empreendimento, mas apenas aquelas que se relacionarem com a quantidade ou a qualidade dos materiais, bens, obras ou serviços ou com a natureza dos encargos ou despesas estipulados no orçamento.

Poderá ser adotado o custo orçado tanto nas vendas à vista quanto na venda a prazo de unidade não concluída. O registro do custo orçado não é obrigatório, mas o não registro para as pessoas jurídicas, que adotam o lucro real, pode ter como consequência a antecipação de carga tributária.

Ressalte-se, ainda, que, se a execução das obras ou melhoramentos se estender além do período-base da venda e o custo efetivamente realizado for inferior, em mais de

\footnotetext{
74 “IRPJ. IMÓVEL. COMPRA E VENDA A PRAZO. CONDIÇÃO SUSPENSIVA. ARGUIÇÃO RECURSAL. ELEMENTOS FUTURO E INCERTO PARCIALMENTE NÃO-TIPIFICADOS. IMPROCEDÊNCIA DO ALEGADO. A condição suspensiva pressupõe a presença de evento futuro e a imprescindibilidade do elemento incerteza. O contrato firmado com os adquirentes de unidades imobiliárias regulares, sem vinculação que subordine o pacto à obtenção de financiamento junto a terceiros - ainda que possa tipificar elemento futuro - não tem fôlego jurídico para subtrair o seu grau de certeza.

IRPJ. IMÓVEL. COMPRA E VENDA. CLÁUSULAS DE IRRETRATABILIDADE E IRREVOGABILIDADE. CONDIÇÃO RESOLUTIVA. A busca, ainda que inicial, de financiamento junto aos agentes financeiros não retrata cláusula condicionante (ou suspensiva) para implementação do negócio, devendo ser interpretada como uma alternativa adicional à disposição dos compradores finais. A não admissão pactuada do arrependimento, ao contrário de ser tão-somente um reforço, ou uma obrigação condicional, conduz o contrato, inexoravelmente, aos princípios de irretratabilidade e irrevogabilidade - faculdades consentâneas com o caráter que se revela resolutivo - tácito e expresso - da convenção contratual em dissídio.” (Acórdão nº 103-20863 e 103-20869, de 2002)
} 
$15 \%$, ao custo orçado computado na determinação do lucro bruto, o contribuinte ficará obrigado a pagar juros de moratórios sobre o valor do imposto postergado pela dedução do custo orçado excedente ao realizado ( $\$ 2^{\circ}$ do artigo 28 do ${\operatorname{DL~} \mathrm{n}^{\circ}}^{1.598 / 77})$.

Não obstante, o tratamento tributário acima exposto, é importante destacar que a RFB, por meio da IN/RFB $n^{\circ} 25 / 99$, manifestou o entendimento de que seria vedada a opção pelo lucro presumido para as entidades que tivessem operações imobiliárias com registro de custo orçado. Ocorre que, conforme já exposto em diversos momentos durante o presente trabalho, a instrução normativa da Receita Federal não é instrumento hábil para criar tributos ou restringir direitos dos contribuintes (princípio da legalidade).

Ao se analisar o artigo 14 da Lei $n^{\circ} 9.718 / 98$, verifica-se que a adoção do custo orçado não é uma das hipóteses de obrigatoriedade de adoção do lucro real. Dessa forma, a restrição, ora em análise, não encontra respaldo legal, em afronta ao princípio da legalidade. Este entendimento é compartilhado pelo STJ:

“TRIBUTÁRIO. INSTRUÇÃO NORMATIVA/SRF No 25/99. LEI No 9.718/98. BENEFÍCIO FISCAL PREVISTO NO DECRETO-LEI N ${ }^{\circ}$ 1.598/77. CUSTO ORÇADO. IMPOSIÇÃO DE RESTRIÇÃO NÃO PREVISTA NA LEI. AFRONTA AO PRINCÍPIO DA LEGALIDADE. (...)

4. Com a edição da Lei 9.718/98, restaram desobrigadas do regime de apuração com base no lucro real, podendo optar pelo lucro presumido, as pessoas jurídicas dedicadas à compra e à venda, ao loteamento, à incorporação ou à construção de imóveis e à execução de obras da construção civil, como decorrência lógica do fato de não constarem do rol elencado no artigo 14, da citada norma legal.

5. Ocorre que a Instrução Normativa SRF 25/99 impôs-lhes condição não prevista no referido diploma legal, ao preceituar que as mencionadas pessoas jurídicas não poderiam optar pelo lucro presumido enquanto não concluídas as operações imobiliárias para as quais houvesse registro de custo orçado. (...)

8. O ato administrativo, no Estado Democrático de Direito, está subordinado ao princípio da legalidade (CF/88, arts. $5^{\circ}$, II, 37, caput, 84, IV), o que equivale a assentar que a Administração só pode atuar de acordo com o que a lei determina. Desta sorte, ao expedir um ato que tem por finalidade regulamentar a lei (decreto, regulamento, instrução, portaria, etc.), não pode a Administração inovar na ordem jurídica, impondo obrigações ou limitações a direitos de terceiros. (...)" (RESP 665880 / RS) 


\subsubsection{3 - Regime de Caixa - (i) Extinção da conta de Resultados de Exercícios Futuros e (ii) Inconstitucionalidade/Ilegalidade da IN/RFB no 84/79}

Conforme já mencionado no Capítulo 4.5, a apuração do lucro pelo regime de caixa pressupõe que as receitas e os ganhos só sejam registrados quando da sua realização em moeda. Não obstante, todos os custos e despesas correspondentes a essas receitas devem ser registrados no mesmo período de apuração, independentemente da saída de caixa (princípio do confronto das despesas com as receitas - Capítulo 2.4.3).

Ocorre que, tendo em vista as peculiaridades que envolvem o ciclo econômico do setor imobiliário, especialmente a venda de unidades imobiliárias para recebimento a longo prazo, a legislação tributária trouxe regulamentação própria e específica, a seguir analisada.

Conforme visto, a regra societária para fins de apuração do lucro imobiliário pelo regime de competência (tanto a regra vigente em 31/12/2007 quanto as regras atuais) pressupõe a contratação da venda e a implementação da condição suspensiva. Contudo, o lucro somente será reconhecido durante a evolução da obra ou com a entrega das chaves (independentemente do pagamento do preço - ingresso no caixa).

Ocorre que, se a venda for realizada a prazo ou em prestações, com pagamentos após o período-base da venda, a legislação tributária estabelece que poderá ser adotado o regime de caixa (opção fiscal), o que está em conformidade com o princípio da realização da renda (garantia de segurança de pagamento do imposto apenas quando recebido o preço).

Como se percebe, trata-se de prerrogativa instituída pelo legislador tributário às entidades imobiliárias em razão da atividade por elas exercidas, uma vez que essas empresas normalmente contratam o recebimento das receitas de venda a médio e longo prazo, podendo ocorrer perdas de fluxo de caixa, decorrentes do pagamento de tributos antes do recebimento integral do preço (ou seja, prevalece o aspecto da segurança para fins de realização da renda). ${ }^{75}$

Neste sentido, o artigo 29 do DL $\mathrm{n}^{\circ}$ 1.598/77 determina que, para efeito de determinação do lucro real, o lucro bruto poderá ser reconhecido nas contas de resultado de cada exercício social proporcionalmente à receita de venda recebida, observadas as seguintes normas: (i) o lucro bruto será registrado em conta específica de resultado de exercícios futuros - REF, para a qual serão transferidos a receita de venda e o custo do imóvel; (ii) por ocasião da venda será determinada a relação entre o lucro bruto e a receita

\footnotetext{
${ }^{75} \mathrm{O}$ mesmo critério prevalece para os contratos de longo prazo em geral, conforme antigo $10^{\circ}$ do DL n $\mathrm{n}^{\circ} 1.598 / 77$.
} 
bruta de venda. Em cada exercício social, será transferida para as contas de resultado a parte do lucro bruto proporcional à receita recebida no mesmo exercício. ${ }^{76}$

Como se pode verificar, o artigo 29 do DL no 1.598/77 estabeleceu tratamento contábil próprio para a apuração do imposto de renda (contabilidade tributária), o qual é distinto dos conceitos estabelecidos na legislação societária (contabilidade societária). Ou seja, este dispositivo estabeleceu o conjunto de normas contábeis necessárias para a apuração do lucro tributável (real, presumido ou arbitrado) pelo regime de caixa.

Neste sentido, é importante destacar que a conta contábil REF estava prevista na alínea $c$ do $\S 2^{\circ}$ do artigo 178 e no artigo 181 da Lei das S/A (trata-se de dispositivo que integrava os métodos e critérios contábeis vigentes em 31/12/2007). Contudo, essa conta foi extinta pela Lei no 11.941/2009 (legislação societária), uma vez que não se adequava aos princípios e práticas contábeis internacionalmente aceitos.

Dessa forma, os valores lançados sob essa rubrica contábil tiveram que ser transferidos para uma conta de passivo representativa de receita diferida, nos termos do artigo 299-B da Lei das S/A.

Independentemente das dificuldades práticas de aplicação da neutralidade tributária por meio do RTT (conforme visto no Capítulo 5.2.1.1.b), é importante destacar que o tratamento fiscal previsto no artigo 29 do DL n ${ }^{\circ}$ 1.598/77 deve ser mantido independentemente da existência ou não da conta REF para fins societários, pois se trata de um conceito contábil tributário (que "transforma" a contabilidade societária, dando contornos tributários próprios para fins fiscais).

Diferentemente do que ocorreu com a extinção da conta de "reserva de reavaliação" (confira-se o Capítulo 5.2.2.1.b), a extinção da conta REF não é impeditivo para a eficácia do regime de tributação previsto para a atividade imobiliária. $\mathrm{Na}$ verdade, o lançamento contábil nesta conta era apenas um mecanismo para aplicação do regime tributário e não um pressuposto para sua eficácia.

Neste sentido, registre-se que a RFB já proferiu o entendimento de que o tratamento fiscal ora em análise deve ser mantido com a utilização da conta de passivo

\footnotetext{
${ }^{76} \mathrm{O}$ pagamento mensal do imposto por estimativa (artigo $2^{\circ}$ da Lei $\mathrm{n}^{\mathrm{o}}$ 9.430/96) também considera receita bruta da atividade imobiliária apenas o valor efetivamente recebido, confira-se o artigo 30 da Lei no 8.981/95: “Art. 30. As pessoas jurídicas que explorem atividades imobiliárias relativas a loteamento de terrenos, incorporação imobiliária, construção de prédios destinados à venda, bem como a venda de imóveis construídos ou adquiridos
} 
não circulante, representativa de receita diferida, independentemente da adoção do RTT. Confira-se:

“SOLUÇÃO DE CONSULTA N 100 de 09 de Abril de 2010

ASSUNTO: Imposto sobre a Renda de Pessoa Jurídica - IRPJ

EMENTA: ATIVIDADE IMOBILIÁRIA. RTT. OPÇÃO. O regime de tributação instituído pelos arts. 27 a 29 do Decreto-Lei $n^{\circ} 1.598$, de 1977, é aplicável às pessoas jurídicas que exerçam as atividades de compra e venda, loteamento, incorporação e construção de imóveis, ainda que não tenham efetuado a opção pelo Regime Tributário de Transição - RTT de que trata a Lei no 11.941, de 2009. Os valores antes registrados em conta de resultados de exercícios futuros devem ser contabilizadas em conta do passivo não-circulante representativa de receita diferida.” (g.n.)

É importante ressaltar a necessidade de cautela ao interpretar o disposto nessa Solução de Consulta, pois a Contabilidade Societária, atualmente em vigor, já se libertou das imposições feitas pelas autoridades fiscais. $\mathrm{O}$ entendimento manifestado por meio dessa solução de consulta representa um resquício do autoritarismo fiscal a que estava sujeita a Contabilidade Societária.

$\mathrm{Na}$ verdade, o critério para registro dos lançamentos societários não é mais definido pela lei fiscal, como supõe a Solução de Consulta. Não obstante, esse entendimento acabou por corroborar exatamente o tratamento fiscal defendido no presente trabalho. Isto porque o entendimento administrativo fiscal condiciona a aplicação dos métodos e critérios contábeis fiscais referentes ao registro do REF (regime de caixa previsto no DL no 1598/77) ao registro na conta de receita diferida para fins societários.

A conta societária de receita diferida somente registra valores que representam pagamentos a título de receita, mas que ainda não foram realizados pelo regime de competência (v.g. adiantamento de clientes). Trata-se, de fato, de mero ingresso financeiro que não pode ser considerado receita.

Em suma, o entendimento da RFB está correto ao afirmar que o tratamento fiscal conferido à alienação de unidades imobiliárias continua vigente, válido e eficaz (DL $\mathrm{n}^{\circ}$ 1598/77). Contudo, na prática, o seu controle não será tão simples, pois envolve uma série de lançamentos contábeis que não serão passíveis de controle simplesmente pelo confronto com a conta de "receita diferida".

para revenda, deverão considerar como receita bruta o montante efetivamente recebido, relativo às unidades imobiliárias vendidas." 
Deverá ser feito o controle fiscal por meio de registros que, na prática, implicará a necessidade de uma efetiva contabilidade fiscal. Esta já era a solução adotada pelas companhias (em especial as de capital aberto) que estavam obrigadas à adoção da Resolução CFC n ${ }^{\circ}$ 963/2003 (regra de apuração da contabilidade societária vigente em 31/12/2007).

Essa regra determinava que a contabilidade societária do setor imobiliário deveria ser feita pelo regime de competência. Dessa forma, para a manutenção do tratamento físcal, era necessário o controle dos lançamentos exigidos pela legislação tributária por meio de uma contabilidade paralela (uma contabilidade fiscal), o que deverá estar reconhecido agora no FCONT.

Por fim, registre-se que a IN/RFB 84/79 incorreu em evidente ilegalidade e inconstitucionalidade ao regulamentar a forma de reconhecimento do lucro no caso de venda de unidade não concluída. Com efeito, conforme se verifica dos itens 12 e 14 da IN/RFB $84 / 79$, determinou-se o reconhecimento do lucro bruto em função do mero recebimento do preço (ingresso financeiro à vista ou a prazo), sem qualquer vínculo com a realização da obrigação do vendedor.

É importante destacar que não é qualquer ingresso financeiro que pode ser considerado como receita, conforme já mencionado no Capítulo 4.5 (sobre a apuração do lucro pelo regime de caixa). Antes de iniciada a realização da obra, os pagamentos antecipados não possuem natureza de receita, pois lhes falta um qualificativo essencial: a materialidade quanto ao direito ao seu recebimento. Trata-se de pagamento adiantados por clientes, devendo ser registrado como passivo para a entidade.

Em outras palavras, não se pode confundir o mero ingresso financeiro com o regime de caixa (disponibilidade econômica). Isto porque o regime de caixa pressupõe o direito ao recebimento da receita (antes do direito definitivo ao recebimento, o ingresso é mero adiantamento de clientes - conta de passivo).

Dessa forma, o procedimento estabelecido pela IN/RFB 84/79 é inconstitucional, pois fere o princípio da realização da renda (ausência de materialidade para o critério de realização, pois não reflete o direito ao seu recebimento).

Outrossim, este tratamento também é ilegal, pois confere tratamento tributário não previsto no artigo 29 do DL $\mathrm{n}^{\circ} 1.598 / 77$, que determina expressamente o reconhecimento da receita recebida. Assim, enquanto o ingresso não possuir natureza de receita, será um mero ingresso financeiro que não pode ser tributado nos termos do Decreto-Lei. 
Não é diferente o entendimento da própria RFB quando regulamenta as "normas para apuração do Lucro Presumido com base no regime de caixa". Segundo o $2^{\circ}$ do artigo $1^{\circ}$ da IN/RFB n ${ }^{\circ} 104 / 98$, os valores recebidos adiantadamente somente configuram lucro quando ocorrer a receita pelo regime de competência ( $v . g$. faturamento, entrega do bem ou conclusão do serviço). ${ }^{77}$

Ante o exposto no presente capítulo, pode-se sintetizar o regime de caixa para as atividades imobiliárias como:

\begin{tabular}{|c|c|}
\hline \multicolumn{2}{|c|}{ Venda à Vista } \\
\hline Unidade Concluída & Unidade não Concluída \\
\hline $\begin{array}{c}\text { Lucro fiscal será integralmente } \\
\text { reconhecido no exercício da venda, pois } \\
\text { todos os custos e despesas já foram } \\
\text { incorridos - coincidência entre os regimes } \\
\text { de competência e de caixa. }\end{array}$ & $\begin{array}{l}\text { Lucro fiscal será reconhecido, conforme o caso: } \\
\text { (i) proporcionalmente à evolução da obra ou (ii) } \\
\text { integralmente na entrega das chaves. Isto porque } \\
\text { é só neste momento que se considera realizada a } \\
\text { renda - coincidência entre os regimes de } \\
\text { competência e de caixa. }\end{array}$ \\
\hline \multicolumn{2}{|c|}{ Venda a Prazo } \\
\hline Unidade Concluída & Unidade não Concluída \\
\hline $\begin{array}{l}\text { Lucro fiscal será reconhecido } \\
\text { proporcionalmente ao recebimento do } \\
\text { preço (ingresso de caixa), pois todos os } \\
\text { custos e despesas já foram incorridos. O } \\
\text { lucro contábil, por outro lado, é } \\
\text { reconhecido integralmente no exercício da } \\
\text { venda, pelo regime de competência. }\end{array}$ & $\begin{array}{l}\text { Numa primeira etapa, reconhece-se o lucro } \\
\text { contábil já incorrido pelo regime de } \\
\text { competência, conforme o caso: (i) } \\
\text { proporcionalmente à evolução da obra ou (ii) } \\
\text { integralmente na entrega das chaves. Após o } \\
\text { reconhecimento do lucro contábil, será tributada } \\
\text { apenas a parcela do preço efetivamente recebida } \\
\text { (regime de caixa). }\end{array}$ \\
\hline
\end{tabular}

\footnotetext{
77 “Art. $1^{\circ}$ A pessoa jurídica, optante pelo regime de tributação com base no lucro presumido, que adotar o critério de reconhecimento de suas receitas de venda de bens ou direitos ou de prestação de serviços com pagamento a prazo ou em parcelas na medida do recebimento e mantiver a escrituração do livro Caixa, deverá:

(...)

$\S 2^{\circ}$ Os valores recebidos adiantadamente, por conta de venda de bens ou direitos ou da prestação de serviços, serão computados como receita do mês em que se der o faturamento, a entrega do bem ou do direito ou a conclusão dos serviços, o que primeiro ocorrer." (g.n.)
} 


\subsubsection{4 - Incorporação Imobiliária - Ciclo Econômico e Regime de Caixa}

O ciclo econômico padrão da atividade de incorporação imobiliária já foi descrito no Capítulo 3 do presente trabalho, conforme se reproduz abaixo novamente:


Conforme destacado, o lucro para fins societários será reconhecido pelo regime de competência, o que pode significar o reconhecimento durante a evolução da obra (quadro 
verde, correspondente à transferência gradual) ou no momento da "entrega das chaves" (momento D2, correspondente à transferência dos riscos e benefícios de uma única vez).

Contudo, a legislação tributária oferece a possibilidade de reconhecimento do lucro do setor imobiliário pelo regime de caixa, para fins de tributação pelo imposto sobre a renda (quadro laranja).

Ocorre que, no caso de venda a prazo de unidade não concluída (em fase de construção), a apuração do regime de caixa pressupõe a verificação prévia do regime de competência. Ou seja, primeiro deve-se analisar o lucro reconhecido pelo regime de competência (quadro verde ou momento D2), pois somente este valor possui natureza de lucro. Posteriormente, confrontam-se os ingressos de caixa com o lucro correspondente, pois somente este valor será passível de tributação pelo imposto de renda.

Caso existam eventuais valores recebidos (ingressos financeiros), mas que ainda não tenham sido realizados pelo regime de competência, tais valores devem ser registrados como passivo exigível (adiantamento de clientes).

\subsubsection{5 - Correção Monetária e Juros na Venda de Imóveis a Prazo}

Os juros e a correção monetária nas operações de venda a prazo de imóveis recebem tratamento específico da legislação tributária, cujas regras serão analisadas após breve exposição sobre a natureza desses institutos nos contratos de financiamento imobiliário.

A correção monetária tem como finalidade a recomposição da perda de valor da moeda no tempo. Portanto, não se trata de uma riqueza nova ou um acréscimo, mas simplesmente da manutenção do poder de compra da moeda. Com efeito, a correção monetária nos contratos de financiamento imobiliário nada mais é do que a atualização do preço de venda, para a manutenção do poder de compra no tempo. ${ }^{78}$

\footnotetext{
78 "(...) 3. União Federal. Pagamento de expurgos inflacionários. Admissibilidade. A correção monetária não se constitui em um plus, não é uma penalidade, mas mera reposição do valor real da moeda corroída pela inflação. Agravo regimental desprovido" (STF, ACO 404 execução-AgR / SP - SÃO PAULO, AG.REG.NA EXECUÇÃO NA AÇÃO CÍVEL ORIGINÁRIA, Relator(a): Min. MAURÍCIO CORRÊA, Julgamento: 03/03/2004, Tribunal Pleno)

“(...) 1. É assente nesta E. Corte de Uniformização Infraconstitucional que a correção monetária não constitui gravame ao devedor, não é um plus na condenação, mas tão-somente fator que garante a integra restitutio, que representa a recomposição do valor real da moeda aviltada pela inflação. Destarte, para que a devolução se opere de modo integral a incidência da correção monetária deve ter por termo inicial o momento dos respectivos desembolsos, quando aquele que hoje deve restituir já podia fazer uso das importâncias recebidas." (STJ, - RESP 737856/RJ; Ministro JORGE SCARTEZZINI, Julgamento 12/12/2006)
} 
Com o advento do Plano Real (Lei n ${ }^{\circ}$ 9.069/95), ficou estabelecido que a cláusula de correção monetária nos contratos em geral somente pode ter periodicidade anual de aplicação (artigo 28), com exceção das operações realizadas ( $\S^{\circ}$ ): (i) no mercado financeiro, (ii) no âmbito do SFH e do SBPE e (iii) aos financiamentos habitacionais de entidades de previdência privada.

Posteriormente, a Lei $\mathrm{n}^{\mathrm{o}}$ 10.192/01 admitiu expressamente a possibilidade de se pactuar, nos contratos com prazo igual ou superior a um ano, a correção monetária ou o reajuste por índices de preços que reflitam a variação dos custos de produção ou dos insumos utilizados (artigo $2^{\circ}$ ), sendo vedada a correção monetária com periodicidade inferior a um ano. Para os contratos que possuam prazo igual ou superior a três anos ( $\S 4^{\circ}$ do mesmo artigo) e tenham como objeto a produção de bens para entrega futura (como é o caso do financiamento imobiliário), foi autorizada a estipulação de atualização das obrigações, a cada período de um ano e no seu vencimento final, considerada a periodicidade de pagamento das prestações (abatidos os pagamentos efetuados no período, atualizados da mesma forma).

Atualmente, por força do artigo 46 da Lei $n^{\circ}$ 10.931/04, a correção monetária nos contratos de financiamento imobiliário em geral (e nos contratos de arrendamento mercantil de imóveis) foi objeto de tratamento legal específico. Neste sentido, para os contratos com prazo mínimo de trinta e seis meses, admite-se a contratação com cláusula de reajuste de periodicidade mensal, por índices de preços setoriais ou gerais ou pelo índice de remuneração básica dos depósitos de poupança.

Os juros, por sua vez, possuem natureza de remuneração pela cessão temporária da disponibilidade sobre unidades monetárias. Segundo ensina Silvio de Savo Venosa, “Juros representam o proveito auferido pelo capital emprestado; são a renda do dinheiro. Serão compensatórios, quando representarem fruto do capital, ou moratórios, quando representarem indenização pelo atraso no cumprimento da obrigação." 79

Feitas essas considerações iniciais, faz-se necessário destacar que a legislação tributária conferiu tratamento específico para a correção monetária e para os juros nos contratos de financiamento imobiliário, conforme a seguir se demonstra.

\footnotetext{
${ }^{79}$ VENOSA, Silvio de Salvo. Direito Civil: Contratos em Espécie, Coleção Direito Civil vol. 3, 8 a ed., São Paulo: Atlas, 2008, p. 189.
} 
Nos casos de venda de imóveis a prazo ou em prestações ( $§ 1^{\circ}$ do artigo 29 do DL $\mathrm{n}^{\mathrm{o}}$ 1.598/77), os juros contratuais serão reconhecidos pelo regime de competência (mesmo que a receita de venda seja reconhecida pelo regime de caixa).

Nos termos do artigo $9^{\circ}$ da Lei $n^{\circ} 9.718 / 98$, as variações monetárias dos direitos de crédito e das obrigações do contribuinte, em função da taxa de câmbio ou de índices ou de coeficientes aplicáveis por disposição legal ou contratual, são consideradas como receita ou despesa financeira, conforme o caso.

Se a venda for contratada com cláusula de correção monetária do saldo credor do preço ( $\S 2^{\circ}$ do artigo 29 do DL $n^{\circ} 1.598 / 77$ ), será reconhecida como receita financeira o resultado da diferença entre (i) a variação monetária sobre o saldo credor e (ii) a variação monetária sobre o saldo do lucro bruto registrado em conta de resultado de exercícios futuros.

Conforme determina o $\S 4^{\circ}$ do artigo 15 da Lei $\mathrm{n}^{\circ}$ 9.249/95 (incluído pela Lei $\mathrm{n}^{\circ}$ 11.196/05), as pessoas jurídicas que explorem atividades imobiliárias (loteamento de terrenos, incorporação imobiliária, construção de prédios destinados à venda, bem como a venda de imóveis construídos ou adquiridos para a revenda) aplicarão o mesmo percentual de presunção de lucro, decorrente da comercialização de imóveis, à receita financeira apurada por meio de índices ou coeficientes previstos em contrato.

De fato, conforme mencionado anteriormente, a venda de imóveis está sujeita à aplicação dos coeficientes de presunção de lucro de $8 \%$ sobre o preço de venda (ou 32\%, caso não haja emprego de materiais). Contudo, as receitas financeiras não se sujeitam à aplicação de coeficientes de presunção de lucro, sendo $100 \%$ tributadas pelo IRPJ (artigo 25, inciso II, da Lei $\left.n^{\circ} 9.430 / 95\right)$.

Neste sentido, a Receita Federal do Brasil proferiu solução de consulta na qual entende que o $\S 4^{\circ}$ do artigo 15 da Lei $n^{\circ}$ 9.249/95 é aplicável inclusive aos juros de mora e multa por atraso no pagamento, desde que esses acréscimos sejam apurados por meio de índices ou coeficientes previstos em contrato, confira-se:

SOLUÇÃO DE CONSULTA Nº 164 de 23 de Abril de 2007

“ASSUNTO: Imposto sobre a Renda de Pessoa Jurídica - IRPJ. EMENTA: Para fins de apuração da base de cálculo do IRPJ pelo lucro presumido, à receita de juros de mora e multa por atraso no pagamento de prestações decorrentes da comercialização de imóveis, auferida por pessoa jurídica que explore atividades imobiliárias relativas a loteamento de terrenos, incorporação imobiliária, construção de prédios destinados à venda, bem como a venda de imóveis construídos ou adquiridos para a revenda, deverá ser aplicado o percentual de que trata o art. 15 da Lei ${ }^{\circ}$ 
9.249, de 1995, desde que esses acréscimos sejam apurados por meio de índices ou coeficientes previstos em contrato." (g.n.)

De fato, da análise do referido dispositivo legal $\left(\S 4^{\circ}\right.$ do artigo 15 da Lei $\mathrm{n}^{\circ}$ 9.249/95), podem-se identificar os seguintes requisitos para que seja aplicado o percentual de presunção do lucro presumido sobre as receitas financeiras especificadas:

(i) somente se aplica às pessoas jurídicas que explorem atividades imobiliárias relativas a loteamento de terrenos, incorporação imobiliária, construção de prédios destinados à venda, bem como a venda de imóveis construídos ou adquiridos para a revenda;

(ii) somente se aplica às receitas decorrentes da comercialização de imóveis;

(iii) somente se aplica às receitas apuradas por meio de índices ou coeficientes previstos em contrato.

Como se percebe, esse último requisito é o que pode gerar mais dúvidas quanto à aplicabilidade do dispositivo, especialmente por falta de uma definição legal sobre os conceitos de índices e coeficientes. Contudo, apesar da falta de conceitos expressos, é possível adotar, ao menos, o seguinte conteúdo semântico:

$\checkmark \quad$ Índice: é um valor numérico que retrata uma variação ou uma oscilação de determinado referencial, em um determinado período de tempo, geralmente tomado em base percentual;

$\checkmark \quad$ Coeficiente: é um valor numérico utilizado como multiplicador de determinado referencial, que pode ser em bases percentuais ou não.

De fato, é bastante comum a referência a índices de preços e correção monetária na legislação. Portanto, havendo a previsão contratual da aplicação desses índices para a correção das prestações na venda a prazo de unidades imobiliárias, será aplicável a essa receita financeira o disposto no $\S 4^{\circ}$ no artigo 15 da Lei $n^{\circ} 9.249 / 95$.

Assim, correto o entendimento da Receita Federal do Brasil de que os juros de mora e a multa de mora podem ser apurados por meio de índices e coeficientes previstos em contrato.

Ademais, é necessário também compreender o conceito e o mecanismo de funcionamento dos principais sistemas de amortização de dívida utilizados nos contratos de venda de unidades imobiliárias a prazo, conhecidos como Tabela Price e SAC.

A Tabela Price, também conhecida como Sistema Francês de Amortização, pode ser definida como “um plano de amortização de uma dívida em prestações periódicas, iguais e 
sucessivas, dento do conceito de termos vencidos, em que o valor de cada prestação, ou pagamento, é composto por duas parcelas distintas: uma de juros e outra de capital (chamada amortização)." 80

Dessa forma, verifica-se que a Tabela Price é um sistema de amortização de dívida que pode ser traduzido em uma fórmula, por meio da qual se obtém o valor de parcelas periódicas fixas, correspondentes aos juros e à amortização do principal. Nas primeiras parcelas, haverá um pagamento maior de juros do que nas últimas parcelas.

O SAC, por sua vez, pode ser definido como "um plano de amortização de uma dívida em prestações periódicas, sucessivas e decrescentes em progressão aritmética, dentro do conceito de termos vencidos, em que o valor de cada prestação é composto por uma parcela de juros e outra parcela de capital (ou amortização)."

Com efeito, o SAC é um sistema de amortização mais simples, pois as amortizações do principal são constantes (e as prestações decrescentes), diferentemente da Tabela Price, em que as amortizações do principal crescem exponencialmente com o decurso dos pagamentos.

Portanto, conforme se verifica dos conceitos acima expostos, tanto a Tabela Price quanto o SAC são sistemas utilizados para fazer o cálculo das prestações mensais que devem ser pagas em um financiamento. Na atividade imobiliária, esses sistemas serão utilizados para determinar o fator multiplicador ao preço do bem para pagamento à vista e determinação do valor de cada prestação para o pagamento a prazo. A principal diferença entre esses dois sistemas é que, na amortização pela Tabela Price, o montante pago a título de juros será maior e mais concentrado nas primeiras parcelas.

Dessa forma, mesmo que os juros cobrados conforme a Tabela Price ou pelo SAC não sejam classificados como índices (que é um conceito mais restrito, vinculado à oscilação de determinado referencial em um determinado período de tempo), tais valores possuem natureza de coeficientes, por se tratarem de multiplicadores de valores precificados à vista para se obter o valor devido na venda a prazo, segundo a fórmula escolhida, motivo pelo qual aplica-se o disposto no $\S 4^{\circ}$ no artigo 15 da Lei $n^{\circ} 9.249 / 95$.

\footnotetext{
${ }^{80}$ SOBRINHO, José Dutra Vieira, Matemática Financeira, 7 ed., São Paulo : Ed. Atlas, 2006, pp. 220 e 221.

${ }^{81}$ SOBRINHO, José Dutra Vieira, Op. cit. (nota 80), p. 230.
} 


\subsubsection{6 - Loteamento}

Importante ressaltar que a atividade de loteamento geralmente envolve dois agentes: (i) o proprietário do imóvel a ser loteado e (ii) o executor do empreendimento. A execução do empreendimento inclui, normalmente, uma diversidade de serviços, tais como a pesquisa de mercado, elaboração de projetos, procedimentos de legalização, execução das obras, divulgação (publicidade), esforço de vendas, entre outros.

Ocorre que a remuneração de ambos os agentes, em geral, decorre exclusivamente da venda futura das unidades imobiliárias, motivo pelo qual o regime de tributação exposto no presente Capítulo é aplicável a ambos. Neste sentido já se manifestou a Receita Federal, por meio do Parecer Normativo CST n ${ }^{\circ} 15 / 84 .^{82}$

\subsection{2 - Regime Especial de Tributação (RET) do Patrimônio de Afetação}

O RET encontra-se regulamentado na Lei $n^{\circ} 10.931 / 2004$, com alterações promovidas pela legislação superveniente. Trata-se de um tratamento tributário favorecido, criado para estimular a constituição de patrimônios de afetação pelos incorporadores (sobre o patrimônio de afetação, confira-se o capítulo 3.3.3.3)

Assim como o lucro presumido, o RET aplicável às incorporações imobiliárias é opcional para os incorporadores, ou seja, é possível a adoção do patrimônio de afetação sem a adoção do RET. Contudo, uma vez feita a opção pelo RET, ela será irretratável até que sejam extintos os direitos de crédito ou obrigações do incorporador perante os adquirentes das unidades imobiliárias, objeto da incorporação afetada.

Para que se possa realizar a opção pelo RET, deverão ser preenchidos os seguintes requisitos: (i) constituição do regime de afetação sobre o terreno e as acessões objeto da

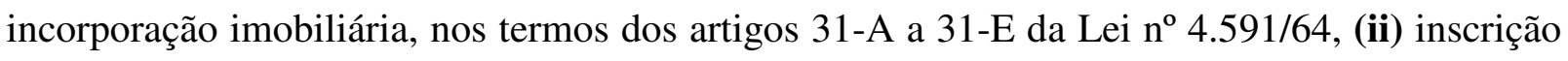
da incorporação afetada no Cadastro Nacional da Pessoa Jurídica - CNPJ e (iii) entrega do termo de opção ao RET na unidade competente da Receita Federal do Brasil.

\footnotetext{
${ }^{82}$ Parecer Normativo CST no $15 / 84$ “(...) 5. De todo o exposto, pode-se concluir que, quando o proprietário de uma área de terras se associa com pessoa jurídica constituída para a prática de operações imobiliárias, à qual assistirá executar e promover o empreendimento de loteamento, e o produto da venda das unidades imobiliárias for rateado entre as partes na proporção estipulada, a referida pessoa jurídica executora do empreendimento de loteamento deve apurar seus resultados segundo as normas consolidadas nos artigos 285 a 288 do RIR/80, assistindo-lhe o direito de optar pelo cômputo do custo orçado e o dever de corrigir os valores por ela investidos no custo do loteamento por ocasião do levantamento do balanço patrimonial."
} 
O RET, aplicável ao patrimônio de afetação, tem como fator de benefício o pagamento mensal unificado do IRPJ, da CSLL, do PIS e da COFINS. Ressalte-se que o pagamento unificado não confere nova natureza jurídica aos tributos mencionados. Neste sentido, quando algum desses tributos estiver com sua exigibilidade suspensa, será possível efetuar o pagamento desmembrado, inclusive com códigos de arrecadação próprios.

O recolhimento unificado confere quitação plena dos tributos mencionados e se opera mediante a aplicação da alíquota de $6 \%$ sobre receita mensal total recebida pela incorporação afetada, ${ }^{83}$ que será assim divida:

\begin{tabular}{|c|c|}
\hline Tributo & Alíquota \\
\hline COFINS & $2,57 \%$ \\
\hline PIS & $0,56 \%$ \\
\hline IRPJ & $1,89 \%$ \\
\hline CSLL & $0,98 \%$ \\
\hline Total & $\mathbf{6 \%}$ \\
\hline
\end{tabular}

É importante destacar que a Lei $n^{\circ} 10.0931 / 2004$ determina a aplicação dessa alíquota unificada sobre a totalidade da receita mensal, ou seja, "a totalidade das receitas auferidas pela incorporadora na venda das unidades imobiliárias que compõem a incorporação, bem como as receitas financeiras e variações monetárias decorrentes desta operação." ( $\left(1^{\circ}\right.$ do $\left.\operatorname{artigo} 4^{\circ}\right)$.

Verifica-se, portanto, que mesmo as receitas financeiras que compõem a incorporação imobiliária afetada estão sujeitas ao pagamento unificado de $6 \%$. Ocorre que a IN/RFB $n^{\circ} 934 / 2009$ estabeleceu, no $\S 8^{\circ}$ do artigo $4^{\circ}$, que as receitas recebidas pela incorporadora, decorrentes da aplicação dos recursos da incorporação submetida ao RET no mercado financeiro, não estariam sujeitas ao recolhimento unificado, devendo ser tributadas na incorporadora.

Contudo, referida interpretação não encontra respaldo na Lei. Isto porque as receitas decorrentes da aplicação dos recursos no mercado financeiro compõem a incorporação e não podem ser distribuídas à incorporadora antes de quitadas as obrigações da incorporação afetada. Trata-se, portanto, de uma ilegalidade cometida pela Instrução Normativa.

Ressalte-se, também, que o pagamento unificado no âmbito do RET é considerado definitivo, motivo pelo qual não estará sujeito a novo cálculo na Declaração de Imposto de

\footnotetext{
${ }^{83}$ Alíquota semelhante à aplicável ao lucro presumido, que é de 6,73\%.
} 
Renda da incorporadora, ou seja, não são passíveis de restituição ou compensação com o valor que for nela apurado.

Com efeito, receitas, custos e despesas próprios da incorporação sujeita ao RET não deverão ser computados na apuração das bases de cálculo do IRPJ, da CSLL, do PIS e da COFINS devidos pela incorporadora em virtude de suas outras atividades empresariais. Os custos e despesas indiretos referentes ao patrimônio afetado serão apropriados proporcionalmente aos custos diretos próprios da incorporação, em relação ao custo direto total da incorporadora. Para o cumprimento das obrigações mencionadas acima, o incorporador deve manter escrituração contábil segregada para cada incorporação submetida ao regime especial de tributação.

Registre-se, também, que, conforme mencionado no capítulo sobre o patrimônio de afetação, o terreno e as acessões, objeto da incorporação imobiliária afetada, não se comunicam com as demais obrigações do incorporador (optante pelo RET ou não). Contudo, todo o seu patrimônio responderá pelas dívidas tributárias da incorporação afetada.

\subsubsection{1 - Construções no Âmbito do Programa Minha Casa Minha Vida (PMCMV)}

O PMCMV foi instituído pela Lei $\mathrm{n}^{\circ} 11.977 / 2009$ com o objetivo de incentivar a aquisição de moradia por famílias de baixo poder aquisitivo. Atualmente, com o advento da Lei $\mathrm{n}^{\mathrm{o}} 12.424 / 2001$, o programa tem por finalidade criar mecanismos de incentivo à produção e aquisição de novas moradias habitacionais ou requalificação de imóveis urbanos e produção ou reforma de habitações rurais.

Dentre os mecanismos criados, estão previstas subvenções econômicas ao beneficiário, pessoa física, no ato da contratação do financiamento. No que tange ao objeto do presente trabalho, é importante destacar a aplicação do RET para os projetos de incorporação de imóveis residenciais de interesse social, cuja construção tenha sido iniciada ou contratada entre 31 de março de 2009 e 31 de dezembro de 2014. 
O fator de benefício fiscal previsto no PMCMV é o pagamento unificado do IRPJ, da CSLL, do PIS e da COFINS à alíquota de 1\%, sobre a receita mensal recebida, que será assim dividida:

\begin{tabular}{|c|c|}
\hline Tributo & Alíquota \\
\hline COFINS & $0,44 \%$ \\
\hline PIS & $0,09 \%$ \\
\hline IRPJ & $0,31 \%$ \\
\hline CSLL & $0,16 \%$ \\
\hline Total & $\mathbf{1 \%}$ \\
\hline
\end{tabular}

Para fins de aplicação do RET à alíquota de $1 \%$, é necessário que os projetos de incorporação de imóveis residenciais sejam qualificados como de "interesse social". Neste sentido, consideram-se de "interesse social" os projetos de incorporação: (i) destinados à construção de unidades residenciais de valor comercial de até $\mathrm{R} \$ 75.000,00$ e (ii) que estejam no âmbito do PMCMV.

O primeiro requisito, correspondente ao limite de valor comercial para venda da unidade residencial, não comporta grande dificuldade de aplicação. ${ }^{84}$ Quanto ao segundo requisito, observa-se que sua aplicação já não é tão clara.

De fato, estar no âmbito do PMCMV pode ser interpretado como ser passível de venda dentro do programa. Contudo, para determinar se uma venda está ou não no âmbito do PMCMV, faz-se necessária a análise "caso a caso" das vendas concretas, pois o programa estabelece diversos requisitos para modalidades distintas, como o da limitação de valor da renda familiar mensal. Assim, somente será possível determinar se a venda se deu no âmbito

\footnotetext{
${ }^{84}$ A RFB manifestou entendimento no sentido de que o valor comercial é o valor de venda à vista da unidade habitacional, não compreendendo os valores cobrados a título de encargos financeiros:

"SOLUÇÃO DE CONSULTA Nº 61 de 05 de Julho de 2010

ASSUNTO: Outros Tributos ou Contribuições

EMENTA: BENEFÍCIO FISCAL. PAGAMENTO UNIFICADO DE TRIBUTOS. PROGRAMA MINHA CASA, MINHA VIDA. Para efeito de fixação do limite de $\mathrm{R} \$ 60.000,00$, o valor comercial é o preço de mercado à vista estabelecido nos contratos relativos a projetos de incorporação de imóveis residenciais de interesse social ou de construção de moradias firmados dentro do Programa Minha Casa, Minha Vida - PMCMV. As receitas de financiamento direto da incorporadora ou construtora, previstas nesses contratos separadamente do preço à vista, não entram no cômputo do referido limite. Para fins do pagamento unificado de tributos equivalente a $1 \%$ (um por cento) da receita mensal recebida em decorrência do contrato relativo a projetos de incorporação de imóveis residenciais de interesse social ou de construção, serão incluídas as atualizações monetárias e as receitas financeiras previstas nos contratos firmados dentro do PMCMV. Inexiste norma tributária autorizando a atualização do limite de R\$ 60.000,00 em operações imobiliárias futuras ou em momento posterior à celebração de contrato a longo prazo relativo a projetos de incorporação de imóveis residenciais de interesse social ou de construção de moradias firmado por empresas incorporadoras ou construtoras contratadas no âmbito do PMCMV."
} 
do PMCMV após a concretização da venda, porquanto parte das unidades residenciais vendidas podem não estar abrangidas pelo programa.

Com efeito, um mesmo empreendimento poderá comportar o pagamento unificado da alíquota de $1 \%$ (caso preenchidos os dois requisitos) e o pagamento unificado de $6 \%$ (para as demais unidades vendidas sem o cumprimento dos mencionados requisitos).

Este, contudo, não foi o entendimento da RFB para os casos em que existam unidades de valor inferior e superior ao limite de $\mathrm{R} \$ 75.000,00$, conforme se verifica da Solução de Consulta no 22/2011. ${ }^{85}$

Ressalte-se, por fim, que o artigo $2^{\circ}$ da Lei ${ }^{\circ}$ 12.024/2009 ampliou o escopo do RET para o PMCMV, visto que incluiu a possibilidade de pagamento unificado da alíquota de $1 \%$ para a atividade de construção das unidades habitacionais de interesse social, aplicável sobre a receita mensal auferida pelo contrato de construção. Portanto, mesmo que o incorporador e o construtor não sejam a mesma pessoa, também será permitido ao construtor aplicar o RET para o pagamento unificado de $1 \%$.

Foram estabelecidos os mesmos requisitos para a aplicação do benefício fiscal ao construtor (construir unidades habitacionais de valor comercial de até $\mathrm{R} \$ 75.000,00$ e estar no âmbito do PMCMV). Neste caso, contudo, estar no âmbito do PMCMV não se vincula às vendas das unidades, uma vez que a receita decorre da construção e não da venda das unidades. Assim, estar no âmbito do PMCMV significa construir unidades habitacionais passíveis de venda dentro do programa (mesmo que a venda se realize fora do PMCMV).

\subsection{3 - Tributação do Leasing Imobiliário}

Conforme visto anteriormente (Capítulo 3.5.6), o leasing imobiliário se constitui em um negócio jurídico realizado entre a arrendadora e a arrendatária e tem por objeto o arrendamento de imóvel adquirido pela arrendadora, mas indicado pela arrendatária, pois será destinado ao seu uso próprio, mediante o pagamento de uma contraprestação.

85 “SOLUÇÃO DE CONSULTA No 22 de 01 de Marco de 2011

ASSUNTO: Normas de Administração Tributária

EMENTA: PROGRAMA MINHA CASA MINHA VIDA (PMCMV). A expressão "valor comercial" a que se refere o art. $4^{\circ}, \S 7^{\circ}$, da Lei $n^{\circ} 10.931$, de 2004, deve ser entendido como o valor ajustado entre o adquirente e o vendedor do imóvel. Num mesmo empreendimento imobiliário enquadrado no Regime Especial de Tributação - RET (art. $4^{\circ}$, caput, da Lei $\mathrm{n}^{\circ}$ 10.931, de 2004), no qual existam unidades imobiliárias residenciais de valor inferior e superior a setenta e cinco mil reais, a incorporadora deve submeter a totalidade das receitas auferidas na venda das unidades imobiliárias que compõem a incorporação (bem 
Ocorre que o tratamento tributário deste contrato encontra-se expressamente previsto nos artigos 11 e seguintes da Lei $\mathrm{n}^{\circ}$ 6.099/74. Conforme disposto nesta Lei, as contraprestações, pagas ou creditadas por força do contrato de arrendamento mercantil, serão consideradas como custo ou despesa operacional da pessoa jurídica arrendatária (independentemente de se tratar de arrendamento mercantil financeiro ou operacional).

Verifica-se, portanto, que a regra fiscal prevista em lei difere do tratamento definido nos normativos contábeis para as operações de arrendamento mercantil financeiro, analisado no Capítulo 4.4.1 do presente trabalho. Contudo, tendo em vista a existência de lei especial para regulamentar o tratamento contábil para fins tributários (Lei n ${ }^{\circ}$ 6.099/74), os normativos contábeis societários não geram qualquer reflexo tributário.

Ressalte-se que, nos termos da legislação fiscal, caso não sejam cumpridas as disposições da Lei que regulamentam o arrendamento mercantil, a aquisição feita pelo arrendatário do bem imóvel será considerada operação de compra e venda a prestação. Neste caso, o preço de compra e venda será o total das contraprestações pagas durante a vigência do arrendamento, acrescido da parcela paga a título de preço de aquisição, devendo-se adicionar os valores que já tiverem sido deduzidos, nos respectivos exercícios, com o recolhimento do imposto não recolhido, acrescido de juros e multa (artigo 11 da Lei no 6.099/74).

Para as pessoas jurídicas arrendadoras, as cotas de depreciação do preço de aquisição de bem arrendado (calculadas de acordo com a vida útil do bem) são admitidas como custo próprio, também independentemente da natureza do contrato (financeiro ou operacional).

Para a determinação da vida útil do bem, considera-se o prazo pelo qual se espera sua efetiva utilização econômica. Na prática, adotam-se as normas previstas pela legislação do imposto de renda para fixação da taxa de depreciação (utilização da vida útil média). No caso de edificações, a taxa de depreciação é de $4 \%$ ao ano (ou seja, vida útil média de 25 anos).

Na hipótese de a venda do bem imóvel objeto de leasing, o valor remanescente do custo de aquisição, que não tenha sido depreciado, será utilizado para efeito de apuração de eventual ganho de capital. Contudo, não será dedutível eventual perda na alienação do imóvel, quando do exercício da opção de compra.

Destaque-se, ainda, que as pessoas jurídicas tributadas pelo lucro real devem apurar a base de cálculo mediante a dedução de custos e despesas, bem como adições e art. $4^{\circ}$, caput, da lei $n^{\circ} 10.931$, de 2004, atendidas as demais exigências da IN RFB nº 934, de 2009." 
exclusões previstas em lei. Ocorre que, por força do inciso II do artigo 13 da Lei n 9.249/95, somente serão dedutíveis as contraprestações de arrendamento mercantil de bens imóveis quando relacionados, intrinsecamente, com a produção ou comercialização dos bens e serviços.

Para o arrendatário, após exercida a opção de compra, o bem imóvel integrará o seu ativo fixo pelo seu custo de aquisição, considerado como o preço pago pelo exercício da opção de compra.

\subsection{4 - Tributação dos Fundos de Investimento Imobiliário - FII}

Conforme já analisados, os FII têm regras societárias específicas de apuração do lucro que será distribuído semestralmente aos quotistas. Faz-se necessário, agora, abordar a forma de tributação dos rendimentos e ganhos de capital por eles auferidos.

Com efeito, podem-se distinguir 3 regimes em que a renda da atividade imobiliária desenvolvida por meio dos FII será tributada: (i) Regra Geral de Tributação do FII (regime previsto na Lei $n^{\circ}$ 8.668/93), (ii) Isenção na Distribuição de Rendimentos do FII à Pessoa Física (regime previsto na Lei $\left.\mathrm{n}^{\circ} 11.033 / 05\right)$ e (iii) Tributação do FII como Pessoa Jurídica (regime previsto na Lei $n^{\circ}$ 9.779/99).

\subsubsection{1 -Regime Tributário 1: Regra Geral de Tributação do FII}

Inicialmente, é importante destacar que, nos termos do artigo 16 da Lei $n^{\circ}$ 8.668/93 (com redação dada pela Lei $\mathrm{n}^{\circ}$ 9.779/99), os rendimentos e ganhos de capital auferidos pelos FII ficam isentos do IRPJ. Neste artigo, reconhece-se que o FII é centro de imputação de direitos e deveres e que apura rendimentos e ganhos de capital. Contudo, tais rendimentos e ganhos de capital foram considerados isentos do imposto sobre a renda.

$\mathrm{Na}$ verdade, os FII não possuem personalidade jurídica, motivo pelo qual não poderiam sequer ser considerados contribuintes do imposto sobre a renda. Todavia, existem situações em que os FII podem ser equiparados à pessoa jurídica para fins de tributação, conforme será demonstrado adiante.

Conforme analisado no capítulo que trata da apuração do lucro contábil societário, o FII fará a distribuição, aos quotistas, do resultado apurado no semestre, no limite mínimo de 95\% deste lucro apurado pelo regime de caixa (capítulo 4.5). 
O lucro pelo regime de caixa corresponde ao ingresso financeiro de valores já registrados contabilmente como receita pelo regime de competência, após o confronto com as despesas. Ou seja, após a apuração do lucro pelo regime de competência, distribui-se apenas a parcela efetivamente realizada em dinheiro (caixa).

Tais rendimentos e ganhos de capital auferidos, quando distribuídos pelos FII a qualquer beneficiário, inclusive pessoa jurídica isenta, sujeitam-se à incidência do imposto de renda na fonte, à alíquota de $20 \%$.

Registre-se que não há regras especiais de dedutibilidade de despesas para a apuração deste lucro a ser distribuído, como ocorre para a apuração do lucro real. Com efeito, o que se tributa é o resultado líquido destes investimentos, diferentemente do que ocorre com o investimento realizado por meio de pessoas jurídicas.

Ademais, os ganhos de capital e rendimentos auferidos na alienação ou no resgate de quotas dos fundos de investimento imobiliário, por qualquer beneficiário, inclusive por pessoa jurídica isenta, também se sujeitam à incidência do imposto de renda à alíquota de 20\%: (i) na fonte, no caso de resgate (ii) às mesmas normas aplicáveis aos ganhos de capital ou ganhos líquidos auferidos em operações de renda variável, nos demais casos.

O imposto retido na fonte pelo FII será considerado: (i) antecipação do devido na declaração, no caso de beneficiário pessoa jurídica tributada com base no lucro real, presumido ou arbitrado; e (ii) tributação exclusiva, nos demais casos.

Não obstante a isenção do imposto sobre a renda no âmbito do FII, ressalte-se que, nos termos do artigo 16-A da Lei $n^{\circ}$ 8.668/93, os rendimentos e ganhos líquidos por eles auferidos, em aplicações financeiras de renda fixa ou de renda variável, sujeitam-se à incidência do imposto de renda na fonte, observadas as mesmas normas aplicáveis às pessoas jurídicas submetidas a esta forma de tributação. Tal imposto, contudo, poderá ser compensado com o imposto que será retido na fonte, pelo FII, quando da distribuição de rendimentos e ganhos de capital.

A compensação do imposto será efetuada proporcionalmente à participação do cotista pessoa jurídica ou pessoa física não sujeita à isenção prevista no inciso III do art. $3^{0}$ da Lei $\mathrm{n}^{\mathrm{o}}$ 11.033/04, que será analisado a seguir (Regime Tributário 2). Neste caso, a parcela do imposto não compensada relativa à pessoa física sujeita à isenção será considerada exclusiva de fonte. 
Ressalte-se que, com a edição da Lei no 12.024/09, estabeleceu-se a não incidência do imposto de renda na fonte sobre as aplicações efetuadas pelos FII nos ativos de que tratam os incisos II e III do art. $3^{\circ}$ da Lei $\mathrm{n}^{\mathrm{o}}$ 11.033/04, quais sejam: (i) letras hipotecárias, (ii) certificados de recebíveis imobiliários, (iii) letras de crédito imobiliário e (iv) quotas de FII admitidas à negociação exclusivamente em bolsas de valores ou no mercado de balcão organizado.

Ressalvada a responsabilidade da fonte pagadora pela retenção do imposto sobre os rendimentos e ganhos líquidos auferidos pelos FII, em aplicações financeiras de renda fixa ou de renda variável, a instituição administradora do fundo de investimento imobiliário é a responsável pelo cumprimento das demais obrigações tributárias do fundo, inclusive acessórias.

\subsubsection{2 - Regime Tributário 2: Isenção de Rendimentos do FII Distribuídos à Pessoa Física}

O segundo regime de tributação previsto para os rendimentos auferidos por meio do FII é a isenção do imposto de renda para as pessoas físicas prevista no artigo $3^{\circ}$ da Lei $n^{\circ}$ 11.033/05 (com redação dada pela Lei n $\left.{ }^{\circ} 11.196 / 05\right)$.

Trata-se da isenção do imposto de renda na fonte e na declaração de ajuste anual das pessoas físicas, na hipótese de rendimentos distribuídos pelos FII, cujas quotas sejam admitidas à negociação exclusivamente em bolsas de valores ou no mercado de balcão organizado.

Entretanto, a isenção somente será concedida nos casos em que o FII possua, no mínimo, 50 quotistas (requisito geral para concessão do benefício fiscal). Ainda, não será concedida a isenção ao quotista pessoa física titular de quotas que representem $10 \%$ ou mais da totalidade das quotas emitidas pelo FII ou cujas quotas lhe derem direito ao recebimento de rendimento superior a $10 \%$ do total de rendimentos auferidos pelo fundo (requisito individual para a fruição do benefício).

\subsubsection{3 - Regime Tributário 3: Tributação do FII como Pessoa Jurídica}

Por fim, ressalte-se que a renda auferida pelo FII pode ter o mesmo tratamento tributário aplicável às pessoas jurídicas, nos termos do artigo $2^{\circ}$ da Lei $n^{\circ}$ 9.779/99. A 
finalidade deste regime de tributação é evitar que os FII sejam utilizados como meros instrumentos de planejamento tributário.

De fato, não fosse essa regra, os incorporadores e construtores poderiam desenvolver seus empreendimentos imobiliários por meio destes fundos, adquirindo a maior parte das suas quotas, com um modelo de negócio muito semelhante ao existente para a realização de empreendimentos imobiliários por meio de Sociedades de Propósito Específico SPE. Assim, os benefícios fiscais aplicáveis aos FII deixariam de cumprir sua finalidade de incentivar o investimento coletivo, transformando-se em ferramenta de planejamento tributário.

Neste sentido, após o advento da Lei n ${ }^{\circ}$ 9.779/99, sujeita-se à tributação aplicável às pessoas jurídicas o FII que aplicar recursos em empreendimento imobiliário que tenha como (i) incorporador, (ii) construtor ou (iii) sócio, quotista que possua, isoladamente ou em conjunto com pessoa a ele ligada, mais de $25 \%$ das quotas do fundo.

Considera-se pessoa ligada ao quotista:

(i) pessoa física: (a) os seus parentes até o segundo grau (b) a empresa sob seu controle ou de qualquer de seus parentes até o segundo grau;

(ii) pessoa jurídica: a pessoa que seja sua controladora, controlada ou coligada, conforme definido no artigo 243 da Lei das S/A.

Com relação às figuras do incorporador ou do construtor do empreendimento imobiliário destinatário dos recursos do FII, é mais fácil a compreensão do conceito previsto no dispositivo ora analisado. Neste sentido, basta que o FII destine recursos à construção de um empreendimento imobiliário e que o incorporador e/ou o construtor deste empreendimento possua mais de $25 \%$ das quotas do fundo.

Contudo, a referida legislação não traz o conceito de sócio do empreendimento imobiliário. Apesar da falta de conceito legal, pode-se ao menos estabelecer as seguintes considerações: ser sócio pressupõe ser participante de algum negócio jurídico associativo que se caracterize como um empreendimento imobiliário.

Neste sentido, conforme se depreende dos empreendimentos imobiliários passíveis de serem destinatários de investimentos do FII, o único investimento que se configura como uma sociedade é o previsto no inciso III do artigo 45 da Instrução CVM nº72/08: ações ou quotas de sociedades cujo único propósito se enquadre entre as atividades permitidas aos FII. 
Com efeito, o sócio do empreendimento imobiliário de que trata o artigo $2^{\circ}$ da Lei $\mathrm{n}^{\circ}$ 9.779/99 é o acionista/quotista de sociedade que também possua como acionista/quotista o respectivo FII. Ou seja, o investidor é sócio do FII em uma outra empresa (v.g. numa SPE):

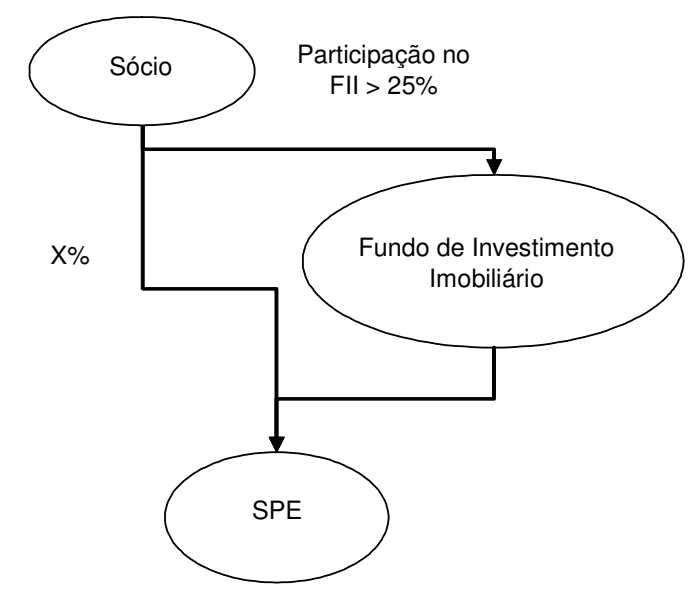

Registre-se, também, que a legislação ora em análise, por ser muito vaga, deixa algumas dúvidas sobre as quais ainda não houve manifestação das autoridades fiscais. Confiram-se algumas delas:

(i) o percentual de participação dos quotistas pode variar no tempo, sendo possível que algum incorporador, construtor ou sócio do empreendimento imobiliário investido ultrapasse o limite de $25 \%$ das quotas do FII por um pequeno período, que pode ser até de 1 dia. Não obstante, a legislação ora analisada não traz limites para determinar qual o prazo necessário para que se aplique o regime de tributação do FII como pessoa jurídica;

(ii) não há previsão legal para a delimitação do período em que o FII estará sujeito à tributação aplicável às pessoas jurídicas. Considerando-se que o requisito para a equiparação do FII à pessoa jurídica para fins de tributação pode ser temporário (o percentual de participação dos quotistas é volátil: pode ser livremente negociado no mercado), resta a dúvida acerca de qual será o período em que o FII permanecerá equiparado à $\mathbf{P J}$ no caso em que algum incorporador, construtor ou sócio do empreendimento imobiliário investido ultrapasse o limite de $25 \%$ das quotas do FII por um pequeno período de tempo;

(iii) não há qualquer tipo de previsão que resguarde o direito dos demais investidores do FII que não tenham vinculação com o incorporador, 
construtor ou sócio do empreendimento imobiliário investido. Ou seja, não há regra que assegure aos demais investidores o direito de não serem tributados como pessoa jurídica;

(iv) nem o administrador do FII, nem os demais quotistas possuem qualquer tipo de controle sobre a negociação das quotas do FII no mercado, motivo pelo qual eles não têm qualquer possibilidade de ingerência quanto à aplicação deste regime tributário, o que pode gerar insegurança jurídica.

Como ainda não há manifestação das autoridades fiscais acerca das dúvidas acima suscitadas, a interpretação e aplicação do dispositivo ora em análise deve se pautar nos princípios da segurança jurídica, da proporcionalidade e da razoabilidade, conforme já se manifestou a antiga $2^{\mathrm{a}}$ Câmara do $2^{\mathrm{o}}$ Conselho de Contribuintes sobre a aplicação da interpretação dentro do razoável (Acórdão no 202-12527), comentada por Humberto Ávila:

"Uma pequena fábrica de sofás, enquadrada como empresa de pequeno porte para efeito de pagamento conjunto dos tributos federais, foi excluída desse mecanismo por ter infringido a condição legal de não efetuar a importação de produtos estrangeiros. De fato, a empresa efetuou uma importação. A importação, porém, foi de quatro pés de sofás, para um só sofá, uma única vez. Recorrendo da decisão, a exclusão foi anulada, por violar a razoabilidade, na medida em que uma interpretação dentro do razoável indica que a interpretação deve ser feita 'em consonância com aquilo que, para o senso comum, seria aceitável perante a lei'. (...)”86 (g.n.)

Com efeito, ao menos algumas soluções mínimas para as dúvidas apontadas no presente estudo já são possíveis:

(i) no caso em que algum incorporador, construtor ou sócio do empreendimento imobiliário investido ultrapasse o limite de $25 \%$ das quotas do FII por um pequeno período, que pode ser até de 1 dia, sem que com isso tenha obtido qualquer vantagem tributária neste período, não seria razoável a tributação do FII como pessoa jurídica. Isto porque não restaria configurada a conduta que a norma tem por finalidade coibir. Pretender equipar o FII à pessoa jurídica para fins de tributação, neste caso, seria o mesmo que excluir uma pequena fábrica de sofás do SIMPLES em razão da importação de 4 pés de sofás, ou seja, trata-se de uma medida absolutamente desproporcional à infração cometida;

\footnotetext{
${ }^{86}$ ÁVILA, Humberto. Teoria dos Princípios - da definição à aplicação dos princípios jurídicos. $3^{\mathrm{a}}$ ed., São Paulo : Malheiros, 2004, p. 105.
} 
(ii) no caso em que está configurado o requisito para a tributação do FII como pessoa jurídica por determinado período de tempo, também não é razoável que o FII esteja sujeito a este regime de tributação por todo o restante de sua existência. Uma interpretação razoável é que o FII seja tributado como pessoa jurídica apenas durante o período em que algum incorporador, construtor ou sócio do empreendimento imobiliário investido ultrapassar o limite de $25 \%$ das quotas;

(iii) como a Lei não confere ao administrador do FII, nem aos demais quotistas, qualquer tipo de controle sobre a negociação das quotas do FII no mercado, é prudente que se estabeleça no regulamento do fundo alguma forma de se resguardar o direito dos demais quotistas, inclusive com a proibição de que qualquer incorporador, construtor ou sócio do empreendimento imobiliário investido ultrapasse o limite de $25 \%$ das quotas, nos termos do disposto nos incisos IX, XIX e XXII do artigo 15 da Instrução CVM n ${ }^{\circ} 472 / 08 .{ }^{87}$

Por fim, ressalte-se que a legislação não trouxe qualquer restrição ao percentual de participação de quotistas que não sejam incorporador, construtor ou sócio do empreendimento imobiliário investido. Com efeito, é possível que um único quotista seja detentor de $100 \%$ das quotas do FII, sem que haja qualquer tratamento tributário diferenciado a este investidor (o qual estará sujeito à regra geral já analisada - Regime Tributário 1).

87 “Art. 15. O regulamento do FII deve dispor sobre: (...)

IX - critérios para a subscrição de cotas por um mesmo investidor; (...)

XIX - percentual máximo de cotas que o incorporador, construtor e sócios de um determinado empreendimento em que o fundo tenha investido poderão, isoladamente ou em conjunto com pessoas a ele ligadas, subscrever ou adquirir no mercado, indicando inclusive as consequiências tributárias; (...)

XXII - descrição das medidas que poderão ser adotadas pelo administrador para evitar alterações no tratamento tributário conferido ao fundo ou aos seus cotistas;" 


\section{CONCLUSÕeS}

Conforme destacado na introdução do presente trabalho, pretendeu-se fazer uma análise abrangente e interdisciplinar do mercado imobiliário, especialmente em relação aos aspectos de Direito Privado (Direito Civil e Direito Contábil Societário), para que, com isso, fosse possível verificar a coerência e adequação dos critérios e métodos de apuração e tributação da renda neste importante setor da economia.

Dessa forma, partiu-se da análise dos aspectos gerais da tributação da renda e das questões específicas do setor imobiliário sob o ponto de vista do Direito Civil e do Direito Contábil Societário (análise do “mapa”). Esta análise, realizada nos 4 primeiros Capítulos, mostrou-se fundamental para o presente trabalho, pois somente a partir da reflexão sobre esses conceitos é que foi possível verificar as peculiaridades e controvérsias existentes quanto às hipóteses de tributação da atividade imobiliária.

No $5^{\circ}$ e último Capítulo foram analisadas as hipóteses de tributação da renda no setor imobiliário, testando-se a coerência e a adequação dos critérios adotados pela legislação tributária e pelas autoridades fiscais (análise dos “caminhos"). Com efeito, foram encontradas importantes questões que envolvem a tributação do setor imobiliário, sobre as quais se apresentam a seguir as principais conclusões.

Inicialmente, verifica-se que a atividade imobiliária apresenta características particulares muito importantes a serem consideradas para fins de tributação. Assim, por exemplo, de uma forma geral, a atividade de construção civil é de suma importância para o desenvolvimento econômico do País, pois agrega um amplo contingente de trabalhadores (geração direta de empregos e renda), mas também movimenta diversas atividades secundárias, como a indústria de material de construção.

Dessa forma, parte-se de um fundamento econômico importante para justificar a necessidade de regras tributárias mais benéficas para a atividade imobiliária, visto que um dos objetivos é o atendimento do princípio geral da ordem econômica correspondente à busca pelo pleno emprego, conforme previsto no inciso VIII do artigo $170 \mathrm{da} \mathrm{CF} / 88$. $^{1}$

\footnotetext{
${ }^{1}$ Art. 170. A ordem econômica, fundada na valorização do trabalho humano e na livre iniciativa, tem por fim assegurar a todos existência digna, conforme os ditames da justiça social, observados os seguintes princípios: (...)
} 
Outro importante preceito constitucional a ser observado pelo legislador tributário é o Direito social à moradia, previsto no artigo $6^{\circ}$ da $\mathrm{CF} / 88$. Trata-se de um direito essencial que deve ser promovido pelo Estado, o que também pode justificar medidas de desoneração tributária e tratamentos fiscais diferenciados para o setor. ${ }^{2}$

Ademais, verifica-se que o ciclo econômico que envolve o desenvolvimento dessa atividade é, em geral, de longo prazo de maturação, motivo pelo qual as regras de tributação devem considerar esse desencaixe do fluxo de caixa entre a realização das operações e o recebimento dos recursos correspondentes.

O desenvolvimento de um empreendimento imobiliário envolve desde atividades preliminares (pesquisa de mercado, elaboração e aprovação de projetos), esforço de vendas e construção, mas o retorno financeiro geralmente não é imediato, pois grande parte das vendas ocorre a prazo. Mesmo o investimento em imóveis já construídos somente costuma gerar retorno a longo prazo (v.g. pela locação ou valorização imobiliária).

Outra característica importante é a necessidade de grandes aportes de capital para o desenvolvimento do empreendimento e para a aquisição da unidade, seja por investidores, seja por aqueles que necessitam do imóvel para constituição de sua residência, razão pela qual verifica-se a existência de um sistema organizado e incentivado para a realização do

\section{financiamento imobiliário.}

Também é importante destacar que o investimento em imóveis caracteriza-se pela baixa liquidez de mercado. Esse fator é muito importante, pois o longo prazo de maturação do empreendimento e os grandes aportes de capital necessários fazem com que se necessite de mecanismos que incentivem maior liquidez para a negociação desses bens.

Das considerações expostas no presente trabalho sobre o conceito de renda, conclui-se que é possível encontrar atividades imobiliárias que se enquadram tanto no conceito de renda-acréscimo quanto no conceito de renda-produto, ambos os conceitos previstos na legislação como passíveis de composição da base de cálculo do imposto sobre a renda.

Não obstante, considerando-se especialmente as características de longo prazo de maturação das atividades e a baixa liquidez dos ativos, o princípio da realização da renda talvez

\footnotetext{
VIII - busca do pleno emprego;"

2 “Art. $6^{\circ}$ São direitos sociais a educação, a saúde, a alimentação, o trabalho, a moradia, o lazer, a segurança, a previdência social, a proteção à maternidade e à infância, a assistência aos desamparados, na forma desta Constituição." (g.n.)
} 
seja o que tenha maior relevância para fins de análise da coerência e adequação da tributação da renda do setor imobiliário.

O princípio da realização manifesta-se pela existência de materialidade, objetividade e segurança quanto ao recebimento da renda. De fato, tendo em vista as características particulares da atividade imobiliária (longo prazo de maturação, necessidade de financiamento e baixa liquidez do ativo), esse princípio se manifesta em grande parte pela aplicação do denominado regime de caixa. Ou seja, o momento do ingresso do dinheiro no caixa é considerado como ponto crítico ideal para a tributação da renda auferida no setor imobiliário, visto que é o momento em que se tem maior segurança quanto ao seu recebimento.

Para as pessoas físicas, o regime de caixa é a regra de tributação. De fato, parte-se da legítima premissa de que as pessoas físicas em geral não possuem capacidade de reconhecimento e tributação da renda antes do momento em que ocorra o ingresso de caixa. Isto porque elas geralmente não possuem um sistema organizado e mobilizado de controle e cobrança como ocorre com as pessoas jurídicas.

Ademais, a legislação tributária estabelece diversos incentivos fiscais à atividade imobiliária com o objetivo de permitir maior liquidez para esses ativos. Em especial, destacamse as diversas isenções do imposto de renda para o ganho de capital na alienação de imóveis ou redução da base de cálculo em função do tempo de investimento. Também existem diversas isenções para rendimentos em aplicações financeiras destinadas ao financiamento imobiliário (securitização de recebíveis, Fundos de Investimento Imobiliário e poupança).

Para as pessoas jurídicas, por um lado, é possível fazer uma divisão em decorrência do seu porte econômico. Com efeito, às pessoas jurídicas que podem optar pelo lucro presumido (empresas de menor porte) também é facultada a adoção do regime de caixa.

Por outro lado, as pessoas jurídicas obrigadas à adoção do lucro real (com faturamento acima de $\mathrm{R} \$ 48$ milhões ao ano, entre outras hipóteses) são obrigadas à adoção do regime de competência como regra para a tributação da renda (tributação independentemente do ingresso financeiro).

Contudo, mesmo para as empresas obrigadas à apuração do lucro real, foi facultada a adoção do regime de caixa para as atividades de compra e venda, loteamento, incorporação e construção de imóveis. Ou seja, trata-se de método de reconhecimento e 
mensuração mais benéfico, aplicado às atividades imobiliárias independentemente do regime de tributação adotado pela pessoa jurídica. ${ }^{3}$

É importante ressaltar a polêmica quanto à aplicação do regime de caixa e do regime de competência para a atividade imobiliária. Essa polêmica decorre, em grande parte, da existência de normas contábeis estabelecidas tanto pela legislação societária quanto pela legislação tributária para tratar do reconhecimento e mensuração do lucro do setor imobiliário.

Também contribui para a complexidade do tema o advento da Nova Contabilidade e a aplicação do Regime Tributário de Transição - RTT. De fato, com as Leis no 11.638/2007 e $\mathrm{n}^{\mathrm{o}}$ 11.941/2009, a contabilidade societária no Brasil passou efetivamente a ser independente das normas de contabilidade previstas na legislação tributária. Ocorre que, mesmo dentro de critérios estritamente societários (aplicando-se os PCGA), verifica-se a grande controvérsia quanto ao reconhecimento e à mensuração do lucro do setor imobiliário de acordo com o regime de competência.

Essa abordagem é de suma importância, porquanto o regime de competência é a regra geral de tributação pelas pessoas jurídicas, embora possa ser afastado em alguns casos em que se permite a apuração do lucro fiscal pelo regime de caixa. Não obstante, mesmo nos casos em que se admite a aplicação do regime de caixa, a análise prévia do regime de competência é fundamental para se distinguirem os ingressos financeiros que efetivamente configurem renda, pois não é qualquer ingresso de caixa que representa renda tributável.

Conforme se expôs durante o presente trabalho, o legislador tributário foi pródigo na criação de normas de contabilidade fiscal para o setor imobiliário. Portanto, torna-se imperativo delimitar não só o âmbito de aplicação dessas diversas normas de contabilidade, mas também a legitimidade das normas de contabilidade fiscal em face dos princípios constitucionais e do conceito de renda.

Neste sentido, verifica-se que a regulamentação fiscal possui diversas inconstitucionalidades e ilegalidades, em especial no que tange às regras de apropriação de custos e de apuração do lucro pelo regime de caixa, uma vez que estabelecem critérios de mensuração e reconhecimento que acabam por determinar a tributação de ingressos financeiros que ainda não representam lucro ou renda.

\footnotetext{
${ }^{3}$ Essa faculdade também é atribuída para os contratos de longo prazo de duração.
} 
A compreensão dos institutos e conceitos de Direito Privado é de grande importância para a aplicação das normas fiscais, bem como para a análise de algumas polêmicas para as quais não há legislação específica.

Neste sentido, merece destaque a polêmica quanto à tributação da permuta. Conforme se verificou dos conceitos de Direito Privado, na permuta não há a definição de preço propriamente dito, como ocorre nos contratos de compra e venda. Na permuta tem-se a obrigação de trocar bens reciprocamente e a legislação tributária estabelece que não haverá resultado tributável nesta operação, pois se atribui ao bem recebido o mesmo valor do bem entregue. Assim, para as pessoas físicas, o valor de alienação será igual ao valor de custo (não havendo ganho de capital a apurar). Para as pessoas jurídicas tributadas pelo lucro real, a receita será igual à despesa, motivo pelo qual não haverá resultado a apurar.

Ocorre que, para as pessoas jurídicas tributadas pelo lucro presumido, a apuração do resultado tributável é realizada por meio da presunção de um percentual de lucro sobre a receita (sendo irrelevante o valor da despesa para esse fim). Dessa forma, a alienação de bens constantes do estoque (destinados à comercialização) do incorporador/construtor, por meio de permuta, ensejará a tributação por meio da aplicação do percentual presumido de lucro. Não obstante, o montante da receita sobre o qual incidirá o coeficiente de presunção será o valor de custo dos bens entregues, pois não há condições de objetividade para se determinar o "preço" de mercado para fins de tributação (princípio da realização da renda).

Citem-se ainda outros tratamentos fiscais privilegiados para a pessoa jurídica que exerce a atividade imobiliária, como (i) as baixas margens presumidas de lucro (no caso de tributação pelo lucro presumido) e (ii) o Regime Especial de Tributação no caso de incorporação imobiliária sujeita ao Patrimônio de Afetação.

Em suma, conforme a análise ampla da tributação do setor imobiliário, verifica-se que, em geral, existem isenções e redução de base de cálculo para as pessoas físicas que não exerçam a atividade imobiliária de forma profissionalizada.

Para as pessoas jurídicas também se verificam baixos coeficientes de presunção de lucro (no caso do lucro presumido) e tratamentos mais benéficos instituídos, por exemplo, por meio do RET do patrimônio de afetação.

Além do aspecto quantitativo da tributação (efetiva carga tributária), verifica-se também o tratamento diferenciado quanto ao momento em que se considera realizada a renda do setor imobiliário, pois são diversas as hipóteses de adoção do regime de caixa. 
Referidas medidas encontram-se em consonância com os preceitos previstos na $\mathrm{CF} / 88$, especialmente a busca pelo pleno emprego, o Direito social à moradia e o princípio da realização da renda. 


\title{
APÊNDICE A - ENTIDADES DE INCORPORAÇÃo IMOBILIÁRIA (OCPC 04)
}

\author{
“Contexto, objetivo e alcance
}

1. A implementação da Interpretação Técnica ICPC 02 , correlata à norma internacional 'IFRIC 15', tem acarretado diversos questionamentos e debates quanto à sua adequação ao ambiente econômico brasileiro. Com o processo de convergência com as normas internacionais de contabilidade (IFRSs), surge o que se considera ser a principal alteração no ambiente normativo brasileiro, ou seja, a mudança cultural na análise, interpretação e implementação das normas de contabilidade. A partir desse novo ambiente, os atos normativos contábeis devem ser lidos e interpretados considerando a essência econômica da(s) transação(ões) que pretendam normatizar, independentemente da forma jurídica de que estejam revestidos. Esse fundamento está expresso no Pronunciamento Conceitual Básico - Estrutura Conceitual para a Elaboração e Apresentação das Demonstrações Contábeis, principalmente seu item $35^{1}$, e no Pronunciamento Técnico CPC 26 Apresentação das Demonstrações Contábeis, principalmente seus itens 23 e $24^{2}$.

2. A estrutura da norma internacional, e agora brasileira, tem como axioma que qualquer norma emitida pelo IASB está subordinada ao objetivo da contabilidade que é o de demonstrar uma visão justa e verdadeira ('true and fair view') da situação patrimonial da empresa.

\footnotetext{
1 “35. Para que a informação represente adequadamente as transações e outros eventos que ela se propõe a representar, é necessário que essas transações e eventos sejam contabilizados e apresentados de acordo com a sua substância e realidade econômica, e não meramente sua forma legal. A essência das transações ou outros eventos nem sempre é consistente com o que aparenta ser com base na sua forma legal ou artificialmente produzida. Por exemplo, uma entidade pode vender um ativo a um terceiro de tal maneira que a documentação indique a transferência legal da propriedade a esse terceiro; entretanto, poderão existir acordos que assegurem que a entidade continuará a usufruir os futuros benefícios econômicos gerados pelo ativo e o recomprará depois de um certo tempo por um montante que se aproxima do valor original de venda acrescido de juros de mercado durante esse período. Em tais circunstâncias, reportar a venda não representaria adequadamente a transação formalizada."

2 "23. Em circunstâncias extremamente raras, nas quais a administração vier a concluir que a conformidade com um requisito de Pronunciamento, Interpretação ou Orientação conduziria a uma apresentação tão enganosa que entraria em conflito com o objetivo das demonstrações contábeis estabelecido na Estrutura Conceitual para a elaboração e Apresentação das Demonstrações Contábeis, mas a estrutura regulatória vigente proibir a não aplicação do requisito, a entidade deve, na maior extensão possível, reduzir os aspectos inadequados identificados no cumprimento estrito do Pronunciamento, Interpretação ou Orientação divulgando:

(a) o título do Pronunciamento, Interpretação ou Orientação em questão, a natureza do requisito e as razões que levaram a administração a concluir que o cumprimento desse requisito tornaria as demonstrações contábeis tão distorcidas e conflitantes com o objetivo das demonstrações contábeis estabelecido na Estrutura Conceitual; e (b) para cada período apresentado, os ajustes de cada item nas demonstrações contábeis que a administração concluiu serem necessários para se obter uma representação adequada.

24. Para a finalidade dos itens 19 a 23, um item de informação entra em conflito com o objetivo das demonstrações contábeis quando não representa fidedignamente as transações, outros eventos e condições que se propõe a representar ou que se poderia esperar razoavelmente que represente e, consequentemente, seria provável que influenciasse as decisões econômicas tomadas pelos usuários das demonstrações contábeis. ...."
} 
3. O objetivo de um ato normativo contábil é assegurar que as demonstrações contábeis retratem adequadamente (reconhecimento, mensuração e divulgação) as transações financeiras efetuadas pela entidade no ambiente econômico onde ela opera. Assim, a não aplicação de um Pronunciamento, de uma Interpretação ou de uma Orientação somente seria possível se (i) estivesse em desacordo com princípios contábeis generalizadamente aceitos, ou (ii) não se adequasse ao ambiente econômico que pretende representar.

4. Submetendo-se a Interpretação Técnica ICPC 02 ('IFRIC 15') ao crivo dessa análise, há a constatação de que não há motivos para arguir-se sua não aderência tanto aos princípios contábeis generalizadamente aceitos, tampouco ao ambiente econômico e jurídico brasileiro.

5. É importante, todavia, alertar que a aplicação da Interpretação Técnica ICPC 02 e desta Orientação às atividades exercidas fora do contexto brasileiro por uma entidade que aplica os Pronunciamentos emitidos por este Comitê, ou que, mesmo exercidas no Brasil, tenham, por disposições legais, contratuais ou outras, condições diferentes das aqui reproduzidas, deve ser feita à luz das condições legais ou contratuais específicas, considerando, se no exterior, a legislação e a jurisprudência específicas. Logo, não se aplica, necessariamente, a tais situações o contido nesta Orientação. Nesse contexto, esta Orientação diz respeito ao que se depreende e se interpreta a partir da Interpretação em questão, considerando as principais características e peculiaridades do ambiente econômico e jurídico em que opera o setor imobiliário brasileiro.

6. O objetivo desta Orientação é o de auxiliar na análise de se os contratos de construção se enquadram mais adequadamente no alcance do Pronunciamento Técnico CPC 17 Contratos de Construção ou do Pronunciamento Técnico CPC 30 - Receitas e assim auxiliar na definição pelos preparadores das demonstrações contábeis do momento do reconhecimento da receita com a incorporação ou construção de imóveis.

Determinação sobre se um contrato se enquadra no alcance do Pronunciamento Técnico CPC 17 ou do Pronunciamento Técnico CPC 30 - Pontos principais de análise

7. A Interpretação ICPC 02 diz que a determinação do momento em que um contrato de construção de um imóvel se enquadra no alcance do Pronunciamento Técnico CPC 17 Contratos de Construção ou do Pronunciamento Técnico CPC 30 - Receitas depende dos termos do contrato e de todos os fatos e circunstâncias relacionados. Essa determinação exige julgamento com relação a cada contrato, com foco na prevalência da essência econômica sobre a forma, conforme o Pronunciamento Conceitual Básico e o Pronunciamento CPC 26 - Apresentação das Demonstrações Contábeis.

8. A transação imobiliária estará na abrangência do Pronunciamento Técnico CPC 17 Contratos de Construção quando o contrato de construção se enquadrar na definição exposta no seu item 5: "um contrato especificamente negociado para a construção de um ativo ou de uma combinação de ativos...". No caso de construção com base no que se 
costuma denominar como "preço de custo", onde o comprador (isoladamente ou coletivamente com um grupo de compradores) contrata a construção de determinado empreendimento imobiliário, em que a entidade contratada é responsável apenas pela construção e gerenciamento da obra, mas a aquisição dos insumos e matérias primas se dá por conta do adquirente (ou à sua ordem) não há normalmente dúvidas de que o modelo contábil a ser seguido é o do Pronunciamento Técnico CPC 17 - Contrato de Construção, com a característica de contrato de prestação de serviços. Algumas dificuldades podem existir apenas para o caso de contrato a preço fixo."

\section{(i) Envolvimento Gerencial Contínuo ou Controle Efetivo}

“9. Para atingir o primeiro objetivo, ou seja, o enquadramento do contrato, deve ser assumida a premissa de que "a entidade analisou anteriormente o contrato de construção do imóvel e seus eventuais aditivos ou contratos relacionados, tendo concluído que não manterá envolvimento gerencial contínuo associado à propriedade, ou o controle efetivo do imóvel construído, em grau que impediria o reconhecimento de parte ou da totalidade da receita" (item 7 da ICPC 02). Deve ser observado que, se as respostas às questões forem positivas, não haverá o reconhecimento parcial ou integral da receita antes do ponto de transferência do imóvel pronto.

10. Mas, no Brasil, a partir do registro do projeto de construção, memorial descritivo e outros materiais em cartório e, principalmente, a partir do primeiro contrato com o adquirente, a entidade não mais pode alterar o projeto ou o memorial descritivo, a não ser com a anuência unânime dos interessados. Nesse momento, normalmente, não há mais envolvimento gerencial no sentido de manipulação conforme a vontade do incorporador/construtor; não há mais possibilidade de alterações por sua vontade (da entidade incorporadora ou construtora). Passa essa entidade a ser subordinada ao contrato e deve cumpri-lo conforme os termos nele contidos.

11. Por outro lado, também os compradores não possuem liberdade para modificar o que quiserem no projeto em execução. Aliás, nem depois da obra pronta existe ampla possibilidade dessa manipulação por parte dos adquirentes. Concorda-se que o relevante, no caso, é que o poder de controle e o envolvimento gerencial que existiam antes da fase de registro em cartório do projeto e dos demais documentos passam a ser exercidos apenas coletivamente pelos adquirentes, e nunca individualmente. De qualquer maneira, o importante é notar que o incorporador/construtor não mais mantém esse envolvimento e esse controle a partir do registro e da primeira venda."

\section{(ii) Compromisso de Compra e Venda}

“12. Um ponto que tem trazido muita dúvida: No setor imobiliário brasileiro, as entidades que 
realizam a incorporação ou a construção de imóveis, diretamente ou por meio de subempreiteiras, firmam contratos antes do término da construção, ou mesmo antes de seu início (na planta) mediante contrato costumeiramente denominado de "promessa de compra e venda'.

13. Na realidade, a utilização do "contrato de compromisso de compra e venda" e não "contrato de compra e venda" se dá, via de regra, pela facilidade de se efetivar a operação entre contratante e contratada, reduzindo o tempo e as custas do registro do contrato formal. Esse contrato tem força de uma operação de compra e venda de unidade futura, sendo, via de regra, irrevogável e irretratável para ambas as partes. Um distrato normalmente ocorre por decisão do comprador ou por inadimplemento às suas obrigações de pagamento, sendo essa efetivada com a imposição de perdas importantes o que pode inibir esse cancelamento. A lei somente admite a desistência pelo incorporador no período de carência de 180 dias após o registro do memorial de incorporação se estiver isso explicitamente considerado no plano de incorporação. Após esse prazo, o incorporador está obrigado à construção e entrega das unidades.”

“14. Nada impede, também, que seja outorgada a escritura definitiva de venda e compra da unidade, mesmo que ainda a ser construída. Com isso, o adquirente pode ser titular do direito de propriedade da unidade futura ou dos direitos de aquisição dessa futura unidade. Mas em ambas as hipóteses têm-se direitos reais. Há casos em que a outorga da escritura definitiva está condicionada a aprovação do vendedor, porém quando esta cláusula estiver vinculada ao fato da compra não ter sido quitada, pode se presumir tratar-se de garantia à liquidação da obrigação do adquirente

15. O adquirente pode dispor livremente sobre os direitos da unidade imobiliária, pagando o imposto de transmissão e demais tributos, se devidos. Isso lhe dá a característica de livre possibilidade de transformação desse direito em dinheiro ou em outro ativo, o que caracteriza controle e detenção de benefícios.

16. Dados evidenciam que a maioria dos contratos tem sido levado a cabo pelos adquirentes, o que faz prevalecer a idéia de que a forma contratada ('promessa de compra e venda') não interfere na essência da transação que é, de fato, uma operação de compra e venda. Assim, não há que se considerar essa forma jurídica como restritiva para decisão da natureza de que trata a Interpretação em análise.”

Neste ponto, é importante um comentário acerca da OCPC 04 que merece ajuste do ponto de vista jurídico. Referida orientação menciona que tanto a promessa de compra e venda quanto a escritura definitiva de compra e venda transferem ao adquirente a titularidade sobre o direito de propriedade da unidade futura. Contudo, é preciso destacar que a titularidade do direito de propriedade somente ocorre com o registro na matrícula do imóvel, o que somente ocorre após o desmembramento das matrículas individualizadas das unidades 
autônomas no Cartório de Registro de Imóveis.

Este equívoco, contudo, não invalida a conclusão da OCPC 04 no sentido de que o adquirente detém o poder de alienar o direito de aquisição da propriedade imobiliária sobre determinada unidade autônoma a construir. De fato, com o pagamento adiantado de parte do preço, o adquirente passa a poder exigir do incorporador o cumprimento de sua obrigação jurídica. Ademais, nos termos dos artigos 1.417 e 1.418 do Código Civil, a promessa de compra e venda registrada em cartório de registro de imóveis possui natureza de direito real (ou seja, oponível contra terceiros). ${ }^{3}$

Dessa forma, mesmo não sendo titular do direito de propriedade, o adquirente da unidade a construir detém o poder do exercício forçado da promessa de compra e venda (adjudicação compulsória), ${ }^{4}$ inclusive perante terceiros no caso de registro do instrumento em cartório.

Assim, a promessa de compra e venda já se configura a transferência dos riscos e benefícios antes mesmo da transmissão da posse ("entrega das chaves"), pois o compromisso é irretratável e o adquirente pode fazer a cessão desse direito a terceiros, auferindo ganho ou perda decorrente da variação do preço de mercado. ${ }^{5}$

\section{(iii) Pagamentos Adiantados (Liquidação de Obrigação Contratual)}

“17. Notamos também que em nosso ambiente, de forma geral, ocorre a assunção da dívida pelo comprador quando do acordo contratual, cuja liquidação ocorre durante o processo de construção, mas não na forma de adiantamento, e sim na de liquidação do compromisso assumido no contrato. Essa é uma característica que diferencia enormemente os contratos brasileiros de outros existentes em muitas outras jurisdições onde o contrato caracteriza muito mais uma opção para compra futura e onde o pagamento é feito na forma

\footnotetext{
${ }^{3}$ CC/2002: “Art. 1.417. Mediante promessa de compra e venda, em que se não pactuou arrependimento, celebrada por instrumento público ou particular, e registrada no Cartório de Registro de Imóveis, adquire o promitente comprador direito real à aquisição do imóvel.

Art. 1.418. O promitente comprador, titular de direito real, pode exigir do promitente vendedor, ou de terceiros, a quem os direitos deste forem cedidos, a outorga da escritura definitiva de compra e venda, conforme o disposto no instrumento preliminar; e, se houver recusa, requerer ao juiz a adjudicação do imóvel."

${ }^{4}$ Ressalte-se que, nos termos da Súmula 239 do STJ, "O direito à adjudicação compulsória não se condiciona ao registro do compromisso de compra e venda no cartório de imóveis."

${ }^{5}$ Neste sentido, confira-se o que dispõe a Lei ${ }^{\circ} 4.591 / 64$ :

“Art. 32. O incorporador somente poderá negociar sobre unidades autônomas após ter arquivado, no cartório competente de Registro de Imóveis, os seguintes documentos: (...)

$\S 2^{\mathrm{o}}$ Os contratos de compra e venda, promessa de venda, cessão ou promessa de cessão de unidades autônomas são irretratáveis e, uma vez registrados, conferem direito real oponível a terceiros, atribuindo direito a adjudicação
} 
de adiantamento e tem alguma característica de prêmio por essa opção.(...)

20. Pagamento: nos casos em que o comprador efetua um adiantamento que será reembolsado apenas se a entidade deixar de entregar a unidade imobiliária concluída de acordo com os termos contratados, caso em que o restante do preço de compra é geralmente pago à entidade apenas ao término do contrato, quando o comprador obtém a posse/propriedade da unidade, fica mais evidente que esse é um contrato de venda de bens, de acordo com o alcance do Pronunciamento Técnico CPC 30 - Receitas.”

\section{(iv) Poder de Definição de Elementos Estruturais}

“18. Outra questão para análise refere-se ao contido no item 11 da ICPC 02, qual seja, "um contrato de construção de imóvel enquadra-se na definição de contrato de construção quando o comprador é capaz de especificar os principais elementos estruturais do projeto do imóvel antes de começar a construção e/ou especificar mudanças estruturais significativas após o início da construção (quer, ou não, o comprador exerça essa possibilidade)". Em projeto de habitação coletiva é impossível a aplicação dessa condição, a não ser nos casos em que os adquirentes tenham deliberado e negociado anteriormente, não somente ao contrato, mas também ao registro em cartório dos documentos comentados anteriormente. Iniciada a construção, é praticamente impossível qualquer mudança estrutural no projeto, por razões óbvias de engenharia. Mas essa incapacidade ocorre também para o incorporador/construtor. Logo, após o registro em cartório da planta, do projeto e do memorial descritivo, nenhuma das partes tem mais condição de provocar mudanças estruturais significativas. Assim, se o comprador não adquiriu essa capacidade, também o incorporador/construtor não a tem mais. Assim, essa questão se torna inócua e sem sentido para exercício de julgamento.”

\section{(v) Fornecimento de Materiais}

“19. O item 16 da Interpretação diz que "se a entidade for requerida a prestar serviços, em conjunto com o fornecimento de materiais de construção, para cumprir sua obrigação contratual, a fim de entregar o imóvel ao comprador, como aqueles aplicáveis aos contratos de venda decorrentes da incorporação de unidades imobiliárias, o contrato é um contrato de venda de bens, devendo ser aplicados os critérios de reconhecimento de receita descritos no item 14 do Pronunciamento Técnico CPC 30 - Receitas”. Ocorre que o contrato brasileiro típico não é o de fornecimento de materiais de construção numa condição em que a incorporadora/construtora seria uma intermediadora comercial. A venda é da unidade imobiliária, e o que a incorporadora/construtora faz é prestar, entre outros, o

compulsória perante o incorporador ou a quem o suceder, inclusive na hipótese de insolvência posterior ao término da obra. (Redação dada pela Lei no 10.931 , de 2004)" 
serviço de aquisição e aplicação dos materiais à unidade imobiliária adquirida pelo cliente. A entidade age, na essência, em nome dos adquirentes dos imóveis, e não em seu próprio como se fosse uma entidade comercial que compra bens e os revende aos clientes. Só ocorre isso no caso das unidades não vendidas."

\section{(vi) Transferência Gradual do Controle, Riscos e Benefícios}

“21. Controle, riscos e benefícios: a entidade pode transferir ao comprador o controle, os riscos e os benefícios da propriedade do imóvel em construção em seu estágio atual de acordo com a evolução da obra. Nesse caso, se todos os critérios do item 14 do Pronunciamento Técnico CPC 30 - Receitas forem continuamente atendidos à medida que a construção avança, a entidade deve reconhecer a receita pelo percentual de evolução da obra. As exigências do Pronunciamento Técnico CPC 17 - Contratos de Construção aplicam-se, em geral, ao reconhecimento da receita e dos correspondentes custos e despesas a medida que a prestação do serviço é realizada. Este é um ponto vital a ser observado, ou seja, se houver transferência contínua dos riscos e benefícios significativos sobre o imóvel em construção, o reconhecimento da receita e custos deve ser efetuado à medida que ocorre a transferência desses riscos e benefícios significativos ao amparo do Pronunciamento Técnico CPC 30.”

Conforme a Orientação OCPC 04 (item 22), são elaborados diversos exemplos de transferências de riscos e benefícios sobre o imóvel em construção, abaixo reproduzidos (com alguns comentários):

“22. Alguns exemplos de transferências de riscos e benefícios sobre o imóvel em construção são:

a) o contrato firmado tem força de escritura pública assegurando ao comprador todos os direitos de livre utilização do bem (alienação, dação em garantia etc.);

b) o contrato normalmente exige a anuência da incorporadora/construtora caso o adquirente queira vender seu bem para terceiros e ainda não tenha concluído o pagamento integral do preço de aquisição; mas isso ocorre em razão da necessidade de análise da qualidade de crédito do candidato a novo adquirente, como ocorre em qualquer transferência de devedor em outras situações;

c) a legislação brasileira determina que para os casos em que o adquirente tenha quitado todo o contrato, este poderá vendê-lo sem a necessidade de anuência ou concordância do incorporador/construtor, bastando sua notificação; ${ }^{6}$

d) as situações anteriores evidenciam que o comprador tem o direito ao bem, e somente ele, e tem a capacidade de transformar seu bem em construção em dinheiro quando quiser e tiver o novo adquirente com condição creditícia aceitável; 
e) no caso dessas revendas, eventuais ganhos por valorização normal ou anormal do imóvel durante a construção beneficiam o adquirente, e não a incorporadora/construtora; eventuais prejuízos dessa natureza também são só do adquirente, o que caracteriza a transferência de riscos e de benefícios;

f) casos reais de desapropriação têm demonstrado que os detentores do crédito à indenização são os compradores. Essas indenizações têm sido distribuídas aos adquirentes proporcionalmente aos valores pagos;

g) a legislação brasileira dá aos adquirentes, em decisão simplesmente majoritária, o direito de trocar a incorporadora/construtora se esta estiver em atraso injustificado e não sanado superior a 30 dias com relação ao cronograma fixado. Obviamente, os transtornos dessa substituição podem não indicar esse caminho como o melhor, e por isso determinados ajustes acabam ocorrendo, em que indenizações são pagas aos adquirentes por causa desse atraso, como pagamento de aluguel pelo prazo adicional etc.; ${ }^{7}$

h) a Lei $n^{\circ} 4.591 / 64$ e a jurisprudência brasileira têm fixado claramente que, no caso de falência da incorporadora, ou da imotivada e não sanada paralisação das obras por mais de 30 dias, ou de retardo excessivo do andamento dessas obras, o direito de destituir a incorporadora e a contratação de outra construtora. Na falência, os bens em andamento não se incorporam à massa falida para atendimento a demais credores; ${ }^{8}$

i) o contrato de promessa de compra e venda ou o definitivo de compra e venda asseguram ao adquirente o direito de dispor de seu patrimônio, tanto seja ele domínio (se houver venda e compra) quanto seja ele direito aquisitivo (se houver promessa de venda e compra) ${ }^{9}$

no caso de problema com a construção do tipo desabamento, a responsabilidade,

\footnotetext{
${ }^{6}$ Trata-se de cessão do direito à aquisição da propriedade, decorrentes da promessa de compra e venda.

${ }^{7}$ Lei $\mathrm{n}^{\circ}$ 4.591/64: “Art. 43. Quando o incorporador contratar a entrega da unidade a prazo e preços certos, determinados ou determináveis, mesmo quando pessoa física, ser-lhe-ão impostas as seguintes normas: (...)

VI - se o incorporador, sem justa causa devidamente comprovada, paralisar as obras por mais de 30 dias, ou retardar-lhes excessivamente o andamento, poderá o Juiz notificá-lo para que no prazo mínimo de 30 dias as reinicie ou torne a dar-lhes o andamento normal. Desatendida a notificação, poderá o incorporador ser destituído pela maioria absoluta dos votos dos adquirentes, sem prejuízo da responsabilidade civil ou penal que couber, sujeito à cobrança executiva das importâncias comprovadamente devidas, facultando-se aos interessados prosseguir na obra."

${ }^{8}$ Lei $\mathrm{n}^{\mathrm{o}}$ 4.591/64: “Art. 43. Quando o incorporador contratar a entrega da unidade a prazo e preços certos, determinados ou determináveis, mesmo quando pessoa física, ser-lhe-ão impostas as seguintes normas: (...)

III - em caso de falência do incorporador, pessoa física ou jurídica, e não ser possível à maioria prosseguir na construção das edificações, os subscritores ou candidatos à aquisição de unidades serão credores privilegiados pelas quantias que houverem pago ao incorporador, respondendo subsidiariamente os bens pessoais deste;"

${ }^{9} \mathrm{Na}$ verdade, trata-se da cessão de direito, seja na escritura de compra e venda, seja na promessa, já que a propriedade somente se transmite pelo registro na matrícula da unidade imobiliária.
} 
juridicamente no Brasil, fica com a incorporadora/construtora, que deve arcar com o prejuízo; todavia, isso não caracteriza, por si só, que os riscos não sejam repassados aos adquirentes. Aliás, esse tipo de responsabilidade independe, de fato, da forma contratada, se genuína execução de serviço por conta de terceiros ou de construção para entrega futura, se o problema derivar de falha da construtora. Assim, pouco interfere na análise presente, inclusive pela baixíssima probabilidade de ocorrência.

Assim, listamos acima alguns exemplos comuns verificados no Brasil que evidenciam que os riscos e benefícios significativos são, como regra, continuamente transferidos ao adquirente durante o período de construção."

Aos exemplos listados acima, acrescente-se que é possível a apresentação de embargos de terceiro para proteger direito sobre imóvel que foi penhorado para garantia de dívida que não é do promitente comprador. ${ }^{10}$

Todos os argumentos listados pela OCPC 04 são exemplos concretos analisados no contexto brasileiro, os quais permitem determinar que as entidades de incorporação imobiliária devem estar sujeitas às regras estabelecidas para os contratos de construção (CPC 17). Portanto, a receita deve ser registrada proporcionalmente aos riscos e benefícios transferidos (com efeito prático semelhante a uma prestação de serviços para fins de reconhecimento contábil).

Contudo, tendo em vista os argumentos no sentido de que a incorporação imobiliária estaria sujeita ao reconhecimento de receitas nos termos do CPC 30, seguem os comentários de como esse Pronunciamento seria aplicável às entidades de incorporação imobiliária:

“23. Nos itens anteriores foram apresentados inúmeros exemplos acerca da aplicação da Interpretação Técnica ICPC 02. No entanto, dada a existência de argumentos em contrário - baseados no entendimento de que o comprador não tem poder de especificar as características do bem construído como ocorre com um navio em um estaleiro, por exemplo - e por isso tais contratos estarem fora do alcance do Pronunciamento CPC 17 - nesta parte se faz uma análise acerca do tratamento contábil do caso concreto brasileiro na hipótese de não enquadramento como contrato de construção. Assim, pretende-se responder à seguinte questão: qual seria o tratamento contábil para o caso de o contrato de promessa de compra e venda ou de compra e venda em uma atividade

\footnotetext{
${ }^{10}$ AgRg no RESP 643.445 (DJ 26/09/2005 p. 363): "Processual Civil. Agravo no recurso especial. Embargos de terceiro. Penhora. Imóvel adquirido mediante promessa de compra e venda. Não inscrição no registro de imóveis. Reexame de provas. - É admissível a oposição de embargos de terceiro fundados em alegação de posse advinda do compromisso de compra e venda de imóvel, ainda que desprovido do registro. - O reexame do acervo fáticoprobatório constante dos autos é procedimento vedado em sede de recurso especial. Negado provimento ao agravo."
} 
imobiliária estar enquadrado dentro do Pronunciamento Técnico CPC 30?

24. Assumindo a hipótese de enquadramento dentro do Pronunciamento Técnico CPC 30, a discussão se desloca para a questão da transferência de controle, riscos e benefícios significativos de forma contínua ou em um único evento (no caso concreto, a chamada "entrega da chave"). A ICPC 02 reconhece que a respectiva transferência pode ser feita de forma contínua ou em um único momento no tempo, conforme a análise conclua. Ou seja, a questão não é dogmática - depende de interpretação da legislação brasileira, dos contratos e, principalmente, do modelo de negócio da companhia. O Pronunciamento Técnico CPC 30 abrange os dois tipos de reconhecimento. É evidente que, se adotado o reconhecimento contínuo, o resultado prático em muito se assemelha, ou até se iguala, ao que se obteria caso tivesse sido aplicado o Pronunciamento Técnico CPC 17.

25. A IFRIC 15, em suas Bases para Conclusões (Basis for Conclusions - BC 26) reconhece que contratos com transferência continuada não são comumente encontrados na prática. No entanto, a IFRIC 15 trata desse tipo de possibilidade por reconhecer que eles são possíveis e ocorrem em algumas jurisdições. O item 27 das Bases para Conclusões da IFRIC 15 comenta que os contratos nos quais o reconhecimento deve ser realizado em um único momento no tempo (entrega da chave em nosso jargão) "somente dão ao comprador um ativo na forma de um direito de adquirir, usar e vender o empreendimento completo em uma data futura11.” Conforme discutido anteriormente, o caso brasileiro, usualmente, não parece se enquadrar nessa situação. No Brasil, o comprador não adquire somente um direito de comprar (uma espécie de opção de compra sobre o imóvel). No Brasil, estão de fato desembolsando parcelas que pretendem liquidar a obrigação contratual diretamente associada ao ativo em construção.

26. O mesmo se dá na doutrina especializada. Existem poucas evidências claras a respeito de como aplicar a transferência contínua, mas alguns comentários adicionais são incluídos no IE3, IE8 e IE11 nos exemplos ilustrativos que acompanham o IFRIC 15. Um dos indicadores importantes do 'envolvimento continuado' parece ser que, se o acordo é encerrado antes que a construção esteja concluída, o comprador retém o trabalho em andamento e a entidade tem o direito de ser remunerada pelo trabalho feito até aquele momento. Como se pode ver, o texto acima discute exatamente a questão central do momento do reconhecimento de receita dentro do Pronunciamento Técnico CPC 30 nas situações nas quais há a chamada transferência continuada. Vale fazer agora uma análise de um caso concreto que ocorre com frequência no Brasil atualmente.

27. Nesse caso, quando ocorre uma interrupção da obra, qual o tratamento dado ao patrimônio já edificado? Existe diferença de tratamento entre os compradores possuidores de andares já finalizados (provavelmente os mais baixos) e os adquirentes de andares superiores? As respostas a essas questões podem elucidar melhor o tratamento contábil que deve ser 
aplicado no Brasil. Inicialmente, pode-se verificar que, na hipótese de interrupção da obra (por um motivo de força maior, por exemplo), o construtor terá direito a receber aquilo que já foi edificado. Se assim o fosse, e ele não tivesse entregue a edificação, não teria direito a receber nada. Não é isso que ocorre na construção civil brasileira. Da mesma forma, o comprador terá posse do ativo e poderá contratar outra incorporadora ou construtora, por exemplo, para terminar a edificação ou mesmo alienar a obra em andamento por decisão coletiva dos compradores.

28. Existe alguma diferença entre os compradores de apartamentos em andares baixos (que já foram parcialmente edificados) e adquirentes de andares superiores que ainda não foram iniciados? Se a resposta for: em nenhuma hipótese, ambos os adquirentes possuem os mesmos direitos. No caso concreto, não seria relevante a entrega de um imóvel específico, mas sim da totalidade da obra.

29. Esse tipo de exemplo - de natureza hipotética - tem como objetivo ilustrar como se dá a transferência de riscos e benefícios significativos. O exemplo interrompe de forma arbitrária em um dado momento a construção e verifica como se comportam os riscos e benefícios significativos naquele momento no tempo. Se os fatos mencionados ocorrerem o construtor tiver direito ao recebimento e o comprador retiver o trabalho em andamento ou puder dispor desse ativo, mesmo que por decisão conjunta dos demais compradores pode-se inferir que o mesmo ocorreria em outros momentos no tempo. Sendo assim, podese concluir que a transferência se dá de forma contínua no tempo. Por que isso pode ser afirmado nesse caso? Porque se a construtora tiver direito à remuneração proporcional ao que tiver empreendido, então ela está transferindo riscos e benefícios significativos à medida que a obra se desenvolve. Ou seja, ocorre a transferência continuada. Da mesma forma, se o comprador retiver a obra em seu estágio parcial de desenvolvimento, ele terá recebido os benefícios até aquele momento relativos ao trabalho finalizado. Ou seja, à medida que a construção avança, os riscos e benefícios vão sendo transferidos.

30. Nesse caso, se o reconhecimento se desse somente no momento da entrega do bem pronto (entrega da chave) teríamos a premissa de que todos os riscos e benefícios significativos estariam sendo transferidos naquele momento específico. Pode-se ver que no caso brasileiro, de forma geral, não é isso que ocorre. Essa transferência se dá de forma continuada como a situação hipotética da interrupção da construção ilustra.

31. Quando a entidade transfere ao comprador o controle, os riscos e os benefícios da propriedade do imóvel, em sua totalidade (ou mesmo parcela mais significativa desses riscos e benefícios), de uma única vez, a entidade somente poderá reconhecer a receita quando todos os critérios do item 14 do Pronunciamento Técnico CPC 30 - Receitas forem satisfeitos.

11 "Such agreements give the buyer only an asset in the form of a right to acquire, use and sell the completed real state at a later date." 
32. Se a entidade estiver obrigada a executar outros serviços, incluindo gastos estimados para fazer face a garantia contratual e legal no imóvel já entregue ao comprador, deverá reconhecer um passivo e uma despesa de acordo com o item 19 do Pronunciamento Técnico CPC 30 - Receitas. O passivo deve ser mensurado de acordo com o Pronunciamento Técnico CPC 25 - Provisões, Passivos Contingentes e Ativos Contingentes. Se a entidade está obrigada a entregar outros bens ou serviços, separadamente identificáveis do imóvel já entregue ao comprador, ela deve identificar os bens ou os serviços remanescentes como componente separado da venda, em conformidade com o item 8 da Interpretação Técnica ICPC 02 - Contrato de Construção do Setor Imobiliário.

\section{Considerações finais}

\section{Contabilização da receita, custos e despesas da incorporação imobiliária}

33. Baseado nos comentários anteriormente efetuados, constata-se que no ambiente econômico brasileiro, usualmente, os contratos de promessa de compra e venda ou contratos de compra e venda de uma unidade a ser entregue no futuro, é necessário, o reconhecimento das receitas e despesas à medida que a construção avança uma vez que a transferência de riscos e benefícios ocorre de forma contínua.

34. Nos casos onde o contrato não puder se enquadrar na definição de contrato de construção, ele deverá se enquadrar no Pronunciamento Técnico CPC 30 - Receitas.

35. Se a entidade não estiver obrigada a comprar e fornecer materiais de construção, o contrato pode ser apenas um contrato de prestação de serviços de acordo com o Pronunciamento Técnico CPC 30 - Receitas. Nesse caso, se forem atendidos os critérios do item 20 do Pronunciamento Técnico CPC 30 - Receitas, é exigido que a receita seja reconhecida tomando por base a proporção dos serviços prestados. As exigências do Pronunciamento Técnico CPC 17 - Contratos de Construção aplicam-se, em geral, ao reconhecimento da receita e dos correspondentes custos e despesas (item 21 do Pronunciamento Técnico CPC 30 - Receitas).

36. Se ficar caracterizado, todavia, que a entidade presta serviços, em conjunto com o fornecimento de materiais de construção, para cumprir sua obrigação contratual de entregar o imóvel ao comprador, mantendo todo o controle, o risco e o benefício sem transferi-los ao adquirente até seu completo término, o contrato é um contrato de venda de bens, devendo ser aplicados os critérios de reconhecimento de receita descritos no item 14 do Pronunciamento Técnico CPC 30 - Receitas.

37. Desta forma, pode existir casos em que uma mesma entidade possua (i) contratos que sejam caracterizados como de prestação de serviços, se atendidos todos os requisitos do Pronunciamento Técnico CPC 17, (ii) contratos de venda de unidades onde ocorram a transferência contínua dos riscos e benefícios significativos sobre tais bens que permitam o reconhecimento das receitas e custos à medida que ocorre essas transferências e (iii) 
contratos que somente permitam a transferência de tais riscos, benefícios e controles quando da entrega do imóvel pronto (entrega da chave), sendo que nesse último caso, o reconhecimento das receitas e custos ocorrerá de uma única vez, quando da entrega do imóvel para uso do comprador, tendo atendido, nesses dois últimos casos, todos os requisitos do Pronunciamento CPC 30. Assim sendo, cada entidade deverá analisar seus contratos (formais e verbais), aditivos, práticas atuais e passadas e, principalmente, seu modelo de negócio a fim de efetuar uma adequada determinação de sua política de reconhecimento de receitas e custos, considerando que o objetivo final é o pleno atendimento do axioma citado no item 2 desta Orientação." 


\section{ApÊNDiCe B - Propriedade PARA InVestimento (ICPC 10) “PROPRIEDADE PARA INVESTIMENTO}

\section{Diferenciação entre ativo imobilizado e propriedade para investimento}

44. Os ativos imobilizados são itens tangíveis que:

(a) são detidos para uso na produção ou no fornecimento de mercadorias ou serviços, para aluguel a outros, ou para fins administrativos; e

(b) é esperado que sejam usados durante mais de um período.

45. A propriedade para investimento é a propriedade (terreno ou edifício - ou parte de edifício - ou ambos) mantida (pelo dono ou pelo arrendatário em arrendamento financeiro) para obter rendas ou para valorização do capital ou para ambas, e não para:

(a) uso na produção ou no fornecimento de bens ou serviços ou para finalidades administrativas; ou

(b) venda no curso ordinário do negócio.

46. A menção da palavra "aluguel" no item 44 e a menção da expressão "para obter rendas" no item 45 se diferenciam basicamente no seguinte: no ativo imobilizado, a figura do aluguel só pode existir quando estiver vinculado a ativo complementar na produção ou no fornecimento de bens ou serviços. Por exemplo, uma fazenda pode ter residências alugadas a seus funcionários, uma extratora de minerais pode construir residências no meio da floresta também para alugar a seus funcionários, etc. Nesse caso, os ativos alugados são, na verdade, parte do imobilizado necessário ao atingimento da atividade-fim da entidade.

47. Se houver investimento para obter renda por meio de aluguel, em que este é o objetivo final, no qual o imóvel é um investimento em si mesmo, e não o complemento de outro investimento, aí se tem a caracterização não do ativo imobilizado, mas sim de propriedade para investimento. A propriedade para investimento, ao contrário do ativo alugado classificado no imobilizado, tem um fluxo de caixa específico e independente, ou seja, ele é o ativo principal gerador de benefícios econômicos, e não um acessório a outros ativos geradores desses benefícios.

48. Algumas propriedades podem ter parte com características de propriedade para investimento e outra como imobilizado. Nesse caso, se essas propriedades geram, adicionalmente, outros benefícios que não aqueles decorrentes da valorização ou obtenção de rendimento por aluguel ou arrendamento, o valor desses outros benefícios deve ser insignificante em relação ao total para que a propriedade seja tratada como para investimentos. A propriedade que seja utilizada prioritariamente como meio para obtenção de rendimentos pela prestação de serviços distintos daqueles vinculados ao aluguel 
(arrendamento) não é uma propriedade para investimentos.

\section{Classificação da propriedade para investimento}

49. A propriedade para investimento deve ser classificada no subgrupo Investimentos no grupo Ativo Não Circulante.

50. As reclassificações de ou para propriedade para investimento somente podem ser efetuadas quando da mudança de uso desses ativos formalmente definida pela administração. As reclassificações não devem ser casuísticas e devem ser efetuadas quando a entidade tiver segurança de que tal ação aprimora a capacidade preditiva das demonstrações contábeis em relação à estimativa de resultado e fluxo de caixa futuros.

\section{Avaliação da propriedade para investimento}

51. A opção pela atribuição de novo custo (deemed cost), incluindo a vedação de revisão da opção em períodos subsequentes ao da adoção inicial, e todos os demais procedimentos pertinentes contidos nesta Instrução para os ativos imobilizados se aplicam igualmente às propriedades para investimento, quando a entidade optar pela adoção do método de custo nos termos do item 56 do Pronunciamento Técnico CPC 28.

52. No método do valor justo e após o reconhecimento inicial, as variações de valor das propriedades para investimento entre dois períodos distintos são reconhecidas no resultado do período. Esse procedimento independe de se a propriedade é detida para obter rendas ou para valorização do capital ou para ambas. Nas propriedades mantidas para renda o resultado é, portanto, afetado por dois eventos econômicos: a receita de arrendamento (aluguel) e o efeito do ajustamento do valor justo entre os períodos.

53. A essência econômica do ajuste, no resultado, da variação do valor justo entre os períodos deve ser considerada quando da definição de seu registro. O Pronunciamento Técnico CPC 28, da mesma forma que o IAS 40, não indica, nem tece comentários, sobre o registro desse ajuste no resultado. Importante é considerar que nas entidades que têm como objeto principal a administração de propriedades com intenção de obter rendimentos, o valor justo é alterado em função de causas internas e externas, ou seja, podem decorrer da gestão direta da propriedade e de fatores externos, que interagem entre si e se complementam. Dessa forma, a classificação do ajuste do valor justo deve ser efetuada em rubrica de resultado antes do resultado financeiro, caracterizando-o como item objetivamente vinculado à operação. Por outro lado, se o investimento em propriedades é especulativo, sendo ou não o objeto principal da entidade, a essência econômica mais se assemelha a instrumentos financeiros avaliados pelo valor justo por meio do resultado. Se assim for, tal ajuste deve ser efetuado no grupo de resultado financeiro. Em quaisquer das situações deve estar demonstrado nas demonstrações contábeis qual o critério de classificação utilizado e os respectivos valores." 


\section{APÊNDICE C - FUNDO DE INVESTIMENTO IMOBILIÁRIO (IN/CVM No 516/11)}

\section{“CAPÍTULO II \\ CRITÉRIOS CONTÁBEIS \\ SEÇÃO I - IMÓVEIS}

Art. $2^{\circ}$ Os FII devem aplicar os critérios contábeis de reconhecimento, classificação e mensuração dos ativos e passivos, assim como os de reconhecimento de receitas e apropriação de despesas, previstos nas normas contábeis emitidas por esta Comissão aplicáveis às companhias abertas, ressalvadas as disposições contidas nesta Instrução.

Parágrafo único. Os ganhos ou as perdas resultantes da avaliação de ativos ou de passivos do fundo, ainda que não realizados financeiramente, devem ser reconhecidos no resultado do período.

Art. $3^{\circ}$ Entende-se por custo dos imóveis adquiridos o preço de aquisição mais todos os gastos da transação diretamente atribuíveis à operação de compra, tais como, taxas cartorárias, tributos incidentes sobre a transferência de propriedade do imóvel, corretagens e honorários advocatícios.

Parágrafo único. Para imóveis destinados à venda no curso ordinário do negócio, o custo engloba também os gastos incorridos para colocar o imóvel em condições normais de venda, tais como, reformas, gastos com engenharia e projetos de arquitetura.

Art. $4^{\circ}$ Entende-se por custo dos imóveis em construção todos os gastos diretamente relacionados à unidade em construção, tais como materiais, mão-de-obra e serviços técnicos especializados.

Art. $5^{\circ}$ O imóvel adquirido ou construído para renda ou para apreciação de capital no longo prazo deve ser classificado como propriedade para investimento, dentro do subgrupo investimento do ativo não circulante.

Art. $6^{\circ}$ O imóvel classificado como propriedade para investimento deve ser reconhecido inicialmente pelo valor de custo.

Art. $7^{\mathrm{o}}$ Após o reconhecimento inicial, as propriedades para investimento devem ser continuamente mensuradas pelo valor justo.

$\S 1^{\circ}$ Entende-se por valor justo o valor pelo qual um ativo pode ser trocado ou um passivo liquidado entre partes independentes, conhecedoras do negócio e dispostas a realizar a transação, sem que represente uma operação forçada.

$\S 2^{\circ} \mathrm{O}$ valor justo de uma propriedade para investimento deve refletir as condições de mercado no momento de sua aferição.

$\$ 3^{\circ}$ A melhor evidência do valor justo é dada pelos preços correntes de negociação em um mercado líquido, de ativos semelhantes, na mesma região e condição e sujeitos a contratos 
similares de aluguéis ou outros.

$\S 4^{\circ} \mathrm{Na}$ impossibilidade de aplicar o disposto no parágrafo anterior, a instituição administradora deve usar, na ordem, as seguintes informações para estimar o valor justo:

I - preços correntes praticados em um mercado líquido de ativos de diferente natureza, condição, localização, sujeitos a diferentes contratos de aluguéis ou outros, ajustados para refletir estas diferenças;

II - preços recentes de ativos semelhantes praticados em mercados menos líquidos, ajustados para refletir quaisquer mudanças nas condições econômicas em relação à data da ocorrência daqueles preços; ou

III - projeções de fluxos de caixa descontados baseados em estimativas confiáveis de fluxos futuros de caixa, consubstanciado nos termos do contrato de aluguel ou qualquer outro contrato existente e, quando possível, em evidências externas de valores correntes de aluguéis de ativos na mesma localização e condição, devendo usar taxas de desconto que reflitam as avaliações atuais do mercado quanto às incertezas no valor e prazo dos fluxos de caixa.

Art. $8^{\circ}$ Se a instituição administradora concluir que o valor justo de uma propriedade para investimento em construção não é mensurável de maneira confiável, a mensuração deve ser feita pelo valor de custo até que o valor justo possa ser determinado de maneira confiável ou quando a construção for completada, o que ocorrer primeiro.

Parágrafo único. A conclusão de que o valor justo da propriedade para investimento em construção não pode ser mensurado de maneira confiável somente pode ser feita no momento do reconhecimento inicial.

Art. $9^{\circ}$ A instituição administradora deve avaliar continuamente a existência de eventos que indiquem a possibilidade de alteração substancial no valor justo do imóvel classificado como propriedade para investimento.

Art. $10^{\circ}$. O imóvel adquirido ou construído para venda no curso ordinário do negócio deve ser classificado como imóveis destinados à venda, dentro do subgrupo estoques do ativo circulante.

Art. 11. Os imóveis destinados à venda no curso ordinário do negócio devem ser avaliados pelo menor entre o valor de custo ou valor realizável líquido.

$\S 1^{\circ}$ O valor realizável líquido corresponde ao valor estimado de venda no curso ordinário do negócio menos as despesas estimadas necessárias para realizar a venda.

$\S 2^{\circ}$ No caso de imóveis em construção, devem ser também deduzidos os custos estimados para completar a construção para a determinação do valor realizável líquido.

Art. 12. Se houver indícios de que o valor de custo dos imóveis registrados em estoques não é recuperável, o valor do imóvel deve ser ajustado até o valor realizável líquido.

$\S 1^{\circ}$ A instituição administradora deverá avaliar continuamente a existência de eventos que indiquem a possibilidade da não recuperação dos valores dos imóveis registrados em estoques. 
$\S 2^{\circ}$ São exemplos de eventos que podem indicar a não recuperação dos valores registrados em estoques:

I - dano;

II - declínio do preço de venda;

III - aumento da estimativa dos valores dos custos a serem incorridos para completar a construção;

e

IV - aumento da estimativa das despesas a serem incorridas para realizar a venda.

$\S 3^{\circ}$ O ajuste ao valor realizável líquido deve ser registrado no resultado do período ao qual a ocorrência do evento se refere.

$\S 4^{\circ}$ A análise e o respectivo ajuste devem ser efetuados individualmente, sendo vedado o ajuste por conjunto de ativos.

Art. 13. Quando, em um período subsequente, o evento que causou o registro da provisão não mais existir ou quando houver evidências do aumento no valor realizável líquido do ativo por motivo de mudanças nas circunstâncias econômicas, o valor dessa provisão deverá ser revertido até o limite do valor do custo ou do valor realizável líquido revisado, entre os dois, o menor.

Art. 14. A transferência de imóveis classificados em propriedade para investimento para estoques somente deve ser feita quando houver alteração de uso, evidenciada pelo início de desenvolvimento com objetivo de venda.

$\S 1^{\circ}$ O valor de custo atribuível ao imóvel para o reconhecimento inicial como estoque é o valor justo do imóvel na data da mudança de uso.

$\S 2^{\circ}$ Entende-se por desenvolvimento o valor gasto na reforma para colocar o imóvel em condições normais de venda.

$\S 3^{\circ}$ Se a instituição administradora decidir vender o imóvel classificado em propriedade para investimento sem desenvolvimento, o ativo deve permanecer registrado como propriedade para investimento até a sua venda, sendo vedada a sua transferência para estoques.

Art. 15. A transferência de imóveis classificados em estoques para propriedade para investimento somente deve ser feita quando houver alteração de uso, evidenciada pelo início de uso com o propósito de obtenção de renda.

$\S 1^{\circ}$ O valor atribuível ao imóvel para reconhecimento inicial como propriedade para investimento é o valor contábil do ativo no momento da mudança de uso.

$\S 2^{\circ}$ Qualquer diferença entre o valor justo do imóvel e o seu valor de reconhecimento inicial deve ser reconhecida imediatamente no resultado do período.

Art. 16. Se a instituição administradora iniciar o desenvolvimento de uma propriedade para investimento já existente com o objetivo de continuar a ser usada no futuro como propriedade para investimento, o imóvel deve permanecer classificado como propriedade para investimento. 
Parágrafo único. Os valores gastos no desenvolvimento são reconhecidos no resultado do período.

\section{SEÇÃO II - ATIVOS FINANCEIROS AVALIADOS PELO CUSTO AMORTIZADO}

Art. 17. Provisão para perdas deve ser reconhecida sempre que houver evidência de redução no valor recuperável dos ativos financeiros do fundo avaliados pelo custo amortizado.

Art. 18. A perda por redução no valor recuperável deve ser mensurada pela diferença entre o valor contábil do ativo e o valor presente do novo fluxo de caixa esperado calculado após a mudança de estimativa.

$\S 1^{\circ}$ Não é admitido o registro de provisão no momento do reconhecimento inicial do ativo financeiro.

$\S 2^{\circ}$ Para ativos com taxa fixa, a taxa de desconto a ser utilizada é a taxa efetiva de juros calculada no reconhecimento inicial.

$\S 3^{\circ}$ Para ativos com taxa flutuante, a taxa de desconto a ser utilizada é a taxa corrente de juros do parâmetro de mercado utilizado.

$\S 4^{\circ}$ A contrapartida do registro da perda deve ser feita no resultado do período.

Art. 19. Para ativos financeiros de crédito relacionados a um mesmo devedor, a perda determinada no artigo anterior deve ser mensurada sobre todo o fluxo de caixa esperado desse devedor, levando em consideração a natureza da transação e as características das garantias, tais como suficiência e liquidez.

Art. 20. A reversão da provisão por perdas anteriormente constituída deve ser feita desde que haja uma melhora na estimativa anterior de perdas de créditos esperadas.

Art. 21. Admite-se, para o propósito do cálculo do custo amortizado, que o fluxo de caixa esperado seja estimado em base individual ou coletiva.

$\S 1^{\text {o }}$ Independentemente da forma escolhida, a estimativa deve sempre ser baseada em perdas esperadas.

$\S 2^{\circ}$ Quando a instituição administradora avaliar o uso de estimativas em bases individuais ou coletivas, ela deve:

I - usar o método que produza a melhor estimativa; e

II - se certificar de que o método utilizado não resulte em dupla contagem de perdas de crédito.

$\S 3^{\text {o }}$ Se a instituição administradora optar por estimar o fluxo de caixa esperado por grupo de ativos, os ativos devem ser agrupados por segmentos e cada grupo dentro do segmento deve possuir características de risco de crédito similares, que sejam indicativas da habilidade do devedor em honrar os compromissos assumidos de acordo com as cláusulas contratuais, considerando fatores tais como:

I - atividade econômica; 
II - localização geográfica;

III - tipo de garantia dada;

IV - histórico de inadimplência; e

$\mathrm{V}$ - grau de endividamento.

Art. 22. A instituição administradora deve evidenciar e explicar, em nota explicativa, as estimativas e mudanças de estimativas que são requeridas para determinar o custo amortizado.” 


\section{Bibliografia}

ABE, Cesar Henrique Shogi. Disponibilidade Econômica da Renda. in Revista Direito Tributário Atual no 21. 2007.

AKERLOF, George A. The Market for "Lemons": Quality Uncertainty and the Market Mechanism. The Quarterly Journal of Economics, vol. 84, nº 3 (Aug., 1970), The MIT Press.

ALEXY, Robert. Teoria dos Direitos Fundamentais, trad. de Virgílio Afonso da Silva, São Paulo: Malheiros, 2008.

ARNOLD, Briean J. Timing and Income Taxation: the principles of income measurement for tax purposes. Toronto: Canadian Tax Foundation, 1983.

ÁVILA, Humberto. Teoria dos Princípios - da definição à aplicação dos princípios jurídicos. $3^{\text {a }}$ ed., São Paulo : Malheiros, 2004.

. Conceito de Renda e Compensação de Prejuízos Fiscais. São Paulo: Malheiros,

2011.

BALEEIRO, Aliomar. Direito Tributário Brasileiro, 11 a ed., Rio de Janeiro: Forense, 2001. . Uma Introdução à Ciência das Finanças. $15^{\mathrm{a}}$ ed. rev. e atualizada por Dejalma de Campos, Rio de Janeiro: Forense, 1997.

BARRETO, Paulo Ayres. Imposto sobre a Renda e Preços de Transferência. São Paulo: Dialética, 2001.

BEVILAQUA, Clovis. Código Civil dos Estados Unidos do Brasil Comentado. $5^{\mathrm{a}}$ ed., vol. 1, Rio de Janeiro: Livraria Francisco Alves, 1936.

BIANCO, João Francisco. Imposto de Renda da Pessoa Jurídica: uma visão geral. In: SANTI, Eurico Marcos Diniz de; ZILVETI, Fernando Aurelio (coord.) Tributação das Empresas. São Paulo: Quartier Latin, 2006.

CARRAZZA, Roque Antonio. Imposto sobre a Renda: perfil constitucional e temas 
específicos. São Paulo: Malheiros, 2005.

CARVALHO, Paulo de Barros, Direito Tributário - Fundamentos Jurídicos da Incidência, $2^{\mathrm{a}}$ ed., São Paulo, Saraiva, 1999.

CARVAlHOSA, Modesto. Imposto de Renda. Conceituação no Sistema Tributário da Carta Constitucional. In: Revista de Direito Público, nº 1, jul-set, 1967.

Considerações sobre Relações Jurídicas em “Shopping Centers”. In PINTO,

Roberto Wilson Renault e OLIVEIRA, Fernando A. Albino de (coord.). Shopping Centers Questões Jurídicas (Doutrina e Jurisprudência), São Paulo: Saraiva, 1991.

CHALHUB, Melhim Namem, Propriedade Imobiliária: Função Social e Outros Aspectos. Rio de Janeiro: Renovar, 2000, p. 134.

COÊLHO, Sacha Calmon Navarro. Curso de Direito Tributário Brasileiro, $8^{\mathrm{a}}$ ed., Rio de Janeiro: Forense, 2005.

COMPARATO, Fábio Konder. A Natureza Jurídica do Balanço. In Ensaios e Pareceres de Direito Empresarial. Rio de Janeiro: Forense, 1978.

COSTA, Alcides Jorge. Direito Tributário e Direito Privado. in MACHADO, Brandão. Direito Tributário - Estudos em Homenagem ao Prof. Ruy Barbosa Nogueira. São Paulo : Saraiva, 1984.

Conceito de Renda Tributável. in MARTINS, Ives Gandra da Silva (coord.). Estudos sobre o Imposto de Renda (em memória de Henry Tilbery). São Paulo: Resenha Tributária. 1994.

COSTA, Regina Helena. Praticabilidade e Justiça Tributária: Exeqüibilidade de Lei Tributária e Direitos do Contribuinte. São Paulo: Malheiros, 2007.

DERZI, Misabel Abreu Machado. Princípio da Praticabilidade do Direito Tributário (Segurança Jurídica e Tributação). In Revista de Direito Tributário, ano 13, nº47. São Paulo: Revista dos Tribunais, jan-mar. 1989.

- Pressupostos da Periodização Aural. In BALEEIRO, Aliomar. Direito Tributário Brasileiro. Atual. por Misabel Abreu Machado Derzi. 11 $1^{\mathrm{a}}$ ed. Rio de Janeiro: 
Forense, 2001.

DINIZ, Maria Helena. Tratado Teórico e Prático dos Contratos, vol. 3, 6 ${ }^{\mathrm{a}}$ ed., São Paulo: Saraiva, 2006.

- Curso de Direito Civil Brasileiro: Teoria das Obrigações Contratuais e Extracontratuais. 24a ed., São Paulo: Saraiva, 2008.

DOWRKIN, Ronald M. Is law a system of rules? In: DWORKIN, Ronald M. The philosophy of law. Oxford: Oxford University Press, 1977.

. Taking Rights Seriously. Cambridge, MA: 1978.

FISHER, Irving. Comment on President Plehn's Address. In: American Economic Review, mar. 1924, p. 64-65. Apud HOLMES, Kevin. The Concept of Income. A Multi-disciplinary Analysis. The Netherlands, IBFD, 2000.

FONSECA, Priscila Maria Pereira Corrêa da. O Regime Jurídico Aplicável aos Shopping Centers, in Revista de Direito Mercantil, Industrial, Econômico e Financeiro, São Paulo, jan./mar. 1987, v.65.

FORTUNA, Eduardo. Mercado Financeiro - Produtos e Serviços. $17^{\mathrm{a}}$ ed., Rio de Janeiro: Qualimark, 2008.

FRANCO, Vera Helena de Mello. Contratos - Direito Civil e Empresarial. $2^{\mathrm{a}}$ ed. São Paulo: Editora Revista dos Tribunais, 2011.

GOMES, Orlando. Traços do Perfil Jurídico de um Shopping Center. In ARRUDA, José Soares e LÔBO, Carlos Augusto da Silveira (coord.). "Shopping Centers" - Aspectos Jurídicos. São Paulo: Revista dos Tribunais, 1984.

. Direitos Reais. $19^{\mathrm{a}}$ ed., atualizada por Luiz Edson Fachin, Rio de Janeiro: Forense.

. Contratos. 26a ed. Rio de Janeiro: Forense, 2008.

GONÇALVES, Alexandre Tadeu Navarro Pereira. Tributação das Operações Imobiliárias. São Paulo: Quartier Latin, 2007. 
GONÇALVES, José Artur Lima. Imposto sobre a Renda: pressupostos constitucionais. $2^{\mathrm{a}}$ tir. São Paulo: Malheiros, 2002.

HENSEL, Albert, Der Einfluss des Steuerrechts auf die Bergriffsbildung des öffentlichen Rechs, in Veröffentlichungen der Vereinigung der Deutschen Staatsrechtslehrer, Heft 3, Berlim, W. de Gruyter \& C., 1927, pp. 93 e ss. Apud VANONI, Ezio. Natura ed Interpretazione delle Leggi Tributrarie. Trad. port. de Rubens Gomes de Sousa. Natureza e Interpretação das Leis Tributárias. Rio de Janeiro : Edições Financeiras, s.d.

HICKS, John Richard. Value and Capital. 2a ed., Oxford: Caredon, 1946, p. 172. Apud HOLMES, Kevin. The Concept of Income. A Multi-disciplinary Analysis. The Netherlands, IBFD, 2000.

HILÚ NETO, Miguel. A extinção do "Ativo Diferido": Reflexos sobre suas Repercussões Contábeis e Tributárias. In: FERNANDES, Edison Carlos; e PEIXOTO, Marcelo Magalhães (coords.). Aspectos Tributários da Nova Lei Contábil: Lei 11.638/07 (com a Lei 11.941/09). São Paulo: MP, 2010.

HOLMES, Kevin. The Concept of Income. A Multi-disciplinary Analysis. The Netherlands, IBFD, 2000.

IUDÍCIBUS, Ségio de. Teoria da Contabilidade. 9a ed., São Paulo: Atlas, 2009.

, MARION, José Carlos. Curso de Contabilidade para Não Contadores - Para as Áreas de Administração, Economia, Direito e Engenharia. 4ª ed. São Paulo: Atlas, 2006.

MARION, José Carlos e FARIA, Ana Cristina de, Introdução à Teoria da Contabilidade - Para o Nível de Graduação, 5a ed., São Paulo: Atlas, 2009.

, MARTINS, Eliseu e GELBKE, Ernesto Rubens, Manual de Contabilidade das Sociedades por Ações (aplicável às demais sociedades), FIPECAFI - Fundação Instituto de Pesquisas Contábeis, Atuariais e Financeiras, $7^{\mathrm{a}}$ ed., 4ª reimpr., São Paulo: Atlas, 2008.

MARTINS, Eliseu, GELBECKE, Ernesto Rubens, SANTOS, Ariovaldo dos. Manual de Contabilidade Societária - Aplicável a Todas as Sociedades - de Acordo com as Normas Internacionais e do CPC. FIPECAFI - Fundação Instituto de Pesquisas Contábeis, Atuariais e Financeiras, FEA/USP, São Paulo: Atlas, 2010. 
KORNHOUSER, Marjorie E. The Story of Macomber: the continuing legacy of realization. In: CARON, Paul L. Tax Stories: an in-depth look at ten leading federal income tax cases. New York: Foundation Press, 2003, p. 53-96. Apud POLIZELLI, Victor Borges. O Princípio da Realização da Renda e sua Aplicação no Imposto de Renda de Pessoas Jurídicas. Dissertação de Mestrado defendida na Faculdade de Direito da Universidade de São Paulo, 2009.

LAULETTA, Andrea Bazzo e NOVELLO, Guilherme Lautenschlaeger. Os Efeitos Tributários Decorrentes das Novas Regras Contábeis de Depreciação. In: MOSQUERA, Roberto Quiroga e LOPES, Alexsandro Broedel (coord.). Controvérsias Jurídico-Contábeis (Aproximações e Distanciamentos). $2^{\circ}$ Vol. São Paulo : Dialética, 2011.

LEMKE, Gisele. Imposto de Renda: os Conceitos de Renda e de Disponibilidade Econômica e Jurídica. São Paulo: Dialética, 1998.

LONGO, Carlos Alberto. Em Defesa de um Imposto de Renda Abrangente. São Paulo: FIPEPioneira, 1984.

LOPES, Alexandro Broedel, GALDI, Fernando Caio e LIMA, Iran Siqueira. Manual de Contabilidade e Tributação de Instrumentos Financeiros e Derivativos. $2^{\mathrm{a}}$ ed., São Paulo: Atlas, 2011.

e MARTINS, Eliseu. Teoria da Contabilidade: uma nova abordagem. São Paulo: Atlas, 2007.

LUI, Ana Paula Schincariol. Imposto sobre a Renda e Proventos de Qualquer Natureza Auferidos pela Pessoa Física - Princípios Constitucionais e Sistemática de Apuração. Dissertação de Mestrado defendida na Pontifícia Universidade Católica de São Paulo, 2007.

MACHADO, Brandão. Imposto de Renda. Ganhos de Capital. Promessa de Venda de Ações. In: Revista de Direito Tributário Atual, v. 11/12, São Paulo: Resenha Tributária/IBDT, 1992. Breve Exame Crítico do art. 43 do CTN. In: MARTINS, Ives G. S. (coord.). Estudos sobre o Imposto de Renda (em memória de Henry Tilbery). São Paulo: Resenha Tributária, 1994.

MARTINEZ, Atonio Lopo, A Linguagem Contábil no Direito Tributário, Dissertação de Mestrado em Direito, São Paulo: PUC-SP, 2002. 
MARTINS, Fran. Curso de Direito Comercial: empresa comercial, empresários individuais, microempresas, sociedades comerciais, fundo de comércio. Ed. rev. e atual. - Rio de Janeiro: Forense, 2009.

MARTINS, Ricardo Lacaz. Tributação da Renda Imobiliária. São Paulo: Quartier Latin, 2011.

MINISTÉRIO DA FAZENDA. Trabalhos da Comissão Especial do Código Tributário Nacional. Rio de Janeiro: Ministério da Fazenda, 1954.

MIRANDA, Pontes de. Tratado de Direito Privado: Parte Geral - Bens. Fatos Jurídicos. Tomo II, atualizada por Vilson Rodrigues Alves, $1^{\text {a }}$ ed., Campinas: Bookseller, 2000.

. Tratado de Direito Privado: Parte Geral - Eficácia Jurídica. Determinações Inexatas e Anexas. Direitos. Pretensões. Ações. Tomo V, atualizada por Vilson Rodrigues Alves, $1^{\text {a }}$ ed., Campinas: Bookseller, 2000.

MONTEIRO, Washington de Barros. Curso de Direito Civil: Direito das Coisas. Vol. III, 20a ed., São Paulo: Saraiva, 1981.

Curso de Direito Civil: Direito das Obrigações. $1^{\mathrm{a}}$ parte, $16^{\mathrm{a}}$ ed., São Paulo: Saraiva, 1981.

Shopping Centers. In ARRUDA, José Soares e LÔBO, Carlos Augusto da Silveira (coord.). "Shopping Centers" - Aspectos Jurídicos. São Paulo: Revista dos Tribunais, 1984.

MOSQUERA, Robeto Quiroga. Renda e Proventos de Qualquer Natureza - O Imposto e o Conceito Constitucional. São Paulo : Dialética, 1996.

. Tributação do Mercado Financeiro e de Capitais. 2a ed., São Paulo: Dialética, 1999.

e LOPES, Alexsandro Broedel. O Direito Contábil. Fundamentos Conceituais, Aspectos da Experiência Brasileira e Implicações.. In MOSQUERA, Roberto Quiroga, e LOPES, Alexsandro Broedel (coord.). Controvérsias Jurídico-Contábeis (Aproximações e Distanciamentos). São Paulo : Dialética, 2010.

NAKAO, Sílvio Hiroshi. Um Modelo de Tributação da Renda por Fluxos de Caixa 
Realizados. Tese de doutorado apresentada ao Departamento de Contabilidade e Atuária da Faculdade de Economia, Administração e Contabilidade da Universidade de São Paulo, São Paulo, 2003.

NISHIOKA, Alexandre Naoki. Do Critério Temporal do Imposto sobre a Renda de Pessoa Física nos Casos de Promessa de Compra e Venda a Prazo. In Revista Direito Tributário Atual, vol. 25, Dialética: São Paulo, 2011.

NOGUEIRA, Ruy Barbosa. Curso de Direito Tributário. 14ª ed., São Paulo: Saraiva, 1995.

OHLSON, J. A., Earnings, book values and dividends in equity valuation. The Contemporary Accounting Research, v. 11, nº 2, 1995, pp. 661-687. Apud LOPES, Alexsandro Broedel e MARTINS, Eliseu. Teoria da Contabilidade: uma nova abordagem. São Paulo: Atlas, 2007.

OLIVEIRA, Ricardo Mariz de. Fundamentos do Imposto de Renda. São Paulo: Quartier Latin, 2008.

PEDREIRA, José Luiz Bulhões. Imposto sobre a Renda: pessoas jurídicas. Vol. 1, Rio de Janeiro: Justec, 1979.

PEREIRA, Caio Mario da Silva Pereira. Shopping Centers - Organização Econômica e Disciplina Jurídica. In ARRUDA, José Soares e LÔBO, Carlos Augusto da Silveira (coord.). “Shopping Centers” - Aspectos Jurídicos. São Paulo: Revista dos Tribunais, 1984.

Súmula do Simpósio sobre os Centros Comerciais. In ARRUDA, José Soares e LÔBO, Carlos Augusto da Silveira (coord.). "Shopping Centers" - Aspectos Jurídicos. São Paulo: Revista dos Tribunais, 1984.

Instituições de Direito Civil. Vol. IV, Direitos Reais, 19a ed., Rio de Janeiro: Forense, 2006.

PINTO, Dinah Sonia Renault. Shopping Center, Uma Nova Era Empresarial. Revista e Atualizada por Vânia Renault Bechara Gomes e Antonio Marcos de Bragança Gomes. Rio de Janeiro: Forense, 2001.

POLIZELLI, Victor Borges. O Princípio da Realização da Renda e sua Aplicação no Imposto de Renda de Pessoas Jurídicas. Dissertação de Mestrado defendida na Faculdade de Direito da Universidade de São Paulo, 2009. 
PRIMON, Henrique Barbosa e MONETTI, Eliane, Implantação e Expansão de Shopping Centers no Brasil: um Estudo da Evolução Recente das Fontes de Investimentos. 10 ${ }^{\mathrm{a}}$ Conferência Internacional da Lares, São Paulo, 2010.

REQUIÃO, Rubens. Considerações Jurídicas sobre os Centros Comerciais (Shopping Center) no Brasil, In ARRUDA, José Soares e LÔBO, Carlos Augusto da Silveira (coord.). "Shopping Centers” - Aspectos Jurídicos. São Paulo: Revista dos Tribunais, 1984.

RODRIGUES, Silvio. Direito civil: parte geral. Vol. 1, 32a ed., São Paulo: Saraiva, 2002.

SCHOUERI, Luís Eduardo. Discriminação de Competências e Competência Residual. In Direito Tributário: estudos em homenagem a Brandão Machado. Coords. SCHOUERI, Luís Eduardo, ZILVETI, Fernando Aurelio. São Paulo: Dialética, 1998.

. Direito Tributário Internacional - Qualificação e Substituição - Tributação no Brasil, de Rendimentos Provenientes de Sociedade de Pessoas Residente na Alemanha, in RDDT $n .^{\circ} 54$.

Normas Tributárias Indutoras e Intervenção Econômica. Rio de Janeiro: Forense, 2005.

Prefácio. In OLIVEIRA, Ricardo Mariz de. Fundamentos do Imposto de Renda. São Paulo: Quartier Latin, 2008.

O Mito do Lucro Real na Passagem da Disponibilidade Jurídica para a Disponibilidade Econômica. In MOSQUERA, Roberto Quiroga, e LOPES, Alexsandro Broedel (coord.). Controvérsias Jurídico-Contábeis (Aproximações e Distanciamentos). São Paulo : Dialética, 2010.

e TERSI, Vinícius Feliciano. As Inter-relações entre a Contabilidade e o Direito: atender ao RTT significa obter neutralidade Tributária? In: MOSQUERA, Roberto Quiroga e LOPES, Alexsandro Broedel (coord.). Controvérsias Jurídico-Contábeis (Aproximações e Distanciamentos). $2^{\circ}$ Vol. São Paulo : Dialética, 2011.

Direito Tributário. São Paulo: Saraiva, 2011

SCOTT, Hal S. International Finance: Law and Regulation, Sweet \& Maxwell, $2^{\mathrm{a}}$ ed., 2007. 
SOBRINHO, José Dutra Vieira, Matemática Financeira, 7ª ed., São Paulo : Ed. Atlas, 2006.

SOUSA, Rubens Gomes de. A evolução do Conceito de Rendimento Tributável. In: Revista de Direito Público, v.14, São Paulo: Revista dos Tribunais, out-dez 1970.

SZTAJN, Rachel. Quotas de Fundos Imobiliários - Novo Valor Mobiliário. In Revista de Direito Mercantil nº 93, 1994.

TILBERY, Henry, A Tributação dos Ganhos de Capital das Pessoas Jurídicas: Comentários ao Decreto-lei $n^{o}$ 1.598/77, São Paulo: Resenha Tributária: Instituto Brasileiro de Direito Tributário, 1978.

. O novo imposto de renda no Brasil: comentários à Lei $n^{o} 7.713 / 88$ ajustado aos novos métodos de atualização monetária. São Paulo: IOB, 1989.

TÔRRES, Heleno, Direito Tributário e Direito Privado - Autonomia Privada - Simulação Elusão Tributária, São Paulo, Revista dos Tribunais, 2003.

TORRES, Ricardo Lobo. Legalidade Tributária e Riscos Sociais. In Revista Dialética de Direito Tributário no 59.

O Princípio da Tipicidade no Direito Tributário. In: Revista de Direito Administrativo, $\mathrm{n}^{\circ} 235$.

VANONI, Ezio. Natura ed Interpretazione delle Leggi Tributrarie. Trad. port. de Rubens Gomes de Sousa. Natureza e Interpretação das Leis Tributárias. Rio de Janeiro : Edições Financeiras, s.d.

VENOSA, Silvio de Salvo. Direito Civil: Contratos em Espécie, Coleção Direito Civil vol. 3, $8^{a}$ ed., São Paulo: Atlas, 2008.

Direito Civil: Direitos Reais, Coleção Direito Civil vol. 5, $9^{a}$ ed., São Paulo: Atlas, 2009.

VERRI, Maria Elisa Gualandi, Shopping Centers - Aspectos Jurídicos e suas Origens. Belo Horizonte: Del Rey, 1996.

WALD, Arnoldo. Da Natureza Jurídica do Fundo Imobiliário. In Revista de Direito Mercantil $n^{\circ} 80,1990$. 
. Direito Civil: Contratos em Espécie. Vol. 3, 18ª ed., São Paulo: Saraiva, 2009.

YAZBEK, Otavio. Regulação do Mercado Financeiro e de Capitais. Rio de Janeiro : Elseivier, 2007.

ZILVETI, Fernando Aurelio. Princípios de Direito Tributário e a Capacidade Contributiva. São Paulo: Quartier Latin, 2003.

. O Princípio da Realização da Renda. SCHOUERI, Luís Eduardo (org.) Direito Tributário. Homenagem a Alcides Jorge Costa, vol. I. São Paulo: Quartier Latin, 2003. . Obrigação Tributária: Fato Gerador e Tipo. São Paulo: Quartier Latin, 2009. 